\author{
UNIVERSIDADE DE BRASÍLIA \\ INSTITUTO DE CIÊNCIAS SOCIAIS \\ DEPARTAMENTO DE ANTROPOLOGIA \\ PROGRAMA DE PÓS-GRADUAÇÃO EM ANTROPOLOGIA SOCIAL
}

ANCESTRAIS E SUAS SOMBRAS

Uma etnografia da chefia kalapalo e seu ritual mortuário

Antonio Roberto Guerreiro Júnior

Brasília

2012 


\title{
ANCESTRAIS E SUAS SOMBRAS \\ Uma etnografia da chefia kalapalo e seu ritual mortuário
}

\author{
Antonio Roberto Guerreiro Júnior
}

Tese apresentada ao Programa de PósGraduação em Antropologia Social da Universidade de Brasília para obtenção do título de Doutor em Antropologia Social

Orientadora: Profa. Dra. Marcela Stockler Coelho de Souza

Brasília

2012 
Ficha catalográfica elaborada pela Biblioteca Central da Universidade de Brasília. Acervo 998591.

G934arrei ro Júnior, Antonio Roberto.

G934a Ancestrais e suas sombras: uma etnografia da chefia kalapalo e seu ritual mortuário / Antonio Roberto Guerrei ro Júnior. - - 2012.

511 f. : il. ; $30 \mathrm{~cm}$.

Tese (doutorado) - Universidade de Brasília, Departamento de Antropologia, Programa de Pós-Graduação em Antropologia Social, 2012.

Inclui bibliografia.

Orientação: Marcela Stockler Coelho de Souza.

1. Índios Kalapálo. 2. Etnologia. 3. Índios da América do Sul - Vida e costumes sociais. 4. Índios - Ritos e cerimônias fúnebres. I. Souza, Marcela Stockler Coelho de. II. Título. 


\section{ANCESTRAIS E SUAS SOMBRAS \\ Uma etnografia da chefia kalapalo e seu ritual mortuário Antonio Roberto Guerreiro Júnior}

Tese apresentada ao Programa de Pós-Graduação em Antropologia Social da Universidade de Brasília para obtenção do título de Doutor em Antropologia Social.

Aprovada por:

Profa. Dra. Marcela Stockler Coelho de Souza (PPGAS-DAN/UnB)

Orientadora

Prof. Dr. Luis Cayón (PPGAS-DAN/UnB)

Profa. Dra. Bruna Franchetto (PPGAS-Museu Nacional/UFRJ)

Profa. Dra. Elsje Lagrou (PPGSA-IFCS/UFRJ)

Prof. Dr. Renato Sztutman (PPGAS/USP) 
Uinguheniko inhani

Para os que me abriram os olhos

Aliju inha

Para Aliju 


\section{AGRADECIMENTOS}

Agradeço em primeiro lugar aos Kalapalo, que me receberam em suas casas (muitas vezes em momentos tristes e difíceis), cuidaram de mim e dividiram comigo suas vidas com inigualável generosidade. Enumü e Itsapü, que já tomaram o caminho a oeste do céu, eram personalidades ímpares, e me acolheram em sua família com carinho e boa vontade. A Nailu, Haja "Senegal”, Kahagahü, Sahati, Aline, Luka, Hinhuka "Tafarel” e Maũ, agradeço pelos cuidados, pelo bom humor, pelas conversas agradáveis, e por tentarem me fazer engordar. A Haihua, por me ensinar seus cantos com paciência e por sempre me trazer de volta para a realidade. Hélio, Kuango, Tuku, Isa, Mansu, Johi, Susema e Jepe foram muito importantes, porque o campo sem essas crianças não teria sido tão cheio de risadas. Agradeço aos caciques Waja, Tühoni e Hagema, que me ofereceram sua hospitalidade e me cederam muito de seu tempo; a Tipüsusu, grande pensadora de seu povo, por ser sempre tão generosa com suas ideias; a meu amigo Hüge Hüti "Orlandinho", por ser sempre tão preocupado, observador e divertido, e por ter passado muitas horas me ajudando no trabalho de transcrição e tradução; a Masinua, por não ter desistido de me ensinar a pescar; a Hikama, pela fineza e eloquência de suas explicações, e por demonstrar sua confiança em mim; a Kalühi, por ser tão detalhista; a Moge, pelos jaraquis; a Tawana, Kamankgagü "Viola", Kayauta, Kohoi, Mataiatsi, Sapuia, Kainahu e Hepia, pela companhia, pela ajuda no trabalho e por me darem todo o apoio no difícil aprendizado de sua língua. A todos os que porventura deixei de mencionar, agradeço por me fazerem sentir à vontade, e por me ajudarem a combater os perigos da saudade.

Ugise merece um agradecimento especial, pois sem ele esta pesquisa teria sido impossível - desde as viagens na chuva, até as complexas interpretações de sua cultura, tudo o que fez para me ajudar é imensurável. Ageu, um observador como poucos (o "cientista político do Xingu", segundo meu amigo Kulumaka Matipu), foi outro pivô deste trabalho. Sou muito grato por sua confiança, sua dedicação como mestre e por ter se preocupado tanto com minha compreensão das coisas. Certa vez, ele me disse: "Quando você contar sobre nossos costumes para os brancos, diga a eles: foi meu tio quem me ensinou. Diga que eu conheço todas as histórias, todos os discursos, porque meu pai me ensinou tudo. Diga que eu só dei isso para você, para mais ninguém". Espero não frustrar suas expectativas, e poder um dia retribuir à altura. 
Fora do Xingu, agradeço a meus pais, de quem nunca me faltou apoio e carinho, e que aprenderam a se interessar pelo que faço, o que não é pouco. Marina Cardoso, na UFSCar, me fez gostar de antropologia e me apresentou aos Kalapalo. Se não fosse por ela, este trabalho sequer teria começado. Agradeço a Marcos Lanna, professor e amigo, pelas conversas criativas e pelo entusiasmo com o tema da política. Jorge Villela também foi importante, me incentivando a cursar o doutorado em Brasília em um momento de indecisão. Ao pessoal da turma de mestrado de 2008, especialmente Carolina Pedreira, Diogo Bonadiman Goltara, Fabíola Gomes, Julia Otero, Pedro MacDowell e Walison Pascoal, agradeço demais por terem me "adotado". Sem a amizade de vocês a antropologia não teria sido tão interessante, e teria sido muito mais difícil chegar (e ficar) em Brasília.

A Marcela Coelho de Souza, motivo pelo qual vim para Brasília, não saberia por onde começar a agradecer. Esta tese teria sido impossível sem suas leituras atentas, sua preocupação com as minúcias do texto, com os duplos sentidos e sua vontade de distorcer tudo que parece óbvio. Mas agradeço sobretudo à sua confiança, por ter aceitado me receber como seu orientando antes mesmo de nos conhecermos, sem eu ainda sequer ter prestado a seleção do doutorado. A Bruna Franchetto, agradeço pelo apoio no Xingu e fora dele, pelas conversas, pela hospitalidade no Rio, e pelas aulas de karib em Küngahünga. A Mara Santos, pelo esforço conjunto com Bruna Franchetto para que saísse o PRODOC Kalapalo, e pela ajuda com a língua karib. Agradeço também a Mutua e Jamalui Mehinaku-Kuikuro, que me ajudaram na transcrição e tradução de um conjunto de cantos em arawak.

A Marina Novo, minha eterna gratidão por fazer de Brasília um lugar muito feliz. Sua paciência e compreensão frente à minha ansiedade, minhas dúvidas, minhas dificuldades, meu mau humor e meu desleixo foram inestimáveis. Seus comentários a uma versão anterior deste trabalho, sua ajuda na revisão e formatação do texto, e seu esforço para me manter no chão na reta final tornaram esta tese possível. Também são dela os créditos pelos mapas e muitas das fotografias.

Obrigado a todos os funcionários do DAN, por terem resolvido com presteza qualquer questão burocrática antes mesmo que eu pudesse pensar em me preocupar.

Agradeço também ao CNPq pela bolsa concedida. 
The best way I have found to define ethnographic interpretation is the classic analogy of three blind men attempting to describe an elephant by touch-one holding its trunk, one its tail, and the other its tusk. Different ethnographers see things different ways, and the contrasting subjective viewpoints of each fieldworker determine the nature of the resulting ethnographic portrait. We, as much as the people who are our subject matter, create the reality of social and cultural phenomena, for we too are acting "culturally" by doing anthropology.

James Weiner, The Heart of the Pearl Shell (1988: 1) 


\section{RESUMO}

Esta tese é uma etnografia da chefia kalapalo (karib) e seu ritual mortuário no contexto do sistema multiétnico e multilíngue do Alto Xingu (MT). Pela descrição e análise de diferentes aspectos do ritual, percebe-se que os chefes apresentam um tipo de dualidade, sendo produzidos e exibidos ao mesmo tempo como pais/consanguíneos para seu povo, e inimigos simbólicos/afins para outros chefes. Sugere-se que a forma assumida por tais agentes está ligada à produção do parentesco no âmbito do sistema regional, e que o ritual cria as condições a partir das quais este processo pode ser concluído e recomeçado.

Palavras-chave: chefia, ritual, parentesco, Alto Xingu, Kalapalo, povos karib 


\begin{abstract}
This thesis is an ethnography of kalapalo (karib) chieftaincy and its mortuary ritual within the multiethnic and multilingual system of the Upper Xingu (MT). By describing and analyzing different aspects of the ritual, it becomes clear that chiefs present a kind of duality, being produced and displayed simultaneously as fathers/consanguines for their people, and symbolic enemies/affines for other chiefs. It is suggested that the form assumed by such agents is related to the production of kinship within the regional system, and that the ritual creates the conditions from which this process can be concluded and restarted.
\end{abstract}

Keywords: chieftaincy, ritual, kinship, Upper Xingu, Kalapalo, karib-speaking peoples 


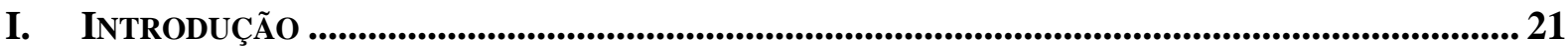

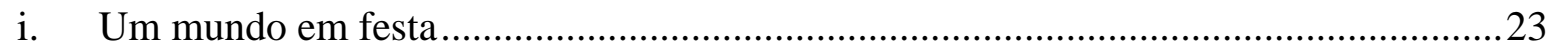

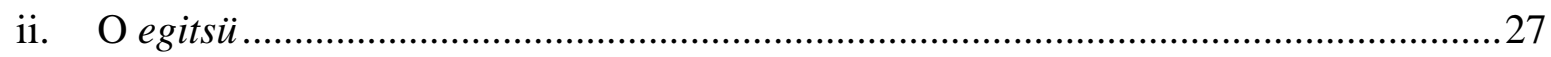

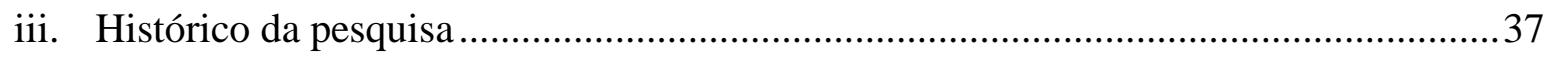

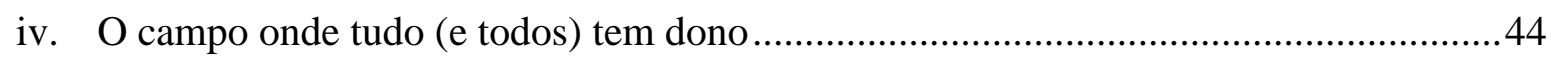

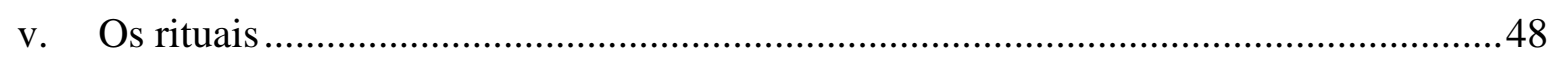

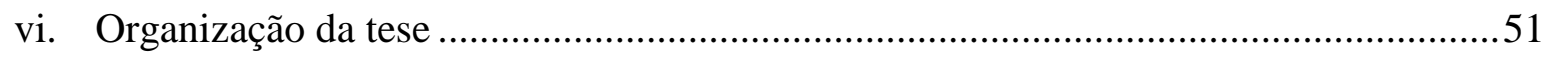

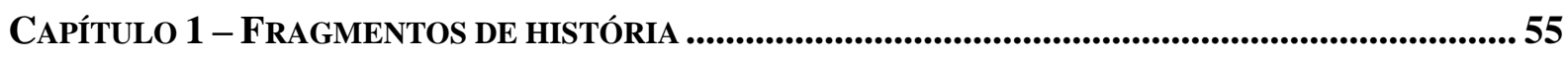

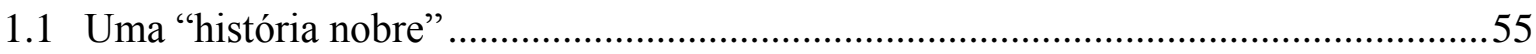

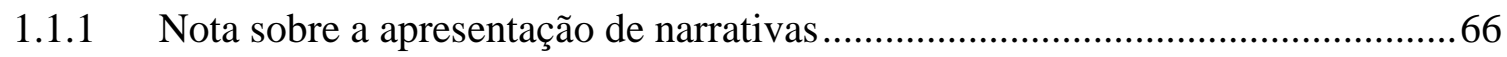

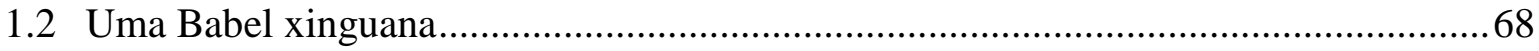

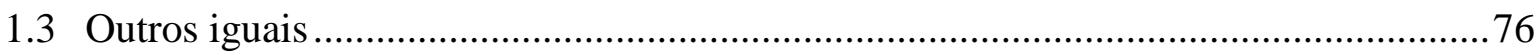

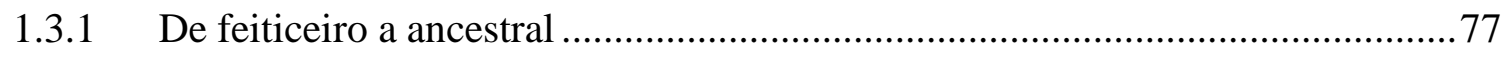

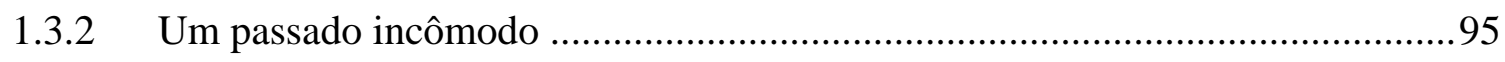

1.4 Os brancos e seu estranho desejo por filhos de chefes .........................................99

1.5 O aparecimento de Orlando, a criação do Parque e a contenção da feitiçaria .............108

Capítulo 2 - Fazendo substitutos: A QUESTÃo da hereditARIEdAdE da CHEFIA ............. 118

2.1 Nascer nobre, ser feito chefe: o "paradoxo" da herança e da fabricação ...................118

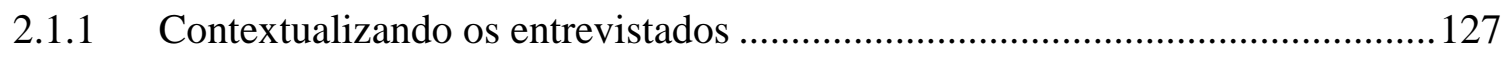

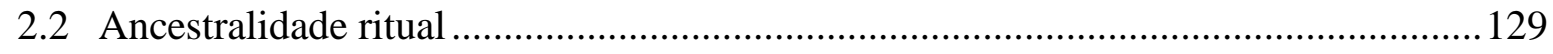

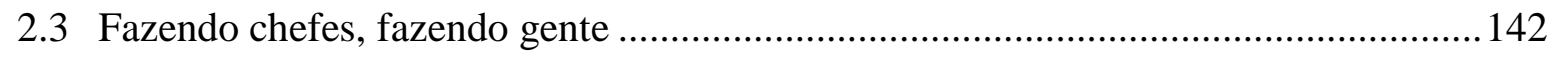

2.4 A filiação como vetor de identificação ............................................................. 150

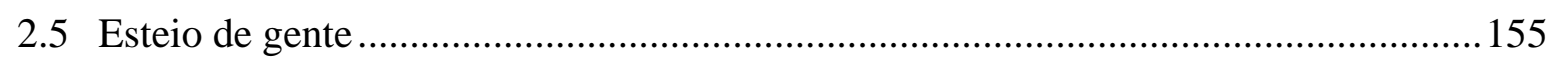

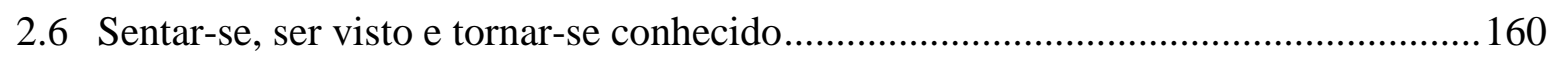


CAPÍTULO 3 - O ENCONTRO COM A ONÇA ...................................................................................................... 171

3.1 A família do Ipê Amarelo e o Morcego Pescador ..................................................... 174

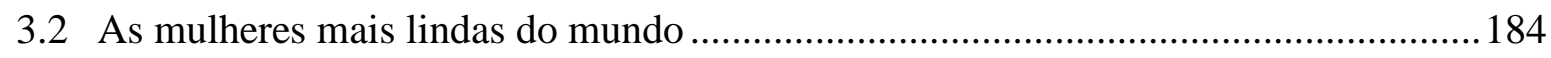

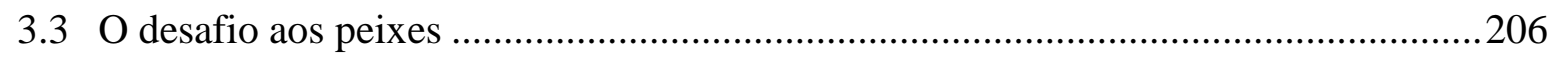

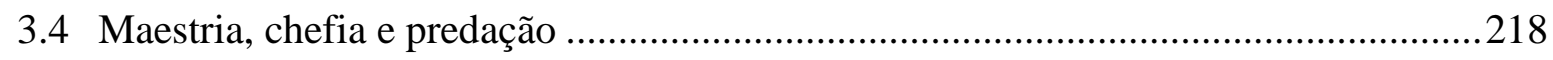

3.4.1 Humanos e animais.............................................................................. 218

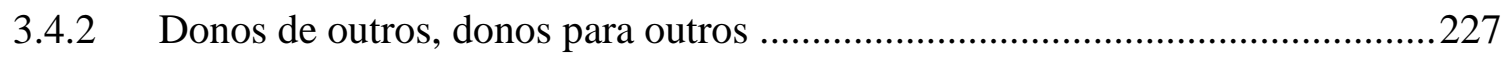

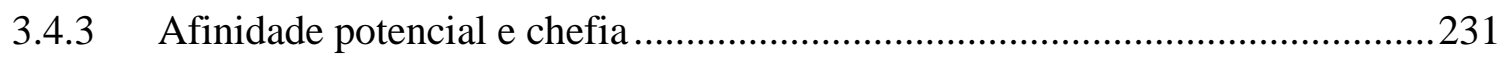

Capítulo 4 - Refazendo o PaRentesco COM Alguns mortos: A PRODUÇÃo de CORPOS-

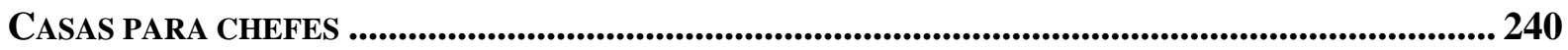

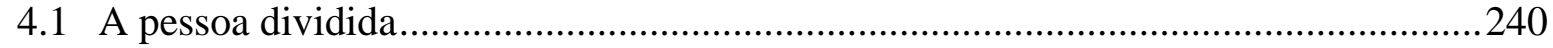

4.2 O enterro e o começo da organização do ritual ........................................................249

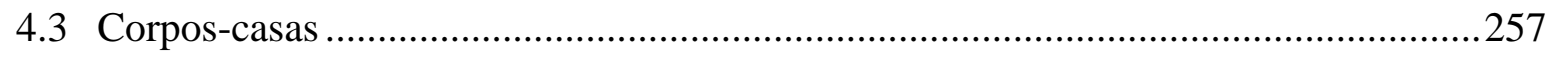

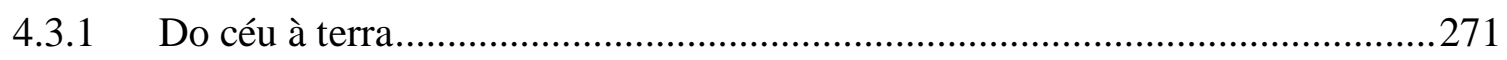

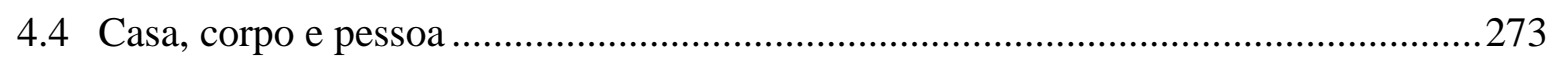

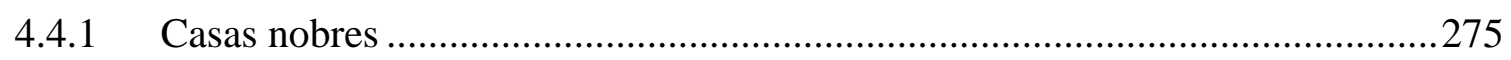

CAPÍTULO 5 - AKITSENE: O SISTEMA DE DISCURSOS RITUAIS DOS CHEFES ................................ 298

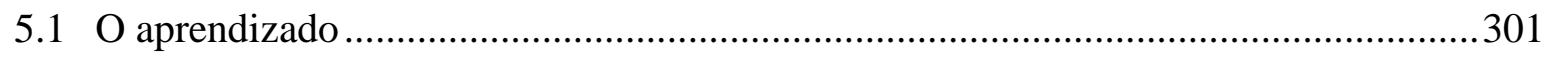

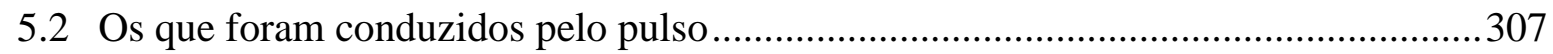

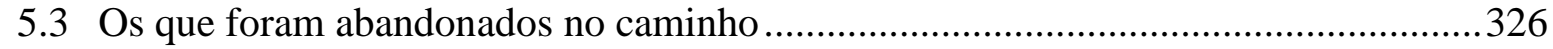

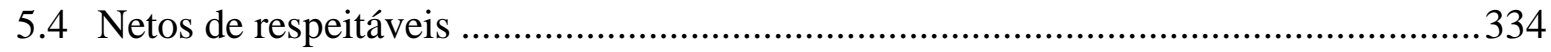

5.5 Breve excurso comparativo: de respeitáveis a irmãos .............................................339

5.6 O Gavião e a Onça: quando o chefe precisa ficar invisível .....................................342

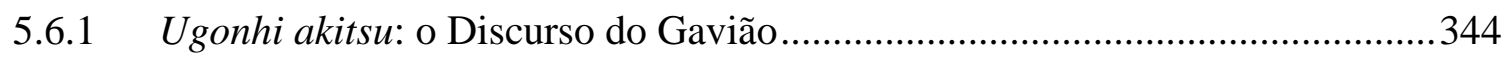

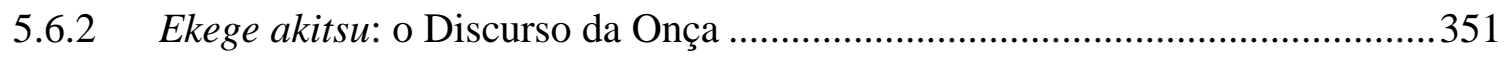

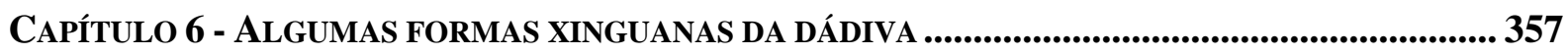

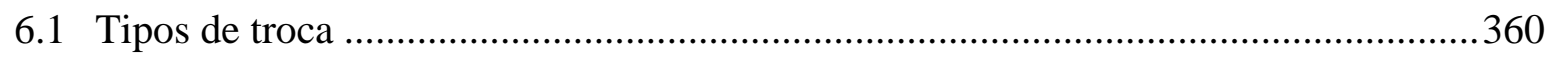




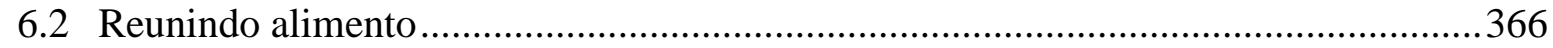

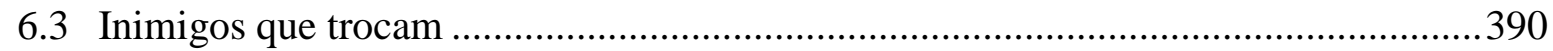

6.4 “Aqui está parecendo um aeroporto": os brancos nos rituais ....................................398

6.4.1 Os brancos também precisam de um dono ................................................ 404

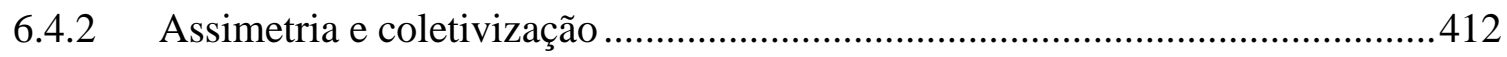

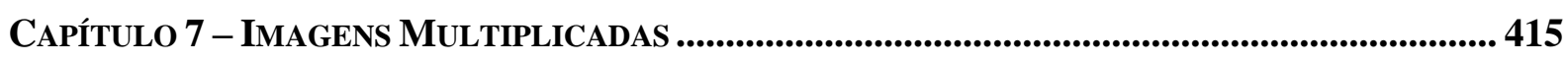

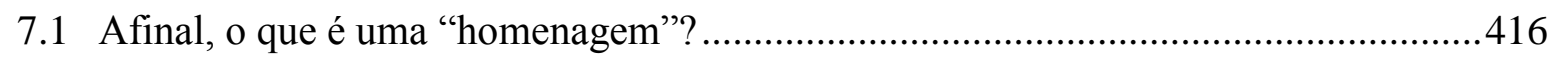

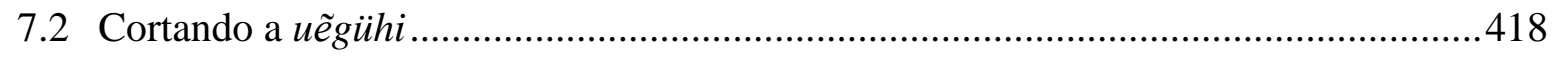

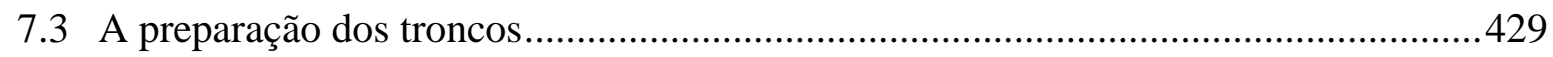

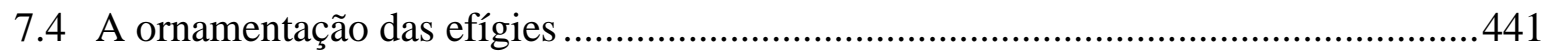

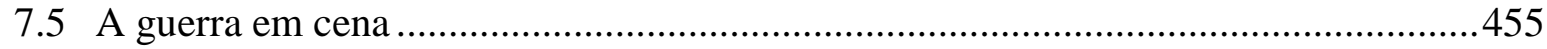

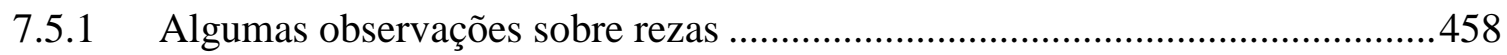

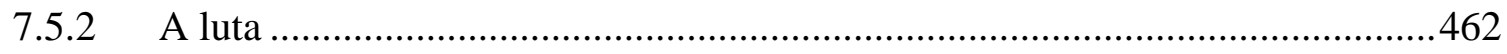

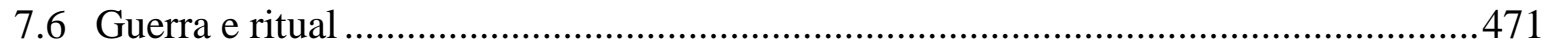

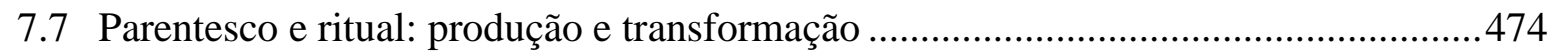

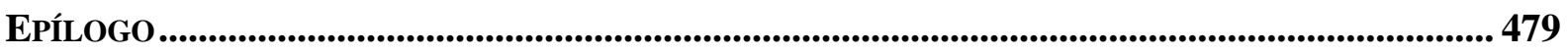

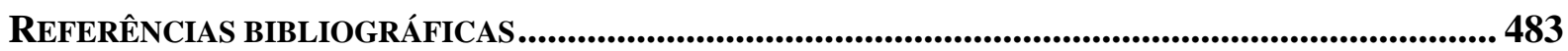

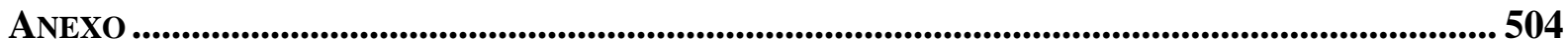




\section{LISTA DE FIGURAS}

FIGURA I.1: PRINCIPAIS PESSOAS ENVOLVIDAS NOS EGITSÜ QUE ACOMPANHEI. ...............................................50

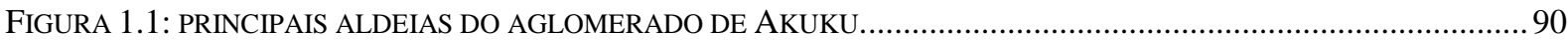

FIGURA 1.2: LOCALIZAÇÃO DE ANTIGAS ALDEIAS E OUTROS PONTOS RELEVANTES.............................................94

FIGURA 1.3: TENTATIVA DE SISTEMATIZAR AS RELAÇÕES CONHECIDAS ENTRE OS KARIB ANCESTRAIS DOS

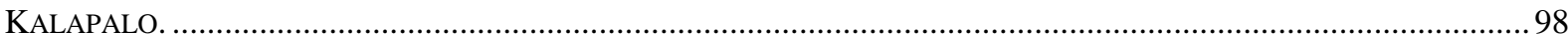

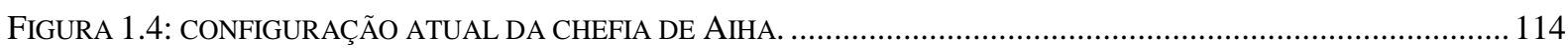

FIGURA 2.1: RELAÇÕES DE PARENTESCO ENTRE OS PRINCIPAIS CHEFES MENCIONADOS NESTE CAPÍTULO. ............ 129

FIGURA 3.1: UM EXEMPLAR DE JUKUKU EM MEIO AO “SEU PESSOAL”, ÀS MARGENS DO CULUENE...................... 182

FIGURA 3.2: UÃGU, PRÓXIMO À ANTIGA ALDEIA KAHINDZU. 190

Figura 3.3: MAPA do Alto Xingu, COM OS Limites do PARQue E A LOCALIZAÇÃo DE MÜGENA E SAGIHẼGU. 208

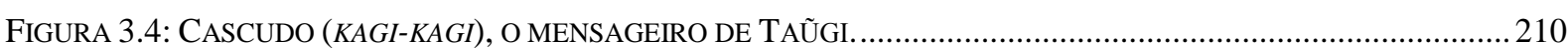

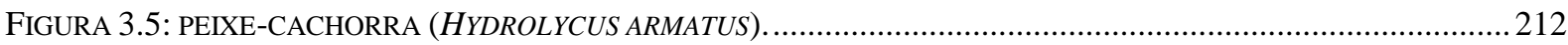

FIGURA 3.6: ALGUNS PONTOS DO CAMINHO DOS PEIXES ATÉ SAGIHẼGU. .....................................................213

FIGURA 3.7: MOTIVO TÜIHITINHÜ (MERECHU) APLICADO SOBRE A EFÍGIE MORTUÁRIA DE UMA MULHER..............2220

FIGURA 3.8: TRANSFORMAÇÕES DE DESENHOS DE PEIXE, DO MAIS ICÔNICO (ABAIXO) AO MAIS ABSTRATO (ACIMA), APROXIMANDO-SE DAS LINHAS EXTERNAS DO MOTIVO TÜIHITINHÜ (MERECHU) ............................................221

FIGURA 3.9: DESENHOS DE HOMEM (À ESQUERDA) E PEIXE (À DIREITA) . ........................................................221

FIGURA 4.1: ESTEIRA DE ESPREMER MANDIOCA COM O PADRÃO INGÜ, O MESMO QUE DEVE SER TRANÇADO NA REDE DE UM NOBRE FALECIDO

Figura 4.2: SEPUlTURA EM UMA ALDEIA AwETI, RETRATAdA PELA EXPEDIÇÃo DE VON DEN STEINEN (1940:

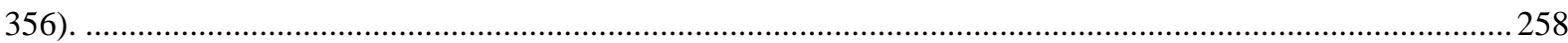

FIGURA 4.3: KUAMBÜ, MÁSCARA USADA POR SERES AQUÁTICOS QUANDO APARECEM PARA OS HUMANOS. ..........266 FIGURA 4.4: PINTURA CORPORAL MASCULINA, CUJOS CONTORNOS BÁSICOS EVOCAM O MOTIVO DAS ELIPSES.....267

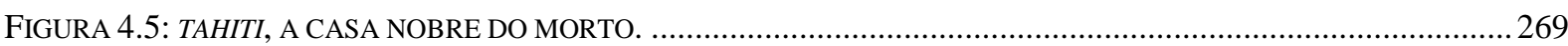

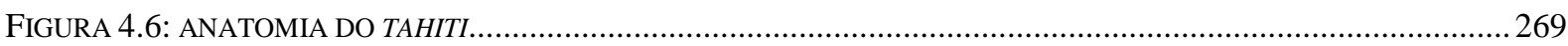

FIGURA 4.7: FRISO EXTERNO DA CASA DOS HOMENS, SEMELHANTE AOS COLOCADOS NA TALÜHE POR FORA (NO

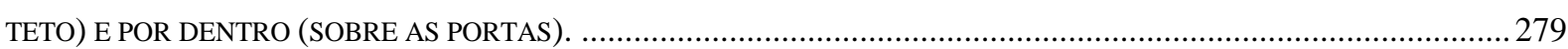

FIGURA 4.8: JOVEM LUTADOR EXIBINDO UMA SUCURI QUE UTILIZARIA PARA FAZER UM HŨBONGO...................282

FIGURA 5.1: DONO DO EGITSÜ DISCURSANDO PARA SE DESPEDIR DOS CHEFES ALIADOS......................................304

FIGURA 5.2: DONOS DO EGITSÜ COM SEUS AKITSOHO SE DESPEDINDO FORMALMENTE DOS CONVIDADOS..............312

FIGURA 5.3: DIAGRAMA MOSTRANDO A TRANSMISSÃO DE NOMES DE CHEFES MENCIONADOS NO ETINHÜ

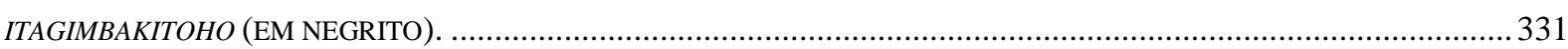

FIGURA 5.4: EX-MENSAGEIRO KUIKURO RECEBENDO UGIHONGO KALAPALO PARA UM HAGAKA.......................... 336

FIGURA 5.5: UM DOS DONOS DO EGITSÜ SE DESPEDINDO DOS CHEFES ALIADOS. .............................................. 338

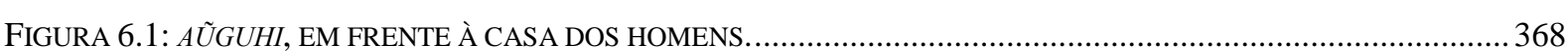

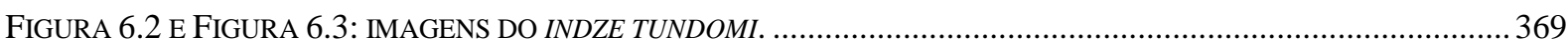

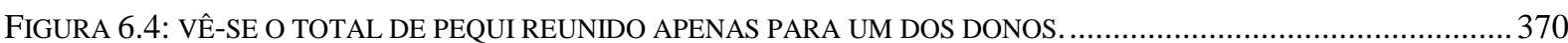


FIGURA 6.5 E FIGURA 6.6: MULHERES COZINHANDO PEQUI NO CENTRO DA ALDEIA.

FIGURA 6.7: DIAGRAMA COM AS RELAÇÕES ENVOLVIDAS NA REUNIÃO DA POLPA DE PEQUI. ...............................373

FIGURA 6.8: DIAGRAMA DAS RELAÇÕES ENTRE ALIADOS E ANFITRIÕES MEDIADAS POR POLVILHO......................374

FIGURA 6.9: DIAGRAMA DAS RELAÇÕES ECLIPSADAS NA PRODUÇÃO DO GRUPO ANFITRIÃO NO EGITSÜ DE 2010...378

FIGURA 6.10: GRANDES PANELAS COM MINGAU DE PEQUI PREPARADAS POR UM DOS DONOS.

FIGURA 6.11: UM DOS TAJOPE DISTRIBUINDO O MINGAU QUE RECEBEU NAS PANELAS LEVADAS PELOS PESCADORES.

FIGURA 6.12: HOMEM KALAPALO ENTREGANDO PEIXES. 380

FIGURA 6.13: DIAGRAMA COM AS RELAÇÕES ECLIPSADAS PELO DONO DA FESTA NA ENTREGA DO ALIMENTO RITUAL AOS CHEFES ESTRANGEIROS. 386

FIGURA 6.14: UGIHONGO MEHINAKU (ALIADOS DOS KALAPALO NO EGITSÜ DE 2010) CHAMANDO SEU "INIMIGO" PARA LHE ENTREGAR UMA GRANDE PANELA DE CERÂMICA (ESPECIALIDADE PRODUTIVA ARAWAK). 392

FIGURA 6.15: PAI DE UGIHONGO KALAPALO EXIBINDO SUA RIQUEZA DURANTE O HAGAKA (VEJAM OS COLARES PENDURADOS EM SUA “LANÇA”). 394

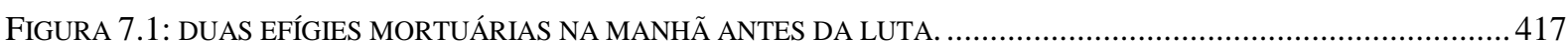

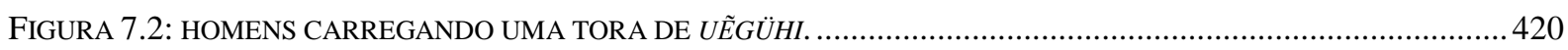

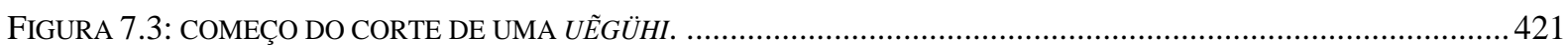

FIGURA 7.4: HOMEM CONFECCIONANDO O SUPORTE DA PANELA DE MINGAU DO ESPÍRITO COM PALHA DE BURITI. 422

FIGURA 7.5: O CHEFE WAJA ENTREGA UMA PANELA DE MINGAU DE PIMENTA AO ESPÍRITO DA ÁRVORE. .............423

FIGURA 7.6: “ANATOMIA SOCIAL” DA UẼGÜHI. 424

FIGURA 7.7: ENQUANTO AgEU (AGACHADO) REZA PARA ACALMAR O ESPÍRITO E DEIXAR A TORA MAIS LEVE, JOVENS A AMARRAM A UM TRONCO QUE USARÃO PARA CARREGÁ-LA. ..........................................................428

FIGURA 7.8: HOMENS CAVANDO OS BURACOS ONDE SERÃO INSTALADAS AS EFÍGIES. ......................................430

FIGURA 7.9: TRONCOS PRESTES A SEREM CARREGADOS PARA O CENTRO DA ALDEIA. ........................................ 431

FIGURA 7.10: GRUPO DE TREZE HOMENS CARREGANDO PARA O CENTRO DA ALDEIA, EM UM SUPORTE ESPECIAL, O GRANDE TRONCO USADO PARA A EFÍGIE DA IRMÃ DO PRIMEIRO CACIQUE.

FIGURA 7.11: OS IRMÃOS E ANETÜ KURIKAGE (À FRENTE) E ULEHE (ATRÁS) REZANDO AO REDOR DOS TRONCOS ENQUANTO SÃO LEVADOS ATÉ O CENTRO.

FIGURA 7.12: TRONCOS NO CENTRO, POUCO ANTES DE SEREM COLOCADOS EM PÉ.

FIGURA 7.13: O TAJOPE ULEHE DELIMITA, COM PALHA DE BURITI, OS LIMITES INFERIOR E SUPERIOR DA SUPERFÍCIE DE PINTURA DA EFÍGIE DO GRANDE PAJÉ E CANTOR ENUMÜ..... 434

FIGURA 7.14: O TAJOPE JAUA RASPANDO A CASCA DA TITA DE ENUMÜ. .....................................................434

FIGURA 7.15: O CINEGRAFISTA TAWANA REGISTRA A PINTURA DA EFÍGIE DE SEU PAI COM TABATINGA. ............. 435

FIGURA 7.16: O “UMBIGO VERMELHO” DE UMA EFÍGIE VISTA DE FRENTE. .......................................................436

FIGURA 7.17: UNA DE UMA DAS EFÍGIES DISPOSTAS NO CENTRO, PRÓXIMAS À CASA DOS HOMENS. 437

FIGURA 7.18 E FIGURA 7.19: À ESQUERDA, O MOTIVO HOTOTO IJATAGÜ, EXECUTADO APENAS EM EFÍGIES MASCULINAS (VISTA LATERAL). À DIREITA, EFÍGIE MASCULINA VISTA POR TRÁS. 
FIGURA 7.20 E FIGURA 7.21: À ESQUERDA, O MOTIVO TÜIHITINHÜ, APLICADO EM EFÍGIES FEMININAS. À DIREITA, A

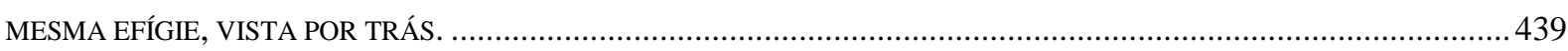

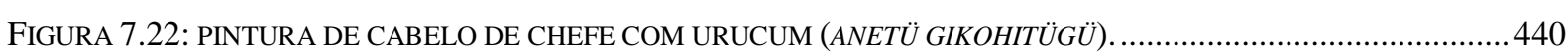

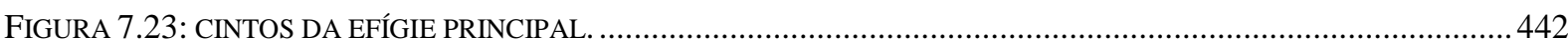

FIGURA 7.24: DONOS DO EGITSÜ CORRENDO PARA O CENTRO, CHORANDO E CARREGANDO OS ENFEITES DA EFÍGIE. 442

FIGURA 7.25: PARENTES CHORANDO AO REDOR DA EFÍGIE. 443

FIGURA 7.26: ENQUANTO OS CHEFES COORDENADORES DO RITUAL ENFEITAM A EFÍGIE, SEUS PARENTES CHORAM AO SEU REDOR 444

FIGURA 7.27: EFÍGIE FEMININA SENDO ADORNADA COM ENFEITES DE ALGODÃO. ...........................................44 444

FIGURA 7.28: EFÍGIES DE HOMENS, AS DUAS DO CENTRO SÃO OS HOMENAGEADOS PRINCIPAIS.......................... 445

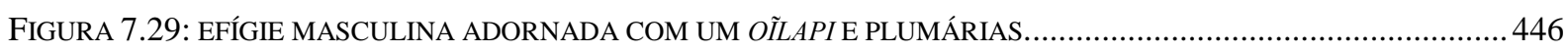

FIGURA 7.30: EFÍGIE FEMININA PRONTA, COM CINTOS, COLAR DE CONCHAS E PLUMÁRIA. ..................................448

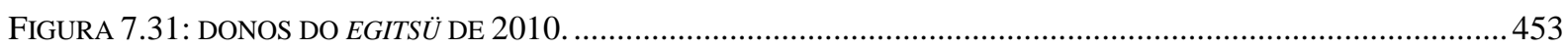

FIGURA 7.32: “FOGO DO MORTO” ACESO SOBRE UMA TAMPA DE ALUMÍNIO, PARA QUE NÃO SE APAGUE. ............456

FIGURA 7.33: LUTADORES SAINDO EM FILA DA CASA DO DONO DO EGITSÜ EM DIREÇÃO AO CENTRO. ...................463

FIGURA 7.34: LUTADORES DA ALDEIA CORRENDO EM CÍRCULO AO REDOR DOS DONOS DO EGITSÜ E DAS EFÍGIES.464

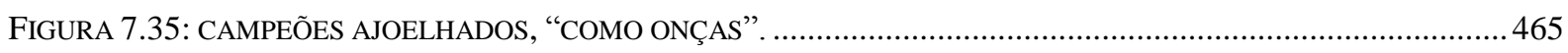

FIGURA 7.36: DONOS DO EGITSÜ ADIANTE DE SEUS CAMPEÕES, POSICIONADOS DE FRENTE PARA O GRUPO QUE SERÁ

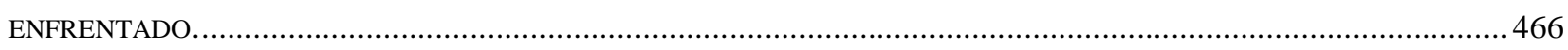

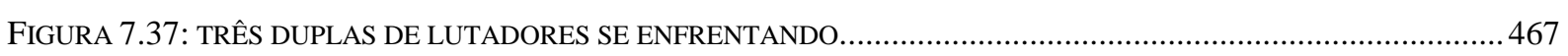

FIGURA 7.38: JOVEM SAINDO DA RECLUSÃO PUBERTÁRIA EM FRENTE AOS CHEFES ALIADOS. .............................469 


\section{LISTA DE SÍMBOLOS}

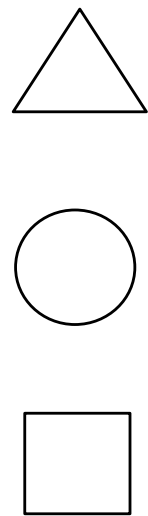

homem

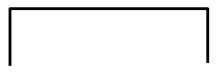

germanidade

mulher

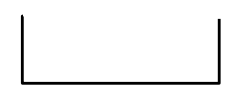

casamento ou irrelevante

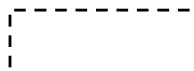

germanidade classificatória<smiles>CC1CC2(C)CC12</smiles>
indivíduo falecido filiação 


\section{CONVENÇÕES}

Esta tese utiliza a notação inglesa para a descrição de relações de parentesco, segundo a qual os marcadores dos kin types são formados pela primeira letra do termo de parentesco em inglês e devem ser lidos da esquerda para a direita. Assim, temos $\mathbf{F}=$ "father", $\mathbf{M}=$ "mother", $\mathbf{B}=$ "brother", $\mathbf{S}=$ "son", $\mathbf{D}=$ "daughter", $\mathbf{C h}=$ "children", $\mathbf{H}$ = "husband", $\mathbf{W}=$ "wife", BD = "brother's daughter", FFBS = "father's father's brother's son", e etc. A exceção é o marcador para "irmã" $(\mathbf{Z}=$ sister $)$, que tem sua letra alterada para evitar confusão com o marcador para "filho" (S); e e y significam "elder" e “younger", e são posicionados à esquerda do marcador. "X" é utilizado para se referir de forma simplificada à relação de "primo cruzado", sendo acompanhado do símbolo masculino $(\widehat{O})$ ou feminino $(+\circ)$ à sua esquerda, indicando o sexo. Os níveis geracionais têm como referência um Ego em geração zero $\left(\mathrm{G}^{\varnothing}\right)$. Cada geração é indicada pela letra $\mathbf{G}$ seguida do número da geração em sobre-texto (por exemplo, $\mathrm{G}^{+1}, \mathrm{G}^{+2}$ e etc. para gerações ascendentes, e $\mathrm{G}^{-1}, \mathrm{G}^{-2}$ e etc. para gerações descendentes). 


\section{GRAFIA E PRONÚNCIA}

Todos os termos e expressões em karib, ou outras línguas indígenas, vão em itálico, à exceção dos nomes próprios. As palavras em karib seguem a ortografia produzida pela linguista Bruna Franchetto, em parceira com professores indígenas dos povos karib do Alto Xingu (ver, por exemplo, Franchetto, 1997). Na segmentação e glosa de palavras, sigo os trabalhos de Santos (2007) e Mehinaku (2010). Contudo, não utilizo a terminologia técnica da linguística ao arriscar análises etimológicas e traduções, o que faço em linguagem leiga baseando-me em interpretações construídas em conjunto com colaboradores indígenas.

Indicações de pronúncia (a partir de Franchetto, 1995, e Santos, 2007):

\section{Consoantes:}

/p/: oclusiva bilabial surda (como $p$ em português)

/b/: oclusiva bilabial sonora (como $b$ em português), sempre pré-nasalizada

/d/: oclusiva alveolar sonora (como em data), sempre pré-nasalizada

/t/: oclusiva alveolar surda (como $t$ em português, não africada)

/j/: oclusiva palatal sonora (semelhante a $d j$ )

/k/: oclusiva velar surda (como $c$ em casa)

/g/: flap uvular

/s/: fricativa alveolar surda (como em saia)

/h/: fricativa glotal sonora (como em inglês hat)

/ts/: africada alveolar surda

/l/: lateral alveolar sonora (como $l$ em português)

$/ \mathrm{m} /$ : nasal bilabial (como $m$ em português)

/n/: nasal alveolar (como $n$ em português)

/nh/: nasal palatal sonora (como em minha) 
/ng/: nasal velar sonora

/w/: aproximante bilabial (como em inglês window)

\begin{tabular}{|l|l|l|l|l|l|l|}
\hline & Bilabial & Alveolar & Palatal & Velar & Faringal & Glotal \\
\hline Oclusiva & $\mathrm{p}\left[{ }^{\mathrm{m}} \mathrm{b}\right]$ & $\left.\mathrm{t}{ }^{\mathrm{n}} \mathrm{d}\right]$ & $\mathrm{j}$ & $\mathrm{k}$ & & \\
\hline Tepe/flap & & & & & $\mathrm{g}$ (flap uvular) & \\
\hline Fricativa & & $\mathrm{s}$ & & & & $\mathrm{h}$ \\
\hline Latricada & & $\mathrm{ts}\left[\mathrm{d}^{\mathrm{z}}\right]$ & & & & \\
\hline Nasal & $\mathrm{m}$ & $\mathrm{n}$ & $\mathrm{nh}$ & $\mathrm{ng}$ & & \\
\hline Aproximante & $\mathrm{w}$ & & & & & \\
\hline
\end{tabular}

\section{Vogais:}

/e/: anterior média (como em português; /ẽ/ quando nasalizada)

/i/: anterior alta (como em português; /î/ quando nasalizada)

/a/: central baixa (como em português)

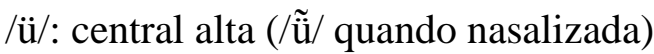

/o/: posterior média arredondada (como em português; /õ/ quando nasalizada)

/u/: posterior alta arredondada (/ũ/ quando nasalizada)

\begin{tabular}{|l|l|l|l|}
\hline & Anterior & Central & Posterior \\
\hline Alta & i & u & $\mathrm{u}$ \\
\hline Média & $\mathrm{e}$ & & $\mathrm{o}$ \\
\hline Baixa & & $\mathrm{a}$ & \\
\hline
\end{tabular}




\begin{tabular}{|c|c|c|c|}
\hline 1 & primeira pessoa & GNR & nominalizador genérico \\
\hline 12 & $\begin{array}{l}\text { primeira pessoa dual } \\
\text { inclusiva }\end{array}$ & INSTNR & nominalizador instrumental \\
\hline 13 & $\begin{array}{l}\text { primeira pessoa plural } \\
\text { exclusiva }\end{array}$ & LOC & locativo \\
\hline 2 & segunda pessoa & $\mathrm{ME}$ & marcador epistêmico \\
\hline 3 & terceira pessoa & MO & marcador de objeto \\
\hline $1 \mathrm{D}$ & dêitico $1^{\mathrm{a}}$ pessoa & NEG & negação \\
\hline $2 \mathrm{D}$ & dêitico $2^{\mathrm{a}}$ pessoa & NMLZ & nominalizador \\
\hline $3 \mathrm{D}$ & dêitico $3^{\mathrm{a}}$ pessoa & PERF & perfectivo \\
\hline ADV & advérbio & PL & plural \\
\hline AENR & $\begin{array}{l}\text { nominalizador de argumento } \\
\text { externo }\end{array}$ & PNCT & aspecto pontual \\
\hline $\mathrm{AF}$ & partícula constativa & PTP & particípio \\
\hline AINR & $\begin{array}{l}\text { nominalizador de argumento } \\
\text { interno }\end{array}$ & PURP & propósito \\
\hline AN & anafórico & REL & relacionador \\
\hline AND & dêitico anafórico & RFL & reflexivo \\
\hline CMPL & completivo & SUBS & substancializador \\
\hline $\mathrm{COM}$ & comitativo & TEMP & subordinação temporal \\
\hline CONT & aspecto continuativo & TR & transitivizador \\
\hline COP & cópula & VBLZ & verbalizador \\
\hline $\mathrm{D}$ & dêitico & QU & palavra interrogativa \\
\hline DDIST & $\begin{array}{l}\text { dêitico de distância (do } \\
\text { falante) }\end{array}$ & & \\
\hline DES & desiderativo & & \\
\hline DTR & detransitivizador & & \\
\hline ERG & ergativo & & \\
\hline EX & passado nominal & & \\
\hline FUT & futuro & & \\
\hline
\end{tabular}




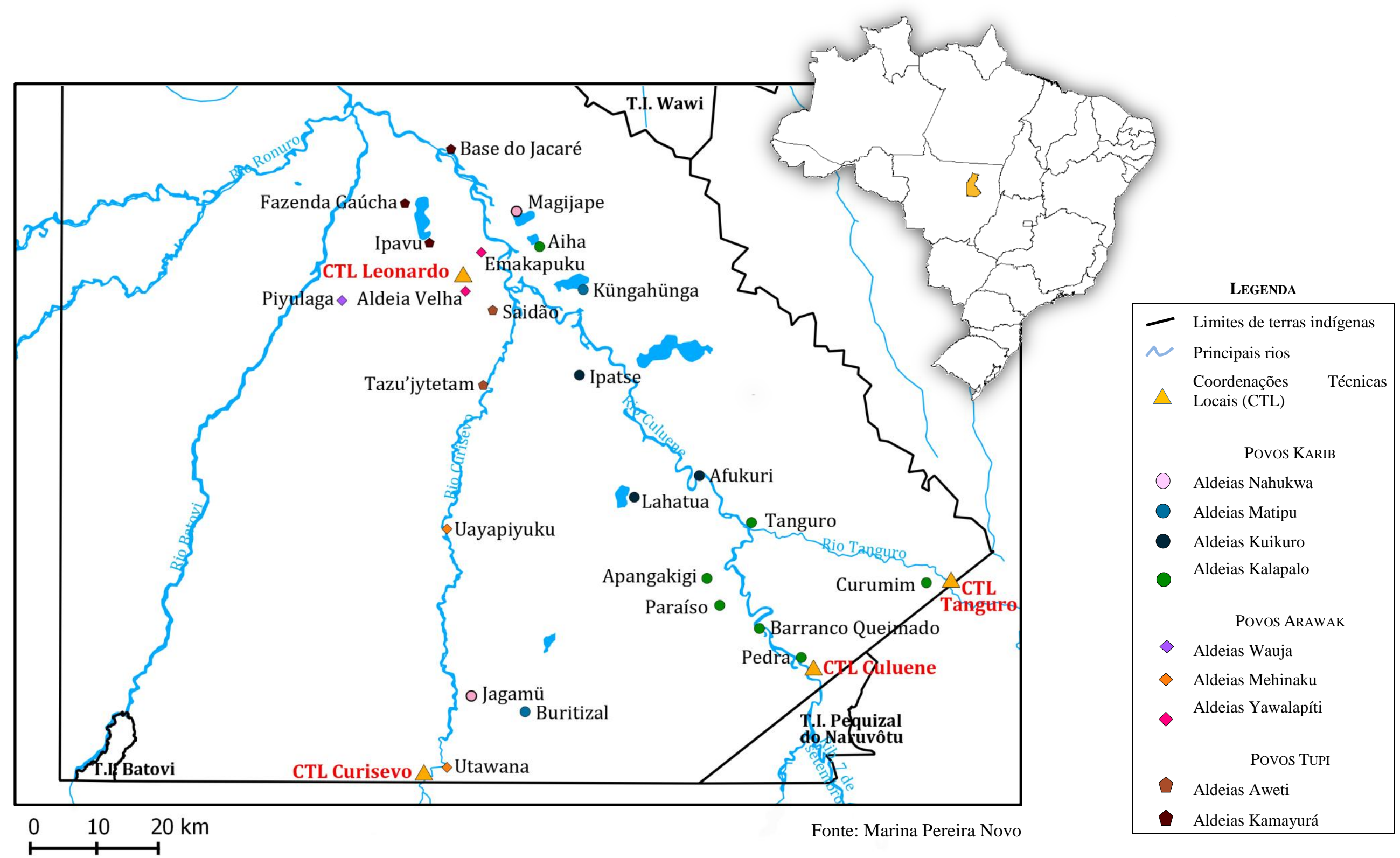




\section{Introdução}

"Essa noite eu não dormi direito. Sonhei que estava em um barco com meu primo, o cacique de Tanguro, quando uma sucuri muito grande pulou da água e tentou me derrubar. Ela não me acertou, e começou a tentar virar o barco. Fiquei com muito medo, e disse ao meu primo: - Vamos parar ali! Deixamos o barco na beira de um barranco e descemos, mas logo em seguida uma onça começou a nos perseguir! Agora eu estou muito preocupado. Você sabe o que é isso? Tem algum feiticeiro tentando nos matar”. Waja, chefe principal da aldeia Aiha, me contou este sonho enquanto tomávamos café após uma noite difícil, na qual sua irmã mais nova, com câncer em estado terminal, havia passado muito mal. Era um período delicado para toda sua família: seu primo paralelo, seu cunhado (marido de sua irmã doente) e seu neto classificatório (neto de sua irmã mais velha) haviam morrido há menos de um ano. Faziam apenas poucos dias, dois xamãs haviam descoberto que a doença de sua irmã fora provocada por flechas de feiticeiros (o tipo mais letal de feitiço) e que não haveria cura. Ele, assim como toda sua família, estava desamparado e assustado - talvez tentando figurar quem seria a próxima vítima.

Em várias conversas, Waja me disse sentir medo por ser anetü ${ }^{1}$ (chefe) - os feiticeiros teriam um prazer especial em atacar pessoas como ele, por inveja de seu "tamanho" (seu reconhecimento) e da "fama" de seu nome. Wanakagü, um dos filhos do chefe Ageu (irmão mais velho de Waja), uma vez me disse: "Eu não quero ser chefe como meu pai, é muito difícil. Dá muito trabalho, e eu tenho medo”. Na mitologia, há algumas narrativas envolvendo chefes que chegam a ser um tanto quanto macabras. Agautanga ${ }^{2}$, um humano que viajara ao outro lado do céu acompanhado da alma de seu melhor amigo falecido, se assustou ao visitar a casa de Ogo, a constelação-pessoa que aparece na última fase da estação chuvosa ${ }^{3}$. No teto de sua casa havia incontáveis cabeças de chefes humanos penduradas por fios de fibra de

\footnotetext{
${ }^{1}$ Palavra nominal formada a partir da raiz ane ("chefe", ou "chefia"), acrescida do nominalizador -tü. O termo anetü pode ser pensado como uma forma substancializada, concreta, da ideia de chefia (uma "forma-chefe"). A raiz ane também pode ser usada para produzir formas transitivas e intransitivas do verbo "chefiar".

${ }^{2} \mathrm{Ou}$ Agahütanga, conforme o narrador.

${ }^{3}$ Ogo significa "jirau", e foi construído pelos genros do Gavião, chefe dos pássaros, a seu pedido. Basso (1987b: 360) a identifica à constelação "Quadrado de Pégaso", formada pelas estrelas Alpha Pegasi (Markab), Beta Pegasi (Beta-Scheat), Gamma Pegasi (Gama-Algenil) e Alpha Andromedae (Alpheratz). Apesar de ser claramente um quadrado, quando o desenharam no chão a meu pedido, alguns Kalapalo o fizeram no formato de duas semi-elipses com as faces abertas voltadas para fora: ) (, forma que, como veremos no capítulo 4, está ligada à antropomorfia e à chefia.
} 
buriti, roídos o tempo todo por gafanhotos. Quando um desses fios se rompe, uma cabeça de chefe corta o céu como uma grande bola de fogo, até cair em alguma lagoa. O barulho de sua queda pode ser ouvido em todo o Alto Xingu como um estrondo grave, e assim que toca a água a cabeça é avidamente devorada por um itseke ("espírito"). $\mathrm{O}$ céu enrubescido pelo fogo não deixa dúvidas: é um sinal de que em breve um chefe morrerá. Outro mito conta a história de um chefe que, antes de sair de madrugada para uma pescaria, teve um sonho: algo corria ao seu redor ateando fogo por onde passava, e o deixou preso no centro de um círculo de chamas. Foi então que o estranho objeto veio rolando pelo chão, se aproximou dele e parou a seus pés: era sua própria cabeça, decapitada. O homem foi pescar, preocupado, e passou o dia todo fora; à noite, enquanto o esperava sentada em sua rede, sua mulher levou um grande susto: a cabeça de seu marido entrara rolando pela porta, parando a seus pés.

Chefes e feiticeiros são dois modelos antagônicos de pessoa. Os primeiros são idealmente generosos, belos e sabem falar bem em público; os segundo não passam de pessoas egoístas, feias e mentirosas, que gostam de espalhar rumores. Eles também se opõem por sua relação com a morte: feiticeiros são as únicas pessoas capazes de provocar a morte de alguém sem violência física direta, e costumam viver muito tempo porque outros feiticeiros têm medo de suas retaliações; chefes, ao contrário, morrem cedo, de tão invejados pelos “artífices da morte" (Barcelos Neto, 2006: 11) que são os mestres do feitiço. Mas a morte de chefes não ocupa um lugar central apenas na mente dos chefes e na mitologia, e desempenha um papel central na capacidade que o complexo alto-xinguano tem de se reproduzir e se expandir. Refiro-me ao egitsü, ou, como ficou amplamente conhecido, Quarup ${ }^{5}-$ o ciclo ritual desencadeado após a morte de chefes ou "pessoas importantes" (parentes de chefes, grandes lutadores e, em casos excepcionais, grandes cantores).

Iniciar um egitsü é sempre uma sugestão de outros chefes (parentes distantes o suficiente do morto para não ficarem de luto), que pode ou não ser aceita pela família do chefe falecido. Em caso positivo, um parente masculino próximo se torna "dono" (patrocinador) da festa ${ }^{6}$, e um complexo ciclo tem início com um sepultamento especial, culminando com a produção, exibição e descarte de (pelo menos) uma efígie de madeira

\footnotetext{
${ }^{4}$ Seres eternos, que existem desde muito antes dos humanos, dotados de grandes capacidades de transformação e agência.

${ }^{5}$ Nesta tese utilizo o termo Quarup apenas quando me referir a versões deste ritual entre outros povos que não os Kalapalo, ou à interface do ritual com o mundo não indígena.

${ }^{6}$ Uso "festa" com o mesmo sentido de "ritual", pois os Kalapalo se referem a estes eventos como ailene, "festejo" (da raiz aili, "alegria").
} 
(tita). Este momento é o clímax do ritual, quando as aldeias convidadas chegam e ocorrem os confrontos esportivos de ikindene (a luta alto-xinguana, conhecida como huka-huka). Também é nesta etapa que se privilegia a recepção de convidados kagaiha ${ }^{7}$ (brancos), e quando os Kalapalo são assediados, dada a grandiosidade do evento, por uma infinidade de produtoras, emissoras de TV, fotógrafos, artistas plásticos, comerciantes de artesanato indígena e aposentados excêntricos (uma grande oportunidade para negociar parcerias e recursos).

Os Kalapalo (bem como seus vizinhos), quando descrevem este ritual usando o português, dizem tratar-se de uma "homenagem", cujos únicos objetivos explícitos são "lembrar-se do morto" e cortar definitivamente os laços entre sua alma e seus parentes vivos, permitindo que estes deixem o luto. Mas que conjunto de ideias os Kalapalo tentam traduzir com o conceito importado de "homenagem"? Ou, fazendo uma pergunta um pouco diferente, por que, para os Kalapalo, é tão importante "lembrar-se" dos chefes produzindo efígies para eles e confrontando seus vizinhos? O objetivo desta tese é responder a tais questões a partir de uma etnografia do egitsü, no intuito de esclarecer o sentido da chefia e seu ritual mortuário na produção da socialidade kalapalo.

\section{i. Um mundo em festa}

O Alto Xingu é um complexo sociocultural multiétnico e multilíngue localizado na porção sul do Parque Indígena do Xingu (doravante, PIX), no nordeste do estado do Mato Grosso (periferia da Amazônia meridional). Dele participam dez povos pertencentes a três dos principais agrupamentos linguísticos sul-americanos, além de falantes de uma língua considerada isolada. São eles os Mehinaku, Wauja e Yawalapíti (falantes de línguas arawak); os Kalapalo, Nahukua, Kuikuro e Matipu (falantes de karib); Kamayurá e Aweti (tupi ${ }^{8}$ ); e os Trumai $^{9}$ (língua isolada). Desde os primeiros registros sobre a região, tem-se observado que

\footnotetext{
7 "Não índio" em karib alto-xinguano.

${ }^{8}$ O Kamayurá é uma língua pertencente à família tupi-guarani, enquanto o Aweti, de classificação mais complexa, é situado no tronco tupi sem ser definitivamente associado a nenhuma família específica. Há indícios de que esta seja uma língua aparentada ao mesmo tempo à família tupi-guarani e à língua Sateré-Mawe, que pertenceriam a um agrupamento maior chamado "Maweti-Guarani” (Drude, 2009; 2011: 157-158).

${ }^{9}$ Os Trumai foram os últimos a entrar no Alto Xingu, e têm uma participação "marginal" no sistema (não são mais convidados para os rituais regionais e perderam sua especialidade produtiva, os machados de pedra). Segundo os Kalapalo, eles sequer são gente alto-xinguana (kuge). Entretanto, optei por "passar por cima" do
} 
estes grupos são culturalmente bastante homogêneos, partilhando uma séries de características como a planta circular das aldeias, a cultura material, a estética corporal, conjuntos inteiros de mitos e rituais, a estrutura das terminologias de parentesco, e etc. Além disso, estes povos são intensamente articulados por meio de casamentos interétnicos, comércio ${ }^{10}$ e grandes rituais regionais, motivos pelos quais a região já foi qualificada de "área cultural” (Galvão, 1979 [1953]), "sociedade" (Basso, 1973: 9; Becker, 1969), "sistema regional” (Menget, 1977; 1993) ou "comunidade moral" (Heckenberger, 2001a: 91).

As pesquisas arqueológicas sugerem que seus primeiros habitantes eram povos ceramistas falantes de arawak, que ali se estabeleceram entre os séculos VIII e IX (Heckenberger, 1996; 2005). Os povos desta família linguística, bem como aqueles influenciados por ela, apresentam diversos traços recorrentes, como a existência de hierarquias sociais, espaços político-rituais bem definidos, sedentarismo e a participação em sistemas regionais multiétnicos e multilíngues (Heckenberger, 2002; Hill e Santos-Granero, 2002; Schmidt, 1917). A análise da história xinguana na longa duração mostra que os povos que chegaram posteriormente, como os karib, no século XVII, e os tupi, no século XVIII, foram integrados ao sistema regional então vigente entre os arawak (cujo apogeu se deu entre os séculos XIII e XVII), que parecem ter fornecido a matriz cultural a partir da qual se desenvolveu o sistema xinguano. Porém, como observa Franchetto,

Não é fácil, contudo, definir quão assimétrico ou simétrico foi o processo que resultou em identidades construídas a partir de uma rede de diferenças. Se há evidências consistentes de uma proeminência e de uma precedência arawak, é não menos claro que o pluralismo cultural e linguístico enriqueceu o sistema como um todo. (Franchetto, 2011b: 7)

ponto de vista kalapalo e incluí-los na lista porque os Trumai são parte importante da história do Alto Xingu, tendo sido os responsáveis pela introdução do jogo de dardos (hagaka, em kalapalo, mais conhecido como jawari) e, possivelmente, do ndühe (ou tawarawanã, que os Kalapalo, todavia, dizem ter sido sua própria contribuição - opinião compartilhada pelos Yawalapíti, segundo comunicação pessoal de João Carlos Almeida). Além disso, eles são um caso interessante para se pensar possíveis pontes entre o Alto Xingu e o Brasil Central, principalmente em direção aos Karajá e Javaé (Menget, 1993: 72; Monod-Becquelin e Guirardello, 2001; Rodrigues, 2008: 208-209; Villas Boas e Villas Boas, 1970: 28).

${ }^{10}$ Há um tipo de sistema de especialização produtiva, no qual alguns grupos são responsáveis pela confecção de objetos exclusivos, como os cintos e colares de conchas dos kalapalo, a cerâmica wauja, os arcos kamayurá e os antigos machados de pedra trumai. 
Os grupos que participam deste complexo regional reconhecem-se mutuamente como "gente" (kuge, em kalapalo), e partilham um ethos "pacífico e generoso" (o famoso ifutisu" de que fala Basso ${ }^{12}$ ) em oposição aos índios não xinguanos (ngikogo), considerados "ferozes" (tükotinhü). A evitação da guerra, sobretudo entre os povos da "comunidade moral" altoxinguana, é considerada por eles próprios como um de seus principais distintivos. Mas que os alto-xinguanos evitem a guerra não quer dizer que eles não a tenham praticado no passado, entre si e com outros, nem que não haja violência nos dias atuais. Há, por exemplo, pelo menos dois grupos de ancestrais dos Kalapalo vistos como exímios guerreiros, um dos quais praticava o canibalismo (os temidos Hukuingi). Menget (1978: 2; 1985: 133-134) faz a interessante observação de que, apesar de reprovarem a guerra, os alto-xinguanos frequentemente levavam vantagem nos confrontos que travavam (o que se confirma por narrativas kalapalo e nahukwa que pude registrar). Há ainda a questão da feitiçaria, que só ocorre nos limites da sociedade xinguana (Coelho de Souza, 2001c: 388; Figueiredo, 2010: 13), e eventualmente desencadeia assassinatos por vingança (cada vez com menos frequência, por motivos diversos). A principal diferença em relação a outras formas ameríndias de guerra é que no Alto Xingu o homicídio não só é improdutivo (não traz sonhos, cantos, nomes, posições) como tem um valor muito negativo (os Kalapalo consideram o fim das guerras uma grande melhora, e, apesar da figura do guerreiro ser vista com admiração, não nutrem qualquer saudosismo pelos tempos nos quais ela era necessária).

Dos "três grandes sistemas de trocas" que articulam este complexo regional (casamentos, comércio e rituais), o sistema cerimonial pode ser visto como o principal distintivo de "xinguanidade", uma espécie de "língua franca" (Menezes Bastos, 1978: 31). Pois enquanto a prática do casamento e do comércio com grupos considerados "não xinguanos" (Kĩsêdjê, Kaiabi, Ikpeng) é relativamente recorrente, apenas a participação plena no sistema ritual torna um grupo verdadeiramente xinguano, ou simplesmente "gente". Os Aweti, por exemplo, narram o processo pelo qual "viraram gente" como o abandono da guerra em prol da adoção do pacifismo ritual, e marcam sua completude no momento em que realizaram seu primeiro Quarup, para o qual convidaram os Kuikuro (Coelho de Souza, 2001c; Figueiredo, 2010: 36).

\footnotetext{
${ }^{11}$ Ihütisu, segundo a grafia atual. Os Kalapalo traduzem o termo como "vergonha".

${ }^{12}$ Becker, 1969; Basso, 1973.
} 
Os rituais alto-xinguanos podem ser divididos em duas grandes categorias, as "festas para espíritos" e as "festas para pessoas importantes" (Fausto, 2007: 30). As primeiras tendem a se restringir ao grupo local ${ }^{13}$, estão ligadas a processos de adoecimento e cura, ao xamanismo, e variam consideravelmente de grupo a grupo (ver Barcelos Neto, 2008 para uma discussão detalhada). Já as festas para pessoas importantes são essencialmente regionais, exigem no mínimo a participação de três grupos ${ }^{14}$ e gravitam em torno do ciclo de vida dos nobres $^{15}$ : furação das orelhas de filhos de chefes (antes do jovem entrar na reclusão pubertária) e morte de nobres.

Estes eventos são os focos das relações pacíficas formalizadas entre os alto-xinguanos, e operam como momentos importantes de produção de pessoas: é só quando um nobre tem suas orelhas furadas que outros meninos também podem passar pelo mesmo processo; somente na ocasião do ritual mortuário de um nobre outros mortos podem ser "homenageados"; é nestes eventos que jovens de ambos os sexos saem da reclusão pubertária e se realizam casamentos; é nos rituais regionais que nomes se tornam "belos" (ou famosos, tuhutinhü) e parte importante da memória genealógica é produzida e articulada a uma história coletiva. O ciclo de vida de qualquer mulher ou homem alto-xinguano é indissociável do ciclo de vida dos nobres, que criam, nos rituais regionais, as condições para que os processos de fabricação de pessoas, tão centrais para os xinguanos e outros ameríndios (Seeger, DaMatta et al., 1979; Viveiros de Castro, 1979), se completem e recomecem - sempre com a participação de estrangeiros.

Nesse sentido, o mundo kalapalo e alto-xinguano é "um mundo em festa", ou, como diz Fausto (2004a), o tempo dos humanos é "o tempo do ritual". No centro disso estão os chefes, figuras que sempre chamaram a atenção dos observadores, dada sua saliência social e simbólica, receberam certa atenção nas etnografias, mas ainda assim permanecem um tanto quanto misteriosas, sobretudo quando comparadas a outras formas ameríndias de chefia e liderança. Em consonância com o que já foi documentado entre seus vizinhos, os Kalapalo dizem que os rituais regionais patrocinados por (e para) seus chefes estão no lugar das

\footnotetext{
${ }^{13}$ Algumas, às vezes, podem ter fases inter-aldeias (como kagutu, a festa das flautas proibidas aos olhos das mulheres, e jamugikumalu, o ritual feminino).

${ }^{14}$ Pelo menos dois povos aliados que confrontam, como um único grupo, um povo convidado para participar como adversário (que também pode comparecer aliado a algum outro).

${ }^{15}$ Utilizo o termo "nobre" (conforme Barcelos Neto, 2003; 2008) para me referir aos chefes e seus parentes em geral, pois mesmo aqueles que não possuem os títulos de anetü ou itankgo (feminino de anetü) também são considerados pessoas diferenciadas pelos Kalapalo (anetü ungugu, "sangue de chefe", ou anetü unkgugu, "descendente de chefe" - tratarei disso no capítulo 2).
} 
guerras ${ }^{16}$ (Gregor, 1990: 113; Viveiros de Castro, 1977: 218). Mas a imagem que os altoxinguanos fazem dos rituais como substitutos da guerra coloca um problema que nem sempre é tratado como tal pelos pesquisadores: "estar no lugar da guerra" é a mesma coisa que "ser o contrário da guerra"? Quando a resposta a essa questão é positiva, tende-se a interpretar os alto-xinguanos (bem como outros povos de matriz cultural arawak) como estando em descontinuidade frente a outras sociocosmologias da América do Sul indígena (Heckenberger, 2002: 115; Hill e Santos-Granero, 2002: 18), enquanto me parece (e este é um dos argumentos desta tese) que os rituais de chefia obviam ${ }^{17}$ a função guerreira, ao mesmo tempo que são uma transformação da mesma. O egitsü, dentre outros rituais da nobreza, não está no lugar da guerra porque a julga dispensável, mas porque a realiza de outra maneira. $\mathrm{O}$ pensamento alto-xinguano parece ter elaborado o clássico argumento de Clausewitz ${ }^{18}$ (1989 [1832]) às avessas: aqui, a política é que é a continuação da guerra por outros meios.

\section{ii. O egitsï}

Egitsü é como os Kalapalo (assim como os demais karib xinguanos) chamam o ritual que ficou mais conhecido como Quarup (uma adaptação do nome que os Kamayurá dão à madeira utilizada na produção das efígies dos mortos, $k w a r y p^{19}$ ). A relação deste ritual com os alto-xinguanos, com a antropologia e com o imaginário nacional tem algumas peculiaridades dignas de atenção. Ele é considerado pelos Kalapalo sua festa mais importante. Eles não hesitam em explicitar que seu estilo de vida, baseado no regionalismo pacífico, nas trocas e no esporte, não só atinge sua expressão máxima no egitsü como depende dele: se um dia deixarem de praticá-lo, é porque terão se transformado em "índios bravos" (ngikogo) ou

\footnotetext{
${ }^{16}$ Na clássica fala de um homem mehinaku registrada por Gregor (1990: 113): "We don’t make war; we have festivals for the chiefs to which all of the villages come. We sing, dance, trade, and wrestle".

${ }^{17}$ De acordo com Wagner (1978: 31), a obviação pode ser descrita como "the process by wich the artificial comes to metaphorize the innate (and the reverse process)". Ou, segundo o uso que faz James Weiner (1988: 143), "obviation concerns the relationship between literal (semantic) and metaphorical usage" e pode ser definida "as the mutual creation of the conventional (or collectivizing) and nonconventional (or differentiating) cultural realms (...)". Weiner utiliza esta definição de obviação para discutir a mútua construção da consanguinidade e da afinidade como análogos um do outro (ibid: 145). No caso da chefia kalapalo, me parece que o conceito pode ser aplicado porque a chefia e seus rituais são metáforas da guerra, entendida aqui, como em outras cosmologias ameríndias, como algo da ordem do "dado" (Viveiros de Castro, 2002a).

18 "War is only a continuation of state policy by other means".

19 "Tronco ou árvore do Sol" (Emmerich, Emmerich et al., 1987: 389), ou "alegria do Sol" (Mehinaku, 2010: 144).
} 
brancos. Mas a tendência tem sido justamente outra, pois o Quarup passou, e ainda passa, por um processo de "inflação" em vários sentidos.

Desde a intensificação do contato com a sociedade nacional, na década de 1940, os grandes rituais regionais se tornaram um importante elemento da socialidade entre índios e brancos. Os irmãos Villas Boas, líderes da Expedição Roncador-Xingu, rapidamente perceberam como as relações pacíficas entre os alto-xinguanos estavam ligadas à participação nos rituais, e começaram a incentivar sua expansão e mesmo sua eventual realização em um espaço imaginado pelos brancos como "neutro" (o Posto Leonardo ${ }^{20}$ ), no intuito de consolidar o regime de paz que viabilizaria a criação do PIX (Menezes Bastos, 1992). Neste contexto, o ritual mortuário dos nobres foi tomando novas proporções, que talvez nunca tenha tido antes do contato $^{21}$. Quando as aldeias eram ainda mais distantes, a pax xinguana não garantia viagens livres de ataques de inimigos, o deslocamento era longo e penoso e, segundo contam os Kalapalo, um egitsü dificilmente reunia mais do que duas ou três aldeias convidadas. Harry B. Wright, quando acompanhou uma viagem da Expedição Roncador-Xingu em agosto de 1948, registrou em vídeo um Quarup, em uma aldeia não identificada, que mostra bem como suas proporções eram muito menores ${ }^{22}$ (Wright, 1948).

Com a aproximação das aldeias e a criação do PIX nos anos 1960, a proporção do Quarup aumentou, e convidar todas as aldeias alto-xinguanas se tornou indispensável (deixar de fazer um convite é considerado bastante ofensivo). Além disso, a introdução de armas de fogo, novos instrumentos de pesca, tesouras, facas, agulhas e algodão industrializado permitiram que as pessoas pudessem dispor de uma quantidade de enfeites como nunca antes, o que do ponto de vista dos Kalapalo foi uma mudança positiva. Eles explicitam isso quando veem fotos das décadas de 1940/1950, lamentando por seus avós que, “coitados" (jatsiko),

\footnotetext{
${ }^{20}$ Antigo polo administrativo desta região do PIX (atual “Coordenação Técnica Local Leonardo Villas Boas") e centro de atendimento à saúde indígena. Como o Posto não pertence a nenhum grupo, os brancos o imaginam como um lugar politicamente neutro. Contudo, seu espaço foi sendo paulatinamente controlado por pessoas e grupos específicos, em função de suas relações de proximidade geográfica e política com o Posto e os irmãos Villas Boas (ver, por exemplo, Viveiros de Castro, 1977 para uma descrição da relação dos Yawalapíti com o Posto Leonardo). Hoje este é um espaço considerado extremamente perigoso pelos índios, um lugar cheio de feitiços (Novo, 2009; 2010), e que, como tudo no Alto Xingu, também tem seus "donos", com os quais é preciso lidar.

${ }^{21}$ A menos que ele já fosse realizado no "período galáctico" da ocupação do Alto Xingu, entre 1250 - 1650 d.C (Heckenberger, 2005: 71; 124-133), quando várias aldeias gravitavam em torno de aldeias maiores e ritualmente mais importantes (ou mesmo de lugares sagrados/centros rituais não habitados, como parece ter sido o caso do sítio kuikuro Heulugihütü - ibid: 90-93).

${ }^{22} \mathrm{~A}$ aldeia onde foi feita a filmagem era muito pequena, as lutas registradas se realizavam em um pátio restrito e com poucas pessoas ao redor. Não aparecem efígies nas imagens, mas é bem provável que se tratasse de fato de um Quarup, pois a época da filmagem (7 de agosto) não é época nem de Jawari (festa de arremesso de dardos), nem de Moitará (festa de trocas).
} 
possuíam poucos objetos. Os mais velhos, contudo, reconhecem que com isso muitos enfeites antes exclusivos de chefes ou grandes campeões de luta, como adornos de couro de sucuri (Eunectes murinus), penas de xexéu (Molothrus bonariensis) ou grandes cintos de algodão, agora são usados indiscriminadamente e perderam seu valor como "objetos de distinção", pois qualquer um consegue facilmente obtê-los ou fabricar cópias com materiais alternativos.

O Quarup também sofreu uma inflação pela presença de não índios, pois se tornou uma grande ocasião para receber jornalistas, políticos, fotógrafos, pesquisadores e personalidades variadas, que desde o final da década de 1940 já haviam passado a divulgar uma imagem da região intimamente ligada aos povos do Alto Xingu, cuja refinada estética ritual e pacifismo se tornaram uma vitrine para o novo modelo de indigenismo do Brasil (Ramos, 2000: 282). Por "indigenismo" me refiro ao mesmo tempo às políticas estatais para lidar com as questões indígenas, em vias de transformação (passando de um modelo "assimilativo" para outro "preservacionista"), e às práticas discursivas voltadas para a construção de imagens e ideias a respeito da alteridade (Ramos, 2001). O Alto Xingu passou a compor o imaginário nacional como uma espécie de "paraíso indígena", habitado por índios dedicados a manter seus corpos belos e fortes, e empenhados em promover a paz por meio de reuniões musicais e esportivas. A antiga imagem do "índio selvagem", nu, guerreiro e canibal, deu lugar à imagem do índio xinguano, de corpo ostensivamente adornado, de comportamento polido e que ultrapassara o "estado de guerra" para viver as benesses de uma civilização fundada na paz. O ritual mortuário dos nobres encontrou uma inserção especial neste imaginário, já que reúne os principais elementos da sociedade xinguana tanto do ponto de vista dos índios quanto dos brancos. Ao converter-se na apoteose da xinguanidade e do momento político que marcou a criação do PIX, o que era para cada povo egitsü, kaumai ou torïp foi se tornando, pouco a pouco, Quarup: uma dobradiça entre a política dos brancos e a política (ritual) alto-xinguana.

A primeira reportagem sobre o Quarup, que também é uma de suas primeiras descrições (talvez a primeira razoavelmente detalhada), é a de Jorge Ferreira, repórter da revista $O$ Cruzeiro, que publicou uma matéria especial sobre o ritual em 1957 (Ferreira, 1957). A revista dedicou a capa e 14 páginas ao Quarup, descrito como uma "festa bárbara e bela" (ibid: 58) presidida por "verdadeiro espírito olímpico" (ibid: 60). A reportagem também relata a ocupação das terras da região por colonos, em relações nada amistosas com os índios, e faz um apelo favorável à aprovação do projeto de criação do Parque. Em 1967, Antonio 
Callado lança seu romance Quarup (Callado, 1967), que narra a história de um padre que alimenta a utopia de criar, no coração do Brasil (o Xingu), uma espécie de "nova terra prometida". Em 1987, a extinta TV Manchete estreou uma série intitulada Kuarup, produzida por Washington Novaes, retratando a preparação e realização de uma festa em memória ao falecido chefe wauja Malakuyawá. Em 1989, o livro de Callado foi transformado em um filme homônimo dirigido por Ruy Guerra.

O Quarup se tornou um ritual tão divulgado e associado à imagem do "bom selvagem", representativo de um modo de vida invejável, que seu nome passou a ser usado com finalidades diversas, que se revelam em uma rápida pesquisa na internet. Já encontrei variantes de "Quarup" servindo de nome a diversos tipos de estabelecimentos, organizações e produtos, como casas de shows, um famoso selo de discos, um resort e uma dezena de escolas. Quando usado por empresas, não são poucas as que fazem questão de disponibilizar em suas páginas na internet pequenas explicações sobre o ritual e sua interpretação como uma "homenagem aos mortos", uma "celebração da vida" e etc.

O valor do Quarup para o imaginário nacional foi atestado quando o Iphan, após a criação do Programa Nacional do Patrimônio Imaterial (em 2000), pretendia prestar uma homenagem à "cultura indígena" fazendo do Quarup o primeiro bem cultural registrado no Brasil (Abreu, 2007). Em 2001, foi encomendado um dossiê sobre o ritual (Coelho de Souza, 2001b), mas os alto-xinguanos não entraram em acordo acerca de seu possível interesse em transformar o Quarup em patrimônio imaterial brasileiro. Segundo me disse uma liderança kalapalo que se lembra da discussão, à época ele entendeu que, caso fosse transformado em patrimônio, o Quarup passaria a ser "do Brasil", o que lhe parecia absurdo: como ele me disse, o Quarup era só deles, e não “do Brasil”.

É motivo de espanto que, diante da centralidade do Quarup tanto para o Alto Xingu quanto para a sociedade brasileira, este ritual tenha recebido relativamente pouca atenção por parte da antropologia. Até hoje o estudo mais detalhado sobre o tema é o de Pedro Agostinho (1974), que, apesar de ser um clássico da etnografia da área, se ocupa pouco com a análise do ritual. Dentre as pesquisas consolidadas sobre a região há, claro, exceções, como os trabalhos de Franchetto $(1986 ; 1993 ; 2000)$ sobre os discursos rituais do egitsü, e as breves discussões de Basso (Basso, 1973: 140-147; Becker, 1969: 320-333) e Viveiros de Castro (2002b: 73-75) sobre esse ritual. Mas, no geral, a produção sobre o Quarup (que se limita a trechos de teses ou artigos), aceita e reproduz com exagerada facilidade os argumentos de que se trata de uma 
"celebração da vida", da "rememoração da criação", da "redução das hostilidades pela luta" e etc. Não que o ritual não seja isso também, mas tais interpretações não deveriam ser um ponto de chegada, e sim objeto de questionamento. Afinal, por que se faz Quarup, e por que ele assume esta e não outra forma?

A primeira abordagem direta deste ritual, e também a mais extensa e detalhada, é a de Agostinho (1974). O autor realizou sua pesquisa junto aos Kamayurá nos períodos de julho e setembro de 1965, setembro e outubro de 1966 e de agosto a outubro de 1969. Agostinho não pôde acompanhar todo o ciclo do ritual, baseando boa parte de seu trabalho em relatos de informantes, mas sua descrição é bastante rica e, além de abranger todas as etapas do ciclo, toca em boa parte dos detalhes relativos ao ritual $^{23}$. Seu livro foi uma importante referência para minha pesquisa de campo, que usei como uma espécie de "check list", e quando o reli enquanto escrevia esta introdução, não só reencontrei detalhes que haviam ficado perdidos em minha memória, como me deparei com questões que ainda sinto não ter conseguido investigar com a devida profundidade.

A obra de Agostinho é repleta de insights valiosos, e dois deles, em especial, podem adquirir um sentido mais complexo se colocados ao lado de discussões mais recentes sobre a socialidade ameríndia. São elas as ideias de que a morte de um chefe põe um problema para a perpetuação do grupo local enquanto unidade distinta no sistema regional (ibid: 154), e de que a unidade da humanidade xinguana precisa ser "cindida" pela luta (ibid: 155). Estas não são respostas aos problemas postos pelo ritual, mas pontos de partida para que se possa perguntar por que a morte de um chefe põe problemas ao grupo, quais problemas são estes e como a produção de efígies e os confrontos esportivos se propõem a lidar com eles. Talvez por seu excesso de detalhes a etnografia de Agostinho tenha intimidado outros pesquisadores a retomar o tema (afinal, parecia já estar tudo ali - pelo menos foi a sensação que eu tive quando a li pela primeira vez). Parte importante das discussões sobre o Quarup que se seguiram tem certa dificuldade para questionar os fundamentos do ritual e escapar de explicações mais ou menos funcionalistas. A ideia de que o Quarup é uma "homenagem" e que ele "celebra" ao mesmo tempo a unidade e a diversidade xinguana é recorrente tanto na literatura mais antiga quanto em trabalhos mais recentes, que por alguma razão não se perguntaram o que "homenagem" poderia significar para os xinguanos.

\footnotetext{
${ }^{23}$ Carneiro (1993: 408) chega a afirmar que a etnografia de Agostinho seria "definitiva".
} 
Basso (Becker, 1969) caracteriza o egitsü em sua tese como uma "ceremony commemorating dead chiefs" (ibid: 320), cuja principal função seria marcar "the release of the kinsmen from mourning the dead, of the widow or widower from seclusion" (ibid: 332). Posteriormente, a autora viria a defini-lo como um "memorial ritual", com a função genérica de "lembrar dos mortos" (Basso, 1985: 139). Ela não explora a semiótica interna ao ritual, pois nota que os Kalapalo e pessoas de outros grupos não puderam lhe explicar o significado da maioria dos símbolos (Becker, 1969: 333). A autora observa, contudo, que para os Kalapalo

the most important aspects of the egitsu are those involving inter-group opposition, atanga dancing by men of different villages, and the general inter-group expressions of hostility and friendship (...). It seems as if the inter-village functions of the egitsu are stressed to the detriment of whatever intra-village symbols are present. (id. ibid.)

Ao se conformar com a dificuldade de obter exegeses, Basso é levada a concluir que

(...) the ceremony is important because of its performance, rather than inherent content. The ability of different village groups to participate, to act out these various steps in the ceremony, is more important than any "meaning" which the steps individually may have. (id. ibid.)

Certamente o sentido do ritual não está dado exclusivamente em seus passos, mas isso não significa que eles sejam irrelevantes; pelo contrário, o que caracteriza um ritual é a especificação e significação minuciosa de cada ação e cada objeto manipulado (Lévi-Strauss, 2009 [1971]; Turner, 1967), e mesmo que se reconheça o caráter "sintético" do sentido do ritual, ele só é produzido pela manipulação de signos específicos. A performance do egitsü é o que é importante do ponto de vista das interpretações explícitas dos alto-xinguanos (e reencontrei isso no campo o tempo todo), mas isso não elimina seu simbolismo interno, nem seus efeitos sobre as pessoas - que é a quem se dirigem as ações rituais. Se o simbolismo ritual fosse irrelevante, por que ele precisaria acontecer daquela maneira específica? Há algo de específico no egitsü, e tal especificidade precisa ser investigada.

Carneiro (1993: 407) descreve o Quarup como 
uma cerimônia realizada anualmente, em base mais ou menos rotativa, em uma das aldeias que permanecem no Alto Xingu. Seu propósito declarado é o de homenagear os membros falecidos da aldeia anfitriã, cortando e decorando um poste de madeira, o quarup, que representa um deles.

Ele nota a importância da luta, que parece ser o que "dá o real incentivo para as tribos visitantes comparecerem ao quarup" (ibid: 420). A despeito disso, argumenta que o valor desse ritual está em proporcionar às pessoas

(...) a oportunidade de se reunir, e interagir de maneira íntima, com membros de todas as outras aldeias da região. Nessa ocasião, eles podem reafirmar os laços sociais, cerimoniais, esportivos e econômicos, que ligam todas as aldeias do Alto Xingu. (...) Sua função é promover a solidariedade social. E deve-se considerar esta função realizada com êxito. (ibid: 427; grifos meus)

Já Zarur (2003: 3) define o Quarup como uma "festa em homenagem a mortos ilustres" e que "revive a narrativa religiosa dos índios do Xingu" (ibid: 7). Considerando sua posição como o maior emblema do sistema ritual xinguano, o autor conclui que o Quarup

afirma a comunidade formada por todos os xinguanos e sua origem comum (...). A idéia da convivência com os vivos sucedendo à morte é a própria idéia de continuidade da vida, de vitórias sobre a morte, pela vida em comunidade, como aparece, também, no cristianismo. (ibid: 14; grifos meus)

Zarur prossegue afirmando que a comunhão da sociedade xinguana no Quarup seria análoga à comunhão católica que faz de todos "um só corpo e um só espírito" (ibid: 14), apenas outra forma "de superar a morte pela vida em comunidade" (id. ibid.). Sem levar em conta os exageros do autor para encontrar os "universais religiosos" (que passam por uma comparação entre o choro ritual xinguano e as carpideiras do Mediterrâneo), não estamos tão longe de uma versão empobrecida de Durkheim (1968 [1912]): o Quarup seria apenas a forma alto-xinguana de "celebrar a vida em comunidade".

Em um texto recente, Junqueira e Vitti (2009: 133) descrevem o Quarup como sendo composto por "práticas voltadas tanto para reafirmar a coesão social como para expressar a 
ambiguidade das relações entre as diferentes aldeias" (grifos meus). As autoras notam que a luta é o ponto alto do ritual (ibid: 144), mas argumentam que ela seria, assim como o arremesso de dardos no Jawari, um mecanismo de "neutralização dos antagonismos nascidos do convívio social" (ibid: 137; grifos meus). Após uma breve descrição de cada etapa do ritual, as autoras concluem que o Quarup

diminui as tensões locais e desperta o sentimento de unidade na aldeia, que vibra durante a luta. No plano externo, reafirma os vínculos entre os povos, mesmo que em meio a ambiguidades: todos são acolhidos com respeito e generosidade, ao mesmo tempo que travam uma batalha silenciosa em que os guerreiros são pajés e espíritos. (ibid: 146)

Mesmo o confronto é lido pelas autoras como algo a serviço da "coesão social". Assim como nas interpretações de Carneiro (1993) e Zarur (2003), segundo esta visão o Quarup seria uma espécie de "válvula de escape" para os dramas da morte e da difícil convivência entre os alto-xinguanos. Nenhuma das interpretações disponíveis sobre este ritual questiona satisfatoriamente alguns de seus detalhes que, justamente pela minúcia com que são tratados pelos xinguanos, constituem alguns de seus pilares: por que ele é feito somente após a morte de chefes e seus parentes?; por que se utiliza troncos de uma árvore específica?; o que é feito, do ponto de vista dos especialistas rituais, como o tronco e seu espírito?; o que torna a luta uma necessidade? Afirmar que o Quarup "comemora" as origens, ou favorece a vida comunitária tanto pelos festejos quanto pela neutralização esportiva de tensões, são explicações que acabam incorrendo no clássico erro pelo qual os funcionalistas foram tanto atacados: tomar os efeitos pelas causas (supondo que estes estejam, de fato, entre seus efeitos do ponto de vista indígena).

Partindo de comentários sobre alguns Quarup pouco usuais, realizados em homenagem aos irmãos Villas Boas, Barcelos Neto (2008: 316) oferece uma visão diferente. Ele compara as efígies às máscaras e aerofones que permitem a familiarização (no sentido de Fausto, 2001) de espíritos por meio de rituais dedicados a eles, transformando seres potencialmente perigosos em "parentes" (os espíritos se tornam "filhos" dos que patrocinam seus rituais) e incorporando-os à socialidade dos humanos. Segundo Barcelos Neto, os Quarup dos irmãos Villas Boas teriam tido um objetivo semelhante: ao serem transformados em efígies pelos alto-xinguanos, estes passaram "para o nível mais elevado da inclusão: o 
reconhecimento pleno de seu status de amunaw [chefe, em wauja]. Mais uma vez, 'objetos' belos surgem como agentes de um processo de 'domesticação' política” (Barcelos Neto, 2008: 316).

Um dos pontos novos de seu argumento é a comparação dos chefes a seres perigosos como os espíritos. Como nota Barcelos Neto, os chefes alto-xinguanos são amplamente associados às onças e outros animais predadores, cuja estética corporal compõe, em contextos rituais, "um mundo de distinções sociais entre amunaw e não-amunaw" (id. ibid.). O autor sugere que, assim como espíritos precisam ser "domesticados" (humanizados e aparentados) em rituais nos quais são materializados sob a forma de objetos (máscaras ou instrumentos musicais), talvez fosse possível pensar a produção das efígies como algo análogo: uma forma de familiarizar/humanizar alguém visto como um ser potencialmente perigoso. Tal proposição tem um sentido claro quando aplicada à inclusão dos brancos no ritual - os kagaiha são chamados de "espíritos", e sua atração para o sistema ritual evoca diretamente o problema de sua "humanização". Mas me parece que esta ideia, de certa forma, pode ser aplicada também aos próprios chefes xinguanos, pois estes passam a vida sendo produzidos ao mesmo tempo como predadores simbólicos (usam adornos de animais como onças, gaviões e sucuris, e são considerados "inimigos" ou "adversários" de chefes estrangeiros nos rituais regionais ${ }^{24}$ ) e como humanos ideais (pacíficos).

Os Kalapalo consideram que realizar rituais para seus chefes é uma forma de "deixálos calmos", "fazer com que seu jeito se torne bom/bonito". Figueiredo (2010) observa algo semelhante entre os Aweti, que decidem "acalmar" homens muito agressivos transformandoos em chefes. A autora argumenta que este seria um processo análogo à domesticação de filhotes de aves selvagens (os animais domésticos prediletos dos alto-xinguanos), e que este processo é "correlato à domesticação de inimigos, já que as aves são inimigas do homem no céu” (ibid: 190). Do ponto de vista aweti, e também kalapalo, é assim que transformam seus chefes em "gente de verdade", pessoas exemplares que, quando atingirem uma idade mais avançada, poderão se referir a seu povo como "crianças". Como prossegue Figueiredo (ibid., loc. cit.), "um homem feito chefe é capturado de sua própria ignorância, contudo, não para tornar-se filho, como a ave, mas para tornar-se pai. (...) Tornar um homem chefe é uma espécie de captura através da instrução moral e cultural (...)”. Na domesticação de um itseke e

\footnotetext{
${ }^{24}$ À exceção do $u l u k i$, a grande festa de trocas, na qual os chefes se tratam como parentes. Discutirei este ritual nos capítulos 5 e 6 .
} 
de um chefe há uma diferença fundamental, pois o primeiro se torna filho e assim permanece, enquanto o segundo se torna "filho da comunidade" (katutolo mugu, uma designação que alguns jovens chefes podem receber durante a reclusão) para que, um dia, se torne pai.

A produção de uma efígie marca a completude do processo de humanização de alguém, pois com isso o morto, de um lado, é igualado ao arquétipo da humanidade (a mãe dos gêmeos criadores dos humanos, a primeira a ser lembrada em um egitsü) e, de outro, passa a levar, na aldeia dos mortos, uma vida marcada pela consanguinidade, livre do sexo e da afinidade. Contudo, os laços dos vivos com o morto precisam ser desfeitos, o que, no campo da chefia, é considerado um problema: a chefia precisa se perpetuar, os chefes mortos precisam ser substituídos, pois uma aldeia sem chefes tende a se dissolver (muitas vezes ouvi as pessoas dizerem que aldeias se dividem muito por não possuírem "chefes de verdade"). Quando uma pessoa morre, seus parentes tendem a deixar a aldeia temporariamente (às vezes para sempre) para se livrar das lembranças do morto, indo para suas "fazendas" familiares (casas e roças construídas longe das aldeias). Quando morre um chefe, os Kalapalo consideram que a eventual dispersão de sua família é indesejável, e a proposta de um egitsü é descrita como uma forma de evitá-la. Os Kalapalo dizem que as pessoas não conseguem viver juntas sem chefes para "cuidar delas", o que poderia levar à fragmentação de uma aldeia. A sugestão de um egitsü é um investimento para que isso não ocorra, pois ao aceitarem patrocinar este ritual, os donos da festa assumem um compromisso tácito de não deixarem a aldeia, de permanecerem ali como uma família de chefes.

Por isso os Kalapalo traduzem o termo akuãpütelü, que designa a produção de efígies, tanto como "homenagear" como "substituir". Quando uma efígie é feita para um chefe, os Kalapalo dizem que este é transformado em îhũgu, "ancestral", e seus parentes vivos, reconhecidos como seus substitutos (itüpohongo), se transformam em suas akuã - almas, imagens, reflexos, sombras. Mas, assim como a identificação final entre um chefe e seu arquétipo só se dá após a morte, tais substitutos nunca conseguem ser, em vida, mais do que imagens imperfeitas dos chefes mortos: não passam de sombras daqueles transformados em ancestrais. 


\section{iii. Histórico da pesquisa}

Não formulei o problema da chefia dessa forma por acaso. Meu interesse original pelo tema, o incentivo que alguns kalapalo me deram para estudá-lo e sua correlação com o egitsü se entrelaçaram pouco a pouco durante minha experiência de pesquisa - que considero não ter se restringido à aldeia, "o campo" em sentido estrito, pois a convivência com os Kalapalo em São Carlos (SP) e Brasília me absorveu de uma maneira que não é possível desconsiderar aqui.

Trabalhar com os Kalapalo não foi exatamente uma "escolha", mas algo que aconteceu mais ou menos por acaso enquanto eu ainda cursava o bacharelado em Ciências Sociais na Universidade Federal de São Carlos (UFSCar). No começo de 2005, meu último ano de graduação, eu estava muito interessado em etnologia, em grande parte por ter assistido, no semestre anterior, a um curso de antropologia política ministrado pelo Prof. Piero Leirner. A Profa. Marina Cardoso trabalhava com os Kalapalo, eu já tinha cursado várias de suas disciplinas e havíamos conversado sobre a possibilidade dela orientar minha monografia de conclusão de curso. A procurei um dia com a ideia vaga de que "queria estudar índios". Ela havia acabado de dar início a um projeto em parceria com os Kalapalo da aldeia Aiha, e me convidou para participar da equipe ${ }^{25}$, se quisesse. Foi assim que comecei a me envolver com os Kalapalo: sem fazer ideia de quem eram, sem nenhuma ideia sobre o que pesquisar e tendo lido apenas um texto sobre o Alto Xingu (o clássico texto de Viveiros de Castro sobre "A fabricação do corpo na sociedade xinguana ${ }^{26 "}$ ).

O projeto se chamava "Formação e capacitação para o cooperativismo indígena" (Cardoso, 2004a), e fora elaborado a pedido das lideranças da aldeia Aiha $^{27}$ e desenvolvido por meio de uma parceria entre a Associação Aulukumã do Alto Xingu (em processo de formalização, à época), o Departamento de Ciências Sociais e a Incubadora Regional de Cooperativas Populares da UFSCar (INCOOP). O objetivo do projeto era oferecer

\footnotetext{
${ }^{25}$ Também composta por Marina Pereira Novo e João Veridiano Franco Neto.

${ }^{26}$ Viveiros de Castro (1979).

${ }^{27}$ Os Kalapalo têm uma relação antiga com a cidade de São Carlos. Na década de 1990, algumas pessoas ligadas um colégio salesiano costumavam ir pescar no rio Culuene, onde conheceram os Kalapalo. Estabeleceram com eles relações de amizade, e vários kalapalo começaram a frequentar aquela cidade e fazer novos contatos com pessoas diversas. Seu primeiro contato com a UFSCar se deu em 1999, quando um dos chefes da aldeia Aiha solicitou a cooperação da Universidade em projetos de saúde, educação e meio ambiente (Cardoso, 1999).
} 
instrumentos para o funcionamento e gestão da Associação, que atuaria também como uma cooperativa de artesanato. A aldeia indicou dois professores indígenas (Jeika ${ }^{28}$ e Ugise) para participarem de um processo de formação na universidade, que se deu em dois períodos intercalados de três meses em 2005 (Guerreiro Júnior, Novo et al., 2005; Novo, 2005; Novo, Guerreiro Júnior et al., 2005).

A Associação foi formalizada e passou a funcionar, mas o projeto de cooperativa não deu certo. Surgiu a questão de como seria feita a divisão do dinheiro proveniente de eventuais vendas coletivas, já que cada pessoa disponibilizaria objetos diversos, de valor e qualidade distintos. Houve uma sugestão, discutida com os professores indígenas, de que os pagamentos fossem feitos individualmente, e apenas uma porcentagem de cada venda ficasse para a associação, mas que não foi aceita. Ao mesmo tempo em que havia uma demanda por uma "associação" e uma "cooperativa", havia uma grande resistência à coletivização da produção e do dinheiro que ela proporcionaria.

Em 2006, ingressei no mestrado e passei a integrar a equipe ${ }^{29}$ do projeto "Sistemas terapêuticos indígenas e a interface com o modelo de atenção à saúde: diferenciação, controle social e dinâmica sócio-cultural no contexto alto xinguano", também coordenado por Cardoso (2005). Em função de meu interesse pela política indígena, decidi abordar, sob sua orientação, as relações entre chefia e casamento (Guerreiro Júnior, 2008), pois na literatura havia várias sugestões a respeito da especificidade dos casamentos de chefes, mas nenhuma pesquisa empírica. O material genealógico que pude levantar me mostrou que o sistema de aliança kalapalo se adéqua em vários aspectos aos sistemas dravidianos de "fórmula rica", operantes em regimes não elementares (Taylor, 1998; Viveiros de Castro, 2002c; Viveiros de Castro e Fausto, 1993), mas me deparei com algumas peculiaridades ligadas aos casamentos entre nobres. Em primeiro lugar, eles são claramente mais endógamos que os demais - chefes tendem a se casar com parentes genealogicamente próximos; em segundo lugar, os filhos dos chefes mais importantes eram os que mais haviam se casado fora de sua aldeia de origem, sempre com filhas de chefes igualmente importantes; por fim, muitas destas uniões são vistas como casamentos com a filha de um irmão ou primo cruzado da mãe (uma MBD), mas cuja mãe não é reconhecida como uma FZ (Guerreiro Júnior, 2011).

\footnotetext{
${ }^{28}$ Jeika se interessou tanto pela questão que, atualmente, cursa bacharelado em Administração na UFSCar.

${ }^{29}$ Formada por Marina Cardoso, Marina Pereira Novo (mestranda), Reginaldo Araújo (doutorando) e eu.
} 
Concluí o mestrado com a sensação de que eu deveria abordar o problema da chefia em um nível mais abrangente: sua interface com o regionalismo. Tive muita dificuldade para transformar a chefia (um problema etnológico) em um objeto empírico (um problema etnográfico), algo que pudesse ser traduzido sob a forma de um projeto de pesquisa delimitado e factível. Quase tudo na vida xinguana está ligado, de uma forma ou de outra, à chefia, fazendo com que transformá-la em um objeto definido, observável e passível de uma investigação em campo sistemática e planejada não seja uma tarefa simples.

Meu interesse pelo egitsü veio (mais uma vez) por acaso, após ter assistido à fase final do ritual em Aiha em agosto de 2008. O evento foi conturbado por conta de questões políticas envolvendo outros xinguanos, pesquisadores, equipes de filmagem, pagamentos e os chefes da aldeia. Não era nada diferente do que eu já havia presenciado em 2006, quando assisti a um egitsü pela primeira vez, mas só então passei a prestar a devida atenção à política imbricada na preparação e execução do ritual. Escolhi assim o egitsü como um objeto etnográfico que me permitiria abordar a um só tempo as inseparáveis questões da chefia e do regionalismo (incluindo eventualmente os brancos), garantindo uma experiência de campo mais "controlada" pelos limites do próprio ritual.

À época eu não podia ver a dimensão da importância que aquele ritual, assim como outros que se seguiriam ele, teria entre os Kalapalo nos próximos anos. Ele foi apenas um momento em uma série de acontecimentos, cujo início remonta pelo menos até 2005. O adoecimento de um jovem chefe e grande lutador de outra aldeia no final daquele ano, que levou à sua transformação em xama $\tilde{a}^{30}$, parece ter sido o ponto de partida. Quando ele adoeceu, o principal chefe da aldeia na qual ele vivia à época foi acusado de ser o responsável por enfeitiçá-lo, e teve de deixar o local. No começo de 2007, o substituto do chefe acusado (seu sobrinho uterino) caiu gravemente doente, sofrendo com desmaios e ficando impossibilitado de andar. O pai do novo xamã acusou um homem com o qual tinha problemas pessoais de ser o feiticeiro responsável pelo adoecimento do novo chefe, alegando que seu filho teria ouvido isso de seus espíritos auxiliares. Contudo, outros dois xamãs bem mais velhos, entre os mais respeitados do Alto Xingu, interviram em defesa do acusado, que era cunhado de um e sobrinho do outro. Segundo eles, os espíritos teriam dito que o responsável seria, na verdade,

\footnotetext{
${ }^{30}$ Este processo foi muito atípico para os padrões xinguanos, e a atuação daquele homem como xamã, marcada por uma série de novidades, foi objeto de muito interesse em todas as aldeias da região. Há trabalhos sobre este caso, como os de Cardoso et al. (2008) e Franco Neto (2010: 241-271).
} 
o jovem xamã - acusação que o levou a se mudar com toda sua família para a aldeia de um de seus tios maternos.

Não muito tempo depois disso, ainda em 2007, um dos xamãs mais velhos que interviram no caso, que vivia em Aiha, começou a se queixar de dificuldades para urinar. Ele também não conseguia mais atuar como xamã, pois sentia sua boca amarga ao fumar, vomitava sempre que tentava entrar em transe, sentia fortes dores de cabeça e tinha muita dificuldade para ouvir seu espírito auxiliar. No final de 2007, um de seus cunhados faleceu (e foi o principal homenageado em um egitsü no ano seguinte). Ele era tio paterno do jovem xamã (primo paralelo de seu pai), e tinha ido à sua aldeia questioná-lo sobre uma dívida que o rapaz havia feito em seu nome. Houve uma grande confusão no local, e o jovem xamã chegou a agredir seu tio fisicamente. Na volta, este homem parou em uma aldeia kalapalo e, conversando com seu primo, disse que, por causa do ocorrido, tinha certeza que seria enfeitiçado e morreria em breve. Em menos de um mês, o homem faleceu subitamente (possivelmente em função de um acidente vascular cerebral), e o jovem xamã foi acusado de enfeitiçá-lo. O falecido era primo paralelo do primeiro cacique ${ }^{31}$ de Aiha, que na época passava por uma crise de legitimidade (havia muitos rumores ruins sobre sua personalidade). Ele chegou a pensar em deixar a aldeia, mas seu genro (eZDH) e segundo cacique, recomendou que ele permanecesse lá, deixando suas atividades e fazendo de seu sobrinho uterino seu substituto. A morte de seu primo paralelo foi uma oportunidade para o chefe manifestar sua escolha. Os outros chefes de Aiha, que enterraram o morto, pediram ao chefe principal que patrocinasse um egitsü em sua homenagem, responsabilidade que passou a seu sobrinho uterino. A partir dali o rapaz começou a ser reconhecido, em todo o Alto Xingu, como o futuro primeiro cacique de Aiha, e desde então considera-se que ele está "à frente da comunidade", pois seu tio materno vem progressivamente deixando de exercer atividades ligadas à sua função.

Este jovem chefe é filho do xamã que adoeceu após intervir em defesa de seu cunhado. Ele permaneceu sem ir ao médico muito tempo, ocupado (e muito empolgado) construindo uma grande casa para seu filho e ajudando-o a patrocinar seu primeiro egitsü. $\mathrm{Na}$ época da festa, ele sentia fortes dores nas pernas, tinha dificuldade para andar (o que, contudo, não o impedia de subir no teto de sua casa em construção para passar a manhã cobrindo-a

\footnotetext{
${ }^{31}$ Os Kalapalo hierarquizam seus chefes em primeiro, segundo e terceiro caciques. Como são expressões tão comuns usadas por eles e que em grande medida retratam posições reais de prestígio, as utilizo como se fossem "categorias nativas", e por isso aparecem italicizadas.
} 
com sapé) e não se alimentava direito (não suportava o cheiro e o sabor de peixe). No final de 2008, ele foi diagnosticado com tumores malignos na próstata, nos ossos e em pelo menos um dos rins, e faleceu no começo de 2009. Para seus parentes isso só poderia ser efeito de um feitiço, e seu autor não poderia ser outro senão o jovem xamã, que estaria se vingando de seus acusadores. Poucos meses depois, sua viúva (irmã do primeiro cacique e mãe do jovem escolhido para substituí-lo), também foi diagnosticada com câncer, vindo a falecer em janeiro de 2010; em menos de seis meses, seu filho mais velho também descobriu um tumor em um dos testículos, que precisou ser removido, mas foi diagnosticado com metástase e passa por um longo tratamento quimioterápico. Ainda em 2010, um dos tios maternos do futuro chefe (que também é um importante chefe da antiga aldeia onde vivia o jovem xamã) foi diagnosticado com tumores malignos no sistema digestivo e, enquanto escrevo, está internado em estado grave na UTI do Hospital Regional da Asa Norte, em Brasília.

A família do outro xamã mais velho também sofreu com algumas mortes: um de seus netos, com pouco mais de um ano de idade, faleceu no final de 2008, e outro, em reclusão pubertária, no final de 2009. Poucas horas depois da morte do menino, o pai de outro jovem anetü de Aiha (um rapaz que havia sido escolhido para ser o "colega", itaginhokongo, do futuro primeiro cacique) caiu doente. Ele não conseguia andar nem falar direito, ficou com seu rosto deformado e parte de seu corpo imobilizado, e faleceu em poucos dias.

Todas as mortes foram atribuídas ao jovem xamã, e os outros alto-xinguanos começaram a se preocupar com a situação dos Kalapalo (foram seis mortes entre o final de 2007 e o começo de 2010, além de outros casos de doenças graves). Dizem que, em uma reunião realizada no Posto Diauarum, os Kayabi teriam se oferecido aos Kalapalo para executar o feiticeiro, se eles desejassem. Os Kalapalo atribuíram tais mortes ao desejo de vingança daquele homem contra os dois xamãs que o acusaram, além da inveja que sentia dos dois jovens escolhidos como futuros chefes kalapalo.

Uma das irmãs mais novas do futuro chefe insistiu que eles deveriam deixar Aiha e abrir uma aldeia própria, a fim de ficarem longe dos olhos invejosos dos feiticeiros. Para poder se afastar um pouco dos assuntos da comunidade e reduzir sua visibilidade, o jovem chegou a tentar deixar seu cargo de tesoureiro na Associação, mas foi convencido a permanecer. Quando contou a suas irmãs sobre sua permanência no cargo, a mais velha logo desabou em prantos, lamentando a situação frágil que viviam por ficarem tão expostos a "fofocas/mentiras" (aũgene). Conscientes dessa situação delicada, os demais chefes de Aiha 
têm se empenhado em mantê-lo na aldeia com sua família, "pedindo" mais e mais rituais: primeiro sugeriram o egitsü de seu pai, que não era chefe, mas sim cantor (só decidiram por sua homenagem quase três meses após sua morte); em seguida, o de sua mãe; agora insistem para que realize um hagaka em memória de seu pai, ainda em 2012; as mulheres da aldeia também o têm pressionado para que patrocine o ritual feminino jamugikumalu, cuja dona era sua mãe, para que o ritual não fique sem dono; e, pelo menos desde 2009, todos já falam em construir para ele uma grande talühe (uma casa de chefe). Quando o jovem chefe negou à sua irmã o pedido para se mudarem, o justificou pelos rituais que estavam patrocinando: ao aceitar patrocinar aqueles rituais, estavam aceitando ficar ali e se tornar "esteios" ou "troncoscorpos" das pessoas (que, como tais, não se movem - estes conceitos serão discutidos em detalhes no capítulo 2).

Fui diretamente afetado por tais acontecimentos e pelo clima criado na aldeia. Desde minha segunda viagem a Aiha, em outubro de 2006, me hospedo na casa do xamã falecido e sua família, que não mediu esforços para tentar me "aparentar" e me fazer sentir muito bem em sua companhia. Acompanhei de perto o diagnóstico e as tentativas de tratamento do xamã e sua esposa em São Paulo e Brasília, oferecendo o suporte que eu podia a eles e seus familiares. Em 2009, passei o momento mais angustiante de minha pesquisa de campo. Após fazer uma sessão de quimioterapia, a esposa do xamã havia desistido do tratamento e decidira deixar o hospital, em Brasília, para "morrer perto de seus netos", como ela tantas vezes me disse aqui, durante minhas visitas à $\mathrm{CASAI}^{32}$. Quando cheguei à aldeia, notei que a região atrás de sua casa estava cheia de grandes buracos, que a princípio imaginei serem tentativas de encontrar um lugar para o gerador de energia da casa (pois estes aparelhos costumam ser colocados em buracos para abafar um pouco seu barulho). Mas na realidade os buracos eram “trincheiras", onde seus parentes faziam vigílias noturnas, armados, a fim de surpreender o feiticeiro responsável por seu sofrimento. Ela não conseguia deixar sua rede para nada, e passou três meses chorando de dor a maior parte dos dias e das noites. Foram raros os momentos de silêncio, que se resumiam a seus poucos minutos diários de sono. Era muito difícil lidar com aquela situação, eu simplesmente não sabia como me comportar. Eu sentia tanta vergonha de estar naquela posição, sem poder fazer nada, que durante toda minha estadia a vi somente quando a própria família se aproximava ao seu redor para lhe fazer uma

\footnotetext{
32 Casa de Apoio à Saúde do Índio, responsáveis por prestar serviços de apoio aos pacientes indígenas encaminhados à rede do Sistema Único de Saúde.
} 
companhia silenciosa. Um dia antes de deixar a aldeia fui me despedir dela, que me disse: “Quando você voltar, eu não estarei mais aqui". E não estava.

Eu nunca havia visto o jovem chefe discursar, o que não faz porque "tem vergonha" e, segundo ele, "não sabe falar bonito". Até que um dia, enquanto eu estava no centro da aldeia passando o tempo com outros homens ao entardecer, o vi sair de sua casa carregando uma espingarda (substituto do arco dos chefes quando discursam ${ }^{33}$ ). Quando ele chegou ao centro, todos o olharam e pararam para ouvir o que tinha a dizer. Não era exatamente um discurso de chefe, mas uma "fala da raiva" (Franchetto, 1986), na qual exprimia sua angústia e criticava os feiticeiros. O rapaz falou do sofrimento de seu falecido pai, de sua mãe e de toda a sua família; questionou o motivo de alguém atacar seus parentes e, em tom de ameaça, disse que já haviam descoberto os responsáveis. Concluiu dizendo que se o feiticeiro não parasse imediatamente de causar dor à sua mãe, alguém ali morreria. Imediatamente engatilhou a espingarda (parei de respirar por um segundo), deu um tiro no chão (voltei a respirar) e se retirou sem olhar para ninguém ou dizer uma palavra sequer. Para minha surpresa, todos voltaram a fazer exatamente o que faziam antes, conversando e brincando tranquilamente, retomando o jogo de dominó que toma conta da casa dos homens naquela hora do dia.

Soube do diagnóstico do irmão do jovem chefe quando passei por Canarana, indo para a aldeia, em junho de 2010. Ele havia sido levado para a cidade com suspeita de caxumba, mas foi identificado um tumor em um dos testículos, que teve de ser removido. Dois meses depois, enquanto eu ainda estava na aldeia, ele voltou para casa e passou mal muitos dias seguidos. Pouco antes de eu sair do campo, ele foi encaminhado para a CASAI de Brasília, onde permaneceu mais de seis meses sendo tratado com quimioterapia (outro tumor havia sido identificado). Liberado para voltar à aldeia por alguns dias, acabou levando mais tempo para retornar a Brasília por falta de transporte, e, quando chegou, os médicos diagnosticaram uma piora no quadro. Ele passou mais cinco meses fazendo quimioterapia, voltou para a aldeia durantes as férias da médica responsável por seu caso, e retornará em breve para fazer novos exames. Nesse período me envolvi ainda mais com sua família, que passou a contar com meu suporte contínuo em Brasília.

Meu envolvimento com os Kalapalo, especificamente com a família que me acolheu, ultrapassou muito os limites de uma mera pesquisa. Vivi os últimos quatro anos em meio à ascensão de um jovem chefe e ao sofrimento pelo qual sua família tem passado, o que vem se

\footnotetext{
${ }^{33}$ Seus akitsoho, "feito para discursar". Sobre o gênero de fala dos chefes, ver capítulo 5.
} 
traduzindo no patrocínio de mais e mais rituais mortuários, um esforço que tem consumido as energias de um grupo doméstico de mais de 20 pessoas. Eu não poderia ter feito outra etnografia.

\section{iv. O campo onde tudo (e todos) tem dono}

Minha entrada no campo foi consideravelmente fácil, pois, tendo trabalhado com Jeika e Ugise em São Carlos, meu nome já era conhecido na aldeia e havia uma expectativa de que, em troca de minha permanência como pesquisador, eu ajudaria os professores na escola indígena e em assuntos diversos ligados à Associação Aulukumã (acordo que já havia sido estabelecido com Marina Cardoso). Durante o mestrado, entre 2006 e 2007, fiz seis meses de pesquisa, e mais sete meses e meio entre 2008 e 2011, durante o doutorado, totalizando 13 meses e meio de campo. Nesse período, presenciei diferentes fases de quatro egitsü. Eu tinha a intenção de acompanhar também a fase final de um quinto egitsü na aldeia Tankgugu em 2009, no qual ocorreria uma festa para furar as orelhas do filho de um chefe. Porém, aquele foi o ano em que o mundo ficou em alerta por causa de uma possível pandemia da gripe A H1N1 (a "gripe suína"), e minha viagem teve que ser adiada várias vezes porque o acesso a terras indígenas estava vetado (menos, claro, para os turistas que entram e saem do Xingu com facilidade).

Nos intervalos entre as viagens, retornei a Brasília para trabalhar com a organização de meus dados, sobretudo na transcrição e tradução do extenso material registrado em áudio (que totaliza mais de 30 horas de gravação). Infelizmente, este trabalho foi praticamente impossível de se fazer na aldeia (e permanece, em sua maior parte, incompleto). Os Kalapalo não dispõem de nenhuma fonte regular de energia elétrica, e para que eu pudesse ouvir, transcrever e traduzir minhas gravações em um computador era indispensável utilizar um gerador particular. Isso obviamente consome muita gasolina, principalmente quando o computador se torna uma ferramenta para fazer várias outras coisas que as pessoas me pediam, como copiar CDs e DVDs, ver fotos e fazer pequenas edições de vídeo. Apesar disso, com a ajuda de vários amigos kalapalo mais do que entusiasmados com a pesquisa, conseguimos transcrever e traduzir na própria aldeia parte razoável do material mais diretamente ligado ao tema da tese, e o restante foi sendo trabalhado em Brasília na medida 
do possível. Contudo, a maior parte deste material (não relacionada ao egitsü ou diretamente à chefia) ainda precisa ser transcrita, trabalho que pretendo iniciar em breve. Este foi o tempo exato para que eu conseguisse trabalhar com as principais narrativas, depoimentos e discursos cerimoniais que compõem este trabalho (sem o que ele teria ficado muito empobrecido), restando-me ainda um ano para a sua redação.

Todo branco tem um "dono", um chefe responsável por recebê-lo, cuidar dele e, no geral, mediar suas relações com a aldeia (discutirei isso no capítulo 6), o que pode ser uma fonte de problemas para xinguanos e pesquisadores. Incontáveis vezes ouvi o primeiro cacique comentar, de forma crítica, sobre a existência de muitos "donos de brancos" em outras aldeias: "Veja aquela aldeia. Lá vive tendo confusão porque cada branco tem um dono diferente: um cacique cuida do enfermeiro, outro cuida do professor, outro cuida do antropólogo". Brancos são recursos em potencial para uma aldeia, seja para trabalhar, seja para fornecer objetos ou dinheiro. Eles também são recursos para seus donos, cujo prestígio é beneficiado pelas alianças de sucesso que conseguem estabelecer com diferentes kagaiha. Quando cheguei em Aiha, eu não tinha um lugar na rede política da aldeia, e isso era um problema para todo mundo. Quatro pessoas tentavam me atrair para seus grupos domésticos, e três tinham conflitos entre si por várias razões. As formas de "atração" são aquelas típicas da "sedução xinguana" (Fausto, 2007): a oferta de objetos, alimentos e ajuda na pesquisa sempre com uma etiqueta e uma gentileza impecáveis. Mas, em todas as brechas possíveis, tentavam me fazer participar de rumores por meio dos quais algumas pessoas se atacavam à época. Isso me deixou em várias situações constrangedoras, pois é impossível estabelecer relações igualitárias de aliança com muitas "facções" (a começar porque quem se alia a todo mundo, não ganha a confiança de ninguém).

Havia também o "problema" da reciprocidade. Eu deveria oferecer algo "à comunidade" em troca de minhas estadias, ao mesmo tempo que os chefes sempre esperavam presentes especiais. Por sua história peculiar em relação à sociedade nacional, os altoxinguanos se acostumaram a receber "autoridades", turistas e pesquisadores estrangeiros, além de turistas brasileiros muito ricos. Acabaram se acostumando a um padrão de "presentes" e pagamentos que para um antropólogo comum é impossível manter. No começo de minha pesquisa eu passei por vários "testes" enquanto os Kalapalo tentavam saber que tipo de kagaiha eu era: aparentemente sem nenhum interesse, me contavam sobre um médico suíço que tem uma casa de três andares em uma praia particular em Salvador e lhes dá 
presentes em dólares; sobre um homem que lhes deu um motor de 40HP de presente; outro que deu um gerador que custa mais de $\mathrm{R} \$ 2000$; alguns turistas que compraram um caminhão para a aldeia com dinheiro próprio. "E você, quanto dinheiro você tem?", eu sentia que queriam saber o tempo todo.

Minha situação começou a melhorar a partir de 2007, quando passei a ser associado a uma parentela específica. Com isso as pessoas de facções rivais deixaram de tentar me envolver em rumores e passaram a se conformar que agora eu tinha "donos". Conforme fui entrando nas redes de reciprocidade, as pessoas deixaram de me comparar aos milionários excêntricos que vez ou outra cruzam seus caminhos. E, com o tempo e a convivência mais próxima em Brasília, a maioria foi percebendo o que eu queria dizer quando contava que vivia com bolsa de estudos e morava de aluguel, e devagar suas expectativas foram se adequando às minhas possibilidades.

Assim como um espírito cuidado por um "dono" se torna um tipo de parente, os brancos também tendem a ser atraídos para as redes de parentesco, com um misto de jocosidade e seriedade. Aparentar é uma forma de criar expectativas sobre as pessoas: trata-se alguém como parente porque se espera que se comporte como tal. Isso implica na adoção de uma lógica de reciprocidade que, para mim, sempre foi muito complexa. Eu demorei muito para aprender a retribuir de forma adequada, tanto em termos de valor quanto em termos do tempo que uma retribuição pode levar. Às vezes fiz pagamentos muito pequenos, às vezes muito caros; às vezes retribuí um presente sincero com tanta rapidez a ponto de ofender o doador, que achou que eu queria comprar seu presente; outras vezes demorei mais do que deveria. Mas, quanto mais eu me envolvia nessas redes, mais crescia minha intimidade com as pessoas e seu interesse em colaborar com minha pesquisa (bem como os custos de minha estadia na aldeia, é fato).

Várias vezes pensei comigo mesmo: "essa história de me tratar como parente é só brincadeira, deve ser pra relaxar as relações". Mas ao mesmo tempo em que eu era confrontado com minha irredutível diferença de kagaiha (afinal, segundo a mitologia, um de meus ancestrais nasceu de espingarda na mão matando gente, outro fazia metal a partir de sangue coagulado de índios capturados... não é um passado que se apague facilmente), as obrigações da afinidade e alguns privilégios do parentesco se puseram na minha frente de forma marcante. Certo dia eu conversava com o chefe principal, e ele mencionou o marido de uma de suas sobrinhas (seu genro, portanto), de maneira anafórica (afins não devem 
pronunciar os nomes uns dos outros). Querendo saber se eu havia entendido de quem ele estava falando, me pediu que dissesse seu nome, o que fiz sem problema nenhum (apesar de tê-lo feito em voz baixa, pois este homem me chama de "cunhado"). O dia passou, e no final da tarde eu estava sentado, como de costume, sobre um tronco que ficava em frente à casa, observando o movimento, quando o homem sobre quem havíamos falado se sentou perto de mim e começou a conversar, mas sem me olhar diretamente. Falamos de coisas variadas, ficamos jogando conversa fora, e num determinado momento ele disse meu nome. Eu, brincando, lhe disse: “cunhado, você chamou meu nome!" (algo muito indelicado e que um cunhado de verdade jamais faria, como fui entender mais tarde). Sua resposta foi muito simples: "Por que você chamou meu nome hoje? Eu ouvi você chamar meu nome para o cacique hoje de manhã. Se você não vai me respeitar, eu também não vou respeitar você”. Me pareceu que havia algo ali que ultrapassava a minha ideia do aparentamento como uma simples forma de misturar intimidade forçada com jocosidade, algo que dava a este processo algum grau de efetividade sobre as relações.

Certa vez, em uma reunião que eu havia convocado na casa dos homens para discutir a questão dos pagamentos a colaboradores (pois havia uma pessoa de outra aldeia tentando impedir minha pesquisa, dizendo que eu ganharia "milhões de dólares" vendendo suas histórias e ensinando sua língua), a fala de um de meus "cunhados" na aldeia foi muito esclarecedora a respeito de suas expectativas. Ele me disse que eu não precisaria pagar por nada, desde que não me esquecesse deles. Ele não conseguia entender - dizia - como os pesquisadores podiam "se esquecer" das pessoas que os recebiam em suas casas. Considerando que eles me recebiam, cuidavam de mim e me tratavam como um parente, não faria sentido se eu simplesmente fosse embora, nunca mais voltasse e os esquecesse. Sua expectativa era que eu me comportasse com o mínimo de humanidade, o que ele e os demais sabem que não se pode esperar de todos os kagaiha (afinal são espíritos!). E só é humano quem é, em alguma medida, parente. Não importava que eu deixasse de trabalhar com eles ele prosseguiu -, interessava que eu não me esquecesse de meus amigos, para que quando eu voltasse nós pudéssemos trocar presentes. Como veremos no capítulo 6, trocar e "pagar" não são exatamente a mesma coisa.

Também tive que entrar em outro circuito de dons, especialmente caro: o dos conhecimentos rituais. Como discutirei em detalhes no capítulo 3, todo conhecimento especializado tem um ou mais “donos" (oto). Narrativas, cantos, rezas, discursos, todos são 
possuídos (otondelï) por alguém, um dono ou mestre que os conhece muito bem, que pode executá-los publicamente e transmiti-los a outras pessoas (por tê-los recebido de outro dono, outro grande conhecedor). Esta situação faz com que os conhecimentos sejam parte de um tipo de "economia", pois a circulação de boa parte deles exige pagamentos sob a forma de objetos valiosos. Esta economia de conhecimentos é inseparável das relações de parentesco, que definem se o aprendiz deve ou não pagar pelo conhecimento, o que poderia ser um pagamento justo, e mesmo se ele está apto a aprender certos conhecimentos. Não é preciso muito esforço para imaginar as consequências disso para a pesquisa de campo, ao mesmo tempo econômicas e políticas: econômicas porque tive que encontrar maneiras de fazer pagamentos justos a diferentes tipos de especialistas sem recursos específicos para isso; e políticas porque trabalhar com tal ou qual especialista sempre dependeu de escolhas feitas nos limites impostos por minha posição em certa rede de relações (havia, por exemplo, pessoas das quais eu não devia me aproximar muito em respeito a meus anfitriões e seus parentes mais próximos).

Estar em um campo no qual tudo tem donos, e as pessoas estão prontas para fazer do pesquisador alguém quanto a quem se possa criar expectativas muito fortes, é viver uma tensão entre proximidade (às vezes forçada) e distância (eternamente intransponível), entre poder ser transformado em alguém próximo (que no mínimo se comporta como "gente/parente") sem nunca deixar de ser irredutivelmente diferente - um "jogo de empurra" que sempre me causou um grande desgaste emocional, e que moldou as possibilidades e limitações desta pesquisa.

\section{v. Os rituais}

Esta tese se baseia em observações feitas durante diferentes fases de quatro egitsü realizados em Aiha em 2006, 2008, 2010 e 2011. Destes, acompanhei mais de perto a organização dos dois últimos, realizados em homenagem aos donos da casa onde me hospedo. Como ao longo da tese não descrevo "um egitsü", mas faço referências a todos os quatro, disponibilizo abaixo um quadro com informações sobre cada um desses rituais (Tabela I.1), após o qual apresento um diagrama das relações de parentesco entre homenageados (Figura I.1), patrocinadores e tajope ("coordenadores"). 
Tabela I.1: lista dos principais homenageados, donos e tajope dos rituais que acompanhei durante o campo.

\begin{tabular}{|c|c|c|c|c|}
\hline Egitsï & Homenageado(s) principal(is) & $\begin{array}{c}\text { Dono } \\
\text { principal }\end{array}$ & $\begin{array}{c}\text { Donos } \\
\text { acompanhantes }\end{array}$ & Tajope \\
\hline $\begin{array}{l}\text { Agosto } \\
\text { de } 2006\end{array}$ & Filho pequeno de Agusahi & Agusahi & $\begin{array}{c}\text { Ageu } \\
\text { Kohi } \\
\text { Akusa } \\
\text { Kamankgagü }\end{array}$ & $\begin{array}{c}\text { Kainahu } \\
\text { Ulehe } \\
\text { Ugise } \\
\text { Waja }\end{array}$ \\
\hline $\begin{array}{l}\text { Agosto } \\
\text { de } 2008\end{array}$ & Aküana & Ugise & Ageu & $\begin{array}{c}\text { Tühoni } \\
\text { Ulehe } \\
\text { Waja } \\
\text { Hehugo }\end{array}$ \\
\hline \multirow{2}{*}{$\begin{array}{l}\text { Agosto } \\
\text { de } 2010\end{array}$} & Enumü & Ugise & $\begin{array}{c}\text { Omã } \\
\text { Aumagi }\end{array}$ & $\begin{array}{l}\text { Kagutua } \\
\text { Janua } \\
\text { Kayauta } \\
\text { Matula* }\end{array}$ \\
\hline & Hehugo & Matula & Lapitsuma & $\begin{array}{c}\text { Aiguana } \\
\text { Jüji } \\
\text { Hankgu } \\
\text { Waja }\end{array}$ \\
\hline \multirow{2}{*}{$\begin{array}{l}\text { Agosto } \\
\text { de } 2011\end{array}$} & Itsapü & Ageu & Waja & $\begin{array}{c}\text { Tühoni } \\
\text { Kagutua } \\
\text { Ulehe** } \\
\text { Haihua }\end{array}$ \\
\hline & Filho pequeno de Magijawü & Ulehe & Magijawü & $\begin{array}{c}\text { Kainahu } \\
\text { Jaua } \\
\text { Masinua } \\
\text { Janua }\end{array}$ \\
\hline
\end{tabular}

* deixou a função de tajope após a morte de seu pai

** deixou a função de tajope após a morte de seu neto 


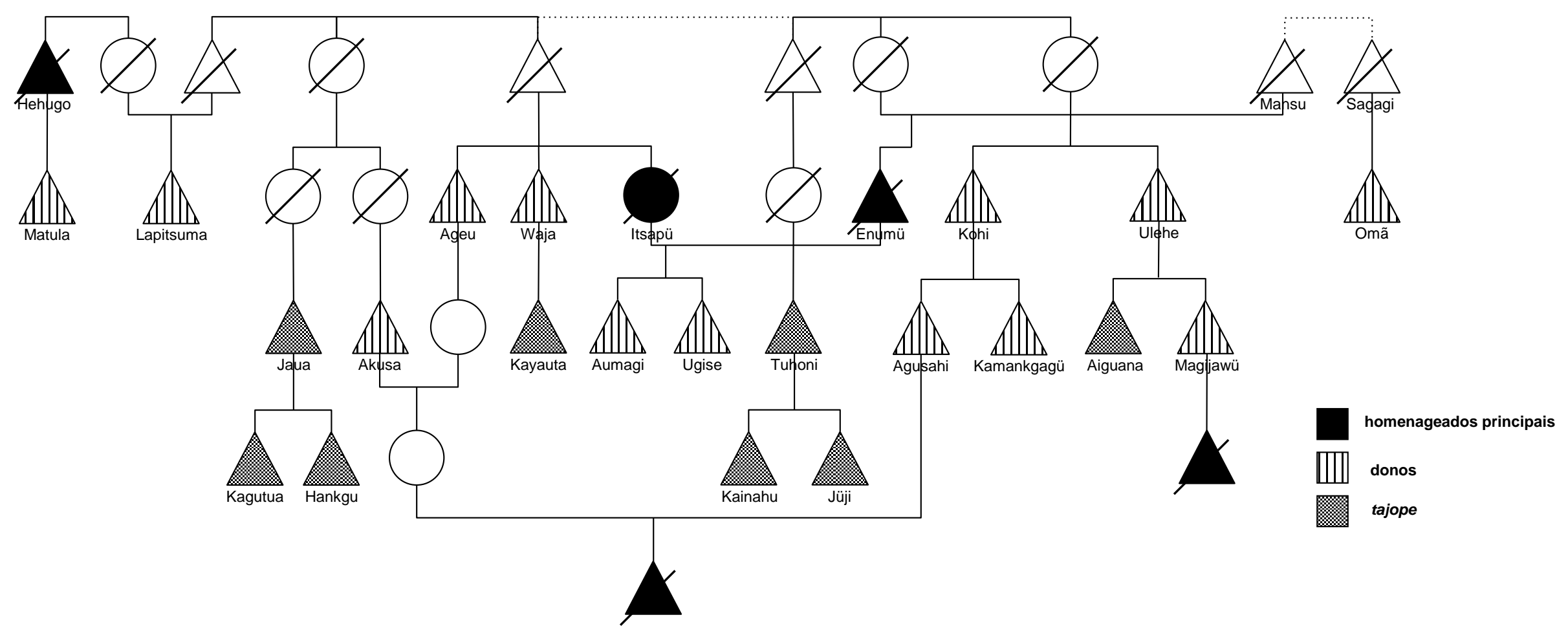

Figura I.1: principais pessoas envolvidas nos egitsü que acompanhei. 


\section{vi. Organização da tese}

As famosas efígies serão abordadas apenas no capítulo final desta tese. Julguei que seria melhor inverter o foco clássico das apresentações do Quarup, pois o momento do ritual ao qual as efígies estão associadas sintetiza tantas ideias, não necessariamente ligadas entre si fora do contexto do ritual, que seria praticamente impossível partir das efígies para se chegar a elas. Como a chefia é uma questão em aberto e tem ocupado um lugar importante em pesquisas recentes (Barcelos Neto, 2008; Figueiredo, 2006; Heckenberger, 2005), julguei que, antes de me perguntar por que os Kalapalo fabricam efígies para seus chefes mortos, seria melhor começar tentando abrir a caixa-preta do problema: o que é a chefia? Esta é, na realidade, a questão de fundo desta tese, e o egitsü e seus temas correlatos são os focos de sua descrição.

Se um dos objetivos explícitos do egitsü é "lembrar" dos chefes mortos, torna-se necessário investigar a relevância de se produzir memória sobre estas pessoas. O capítulo 1 trata das dinâmicas de diferenciação e mistura pelas quais a identidade coletiva kalapalo vem se produzindo e se transformando, e qual o lugar ocupado nelas pela memória de antigos chefes. Na primeira parte do capítulo apresento e discuto algumas narrativas de cunho etnohistórico (isto é, cujos personagens são identificados como ancestrais de grupos ou pessoas específicos). Mostro que tais narrativas focalizam eventos envolvendo chefes e seus familiares, e que alguns dos mais importantes descrevem movimentos de diferenciação da humanidade xinguana. Os chefes são tomados como protagonistas de processos pelos quais os povos se distinguiram e, no subsistema karib, como os ancestrais dos Kalapalo simultaneamente se diferenciaram de alguns grupos e fortaleceram suas alianças com outros. Cruzando nomes de pessoas e lugares, é possível remontar parte das relações que levaram à constituição dos Kalapalo, que identifico como sendo o resultado da reunião de pelo menos dois grandes grupos karib, Amagü e Akuku. Na segunda parte trato da história kalapalo desde o contato oficial, em 1946, até os dias atuais, focalizando a sucessão de chefes, transformações na chefia e processos de fissão e reconfiguração das relações regionais. Argumento que tais fissões coincidem com a reemergência de antigas diferenças entre grupos cuja mistura compôs os Kalapalo, e que assim como os chefes são elementos que estabilizam identidades coletivas ao longo do tempo, também é ao redor deles que podem ocorrer fraturas. 
No capítulo 2, retomo a questão da relação entre "herança" e "fabricação" na chefia, o que decidi fazer a partir da apresentação de trechos de depoimentos de alguns chefes, transcritos em kalapalo e traduzidos para o português. Ao fazer isso, minha intenção foi que o leitor pudesse ter alguma ideia do "tom" no qual os Kalapalo falam sobre o assunto, e que eu pudesse manter minhas descrições vinculadas a conceitos usados pelos falantes em seus próprios depoimentos (pois apesar de muito já ter sido escrito sobre a chefia, sabemos efetivamente pouco o que os alto-xinguanos têm a dizer sobre o tema). Analisando os conceitos de esteio (iho) e tronco-corpo (ihü), mostro como um idioma simultaneamente arbóreo e corporal é usado para descrever a chefia e o parentesco em diferentes níveis. Também mostro que, assim como há um discurso que enfatiza a importância da ascendência nobre, da "endogamia de status" e do "sangue de chefe" para a transmissão da chefia (tratada como "eterna"), esta é vista como o resultado de processos de fabricação que têm início não na relação entre pais e filhos, mas nas relações com outros chefes (do grupo local ou de povos estrangeiros).

No capítulo 3, abordo a correlação entre o lado "vegetal/consanguíneo" dos chefes e seu lado "animal/afim", a partir dos principais mitos do ciclo de criação da humanidade e do primeiro egitsü. Veremos que os chefes das espécies animais são identificados por sua capacidade predatória e/ou seu tamanho exagerado, enquanto os chefes vegetais são associados à dureza, à beleza, ao crescimento lento e à sua durabilidade. Na relação entre humanos e animais, são os espíritos mais perigosos, ou aqueles considerados donos/chefes, os mais capazes de se apropriar das almas humanas e transformá-las em seus filhos adotivos e parentes de sua espécie. Isso porque só os seres considerados perigosos conseguem criar um ponto de vista próprio para o qual podem atrair outras pessoas, que se veem da mesma forma que seu dono/chefe. Sugiro que na chefia kalapalo estão em jogo as mesmas questões, e que os chefes humanos são uma variedade dos muitos tipos de donos ou mestres espalhados pelos cosmos kalapalo e pela América do Sul indígena em geral. No contexto sociológico, os chefes precisam se apresentar como animais predadores porque só assim podem ser produzidos como sujeitos autônomos, condição para que as pessoas se aglomerem ao redor de diferentes troncos-corpos e produzam distintos corpos de parentes. A partir disso sugiro que o vetor assimétrico de aparentamento e produção de identidade está submetido a uma lógica simétrica de oposição dos chefes entre si, voltada para sua diferenciação. 
A partir do capítulo 4, a tese se dedica a quatro elementos específicos do egitsü: a construção do túmulo-casa do chefe (o tahiti); a execução de discursos rituais; a dádiva; e, por fim, a fabricação das efígies. Descrições muito lineares de rituais costumam tornar a leitura cansativa, e nem sempre tudo o que se descreve pode ser aproveitado. Por isso me restringi a descrever elementos do ciclo ritual nos quais a condição de chefe e a dualidade que a marca (a reunião de elementos vegetais/consanguíneos e animais/afins) são intencionalmente tornadas visíveis.

No capítulo 4, discuto os destinos da alma e o tratamento que os chefes recebem após a morte. Focalizando a construção de seu túmulo, que também é visto como uma casa e como um corpo, sugiro que o egitsü realiza um esforço para recuperar as relações de parentesco com o chefe rompidas por ocasião da morte. Como a alma do morto não é exatamente humana, é preciso familiarizá-la novamente, e isso é feito da mesma forma que o parentesco entre os vivos é produzido: pela fabricação de (novos) corpos.

No capítulo 5 discuto o sistema de discursos rituais ligados ao egitsü, procurando abordá-lo em relação a outros dois conjuntos de discursos: aqueles realizados durante a cerimônia de trocas (uluki) e os que, idealmente, deveriam ser executados diariamente por um grande chefe ao amanhecer e ao entardecer. Veremos que por meio da temática dos discursos e de sua poética, os chefes constroem imagens de si e de seus coletivos, e que uma das condições para que possam personificar o grupo em sua fala é retirando dela sua individualidade.

No capítulo 6, abordo a circulação de dons no egitsü em três dimensões: os rituais para a reunião de alimentos (pequi, polvilho e peixe); a troca de objetos de luxo entre os "coordenadores" do povo anfitrião e os chefes dos povos convidados; e a entrada de não índios e seus recursos nos rituais. Veremos que as relações de troca nos rituais de reunião de alimento intencionalmente fazem o dono da festa aparecer como um doador perante os seus, e que o eclipsamento dessas relações é um dos movimentos que lhe permite aparecer como um chefe perante os estrangeiros. Sobre a troca de dons entre os ex-mensageiros e os chefes convidados, argumento que esta é uma das formas pelas quais cada grupo se diferencia de uma humanidade xinguana genérica, exibindo sua especificidade sob a forma de especialidades produtivas. Ainda, veremos que dinheiro, mercadorias e agentes não indígenas participam do ritual a partir da lógica do dom, criando ou catalisando tensões entre os chefes. 
Por fim, o capítulo 7 é dedicado ao clímax do ritual, com a produção das efígies mortuárias e os enfrentamentos entre os grupos pela luta. Nele abordo todo o processo de produção das efígies, desde a escolha e corte da árvore até seu descarte após o ritual. Argumento que a efígie é produzida como um corpo alternativo para o morto, dotado de duas características importantes: trata-se de um corpo não antropomorfo e andrógino. Seu modelo é o corpo da mãe dos gêmeos criadores da humanidade, a primeira "chefe humana", e a identificação do chefe morto ao arquétipo da chefia tem como efeito a potencial reunião de toda a humanidade ao seu redor. A luta, por sua vez, aparece como o principal meio de diferenciação da humanidade xinguana, viabilizando a produção de grupos heterogêneos articulados por diferentes chefes.

A maior parte dos temas tratados aqui pode ser reencontrada, de uma forma ou de outra, na vasta etnografia sobre o Alto Xingu. Se há alguma novidade nesta tese, ela se situa em dois pontos: de um lado, procurei oferecer uma descrição da chefia a mais próxima possível das formas pelas quais os Kalapalo a tornam reconhecível e eficaz, tentando me distanciar de descrições que a tratam a partir de problemas e conceitos enraizados em nossas próprias ideologias políticas (como "poder", "autoridade", "controle" ou "economia política"); de outro lado, procurei ressaltar elementos que permitem pensar o sistema político do Alto Xingu como uma transformação de outras formas sociais ameríndias, evitando o seu fechamento enquanto "área etnográfica".

Mas esta tese nunca teve a pretensão de ser uma pesquisa sobre "o Alto Xingu" enquanto sistema regional, nem uma pesquisa comparativa. Meu interesse é oferecer uma descrição de alguns aspectos da chefia kalapalo e seu ritual mortuário que me parecem pouco detalhados na literatura e que, ao mesmo tempo, são relevantes para o sistema regional. Se às vezes escrevo sobre a chefia e o regionalismo de maneira muito geral, é ciente de que o faço a partir de uma posição específica no sistema regional. Tal posição sequer coincide com os Kalapalo enquanto povo, internamente diferenciado (e que não para de se autodiferenciar), mas se restringe ao lugar que, pouco a pouco e sem perceber direito, fui ocupando na rede de relações da aldeia onde trabalhei. 


\section{Capítulo 1 - Fragmentos de história}

Considerando que um dos objetivos explícitos do egitsü é "lembrar dos chefes mortos", minha intenção neste capítulo é investigar o lugar ocupado por estes agentes na memória coletiva. Farei isso apresentando os Kalapalo de uma perspectiva etno-histórica, discutindo a forma como chefes são lembrados em narrativas sobre os processos de diferenciação e identificação que levaram à constituição deste povo tal como o conhecemos.

\subsection{Uma "história nobre"}

Os Kalapalo são um dos quatro povos que falam a Língua Karib do Alto Xingu (LKAX). Vivem em sua maioria em aldeias próximas ao rio Culuene e, segundo dados da Rede Nacional de Estudos e Pesquisas em Saúde dos Povos Indígenas, da Fundação Nacional de Saúde (RENISI/FUNASA), contam com uma população de cerca de 620 pessoas (RENISI, 2011). Atualmente eles se encontram distribuídos majoritariamente em 10 grupos locais, sendo duas aldeias principais e outros oito aldeamentos pequenos (dos quais dois são contíguos às Coordenações Técnicas Locais Kuluene e Tanguro). Também há um grande número de kalapalo vivendo em aldeias de outros povos, mas cuja quantidade não é possível estimar.

As duas maiores aldeias são Aiha (onde desenvolvi meu trabalho de campo), localizada a cerca de $4 \mathrm{~km}$ da margem direita do Culuene, e Tankgugu (Tanguro, no "português de contato" ${ }^{1 "}$ da região), localizada na foz do rio Tanguro, afluente leste do Culuene. Os Kalapalo dizem que aldeias como estas são "aldeias de verdade" (ete hekugu),

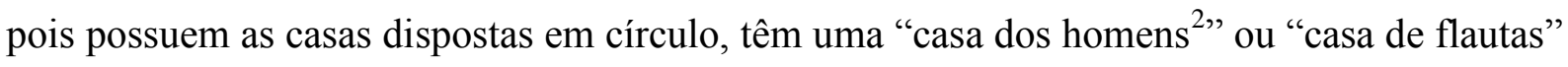
$\left(k_{u a k u t u}^{3}\right)$ e são, em razão disso, capazes de realizar "festas" (rituais regionais e para espíritos). Isso é visto como o resultado da existência de pelo menos um anetü (chefe) respeitado, capaz de agregar muitas pessoas ao seu redor por um longo período de tempo. Tal

\footnotetext{
${ }^{1}$ Emmerich, 2008.

${ }^{2}$ Uma pequena casa construída um pouco a oeste do centro da aldeia, onde os homens se reúnem para conversar ou se preparar para rituais. Ela também é chamada de "casa das flautas", pois é onde são guardados os kagutu, aerofones proibidos aos olhos das mulheres (para uma etnografia de seu ritual, ver Piedade, 2004).

${ }^{3} \mathrm{Kuau}$, em kalapalo antigo (praticamente caiu em desuso).
} 
distinção entre as aldeias cria, como discutirei, algumas assimetrias regionais. Estas aldeias principais são vistas como iho ("esteio", "eixo" ou "chefe") das menores, funcionando como centros rituais e pontos de referência para a produção do parentesco e da história (o conceito de iho será discutido em detalhes no capítulo 2). Também vale notar que uma "aldeia de verdade" não se forma ao redor apenas de um anetü, mas supõe uma continuidade geracional entre chefes e uma memória sobre os que estão sepultados nela. Em uma viagem que fiz com alguns kalapalo a uma região repleta de sítios históricos ${ }^{4}$, o homem que nos guiou usava a presença ou ausência de sepulturas de chefes para escolher quais sítios deveriam (“mereciam?”) ou não ser visitados. Quando eu sugeri visitarmos certo lugar, ele me disse: "Pra que nós iríamos para lá? Lá não há sepulturas de chefes, só há três talokito (pessoas comuns) enterrados ali”, e fez o mesmo em relação a outros sítios. Já nos locais que visitamos, ele era perfeitamente capaz de listar nomes de chefes enterrados em cada um.

Von den Steinen $(1940 ; 1942)$ não menciona os Kalapalo em nenhuma de suas duas viagens (1884 e 1887), apesar de citar a existência de vários grupos karib (dentre os quais os Nahukua $^{5}$, que visitou em 1887). O etnólogo alemão ouviu falar da região habitada pelos karib ainda em sua primeira viagem, quando um velho Suyá lhe forneceu a localização das aldeias de vários grupos rio acima (Von den Steinen, 1942: 255). No croqui reproduzido a partir do desenho do homem suyá consta, por exemplo, uma aldeia "Guicurú" (Kuikuro), próxima a um afluente da margem esquerda do rio Curisevo (que, três anos depois, Von den Steinen descobriria se tratar na verdade de outro rio, o Culuene). Na margem direita o homem suyá indicou os Aratá, Uanaquá (Nahukua), Guafirí, Fauricumá ou Famuricuruá (possivelmente "Jamurikumã", designação da antiga aldeia kalapalo Angambütü), Autihü ou Amatihü (possivelmente Matipu) e Caiuquará.

Foi somente em 1887 que Von den Steinen encontrou pela primeira vez um índio nahukwa, que estava junto dos Bakairi em uma de suas aldeias (“Kuyaqualiéti”). Ele nota que as relações entre os dois povos pareciam ser intensas, já que os Bakairi em geral conheciam várias palavras nahukwa e um homem teria vivido entre eles por um tempo (Von den Steinen, 1940: 125). Von den Steinen partiu para a aldeia dos Nahukua acompanhado de alguns bakairí e do homem nahukwa que estava com eles, de onde seguiriam em direção aos Mehinaku. O

\footnotetext{
${ }^{4}$ Durante a execução de uma fase do Prodoc Kalapalo, projeto integrante do Programa de Documentação de Línguas e Culturas Indígenas do Museu do Índio/FUNAI.

${ }^{5}$ Essa designação é confusa, pois o explorador alemão chamava todos os karib alto-xinguanos (à exceção dos Bakairi) de "anauquás".
} 
objetivo de sua segunda viagem era coletar objetos para uma coleção etnológica do Museu de Berlim, sob a direção de Adolf Bastian, e reunir informações etnográficas sobre os povos da região.

Contudo, sua visita aos Nahukua foi complicada. O rapaz nahukwa que acompanhava a expedição foi à frente para avisar a aldeia sobre sua chegada, o que atrapalhou os interesses de Von den Steinen ali. Quando ele e sua equipe chegaram ${ }^{6}$, os índios aparentemente haviam escondido todos os seus pertences e enviado as mulheres para a mata, pois não havia quase nada nas casas e na aldeia não havia ficado nenhuma mulher que já não fosse idosa. E além de não poderem adquirir os objetos que desejavam, os Nahukua pareciam muito ansiosos para que os visitantes fossem embora o mais rápido possível.

A aldeia Nahukua contava à época com 12 casas, e uma casa das flautas grande e bem construída. Por estarem subindo o Curisevo em direção aos Mehinaku, é muito provável que a aldeia visitada por Von den Steinen tenha sido a antiga Jagamü, próxima à confluência daquele rio com o Culuene e caminho para o território mehinaku (onde existe atualmente uma aldeia, chefiada por um homem que, segundo os Kalapalo, é um dos últimos verdadeiros chefes nahukwa). Suspeito que nesta aldeia os alemães tenham registrado o encontro com um ancestral dos Kalapalo. Havia um homem que se dizia "Yaurikumá" (provavelmente “Jamurikumã”) e que morava a leste, nas margens do Culuene (Von den Steinen, 1940: 128). Segundo os Kalapalo, "Jamurikumã” poderia ser uma referência a uma aldeia chamada Angambütü ("lugar de muitos jenipapeiros"”), local onde, no tempo mítico, as Hiper Mulheres ${ }^{8}$ que deram origem ao ritual Jamurikumã teriam estabelecido residência depois de

\footnotetext{
${ }^{6}$ Aqui talvez caiba um parênteses para comentar as formas pelas quais Von den Steinen descreve a recepção de sua equipe em várias das aldeias do Alto Xingu, pois há um padrão curioso. Frequentemente, os anfitriões faziam os visitantes esperarem um pouco longe do centro da aldeia, enquanto procuravam banquinhos que seriam dispostos no centro, para os quais os visitantes eram levados pelas mãos e acomodados. Em um dos casos, Von den Steinen (1940: 137) nota que um chefe caminhou em direção a eles discursando ininterruptamente. Em outro, depois de os terem feito sentar-se no centro, lhes ofereceram muita comida e tabaco (Von den Steinen, 1940: 127-128); em seguida, vários índios doentes foram até ele e seus companheiros de viagem pedir que soprassem a fumaça de seus cigarros em partes de seus corpos (uma das principais práticas curativas dos pajés) - o que eles faziam sem ter a menor ideia do que se tratava. É inevitável reconhecer nesse padrão um misto de recepção de chefes e domesticação de espíritos: bancos e discursos são para os primeiros, tabaco é para os últimos. Aparentemente os alto-xinguanos viam Von den Steinen como uma espécie de chefe e espírito ao mesmo tempo, um chefe que precisava ser conduzido pelo pulso e sentado, tal qual os chefes que chegam para um ritual, e um espírito que gostaria de receber seu alimento favorito - tabaco.

${ }^{7}$ Genipa americana.

${ }^{8}$ Itaõ Kuẽgü. São mulheres que, depois de seus maridos terem se transformado em queixadas, deixaram a aldeia onde viviam e se transformaram em itseke ("espíritos"). Os cantos que executaram durante sua transformação e sua migração passaram a compor o ritual feminino jamugikumalu (em karib) ou jamurikumã (em arawak). Para mais detalhes acerca do mito e do ritual, ver Franchetto (2003b) para os Kuikuro e Mello (2004) para os Wauja.
} 
saírem dos arredores do lago Tahununu' ${ }^{9}$ Por isso o local teria ficado conhecido como Jamurikumã etupe ou Jamugikumalu etupe ("antiga aldeia das Hiper Mulheres"). Este local era habitado quando as aldeias Kalapalo e Kunugijahütü ainda coexistiam, o que estimo ter sido no final do século XIX, já que pelas narrativas o lugar de nome "Kalapalo" não era mais habitado na época da chegada de Ramiro Noronha às cabeceiras do Culuene, em 1920. Assim, é possível especular que o homem "Yamurikumã" de Von den Steinen fosse um ancestral daqueles que ficariam conhecidos como Kalapalo.

Von den Steinen soube pelos Bakairi que a região de um rio chamado "Kuluëne" seria o núcleo dos "Nahuquá" (Von den Steinen, 1940: 79-80; 96). Era a primeira vez que se registrava o nome deste rio, pois apesar de ser conhecida a existência de um curso d’água vindo do sudoeste em direção ao Xingu, acreditava-se que este fosse o próprio Curisevo. $\mathrm{O}$ viajante alemão identificou, corretamente, a língua dos nahukwa como pertencendo à família karib, e enumerou várias aldeias falantes dessa mesma língua. A partir da aldeia Bakairi "Kuyaqualiéti”, Von den Steinen situou os Angahukua a sudeste; os Aluiti ou Kanaluiti a leste; os Yamurikumá de leste para leste-sudeste; os Apalaquiri a leste-nordeste; os Puikuro a leste-nordeste; e os Mariapé a nordeste. “Apalaquiri”, segundo os Kalapalo, é como os brancos (kagaiha) chamavam Apangakigi (local reocupado no final de 2007), uma das aldeias da região de Kunugijahütü. Em função de pertencerem a uma mesma comunidade linguística, Von den Steinen concluiu que se tratava de uma única tribo espalhada em diversas aldeias. No mapa de 1887 nota-se uma aldeia "Mariape-Nahuquá", outra de nome "Nahuquá" na confluência do Curisevo com o Culuene e, ao longo do curso do primeiro, outra aldeia Nahuquá. A primeira é certamente a aldeia nahukwa atual (Magijape), enquanto a segunda possivelmente é, como já mencionei, Jagamü.

O primeiro registro do nome "Kalapalo" foi feito por Hermann Meyer (1900), que mediu moradores de uma aldeia com esse nome quando esteve na região fazendo uma pesquisa antropométrica. Mas o primeiro registro sobre as regiões habitadas por eles parece ser o do Capitão Ramiro Noronha (1952), encarregado pela Comissão Rondon de explorar as

\footnotetext{
${ }^{9}$ Um grande lago situado a leste do Culuene, ao redor do qual os karib alto-xinguanos estabeleceram algumas de suas aldeias mais antigas (talvez as mais antigas). Os Kalapalo dizem que ali teriam convivido com os ancestrais dos Kamayurá, com os quais mantinham relações amigáveis, informação confirmada pelos Kuikuro (comunicação pessoal de Bruna Franchetto). Heckenberger (2005: 103-112) identificou na região vestígios de pequenos aldeamentos não fortificados, com estruturas circulares que parecem ter sido grandes casas comunais, semelhantes aos padrões habitacionais de outros karib. Por esta razão, estima-se que a região do Tahununu tenha sido um dos pontos de chegada dos karib alto-xinguanos, no século XVII.
} 
cabeceiras do Rio Culuene. Em 1920, Noronha partiu de Cuiabá em direção ao Culuene, e sua equipe contava com alguns bakairi e nahukwa. Perto da confluência com o ribeirão Sete de Setembro, o grupo de Noronha avistou duas canoas que subiam o rio, nas quais estavam alguns índios nahukwa e kalapalo. Em uma das embarcações estava um chefe nahukwa "Cabuzala", e na outra um chefe kalapalo de nome "Caluvocu". O primeiro pude identificar como Kahusala, um importante chefe da aldeia Jagamü lembrado como um grande "mestre do arco" (tahaku oto) em histórias de conflitos que os Nahukua travaram com os Ikpeng no começo do século XX. Já o chefe kalapalo só pôde ser parcialmente identificado; seu nome seria Kaluhuku, mas não encontrei ninguém que se lembre de um chefe com esse nome. Daquele ponto, o capitão partira para a aldeia "Naruvôtu" (Angaguhütü) e de lá para uma pequena aldeia Kalapalo (não nomeada), situada a um dia de caminhada e chefiada por um homem chamado "Amutuá" (possivelmente Mutua, nome do falecido pai de um dos chefes de Tankgugu ${ }^{10}$ ).

Infelizmente, o relatório do capitão Noronha é muito pobre e não permite saber quase nada sobre a situação dos Kalapalo à época. As informações sobre o caminho percorrido são de uma brevidade telegráfica, e o capitão e sua equipe se perderam várias vezes. Noronha menciona que os índios pareciam habituados a encontrar brancos por ali, mas não dá nenhuma informação sobre o que se sabia daqueles povos até o momento (e sequer menciona os nomes das aldeias de cuja existência tomou conhecimento). Com efeito, em várias passagens o capitão dá a entender que a presença dos índios em sua equipe só era tolerada pela capacidade que eles tinham de servir de mão de obra barata e emprestar seu conhecimento para evitar que a empreitada fracassasse.

O capitão conclui seu relatório mencionando que todos os que regressaram com ele haviam caído doentes (sem, contudo, informar que tipo de doença). É possível que a passagem de Noronha tenha sido responsável por dizimar os Angaguhütü que, já na década de 1940, não tinham mais aldeia própria e apenas uma família de sobreviventes havia se refugiado em Nhagü Hatoho (onde os Kalapalo viviam na época da chegada dos Villas Boas, nas imediações de Kunugijahütü ${ }^{11}$ ). Pelas narrativas kalapalo é possível presumir que na época de Noronha havia outras aldeias além desta e Angaguhütü (mas menores), como Angambütü e Ihumba, cujos habitantes teriam desaparecido rapidamente porque "se mataram

\footnotetext{
${ }^{10}$ Segundo comunicação pessoal de Carlos Eduardo Costa.

${ }^{11}$ Onde também existiram as aldeias Siluhütü e Atütüpe.
} 
com feitiço", ainda na primeira metade do século XX. A passagem de Noronha deve ter sido letal para estes karib.

Os Kalapalo se tornariam um povo importante para a Expedição Roncador-Xingu 26 anos depois. Eles foram os primeiros índios contatados pela Expedição, em 7 de outubro de 1946 (Câmara Cunha, 1976: 27), e em uma região relativamente próxima de sua aldeia, na margem esquerda do Culuene (chamada Kahindzu ${ }^{12}$ ), é onde foi construída a primeira pista de pouso do Alto Xingu, a partir de onde a Expedição prosseguiu. Quando a Expedição atingiu os Kalapalo, eles viviam em uma única aldeia, distante cerca de $15 \mathrm{~km}$ da margem esquerda do Culuene, chamada Nhagü Hatoho.

Rapidamente os Kalapalo começaram a passar temporadas ao lado da base da Expedição, onde ergueram uma aldeia (também chamada Kahindzu), e um ano depois aquela base se tornou o principal polo de remessa de instrumentos e medicamentos para a Base do Jacaré, mais abaixo no rio Culuene. Os Kalapalo contam que esta proximidade lhes parecia muito boa à época, pois podiam obter ferramentas e comida com facilidade, às vezes em troca de trabalho. Porém, foi essa mesma relação que fez deles as principais vítimas das epidemias de gripe e sarampo que aconteceram em 1946 e 1954, respectivamente ${ }^{13}$. O chefe kalapalo à época, Sagagi, reconhecido pelos Kalapalo e pelos Villas Boas como um grande chefe, rapidamente se tornou uma vítima desta proximidade excessiva, e morreu de pneumonia apenas três anos após o contato, em 1949.

Na década de 1940, a situação demográfica era certamente bem diferente da época de Von den Steinen, pois diferentemente das nove aldeias falantes de karib registradas por ele no século XIX (e certamente havia outras desconhecidas do autor, como a própria aldeia Kalapalo), a Expedição encontrara cada povo alto-xinguano restrito a uma única aldeia (situação que perdurou até a década de 1970, quando a população voltou a crescer) e os karib reduzidos a três aldeias. Como mostra Menezes Bastos (1983; 1990; 1995), esta coincidência entre povo e aldeia acabou favorecendo a reprodução da ficção das "tribos" ou "povos" como se fossem unidades discretas preexistentes ao sistema xinguano, o qual só existiria porque elas

\footnotetext{
${ }^{12}$ Nome daquele trecho do Culuene. Esse local é conhecido como "Barranco de Jakuí", em memória a uma mulher kalapalo que se casou com o sertanista Ayres Câmara Cunha, membro da Expedição, em 1952. Jakui era órfã, e foi oferecida por seu tio Kumatsi ao sertanista. Jakuí engravidou e deu à luz uma menina, mas morreu logo após o parto, em 1953. Ayres não estava na aldeia, e quando chegou foi surpreendido com a notícia. Ele levou sua filha para ser criada por sua mãe em Uruguaiana, no Rio Grande do Sul, e colocou em Kahindzu um pequeno marco em memoria de sua falecida esposa, que está lá até hoje.

${ }^{13}$ A taxa de mortalidade da epidemia de gripe foi de 13,8\%, e a de sarampo de 26,66\% (Franchetto, 1998: 353).
} 
teriam, enquanto grupos individuais, entrado em relação. Perdeu-se com isso uma dimensão fundamental da composição dos grupos locais, que é sua heterogeneidade interna, tanto étnica quanto linguística. Em sua pesquisa sobre os Kamayurá, Menezes Bastos (1990; 1995) observa que o que se chamava de "os Kamayurá" era, de fato, uma reunião não aleatória de pessoas de diferentes agrupamentos (tupi e outros), cuja rede de relações havia se cristalizado temporariamente em uma aldeia. No decorrer de uma complexa história de conflitos e alianças, o que aparecia como um povo (na prática, uma aldeia) era o resultado da fixação, em um determinado local, de parte de uma rede maior de parentes e afins.

Tal fato chama a atenção para o caráter processual e relativamente instável das identidades, tanto pessoais quanto coletivas ${ }^{14}$. "Os Kalapalo”, “os Kamayurá”, “os Wauja” e etc., longe de constituírem unidades étnico-políticas dadas de antemão, são antes o produto de recortes e sobreposições de redes mais extensas, e os povos xinguanos atuais devem ser vistos mais como o resultado das relações regionais do que como unidades discretas que teriam, em um dado momento, entrado em relação (Menezes Bastos, 1995). Mas, ao mesmo tempo, a partilha de uma mesma identidade coletiva por vários grupos locais nos obriga a perguntar como certas aldeias podem se considerar "outros semelhantes" (otohongo) ou "diferentes" (telo), membros ou não de um mesmo povo. Já no relato de Noronha, vemos a existência de um grupo que se considerava "kalapalo" e que não se restringia a uma aldeia (semelhante à situação atual da maioria dos povos do Alto Xingu). Contudo, mesmo esses grupos eram mais uma vez, como hoje - formados por pessoas das mais variadas origens, o que faz das identidades coletivas algo nada trivial (como seria possível supor a partir das ideias de "povo" ou "tribo"), mas um problema. Com efeito, não se trata apenas de um problema etnológico, mas, sobretudo, de um problema político para os alto-xinguanos, que em diferentes ocasiões e por variadas razões escolhem fundir diferenças sob uma mesma identidade coletiva, ou então ressaltá-las em situações de conflito.

Os outros povos xinguanos são chamados de tekinh $\ddot{u}^{15}$ pelos Kalapalo, palavra que pode ser glosada como "os de outras aldeias". Contudo, os Kalapalo são enfáticos ao dizer que a expressão não pode ser usada para se referir aos moradores das outras aldeias kalapalo. O que faz de um conjunto heterogêneo de 10 aldeias algo como um povo? Ou melhor, já que

\footnotetext{
${ }^{14}$ Muitos pesquisadores já frisaram a "fluidez" das identidades xinguanas, manifesta em indivíduos "meio kuikuro", "meio aweti", etc. Para uma discussão detalhada da questão da mistura no Alto Xingu, ver Mehinaku, 2010.

${ }^{15} T$-e-ki-nhü (RFL-aldeia-INST-AINR).
} 
não se pode chamar seus habitantes de tekinhü, "de outras aldeias", o que faz com que essas pessoas sejam consideradas como vivendo "em uma mesma aldeia"? De um ponto de vista sincrônico, a razão é que o aglomerado ${ }^{16}$ kalapalo possui uma aldeia que é seu iho, isto é, seu "esteio", "eixo" ou chefe (no caso, Aiha ${ }^{17}$ ). A principal característica de uma aldeia-chefe ou iho é sua centralidade ritual: é lá que se enterram os mortos, onde se fazem festas para espíritos, onde se realizam os rituais em memória de nobres falecidos, e - uma das coisas mais importantes - é para onde outros povos enviam os convites para seus próprios rituais. Assim como os chefes estão no centro da vida ritual de uma aldeia, uma aldeia-chefe ou aldeia-esteio está no centro da vida ritual de um nexo regional. Como os Kalapalo de Aiha insistem que não se pode dizer que os moradores de suas outras aldeias são tekinhü, me parece plausível sugerir que os aglomerados são uma espécie de aldeia em escala regional ${ }^{18}$.

Heckenberger (2005: 124-133) argumenta que o sistema xinguano deve ter passado, entre os séculos XIV e XVI, por um momento histórico que ele chama de "período galáctico". Com este conceito o autor se refere à existência de organizações regionais hierarquizadas, constituídas por algumas aldeias satélites gravitando ao redor de pelo menos uma aldeia principal. Tal aldeia (e, especificamente, sua praça e sua casa dos homens) funcionaria como centro ritual, e as aldeias satélites frequentemente se disporiam ao seu redor de acordo com os pontos cardeais (como ocorre na organização do espaço de uma única aldeia, pensada segundo os eixos N-S e L-O). Uma configuração regional desse tipo se disporia exatamente como uma única aldeia: pelo menos quatro "pessoas" (casas e seus donos) ao redor de uma praça. Este espaço central, bem como aqueles que os ocupam - os chefes - também são considerados iho, esteios: as praças são iho das aldeias, enquanto os chefes são os "esteios das pessoas" (kuge iho), responsáveis por sua agregação em um grupo local (objeto do capítulo 2). Em um depoimento do chefe da aldeia Jagamü sobre a saída de seus ancestrais de uma aldeia chamada Timpa ${ }^{19}$, ele diz que lá havia "cinco pessoas" ao redor da "praça", e depois explica que havia cinco aldeias periféricas em relação a Timpa: cada aldeia era uma pessoa,

\footnotetext{
${ }^{16}$ Utilizo "aglomerado" para substituir o termo cluster em inglês, aplicado por Heckenberger (2005). O termo designa conjuntos de aldeias ligadas entre si no sistema regional, nos quais uma aldeia é tomada como "referência" para a identidade coletiva e atividades rituais das demais.

${ }^{17}$ Certamente há controvérsias sobre isso, já que os moradores de Tankgugu não parecem considerar Aiha como seu iho.

${ }^{18}$ O chefe principal de Aiha diz que todas os outros grupos locais kalapalo são "ramos de mandioca" de sua aldeia.

${ }^{19}$ A narrativa foi registrada por Bruna Franchetto e Mara Santos em Canarana (MT) em 5 de novembro de 2009. A gravação faz parte do acervo coletado durante a execução do Projeto de Documentação Matipu e Nahukwá, coordenado por Franchetto e apoiado pelo CFDD-MJ e Museu do Índio/FUNAI.
} 
dispostas ao redor da "praça" Timpa. A organização assimétrica de um único grupo local ou de um conglomerado regional parecem ser homólogas.

Não é possível verificar etnograficamente organizações regionais com uma disposição espacial semelhante à descrita para o período galáctico, mas existe de fato uma tendência de organização assimétrica de algumas relações rituais regionais. Contudo, ao menos em relação à situação contemporânea, não se pode dizer que a assimetria regional entre uma aldeia-iho e aldeias menores seja um "modelo de organização" (este é geralmente apenas um estado transitório, pois cada aldeia se quer iho de si própria). Isso fica claro na relação atual entre Aiha e Tankgugu. A primeira costumava ser iho de todas as aldeias Kalapalo, mas conforme a população de Tankgugu vem crescendo e suas atividades rituais aumentando ${ }^{20}$, a centralidade ritual de Aiha vem diminuindo (apesar de ainda ser considerada pela maioria a "capital kalapalo", como dizem).

Considerando que estes esteios, eixos ou chefes operam na constituição de coletivos tanto no plano local (uma única aldeia) quanto no plano regional (um aglomerado de aldeias), eu gostaria de abordar neste capítulo o seguinte problema: como fica a constituição de coletivos em uma escala diacrônica? Seriam as relações entre grupos do passado e do presente formuladas de acordo com um mesmo modelo de organização assimétrica focalizado em certos iho? Dado que estes conceitos se referem aos "chefes" (sob a forma de pessoas singulares ou coletivas, indivíduos ou aldeias), dois aspectos dessa questão precisam ser abordados: de um lado, o lugar dos anetï $^{21}$ na produção da história coletiva; de outro, o lugar da história coletiva na produção dos anetü.

Não faz muito tempo que passamos a compreender melhor a história xinguana na longa duração, da qual os karib são parte fundamental (Heckenberger, 1996; 2001b; 2005),

\footnotetext{
${ }^{20}$ Até não muito tempo (menos de dez anos, pelo que se comenta), poucos rituais regionais eram realizados em Tankgugu, e os chefes daquela aldeia patrocinavam seus rituais em Aiha. Essa situação vem mudando, e cada vez mais Tankgugu faz questão de promover seus próprios rituais (em parte pela vantagem de poder receber visitantes brancos para as festas, que geralmente pagam por sua estadia em dinheiro ou coisas de valor. A apropriação dos rituais como forma de relacionamento com os brancos será abordada no capítulo 6). Esta "independência” de Tankgugu não passa sem criar tensões. Em uma aldeia, quando há dois chefes importantes, um é dito ser o otohongo (“outro igual”) do outro, colocando os chefes em posições simétricas e potencialmente conflituosas, e o mesmo acontece entre aldeias. Quando outro povo envia mensageiros para convidar os Kalapalo para seus rituais, espera-se que eles vão para Aiha e que seus chefes conduzam todos os Kalapalo à aldeia anfitriã (i.e., que sejam iho de todos). Mas quando, por questões políticas, os convites eventualmente chegam a Tankgugu, os chefes de Aiha só aceitam participar do ritual se forem convidados pelos chefes daquela aldeia para também atuarem como coordenadores. Pode haver muitos iho em potencial, sejam pessoas ou aldeias, mas nas ocasiões rituais estas posições são necessariamente hierarquizadas em relação a um centro considerado mais legítimo do que outros centros possíveis.

${ }^{21}$ A palavra anetü pode ser tanto singular quanto plural (comunicação pessoal de Bruna Franchetto).
} 
mas ainda assim, o que sabemos sobre a história específica do subsistema karib precisa ser ampliado e aprofundado. Quem eram os ancestrais dos Kalapalo atuais? Teriam eles uma origem comum com outros karib? Se sim, reconhecem essa origem? Em que se fundamentaram os processos de diferenciação e fusão, conflito e aliança, dentro desse subsistema, e como eles podem afetar dinâmicas sociais mais recentes?

Como diz Basso (2001: 295), é muito difícil falar de uma "história Kalapalo", já que estes "como os entendemos hoje, parecem ser o amálgama de indivíduos criados em grupos comunitários distintos, que sobreviveram e se mantiveram unidos após epidemias e ataques inimigos que dizimaram sua população”. Muitas das histórias que eles contam são sobre os processos que levaram à emergência de comunidades locais específicas, diferenciadas das que já existiam. Neste capítulo apresentarei o que me foi possível apreender dessa "história Kalapalo" a partir de algumas narrativas esparsas, sem relações explícitas entre si, que ouvi em campo. Apesar do caráter fragmentado dessas narrativas, elas utilizam referências geográficas e genealógicas que as conectam entre si e ligam o passado ao presente (Basso, 2001: 295-296). Meu objetivo não é, de forma alguma, reconstituir qualquer "história sequencial”, já que linearidade não é um elemento relevante para as narrativas que vamos discutir (e nem para a forma como os Kalapalo elaboram sua memória coletiva). Meu interesse é discutir alguns eventos que os Kalapalo acharam por bem preservar de um passado que, apesar de partilhado com diversos outros karib, eles consideram como sendo "seu" (e não de outros) e como tendo gerado uma identidade coletiva capaz de se reproduzir no tempo.

Na primeira parte deste capítulo tento criar uma espécie de "mapa sociológico" dos principais grupos karib que os Kalapalo consideram como seus ancestrais mais próximos, procurando relacioná-los entre si. Como veremos, os Kalapalo reconhecem a existência de um passado no qual havia uma identidade karib mais ou menos difusa, espalhada entre várias aldeias, relacionada em grande medida à partilha de uma mesma língua. Esta identidade difusa passou por processos nos quais diferentes grupos se uniram e se separaram, referenciados por eventos que envolvem algumas pessoas memoráveis. Estas pessoas são todas anetü: é por causa de coisas que aconteceram com eles que as pessoas deixaram ou fundaram aldeias, ou que estreitaram relações de aliança com outras.

Estas pessoas e suas aldeias são pontos de apoio mnemônicos, ou ainda, pode-se dizer que o que acontece com eles, acontece também com um grupo - uma homologia entre pessoa e coletivo cuja exploração é um dos objetivos desta tese. Esta questão toca em um ponto 
importante do egitsü, já que este ritual é feito, entre outras coisas, para "se lembrar" de chefes mortos. Heckenberger (2005: 246) nota que nomes de chefes "are permanent markers of past settlements, whereby the memory of the settlement is, to some degree, isomorphic with the chief". O movimento que culmina no aparecimento de algo que podemos chamar de "os Kalapalo" é um movimento de diferenciação em relação a um "fundo comum", partilhado por vários grupos, do qual os protagonistas emergem como anetü. Há muito tempo, uma série de grupos partilhavam uma condição comum de se considerarem, reciprocamente, kukuge $e^{22}$, "nossa gente". Desse fundo comum é que foi (e ainda é) preciso extrair, por meio de sucessivas diferenciações, algo como "os Kalapalo". Relacionando chefes a certos lugares e conectando-os aos chefes atuais, os Kalapalo fazem surgir uma identidade que atravessa o tempo - mas suscetível a fraturas justamente em torno da chefia. Não que já não houvessem diferenças claras - já no tempo do lago Tahununu os ancestrais dos Kuikuro e Kalapalo eram considerados diferentes (em grande medida pela diferença linguística): enquanto várias aldeias eram de "kalapalo îhügu", ancestrais dos Kalapalo, outras tantas eram de ancestrais dos Kuikuro. O ponto é como estas diferenças se refinam e se cristalizam em conjunto com a produção de uma memória coletiva específica.

Na segunda parte do capítulo, analiso relatos sobre o contato com os brancos e seus possíveis impactos sobre a chefia. Começo pelo aparecimento dos brancos quando os Kalapalo viviam na região do Buritizal (Angahuku), focalizando a chegada de Õdoni ${ }^{23}$ (o primeiro kagaiha que esteve entre os Kalapalo e que, dizem, teria vivido cinco anos entre eles) e as memórias dos ataques e sequestros de filhos de chefes. Veremos que no primeiro contato já existia, em potencial, um modelo de relacionamento com os brancos, do qual tratarei em mais detalhes na seção sobre os "donos dos brancos" (kagaiha oto) no capítulo 6: uma forma de domesticação e aparentamento análoga àquela entre humanos e espíritos. Além disso, a violência sofrida com as incursões dos bandeirantes criou uma situação na qual, dizem os Kalapalo, "a chefia ficou confusa", pois os "herdeiros" ideais de seus chefes teriam sido aniquilados. Em seguida, abordo a história kalapalo a partir da chegada da Expedição Roncador-Xingu, apresentando um panorama do que aconteceu com a chefia dos anos 1940 até os dias de hoje. Investigo a sucessão de chefes em relação às redes de parentesco, a situação de tensão entre os dois chefes principais descrita por Basso (Basso, 1973; Becker,

\footnotetext{
${ }^{22}$ Ku-kuge (12-gente).

${ }^{23} \mathrm{Ou}$, segundo outro mestre de histórias, Ãtoni.
} 
1969) no final dos anos 1960, alguns de seus efeitos posteriores, e me pergunto se tensões contemporâneas não podem ser relacionadas à reemergência de diferenças que fizeram parte de processos mais antigos de fusão e fissão.

A partir disso, sugiro que os chefes podem ser pensados como pontos de referência para a produção e continuação de identidades coletivas ao longo do tempo. Eles não apenas são indispensáveis para a produção e manutenção de "coletivos individuais" (aldeias) ou de “coletivos regionais" (aglomerados), mas também para a reprodução de uma ideia de coletivo que pode abarcar várias aldeias em diferentes momentos do tempo. A existência de uma "forma-chefe" é indispensável para a produção de uma única aldeia, de um aglomerado e também de algo durável no tempo como um "povo", sendo um elemento capaz de efetuar recortes tanto sincrônicos quanto diacrônicos. Um dos argumentos desta tese é que a estabilização de tais recortes está associada à transformação intencional de certas pessoas em "memoráveis", parte importante do processo de produção do parentesco e uma das razões pelas quais os chefes precisam ser construídos como ancestrais no egitsü.

\subsubsection{Nota sobre a apresentação de narrativas}

Há uma longa lista de trabalhos sobre as artes narrativas dos Kalapalo (Basso, 1985; 1986; 1987b; 1995; 2001) e Kuikuro ${ }^{24}$ (Franchetto, 1986; 1993; 1998; 2000; 2003b). Cada história (akinha) compõe uma unidade narrativa que se distingue da fala corriqueira por uma série de mecanismos: sentenças de abertura e conclusão; divisão em linhas e blocos definidos por temas, referências espaciais ou temporais, e organizados por macro e micro paralelismos; a entonação da voz do narrador (o "dono de histórias" ou "mestre de histórias", akinha oto); e a exigência de um interlocutor especial, que Basso (1985) chama de what-sayer (tütsoho algo como "que serve para perguntar", ou "perguntador"). Passa-se com muita facilidade da fala cotidiana para uma narrativa estruturada, mas um ouvido atento percebe, pela mudança de tom, pelas repetições e pelo grau de atenção dos demais, quando alguém está narrando uma akinha.

\footnotetext{
${ }^{24}$ Análises que certamente também são válidas, ao menos em linhas gerais, para os demais karib xinguanos.
} 
Todo tipo de narrativa é chamada de akinha, palavra formada a partir da raiz aki, "palavra" (Franchetto, 1986). O termo é usado para se referir a qualquer tipo de relato, seja algo tão importante e mítico como o nascimento dos gêmeos Taũgi e Aulukumã, ou algo tão corriqueiro quanto a pescaria de alguém que foi atrapalhada por um grupo de ariranhas. Não há nenhum termo que se refira especificamente a "mitos", mas, ainda assim, algumas akinha são chamadas de akinha hekugu, isto é, "histórias verdadeiras/boas", que se referem geralmente a acontecimentos sérios e muito antigos. Já as "histórias feias/ruíns" (akinha hesinhügü), são geralmente narrativas de conotação sexual e que não estão ligadas a nenhum evento importante, tendo apenas a função de divertir ${ }^{25}$.

O paralelismo de sentenças é amplamente utilizado em pontos chave das narrativas, especialmente quando o narrador deseja marcar nomes de lugares, eventos e nomes de pessoas. Às vezes as repetições utilizam recursos de topicalização (Franchetto, 2003b), produzindo mudanças de foco ou ponto de vista sobre um evento, e funcionam como elementos de memorização para os que ouvem uma narrativa (Fausto, Franchetto et al., 2011). O recurso à repetição contribui para a fixação de informações na memória dos ouvintes, e é nestas ocasiões que o narrador espera que o what-sayer também repita o que está sendo dito. Além disso, as repetições fazem parte de uma história bem contada, e marcam a capacidade de um narrador como "mestre de histórias" (akinha oto).

Seria muito interessante apresentar as histórias seguindo suas próprias divisões em linhas e blocos, para que o leitor tivesse ideia do ritmo que uma narrativa kalapalo segue e de onde são colocadas suas ênfases. Porém, por uma questão de economia de espaço e fluidez na leitura, apresentarei principalmente resumos de traduções; apenas algumas passagens serão apresentadas em kalapalo, quando eu julgar que elas são especialmente elucidativas ou que contêm palavras importantes para a análise. Nestas ocasiões, linhas com diferentes tabulações indicam paralelismos e mudanças de tom de voz (cada tabulação indica uma queda na entonação e, na maioria das vezes, no ritmo da fala ${ }^{26}$ ).

\footnotetext{
${ }^{25}$ Não que as akinha hekugu não possam ser divertidas, sendo algumas dedicadas à narração de eventos muito engraçados (como o conjunto de histórias sobre Ahasa, o espírito canibal da mata).

${ }^{26}$ Mudanças no ritmo e na entonação são um traços comum a toda performance narrativa, conforme já notado por Basso (1985: 25-28) e Franchetto (1986: 324).
} 


\subsection{Uma Babel xinguana}

Os Kalapalo possuem uma história fantástica a respeito de uma grande aldeia, localizada pouco acima da confluência do ribeirão Sete de Setembro (Tügüingi, em kalapalo) com o Culuene. Esta aldeia ficava perto das margens do rio e se chamava Kuakutu exatamente como a casa dos homens (kuakutu). A palavra parece ter origem arawak (kuwakuho em wauja, ou kuwakuhü em mehinaku ${ }^{27}$ ), cuja tradução desconheço. O interessante é que, em kalapalo, Kuakutu é também o nome de um itseke ("espírito"), uma onça pintada gigante que é o dono da curva do Culuene em cujas margens ficava a aldeia de mesmo nome ${ }^{28}$. Ali havia uma espécie de "Babel xinguana", pois lá teriam vivido juntos os ancestrais de todos os povos do Alto Xingu, cada um falando sua língua e liderado por seus respectivos chefes. Kuakutu incluía todos os tipos de kuge, gente xinguana, menos os "índios bravos" (ngikogo). É muito curiosa essa coincidência entre a capacidade de aglutinação da aldeia Kuakutu no tempo mítico e do kuakutu atual, a casa dos homens: tanto uma quanto outra têm a capacidade de reunir a grande heterogeneidade dos povos xinguanos, variedade marcada justamente pelas línguas e pelos chefes (dois grandes focos das performances em frente à casa dos homens durante os rituais regionais).

Kuakutu fora chefiada por um grande anetü chamado Aküana, considerado pelos Kalapalo como um ancestral importante, um dos "maiores" e "mais famosos". De início pensei: “bom, sendo a versão deles da história, é claro que a aldeia será kalapalo e seu chefe será seu ancestral". Contudo, nas idas e vindas entre Canarana e a área dos arredores de Kuakutu (o porto da Fazenda Sayonara, onde costumo embarcar para Aiha), pessoas Kuikuro, Matipu e Nahukua me disseram, em diferentes ocasiões, que aquela aldeia pertencera de fato a ancestrais dos Kalapalo (e não Kuikuro, Matipu ou Nahukua...). Aküana é lembrado como um grande anetü nos discursos que os chefes kalapalo fazem para recepcionar mensageiros estrangeiros, nos quais evocam nomes de chefes do passado (cf. capítulo 5). É interessante que o chefe da aldeia matipu Küngahünga, que herdou a chefia de seu avô materno, um anetü kalapalo, também menciona Aküana nos discursos que faz. Conheci um homem kalapalo que portava esse nome, filho de nobres e ligado à principal parentela de chefes de Aiha (homenageado no egitsü de 2008), e sei de um grande anetü kuikuro, casado com uma mulher

\footnotetext{
${ }^{27}$ Franchetto, 2011, Anexo I (sem página).

${ }^{28}$ Os Kalapalo dividem os rios segundo suas curvas, que delimitam regiões dominadas por algum espírito.
} 
kalapalo, que também se chamava Aküana (mas que não aparece nas versões kuikuro disponíveis do discurso de recepção).

Os Kalapalo dizem que esta é a aldeia mais antiga de que se lembram, e todos para quem perguntei dizem conhecer apenas uma única história sobre ela. A narrativa trata do evento que levou à dispersão e reorganização dos moradores de Kuakutu, o que teria dado origem a diferentes grupos que os Kalapalo situam a meio caminho entre o tempo de Kuakutu e o tempo de Kuapügü (a principal aldeia em relação à qual constroem sua identidade coletiva - chegaremos lá no momento oportuno). Não se trata, à primeira vista, de um grande evento, pois veremos que os moradores de Kuakutu a abandonaram porque a esposa de Ahema, tio materno do chefe e mestre do arco Aküana, fez sexo com um índio feroz (ngikogo; aqui chamado de "fedorento", tühitsenhekinhü) durante um ritual de furação da orelha dos meninos (tiponhü). Esta narrativa é interessante porque lida com a relação entre unidade e multiplicidade na continuação do processo de diferenciação dos grupos humanos após a criação. Quando fez os humanos, Taũgi (Sol) já havia dado a cada povo uma língua, objetos e feito alguns chefes, separando a gente xinguana dos outros índios e criando diferenças entre os próprios xinguanos. Mas naquele tempo, e naquele lugar específico, a humanidade xinguana cabia toda em uma só aldeia.

\section{Mito 1: Um Fedorento fez sexo com a esposa de Ahema (Ahema hitsï ikupügü) ${ }^{29}$}

Havia uma grande aldeia no local onde hoje é a fazenda Sayonara, e lá viviam ancestrais de todos os povos do Alto Xingu, cada um falando sua língua. O dono da aldeia e chefe principal era Aküana, um mestre do arco, e ele tinha um tio materno chamado Ahema. Lá, Aküana estava patrocinando um tiponhü (festa de furar a orelha dos meninos), e enquanto as pessoas cantavam, à noite, um Fedorendo ${ }^{30}$ se aproximou da aldeia sem ser percebido. Ele cobriu sua cabeça com palha de buriti para se disfarçar e foi até o meio das pessoas que cantavam no tiponhü. Ele agarrou a esposa de Ahema, a levou para o mato e fez sexo com ela. Depois, a esposa de Ahema voltou sem ser notada, e enquanto ela dançava outras mulheres perceberam que ela estava com um cheiro ruim. "Credo!", começaram a dizer entre si e cuspindo no chão, "Que horror esse cheiro da esposa de Ahema! Um Fedorento fez sexo com a esposa de Ahema!". Ahema acabou ouvindo, e por causa disso bateu em sua mulher. Todos fugiram de

\footnotetext{
${ }^{29}$ Narrada por Ageu em maio de 2007, em sua casa na aldeia Aiha.

${ }^{30}$ Um "índio bravo", ngikogo. Os Kalapalo chamam de "fedorentos" seus inimigos que passavam óleo de tucum no corpo como, por exemplo, os Kayabi.
} 
Kuakutu com muito medo. A aldeia se dividiu, e enquanto alguns subiram o rio, outros desceram. Aqueles que foram rio acima eram parte dos ancestrais dos Yawalapíti (Agahütü, para os falantes de karib), falam exatamente sua língua, e ficaram conhecidos como Agahütü Kuẽgü.

Aküana não fugiu, e ficou em Kuakutu apenas com sua mãe. Depois de cinco dias, ele disse a ela que ia para o mato, mas era mentira. Ele namorava uma reclusa, filha de seu tio materno Ahema, e foi atrás dela. Ele andou por cinco dias, até que encontrou um lugar onde seu tio estava construindo uma casa provisória, no meio do mato. À tarde ele foi até a reclusa, disse que estava ali para levá-la de volta para Kuakutu e eles fugiram. Seus pais deram sua falta e foram procurá-la, mas nem sinal da jovem. Até que viram pegadas sobre um morrinho de terra, e imaginaram que Aküana a tivesse roubado. Então, eles voltaram para Kuakutu atrás de sua filha. Após reconhecerem que Aküana havia se tornado seu genro ${ }^{31}$, decidiram voltar a morar ali. Pouco depois, muitos dos que haviam descido o rio voltaram para Kuakutu e aldeia cresceu muito. Mas os Agahütü Kuẽgü, que talvez tenham ido em direção a Angahuku (Buritizal), nunca mais foram vistos.

Várias coisas fazem desta narrativa um relato interessante. Primeiro, não conheço nenhum mito semelhante que tenha sido registrado entre os Kalapalo ou mesmo entre outros xinguanos. Quando complementado por outras informações a respeito de Kuakutu e pelo que se sabe de aldeias que vieram depois, ela soa como uma espécie de "mito de origem política" da sociedade xinguana. O movimento geral descrito pela história é a divisão da grande Kuakutu, onde viviam todos os ancestrais dos povos xinguanos, após a qual um grupo de ancestrais dos Yawalapíti teria subido o rio Culuene e se mudado provavelmente para a região do alto rio Buritizal, a leste, enquanto outros teriam descido o rio. Os primeiros nunca mais voltaram e se tornaram um grupo que ficou conhecido entre os karib como Agahütü Kuẽgü ${ }^{32}$, e entre os próprios Yawalapíti como Yawalapíti-kumã. Isto porque, ao se separar dos ancestrais dos Yawalapíti, este grupo teria se tornado kuẽgü (em karib), ou kumã (em arawak): outro, distante e que pode apresentar algum perigo (Franchetto, 1986; Viveiros de Castro, 1977; 2002b). Segundo os Kalapalo, eles seriam propensos a roubar mulheres, mas não à guerra ${ }^{33}$.

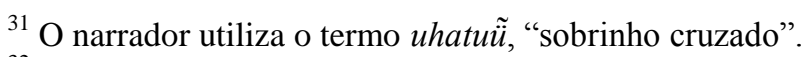

32 Os “Agavotoqueng” da literatura (Villas Boas e Villas Boas, 1970: 46-47).

${ }^{33}$ Contudo, Basso (2001: 296) afirma que a aldeia Akuku teria sido frequentemente atacada por eles.
} 
Neste ponto, as tradições orais yawalapíti e kalapalo se cruzam de perto, pois os Yawalapíti afirmam que este outro contingente de seus ancestrais (Yawalapíti-kumã) teria migrado para o alto Culuene, justamente a região de Kuakutu e o sentido de sua migração descrito na narrativa. A aldeia mais antiga da qual os Yawalapíti se lembram é a da qual deriva seu etnônimo (Yawalapíti, "lugar de muitas palmeiras tucum"'), localizada mais ao norte, em algum lugar entre o Posto Diauarum e o Morená (Viveiros de Castro, 1977: 64). Seus ancestrais teriam começado a migrar em direção ao sul por causa de frequentes ataques que sofriam dos Manitsawá (tupi, já desaparecidos) ou dos Trumai. Após a morte do chefe Tatĩwálu (o ancestral histórico mais antigo dos Yawalapíti), outros dois chefes (seu irmão Uaripirá e seu primo cruzado Yanumaka) lideraram seu povo ao longo do Culuene. No local onde está a aldeia Yawalapíti atual, Emakapúku, na boca do rio Tuatuari, houve um desentendimento entre estes dois chefes. Yanumaka decidiu se estabelecer em Yakunipü, no que foi a primeira aldeia dos Yawalapíti na região em que se encontram hoje; já Uaripirá teria continuado a migração para o sul com parte do povo, subindo até as cabeceiras do Culuene e seguindo o curso do ribeirão Sete de Setembro.

É tentador ver nos Agahütü de Kuakutu os dissidentes do grupo do chefe Uaripirá. Aqueles que, segundo os Kalapalo, ainda eram apenas Agahütü, já haviam se tornado “outros" para os Yawalapíti que ficaram na região onde estão hoje (já eram Yawalapíti-kumã para seus parentes). Segundo o narrador e a pessoa que me ajudou na tradução, alguns Agahütü também teriam descido o Culuene, dando origem aos Yawalapíti conhecidos - o que contrasta com a memória yawalapíti, que recorda sua chegada pelo norte. Mas seria interessante investigar se os Yawalapíti conhecem algo sobre parte dos dissidentes terem voltado das cabeceiras do Culuene, o que poderia aproximar ainda mais as duas tradições orais.

Dos que desceram o rio, muitos voltaram para Kuakutu, mas não todos, e desta divisão teriam resultado aldeias de vários povos alto-xinguanos. Daí, ou pouco depois - nenhum mestre de histórias em Aiha soube precisar -, é que teriam surgido os Akuku otomo ${ }^{35}$, um dos principais grupos ancestrais dos Kalapalo (mencionados por Becker, 1969: 12; Franchetto, 1986: 65; Franco Neto, 2010: 68). Eles e as aldeias que se formariam a partir de divisões de

\footnotetext{
${ }^{34}$ Astrocaryum vulgare.

${ }^{35}$ Coletivo de oto, “dono". Refere-se aos moradores de um lugar, e as aldeias xinguanas são designadas em karib por X otomo, onde X é geralmente um topônimo (Franchetto, 1986: 67).
} 
Akuku ocuparam principalmente a região do alto Culuene e seus afluentes. Segundo Franchetto (1986: 63), Akuku ficaria a sudeste da confluência deste rio com o Tanguro. Uma vez que Kuakutu havia sido dividida, a multiplicação de grupos locais introduziu novas diferenças na série dos kuge. Cada povo já tinha sua língua, seus chefes e suas especialidades produtivas, e agora cada um tinha também aldeias próprias.

Da ênfase na divisão, a narrativa passa para a reorganização da aldeia. Quando Aküana consegue roubar sua namorada (fazendo dela sua esposa), com ela resolvem voltar também seus pais ${ }^{36}$ (que reconhecem que Aküana se tornara seu "sobrinho uterino" - i.e., seu genro) e "todos os outros" (menos os que se tornaram Agahütü Kuẽgü). Um dado importante é que a narrativa marca Aküana como um mestre do arco, um tahaku oto. Basso $(1989 ; 1995$ : 91-189) já explorou de forma bastante extensa e detalhada algumas dessas figuras e, por isso, vou retomar apenas o seu argumento central. Os mestres do arco eram homens preparados desde crianças por seus pais para se tornarem arqueiros habilidosos, pessoas fortes, ágeis, dotados de grande inteligência estratégica e de extrema beleza. Eram os responsáveis por defender sua aldeia e eventualmente realizar ataques de retaliação a aldeias de inimigos. Segundo Basso (1995: 97-104), eles eram uma figura fundamental quando as relações bélicas na região eram mais aquecidas, os ancestrais dos povos xinguanos ainda não tinham se adaptado a um mesmo ethos e o sistema regional parecia longe de ser pacífico. A ampliação do que Basso chama de "campo de julgamento ético" (field of ethical judgement; ibid: 132), isto é, o alcance do ethos xinguano, idealmente pacifista, progressivamente teria reduzido a importância dos mestres do arco nas relações regionais e aumentado a dos chefes, indicando uma mudança de um período mais guerreiro para um marcado pela interação ritual.

No tempo dos mestres do arco, estes tipos de pessoa pareciam indispensáveis para garantir a unidade de uma aldeia, e mesmo a viabilidade de se manter várias aldeias próximas em uma região, sobrepondo-se à figura dos chefes. O caso mais exemplar que tenho em mente é o do passado dos karib ao redor do grande lago Tahununu. Os Kalapalo contam que seus ancestrais se sentiam seguros vivendo naquela região quando o lago tinha como dono, não um espírito, mas um humano, o maior de todos os mestres do arco e ancestral dos Kuikuro: Tamakahi (ou, como os Kalapalo gostam de chamá-lo, "Rambo"). Às margens do Tahununu havia uma grande quantidade de grupos falantes de karib e tupi (especificamente do tupi

\footnotetext{
${ }^{36}$ Um caso peculiar no qual um sogro se desloca em direção a seu genro, enquanto a tendência à residência uxorilocal tende a fazer o genro se deslocar em direção a seu sogro.
} 
kamayurá, e não do aweti), cujas relações oscilavam entre guerras e alianças (inclusive alianças interétnicas no combate a outros grupos). Isso se deu provavelmente no século XVIII, quando os grupos proto-kamayurá devem ter chegado à região (Heckenberger, 2005; Menezes Bastos, 1990; 1995). Tamakahi protegia o lago, tinha roças imensas, era o homem mais desejado pelas mulheres da região e era invencível. Por causa disso, era muito invejado pelos ngikogo canibais (ancestrais de outros tupi, talvez?) e depois de grandes batalhas narradas longa e detalhadamente, é finalmente morto e devorado ${ }^{37}$. As grandes migrações do Tahununu começaram a acontecer, segundo os Kalapalo, após a morte de Tamakahi. Em Agahahütü ("lugar de agaha", uma espécie de peixe), a principal aldeia de ancestrais dos Kalapalo naquela região, as mulheres faziam canções sobre seus namorados e amantes, principalmente Tamakahi, seus primos e filhos de chefes, que deram origem ao tolo (um importante gênero musical feminino ${ }^{38}$ ). Depois da invenção do tolo e da morte do dono da lagoa, as pessoas do Tahununu começaram a se dispersar, e seus arredores foram sendo progressivamente abandonados.

No caso de Aküana, menciona-se que ele era um mestre do arco, e as pessoas voltam para Kuakutu sem muita explicação. Me parece que estas duas coisas podem estar ligadas, na medida em que ter um mestre do arco em uma aldeia era, naquele tempo, indispensável. Os moradores de Kuakutu haviam abandonado a aldeia, onde ficaram apenas Aküana e sua mãe, por medo dos ngikogo, e voltam aparentemente sem nenhuma razão - mas a menção à sua condição de mestre do arco pode ser a chave, pois só um mestre do arco seria capaz de trazer segurança à aldeia e, assim, mantê-la.

A menção às casas em construção e à distância das mudanças (Aküana leva cinco dias para encontrar o abrigo que seu tio construía) sugerem que os que fugiram não pretendiam voltar. Esta história toca em uma das principais características de um grande anetü: ele é uma pessoa capaz de agregar, fazer com que as pessoas desejem viver juntas em sua aldeia - e não em outra. As pessoas podem se mudar para onde bem entenderem e quando bem quiserem, mas o que provoca esse tipo de movimento é, ou a criação de uma aldeia própria, ou o desejo de viver na aldeia de outro chefe. Como veremos em mais detalhes no capítulo seguinte, o chefe é pensado como um protetor, alguém que cuida de suas "crianças" (seu povo)

\footnotetext{
${ }^{37}$ Vale a pena notar a teoria kalapalo sobre o canibalismo: os inimigos de Tamakahi queriam comê-lo para obter sua força e beleza.

${ }^{38}$ Uma pesquisa sobre este gênero musical entre os Kalapalo, cuja origem é atribuída a seus ancestrais, traria contribuições valiosas para a etno-história karib.
} 
oferecendo comida, objetos e conselhos. Em alguma medida, os mestres do arco também tinham essa capacidade de "cuidar" e, portanto, se adequavam mais ou menos a uma formachefe que parece indispensável para a produção e manutenção de coletivos. Isto aproxima, de maneira talvez um pouco torta (mas o objetivo aqui é, justamente, torcer), a chefia xinguana atual de lideranças guerreiras do passado e, assim, de outras formas de liderança conhecidas entre povos geralmente colocados no extremo oposto dos alto-xinguanos - como os jívaro e os "tipos ideais" de povos tupi, por exemplo, nos quais os guerreiros eram as pessoas propensas a sustentar unidades sociais mais abrangentes em situações de conflito (Descola, 1988; Sztutman, 2005).

Se voltarmos um pouco no tempo, vemos que já houve outra aldeia (que será abordada com mais detalhes no capítulo 3), além de Kuakutu, que reunia uma variedade enorme de pessoas - não a gente do tempo dos xinguanos, os seres humanos criados por Taũgi, mas os animais terrestres (ngene) do tempo mítico. Todos viviam em Haukugu, uma aldeia no alto Culuene (bem mais acima do que Kuakutu) chefiada pela onça mítica Enitsuẽgü, chefe de todos os animais terrestres (inclusive das outras onças). Foi somente após uma guerra dos humanos criados por Taũgi contra o povo de seu pai-onça, e a partida de Enitsuẽgü para o céu, que os animais terrestres se espalharam pelo mundo em aldeias diversas. Há correlações curiosas entre estas duas aldeias: no tempo antes dos humanos, a aldeia do grande chefe Onça reunia todos os animais, e um episódio importante da saga da criação dos humanos narra sua dispersão; em outro momento, já no tempo humano, outra onça-chefe (Kuakutu) é apresentada como o espírito dono da região onde uma aldeia homônima reunia todos aqueles considerados kuge, e cuja história também narra sua dispersão.

Onças, a capacidade de conter ou unificar e tendências à fragmentação não aparecem juntos por acaso. Esta situação guarda várias semelhanças com a descrição feita por Costa (2007) dos Kanamari, um povo de língua katukina da Amazônia Ocidental, que habita a região da bacia do rio Juruá. Segundo Costa (ibid: 182), os Kanamari dizem que havia um tempo no qual todos viviam de acordo com um modelo de "endogamia de subgrupo". Neste modelo de organização social, cada subgrupo estaria circunscrito a uma bacia hidrográfica na região do Juruá e seria composto por diversas aldeias. Uma delas seria a aldeia do chefe do subgrupo, sempre localizada no alto curso do principal rio da bacia, enquanto as demais aldeias, pertencentes a chefes menores, se localizariam no curso mais baixo dos tributários deste rio principal. Ainda segundo Costa, esta capacidade de produzir unidade seria uma 
característica dos Jaguares: todos os seres-Jaguar seriam, no tempo mítico, os continentes de toda a variedade dos seres, que passaram a existir separadamente conforme as formas-Jaguar foram se decompondo em formas menos potentes e menos englobantes. De seus corposcontinentes, únicos, imóveis e predadores, teriam saído todos os outros seres e coisas, múltiplos, móveis e em condição de presa. Segundo o autor (Costa, 2007: 211):

Como numa espécie de Big-Bang, o universo primordial emergiu comprimido no 'corpo' (-warah) do Jaguar e, através de repetidos ataques a este corpo, começa a esvair-se dele, tornando-se sucessivamente menos Jaguar (...).

Teríamos então uma associação análoga à descrita por Costa, com "aldeias-onça” rio acima (Haukugu e Kuakutu) exibindo uma grande capacidade de contenção/unificação da diversidade - mas em uma unidade sempre prestes a se desfazer. De um lado, o chefe onça que continha todos os animais em sua aldeia (Enitsuẽgü e seu povo em Haukugu), e de outro, a aldeia-com-nome-de-onça (Kuakutu) que continha em si toda a diversidade sociopolítica do Alto Xingu. E por que não chamar também a própria casa dos homens, o kuakutu, de casaonça, já que leva o nome desse espírito felino? Só ela é capaz de abrigar em seu interior todos os espíritos com os quais os humanos se relacionam, de maneira controlada (as perigosas flautas kagutu ${ }^{39}$, o Redemoinho, o Arraia Gigante, o Hiper Papagaio - qualquer um), e em sua frente, durante o egitsü, toda a variedade humana do Alto Xingu. Haukugu, Kuakutu e kuakutu - a aldeia da Grande Onça, a aldeia no lugar dominado por uma Onça-espírito e a casa dos homens que carrega o nome desta onça - podem ser vistas como formas-onça equivalentes às descritas por Costa entre os Kanamari, corpos capazes de conter, de maneira instável, a heterogeneidade dos seres em diferentes escalas. Mas por que a onça, esse emblema máximo da predação, em um lugar como o Alto Xingu, onde as atividades "predatórias" (guerra e caça) são vistas como perigosas e improdutivas? As ideias xinguanas sobre a chefia foram tão negligenciadas que é preciso ir por partes, e essa questão só será abordada a partir do capítulo 3 (mas nos acompanhará até o final da tese).

Apesar de seu grande potencial para produzir unidades abrangentes - a capacidade de conter uma grande heterogeneidade sob formas unitárias -, estas formas-onça estão fadadas a se dissolver. Haukugu acaba e os animais se dispersam, Kuakutu se divide e cada povo cria

\footnotetext{
${ }^{39}$ Aerofones que não devem ser vistos pelas mulheres.
} 
suas próprias aldeias, e mesmo a casa dos homens não pode sustentar uma vida ritual contínua. Ninguém parece ser capaz de produzir uma unidade permanente, pois sempre que alguma unidade é atingida, é sob a condição de se retalhar em seguida.

\subsection{Outros iguais}

Todos os mestres de história reconhecem que há um enorme intervalo de tempo entre o desmembramento de Kuakutu e as aldeias das quais os Kalapalo se lembram em seguida. É unanimidade que Kuakutu é muito mais antiga do que qualquer outra das aldeias karib nomeadas, e nenhum mestre de histórias soube me dizer se qualquer uma delas teria ou não coexistido com Kuakutu. Dois deles me disseram que algumas pessoas que saíram de Kuakutu teriam aberto Akuku, importante ponto de referencia histórico, territorial e político para os Kalapalo, a partir de onde outras aldeias (Hagagikugu, Kankgagü e a primeira Angaguhütü) teriam sido abertas ainda mais ao sul.

A literatura frequentemente associa os Kalapalo a Akuku (Becker, 1969; Franchetto, 1986; Franco Neto, 2010), possivelmente abandonada em meados do século XIX. Franchetto (1986: 65-66) diz que, durante sua pesquisa de doutorado, os Kuikuro mais velhos chamavam os Kalapalo apenas de Akuku otomo, “os donos de Akuku” ou “o povo de Akuku”. Quando fui a Aiha pela primeira vez, também ouvi um homem dizer que Kalapalo não seria o "nome verdadeiro" de seu povo, e sim Akuku. Mas rapidamente chamaram minha atenção para a complexidade dessa informação, pois quando eu tentava checá-la, sempre me deparava com afirmações de que "não era só Akuku", que "antigamente havia muitos povos Kalapalo", ou que antigamente havia "Kalapalo otohongo tuhugu" ("muitos outros iguais aos Kalapalo").

As duas últimas afirmações podem parecer um pouco estranhas de início, mas na prática elas são bastante precisas. Os Kalapalo identificam vários grupos antigos como sendo "outros iguais aos Kalapalo", em parte porque falavam sua língua e, em parte, porque tinham com eles, relações de parentesco muito próximas. Não que os ancestrais dos Kuikuro, Matipu e, principalmente, Nahukua, também não mantivessem relações próximas com os ancestrais dos Kalapalo, mas há que se considerar os aspectos sociopolíticos destas distinções. A visão de que havia "outros iguais aos Kalapalo" ou "muitos povos Kalapalo" está ligada não só à proximidade linguística, mas às alianças entre os grupos - alianças bélicas, rituais e 
matrimoniais - que, no decorrer da história, permitiram que alguns se misturassem mais do que outros (misturas que vieram acompanhadas de novas diferenciações). Este passado de diferenças não se apaga, e sua memória esteve no centro de processos de fissão desde, pelo menos, a virada do século XIX para o XX.

A seguir, acompanharemos a história da mudança de um homem viúvo (chamado Temetihü), seus cinco sobrinhos uterinos, suas noras e seus netos, de uma aldeia chamada Amagü para um lugar chamado Kuapügü, onde foi erguida a aldeia considerada o grande ponto de referencia da "identidade kalapalo" - todos os karib reconhecem que os Kalapalo atuais são os descendentes dos vários falantes de karib que viveram naquela aldeia. Ao final desta narrativa, acrescentarei uma breve versão dos Nahukua sobre sua história e observações de duas mulheres angaguhütü sobre suas origens, que me permitirão lançar algumas hipóteses: 1) os Kalapalo atuais descendem principalmente de dois contingentes karib, Akuku e Amagü, que parecem ter realizado migrações paralelas, mas se reuniram em Kuapügü por causa de relações rituais e da mudança de um chefe; e 2) o reconhecimento dessa diferença parece ter feito parte de alguns processos de fissão, como por exemplo o surgimento dos Angaguhütü na virada do século XIX para o XX e a criação da aldeia Tankgugu entre o final dos anos 70 e o começo dos 80 .

\subsubsection{De feiticeiro a ancestral}

Durante o campo ouvi a história de Temetihü cinco vezes, quatro em kalapalo e uma em português. Eu poderia apresentar qualquer uma das versões (inclusive a em português), pois a precisão com a qual os detalhes se replicam é impressionante. Optei por trabalhar com versão aqui apresentada pelo contexto em que foi contada, durante uma conversa na qual eu havia perguntado ao narrador sobre a possibilidade dos Kalapalo e os Nahukua terem vivido juntos em uma aldeia chamada Timpa, próxima ao rio Mirassol. Eu só tinha ouvido falar de Timpa uma vez, em um texto de Basso (2001), mas este nome e esta questão foram levantados por um professor da aldeia Jagamü durante uma oficina de documentação linguística na aldeia Küngahünga ${ }^{40}$, da qual participei. A pergunta causou algum furor nas

\footnotetext{
40 A oficina, coordenada por Bruna Franchetto e Mara Santos, foi parte do projeto "Levantamento SócioLinguístico e Documentação da Língua e das Tradições Culturais das Comunidades Indígenas Nahukwa e
} 
pessoas da casa (inclusive em outro dono de histórias que chegou no meio da conversa e em uma mulher já bem idosa), pois ninguém nunca tinha ouvido falar de Timpa, a não ser os dois donos de histórias, superficialmente.

O narrador se pôs a esclarecer que havia duas versões sobre a origem dos Kalapalo, cada uma contada por um dos dois últimos grandes chefes de Aiha, e só quem manteria a versão sobre Timpa atualmente seria, na verdade, o chefe da aldeia Jagamü. Em vários momentos, o narrador observa que com seu pai ele aprendera uma versão específica, mas que isso não excluiria a outra, pois, como ele mesmo diz, "as histórias são misturadas". Esta história tem ainda uma peculiaridade: o personagem principal, que se muda de Amagü para abrir Kuapügü, onde se torna um grande chefe, é um homem acusado de feitiçaria. Tendemos a associar "histórias de ancestrais" a grandes nobres, pessoas importantes - mas a um feiticeiro? Justamente o antípoda da sociedade xinguana é quem se torna iho, "chefe/esteio", de Kuapügü.

\section{Mito 2: Kuapügü foi aberta (por Temetihü) ${ }^{41}$ \\ Ageu Inhalü aketsange egea api ngipi uãke}

Seu avô não tinha assim

Toko Tüma?

O quê?

Ageu Timpa ta benaha egei iheke

Ele está falando de Timpa

Ugise Timpate nãke kukotsogijü agetsingoi gele Jagamü ake uãke, ta iheke

Ele está dizendo que nós e os Jagamü teríamos aparecido juntos

Jamiku akinhagü aketsange egei

Mas isso é história do Jamiku [chefe da aldeia Jagamü]

Ageu Jamiku akinhagüha egei

Isso é história do Jamiku

Toko Tübena egei Timpai?!

O que é isso, Timpa?!

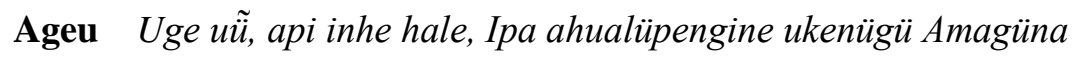

Matipu do Alto Xingu" (executado com o apoio do Ministério da Justiça por meio de um termo de cooperação com a UFRJ-Museu Nacional).

${ }^{41}$ Kuapügü ikenügü (Temetihü heke). Narrada por Ageu em 31 de outubro de 2009, na casa de seu sobrinho Ugise, em Aiha. 
Mas para meu pai, seu avô, dos arredores da Lagoa [Tahununu] nós viemos para Amagü

Tsetalüpengine hale Kuapügü iketa hale egei nãke lahale

E aí de lá é que Kuapügü foi aberta

Amagü tongopengine

Vindo de Amagü

Egea benaha angaũpügü, Müra igehüngü inhe, Timpa gongopengine Kuapügü ikenügü, inhalü uãke angaũpügü inhe egea hale

Era assim para seu avô, já para Müra [outro chefe kalapalo] não era assim, a partir de Timpa, Kuapügü teria sido aberta, mas não era assim para seu avô

Inhalï

Não

Ipa tongopengine - luale nhigatomi uhametigüpe - Agamaniha, Agamaniha ukanetügüi Ipa ahua

Vindo da Lagoa - por favor eu vou chamar meu finado cunhado - Agamani, Agamani nos chefiava nos arredores da lagoa

Ipa ahua tügüha kotote ketihũtelü

Ao redor da Lagoa todos nós aparecemos

Kotote leha tekinhü ĩhũgu telü tuhugu, tekinhü îhũgu telü lá tuhugu, Kamayula

Todos mesmo, os ancestrais de outros povos foram para lá, os ancestrais de vários outros povos foram, Kamayurá também

Lá tuguha

Foi assim

Kukugeha Angahuku kaenga bekuha

Nossa gente foi para o Buritizal

Amagünaha

Para Amagü

Kukugeha helei

Ele [Agamani] era nossa gente/chefe

Egea ekuaketsange api inheha

Para seu avô é assim que foi de verdade

Ugise Müra inheha Timpa gongopengine, ekü ikenügü, ige Kuapügü ikenügü?

Para Müra, vindo de Timpa foi aberta... Kuapügü foi aberta?

Ageu $\tilde{E}$

$\operatorname{Sim}$

Ugise Timpate ketihũtelü ngeleha Müra inhongo Timpate ketihũtelüi gehale?

Para Müra nós aparecemos, para ele, Müra, nos aparecemos em Timpa também?

Ageu Api inhe hale, Amagü tongopengine tsahale egei Kuapügü ikenügü hale kupehe hale 
Já para seu avô, vindo de Amagü é que abrimos Kuapügü

Temetihü heke tsüha, Makala heke, Makala ititüi hale kuge ekugu

Foi Temetihü, Makala - seu nome era Makala, ele era uma pessoa verdadeira

Ihütengibungu hale egei

Ele não ficava parado

Akutungube Temetihü Jali, Jali anümi hale egei

Como Temetihü não se cansava, ele ficou sendo chamado de "Anta",42

[conversa sobre outra história; o narrador prossegue:]

\author{
Ageu Tsakeha \\ Ouça \\ Egehungu aketsegei \\ É deste jeito

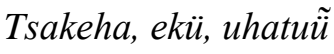 \\ Ouça, meu sobrinho
}

Tahununute uãke kuge betüja ilá tekinhü îhũgu tuhugu

No Tahununu havia muitas pessoas, vários ancestrais dos povos de outras aldeias

Tsetalüpengine hale egei Agamaniha sanetügüi

Lá eles eram chefiados por Agamani

\title{
Agamaniha sanetügüi
}

Agamani era seu chefe

Ipa ahua

Nos arredores da Lagoa

Agahahütü ipagüte

Na lagoa de Agahahütü

Angi gele tüha Kalapalo ĩhũgu hügipe

Lá ainda existem flechas dos ancestrais dos Kalapalo

Awa heke, Haitsehü heke, ihanügü uinha, "angi gele eĩhũko engüpe hügipe geleha", nügü iheke

Meu tio materno, Haitsehü, contou pra mim: "ainda estão lá as coisas de seus ancestrais, suas flechas", disse ele

Ta uãke iheke, api kita tsüha

Assim ele disse, assim seu avô dizia

Itsuni huja bele atühügü leha, nügü iheke, itsuni huja hügepe atühügü

\footnotetext{
${ }^{42}$ A raiz de seu apelido é teme, "anta" em arawak, mas às vezes ele é chamado de Jalitihü, formado a partir de jali, "anta" em karib.
} 
"Elas ficaram bem no meio do mato", disse ele, as antigas flechas ficaram no meio do mato

Amagoha, eĩhũguko hügipe

"As flechas dos seus ancestrais"

Tsetatü itão tolokingunda

Lá as mulheres fizeram tolo

Agahahüte atanini

No tempo de Agahahütü

Igei higei, toloi tsüha igei, ago ngipi

É isso, isso é o tolo que elas têm

Aküngi ojotseko tolotega betuhuguha ihekeni

Elas cantavam tolo para muitos grandes campeões

Ah, tüajoko tolotega ihekeniha

Ah, elas cantavam tolo para seus namorados

Lepene lahale egei atahagatsipügüko Tahununu tongopengine Amagüna

Depois disso eles se mudaram todos do Tahununu para Amagü

Amagüna

Para Amagü

Egea ekutsahale uãke apa inhe hale, Kambetse inhe hale uãke

É assim que foi de verdade para meu pai, para Kambetse

Müra igehüngü inha beha Timpa nanümi leha gehale, nanümi, lango aketsegei

Para Müga era diferente, teríamos ficado em Timpa também, é assim

Egea tsale uãke api ngipiha

Mas era assim que seu avô tinha

Api ngipiha

Seu avô tinha

Tsetabe Amagüte kutsa, ah, aküngi beja!

Nós estávamos lá na grande Amagü, ah!, éramos muitos mesmo

Aküngi beha kutsa beha

Muitos de nós ficavam lá

Tsetalüpengine hale egei, inke mukeapa ande etinkgane

Mas lá, veja só, acusações começaram

Etinkgane

Acusações

Akago inkgataha take hutühügü itsaeni

Acusaram de fazer um desenho para atrair muriçoca 


\section{Üngele beha jali toho Temetihü}

Aquele que era chamado de Anta, Temetihü

\section{Makala bahale ititüi}

Mas seu nome mesmo era Makala

Makala ekuhale sukugetegoho itituii

Makala era seu nome verdadeiro, o que fazia dele gente

[continuação da história]

Em Amagü havia um homem chamado Kahunuma, o grande Kahunuma. Um dia ele foi para o mato e encontrou o espírito Nhahügü (uma mulher itseke que vive na mata). Assustado, Kahunuma fugiu, mas a mulher o seguiu. "Kahunuma, me espere! Por que você está fugindo de mim? Eu estou esperando para te contar que seu irmão te pegou com um feitiço bem aqui, na sua barriga". Então ela passou a unha sobre a barriga dele, tirou o feitiço e se tornou sua esposa. Ela o levava para vários lugares e ensinava seus nomes. Ela o levou até para as aldeias dos brancos, para debaixo da terra e para dentro das árvores, ensinando a ele o nome de tudo.

Na grande Amagü, havia muita muriçoca e ninguém conseguia dormir. Por isso, as pessoas iam dormir no meio do mato e só voltavam para a aldeia quando o sol já estava nascendo. Então o grande Jukagi, chefe de Amagü, disse para Temetihü: "Pergunte a nosso irmão Kahunuma se nossa avó lhe mostrou algum lugar chamado de Kuapü" ("não se sabe como Jukagi já conhecia aquele nome!”, o narrador observa com espanto). Temetihü perguntou a Kahunuma se havia um lugar bom para eles trabalharem, que disse que sim, que havia visto um lugar chamado Kuapügü. Era um lugar muito grande, de muita terra preta ${ }^{43}$, no meio do campo, e que Temetihü poderia ir pra lá. Antes que Temetihü partisse, Kahunuma foi com sua esposa Nhahügü para deixar marcas no caminho. No local definitivo, próximo a um córrego, eles deixariam galhos quebrados. Ele lhe disse então o nome de todos os lugares de Kuapügü até Amagü: começou pelo córrego Hotogi, ao lado de Kuapügü; de lá para Amagü, ele marcaria os lugares Euẽ Akegü, Takeinhü, Tahugape, Ogoko e a plantação de bambu de flechas de Ahagi.

No dia seguinte, seus sobrinhos pediram para que seu tio fosse dar uma olhada. Temetihü era viúvo e sem filhos, tinha cinco sobrinhos uterinos que, junto com suas esposas, cuidavam dele. Ele então foi seguindo o caminho indicado por Kahunuma. Quando chegou a Euẽ Akegü, viu que havia muitas flores bonitas de ipê amarelo no campo, e logo pensou em se mudar para lá,

\footnotetext{
${ }^{43}$ Solo muito fértil de origem antrópica.
} 
de tão bonito que era. Em seguida andou até encontrar os galhos quebrados perto do córrego Hotogi. Lá havia muitos peixes trairões (Hoplias lacerdae) que, de tão grandes, pareciam com os pedaços de madeira usados como peso para as redes de embira. Quando viu aquilo, ele teve certeza que ali seria sua aldeia. Preparou seu mingau, pegou suas flechas e matou cinco trairões. Acendeu uma fogueira, assou seus peixes e ficou ali comendo, em um acampamento improvisado. Ele colocou os trairões que sobraram em um ha (espécie de "mochila" feita do oco de um tipo de palmeira) e veio embora. No dia marcado para seu retorno, a esposa de um de seus sobrinhos pediu que ele fosse procurar seu tio, que estava demorando. Ele foi com seu filho e encontraram Temetihü no caminho. Lá eles se sentaram um pouco, e ele contou a seu sobrinho que havia encontrado um lugar muito bonito e com muitos peixes.

\section{Ilango tsale egei}

Pois é assim mesmo

Lá, lá aketsange

Assim, é assim

Api inhongo taketsegei ungihatanümi

Eu estou contanto como era para seu avô

Api

Seu avô

Tetsualü benaha akinhai

Histórias são misturadas

Teloha egei ngipi akinha, teloha egei, ilango benaha akinha higei

Outros têm histórias diferentes, assim mesmo é que são as histórias

Quando chegou em casa, Temetihü contou a seus sobrinhos. O mais velho disse que eles deveriam se mudar para lá, pois em Amagü seus irmãos estavam falando mal deles, acusandoos de feitiçaria. Temetihü foi para Kuapügü mais uma vez, agora com seus sobrinhos, e foi mostrando a eles o caminho, repetindo os nomes contados por Kahunuma. Lá eles mataram muitos trairões e acamparam. Dormiram tranquilos, pois não havia muriçocas como em Amagü, e acordaram com o canto dos papagaios. Depois de dois dias, voltaram para Amagü para buscar as esposas de seus sobrinhos e massa de mandioca, para começar a abrir a aldeia, e 
passaram muitos dias em Kuapügü. Começaram a limpar o lugar de sua roça de mandioca e de sua casa.

Andeha kuge Akukute gehale kukuge geleha

Havia gente também em Akuku, nossa gente

Kukuge gehale

Nossa gente também

Kukugele tsüha ahütü tsüha engühüngü

Nossa gente mesmo, não eram outros

Kukuge lango bale, kukuge

Eles são nossa gente, nossa gente

Kagaketühügü tsüha

Os que se separaram de nós

\begin{abstract}
Ah, eles cresceram muito! Mas sempre voltavam para Amagü para buscar ramos e massa de mandioca. Sempre que eles estavam em Kuapügü matavam muitos trairões. Começaram a queimar o lugar de sua roça, plantaram muita mandioca e cultivaram muita comida. Fizeram uma casa provisória, que cobriram com palha de sahũaga (uma planta abundante na região, principal alimento dos caracóis usados na produção de cintos e colares). Depois plantaram milho, do outro lado de sua casa. Lá eles ficaram cuidando de suas roças e, conforme foram crescendo, foram aumentando suas roças.
\end{abstract}

Aka benaha sakünginduko!

Nossa, eles eram muitos!

Inhüngüko etükilü

A casa deles cresceu

Ande beha - buh! - ah kuge gele Amagüte etsuhukilükoingo hegei segati leha As pessoas que ainda estavam em Amagü se mudaram para lá

Segati leha

Para lá 
Etsuhukilüko leha

Se mudaram

Tünkgülükoinha etetako

Eles foram para que pudessem dormir

Üngelepe ihetunda leha tseta leha

Eles ficavam gritando lá [em Amagü]

Take hüngene heke, take hüngene beja hm

Por causa das muriçocas

Take hüngene heke beja tüita leha

As muriçocas faziam isso

Aiha

Bom

Aiha tünkgünhangoko tengalü

Pronto, as pessoas iam sempre para lá dormir

Aibegehale tünkgülükonhango telü

E outra vez iam para dormir

Ah tütüki bele etsuhukilüko - buh! - nügü bele Kuapügüte leha

Ah, bem devagar se mudaram para Kuapügü

Tsakeha egehungu tsaketsegei

Ouça, é desse jeito

Api inhongo aketsegei ungihatanümi

Eu estou contando como era para seu avô

Api inhongoha

Como era para seu avô

Ungihatanümi tiha

Eu estou contando

Telo naha Müra igehüngü ngipi tsake apa Timpage ta naha iheke

Para Müga era diferente, não era assim o que ele tinha, ouça, ele falava de Timpa

Timpageha

De Timpa 
Üleki naha egei uhunügü uheke

Esse é o jeito que eu sei

Látsale api inhe hale

Era assim para seu avô

Apunguko bahegei lahale tseta lahale

Eles acabaram lá [em Amagü]

Tseta leha

Lá mesmo

Üngele bele sanetügükope enügü beja inha leha

Até mesmo seu antigo chefe [Jukagi] também foi para lá

Ünago beja iketinhibüngü itsa ihokoi sanetügükoi leha

Aquele que abriu a aldeia se tornou seu esteio, o chefe de todos eles

Temetihü

Depois que Amagü já havia acabado, Kuapügü cresceu muito e ficou cheia de casas, não cabia mais ninguém. Como o lugar era muito bom e ninguém queria sair dali, resolveram abrir uma nova aldeia do outro lado do córrego Hotogi, no lugar chamado Asã Hugogu ("praça do veado"), e lá se tornou a aldeia de nome Kalapalo.

Ilango salegei

Pois é assim

Tsekegü hegei tseta etepei

Lá era muito grande, esta antiga aldeia

\section{Kalapaluteha}

Em Kalapalo

Kalapalu tongopengineha egei

De Kalapalo

Inatsüha egei kumodipügüko Kunugijahütü, Kunugijahütü ititüi

Nós nos mudamos para cá, para Kunugijahütü, Kunugijahütü é o nome

Tana uãke api kita 
Seu avô dizia

Kunugija anügü atehe tseta üle atehe Kunugijahütüi anügü

Há muita kunugija $a^{44}$ lá, por isso se tornou "lugar de muita kunugija" (Kunugijahütü)

Tsakeha

Ouça

Kapitabeha

O grande Kapita

Kankgagü taketsange uãnke elei api kita naha uãke Kankgagü tepügü ingila segati

Seu avô dizia que ele era Kankgagü, Kankgagü, mas que foi cedo para lá

Ülepe Kuapügü anetügüi

Depois se tornou chefe de Kuapügü

Kapita $\tilde{e}$

Kapita, sim

Tsakeha

Ouça

Aiha

Pronto

Upügü aketsegei

Este é o fim

Esta narrativa tem em comum com a anterior começar focalizando um local (Agahahütui) e um chefe (Agamani), uma referência geográfica e outra sociológica. Fala-se desta aldeia ao redor do Tahununu como uma forma de contextualizar o local onde a história se passará de fato, resultado de uma migração de Agahahütü, e novamente são eleitos como referência um lugar (Amagü) e alguém que se tornará chefe (Temetihü). Não encontrei nenhuma história específica sobre a saída dos ancestrais dos Kalapalo de Agahahütü, mas o narrador comenta que isto foi depois que as mulheres começaram a cantar para os grandes lutadores e arqueiros, seus amantes. É importante notar que Agamani também era um mestre do arco, apesar disso não ser mencionado nessa história. No Alto Xingu que conhecemos, os

\footnotetext{
${ }^{44}$ Tipo de bambu usado antigamente para furar as peças dos cintos e colares de concha.
} 
chefes devem ter sido, via de regra, grandes lutadores, mas a etno-história kalapalo sugere que, no passado, a condição de guerreiro era indispensável - veja-se Aküana, Tamakahi e Agamani (ou mesmo o chefe e arqueiro nahukwa Kahusala, encontrado por Ramiro Noronha e mencionado no começo do capítulo). Note-se ainda como o narrador se refere a Agamani no começo da narrativa: "Ele era nossa gente" (Kukugeha helei). Com isso ele queria dizer que Agamani era seu chefe, pois gente e chefe são sinônimos (reencontraremos essa identificação várias vezes, mas ela só será discutida a fundo no capítulo 2).

Amagü ficava na região conhecida como Angahuku (Buritizal), no alto curso do rio Buriti (Mirassol). Além de servir como topônimo de uma região específica, angahuku é o nome pelo qual se designa qualquer região com muitos buritis. É possível que a origem do termo "Nahukua" esteja ligada ao período de concentração dos karib naquela região, pois ao se falar de alguém que mora no Buritizal pode se dizer que mora "Angahuku kua", onde kua é um locativo, e a semelhança sonora com "nahukwa" é tentadora. É possível que "Angahuku $k u a$ " fosse uma referencia geral aos karib daquela região, explicando a percepção de Von den Steinen de que várias comunidades falantes de karib pertenceriam a uma mesma "tribo dos Nahukuas". Outra versão cogitada pelos Kalapalo e igualmente plausível é a de que o termo seria uma distorção da forma pela qual os falantes de arawak chamavam todos os falantes karib: Yanapukuá ${ }^{45}$. Segundo o atual chefe de Jagamü, ele ouvia seu pai e seu avô contarem que os brancos teriam começado a chama-los de "Nahukua" por encontrarem falantes de arawak em seu caminho, no rio Buriti.

Conta-se que Amagü era uma aldeia enorme, contemporânea de pelo menos outras quatro importantes aldeias karib (falantes, aparentemente, de uma mesma variante ou variantes aproximadas ${ }^{46}$ ): Gipangahütü, Akuku, Hagagikugu e Kankgagü. Segundo uma história Kuikuro sobre a origem do tolo, registrada por Franchetto (2007b), é possível especular que Akuku já existia antes da saída do grupo que foi para Amagü (e eventualmente outros lugares também?), pois o primeiro canto de tolo, executado ainda em Agahahütü, é sobre homens da aldeia Hagagikugu, situada no rio Mirassol, formada após uma divisão de Akuku. Hagagikugu se dividiu e deu origem a Kankgagü, no alto curso do rio Culuene, em uma região atualmente fora dos limites do Parque. Por fim, segundo um narrador, de uma divisão de Kankgagü teria se originado a primeira aldeia Angaguhütü.

\footnotetext{
${ }^{45}$ Mehinaku (2010: 16) também faz as mesmas aproximações.

${ }^{46}$ Pois os Kalapalo dizem que, àquela época, sua língua já era diferente do Kuikuro e do Matipu.
} 
É difícil saber detalhes sobre esta aldeia, pois em Aiha a única pessoa que poderia conhecer a história do local é Kugiua, uma mulher muito idosa cuja memória já foi muito afetada pela idade e, por isso, disponho de poucas informações. Pelo depoimento que gravei com ela, seu avô paterno Javanava teria aberto Angaguhütü vindo de Akuku. Já a versão de seu genro Waja é um pouco diferente, e Javanava teria saído de Kunugijahütü para o novo local. E de acordo Ageu, na realidade, a primeira aldeia naquele lugar teria sido aberta por alguém que saiu de Kankgagü; a aldeia teria durado pouco tempo, e só anos depois Javanava teria aberto outra aldeia no local, vindo de Kunugijahütü (o que parece ser a versão mais detalhada). De qualquer maneira, o mais interessante é a relação entre Akuku e Angaguhütü: Kugiua se diz angaguhütü e "descendente de Akuku" (Akuku unkgupügü ${ }^{47}$ ), e diz o mesmo dos chefes de Tankgugu (o homem que abriu a aldeia e era seu chefe principal até 2007 tem o "nome famoso" - nome de chefe - do bisavô paterno de Kugiua).

\footnotetext{
${ }^{47}$ Sobre a noção de "descendente” (unkgu), ver capítulo 2.
} 


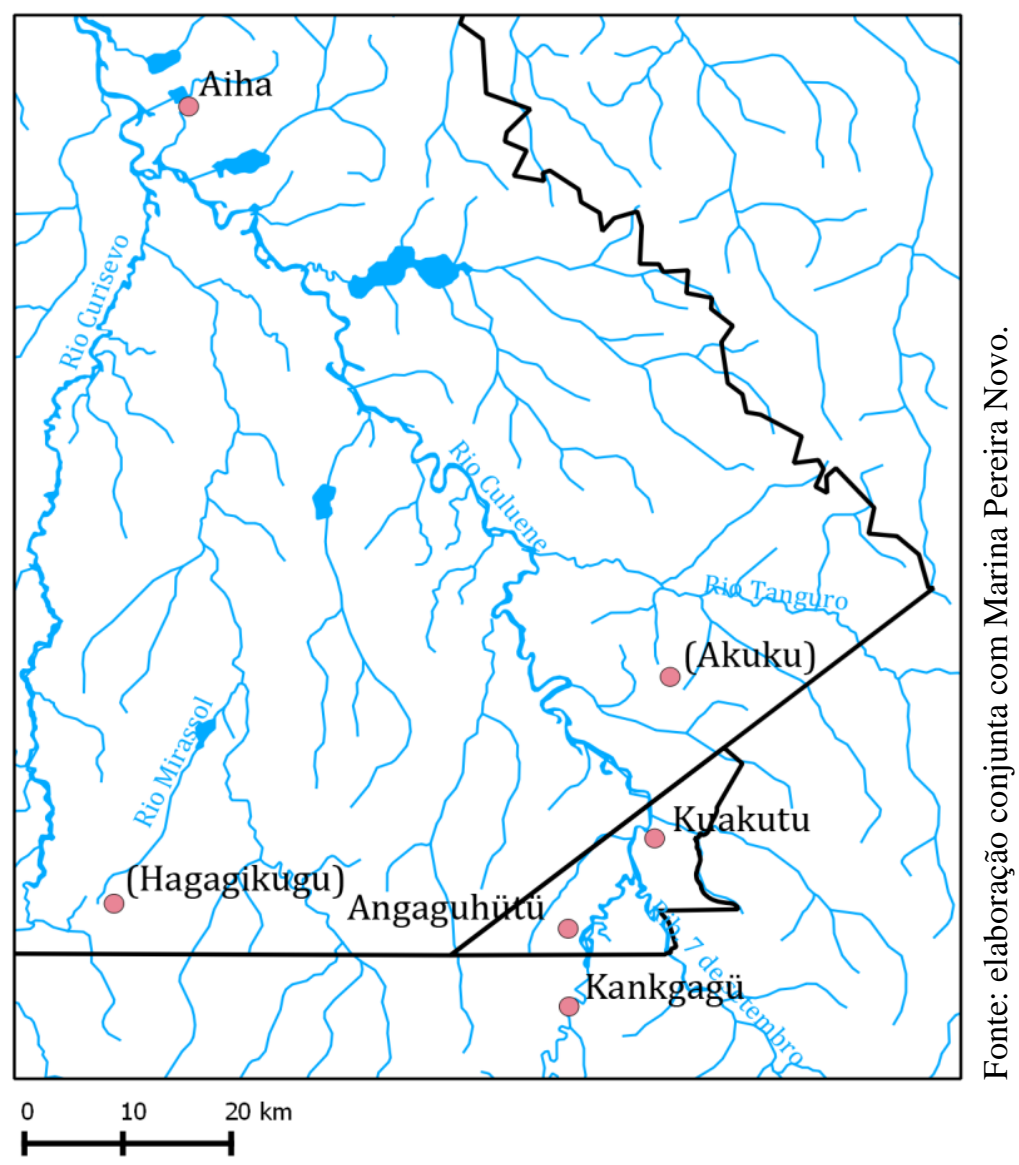

Figura 1.1: principais aldeias do aglomerado de Akuku.

Aiha foi incluída como referência. As aldeias entre parênteses foram marcadas aleatoriamente na região que ocuparam apenas para dar uma ideia de sua distribuição.

Tanto Akuku quanto Hagagikugu foram palcos de eventos míticos centrais para o complexo ritual xinguano: na primeira vivia Jagihunu, o homem que aprendeu a festa ndühe (conhecida como tawarawanã) com os peixes; e na segunda vivia Kumagisa, um homem que se casou com uma Hiper Sucuri e aprendeu com as cobras a suíte de cantos Hagagikugu, uma das principais suítes do repertório kalapalo do egitsü.

A história de Temetihü é a história de uma acusação de feitiçaria. Na versão que apresentei aqui, vemos seu sobrinho uterino mais velho ansioso para ir embora, porque "seus irmãos" (coaldeões) os acusavam de serem "donos de feitiço" (kugihe otomo). Isto certamente não está dissociado de seu apelido, já que uma das características das pessoas de "moralidade duvidosa" é que, assim com antas, não param quietas, vivem se mudando de aldeia em aldeia; e gente que não para quieto em um lugar, que vive "como anta" ou "como abelha", deve ser 
porque está com medo de ter suas atividades como feiticeiro descobertas. Temetihü também é representado como uma figura estranha: já é velho, viúvo e não tem filhos, apenas sobrinhos uterinos (que não são nomeados em nenhuma versão), casados com mulheres cujos nomes não se sabem. Mas ele também é descrito como "incansável”, uma qualidade ambígua: ele é "como uma anta" por não parar quieto, mas também por ser capaz de trabalhar incansavelmente e, como a história deixa claro, isso se mostra uma grande qualidade.

Nesta e nas demais versões que conheço, a história começa com o encontro de Kahunuma com Nhahügü (um itseke feminino que vive na mata), que revela que ele havia sido enfeitiçado, retira o feitiço de seu corpo e se torna sua esposa. Este é um casamento curioso, pois qualquer encontro com este tipo de espírito é sempre fatal. Depois deste episódio é que o chefe Jukagi pede a Temetihü que pergunte a Kahunuma se sua esposa espírito já não teria lhe mostrado algum lugar onde pudessem erguer uma nova aldeia. Mas por que Jukagi pediria a Temetihü que procurasse uma aldeia? Isto certamente foi uma forma indireta de sugerir a Temetihü que ele deixasse Amagü - algo pelo que seus sobrinhos parecem bastante ansiosos. Nem sempre o que chamamos de acusações de feitiçarias são coisas explícitas; pelo contrário, na maioria das vezes é o aquecimento dos rumores que leva alguém a se mudar de aldeia por um misto de medo e vergonha. Mas se Temetihü era acusado de feitiçaria, por que Nhahügü indicaria um lugar excelente?

Uma interpretação possível está ligada à possibilidade de "acalmar" um feiticeiro, fazendo dele um grande chefe. Segundo dizem, um dos desejos de qualquer feiticeiro é ser um grande anetü. Quando ninguém consegue acusar um feiticeiro, uma solução pode ser fazer dele um grande chefe, para que ele "fique bom", calmo. Os Kalapalo dizem que os feiticeiros sabem disso, e muitos acreditam que serão feitos chefes para deixarem de atacar as pessoas usam o medo como forma de ascensão. Será que Temetihü deixaria as pessoas em paz se encontrasse uma aldeia boa, onde pudesse se tornar um grande chefe? Apesar de ninguém ter mencionado para mim nenhum caso recente de feiticeiro transformado em chefe ${ }^{48}$, esta é uma interpretação possível e que faz parte da "teoria política da feitiçaria" dos próprios Kalapalo. Os Aweti parecem pensar da mesma forma. Segundo Figueiredo (2010: 190), quando os Aweti fazem um chefe, eles estão "acalmando" alguém, transformando-o em uma pessoa pacífica, generosa - o exato oposto de um feiticeiro. Como se, ao invés de alguém com essas

\footnotetext{
${ }^{48}$ Já o inverso, em compensação, é bastante comum.
} 
qualidades se tornar chefe, os que são feitos chefes acabassem inevitavelmente por desenvolvê-las.

O resumo apresentado não permite ter essa noção, mas o caminho entre Amagü e Kuapügü é repetido várias vezes. Nhahügü o apresenta a Kahunuma, que o repete para Temetihü, que o repete para seus sobrinhos uterinos e, por fim, repete para suas noras - como se a história se esforçasse para compor e arquivar uma espécie de "mapa". A narrativa também enfatiza a abundância de peixes no córrego perto de Kuapügü. Isso possivelmente esteve ligado ao processo de mudança de hábitos alimentares implicado na adequação dos ancestrais dos Kalapalo ao modelo xinguano de pessoa. Esta versão não toca no assunto, mas em outras versões e em conversas informais, meus interlocutores descrevem a vigência de um sistema alimentar em Amagü bastante diferente do ideal xinguano. Lá não se comia peixe, mas animais terrestres, aves, algumas cobras e uma espécie de sapo ${ }^{49}$ (que alguns velhos ainda comem); a dieta alto-xinguana só passou a ser adotada de forma mais rígida em Kuapügü. A esta mudança alimentar também está ligada uma mudança no comportamento, pois os Amagü eram conhecidos por serem guerreiros. Segundo um narrador, os Amagü seriam o mesmo grupo conhecido como Hukuingi, famoso por seu belicismo e seu hábito de comer placentas cozidas. Muitos negam essa identificação, e sugerem que os Hukuingi seriam outro povo (mas reconhecem que seriam falantes da mesma variante de karib dos Kalapalo e Nahukua). A mudança para Kuapügü é onde os Kalapalo localizam sua origem porque é lá que a ambiguidade de seu comportamento e seu sistema alimentar deu lugar a uma forma mais plena de "xinguanização", onde o processo de "virar gente" (como dizem, por exemplo, os Aweti - cf. Coelho de Souza, 2001) - isto é, o abandono da guerra e de seu correlato alimentar (a caça) - se completou.

Quando todos já haviam trocado Amagü por Kuapügü, eles decidiram dançar ndühe. Em Kuapügü havia apenas um cantor, Jamanike, que só sabia uma música e as pessoas já não aguentavam mais ouvi-lo repetir a mesma canção. Um dia, começaram a ouvir de muito longe um cantor executando excelentes cantos de ndühe. Isto é, magicamente de muito longe, pois quem eles ouviam era um cantor de Akuku, há dias de distância de Kuapügü. O sobrinho mais velho de Temetihü (o próximo chefe de Kuapügü após sua morte) foi até o lugar de onde vinha o som buscar o cantor, para que eles pudessem fazer uma grande festa. $\mathrm{O}$ cantor de Akuku era Kajü Ihegü, chefe daquela aldeia, que sabia todas as músicas muito bem, pois elas

\footnotetext{
${ }^{49}$ Asuti.
} 
haviam sido trazidas diretamente da aldeia dos peixes por Jagihunu, um morador de Akuku. Kajü Ihegü foi trazido até Kuapügü, onde cantou por dias seguidos. Os moradores daquela aldeia gostaram tanto dele que o convidaram para se tornar chefe lá, onde recebeu uma casa e uma roça ${ }^{50}$. Os moradores de Akuku e Amagü já deviam se relacionar há muito tempo, mas naquele momento estes dois contingentes devem ter estreitado seus laços.

Kuapügü cresceu muito e com tanta fartura que as pessoas não tinham interesse em ir embora do lugar. O círculo de casas ficou tão cheio, que decidiram abrir outra aldeia ali mesmo, na margem do córrego Hotogi oposta àquela ocupada por Kuapügü. Esta é a aldeia que ficou conhecida como "Kalapalo", palavra de origem arawak que significa "do outro lado". Os Kalapalo tinham relações muito estreitas com os Mehinaku quando viviam na região de Angahuku (muito importantes até hoje), os quais se referiam ao novo agrupamento, em sua língua, como a aldeia kalapalo, "do outro lado".

Quem abriu Kalapalo foi Kapita, um homem de origem Kankgagü (Akuku, portanto), que cresceu em Kuapügü. Os Kankgagü eram um dos “outros iguais” dos Kalapalo, mas tinham a peculiaridade de serem bastante guerreiros (por isso são considerados "um pouquinho índios", bravos, e atacavam inclusive seus parentes karib próximos). Os Kalapalo se referem a eles como tahaku otomo (mestres do arco), pois, diferentemente de outros inimigos da região cuja principal arma era a borduna (os $i$ otomo, "mestres do pau"), os Kankgagü seriam exímios arqueiros. A relação entre os grupos karib à época era muito complicada, e era claro que eles estavam bem longe do ideal pacifista pelo qual o Alto Xingu é descrito, hoje largamente professado pelos próprios xinguanos. Há uma narrativa segundo a qual os Amagü otomo teriam dizimado os Gipangahütü otomo, dos quais apenas um menino teria sobrevivido e se refugiado em Akuku. Já crescido, o rapaz foi enviado para junto de seus tios em Amagü, onde descobriu por acaso que eles haviam sido os responsáveis pela morte de seus parentes. O jovem começa então uma "peregrinação" por outras aldeias karib oferecendo muitos objetos valiosos como pagamento pela sua vingança, e cria uma aliança entre diferentes aldeias para exterminar os Amagü otomo em uma emboscada realizada durante um ritual de trocas (uluki) na aldeia Hagagikugu, do qual participaram os Amagü, Akuku e Kankgagü. Dado que o chefe Kapita era um homem Kankgagü/Akuku, fica mais claro o

\footnotetext{
${ }^{50}$ Por algum motivo, nota-se na narrativa que quando se mudou para Kuapügü, Kajü Ihegü tinha uma filha reclusa.
} 
porquê da referência aos Kalapalo como Akuku otomo: é uma referência a seu chefe e provavelmente às pessoas que o acompanharam nesta nova aldeia.

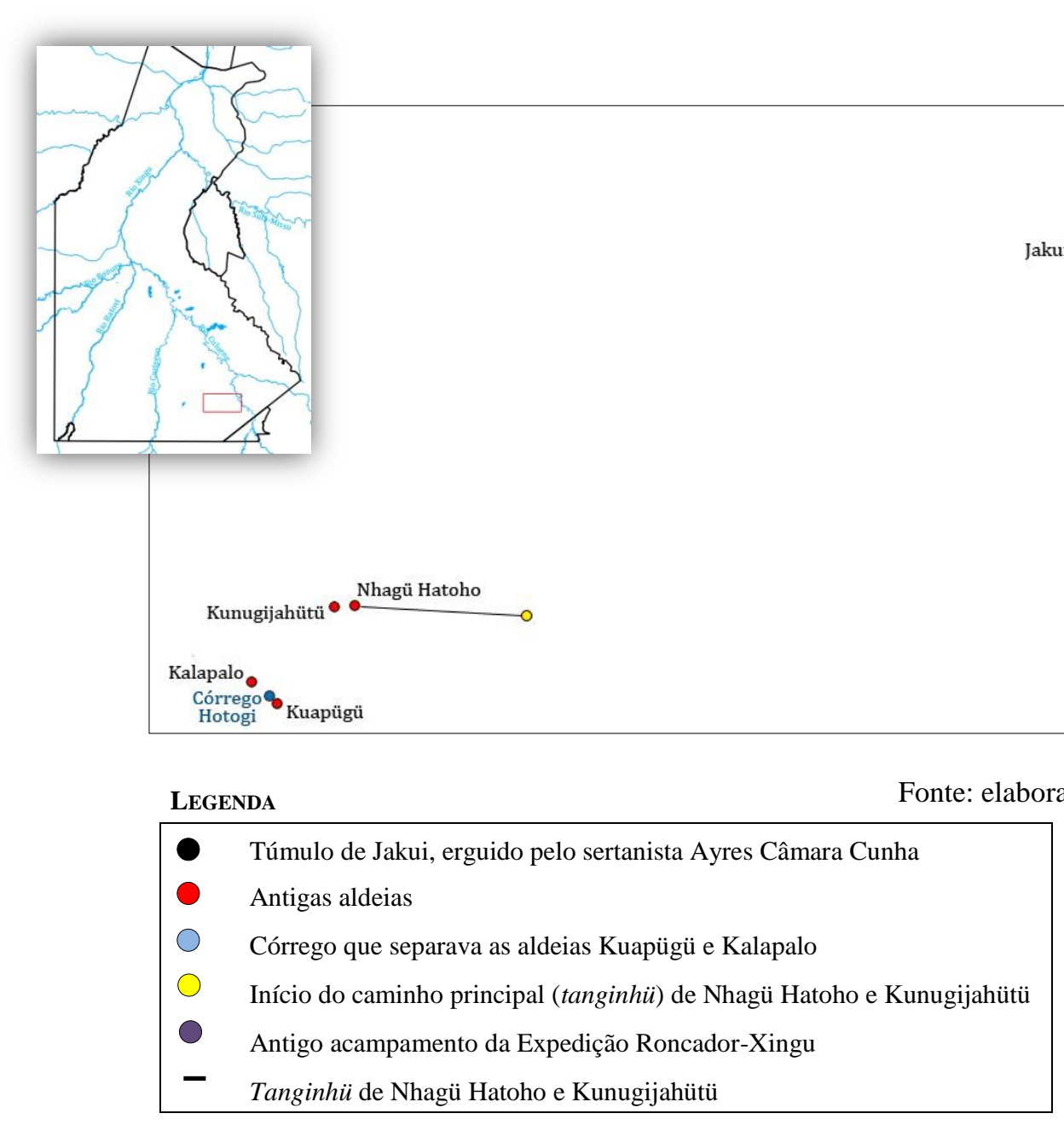

Figura 1.2: localização de antigas aldeias e outros pontos relevantes.

Ao mesmo tempo que os narradores de Aiha enfatizam sua relação com os Amagü otomo, sugerem que os chefes de Tankgugu seriam parentes mais próximos dos Akuku otomo, pois seriam descendentes de Angaguhütü. Entre alguns chefes daquela aldeia tem de fato havido um movimento interessante ligado ao "ressurgimento" de uma identidade angaguhütü (e não só entre os chefes, pois segundo Fiorini, 2005, eles seriam atualmente 81 pessoas). Quando comecei a trabalhar em Aiha, sempre me disseram que só havia três pessoas angaguhütü: duas mulheres vivendo em Aiha e uma em Tankgugu (sendo uma mãe e suas duas filhas). Porém, essa situação começou a mudar com o processo de identificação da Terra 
Indígena Pequizal do Naruvôtu. Este território começou a ser pleiteado em 2004, foi identificado e aprovado em 2006 pela FUNAI e está em processo de demarcação. Os Kalapalo decidiram que quem participaria do processo de identificação deveria ser Tankgugu e não Aiha, porque os chefes da primeira seriam descendentes daquele grupo. Conversando com a mulher angaguhütü mais velha, ela disse que, de fato, dois dos chefes de Tankgugu também seriam angaguhütü e que seriam, como ela, Akuku.

A criação de Tankgugu foi a maior cisão que os Kalapalo experimentaram no século XX, e os eventos recentes relacionados à demarcação da TI Pequizal do Naruvôtu sugerem que a divisão Aiha/Tankgugu evoca, de alguma maneira, a diferença Amagü/Akuku - e se essa diferença é algo difusa entre todos os Kalapalo, em certos contextos ela pode parecer mais relevante para seus chefes. Assim como uma aliança ritual estabelecida entre Amagü e Akuku por meio de seus chefes (o sobrinho de Temetihü e o chefe cantor) deve ter favorecido a mistura destes dois contingentes, é também na vizinhança da chefia que esta diferença pode reaparecer.

\subsubsection{Um passado incômodo}

Os Nahukua afirmam categoricamente que têm uma origem comum com os Kalapalo - coisa que os Kalapalo (de Aiha, pelo menos) não fazem em hipótese alguma. Segundo eles, seus ancestrais também teriam vivido em Agahahütü, nos arredores do Tahununu, e de lá teriam se mudado, junto com os ancestrais dos Kalapalo, para Óti, um complexo de aldeias na região do Buritizal (Angahuku) onde viviam, até onde sabemos, os ancestrais dos Kuikuro e Matipu (Franchetto, 1986: 76-77; 2001: 134-135). Segundo a história oral Kuikuro, após um desentendimento entre chefes por causa da construção de uma casa (uma casa de chefe), alguns deles teriam deixado Óti para fundar Kuhikugu ${ }^{51}$; os que ficaram teriam se tornado Uagihütü, ancestrais dos Matipu.

Na versão nahukwa da história, em Óti uma mulher teria se casado com um itseke (a semelhança com o casamento de Kahunuma e Nhahügü é interessante: em Amagü, um

\footnotetext{
51 Segundo uma narrativa registrada por Franchetto (1986: 95-110, volume III), teriam jogado fora o poste cortado por um chefe para a construção dessa casa. Ele se sentiu muito ofendido, deixou Óti e junto com outros chefes fundou a aldeia Kuhikugu.
} 
homem se casa com uma mulher itseke; em Óti, uma mulher se casa com um homem itseke). Deste casamento nasceu o primeiro grande anetü nahukwa, cujo nome desconheço. De lá este anetü filho de itseke teria se mudado com um grupo de pessoas para Timpa, local próximo ao rio Mirassol, onde seu filho Ahiguata se tornou chefe. Segundo a visão Nahukua, de lá é que algumas pessoas teriam se mudado e se tornado Kalapalo (por isso sua língua seria a mesma). Vejamos o resumo de parte dessa história (a partir de Timpa ${ }^{52}$ ) feita por Mehinaku (2010: 134-135):

Conta-se que os antepassados dos Kalapalo e os Jagamü, os antigos Nahukwá, viviam juntos na grande aldeia de Timpa, segundo narrativa dos Matipu, hoje. Já na versão dos Kalapalo, conta-se que eles teriam passado a viver junto na outra grande aldeia de Kuakutu, da qual os Kalapalo têm memória.

O mestre de narrativas Jamiku Matipu (66 anos) conta que na Aldeia Timpa tinha muita gente; de fato, havia cinco grandes aldeias uma ao lado da outra. Assim sendo, nos seus rios e lagos não havia mais peixes. As pessoas começaram a sobreviver de caça, começaram a comer anta, veado, porque não tinha mais nada. Eles já estavam tendo escassez de peixe. Para resolver o problema, conta-se que um índio bravo estava andando na região e foi procurar a aldeia de Timpa seguindo a direção de onde se via fumaça de fogo. De repente, escutaram o grito de um individuo no outro lado do rio. Eles perceberam que aquele grito era estranho e foram contar para o anetü Ahiguata. Por sua vez, o anetü (chefe) mandou uma pessoa que entendia qualquer língua de outros povos. Explicam que essa pessoa tinha escutado a 'fala' do pássaro xexeu depois do ritual de furação de orelha, por isso entendia tudo.

Este poliglota viu que quem estava gritando era um Bakairi manso chamado Koisa, que estava avisando que havia encontrado um lugar com peixes. Assim, os dois anetü de Timpa resolveram dividir a aldeia. Metade foi fazer uma aldeia nova. Chegaram ao lugar que eles queriam, onde, de noite, escutaram o esturro de uma onça chamada na nossa língua Ahua. Os chefes resolveram nomear essa sua nova aldeia de Ahuahütü, 'lugar de Ahua'. Lá eles ficaram muito felizes de ver fartura de peixe e macaco para caçar. Constituíram uma nova comunidade nesse lindo lugar. Contam que foi neste momento que Steinen apareceu (estaríamos, então, no final do século XIX?). Eles ficaram muito tempo lá, assim os Brancos começaram a aparecer e vir, trazendo suas ferramentas. A aldeia de Ahua ficou como ponto de chegada dos Brancos, causando inveja nos vizinhos que começaram a kugihe hagatelü, a 'fincar feitiço forte' para acabar com o povo. Por causa disso, o restante resolveu mudar para Ihumba e outras famílias foram encontrar seus familiares na aldeia antiga dos Kalapalo, provavelmente Kuakutu.

É interessante que, do ponto de vista dos chefes kalapalo, pelo que vimos na história de Temetihü, estaria em disputa quem teriam sido os responsáveis pela abertura de Kuapügü -

\footnotetext{
${ }^{52}$ Não disponho de nenhuma versão sobre a mudança dos ancestrais dos Jagamü de Agahahütü para Óti. O pouco que sei foi contado por um homem que me disse não conhecer bem a história.
} 
isto é, quem foram seus primeiros donos/chefes (como nota o narrador, segundo o chefe Müra, Kuapügü teria sido aberta por pessoas saídas de Timpa). Mas esse não é o ponto da narrativa do chefe jagamü, segundo a qual seus ancestrais teriam se mudado de Ahuahütü (após a divisão de Timpa) para uma aldeia já aberta pelos Kalapalo, possivelmente Kuakutu $^{53}$. Se Von den Steinen já havia aparecido, os eventos se passam no final do século XIX, e a Kuakutu de que fala o narrador não deve ser a aldeia mítica de Aküana. De qualquer maneira, essa região mais ao sul parece ter sido ocupada pelo aglomerado de Akuku (isto é, a própria Akuku, iho das demais, e pelo menos Hagagikugu, Kankgagü e Angaguhütü, as mais famosas) e pode ser que os ancestrais dos Jagamü tenham se misturado com eles ou outras aldeias relacionadas. Um dado favorável a essa hipótese é a coincidência de nomes de chefes angaguhütü falecidos e chefes proto-nahukwa, como Jamiku (atual chefe de Jagamü) e Ahiguata (o chefe de Timpa e Ahuahütü). Também já ouvi pessoas afirmarem que os Akuku seriam “diferentes" (telo, e não otohongo, "outros iguais”), e que Hagagikugu seria uma aldeia jagamü. Considerando que alguns chefes de Tankgugu têm se identificado com os Angaguhütü e que Müra era o principal anetü da parentela de onde eles se originaram, essa poderia ser a razão para Müra reproduzir uma narrativa de origem comum com os Jagamü. Se isso for verdade, teríamos dois "mitos de origem" associados não apenas aos dois últimos grandes chefes de Aiha, mas a dois contingentes proto-kalapalo: um reconhecidamente amagü, outro akuku/angaguhütü possivelmente misturado com proto-jagamü (ex-moradores de Ahuahütü). Mas, como Ageu tanto frisa, “as histórias são misturadas” (tetsualü benaha akinhai) - tão misturadas como os próprios Kalapalo.

\section{$* * *$}

Estas narrativas têm um inegável "ar histórico", mas não deixam de pertencer ao passado mítico: Kahunuma era casado com um itseke; os moradores de Kuapügü ouvem o cantor de um povo que mora a dias de distância e o povo do cantor aprendeu os cantos com

\footnotetext{
${ }^{53}$ Segundo Costa (2011: 4), um chefe de Tankgugu lhe disse que todos os povos xinguanos teriam vivido juntos em "Ahuã hutu" (certamente Ahuahütü), uma aldeia localizada onde é hoje a Fazenda Sayonara, e que de lá teriam se mudado para Kuapügü. Quando questionei o mestre de histórias Ageu sobre isso, ele disse desconhecer tal história, e que Ahuahütü teria sido uma aldeia nahukwa. Na versão de Costa, Ahuahütü desempenha o papel agregador de Kuakutu, e tal variante permite supor que de fato os Kalapalo e Nahukwa devem ter vivido juntos naquela região.
} 
alguém que visitou a aldeia dos peixes. Apesar disso, os nomes dos chefes e os lugares onde os eventos aconteceram transformam este passado em um passado de alguém, diferentemente do passado de Taũgi e Aulukumã e várias outras pessoas/itseke que não são ancestrais de ninguém em especial (por serem, justamente, ancestrais de todos os xinguanos). É diferente com Aküana, que tem um "neto" que quer aprender as histórias de seu "avô" e gostaria de abrir uma aldeia onde é hoje a fazenda Sayonara; é diferente com Makala (Temetihü), que agora não tem mais descendentes porque sua única "neta" que sobreviveu ao sarampo faleceu sem deixar filhos; com Jukagi, cujo "neto" é um anetü hekugu ("chefe verdadeiro") reconhecido por descender de chefes importantes. Nomes de pessoas (chefes) e lugares marcados nas narrativas etno-históricas fazem com que este passado mítico seja, na prática, um passado partilhado apenas por alguns, cuja especificidade se manifesta em diferentes tradições narrativas.

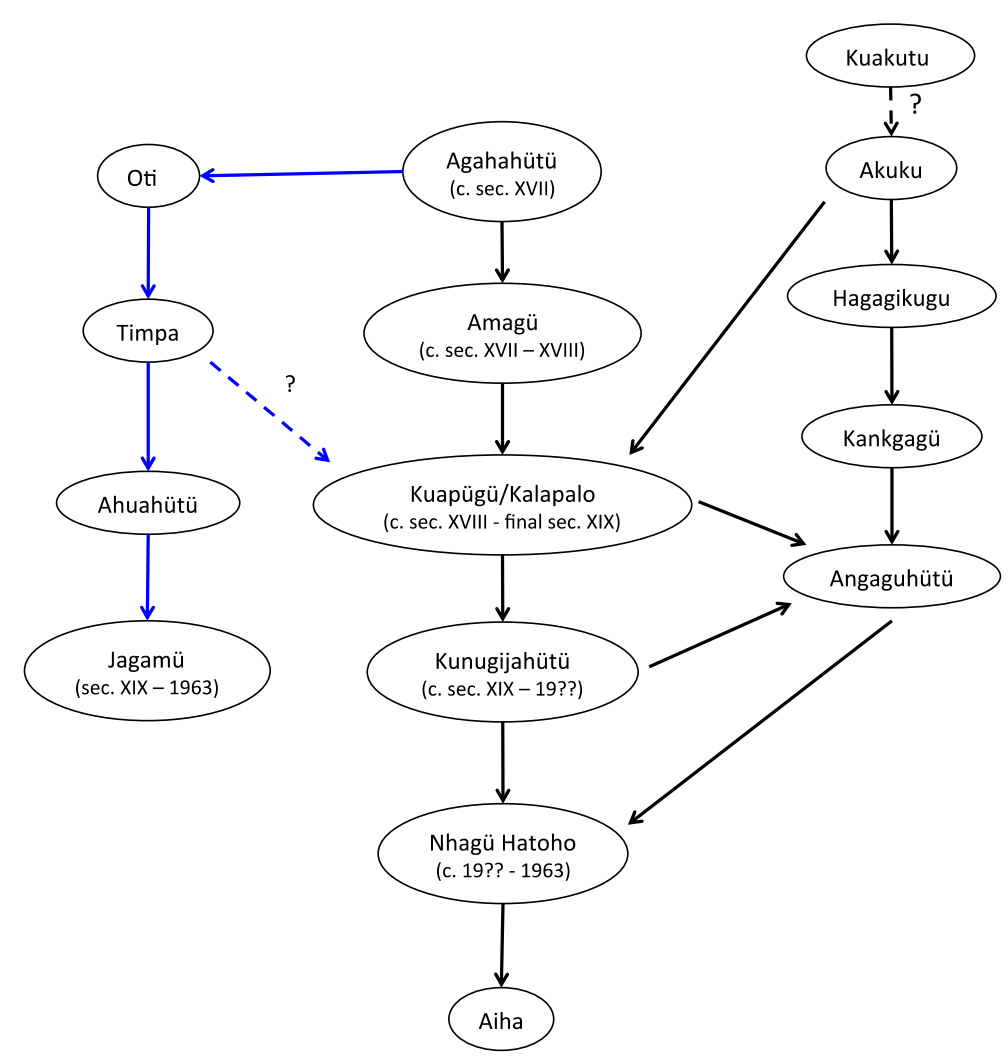

Figura 1.3: tentativa de sistematizar as relações conhecidas entre os karib ancestrais dos Kalapalo.

A não ser quando explicitado, o diagrama não representa relações temporais, pois muitas aldeias coexistiram por períodos desconhecidos de tempo. Setas pretas sólidas indicam divisões/migrações segundo a tradição oral de

Aiha; setas azuis sólidas, divisões/migrações segundo tradição oral nahukwa; e setas tracejadas, relações especulativas. 


\subsection{Os brancos e seu estranho desejo por filhos de chefes}

Como já sabemos, Kalapalo foi primeiro chefiada por um homem chamado Kapita, que era kankgagü, mas vivia em Kuapügü e lá se tornara chefe. Ele é o protagonista de uma narrativa que conta um dos primeiros encontros dos Kalapalo com os brancos naquela região, mas que é mais interessante do que isso: ela fala sobre a origem da palavra kamaga, usada pelos karib xinguanos para se referir aos não chefes. Esta é provavelmente uma corruptela de "camarada", mas que parece ter sido incorporada ao karib há muito tempo. Ela dificilmente é ouvida em sua forma não possuída, aparecendo sempre como X kamagagü (“camarada de X”) ou itsamagagü (“camarada dele”), referindo-se ao pessoal de algum anetü específico.

Para os Kalapalo, a origem deste termo está ligada a um "mistério" que eles até hoje tentam entender. Os brancos começaram a aparecer quando eles viviam em Kuapügü, de onde muitas pessoas foram raptadas. Homens e mulheres, principalmente jovens, eram eventualmente levados pelos kagaiha, que os abordavam nos arredores de algum rio ou então vinham à sua aldeia, armados com "facões gigantes" (espadas?) e carabinas. Às vezes era possível fugir, pois os kagaiha tinham o hábito de chegar na aldeia cantando (uma mulher kalapalo, que infelizmente já faleceu, era a única que conhecia uma dessas canções dos kagaiha). Mas os kagaiha não roubavam qualquer pessoa, apenas chefes e seus filhos. Ninguém sabe como, mas quando um chefe tinha algum filho ou filha que também começava a se tornar chefe, logo vinham os brancos para capturá-lo. Por isso, essa época é lembrada com muita tristeza, pois os chefes estavam se acabando e muitas pessoas morriam, ou pelas mãos dos kagaiha, ou pela ação desenfreada dos feiticeiros (que naquela época começaram a usar feitiços que se espalhavam sobre aldeias inteiras - epidemias que chegavam com o contato). Nas histórias deste período, há lembranças de corpos de filhos de chefes encontrados pelos Kalapalo no caminho dos kagaiha, que os abandonavam quando estes apresentavam resistência ou não aguentavam a sede e a fome. Alguns dos chefes mortos ou desaparecidos naquela época são lembrados nos discursos de recepção de mensageiros e há alusões a eles em várias execuções de discursos formais, reproduzindo uma memória sobre este passado nas ocasiões rituais (ver capítulo 5). A história de Kapita está ligada a esse estranho conhecimento dos brancos a respeito dos chefes: os Kalapalo capturaram um branco (o primeiro kagaiha que 
viram de perto), chamado Õdoni ou Ãtoni (Antonio?), que sabia o nome do chefe Kapita! É uma história peculiar, pois este branco teria vivido muito tempo entre os Kalapalo, aprendido sua língua, e depois teria ido para os Wauja, que tentaram - em vão - matá-lo.

\author{
Mito 3: Kapita ${ }^{54}$ \\ Ageu Kapita telü... \\ Kapita foi... \\ Segitsunda beja, Kapita egitsunda \\ Ele estava fazendo egitsü, Kapita estava fazendo egitsü \\ Ugise Kapita helei kuge? \\ Kapita era gente/chefe? \\ Ageu Kuge beja, Kalapalo \\ Uma grande pessoa/chefe, um Kalapalo \\ Ekü aketselei Kankgagü ngihütoho \\ Ele é de origem Kankgagü \\ Kalapalo hujati hale etepügü, tseta leha sanetu leha, ilango aketselei \\ Ele se mudou para os Kalapalo e lá ele chefiou, ele é assim
}

Kapita saiu de sua aldeia para buscar uma grande panela de cerâmica que havia ficado no acampamento onde eles haviam pescado para a festa, o lago Aitsagü (perto de onde hoje é a aldeia Nhütisüpe, conhecida como Kaluani ou Paraíso). Certa noite, ele sonhou que uma "borboleta de Ahasa" (um tipo de borboleta cuidada pelo itseke Ahasa ${ }^{55}$ ) vinha ao seu encontro. Quando acordou, ele disse à sua esposa que no dia seguinte iria buscar a panela. Ele dormiu e sonhou mais uma vez com uma borboleta de Ahasa vindo em sua direção. Os antigos diziam que sonhar com essa borboleta era um pesadelo com kagaiha, e significa que a pessoa seria morta por um branco. Kapita acordou de madrugada e avisou sua irmã:

Ah! Ahasa hototogu heke aketsange ulopenügü nügü iheke

"Ah! Uma borboleta de Ahasa veio em minha direção", disse ele

\footnotetext{
${ }^{54}$ Narrada por Ageu em 02 de julho de 2010, em sua casa na aldeia Aiha.

${ }^{55}$ Um itseke canibal desajeitado, muito alto, que detesta crianças e vive na mata.
} 
Itseke heke aketsange uhelüingo nügü iheke

"Um espírito vai me matar", disse ele

Hm, uelüingo itseke heke nügü iheke

Hm, "um espírito vai me matar”, disse ele

Itseke heke nügü iheke

Um espírito, disse ele

"Cuide do seu filho!", disse à sua irmã. Kapita foi buscar a panela junto com alguns companheiros, também chefes. Kapita lhes contou sobre seu sonho, e avisou que encontraria um kagaiha em sua viagem. Disse que iria na frente, e que se eles o ouvissem gritar deveriam vir para tentar agarrar o "espírito". Quando ele vinha pelo caminho, perto de seu destino ele viu aquele com quem havia sonhado. Era um homem que tinha a cabeça bem branca e estava pegando frutas da árvore kumigu, que guardava no bolso de sua camisa. Seu nome era Õdoni. Kapita se aproximou furtivamente por trás de uma moita e o agarrou. Quando foi pego, Õdoni começou a gritar: "Kapita, Kapita, Kapita, Kapita!”.

Sanetu uhunügü leha iheke

Ele reconheceu sua chefia

Sanetu uhunügü

Reconheceu sua chefia

Lepene

Depois

Ka!, aibeha, akago heke itsatomi

Ka!, ele gritou para que os outros ouvissem

Akago heke itsatomi

Para que eles ouvissem

Tuhisükinhüko heke

Seus companheiros ouvissem

Angi aketsange koto hetunda nügü iheke tühisü heke

"Nosso dono/pai está gritando", disse um de seus companheiros

Isinünkgo leha ijopetigi 
Eles vieram para encontrá-lo

\section{(...)}

Kangamuke nügü iheke

"Crianças"

Ah nügü beja iheke

$\mathrm{Ah}$, ele disse

Ah itseke aketsegei kagaiha nügü iheke

"Ah, este é um espírito kagaiha"

Osi hõhõ ihetüe hõhõ nügü iheke

"Vamos lá, agarrem-no"

Ihetüe hõho

"Agarrem-no"

Euhutokomi iheke nügü iheke

"Para que ele os conheça"

\section{Euhutokomi}

"Para que ele os conheça"

Ẽhẽ nügü iheke

Sim

Tu! tiheti iheke: “ah, kamaga, kamaga!” nügü leha iheke

Tu! quando o agarraram ele gritou: “ah, kamaga kamaga!”

Inguhenkgilüko bele iheke kukinha bahale aneta $\tilde{\sigma}^{56}$ mebege

Ele se confundiu mesmo, pois para nós eles eram chefes

O mais novo correu para avisar as pessoas em Kuapügü e chegou gritando. Depois de ouvir a notícia, Ahua, irmã de Kapita, enviou seu filho para seus parentes em Amagü: "vá para seu tio materno!". Ahua disse que iria ao encontro de Kapita para ser morta por um branco pela mesma flecha que o matasse. Mas então ela viu que eles estavam chegando. Õdoni era bem alto, e vinha na frente. As pessoas ficaram ao seu redor e Kapita disse: "Crianças, este é um espírito, um kagaiha". Kapita o levou para sua casa, onde ele viveu por cinco anos. Ele

\footnotetext{
${ }^{56}$ Coletivo de anetü.
} 
aprendeu a língua dos Kalapalo, se pintava e dançava com eles, e ficou sendo como um filho para Kapita.

Um dia ele pediu a seu pai adotivo que o levasse de volta, para buscar facões, machados, enxadas, tesouras. Eles o levaram para o barranco Kahitsü Ekugu, no alto Culuene.

\section{Üginabe naha egei}

Lá é um barranco

\section{Kahitsü Ekugu}

Kahitsü Ekugu [“lugar de kahitsü”, um tipo de árvore]

Kagaiha ĩhũgu atsakigatühügü tsügüha egei

É onde os ancestrais dos brancos apareciam

$\tilde{E}$, ngiholo inha tsügüha, $\tilde{e}$

Sim, para os antigos, sim

Ngiholo inha tsetinge kagaiha ĩhũgu enta uãke

Para os antigos é de lá que os ancestrais dos brancos vinham

Ukeale beha ingila uãke

Para nos matar, há muito tempo

Õdoni disse que voltaria na próxima estação seca trazendo muitos objetos. No ano seguinte ele retornou com outros quatro kagaiha por outro caminho, pelo rio Batovi, e chegaram nos Wauja, que os hospedaram em sua casa dos homens. Kapita ouviu a notícia e foi até lá buscálos. Kapita chegou no final da tarde, e Õdoni foi encontrá-lo na entrada da aldeia wauja para dizer que eles deveriam fugir imediatamente, pois ele estava desconfiado que os Wauja planejavam matá-los naquela noite. "Não dá", disse Kapita, "eu estou com o corpo todo dolorido por ter vindo remando, vamos amanhã". Naquela noite, os Wauja os atacaram para roubar seus machados e enxadas, e mataram os quatro companheiros de Kapita. Ele conseguiu fugir, levando alguns machados, e foi chamar Kapita para fugir com ele. Eles chegaram em Kuapügü e Õdoni deu alguns machados para Kapita, que os distribuiu - mas não foram suficientes. Õdoni pediu então que o levassem de volta para Kahitsü Ekugu e que dessa vez ele iria embora para sempre. 
Eles nunca mais viram Õdoni, mas Kahitsü Ekugu continuou a fazer parte da história dos Kalapalo como o lugar de onde vinham os brancos para capturá-los e matá-los. O Kapita desta história é o mesmo mencionado na narrativa anterior, o que situa estes acontecimentos não muito tempo depois da fundação de Kalapalo. No começo, o sobrinho do mestre de histórias pergunta: "Kapita era gente (Kapita helei kuge?)"? Com isso, ele próprio me disse, queria saber se Kapita era anetü: mais uma vez gente e chefe aparecem como sinônimos. Há detalhes interessantes, como as observações sobre sua camisa com bolsos, sua "cabeça branca", sua altura, o episódio conflituoso com os Wauja ${ }^{57}$ e o lugar do rio onde ele aparecera. Mas duas coisas chamam a atenção: a forma como Õdoni interpela os que o agarraram e sua adoção pelo chefe kalapalo. Quando Õdoni grita "Kapita, Kapita, Kapita, Kapita!”, alguns jovens hoje especulam que ele talvez estivesse dizendo "capitão", e que os antigos devem ter ouvido errado. Um mestre de histórias de Tankgugu corrobora essa interpretação, e diz ainda que o chefe kalapalo provavelmente tinha outro nome, mas teria adotado "Kapita" depois do ocorrido. Já o narrador da versão que apresento é categórico ao dizer que não, que Kapita era seu nome verdadeiro e Õdoni o adivinhou por um motivo óbvio: os itseke podem saber de tudo! Mas ele se enganou quando foi agarrado pelos companheiros de Kapita: os chamou de kamaga porque não sabia que eles também eram chefes. Mas o mito não pode ser considerado contraditório. Apesar de serem todos chefes, em algumas passagens Kapita chama seus companheiros de kangamuke (crianças), e estes se referem a ele como ukoto $^{58}$ (nosso dono/pai). Considerando que a filiação é o modelo da relação entre um chefe e seu povo, no final das contas o itseke estava certo: eles eram Kapita kamagagü, "pessoal do Kapita”.

Kapita pensa que vai morrer e, por precaução, deixa sua irmã de sobreaviso para que proteja seu filho. Ahua ${ }^{59}$ fica tão desesperada quando a notícia da captura de um itseke chega à aldeia que envia seu filho para outro de seus tios maternos em Amagü ${ }^{60}$ e diz que vai ao encontro de seu irmão para ser morta pelo espírito. Os kagaiha já eram, logicamente, vistos como perigosos, mas mesmo assim Kapita estava disposto a capturar um. Ele o fez e transformou o espírito em seu filho adotivo, até que ele se tornou como os Kalapalo: falava,

\footnotetext{
${ }^{57}$ Não consegui encontrar registros do contato com os Wauja que me permitissem cruzar as histórias. Aristóteles Barcelos Neto (comunicação pessoal) afirma nunca ter ouvido algo semelhante.

${ }^{58}$ Uk-oto (12-dono/pai).

${ }^{59}$ Reencontraremos Ahua nos discursos cerimoniais apresentados no capítulo 5.

${ }^{60} \mathrm{O}$ que significa que a aldeia não acabou de fato, como sugere a narrativa da abertura de Kuapügü.
} 
se pintava, dançava (mas dizem que nunca se casou). Kapita fez com aquele tipo peculiar de espírito o que se deve fazer com qualquer itseke que ataque alguém ou apareça em seus sonhos: o adotou e humanizou. Quando se sonha com um itseke, isso é um índice de que a pessoa já está sendo atacada por ele, já está doente, e por isso Kapita tinha tanta certeza de que seria morto por um espírito (se via um em seus sonhos é porque já estava "morrendo um pouquinho"). Mas assim como a reversão dessa situação se dá pela familiarização do itseke por seu “dono" (Barcelos Neto, 2008; Franco Neto, 2010), Kapita tentou fazer o mesmo com Õdoni ${ }^{61}$.

Depois de Õdoni e até a época de Von den Steinen, os Kalapalo só conheceram kagaiha violentos. Uma das narrativas mais famosas sobre a violência dos brancos é a história de Saganaha, um épico da história oral karib (que, junto com o rapto da bela Ahuseti, dariam filmes incríveis). Basso (1993; 1995: 41-61) já apresentou uma longa versão dessa narrativa que não difere das que ouvi em campo, a não ser por pequenos detalhes, e por isso vou me limitar a resumi-la. O herói é capturado, casa-se na cidade, tem filhos e retorna à aldeia, onde se casa novamente e se torna um importante chefe. É desse casamento na cidade que resulta a maior onda de ataques de kagaiha, não só aos Kalapalo, mas a todos os índios da região, pois segundo a história, os brancos seriam chefiados pelos filhos de Saganaha que atacariam as aldeias em busca de seu pai. O condutor dos ataques seria seu filho mais velho, Paipegü. Não estamos muito longe dos eventos com Õdoni, pois o chefe de Kuapügü à época do rapto de Saganaha era Haja/Juaikumã ${ }^{62}$, um dos companheiros de Kapita (o mais velho de seus acompanhantes). Os Kuikuro também falam sobre ataques no tempo em que estavam no Buritizal, em Óti:

Os antepassados dos caraíba chegaram muito tempo atrás. Os antepassados caraíba vieram até o Kuluene, montaram acampamento em Turi, construíram muitas canoas de casca de jatobá, muitas enfileiradas para matar nossos antigos. Estavam em Agahúku [...]. (Franchetto, 1998: 344)

\footnotetext{
${ }^{61}$ Esse modelo de relação vigora em grande medida até hoje: os brancos precisam de um dono (um chefe). Este tema será objeto de parte do capítulo 6.

${ }^{62} \mathrm{Um}$ homem de mesmo nome foi o principal chefe entre os Kalapalo antes de Sagagi (começo do século XX), outro Juaikumã (seu neto, possivelmente) foi identificado como chefe na época da Expedição Roncador-Xingu por Orlando e Cláudio Villas Boas (1970: 33), seu filho foi chefe em Aiha (falecido em 2009 e homenageado em um egitsü em 2010) e hoje o neto mais velho deste homem foi indicado para substituir seu pai. Semelhante continuidade de chefes é incomum para os padrões alto-xinguanos conhecidos, mas revela tanto a importância da genealogia quanto o valor dos "nomes famosos".
} 
Os brancos iam de aldeia em aldeia, à noite, matando as pessoas, roubando mulheres e procurando os chefes: “Juntaram os mortos e perguntaram: 'Onde está o chefe? Onde está Kujaicí?'. Lá não estavam os chefes, nem Kujaicí, nem Aráhi, nem Painigkú. Os caraíba foram procurá-los, foram procurar Kujaicí. (...)” (Franchetto, 1998: 344). Franchetto nota que os chefe mencionados na narrativa Kuikuro são os mesmos "celebrados como epônimos dos Kuikuro no discurso cerimonial que apresenta a identidade distintiva do ótomo kuikuro (...)" (id. ibid; ver capítulo 5). Dole (1984: 319) diz que os Kuikuro confirmam conflitos com homens que, "vestindo lenços azuis e amarelos", destruíram muitas de suas plantações.

Dole sugere que estes ataques talvez tenham sido conduzidos pelo bandeirante paulista Antônio Pires de Campos (cf. também Franchetto, 1998: 345). Não há informações sobre ele ter conduzido ataques pelo Culuene, mas a proximidade de seu nome em karib (Paipegü ou Paypegi) e a forma pela qual era chamado pelos Bororo (Pai Pirá) torna a aproximação tentadora. Pires de Campos tinha um grupo de soldados bororo que o ajudava nas bandeiras, e a referência a índios que atacavam as aldeias junto com Paipegü (filhos de Saganaha, segundo a narrativa kalapalo) é outro ponto favorável à especulação. Dole ainda sugere que, se Pires de Campos não esteve no Culuene, talvez os ancestrais dos karib xinguanos tenham estado mais a leste, no Rio das Mortes, onde Pires de Campos conduziu expedições para escravizar índios. É uma possibilidade, mas a marcação do local destes eventos, Kuapügü/Kalapalo, entre o Buritizal e o oeste do Culuene, não sugere isso. Os formadores do Xingu eram pouco conhecidos e não é improvável que o Buritizal tenha sido uma via de acesso dos bandeirantes à região (com efeito, os Kalapalo dizem que Paipegü chegava descendo o córrego Hotogi, que se origina no Buritizal e deságua em Lahatua, uma lagoa cuja região é ocupada pelos Kuikuro). Estaríamos no máximo em 1760, quando se especula (Martini, 2008: 7) que Pires de Campos tenha morrido com uma flechada durante um encontro com índios (a data exata é desconhecida; sugere-se que ele tenha morrido entre 1750 e 1760). Neste ponto, a história se cruza novamente com a memória indígena, desta vez dos Kuikuro. Os historiadores dizem que Pires de Campos teria sido morto por uma flechada em um confronto com os kayapó, e carregado em uma rede por seus soldados bororo até o quartel (Martini, 2008: 7). Os Kuikuro contam que um de seus antepassados, Kuirálu (um personagem "vingador"), teria matado o chefe dos brancos hostis (Paipegü) com uma flechada, enquanto era carregado em sua rede (Franchetto, 1998: 346): 
Kuirálu estava lá para matar o chefe dos caraíba, ele tinha fugido com seu sobrinho. Cavou um buraco na beira d'água [...] os caraíba chegaram queimando a mata. À noite, os soldados foram se banhar; no meio deles estava seu chefe, carregado na rede até a água. Flecharam e Kuirálu voltou correndo para se esconder no buraco.

Depois disso, os Kuikuro contam que os chefes de Óti foram aprisionados pelos brancos, mas acabaram voltando com eles "amansados":

Esse acontecimento é importante por marcar um corte na história das relações com os brancos, uma mudança relatada como abrupta e possível graças aos chefes aprisionados, aos quais se atribui o papel de verdadeiros 'pacificadores', 'civilizadores' dos caraíba selvagens e assassinos. (ibid: 347 )

Mas por que filhos de chefes? Os Kalapalo prontamente dizem que os índios eram roubados para trabalhar para os kagaiha, mas ainda assim, não poderiam os brancos roubar pessoas comuns? Grande parte das coisas que acontecem nas histórias são com chefes e, na visão kalapalo dos ataques dos brancos, não era diferente. Essa aparente "obsessão" por identificar os protagonistas das histórias a chefes sugere que a própria chefia pode ser vista, ao menos em parte, como um efeito narrativo. Não que apenas "chefes de verdade" sejam eleitos como personagens, mas a recorrência da identificação entre chefes e protagonistas históricos é tão grande que é preciso perguntar se, ao protagonizar uma história, alguém não seja automaticamente "interpretado" como chefe. Quando um grupo é "representado" por alguém nos rituais, ele é personificado por chefes. São eles as pessoas capazes de agir no lugar do grupo, que assumem a posição de sujeitos nessas relações (no sentido de Lima, 2005). Algo semelhante parece se passar com a memória histórica. Se a memória de eventos envolvendo grupos é associada a acontecimentos na vida de pessoas específicas, estas assumem a posição de sujeitos e são, logicamente, equiparadas a chefes. Não quero dizer que os eventos não tenham "acontecido de verdade" com chefes, pois esta seria uma questão irrelevante. Chefe é quem é feito chefe, e a forma da memória histórica kalapalo, tão biográfica, como Basso (1989) já discutiu, ao narrar eventos de pessoas que "stand for the group", pode equacioná-las a chefes - assim como os ex-moradores de Amagü mudaram sua visão sobre Temetihü que, de acusado de feitiçaria, se tornou o principal ancestral do grupo que é o "ponto zero" da identidade kalapalo. 


\subsection{O aparecimento de Orlando, a criação do Parque e a contenção da feitiçaria}

Em 1946 o chefe kalapalo Tajui preparava uma festa para as flautas kagutu, das quais sua esposa era dona ${ }^{63}$. A fim de conseguir peixe para a festa, saiu de Nhagü Hatoho acompanhado de várias pessoas para uma pescaria em um lago rio Culuene acima, perto da boca do ribeirão Sete de Setembro (Tügüingi hotagü). De lá, avistaram um avião sobrevoando a região e imaginaram que deveria ser coisa dos kagaiha. No dia seguinte, 7 de outubro, ouviram um barulho muito estranho. Avistaram então alguns barcos que vinham rápido e fazendo um barulho enorme, cheios de kagaiha dentro. Era a frente da Expedição RoncadorXingu que atingia o Culuene, na qual estavam Cláudio, Leonardo e Orlando Villas Boas, chefes da Expedição. Os Kalapalo os levaram até Kahindzu, um lugar na beira do Culuene que servia de "porto" para Nhagü Hatoho, onde dormiram antes de seguir viagem no dia seguinte. Muitos kagaiha ficaram no acampamento em Kahindzu, enquanto apenas alguns seguiram para a aldeia. Quando os pescadores retornaram com os brancos, foi uma grande surpresa.

Já fazia muito tempo que as pessoas "morriam sem parar". Aldeias como Angambütü e Angaguhütü desapareceram provavelmente no começo do século XX e, quando a Expedição chegou nos Kalapalo, havia apenas uma família angaguhütü morando com eles. Segundo os Kalapalo, eles próprios teriam se matado com feitiçaria (kugihe). Vivendo em uma região distante de qualquer rio, os moradores de Nhagü Hatoho ficaram protegidos das ondas de feitiçaria/epidemias que assolavam seus parentes, até 1946. Primeiro foi uma epidemia de gripe, logo após a chegada da expedição (que matou cerca de 25 pessoas) e depois a catástrofe do sagampu (sarampo) em 1954. Os feiticeiros daquela época eram poderosos: possuíam feitiços que eram como rojões, que explodiam no céu e atingiam a todos que estivessem em baixo, provocando muitas mortes rápidas e simultâneas. Os brancos conheciam muito bem esse tipo de feitiço, pois também são seus mestres, e grande parte das mortes do começo do século são atribuídas a eles. Outro feitiço comum era feito com bonecos de forma humana,

\footnotetext{
${ }^{63}$ Quando uma mulher é dona de uma festa, seu pai ou seu marido (às vezes os dois juntos) assumem a responsabilidade por seu patrocínio.
} 
enterrados no centro da aldeia (chamados agutoho). Conforme as pessoas passavam perto do boneco, adoeciam e morriam.

O falecido xamã de Aiha contava que era criança na época do sarampo, e viu quase toda sua família morrer. Tendo ficado órfão, foi criado junto com uma irmã por sua tia materna. Não dava tempo de abrir covas para enterrar todos os mortos, e foi preciso cavar dois grandes buracos ao lado da aldeia (um para homens e outro para mulheres e crianças), próximos ao rio, onde os corpos dos mortos eram jogados dia e noite. Mães adormeciam com seus filhos e nunca mais acordavam, e os brancos também começaram a morrer (segundo o xamã, apenas dois funcionários da Expedição sobreviveram). Os brancos da região dizem até hoje que a principal causa da mortalidade indígena se deu porque estes, ao se sentirem com febre, iam para o rio refrescar o corpo, o que "empurra o sarampo para dentro" e, aí sim, o torna letal. No final daquele ano, o saldo era terrível: a população fora reduzida pela metade e a situação só foi se estabilizar nos anos 60, feito que os Kalapalo atribuem a Orlando Villas Boas. Não pela implantação do atendimento à saúde na região, mas porque ele teria convencido muitos feiticeiros a "se aposentar", verdadeira causa da redução da mortalidade. A feitiçaria nunca desapareceu, mas depois da criação do Parque, os feitiços-rojão, de índios e brancos, e os agutoho, nunca mais foram usados.

Após 1961, ano da criação do Parque, os Kalapalo se viram em um dilema cuja lembrança traz para os mais velhos um sentimento indescritível de tristeza: abandonar Nhagü Hatoho para um lugar mais perto do Posto Indígena Leonardo Villas Boas ${ }^{64}$, a fim de facilitar o atendimento à saúde. Não há um único homem ou mulher Kalapalo que, ao se lembrar do dia definitivo da mudança, não comece a falar dos parentes mortos no sarampo, das casas e objetos deixados para trás intactos (pois não havia como carregar tudo), das lembranças de viagens que faziam com seus pais à antiga aldeia para coletar conchas de caracóis e buscar pequi. A mudança para Aiha, entre 1962 e 1963, foi muito brusca emocionalmente, e também teve seus efeitos políticos.

Quando a Expedição encontrou os Kalapalo, seu principal chefe era Sagagi, reconhecido como um dos maiores chefes kalapalo. Em 1925, ano em que o Coronel Fawcett apareceu em Kunugijahütü, Sagagi já era o chefe principal, como a narrativa de uma mulher que era criança à época deixa claro. Na mesma época, também eram chefes junto com ele

\footnotetext{
${ }^{64}$ Antigo Posto Indígena Capitão Vasconcelos, rebatizado em 1961 em homenagem a Leonardo, falecido naquele mesmo ano.
} 
Agihiga, Ageu (um homem considerado "pai” classificatório de ambos) e Enumü. Antes de Sagagi, sabe-se que houve um grande chefe chamado Juaikumã, mas não consegui recuar mais do que isso. De Sagagi até a geração dos pais dos atuais chefes adultos, porém, todos oferecem a mesma ordem de sucessão: 1) Sagagi; 2) Agihiga; 3) Kumetsi; 4) Tajui; 5) Ausuki $^{65}$; e 6) Kambetse ${ }^{66}$.

Dizem que após a morte de Tajui, ainda em Nhagü Hatoho, a chefia "ficou confusa". Como muitos nobres haviam morrido no sarampo, havia poucas pessoas aptas a assumirem seus lugares, e os anetü Ausuki e Kambetse dividiam a posição de chefes principais. Ausuki era reconhecido como um grande chefe, mas sua posição nunca foi muito clara. Ele era filho de uma itankgo (feminino de anetü) importante, mas ocupava uma condição complicada porque seu pai era um chefe mehinaku que, depois de ter sido acusado de feitiçaria em sua própria aldeia, fugiu para os Kalapalo em busca de refúgio junto aos parentes de sua esposa (o próprio Ausuki nascera na aldeia mehinaku). Kambetse, apenas um pouco mais novo que Ausuki, foi outro grande chefe, e que segundo Basso (1973: 134) teria herdado a chefia de seu FB.

Na época da criação do Parque, um grande chefe e xamã kamayurá, Takumã, foi o responsável por negociar com os Kalapalo e os Nahukua sua mudança para mais perto do Posto Leonardo, assim como encontrar para eles lugares onde pudessem erguer suas aldeias (já que a região não é território tradicional karib, mas kamayurá). Kambetse era terminantemente contra, enquanto Ausuki, primo de Takumã, era favorável à aproximação do Posto. Os Kamayurá haviam escolhido dois lugares para que os Kalapalo e Nahukua se mudassem, Aiha e Magijape. As terras de Magijape são excelentes, sendo possível encontrar terra preta bem perto da aldeia. Além disso, o sítio já havia sido ocupado pelos karib no final do século XIX, como apontado por Von den Steinen (1940). Já em Aiha, a terra é muito vermelha e pouco fértil, as poucas terras pretas da região são consideravelmente distantes e não havia qualquer memória de ocupação karib daquele local, apenas kamayurá - o que não agradou os Kalapalo. Contudo, Aiha é uma região muito "segura", sem espíritos muito

\footnotetext{
${ }^{65}$ Apihũ, Ulutsi ou Müuda nos trabalhos de Basso (1973; 1985; Becker, 1969). É ele o chefe chamado de Müra na história de Temetihü.

${ }^{66}$ Bïjijï ou Kambe nos trabalhos de Basso. Nunca entendi a grafia usada pela autora para seu primeiro nome, que era Bogogo - cuja sonoridade não deixa de evocar proximidades com o nome "Bororo". Essa relação fica ainda mais curiosa se notarmos que há um jovem em Aiha chamado Meruri, o mesmo nome de uma aldeia bororo. Se Paipegü era realmente Pires de Campos, e os índios com os quais ele atacava eram os Bororo, fica a questão sobre que relações, além das bélicas, estes poderiam ter estabelecido com os Kalapalo.
} 
perigosos. Magijape, em contrapartida, fica próxima de uma lagoa onde vive um perigoso Hiper Peixe Bicuda (Johi Kuẽgü), que anda pelos arredores toda noite. Takumã disse a Ausuki que, como ele era seu primo, se ele aceitasse conduzir os Kalapalo para mais perto do Posto daria a eles o território de Aiha, não tão fértil quanto Magijape, mas livre de grandes perigos sobrenaturais. Ausuki convenceu todos a se mudarem, mas Kambetse ainda era contra e se mudou contrariado.

Ninguém sabia ao certo se aquele local tinha um nome em karib, e foi o chefe dos Yawalapíti à época quem se lembrou do nome da região, dado em função de um lago (que, diferentemente do que diz Basso, não é a lagoa próxima à aldeia). Tendo organizado a mudança e recebido o território de Takumã, Ausuki se tornou o "dono da aldeia" (ete oto) e o primeiro cacique. A aproximação do Posto, passada a tristeza da mudança, mostrava os benefícios do atendimento à saúde e acesso a objetos industrializados, rendendo a Ausuki ainda mais prestígio e deixando Kambetse mais desconfortável. Foi nesse contexto politicamente complicado que Basso realizou sua pesquisa de campo e retratou a tensão entre estes dois chefes e suas parentelas (Basso, 1973; Becker, 1969). Ela também nota que "the conflict between these men probably began around the time when pressure was put upon the Kalapalo to move their village closer to the Post" (Basso, 1973: 119).

Basso utiliza o termo "facção" para descrever as relações desiguais de prestígio e influência, que ela define da seguinte forma: "It is convenient to refer to the persons upon whom a leader may depend for support during disputes as a 'faction"' (ibid: 119). Apesar de todos terem parentes e afins que os ajudam em ocasiões variadas, apenas alguns se oporiam como grupos conflitantes: "The opposition of Kalapalo factions as 'conflict groups' is manifested in verbal disputes, or more exactly (because they are rarely direct confrontations) in verbal statements and in physical avoidance" (ibid: 119). A autora também afirma que uma das principais fontes de conflito entre facções eram as afirmações de seus líderes como chefes: alguns anetü ativos eram (e ao que tudo indica sempre serão, pois a situação atual é muito semelhante) questionados acerca da legitimidade de seu status. Segundo a autora, entre 1966 e 1968 havia sete homens considerados anetü em Aiha, dos quais três nunca exerciam papeis associados a esta condição (ibid: 133):

- Ausuki, o mais velho e considerado o principal chefe à época; 
- Kambetse, apenas um pouco mais novo do que Ausuki, e que disputava com ele a condição de chefe principal;

- Yahula, filho do grande Sagagi;

- Tuhule, o mais jovem (em torno de 26 anos) e o único que indiscutivelmente era um anetü hekugu ("chefe de verdade");

- Nakü, filho do chefe Juaikumã, mas que nunca assumiu a posição de anetü;

- Majuta, considerado anetü hekugu, filho e neto de dois grandes chefes, mas que não exercia suas funções em respeito a seus dois cunhados mais velhos, Ausuki e Kambetse;

- Sagama, um importante chefe jagamü e que chefiara a aldeia Angaguhütü antes de sua dispersão.

Basso nota diversas vezes que Kambetse questionava a posição de Ausuki como anetü por sua origem mehinaku. Quando Ausuki patrocinava algum ritual, Kambetse não saía de sua casa, e os dois sempre se sentavam em lados opostos no banco em frente à casa dos homens (Basso, 1973: 120). A despeito das hostilidades pessoais, eram primos paralelos e suas parentelas sempre foram intimamente ligadas por relações de parentesco e casamento. Quando Ausuki ficou velho e deixou de exercer suas atribuições de chefe, Kambetse se tornou o primeiro cacique, posição que ocupou até sua morte, em 1984, quando seu filho mais velho Ageu assumiu temporariamente seu lugar. Ausuki faleceu em 1992.

Uma grande divisão aconteceu em Aiha entre o final da década de 1970 e o começo dos anos 1980, culminando na criação de Tankgugu. Este é um assunto sobre o qual ninguém gosta de conversar e, quando o faz, é sempre de forma rápida e evasiva. Várias pessoas me disseram que Aiha havia sido "cortada ao meio" e que houve uma "grande confusão", mas ninguém nunca admitiu saber a razão da mudança. Dizer que não sabe o que aconteceu, que "só quem foi embora é que pode saber", é a atitude padrão em casos que envolvem acusações de feitiçaria ${ }^{67}$, pois há um duplo esforço das pessoas para evitar se posicionar (a fim de evitar rumores sobre si e eventuais retaliações - reais ou mágicas) e fazer o possível para não remoer as acusações. Este último ponto é uma das coisas que mais me chama a atenção até hoje. É incrível como durante os rituais, quando todos se juntam, alguém que ameaçou outra pessoa de morte por causa de feitiçaria pode se sentar ao seu lado, pedir que lhe ensine uma música e passar bons minutos se divertindo. Pessoas que vivem se acusando, quando se

\footnotetext{
${ }^{67}$ Segundo alguns Yawalapíti, teria havido alguma morte e os Kalapalo teriam prendido o acusado e sua família em uma espécie de "gaiola" fora da aldeia (comunicação pessoal de João Carlos Almeida).
} 
encontram comem juntos, conversam, dançam, dão risada. Há um esforço deliberado para mascarar (mais do que esquecer) as acusações.

Tankgugu foi aberta por um homem casado com a irmã mais nova de Ausuki (ele era seu segundo marido, o primeiro já havia falecido). Dizem que ele teria aberto a aldeia por insistência de sua esposa, que se sentia "mais mehinaku do que kalapalo" (de fato, ela havia nascido lá). A situação se complicou quando um dos maiores xamãs do Alto Xingu ${ }^{68}$ foi acusado de matar por feitiçaria o primogênito de seu "neto" classificatório (seu BDS). O pai do menino morto acusou o xamã em público, que se mudou para Tankgugu, onde já estavam outros de seus parentes. Ele acabou levando muita gente para a nova aldeia, pois como se vê na etnografia de Basso, ele era um homem de grande prestígio e, no final dos anos 1960, tinha o maior grupo doméstico de Aiha, ligado por parentesco e aliança às facções dos dois chefes principais.

Hoje, existem seis anetü (homens) adultos ativos em Aiha. Dois deles (o filho mais novo de Kambetse e o neto mais velho de Ausuki, respectivamente) são "hierarquizados" como primeiro e segundo caciques, enquanto os outros "podem ser terceiro, quarto, quinto... tanto faz", como já ouvi várias vezes. Isso é importante, pois mostra que a chefia não se organiza segundo um princípio hierárquico global capaz de posicionar "all members of Xinguano sciety in an overarching hierarchical structure", como sugere Heckenberger (2005: 262). Em kalapalo, o "segundo" em relação a um grande chefe é isotohongo, "seu outro igual", indicando geralmente uma situação de simetria, acompanhada de conflito em potencial. Atualmente, um dos motivos pelos quais a situação é tranquila é porque o segundo cacique é genro do primeiro (ZDH), o que impõe entre eles uma relação de grande respeito. Contudo, quando havia outro anetü em Aiha, que era considerado o otohongo do primeiro cacique, os dois viviam em conflito. Além dos adultos, há outros 16 jovens chefes (12 homens e 4 mulheres), entre 15 e 35 anos de idade. Vejamos a configuração da chefia atual de Aiha no diagrama abaixo:

\footnotetext{
${ }^{68}$ Desde os anos 1960, Basso diz que ele já era requisitado em outras aldeias xinguanas.
} 


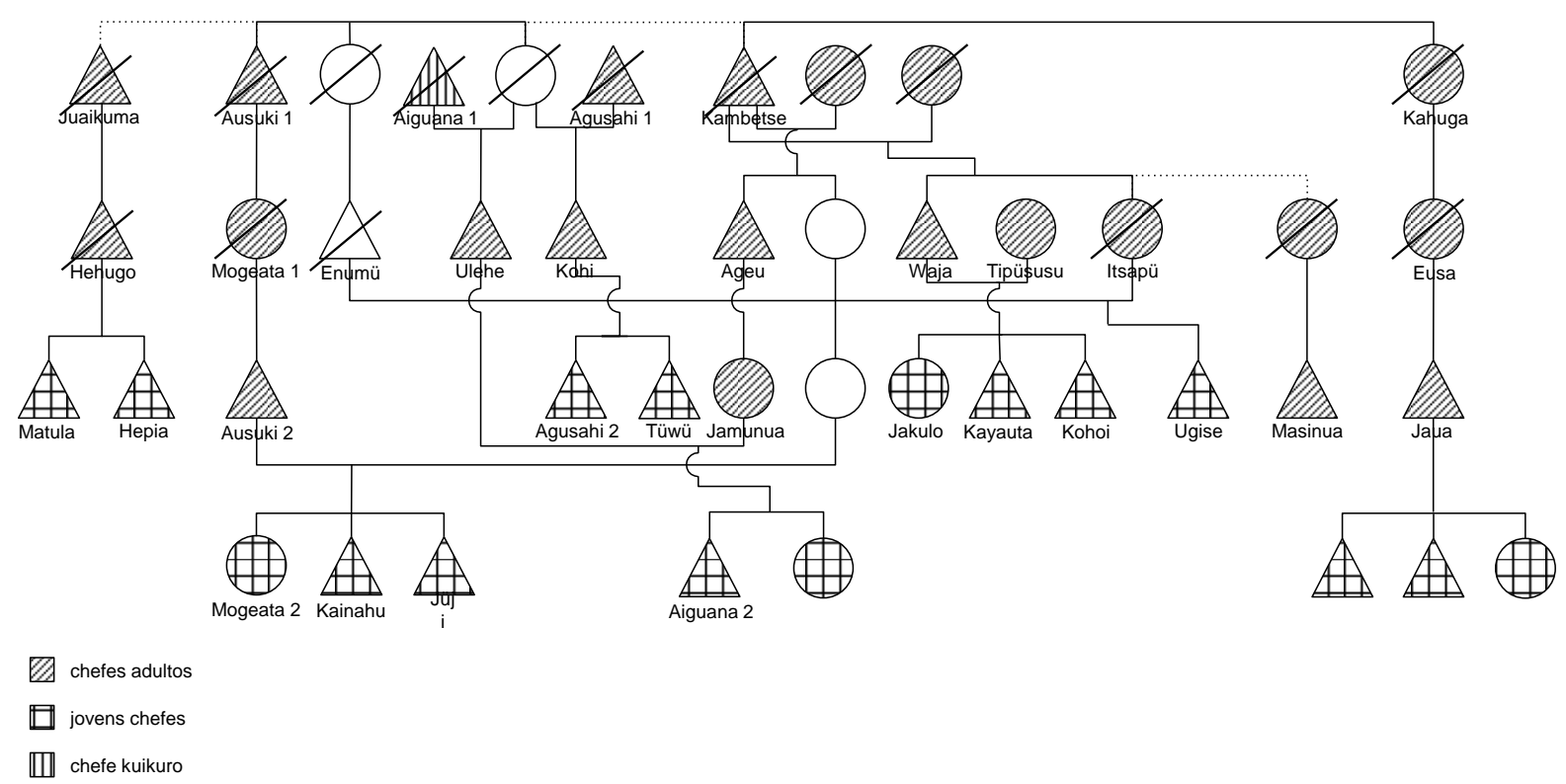

Figura 1.4: configuração atual da chefia de Aiha.

Nota-se que quase todos os chefes adultos estão muito perto de Ausuki e Kambetse. A sucessão de Kambetse não foi nada simples. Ageu, seu filho mais velho, foi muito preparado por seu pai para substituí-lo (é um grande conhecedor de histórias, cantos, rezas, discursos) e Basso afirma que ele havia se tornado o líder principal após a morte de seu pai (Basso, 2009: 255). Porém, ele foi substituído por seu irmão mais novo, Waja, escolhido pessoalmente por Orlando Villas Boas. Como ele mesmo conta, poucos anos depois da morte de seu pai Orlando pediu que ele "assinasse um papel”, "que ele levaria pra Brasília", para que se tornasse o chefe kalapalo. Isso porque ele já falava um pouco de português (ao contrário de seu irmão mais velho) e fez parte de um grupo de jovens chefes que o próprio Orlando tentou preparar para administrar o contato no Alto Xingu. Waja conta que foi levado por Orlando duas vezes para São Paulo e Brasília, onde passou temporadas de alguns meses com os filhos de outros chefes alto-xinguanos, quando Orlando aproveitava para mostrar a eles os costumes dos brancos e ensinar um pouco de português. Ele não foi tão preparado quanto outros, pois depois da segunda viagem seu pai não permitiu mais que ele deixasse a aldeia. Um pouco mais novo do que ele, um dos netos de Ausuki (que recebeu seu nome) também se tornou chefe e divide com ele a chefia.

Outro chefe entrou em cena no final dos anos 1990, um neto do anetü Agihiga casado com uma mulher yawalapíti, e que vivia na aldeia de seus afins desde a década de 1970. Ele não era considerado anetü naquele grupo, mas tinha muitos contatos na cidade e viajava 
muito. Os Kalapalo decidiram que precisavam de alguém para "cuidar dos brancos", e não tinham ninguém em sua aldeia que tivesse a experiência necessária. Decidiram, então, trazer esse homem e fazê-lo chefe, construindo para ele uma casa. Ele se tornou o segundo cacique e permaneceu em Aiha até o final de 2007, quando abriu sua própria aldeia. Nesse período, ele conseguiu vários aliados brancos para os Kalapalo de Aiha, o que proporcionou certo fluxo de visitantes, dinheiro e projetos para a aldeia, lhe rendendo muito prestígio.

Como se vê, a condição de chefe é realmente indissociável do parentesco, pois não há ninguém que tenha sido "feito chefe" sem ser filho de um anetü ou uma itankgo (questão que será abordada em detalhes no capítulo seguinte). Além disso, a transmissão de nomes parece objetivar essas relações genealógicas em seus portadores, pois não deve ser por acaso que jovens preparados para a chefia recebem muitas vezes (mas nem sempre) nomes de chefes famosos. Todavia, isso não implica, como Heckenberger (2005: 270) sugere, nenhuma hierarquização rígida de linhas de descendência entre chefes. Segundo este autor, a hierarquia entre mais velhos e mais novos criaria, ao longo do tempo, linhas de descendência hierarquizadas: filhos de irmãos mais velhos seriam mais importantes que filhos de irmãos mais novos, gerando uma estrutura semelhante ao "clã cônico" de Sahlins (1968). Vemos que, na realidade, a primazia da chefia circula muito, não obedecendo a qualquer hierarquia dada de antemão. Nem sempre o filho de um primeiro cacique ocupará sua posição, algo que depende de como cada chefe é preparado, como se comporta, sua idade relativa, seu envolvimento em rumores e conflitos, aqueles com os quais têm relações de afinidade, etc. A própria historicidade interna ao sistema impede que ele se cristalize sob uma forma hierárquica fixa, atrelando a chefia a pessoas específicas e não a unidades sociais.

$* * *$

Podemos imaginar então um duplo movimento na produção diacrônica do grupo que ficou conhecido como Kalapalo. Um, é a diferenciação: desde o tempo mítico, quando obtiveram sua especialidade produtiva (cintos e colares de conchas) e sua língua, os karib se diferenciaram progressivamente uns dos outros e fixaram diferentes identidades coletivas. Mas este processo é indissociável de outro, a mistura, pois as relações regionais sempre fizeram com que todo grupo fosse heterogêneo de saída. Como mostra Mehinaku (2010), a 
mistura e a pureza, o amálgama e a diferenciação, são duas formas de se perceber o sistema alto-xinguano em movimento. Mesmo um "kalapalo puro" tem ancestrais de outros grupos, assim como pessoas "misturadas" podem, eventualmente, se tornar grandes chefes kalapalo. Gerar uma identidade específica é que sempre o foi problema, e qualquer "povo" (um conjunto de aldeias que se identifica a uma aldeia iho) sempre foi uma cristalização particular e transitória de redes de parentesco mais amplas.

A história kalapalo, do tempo do lago Tahununu aos dias de hoje, se vê em um fluxo constante entre a supressão da diferença e sua inevitável reemergência. Isso é muito visível nas fissões de Aiha dos últimos anos, pois como já notei em outra ocasião (Guerreiro Júnior, 2008: 39), algumas das novas aldeias às vezes são vistas como "jagamü" ou "matipu" em função da ascendência de seus respectivos chefes. Ao mesmo tempo que os chefes são pontos de referência históricos, símbolos de redes de parentesco que se cristalizaram para formar uma aldeia ou um povo, e que norteiam a produção contemporânea de identidades, é também ao redor da chefia que acontecem muitos dos processos de fissão (que, por sua vez, são simultâneos a novos movimentos de reorganização e identificação ${ }^{69}$ ). Como já chamei a atenção, Franchetto $(1986 ; 1998)$ mostrou ter sido este o caso entre os ancestrais dos Kuikuro e Uagihütü, e Viveiros de Castro (1977) comenta algo semelhante entre os Yawalapíti.

Como nota Basso (1989: 552-553), grande parte das “narrativas históricas" kalapalo é sobre pessoas específicas e suas reações a certos eventos, nos quais suas lealdades e modo de vida são postos em cheque e são obrigadas e escolher diferentes formas de agir. Estas pessoas e os lugares onde viveram são uma ponte entre o presente e um passado que insiste em tocar no mundo mítico, um passado representado como um quebra-cabeça, cujas peças cada um é convidado a tentar colocar no lugar (com o diferencial de que várias peças podem se encaixar em vários lugares ao mesmo tempo). Cada referência a pessoas e lugares contribui para que os Kalapalo produzam algo como um "nós", em contraste com um fundo geral de humanidade (afinal, no passado havia "muitos outros iguais" aos Kalapalo). Por meio de narrativas, é possível entender melhor a composição deste grupo e o lugar que a chefia vem desempenhado em seus processos de coletivização/identificação e autodiferenciação. Mas é preciso notar que este não é um processo acabado em nenhuma de suas direções: é preciso sempre lembrar dos

\footnotetext{
${ }^{69}$ Este tipo de fluxo é homólogo ao dos caminhos seguidos pelas redes de parentesco: por questões genealógicas ("apagamento" das relações de cognação), sociais ou espaciais alguns parentes se distanciam e se transformam em afins potenciais, até que se transformem em afins efetivos pelo casamento e produzam, novamente, parentes próximos (Guerreiro Júnior, 2008).
} 
chefes do passado através das histórias e dos discursos cerimoniais, assim como antigos antagonismos podem ser acionados em novas diferenciações. A história é usada o tempo todo para refazer ou desfazer os Kalapalo. 


\section{Capítulo 2 - Fazendo substitutos: a questão da hereditariedade da chefia}

- Veja só, a lua está sentada.
- Você está falando da lua cheia? Por que ela está sentada?
- Porque ela está chefiando seu pessoal na festa de outra
aldeia. Veja como ela está grande e bonita.
(Conversa em frente de casa, em uma noite de lua cheia)

Inhalübeha engü uhutinhihüngü ngipi inhalü Os que não são conhecedores não têm/sabem nada dessas coisas, não

Tükima uhunalü ihekeni?

Para que eles saberiam?

(Ageu, falando sobre o conhecimento da fala ritual)

Por todas as etnografias disponíveis sabemos que a ascendência nobre é necessária para o exercício da chefia, mas é insuficiente: ninguém se torna anetü se não for feito chefe por seus pais e pelo grupo. Ao mesmo tempo, a lógica da fabricação também não dá conta sozinha do problema, pois não explica porque qualquer pessoa não pode ser feita chefe. A princípio seria possível supor que a chefia é composta de algo "dado" (expresso pela hereditariedade) e algo "construído" (pela educação, as reclusões, o patrocínio de rituais); porém, além de não sabermos nada sobre o que seria esse "dado", há casos que mostram que a chefia de alguém pode simplesmente "acabar" de uma geração a outra, colocando em dúvida a existência de algo de inato na nobreza. O objetivo deste capítulo é analisar a relação de filiação entre chefes, no intuito de compreender melhor o que está por trás da hereditariedade da chefia kalapalo.

\subsection{Nascer nobre, ser feito chefe: o "paradoxo" da herança e da fabricação}

Antes mesmo de figurar como uma questão importante nas etnografias, os chefes altoxinguanos já faziam parte da realidade do contato. Ramiro Noronha (1952), em 1920, já falava dos "caciques" e "capitães" xinguanos, e vê-se por seu relato que os Bakairi já traduziam a diferença entre chefes e não chefes sob a forma da oposição capitão/camarada 
(certamente desde muito antes ${ }^{1}$ ). Dos anos 1940 em diante, a figura dos chefes ficou ainda mais marcada, pois eles é que se tornaram, na maioria das vezes, os intermediários oficiais do contato - ou, como os Kalapalo gostam de dizer, foram eles que se tornaram amigos dos irmãos Villas Boas. Uma forma recorrente de se descrever as relações entre chefes, sejam de uma mesma aldeia ou de aldeias diferentes, é como amigos (ato), pois são "aqueles que conversam" (itaginhokongo - referência às conversas rituais no registro da "fala dos chefes") e se comportam como parceiros de troca - dois aspectos marcantes da relação de amizade xinguana. Conforme já discuti em outra ocasião (Guerreiro Júnior, 2010) e como ainda veremos em detalhes, este modelo da relação entre amigos como um modo de lidar com o contato se reproduz até hoje, certamente não sem criar problemas ou catalisar conflitos já existentes.

Assim, quando as primeiras monografias sobre os alto-xinguanos começaram a ser escritas, a existência de pessoas conhecidas como "chefes" já era uma daquelas coisas que se sabe de antemão. No contexto do contato, essas pessoas se tornaram de fato um tipo de "representantes" de seus povos perante os agentes da sociedade nacional. Mas ao falar sobre povos que, de saída, imagina-se que possuem "chefes" e "representantes", fica difícil esvaziar estas palavras dos sentidos que elas têm nas nossas ideologias políticas. No exato momento em que pensamos em chefia, inevitavelmente pensamos em autoridade, poder, hierarquia; e, de forma semelhante, é difícil para o pensamento moderno conceber alguma forma de representação sem supor a existência de uma totalidade representável - o que nos leva de volta ao problema da hierarquia e do poder (Dumont, 2000 [1983]), criando um círculo vicioso. Ao analisar uma realidade indígena sem a devida crítica a tais categorias, passamos mais tempo patinando sobre a ideologia moderna do que descrevendo e compreendendo outra forma de pensamento.

Segundo Lima (Lima, 2005; 2008), não seria possível utilizar o conceito dumontiano de hierarquia para pensar os coletivos ameríndios, dada a impossibilidade de se encontrar, entre estes, um conceito de "totalidade", mas ele certamente é útil para pensar a produção antropológica sobre a política alto-xinguana. De acordo com Dumont (2000 [1983]: 79),

\footnotetext{
${ }^{1}$ Os Bakairi do rio Arinos estão em contato com os brancos desde o século XVIII, quando foram alcançados pelas bandeiras e engajados em atividades mineradoras; os do Paranatinga, mais próximos dos alto-xinguanos, se envolveram com pecuaristas e agricultores já na primeira metade do século XIX (Barros, 2003).

${ }^{2}$ De forma resumida, isso seria uma característica das ontologias perspectivistas, nas quais não é possível encontrar um ponto de vista capaz de englobar todos os demais e produzir uma noção de totalidade (Lima, 2005; 2008).
} 
haveria duas formas de se conceber a ordem social: uma delas veria o homem e a sociedade como parte da organização mais geral dos cosmos, como parte de uma totalidade maior; outra veria o indivíduo como a única entidade real, distinta e separada da ordem natural, a partir da qual se organizariam as relações sociais. No primeiro caso, o holismo e a hierarquia seriam os princípios responsáveis pela organização do mundo; no segundo, toda ordem só poderia ser vista como o resultado de uma imposição exterior sobre o indivíduo, dando origem à forma moderna do conceito de poder:

Quando nada mais existe de ontologicamente real além do ser particular, quando a noção de "direito" se prende, não a uma ordem natural e social, mas ao ser humano particular, esse ser humano particular torna-se um indivíduo no sentido moderno do termo. Um corolário imediato da transformação é a ênfase dada à noção de "poder" (potestas), que se apresenta assim como um equivalente funcional moderno da idéia tradicional de ordem e hierarquia. (id. ibid.)

O desenvolvimento da categoria política e do Estado moderno está ligado à atribuição à humanidade de uma condição universal, dada e imutável, a partir da qual se constroem, $a$ posteriori, as ordens social e política. Concebido um mundo feito de indivíduos livres e iguais, para a ideologia moderna o "equivalente funcional" da ordem e da hierarquia só pode aparecer sob a forma de algo externo e posterior a eles, ou seja, sob a forma de autoridade, de poder. Esta é a razão pela qual o pensamento moderno tem tanta aversão a discussões sobre hierarquia, pois antes de ver neste fenômeno um princípio de organização do pensamento, o identifica àquilo que limita um dos princípios fundadores do individualismo: a liberdade. Como diz Dumont, "a hierarquia é o anverso social, a força o reverso atômico da mesma medalha. Assim, um acento sobre a consciência e o consentimento produz imediatamente um acento sobre a força ou o poder” (2000: 101). Do ponto de vista moderno, a natureza do político só pode ser o poder - o que valeria tanto para as teorias do Estado quanto para diversas interpretações das formas ameríndias de chefia.

No caso do Alto Xingu, este enraizamento do problema da chefia na ideologia moderna acabou se transformando em outro, de ordem etnográfica: como descrever a chefia? Uma colocação de Wittgenstein usada por Renato Sztutman (2005: 227), como epígrafe de um capítulo de sua tese sobre a ação política ameríndia, traduz bem o espírito desta questão, e tomo a liberdade de reproduzi-la: 
We come to an alien tribe whose language we do not understand. Under what circumstances shall we say that they have a chief? What will occasion us to say that this man is the chief even if he is more poorly clad than the others? The one whom the others obey - is he without question the chief?

What is the difference between inferring wrong or not inferring? Between adding wrong and not adding? Consider this. (Wittgenstein, 1998 [1956]: 352)

As atitudes dos autores perante essa dificuldade são variadas, pois a própria tarefa de se definir o que é um chefe alto-xinguano ou, pra começar, de se escolher termos como "chefe", "líder" ou "representante" para traduzir os termos nativos, está longe de ser simples. Boa parte das etnografias mais antigas focaliza, sobretudo, a relação dos chefes com o interior do grupo local (seus coaldeões), se detendo sobre temas como poder, hierarquia, autoridade e, o que talvez seja mais interessante, utilizando como recurso descritivo uma noção mais ou menos difusa de "economia política", bastante aparentada da concepção moderna. O trabalho de Zarur (1975) sobre os Aweti talvez seja o exemplo mais claro disso. Ele se refere às categorias de morekwat ("liderança autêntica da aldeia"), capitão ("representante da sociedade nacional dentro de uma aldeia") e camára ("que não pertencem a nenhuma das outras duas categorias") como "status de poder" (ibid: 39). Referindo-se aos morekwat, ele diz que a "base de seu poder" (id. ibid.) viria de uma regra de residência pós-marital diferenciada para seus filhos e da prerrogativa dos casamentos poligínicos: como os chefes têm várias esposas $^{3}$ e a residência para seus filhos e filhas casadas é patrilocal ${ }^{4}$, estes homens controlariam grupos domésticos muito maiores que os demais, capazes de mobilizar muito mais trabalho para patrocinar rituais. "A regra de localidade não apenas aumenta o número de afins no grupo doméstico, como, permitindo o aumento do número de esposas de seu chefe, aumenta globalmente o potencial de trabalho, permitindo que o chefe realize rituais essenciais para a vida comunitária" (ibid: 42; grifos meus).

A perspectiva de Basso (Basso, 1973; Becker, 1969) não está tão distante da tese de Zarur. Ela chega a tocar em um ponto importantíssimo da chefia, que é o fato dos anetü atuarem principalmente como "village representatives" (Basso, 1973: 107) nas relações rituais

\footnotetext{
${ }^{3}$ Zarur vê a poligamia como um privilégio dos chefes. Contudo, entre os Kalapalo ela não lhes é exclusiva, apesar de ser mais fácil para um anetü conseguir mais esposas (de um lado, as mulheres tendem a se interessar mais por chefes; de outro, estes homens têm maior chance de receberem a aprovação de seus sogros).

${ }^{4}$ Considerando que o modelo de residência pós-marital para os homens em geral é a uxorilocalidade.
} 
entre diferentes povos (diferentemente dos village leaders, que poderiam influenciar pessoas mesmo sem serem anetü). Contudo, infelizmente ela abandona este ponto, talvez por achar que "most elements of the ritual are without much significance to the performers" (ibid: 153), e também acaba focalizando quase que exclusivamente a questão do poder e da capacidade de acumular potencial de trabalho alheio. Para a autora, o que caracteriza um líder é a capacidade de "consistently influence the decisions and control the initiative of a large number of individuals, and thus implement power" (id.: 107; grifos meus). Mas o que seria o "poder de controlar as decisões e iniciativas de outros" de que fala Basso? Controlar como, e decisões sobre o quê? Em outra passagem ela se refere a esse controle como "the authority to direct the subsistence activities of a relatively large number of adults, as well as less mature relatives. Thus, the potential for food production in these groups is higher than in others" (id.: 108; grifos meus). Esse potencial mais elevado de produção de alimentos seria utilizado para patrocinar rituais, o que permitiria aos grandes patrocinadores pedir trabalhos para a aldeia, exibir o ideal de comportamento generoso, ganhar prestígio e, assim, se tornarem capazes de mobilizar ainda mais parentes e afins para suportarem suas futuras atividades rituais, realimentando suas fontes de prestígio e influência (ibid: 107).

Basso e Zarur descrevem a "política interna" das aldeias xinguanas como uma economia política na qual prestígio e parentes desempenham o papel de recursos escassos: seria preciso prestígio para se dispor do trabalho de parentes $^{5}$, patrocinar rituais, adquirir mais prestígio, expandir a capacidade influenciar parentes mais distantes e realimentar todo o ciclo. Por suas relações com o sistema cerimonial e por já contarem com o apoio de amplas parentelas, os anetü de saída teriam uma vantagem nesta corrida política, dispondo de condições mais favoráveis à acumulação destes estatutos e de exibição pública do comportamento xinguano ideal (Basso, 1973).

Outros autores, sem interessar-se tanto pelo poder enquanto uma questão de economia política, colocam o problema da existência ou não de poder coercitivo, e da capacidade dos chefes de sancionar regras, como a questão de fundo de suas investigações - uma preocupação direta com o "controle social”. Dole (1966), por exemplo, tenta explicar como poderia haver "controle social" (ibid: 296) entre os Kuikuro dado que o anetü é uma figura totalmente desprovida de poder coercitivo, frequentemente ignorada. Como consequência

\footnotetext{
5 "Potencial de trabalho", para Zarur, e "potential for food production" para Basso - as expressões são praticamente as mesmas.
} 
desta "falta de poder" do anetü, Dole descreve a sociedade kuikuro como "frouxamente estruturada" (ibid: 295) e "sem controle social efetivo" (ibid: 296) - imagem clássica do Alto Xingu no momento anterior às etnografias de Basso (Becker, 1969) e Viveiros de Castro (1977), os primeiros a tentarem se aproximar dos idiomas nativos de organização das relações sociais. Ainda segundo Dole, o mecanismo de controle do qual os Kuikuro dispõem seria o medo que as pessoas têm de serem acusadas de feitiçaria caso não se adequem aos padrões morais. Nos termos de Gregor $(1977 ; 1990)$, isto geraria uma espécie de "paz negativa", que não é o resultado de "leis", mas do receio de não se adequar a um padrão ético (que pode ter consequências letais, já que pessoas acusadas de feitiçaria correm o risco de serem executadas por vingança).

Numa perspectiva diferente, que confere aos chefes um papel bem importante, Ireland (1993a; b) também manifesta um interesse explícito pela relação do chefe wauja com a “ordem interna”, e parece ver o amunaw (“chefe", em wauja) como um tipo de juiz, alguém responsável por reprovar ou sancionar comportamentos segundo regras. Em um artigo (Ireland, 1993a) a autora narra o episódio no qual um garoto de quatro anos foi estrangulado pelo padrasto. A esposa do homem concebeu a criança quando era viúva, e o menino não tinha um pai reconhecido publicamente. Na ocasião, o chefe não estava na aldeia e demoraria a voltar, e os Wauja pareciam esperar seu retorno para que ele comunicasse sua decisão sobre o que fazer em relação ao padrasto agressor. Para a surpresa da antropóloga, depois de ninguém dizer nada ao chefe sobre o ocorrido e ela própria ter lhe contado o fato, ele não pronunciou uma palavra sequer e ninguém nunca mais tocou no assunto. Segundo Ireland (ibid: 23), “(...) the chief expressed a legal decision by maintaining silence. In his behavior, the chief acknowledged the gravity of the situation while communicating his decision that no action against the man was to be taken" (grifos meus).

A autora apresenta o evento como se fosse uma questão da precedência de uma regra sobre outra, dizendo que “(...) the conflict brought into conflict two rules (...)" (ibid: 24): a) que filhos ilegítimos não devem viver; e b) que ninguém deve tirar a vida de outra pessoa. "By not denouncing the killer as a murderer, the chief had clearly decided that the rule requiring that illegitimate children be destroyed took precedence and that the incident was to be viewed as delayed infanticide" (id. ibid.; grifos meus). Mas seria mesmo uma questão de "regras", e caberia de fato ao chefe "resolver" a questão, tomar uma "decisão legal" (ibid: 23)? 
Estes autores focalizam os nobres (independentemente da terminologia adotada por cada autor) a partir de questões ligadas à administração das relações internas, como o poder, a capacidade de centralizar trabalho e riquezas em relação a seus coaldeões ou o controle social. Essas perspectivas acabam sendo tributárias, voluntariamente ou não, das imagens da política ameríndia produzidas desde o clássico trabalho de Lowie (1948) sobre o tema, que afirma de saída que o problema a ser investigado é se a chefia tem ou não "poder". Como Menezes Bastos $(1983$; 1992; 1995) já demonstrou, muitas etnografias sobre o Alto Xingu tratam os grupos locais como se fossem unidades que supostamente preexistiriam à formação do sistema regional. Dito de outro modo, tratam as aldeias como totalidades, o que facilmente leva a pensar a chefia exclusivamente a partir dos temas da hierarquia (correlato da ideia de totalidade) e do poder (correlato ocidental-moderno da ideia de hierarquia - cf. Dumont, 2000).

Se, porém, as relações regionais forem vistas como constitutivas de um sistema de "fronteiras abertas e moventes" (Menezes Bastos e Menezes Bastos, 2002: 133; Menget, 1977), o foco necessariamente muda. Menget (1993: 60-61) define a política como sendo o campo pelo qual cada sociedade distingue entre um "interior" e um "exterior", e regula estas distinções tendo em vista a criação de um interior segundo um modelo desejado. Segundo o autor (ibid: 73), os chefes seriam os responsáveis por regular as fronteiras entre os povos, entre xinguanos e não-xinguanos, vivos e mortos, consanguíneos e afins. Antes de serem “controladores" ou "acumuladores", para Menget os chefes são mediadores por excelência. O autor também chama a atenção para a importância da preparação do chefe que, para assumir seus papéis, deve "sintetizar os pontos cardeais do homem ideal" (Menget, 1993: 68). Viveiros de Castro já havia discutido essa correlação entre a fabricação do chefe como modelo ideal da pessoa xinguana e seu lugar nas relações regionais: "O amulaw [anetü em yawalapíti] só existe 'para fora' - é uma personalidade ideal, alguém que se aproxima mais do modelo que os comuns, e representa seu grupo, 'seu pessoal', 'seus filhos', na interação cerimonial” (Viveiros de Castro, 1977: 220). Assim, outra forma de ver a chefia é a partir da questão da produção de chefes e suas relações com o regionalismo.

Mas os chefes não estão ligados apenas aos rituais regionais, e também podem ser vistos como "mediadores" importantes frente aos espíritos. Os trabalhos de Barcelos Neto (2003; 2004; 2008) apresentam descrições e análises esclarecedoras sobre isso, pois mostram que as relações dos chefes com os espíritos (apapaatai, em wauja), por meio dos rituais de 
máscaras, também contribuem para seu "engrandecimento". Chefes que se tornam donos de muitos rituais para espíritos dispõem de muitas pessoas plantando roças para suas festas ${ }^{6}$, o que lhes permite patrocinar esses eventos com mais facilidade. Além de ter seus parceiros rituais trabalhando para ele, com o patrocínio de festas um chefe consegue desempenhar o papel de "provedor" que se espera dele, exibir o ideal de comportamento generoso e expandir sua capacidade de influência. A conjugação da ascendência nobre com o patrocínio de rituais para espíritos torna possível para os chefes levar a cabo projetos de engrandecimento, mostrando que "os apapaatai são bens preciosos que permitem a transformação de um poder ‘metafísico' em um poder ‘econômico”’ (Barcelos Neto, 2008: 271).

Podemos dizer então que os principais trabalhos sobre a chefia abordam a questão de dois pontos de vista complementares: um que focaliza a relação dos chefes com o interior do grupo local (incluindo a ascendência e a economia política do prestígio), e outro que chama a atenção para suas relações com o "exterior" (estrangeiros ou espíritos). Essa dualidade pode ser traduzida em outra, talvez menos explícita: a relação entre o que é dado e o que é construído na chefia xinguana. Pois pelas etnografias somos levados a pensar que é de uma combinação entre algo inato ("hereditário") e algo construído (o corpo, o comportamento, a atuação em rituais) que se faz a chefia. O problema é que aquilo que é visto como inato acaba ficando à margem de qualquer análise.

Barcelos Neto $(2003 ; 2008)$ é quem oferece a discussão mais detalhada desta dupla composição da chefia através da "herança" vertical de algum tipo de característica e relações com potências exógenas que podem ser revertidas para o interior do grupo. O autor utiliza a expressão "substância nobre" para se referir à condição hereditária da chefia, que vê como algo mais ou menos "quantificável": "Todo amunaw, antes de ser propriamente um chefe político, é alguém que possui substância amunaw, herdada patri e/ou matrilinearmente. Se herdada de apenas uma linha, a quantidade de substância será menor" (Barcelos Neto, 2008: 263). A quantidade de substância herdada também seria função da ordem de nascimento, pois segundo o autor ela "decresce do primeiro filho para os subsequentes" (ibid: 264-265). Mas como ele observa, é preciso "potencializar" essa substância por meio da participação em rituais regionais da nobreza e/ou do patrocínio de rituais de espíritos: "Um grande chefe

\footnotetext{
${ }^{6}$ Entre os Wauja, as pessoas que personificam o espírito responsável pela doença de alguém e ajudam no processo terapêutico (kawoká-mona), também se tornam responsáveis por plantar roças "para o espírito", cujo produto é utilizado pelo ex-doente para o patrocínio de rituais (Barcelos Neto, 2008).
} 
wauja não é exata e necessariamente alguém que nasceu com excepcional quantidade de substância amunaw, mas aquele que conseguiu potencializar a que herdou, mesmo que não seja muita" (ibid: 266).

Haveria de fato uma "substância nobre"? Se sim, em que ela consiste? Seria ela uma substância "de fato" (uma coisa que se transmite) ou seria o idioma de algum tipo de relação (sua objetificação) que não percebemos ainda? Penso que é prudente tentar responder a essas perguntas a partir do que os índios possam ter a dizer. Afinal, quando os Kalapalo querem falar sobre seus chefes, sua produção, suas relações com os antepassados e as pessoas comuns, sua relação com os rituais, o que eles efetivamente falam, e como falam? A seguir, apresento ideias kalapalo sobre a chefia a partir de trechos de depoimentos gravados com os principais anetü de Aiha. Isso é uma tentativa de questionar o que geralmente se prioriza nas análises sobre a chefia xinguana, a partir de ideias focalizadas pelos atores em seus depoimentos. É importante deixar claro que não tenho a menor ilusão de que, ao apresentar trechos de depoimentos de chefes, eu esperaria que eles pudessem "falar por si sós". As pessoas com quem escolhi conversar e as perguntas que escolhi fazer já são o resultado de uma seleção orientada por questões etnográficas e teóricas que, ao mesmo tempo, antecedem e ultrapassam minha experiência de campo. Minha intenção é reembaralhar as cartas, investigar que tipo de categorias os chefes kalapalo usam para falar sobre si e testar até que ponto o levantamento e análise de um "léxico" sobre a chefia pode ajudar a colocar questões para as etnografias disponíveis e melhorar nossa compreensão das ideias kalapalo sobre a diferença entre chefes e não chefes. Pois no que toca às discussões sobre política, a literatura mostra que quando não prestamos atenção aos conceitos nativos, a etnografia muitas vezes acaba imputando ideias e intenções estranhas aos índios, que às vezes se tornam suspeitamente clastreanos, deformadamente tupi, estranhamente polinésios ou defectivamente andinos. 


\subsubsection{Contextualizando os entrevistados}

Os depoimentos utilizados neste capítulo foram registrados com pessoas reconhecidas como os principais anetü de Aiha, em situações previamente combinadas ${ }^{7}$. As entrevistas foram totalmente abertas, e as únicas questões fixas eram perguntas genéricas sobre o que era o "costume dos chefes" (anetü ügühütu) e sobre a forma como os entrevistados haviam se tornado anetü. Para garantir uma melhor compreensão do que era dito e para que eu pudesse fazer perguntas mais precisas durante as conversas, contei alternadamente com a ajuda de três tradutores que, em certos intervalos, faziam um resumo do que os narradores haviam dito e tiravam minhas dúvidas sobre palavras ou expressões que haviam utilizado. $\mathrm{O}$ trabalho de transcrição e tradução dos depoimentos foi feito em conjunto por meus colaboradores e eu. A seguir faço uma pequena apresentação das pessoas mencionadas neste capítulo, para que o leitor possa compreender melhor suas posições na rede de parentesco de Aiha:

- Ageu, cerca de 75 anos: um dos homens mais velhos da aldeia, primogênito do falecido chefe Kambetse (um dos dois últimos grandes chefes de Aiha). É quem seu pai preparou de forma mais intensa e completa para substituí-lo, tendo transmitido a ele todas as suas histórias, discursos, cantos e rezas, além de fazer dele um xamã. É sempre ele quem recebe mensageiros de outras aldeias, mas foi considerado o chefe principal durante pouco tempo depois da morte de seu pai, quando então Waja, seu irmão mais novo, foi escolhido (sob influência direta da FUNAI) para assumir a chefia. Apesar disso, ele se considera o principal chefe de Aiha, por causa de seus conhecimentos especializados e de sua prerrogativa de receber mensageiros. Tem sido meu principal narrador e "professor" de rezas e discursos.

- Waja, pouco mais de 50 anos: irmão de Ageu, é o filho mais novo de Kambetse, e é considerado por todos como o primeiro cacique de Aiha. Foi um dos jovens nobres do Alto Xingu preparados por Orlando Villas Boas para administrar melhor o contato com os brancos, e se tornou o chefe principal por causa da influência da FUNAI, que procurava alguém preparado para isso e que falasse um pouco de português.

\footnotetext{
${ }^{7}$ Agradeço a meus amigos Hüge Hüti “Orlandinho”, Ugise, Kamankgagü, Sapuia, Kapuringa e Jeika por terem me ajudado, de uma forma ou de outra, com as entrevistas e suas transcrições, traduções e interpretações. Agradeço também aos chefes kalapalo, por me cederem seu tempo e partilharem comigo aquilo que "os que não são conhecedores" não precisam saber.
} 
- Tipüsusu, pouco mais de 50 anos: esposa de Waja, filha de um chefe jagamü com uma mulher angaguhütü. É a itankgo ${ }^{8}$ (feminino de anetü) mais velha e mais importante de Aiha, e uma grande mestra de histórias, cantos e conhecedora de remédios. Foi muito preparada por seu pai, e conhece em detalhes os discursos cerimoniais dos chefes (executados apenas por homens).

- Tühoni, quase 50 anos: É sobrinho uterino (FBDS) e genro (eZDH) de Waja e Ageu. É neto (DS) de Apiũ, primo paralelo de Kambetse, que dividiu com ele a chefia desde o final dos anos 1950 (após o sarampo) até o final dos anos 1980 (quando Kambetse faleceu). Era considerado terceiro cacique de Aiha até 2008, quando se tornou segundo após a saída de um chefe.

- Ugise, 34 anos: filho da irmã mais nova de Waja e Ageu (uma grande itankgo falecida em janeiro de 2010) com um sobrinho uterino de Apiũ. É anetü desde muito jovem, mas em 2008 foi escolhido por Waja para ser seu primeiro substituto (o que colocou em segundo plano seu filho mais novo e, em terceiro, seu filho mais velho'), e foi preparado para isso por sua mãe desde os oito anos de idade. Por causa de sua posição na rede de parentesco, ele é uma "ponte" entre as parentelas dos dois últimos grandes chefes de Aiha que, a despeito dos conflitos, veem nele um futuro grande chefe. Além disso, foi um dos dois primeiros professores indígenas da aldeia, fala um bom português e atualmente é o anfitrião oficial dos brancos, reunindo ao mesmo tempo as qualidades de um chefe tradicional e de um dono dos brancos.

\footnotetext{
${ }^{8}$ Segundo Franchetto (2000: 488), o termo seria um plural de "mulher" (itaõ-ko, mulher-PL).

${ }^{9}$ Uma situação que põe em cheque a validade do princípio de primogenitura entre os Kalapalo.
} 


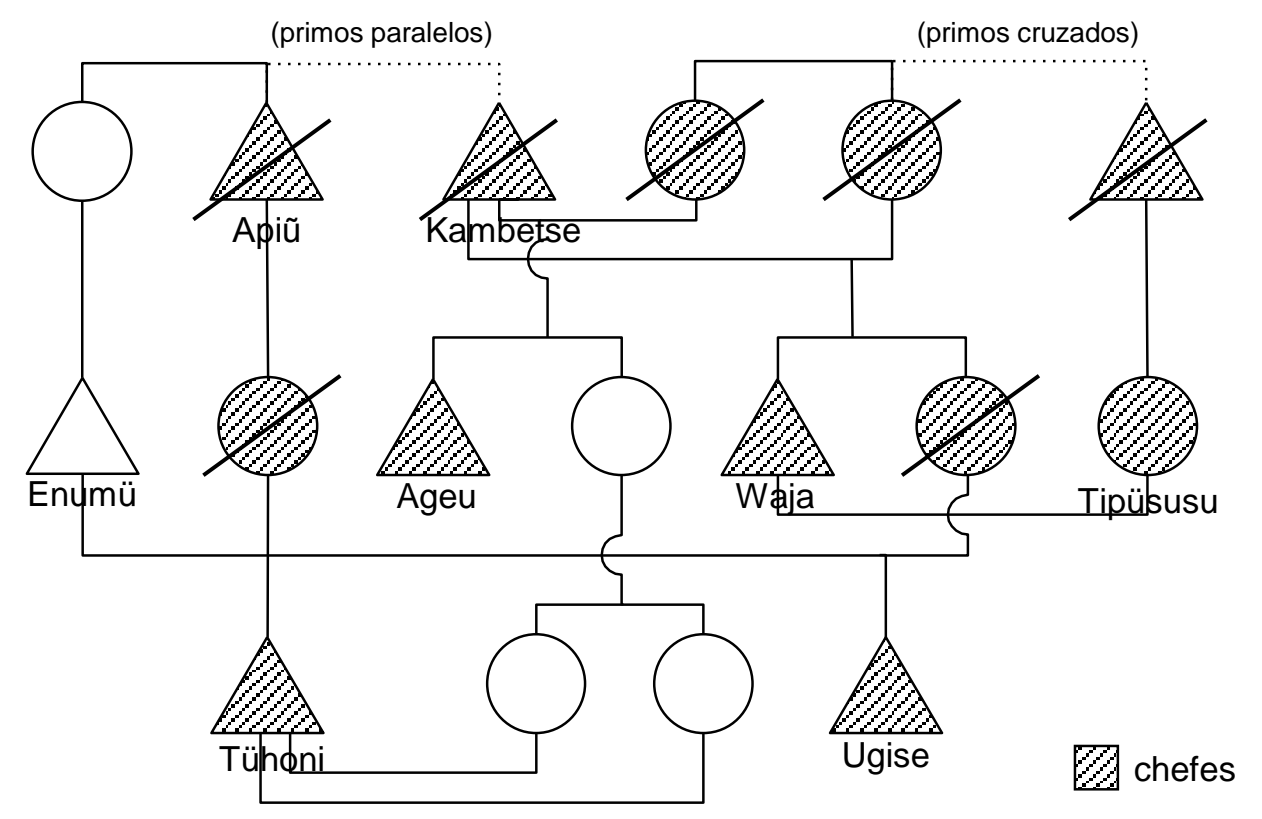

Figura 2.1: relações de parentesco entre os principais chefes mencionados neste capítulo.

Eu também poderia ter gravado depoimentos de outras pessoas, como chefes menos importantes e não chefes, mas haveria complicações. Quanto aos não chefes, o problema é muito simples: não se fala sobre aquilo que não se é sem ter vergonha, e poucas pessoas que não são chefes apresentavam interesse em discutir esse tipo de assunto comigo (o que frustraria qualquer tentativa de registrar em áudio alguma visão pessoal sobre a chefia). Quanto aos chefes menores, eu fui desencorajado diversas vezes a entrevistá-los, pois me diziam que eles eram "cacique pouquinho" e não sabiam nada dos costumes dos chefes. Obviamente eles sabem, talvez até demais; mas entrevistá-los formalmente poderia causar alguma tensão com a parentela de meus anfitriões, os principais chefes da aldeia, e por isso optei por me restringir a conversas informais, transcritas em meu caderno de campo, que serão incorporadas nos momentos oportunos.

\subsection{Ancestralidade ritual}

Passemos aos depoimentos. Na contramão das etnografias que trataram a chefia xinguana como um domínio quase exclusivamente masculino, é melhor começar citando 
trechos do depoimento que Tipüsusu me deu em 07 de julho de 2010, na área de trabalho nos fundos de sua casa, quando lhe perguntei o que era o trabalho ${ }^{10}$ de uma itankgo:

\section{Tipüsusu:}

Itankgo helei... anetü igatoho egei tiheke itankgo, itaõ igatoho, itankgo

Uma itankgo é... itankgo é uma forma de dizer anetü, serve para chamar mulheres, itankgo

Ingila uãke, ekü, tisĩhũgu heke beja egea igata

Muito antes, nossos ancestrais chamavam assim

Ekü hekeha, Taügi heke

Taũgi chamava

Taũgi heke igatatühügü, tütiko igatatühügü itankgoi

Taũgi chamava assim, ele chamava sua mãe de itankgo

“Itankgo, itankgo”, ta uãke, Taũgi kita uãke tütiko heke

"Itankgo, itankgo", ele dizia, Taũgi dizia para sua mãe

Inhalü “ama, ama” nümi ihekeni tütiko heke

Eles [Taũgi e seu irmão Aulukumã] não diziam “mãe, mãe” para ela

Itankgo helei, egea itankgo, itankgo

Ela era itankgo, assim ficou itankgo, itankgo

Enitsuẽgü hitsü heke igata ihekeni

Assim eles chamavam a esposa de Enitsuẽgü

Enitsuẽgü hitsü heke igata hegei ihekeni, itankgo

Assim eles chamavam a esposa de Enitsuẽgü, de itankgo

Tisĩhũgu helei, Enitsuẽgüi

Ele é nosso ancestral, Enitsuẽgü

Tisĩhügu

Nosso ancestral

\footnotetext{
${ }^{10}$ Os Kalapalo usam a raiz de "trabalho" $(\mathrm{ka})$ para se referir às atribuições de alguém, inclusive os chefes (anetü kasu, "trabalho de chefe").
} 


\section{Tisinũgu helei}

Ele é nosso ancestral

\section{Tisĩhũgu}

Nosso ancestral

Egeaha, ekü bejaha, ihitsü hale imaguha, eküi, tisĩhũgui

É deste jeito, pois sua esposa deu à luz nossos ancestrais

Um dos aspectos da chefia kalapalo é o que se pode chamar provisoriamente (na falta de termo mais apropriado no momento) de "hereditariedade". De acordo com Basso (1973: 133-134), herdar a condição de anetü por meio de uma ou duas linhas (paterna e materna) é uma das formas pelas quais os chefes se diferenciam uns dos outros. Somente aqueles que herdaram a condição ao mesmo tempo do pai e da mãe seriam "chefes de verdade" (anetï hekugu), enquanto os que a receberam só de um lado seriam "chefes pequenos" (indzonho anetï). Ainda, nessa escala que relaciona ascendência e grandeza haveria uma preeminência da patrilinearidade em detrimento da matrilinearidade: seria mais "nobre" quem descendesse apenas de um pai chefe do que de uma mãe chefa. De modo geral, os Kalapalo expressam um ideal de transmissão patrilinear da chefia, mas reconhecem que a transmissão pela via materna não impede alguém de se tornar um grande chefe (veja-se, por exemplo, o caso de Ugise).

Como discuti no capítulo 1, os chefes podem ser pensados como uma conexão entre o presente e um passado específico, pessoal, nomeado e localizado, do qual nem todos participam por igual. São as relações de continuidade entre os anetü do presente e do passado que permitem produzir, refinar e perpetuar identidades coletivas duráveis no decorrer do tempo (para um argumento semelhante, ver Heckenberger, 2011). Mas além da memória etnohistórica, vê-se que também há uma ideia de que a chefia remonta ao tempo mítico, especificamente aos episódios envolvendo o nascimento dos gêmeos Taũgi e Aulukumã ${ }^{11}$. É por causa deles que os Kalapalo chamam algumas pessoas de anetï e itankgo, pois é como os gêmeos passaram a chamar seu pai-onça (Enitsuẽgü) e sua mãe adotiva (Tanumakalu, irmã de sua verdadeira mãe) depois que descobriram que sua avó paterna (Kahisatigo) havia cortado o pescoço de sua mãe e que eles haviam ocultado o fato. Essa cena parece fazer parte do

\footnotetext{
${ }^{11}$ Questões relacionadas a esse mito serão tratadas em detalhes no capítulo seguinte, quando analisarmos a mitologia ligada ao egitsü.
} 
"núcleo duro" do mito de origem dos gêmeos ${ }^{12}$, pois reaparece da mesma forma em todas versões que ouvi entre os Kalapalo.

Mas como poderíamos descrever estas relações entre os chefes, digamos, "históricos", do tempo dos humanos, e os chefes do passado mítico, principalmente Enitsuẽgü, suas esposas e os gêmeos? Os alto-xinguanos parecem ter teorias diferentes a esse respeito. Segundo Barcelos Neto (2008: 61), para os Wauja a diferença entre chefes e comuns teria se originado da natureza dos materiais a partir dos quais os humanos foram criados por Taũgi: os primeiros chefes foram feitos a partir de arcos de madeira, e as pessoas comuns de bambu de flecha (ubá ${ }^{13}$ ). Já para os Kalapalo, a origem dessa diferença ainda me parece obscura. Uns dizem que algumas pessoas já teriam sido criadas como anetü, mas sem qualquer referência ao uso de materiais diferentes - todos os humanos teriam sido feitos de bambu de flecha (uma versão enfraquecida do mito wauja). Já outra versão diz que Taũgi teria organizado uma festa para furar a orelha de alguns jovens (humanos), que se tornariam os primeiros chefes.

Esta última é especialmente interessante, porque aponta para uma relação de "parentesco fictício" ou, especificamente, de filiação adotiva entre Taũgi e os primeiros chefes, uma espécie de "ancestralidade ritual". Nenhuma versão sugere que houvesse qualquer continuidade genealógica entre Taũgi (e, logo, sua parentela) e os primeiros anetü, mas o ritual de furação das orelhas (patrocinado por um pai para um filho que se tornará chefe) os coloca em uma espécie de relação de filiação. Ainda que os chefes não tenham relações de consanguinidade com o chefe-onça, sua esposa e Taũgi, esta versão trata os primeiros chefes como seus filhos adotivos e marca ao mesmo tempo uma separação e uma continuidade entre o tempo dos grandes chefes míticos e o tempo dos chefes humanos.

Deixando de lado a relação com o mundo mítico e atendo-nos ao tempo propriamente humano, como seria possível descrever as relações de parentesco entre os nobres? De acordo com Tipüsusu, a condição de anetü está diretamente ligada à filiação e é virtualmente eterna:

\footnotetext{
${ }^{12}$ E mesmo em versões registradas por outros pesquisadores, como Basso (1987b) e Carvalho (1951). Contudo, não encontrei nenhuma passagem semelhante nos mitos de outros povos.

${ }^{13}$ Gynerium sagittatum.
} 


\section{Tipüsusu:}

\section{Tisanetu higei inhalüma setijüi}

Esta é nossa chefia, ela não se tira

Katote egea, katote tekinhü anetügü, Kuikuro anetügü, Auga anetügü, katote. Inhalü setijüi

Todos são assim, os chefes de todos os outros povos, os chefes dos Kuikuro, os chefes dos Wauja, todos. Eles não são removidos.

Amago hale anetuko etisaleniha

Já a chefia de vocês pode ser tirada

Etijüko, telope inhügü

Quando vocês tiram alguém, vem um próximo

\section{Telope inhügü}

Vem um próximo

Ilango hale amago anetugu, sagingoila tisuge, tisatipüg $\ddot{i ̈}^{14}$ gehale tisetijilaha

É assim a chefia de vocês, não é como nós, não se tira os que cresceram conosco

Tisĩhũgupinhe, tisĩhũgu etijita uãke üngelepe upinhe geleha anetüi etijipügü inhügü

É por causa dos nossos ancestrais, nossos ancestrais tiveram filhos, e seus filhos ficaram em seu lugar

Anetüi gehale inhügü, ihigüpe inhügü gehale anetüi

Eles também se tornaram chefes, seus netos também se tornaram chefes

Tütemi

Para sempre

Como diz Tipüsusu, a condição de anetü é vitalícia ("nossa chefia não se tira") e é transmitida por aqueles considerados "ancestrais" (ĩhũgu) para seus descendentes "para sempre" (tütemi). Com efeito, não se pode dizer de nenhum anetü vivo que ele seja "exchefe" (anetüpe), ainda que este tenha sido acusado de feitiçaria e obrigado a se mudar, ou que tenha escolhido viver junto a um grupo onde não exerça funções de chefia. $\mathrm{O}$ caso do

\footnotetext{
${ }^{14}$ Tis-ati-pügü (13-crescer/brotar-PERF). A raiz ati designa o crescimento vegetal, e aqui esta palavra significa "nossos chefes" (o que discutirei adiante).
} 
filho mais velho de Sagagi, o homem que chefiava os Kalapalo à época da chegada da Expedição Roncador-Xingu, é um exemplo do segundo tipo de situação. Desde o começo de meu trabalho de campo me diziam que um dos maiores chefes kalapalo vivia entre os Yawalapíti, e que se ele decidisse se mudar para Aiha seria considerado o primeiro cacique. "Mas por que ele não voltava?", me perguntei muitas vezes. Ele simplesmente havia escolhido deixar de ser chefe - algo mais comum do que se imagina ${ }^{15}$. O chefe principal dos Yawalapíti, que também foi o homem preparado pelos Villas Boas para se tornar o "cacique geral" do Alto Xingu no âmbito das relações políticas com os brancos, certamente não haveria de se casar com mulheres que não pertencessem a uma importante parentela de nobres, e se casou com duas filhas deste chefe kalapalo. Após o casamento, suas filhas o convenceram a se mudar com elas para a aldeia yawalapíti, pois elas diziam que em Aiha havia pessoas falando mal de seu comportamento e dizendo que ele não seria um chefe verdadeiro. Ainda assim, apesar de cerca de 30 anos vivendo entre os Yawalapíti, ele ainda era reconhecido como um dos maiores anetü kalapalo.

Vale notar o uso da palavra tisatipügü (marcada em negrito na transcrição e traduzida como "os que cresceram conosco"), cuja raiz ati significa brotar ou crescer (aplicado somente ao crescimento vegetal). Tisatipügü tem dois sentidos: de um lado, o termo quer dizer "nossos consanguíneos", pois se refere aos parentes muito próximos, àqueles que "brotaram" juntos das mesmas "raízes" (isto é, que compartilham avós), veiculando uma forte imagem genealógica e fornecendo uma boa metáfora para a consanguinidade. De outro lado, nesta fala o termo significa "nossos chefes", e penso que se refere tanto à continuidade genealógica entre os anetü (que "brotam" uns dos outros) quanto à analogia entre chefes e troncos que será explorada adiante. "Os que cresceram conosco" são tanto "nossos parentes consanguíneos" quanto "nossos chefes" porque a (re)produção de troncos-chefes, como veremos, é parte essencial da produção do parentesco.

A importância da ascendência também é notada pela forma ideal de casamento das mulheres chefe:

\footnotetext{
${ }^{15}$ Há vários casos de pessoas que desistiram de ser chefes e se mudaram para outros povos onde tinham parentes, no intuito de ficarem menos expostos e, assim, menos sujeitos a ataques de feiticeiros. Há um grande chefe jagamü vivendo entre os Kalapalo, que decidiu se mudar para Aiha depois que toda sua família morreu de feitiço, o que ele associa à inveja crônica que os feiticeiros têm dos anetü. Também há filhos de chefes que se recusam a assumir o lugar de seus pais, pois têm medo de sofrer ataques mágicos.
} 


\section{Tipüsusu:}

\section{Takihekuginhü... inhalüha telo kinhotui}

Com alguém cujo jeito/fala é verdadeiro/bom... nós não tomamos alguém diferente como marido

Tüagingoki gele anetü heke tetijipügü atohondelü, tüanetuhunguki

Os filhos de um chefe sempre se casam com alguém semelhante, com alguém cuja chefia seja parecida

Sagage gele etijitomi, anetüibe etijitomiha egei

Isso é para que tenham filhos parecidos com eles, para que nasçam grandes chefes

Anetü hekugu itsomi

Para que sejam chefes verdadeiros

Apesar da forma ideal de transmissão da chefia ser entre pai e filho, a ascendência nobre materna parece muito importante. Já ouvi algumas vezes chefes considerados "grandes" serem chamados de anetü tehualüpe, "que esteve no ventre de uma chefe", com o que subentende-se que a pessoa tem pai e mãe chefes. No ritual de furação de orelhas, o chefe patrocinador fala de seu filho que será apresentado como futuro chefe como "o que foi encontrado no ventre daquela chefe". Outros autores já notaram uma tendência à "endogamia de status" dos nobres (Barcelos Neto, 2008: 68; Galvão, 1979 [1953]; Heckenberger, 2005: 264; Oberg, 1953), mas há poucas pesquisas concretas sobre isso e menos ainda sobre suas consequências para as redes de parentesco. Em outros trabalhos mostrei a existência de tal endogamia na chefia kalapalo, e que ela se conjuga a diferentes regimes de aliança e residência para chefes e comuns (Guerreiro Júnior, 2008; 2011). No trecho acima temos uma visão indígena sobre a endogamia, que idealiza casamentos "com um semelhante" (tüagingoki) visando a reprodução da chefia dos pais, o nascimento de "grandes chefes" e "chefes verdadeiros". Dizem que a "mistura" de nobres com pessoas comuns não só é indesejável porque ameaça a reprodução de bons chefes, mas também porque apresenta o perigo do aparecimento de "chefes pequenos", às vezes vistos pelos maiores como invejosos e feiticeiros em potencial. 
Uma das formas pelas quais as relações de parentesco próximo entre chefes é codificada é em termos de sangue (ungu):

\section{$\underline{\text { Ugise: }}$}

Ekü beja, anetühüngü helei

Bom, se a pessoa não for chefe

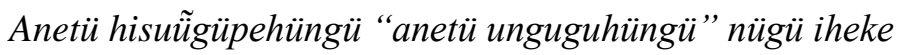

Para quem não é parente de chefe, se diz que "não é sangue de chefe"

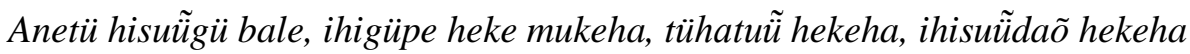

Já para o parente de um chefe, para seu neto, seu sobrinho uterino, para seus parentes

Nago anügü “anetü ungugu” nügü iheke

Para eles se diz "sangue de chefe"

Esta fala remete ao problema do "sangue" na etnofisiologia xinguana. Afinal, o que significa dizer que uma pessoa é "sangue" de outra (ungu-gu, sangue-REL)? Coelho de Souza (1992: 138) nota que em quase todas as etnografias emerge um problema que

(...) consiste na relação entre as "teorias da concepção", de um lado, com sua ênfase praticamente exclusiva sobre o papel do homem na reprodução, e, de outro, a "bilateralidade", seja da filiação, seja do "grupo de substância" - o núcleo de parentes imediatos que por considerarem partilhar uma substância comum observam uns pelos outros certas restrições - alimentares, sexuais, etc - em caso de doenças e outras situações de liminaridade (pós-parto, reclusão pubertária...).

A maioria dos grupos xinguanos considera que apenas o pai participa da produção do feto, que se formaria a partir do progressivo acúmulo de sêmen no útero ${ }^{16}$, sem que a mulher desse qualquer contribuição "substancial". No geral, os Kalapalo partilham essa visão, mas frequentemente especulam que talvez o sêmen do pai se misture com o sangue materno, já

\footnotetext{
${ }^{16}$ Para os Kalapalo o útero não é um órgão específico, mas é o "interior da vagina”, egü atalü.
} 
que a mulher deixa de menstruar. A unilateralidade da concepção soa estranha quando se leva em conta a bilateralidade da filiação, reconhecida em todos os trabalhos. Menezes Bastos (1990: 477-478) afirma que essa contradição não existiria entre os Kamayurá, para quem o sangue materno atuaria na constituição do feto tanto quanto o sêmen paterno. Ainda, alguns xinguanos parecem eventualmente equacionar o sêmen masculino ao sangue feminino. Viveiros de Castro (1977: 205) afirma que entre os Yawalapíti, apesar de sangue e sêmen formarem uma oposição, “o 'sangue' parece ser o idioma da substância, enquanto que o esperma é a substância mesma" (grifo no original). Ideia semelhante também está presente entre os Kalapalo, que ao levantar a hipótese da mistura do sêmen com o sangue tendem a traduzir o primeiro nos termos do segundo: o sêmen paterno seria uma espécie de veículo para o "sangue" masculino.

Viveiros de Castro (1977) mostra que o problema aqui não é nenhuma eventual dificuldade para identificar a "substância verdadeira" da qual se fala, mas a potencial confusão entre o lugar das substâncias na etnofisiologia e a linguagem da substância como codificação das relações sociais: “(...) a lógica da substância é uma sociológica, isto é, um sistema de premissas apenas parcialmente apoiado numa lógica da substância fisiológica. Ela exprime um princípio social, não uma metafísica da biologia levada às suas últimas consequências" (ibid: 207, nota 1; grifos no original).

O autor também argumenta que as relações de abstenção da ingestão de certas substâncias em ocasiões como a doença, o pós-parto e a reclusão pubertária mostram que, para além da teoria da concepção, todos os parentes participam de relações que poderiam ser caracterizadas de alguma maneira como "substanciais" (ibid: 203-216). O único porém é que, atestando a partilha mútua de substâncias, ficamos "diante de uma segunda versão do paradoxo posto pela unilateralidade da teoria fisiológica" (Coelho de Souza, 1992: 77). Segundo Viveiros de Castro (op. cit.: 206, nota 1) esse paradoxo sugere que

(...) a noção antropológica de substância não deve tropeçar no obstáculo 'substancialista' levantado pelas sociedades objeto da antropologia. A abstinência pela mãe, justificada em termos de 'mesmo sangue' - embora os Yawalapíti achem que só o esperma é que forma o corpo, indica que a relação substantiva pode ser metafórica ou metonímica; que a continuidade corporal pode ser externa, ou pelo menos em termos de continente/conteúdo. 
Ou como diz Coelho de Souza (op. cit.: 78), "a relação é substancial não porque é estabelecida através de uma substância específica mas porque é conceituada em termos de continuidade corporal". Portanto, o "sangue" evocado na fala transcrita anteriormente não deve ser visto como uma substância material, objetiva - algo como uma "substância nobre" de fato transmitida entre algumas pessoas. Ao que parece, nenhuma substância no Alto Xingu é algo que se transmite enquanto tal (veja-se como o sêmen pode aparecer como "sangue"), mas são formas pelas quais as relações entre parentes podem ser traduzidas e objetificadas.

No limite, todos os moradores de uma mesma aldeia podem ter o mesmo "sangue", em contraste com os moradores de outra. Aqui a ideia se aproxima do conceito geral para

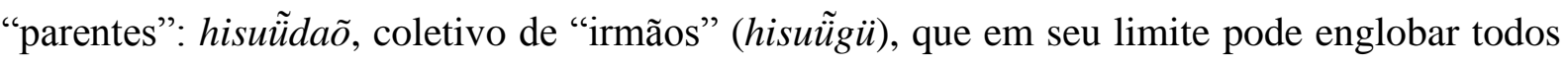
os parentes cognáticos, os afins, e mesmo uma aldeia inteira (Guerreiro Júnior, 2008: 65-66).

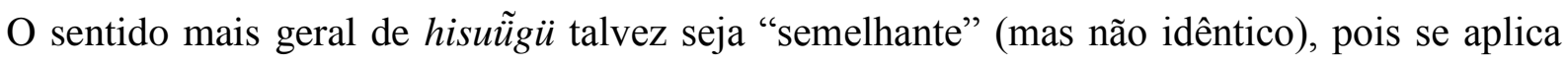
também a animais e objetos parecidos. Assim como as pessoas distinguem entre "parentes verdadeiros" e "parentes de longe", o sangue está sujeito a um princípio de gradação. Deixando de lado seu campo de aplicação mais englobante (a aldeia), o "sangue" efetua um recorte no universo dos parentes, pois exclui os afins e parentes com os quais não se reconhece laços genealógicos claros. Os parentes de sangue propriamente ditos são aqueles com os quais se reconhece claros laços genealógicos, e mesmo cognatos que vivem em aldeias distantes e não se veem muito nunca deixam de partilhar o mesmo sangue. Destes, ainda, os "verdadeiros" parentes de sangue são aqueles que conjugam proximidade genealógica, convivência e comensalidade (este último ponto é importante, pois os alimentos são importantes na produção do sangue no corpo ${ }^{17}$ ). Por fim, ninguém partilha um mesmo sangue tanto quanto pais, filhos e germanos: se a cognação é o mínimo exigido para se falar em sangue "de verdade", a (co-)filiação é seu núcleo duro.

Ter ou não o mesmo sangue é o principal critério para a adesão a restrições alimentares quando se tem parentes doentes. Como se sabe, quando alguns parentes adoecem outros não podem ingerir certos alimentos. O peixe é o principal deles, pois "prende o sangue", causando dores, diarreia, febre, e por isso deve ser evitado. Quando alguém é operado, ou sofre um corte grave, nem ele nem seus parentes devem comer pimenta ou peixes

\footnotetext{
${ }^{17}$ Por isso se associa sangue e peixe, por exemplo; espinhas são vistas como o aparecimento na pele de coisas em excesso no sangue, como arroz ou ovas de peixe. Também se diz que os mortos são quase sem sangue porque comem gafanhotos (sobre a alimentação dos mortos, ver capítulo 4).
} 
com dentes pontiagudos, que provocam dores na pessoa machucada. Peixes gordurosos também são problemáticos, pois a gordura engrossa o sangue e o deixa "ruim”, provocando os mesmos males do sangue "preso". A fronteira entre quem tem ou não o mesmo sangue é sutil: Viveiros de Castro (1977: 207) diz que, segundo os Yawalapíti, netos já não teriam o mesmo sangue que os avós, mas entre os Kalapalo já vi várias vezes avós se abstendo de comer peixe por causa de seus netos, tratados como seu "sangue". Já outros parentes que também são de "mesmo sangue" (cognatos), mas mais distantes (como primos, paralelos ou cruzados), não se abstém uns pelos outros.

No seu limite externo, "sangue" é a mesma coisa que "parente", e assim como a convivência e a comensalidade aparentam, elas podem transformar um estrangeiro em "sangue de Kalapalo", por exemplo. Mas outra coisa é o "sangue verdadeiro", das pessoas que são consideradas parecidas e combinam proximidade genealógica e comensalidade. Se o idioma do "sangue" é preferido em certas situações (como para falar das pessoas que se abstêm umas pelas outras, ou para dizer que alguém é "sangue de chefe") em relação ao termo de parentesco mais inclusivo, deve ser porque se quer realizar aqui uma exclusão que hisuãugü, apesar de poder realizar, não o faz com eficiência, já que é um termo obviamente mais elástico e, portanto, ambíguo. O sangue objetifica uma noção de "parentes verdadeiros", que costura os recortes genealógico e interacional, com ênfase na filiação. Por isso "sangue de chefe" veicula alguma ideia de "descendência" em sentido amplo.

Há uma expressão para "descendente de chefe", que trata de parentes cognáticos ao mesmo tempo em que faz uma distinção geracional: anetü unkgugu (forma possuída de unkgu). Demorei para encontrar uma tradução para unkgu que me deixasse satisfeito, pois a expressão era alternadamente traduzida como "parente" ou "filho". A segunda tradução deve ser descartada, pois para testá-la comecei a investigar se seria possível dizer que alguém era unkgu de um avô ou avó, o que foi confirmado. Porém, este termo não é usado em relação a irmãos: eu não sou unkgu de meus irmãos, apesar de poder dizer que somos uns o sangue dos outros e que, enquanto um grupo de irmãos, aí sim somos unkgugu em relação a nossos pais e avós. Por isso me parece plausível dizer que unkgu significa "descendente", o que explica a oscilação de sua tradução entre "parente" e "filho": quem é unkgu de alguém é certamente um parente, mas fica implícito que se trata de uma relação intergeracional. Segundo Hüge Hüti, um agente de saúde que me ajudou em diversas transcrições e traduções, anetü unkgugu seria 
uma expressão comum para se referir a parentes de anetü que não usam o título, e Ugise, outro interlocutor importante, me disse a mesma coisa em outra situação.

Mas o uso dessa expressão para descendentes de chefes que não são efetivamente anetü atesta uma disjunção entre a filiação e a herança da chefia. Apesar de toda a importância que os falantes atribuem à ascendência nobre e ao "sangue", há casos que mostram que a filiação sozinha não só não garante a condição de chefe como, na passagem de uma geração a outra, a chefia de alguém pode "acabar", mesmo que a pessoa tenha descendentes (na contramão da ideia de "eternidade" que já vimos).

Um dia, fui à casa de um dos chefes fazer uma visita e ver se havia alguma coisa para comer por lá. Ele não estava, e sua esposa desenrolou uma rede pendurada em um varal, me disse que aquela era a rede de seu filho mais novo e que eu poderia me deitar ali enquanto esperava uma panela de pequi acabar de cozinhar. Como eu não o tinha visto desde minha chegada, perguntei por ele; eu mal acabara de falar seu nome e ela e suas filhas começaram a criticá-lo severamente por uma "loucura": ele havia se casado de novo, com alguém que elas não aprovam. Ele decidira se casar, mesmo contra a vontade de seus pais, com a filha do principal chefe de outro povo karib, e se mudou para a casa de seu novo sogro. Sua primeira esposa, decepcionada, foi embora levando seus dois filhos pequenos.

Por que ele fez isso?! - sua mãe dizia inconformada. Ele se mudou para aquela aldeia, ele é louco [sidigü]! Quando ele vier pra cá você deve brigar com ele, diga a ele que ele é louco por ter se casado com aquela mulher. O pai dela é um feiticeiro, seus filhos serão péssimos! A chefia dele vai acabar [tanetupe etsuhukilüingo ${ }^{18}$ ] se ele ficar lá com ela, seus filhos crescerão como pessoas ruins [hesinhü ekugu sakisüko inhümingo ${ }^{19}$ ]. Veja, sua ex-mulher é uma chefe; o pai dela é um grande chefe; sua mãe é uma grande chefe; seu avô paterno era um grande chefe. Quando você o vir peça a ele que volte pra cá, assim quando o pai dele morrer ele se tornará chefe [sanetuingo], seus filhos se tornarão chefes, seus netos, pra sempre. Se ele ficar lá, será o fim.

Isso é um resumo do que ela me disse, da forma como pude transcrever em meu caderno de campo, mas sua fala foi bastante repetitiva e suas filhas só intervinham para

\footnotetext{
${ }^{18}$ Etsuhukilü, “acabar”, “estragar".

${ }^{19}$ Lit. "seu jeito será realmente ruim".
} 
chamar seu irmão de "louco" e reafirmar o que sua mãe dizia. Fiquei impressionado com a preocupação dela, inconformada com a escolha do filho. Ela insistia que eu deveria lhe dizer essas coisas porque ela, como mãe, não deveria brigar com seu filho, mas eu poderia dizer tudo o que ela pensava. As falas que vimos até agora deixam clara a importância da filiação na reprodução da chefia, mas a visão desta mulher sobre o casamento de seu filho complica as coisas. Se admitíssemos que a chefia é algo "hereditário", como ela poderia simplesmente "acabar" para descendentes de chefes?

Há outro caso semelhante. O leitor deve se lembrar do chefe kalapalo já mencionado que foi viver entre os Yawalapíti. Ele faleceu no começo de 2010, e comentando o assunto comigo Tipüsusu disse que agora "sua chefia acabou", apesar dele ter deixado um filho homem e netos. Quando souberam de sua morte, os Kalapalo quiseram buscar seu corpo na aldeia yawalapíti para enterrá-lo em Aiha, onde já planejavam fazer um egitsü para ele. Porém, os Matipu da aldeia Küngahünga fizeram questão de enterrá-lo lá, pois sua mãe e avó materna eram matipu ${ }^{20}$, e também pretendiam homenageá-lo em um egitsü. Sabendo que os Kalapalo não concordariam, os Matipu se apressaram, foram até os Yawalapíti, pegaram o corpo e depois avisaram os Kalapalo pelo rádio. Quando o corpo chegou à aldeia, seu único filho não estava presente, pois havia saído para pescar há pouco tempo e demoraria a voltar; quando retornou, o corpo de seu pai já havia sido enterrado. Os chefes matipu pediram a ele que patrocinasse um egitsü para seu pai, o que recusou. Segundo ele próprio, por ter poucos parentes não teria condições de patrocinar a festa sozinho; mas a informação que corre é que ele teria se sentido ofendido por não terem esperado sua chegada para enterrar o corpo de seu pai.

Os Kalapalo decidiram que ele deveria ser lembrado em um egitsü junto com os dois principais homenageados de Aiha em 2010. Mas, por ter sido enterrado em outra aldeia, o falecido chefe não poderia ser homenageado como anetü, apenas como anda, "companheiro/seguidor" dos homenageados principais. Seu filho aceitou, e seu pai teve direito a uma efígie de pessoa comum no egitsü. Porém, como o chefe morto nunca havia feito seus filhos ou netos assumirem papeis de chefes em rituais enquanto ainda era vivo, agora "sua chefia acabou". Sendo assim, minha impressão é que na realidade não há nada que seja propriamente "dado" na nobreza, inato aos chefes e seus parentes, que permita falar em

\footnotetext{
${ }^{20}$ Após a morte de sua primeira esposa, uma mulher kalapalo, ele também se casou com uma mulher matipu (também falecida em 2010, poucos meses depois de seu marido).
} 
hereditariedade. O real problema é que não sabemos bem o que é a filiação no Alto Xingu. Mesmo a ideia de "substância nobre" (Barcelos Neto, 2008), que, em alguma medida, poderíamos dizer ser o "sangue", não parece ser algo que se transmite, mas um idioma de relações. Se estivesse em jogo na filiação alguma "substância", como ela poderia ser anulada a ponto de inviabilizar sua retransmissão?

O ponto é que a fabricação dos chefes é tão importante quanto a ascendência; ou melhor, a ascendência em sentido forte (aquela que permite reproduzir chefes) também é fabricada (como dada). Quando os nobres preparam um futuro anetü, se esforçam para produzir uma pessoa ideal, alguém que possa ser chamado de "gente" (kuge) em comparação aos demais: pois "gente", sem qualquer qualificação, quer dizer simplesmente chefe - o que significa que o processo pelo qual se produz um anetü é um processo ideal de humanização. Ainda, esse processo é pensado como uma relação de substituição cujo princípio é a filiação: a ascendência é importante porque é preciso substituir alguém. É na combinação entre filiação, substituição e humanização que se encontra o princípio que faz as relações entre chefes parecerem "hereditárias".

\subsection{Fazendo chefes, fazendo gente}

Já foi amplamente observado que ninguém nasce um chefe "pronto", mas que é preciso ser feito chefe ao longo de toda a vida. Viveiros de Castro (1977) afirma que os jovens chefes passam por períodos de reclusão bem mais longos que as pessoas comuns, algo que pode ser reencontrado em outras etnografias (Avelar, 2010; Costa, 2011). Nesses processos, o corpo e o ethos da pessoa são fabricados um por meio do outro, e a emergência de um chefe resulta de uma fabricação muito longa e cuidadosa do corpo, o qual deve "sintetizar os pontos cardeais do homem ideal" (Menget, 1993: 68). Dos atuais chefes de Aiha, os três mais importantes afirmam terem ficado cerca de 10 anos em reclusão, alternando entre períodos de maior e menor invisibilidade pública. Conhecem detalhadamente as plantas que utilizaram para se tornarem lutadores ${ }^{21}$, mitos e canções que aprenderam neste período, e dizem com clareza que suas posições de chefes são fruto dessas reclusões bem-sucedidas. Ser chefe

\footnotetext{
${ }^{21}$ Muitas plantas são propriedade de espíritos, e através delas (usadas como remédios após a escarificação) é possível obter força destes seres, procedimento indispensável para a transformação de alguém em lutador (necessário, por sua vez, para a transformação em chefe).
} 
também implica no direito de usar pinturas e enfeites exclusivos (como objetos feitos com couro e garras de onça, brincos de pena de rei congo ${ }^{22}$ ), e receber tratamentos corporais diferenciados nos rituais (um jovem chefe que seja foco de um tiponhü terá sua orelha furada com um osso de onça; nobres têm direito a um túmulo-casa especial). Em suma, ser chefe é, antes de tudo, ser/ter um tipo específico de corpo, manipulado e exibido de formas peculiares. Heckenberger $(2003 ; 2011)$ também afirma que a diferença dos chefes está no corpo. Com uma crítica à tese de Clastres (2003a [1974]) sobre a suposta "função equalizadora" das marcas corporais na América do Sul, Heckenberger argumenta que o objetivo da fabricação do corpo no Alto Xingu é justamente produzir corpos diferentes: corpos de chefes e corpos de não chefes. Contudo, vale notar que o corpo do chefe não é um corpo humano com um "algo a mais"; ao contrário, os corpos das pessoas comuns é que são versões enfraquecidas do corpo arquetípico dos chefes.

Em seus depoimentos, todos os chefes entrevistados dizem em algum momento que foram feitos por alguém - geralmente seus pais e, eventualmente, outros chefes que os tenham indicado para isso:

\section{Ageu:}

Uge uün, apa heke uãke

Meu pai, meu pai me fez

Apa heke uãke uӥilü uãke tüitüpohongoi

Meu pai me fez seu substituto

Apaju hekeha

Meu querido pai fez

Apaju heke uüilü anetüi tiha ü̈ilü uãke iheke

Meu querido pai me fez anetü, ele me fez

Üle hata leha

Enquanto isso

Sakinhagü ihata iheke ukitohoingo jetaha tuhugu akinha ülebeja sakinhagü

\footnotetext{
${ }^{22}$ Também conhecido como japu (Psarocolius decumanus).
} 
Ele me contou suas histórias, para que pudesse contá-las todas

\section{Tünolü ügühütu}

O costume de seu discurso

Anetü nolüha - anetü nolüha ülegoteha Kuarup tüigote, uluki entote

Como os chefes discursam - os chefes discursam quando acontece isso, quando há Quarup, quando o $u l u k i^{23}$ chega

Ülekiha uãke uinguheta

Ele me ensinava sobre isso

Ülepe tiha ungipi anümi, ungipi tsügütse naha anügü agetsi inhalü, inhalü benaha ago ngipi hale

Por isso eu tenho/sei bem, só eu tenho/sei bem, só um, mas os outros não têm/sabem

$\tilde{E}$ inhalü benaha ago ngipi uge tsügütse tiha ungipi

É, eles não têm/sabem, só eu tenho/sei de fato

Üle sügühütuha egei ülegote bejaha kunolü beha

Isso é o seu costume, quando há algo assim nós discursamos

Anetü engü beha

Isso é coisa de chefes

Uge tiha ago inha ihalü heke sügühütu ihanalü heke üle ügühütuha

Só eu mesmo, para que ele ensinaria seu costume para eles, esse costume?

Anetão inha

Para os outros chefes?

Inhalü beha engü uhutinhihüngü ngipi inhalü

Os que não são conhecedores não têm/sabem nada dessas coisas, não

Tükima uhunalü ihekeni?

Para que eles saberiam?

\footnotetext{
${ }^{23}$ Ritual de trocas entre dois grupos.
} 
Ageu utiliza a raiz üi para dizer que foi feito substituto (itüpohongo) de seu pai. Esta raiz descreve um fazer abstrato, em contraste com a raiz $h a$, que se refere a um fazer concreto (produzir, construir, manufaturar). $\ddot{U} i$ pode ser usada para falar do preparo de alimentos, da realização de uma pesquisa, do fazer fogo; aparentemente ela se refere a processos de transformação. $H a$ é mais usada para a produção de objetos materiais, como casas, ferramentas, utensílios, instrumentos musicais, enfeites, etc ${ }^{24}$. Este fazer abstrato dos chefes está associado a uma concepção da condição de anetü como o resultado de um processo complexo de aprendizado de conhecimentos específicos (nesta fala, exemplificado pelo aprendizado dos gênero de fala ritual - objeto do capítulo 5 - e de um extenso corpo de narrativas).

Itüpohongo é "o que vai em cima/sobre as costas" de algo ou alguém, e pode ser usado para falar de substitutos de coisas ou pessoas. Quando aplicado a objetos, itüpohongo tem uma forte conotação de identidade: caso eu quebre um objeto de outra pessoa e lhe dê outro igual, este é itüpohongo do primeiro; caso ele seja um pouco diferente, o correto é dizer telope, "próximo". Aplicado a pessoas, o termo pode ser usado para qualquer tipo de substituição, como a de um trabalhador por outro, de um cantor por outro. Se o dono de uma casa morre e um de seus filhos se torna seu novo dono, pode-se dizer que ele é seu itüpohongo; se o melhor cantor de uma aldeia morre e outro assume sua posição, ele pode ser dito seu itüpohongo. Mas não posso dizer que todos os filhos de um homem ou todas as filhas de uma mulher são seus "substitutos" em sentido genérico, e o mesmo vale para os chefes: apenas alguns de seus filhos ou netos são intencionalmente preparados como tais. Esta é necessariamente uma relação entre pessoas de mesmo sexo, pois homens substituem apenas homens e mulheres substituem apenas mulheres. Quando perguntei ao chefe Tühoni quem ele gostaria que fosse seu substituto, ele disse que esta seria sua filha ${ }^{25}$ (que já é itankgo), por seu temperamento - se ela não fosse mulher... Caso algum dos filhos dela se torne anetü, ele será substituto de seu avô materno, e não de sua mãe. E a substituição não é uma relação exclusiva, de um pra um, pois cada anetü pode fazer tantos substitutos quantos quiser. Ageu, por exemplo, diz ter preparado dois:

\footnotetext{
${ }^{24}$ Esta não é uma oposição rígida, mas apenas aproximativa. A raiz ha parece ter origem em ka, "trabalho", raiz que pode ser aplicada tanto a fazeres abstratos/transformadores, quanto a atividades concretas de construção ou fabricação (comunicação pessoal de Bruna Franchetto).

${ }^{25}$ Ela é substituta de sua avó paterna, de quem herdou seu nome mais "famoso".
} 


\section{Ageu:}

\section{Takikoha ungüipügü}

Eu fiz dois

Takikoha ungüipügü angiha umugu ege hametigü takikoha ungüipügü anetüi ungüipügü akagoi

Eu fiz dois, há meu filho e o cunhado dele ${ }^{26}$, eu fiz dois, eu os fiz chefes

Quando voltei a campo depois dessa gravação, em 2009, soube que ele havia começado a fazer um terceiro substituto, um de seus netos (um menino de cerca de 10 anos). Vale notar que nesse caso nem o pai nem a mãe do menino são chefes de fato. O pai é, obviamente, anetü unkgugu, mas por causa de seu temperamento nunca foi preparado por seu pai e não é considerado anetü; a mãe do jovem também é anetü unkgugu, mas "de longe" (seu avô paterno foi chefe, mas seu pai nunca atuou como anetü; sua bisavó materna também foi itankgo, mas sua mãe mesmo não é). Nesse caso, o menino será substituto de seu avô paterno, e não de seu pai. A única possibilidade de isso acontecer é com seu avô ainda vivo, pois caso ele morresse, seu pai sozinho não poderia fazê-lo chefe.

Quando alguém é feito chefe, seus pais também passam por uma fabricação no mesmo sentido. Um homem da aldeia Tankgugu conta que "ficou com o jeito bom" ou "ficou com palavras verdadeiras" (akihekutipügü) depois que seu filho começou a ser feito chefe por sua mãe, que é itankgo (neta de Sagagi). Apesar do homem também ser descendente de grandes chefes, ele mesmo diz que nunca foi anetü porque, antigamente, ficava bravo com as pessoas com facilidade. Hoje, em compensação, ele se considera "um pouquinho anetü” porque seu jeito com as pessoas melhorou. Como ele me explicou, seu jeito tinha que melhorar para que ele pudesse educar seu filho da maneira apropriada. Sempre me disseram que para alguém se tornar anetü de fato, seu pai ou sua mãe deveria sê-lo. O caso deste homem de Tankgugu mostra que, na realidade, a chefia não consegue simplesmente "pular gerações": o jovem começou a se tornar chefe por causa de sua mãe e seu avô materno, movimento que fez seu próprio pai começar a se tornar "um pouquinho" anetü. De certa forma, a chefia pode se "transmitir" de baixo para cima - é isso que tinha em mente quando mencionei que a ascendência pode ser vista como fabricada.

\footnotetext{
${ }^{26}$ Referindo-se a um de seus netos (DS), cunhado de um jovem que sentava perto de mim.
} 
As pessoas "vão em cima/sobre as costas" de alguém porque são parecidas com a pessoa substituída (como no uso de itüpohongo para os objetos, onde essa palavra só é apropriada quando o substituto é idêntico ao primeiro). A relação de substituição é a replicação de um modelo, o modelo de pessoa do chefe. Esta relação entre um arquétipo e sua atualização (Franchetto, 1986; Viveiros de Castro, 1977) é importante, pois o chefe é ele mesmo o modelo da pessoa xinguana, como todos os autores notam. Isso explica porque perante os outros, só chefes podem ser chamados simplesmente de kuge, "gente": são a forma viva do modelo humano. E o humano xinguano ideal é o humano calmo e honesto, o único tipo de pessoa que pode chefiar:

\section{Ageu:}

Apa heke uãke uinguheta

Antigamente meu pai me ensinava

Uinguheta tiha akihekugeneki

Me ensinava sobre a prática das palavras verdadeiras

Uinguheta tiha iheke ülekiha

Ele me ensinava sobre isso

“Anetüiha uitüpohongoi hetsange eitse”, apaju kilü tiha uheke

"Seja um chefe, meu substituto", meu querido pai me disse

(...)

“Inhalü tükotinhü tüilüi kupehe” apaju kitaha uãke "inhalü tükotinhü akanenümi kupehe, okoha!"

"Não se faz pessoas bravas", meu querido pai me dizia, "não se faz sentar pessoas bravas, não mesmo!"

"Takihekuginhü, takihekuginhü takaneti kupehe”

“Aqueles que têm palavras verdadeiras, aqueles que têm palavras verdadeiras nós fazemos sentar"

Apaju kitaha uãke uheke

Meu querido pai me dizia 
Inhalü ukotui inhalü uetigotui

Eu não fico bravo, eu não brinco

\section{Inhalü uetigotui}

Eu não brinco

Apaju akisü tagatühügü tiha uheke

Eu ouvia as palavras do meu querido pai

$(\ldots)$

Ago mugu tükotinhü inhalü tüilüi uheke, inhalü tüilüi uheke

Se meus netos ${ }^{27}$ forem bravos, eu não os farei, eu não os farei

Tükotibüngü anetüi tüi kupehe

Os que não são bravos são feitos chefes

Itsotundüingi hugombo

Para que não fiquem bravos no centro

Ilá sügühütu igehungu ügühütu

É assim o seu costume [de fazer chefes], seu costume é desse jeito

Inhalü tükotinhü akanenümi kupehe

Nós não sentamos os bravos

Tükotibüngü takaneti kupehe - tah! - hekite hegei sakisü itsomi

Os que não são bravos são feitos sentar - $t a h^{28} !$ - para que seus modos/sua fala sejam bons

A imagem do "fazer chefes" nesta fala é fazer os futuros anetü se sentarem sobre bancos rituais (ugi). "Aquele que vai sobre o banco" (ugihongo, ou simplesmente ugiho) é quem conduz seu povo aos rituais em outras aldeias, e é sendo ugihongo que um rapaz ou uma moça podem começar a ser chamados efetivamente de anetü ou itankgo ${ }^{29}$. Até então eles

\footnotetext{
${ }^{27}$ Traduzi "meu netos" para evitar ambiguidades, mas Ageu diz "filhos deles" (ago mugu), apontando para alguns de seus filhos que estavam próximos de nós.

${ }^{28}$ Tah!, assim como teh!, é uma interjeição que expressa admiração por algo ou alguém muito bonito.

${ }^{29}$ Isto evoca a figura do "homem sentado", bastante difundida na iconografia pré-colombiana e no pensamento ameríndio de modo geral (Pineda Camacho, 1996; Urbina, 1994). Para os Kaxinawa, por exemplo, o homem ideal é aquele que sabe "ouvir sentado" (comunicação pessoal de Elsje Lagrou). Para os Makuna, os bancos são
} 
podem ser "parentes de chefe" (anetü ungugu) ou "descendentes de chefe" (anetü unkgugu), mas o uso do título está condicionado a "ir sobre o banco" ao menos uma vez. Dizem que antigamente só os chefes possuíam esses bancos, e que um ugi deveria ser dado a alguém por seu pai ${ }^{30}$. Um chefe é inclusive chamado de "banco"31" (iküpo) do seu povo, como Kalapalo iküpo, Kuikuro iküpo, etc. (ver também Fausto, 2007: 34). Os bancos são um importante índice de chefia, e as etnografias apontam uma associação específica com bancos esculpidos em forma de urubu bicéfalo (ver, por exemplo, Figueiredo, 2010: 255). Na verdade, para os Kalapalo, o banco de chefe padrão não é zoomorfo (seu assento é retangular), mas eles também reconhecem que os bancos em formato de urubu bicéfalo e de gavião são exclusivos de chefes, e não deveriam ser usados por outras pessoas (muito menos fora dos contextos rituais). Essa associação dos chefes das aves aos bancos provavelmente vem dos mitos nos quais o gavião ou o urubu rei, conforme a versão, ficam sentados em seus bancos ressuscitando pássaros que os humanos matam durante os eclipses.

O conceito central aqui é akihekugene (aki-hekuguN-ne; palavra/jeito-verdadeiroNMLZ). Em seu sentido mais geral, a expressão aki hekugu, "palavra verdadeira", descreve qualquer fala boa, bonita, calma, apaziguadora ou incentivadora, e alguém que seja reconhecido por falar a verdade é chamado de akiheku ou takihekuginhü (“cujas palavras são verdadeiras"). Já em seu sentido mais específico, ela se refere à fala dos chefes que, por definição, precisam ter sido preparados para se tornar pessoas de comportamento e capacidade oratória excelentes, capazes de orientar seu povo com uma fala tranquila e humilde, sem nunca dar ordens ou deixar transparecer raiva. Mas aki não significa apenas palavra, e também pode ser entendida como "jeito": sakisü pode significar tanto "a língua dele" quanto “o jeito dele". Assim, takihekuginhü é quem tem ao mesmo tempo uma boa fala e um bom comportamento, que lida com as pessoas da maneira ideal. Por isso Ageu enfatiza a importância de só transformar em chefes pessoas de jeito bom, que não ficarão bravas no centro (lugar dos rituais e dos chefes, onde deve prevalecer o ethos xinguano em suas melhores expressões). Como me disse outro anetü: "Só dois de meus filhos já se sentaram.

artefatos invisíveis associados a substâncias e objetos que compõem a pessoa, sendo particularmente ligados ao pensamento (Cayón, 2011).

${ }^{30}$ Assim como as flautas atanga, que só podem ser possuídas por campeões ou filhos de chefes e devem ser encomendadas e pagas por seus pais. O primeiro cacique conta que ganhou um ugi de seu pai pouco depois que começou a ser ugihongo em rituais.

${ }^{31}$ Assim como o chefe "vai sobre o banco", é como se um povo fosse "sobre o chefe", passando uma imagem de homologia do chefe com seu povo: dependendo de quem se leve em consideração, muda apenas a natureza do banco (se é um objeto de madeira ou uma pessoa). 
Seu jeito é bom, falam bem, e por isso se sentaram. Meu outro filho não; seu jeito é ruim, ele sempre fica bravo, e por isso não se sentou".

Mas reconhecer a importância da fabricação não resolve nada, apenas coloca o problema em outros termos: porque é preciso fazer interferir algo que se parece com um "princípio de descendência"? Por que não basta fabricar chefes, é preciso fabricá-los uns a partir dos outros? A resposta está na natureza da relação de filiação, que faz com que só um anetü consiga produzir outro anetü.

\subsection{A filiação como vetor de identificação}

O pai e a mãe de uma pessoa são seus donos $\left(\right.$ otomo $\left.^{32}\right)$. Apesar deste não ser exatamente um termo de parentesco nem ser usado como vocativo, dois irmãos podem, em um conversa séria e em sinal de respeito, se referir a seus pais como ukotomo, "nossos donos $^{33}$ ". Descrever a filiação a partir desse conceito pode ser interessante porque ele dá conta de dois aspectos importantes (mas não os únicos) dessa relação, que são a concepção e a criação. O segundo é importante para nossa discussão porque ele implica em assemelhamento: criar alguém é transformá-lo em alguém parecido consigo.

Já a ideia de concepção nos remete a um dos sentidos de oto que é "origem/causa" ou "produtor" (ver também Fausto, 2008): o dono do trovão e o dono do vento são considerados como tais por serem a origem desses fenômenos; os Kalapalo são os donos dos objetos de conchas porque são seus produtores; um pé de pequi é possuído (otondelü; lit. "dotado de um oto") porque foi plantado por alguém. Nesse mesmo sentido, os pais de alguém, de saída, são seus donos porque o geraram. Quando uma mulher fica grávida, tem início um trabalho de fabricação do corpo da criança. Apesar da concepção do bebê poder começar depois de uma única relação sexual, é preciso um esforço contínuo do pai para que o corpo do bebê cresça no útero materno. Isso é literalmente um trabalho, pois os Kalapalo dizem que no ato sexual os homens "trabalham" suas mulheres, usando para isso a raiz $k a$, empregada na descrição de qualquer tipo de esforço sistemático orientado em relação a uma finalidade específica. A

\footnotetext{
32 Basso, 1973; Franchetto, 1986; Guerreiro Júnior, 2008.

${ }^{33}$ Este uso aparece no registro formal do discurso de recepção de mensageiros, como será discutido no capítulo 5 .
} 
finalidade deste trabalho é fazer filhos, também descrito pela raiz verbal üi que, como já mencionei, se refere a um fazer abstrato.

Fornecer matéria para a formação do feto é responsabilidade principalmente do pai que, por meio de repetidas relações sexuais, deve encher sua mulher de esperma, que se acumulará e começará a se transformar no corpo de um bebê ${ }^{34}$. Este processo de encher a mulher é a contrapartida de um esvaziamento difícil, porém necessário, do homem. O sexo enfraquece os homens (principalmente os lutadores), mas o esperma, que fica alojado na região lombar (üntisü), quando se acumula demais pode provocar fortes dores nas costas, preguiça e dificultar o trabalho na roça e nas pescarias. Quando um homem "trabalha sua mulher", esvaziando sua região lombar e enchendo o útero de sua esposa, ele também cria condições para que ele próprio possa fazer seus principais trabalhos ligados à vida conjugal: roçar e pescar. Diferentemente dos arawak xinguanos (Gregor, 1977; Viveiros de Castro, 1977), para os quais o sêmen de vários homens podem contribuir para a formação do bebê (criando situações de "paternidade múltipla"), para os Kalapalo a mistura de sêmen de homens diferentes pode apodrecer o feto e provocar aborto. Basso (1973: 76) nota que "a woman who has promiscuous intercourse with many men cannot become pregnant; rather, she is in danger of falling seriously ill".

Entre os Kalapalo, há certa especulação sobre o papel da mãe na concepção. Alguns dizem que ela não contribui com nada, outros dizem que o sêmen poderia se misturar com o sangue menstrual, que se acumularia no útero. Dentro do útero feminino vive um itseke, a Placenta (lijumbe). Ela é quem decide se deixa ou não o esperma do homem entrar no útero, sendo uma espécie de "idealizadora" da fecundação. O útero tem uma abertura que a Placenta pode fechar, para evitar que o sangue saia, e abrir durante as relações sexuais, para que mais sêmen possa entrar. Esse itseke também é chamado de itsü, "raiz" ou "avó" do bebê. O termo avó aqui não tem nenhum sentido cognático, e é utilizado pelo fato da Placenta ser um espírito feminino muito velho, uma "senhora" (como os Kalapalo traduzem o termo hagü), que dizem ser bem pequena, como uma criança de cinco anos, com o cabelo bem comprido e bem branco. Ela é a responsável pela "modelagem" do feto, pois é sua "roupa" (kangamuke ingü, "roupa da criança") que, assim como as "roupas" de espíritos, configura um corpo com forma

\footnotetext{
${ }^{34}$ A capacidade do esperma de contribuir para a formação do corpo não se restringe ao desenvolvimento do bebê no útero, mas também é ativada durante a reclusão pubertária masculina, período no qual o jovem não deve fazer sexo nem se masturbar, com o risco de ficar baixinho, fraco e feio.
} 
e capacidades específicas (Barcelos Neto, 2008; Figueiredo, 2010: 153-156; Franco Neto, 2010: 221). Também é ela quem cuida e alimenta o feto (já me foi sugerido que ela talvez usasse o sangue materno com essa finalidade).

Durante a gestação, a Placenta desenvolve um grande afeto pelo bebê. Esta situação coloca a criança em uma posição liminar entre os espíritos e os humanos, pois enquanto a matéria de seu corpo é fornecida por seu pai, ele é modelado e nutrido por sua "avó" itseke, gerando uma tensão no momento do nascimento e que dura pelos dois primeiros anos de vida da criança. Uma das primeiras coisas que as mulheres fazem quando nasce um bebê é verificar se seu corpo é perfeito. Caso apresente qualquer tipo de deformação, ele deve ser enterrado em uma cova aberta atrás da casa dos pais. Isso porque um corpo deformado de recém-nascido não é um corpo humano, e se diz de um bebê com defeitos físicos que ele "se parece" com itseke. Para dizer isso, os Kalapalo usam a raiz etinki, que não designa mera "semelhança”. Algo parecido com outra coisa é ihukingo, cuja raiz é hu, "imitar", e pode ser usado para dizer que uma cópia está parecida com o original, ou que o desenho de uma pessoa ou objeto se parece com o modelo. Já a raiz etinki pode ser usada para se falar de metamorfose: "üngelepe etinkipügü itsekei” ("aquele que morreu se transformou em espírito"). Um bebê deformado não simplesmente "se parece" com um itseke, mas tem um corpo que é parcialmente de itseke, impossibilitando sua humanização (o que fica claro pelo local onde ele é enterrado, fora do círculo da aldeia; o único sepultamento menos humano do que o de um bebê defeituoso é o de um feiticeiro, enterrado no mato por seus parentes mais próximos $^{35}$ ). Isso acontece porque a Placenta pode transformar o bebê em itseke, às vezes por vontade própria (afeto excessivo pelo bebê), mas na maioria das vezes por influência de algum feiticeiro.

Após o parto, a barriga da mulher é fortemente pressionada por uma parteira para que a placenta saia. Ela deve ser recolhida com cuidado por uma das mulheres que ajudam no parto, e logo enterrada atrás da casa. O buraco deve ser forrado com folhas do arbusto kejite, e a placenta coberta com mais folhas desta planta antes do buraco ser tapado. O kejite é uma planta de cheiro muito forte e agradável, e uma de suas utilidades (que os Kalapalo associam explicitamente a seu cheiro "um pouco dolorido" - lembra menta) é impedir metamorfoses ${ }^{36}$.

\footnotetext{
${ }^{35}$ É digno de nota que o feiticeiro seja a única pessoa sepultada pelos parentes mais próximos, pois qualquer pessoa é idealmente sepultada por afins ou parentes distantes (ver capítulo 4).

${ }^{36}$ Nos mitos, porém, ela quase sempre é usada para provocar ou acelerar mudanças corporais. O kejite tem várias outras utilidades, como por exemplo tratar febres, resfriados e dores de cabeça.
} 
Em certas situações, esfrega-se kejite no corpo para proteger os vivos da presença perigosa da alma de pessoas que acabaram de morrer. A mesma técnica de enterro da placenta é usada pelos feiticeiros para guardarem suas "roupas de bicho", que utilizam para se transformar em animais e percorrerem grandes distâncias na terra, na água ou no ar. O kejite é importante para eles porque, caso enterrassem suas roupas diretamente na terra, elas se transformariam em itseke e deixariam o local.

A placenta deve ser manuseada com todo o cuidado, para evitar que ela se zangue; deixá-la cair no chão ou jogá-la com descaso no buraco seria letal para o recém-nascido. O espírito da Placenta permanecerá ao lado da criança durante cerca de dois anos, e nesse período estará em uma relação tensa com os pais - pois ela gostaria de levar o bebê para sua própria aldeia, o que significaria a morte da criança. Ela não faz isso por maldade, mas por excesso de afeto: ela gosta muito do bebê e sempre quer vê-lo bem alimentado, alegre e querido. Caso os pais não ofereçam essas garantias à criança, ela vê motivos para tentar levála consigo, e a capacidade da Placenta em obter êxito depende de como os pais cuidam de seu filho. Já vi vários casos de crianças que não estavam muito bem e cujos problemas eram atribuídos às ações da Placenta, sempre provocadas pelos pais. Certa vez, um menino estava com vários furúnculos nas pernas que não se curavam. O pai, muito triste, reconheceu sua própria culpa, lembrando-se que uma semana antes do aparecimento das feridas ele havia deixado seu filho sozinho com a mãe, sem ninguém para pescar pra ele, para participar de uma competição de futebol no Posto Leonardo. Outro caso foi letal. Uma criança com menos de um ano de vida faleceu após alguns furúnculos terem aparecido em sua cabeça. Várias pessoas comentaram que certamente a Placenta havia levado a criança, pois corria o boato de que sua mãe não a queria desde a gravidez e que, depois do nascimento, vivia se queixando de seu filho a todos, dizendo que ele "era ruim", e maltratando a criança.

Esses aspectos da gestação, do nascimento e dos primeiros anos de vida, ligados à Placenta, sugerem que um recém-nascido ainda não é nem completamente humano, nem completamente parente. Estas duas afirmações são na verdade redundantes, pois entre os Kalapalo, como entre outros ameríndios, as condições de "humano" e "parente" são mutuamente dependentes, coextensivas (Coelho de Souza, 2001a; 2002; 2004; Gow, 1997; Vilaça, 2002). Pois quais pessoas podem se ver mutuamente como "gente"? São, necessariamente, pessoas que se veem como parentes em alguma medida. Isso fica muito claro no caso de adoecimento por sequestro da alma por itseke, quando a pessoa se torna, do 
ponto de vista de seus parentes humanos, "um pouquinho itseke", enquanto de seu próprio ponto de vista, quando está inconsciente ou dormindo, ela continua humana, mas também vê os itseke como humanos e como seus parentes. Tornar alguém humano e aparentar são duas faces de um mesmo processo, para o qual a noção de dono/pai é central. Oferecendo proteção, afeto e nutrição, um dono/pai (seja um humano cuidando de seu bebê, seja um itseke cuidando da alma de um doente) faz um filho construindo seu corpo como um corpo semelhante ao seu. O primeiro passo para a filiação "real" é a concepção, mas os cuidados e a fabricação do corpo do filho nos primeiros anos são fundamentais para que a relação se estabilize e ele se torne definitivamente humano.

A fabricação de um filho dura muito tempo, até mesmo depois da reclusão pubertária. Parte dela consiste na aprendizagem dos costumes xinguanos, dos modos corretos de se comportar, de se relacionar com os parentes. Os processos de ensino e aprendizagem são corporais na medida em que estão ligados à visão, à audição e à fala. A raiz para "pensar" é olho (ingu), que combinada à raiz para "abrir" (he) forma a palavra verbal que os Kalapalo usam para dizer ensinar: inguhelü, que significa literalmente "abrir os olhos". Outra forma de falar sobre o que se ensina é o que os Kalapalo traduzem como "orientar", hangaküjü, cuja raiz é hanga, "orelha". A fala ocupa um processo central nisso tudo, pois é com a fala verdadeira (aki hekugu) que se ensina e orienta, e é na sua prática (akihekugene) que se demonstra o que se aprendeu. Caso não use a fala verdadeira/boa, é sinal de que o jovem esqueceu o que lhe foi dito (um processo que de alguma forma passa pelos ouvidos, pois "orelha”, hanga, também é a raiz de esquecer - hangaginügü).

A relação de filiação, entendida como um longo processo de fabricação da pessoa por meio de seu corpo, é o vetor do aparentamento e da humanização. Uma criança só é filha de um pai e de uma mãe humanos porque eles fizeram com que ela não se tornasse filha de um itseke, a Placenta: os pais assumem a condição de donos porque é enquanto tais que se relacionam, de maneira antagônica, com outro dono em potencial ${ }^{37}$. Pode-se dizer que a filiação é uma relação de "assemelhamento": transformar alguém em um filho é fazê-lo se tornar parecido com os pais - seu hisuägü, parente ou semelhante. Isso significa que alguém só consegue produzir filhos parecidos consigo, e por essa lógica só um kuge (gente) verdadeiro consegue produzir outro kuge verdadeiro, ou, dito de outra forma, só um anetü consegue produzir outro anetü.

\footnotetext{
${ }^{37}$ A questão dos "donos" será retomada em detalhes no capítulo seguinte.
} 
Já observei que uma das formas mais comuns pelas quais os Kalapalo se referem aos chefes é simplesmente como kuge, fazendo da condição humana e da chefia sinônimos. Em uma escala que vai do limiar entre o não humano (o recém-nascido), o humano médio e a humanidade xinguana plena, um chefe ocupa este último polo da escala, enquanto os demais ocupam os espaços intermediários. Se a filiação é uma relação de assemelhamento, a transmissão intergeracional da chefia tenta levar esta relação a sua forma máxima, que é a replicação ou substituição. Sendo assim, entende-se porque quanto mais chefes atuantes uma pessoa tiver em seu passado genealógico mais chances ela tem de se tornar anetü, e porque a chefia de alguém pode acabar de uma geração a outra: eu sempre preciso que alguém tenha sido feito kuge antes de mim para me fazer kuge. Vista sob esse ângulo, a "descendência" na chefia xinguana nada mais é do que o efeito produzido pela tentativa de se replicar arquétipos, da substituição de um "modelo vivo" por outro, que só se realiza pela filiação. Se sou chefe, isso só é possível porque fui feito como tal por meu pai, que só pôde fazê-lo porque também foi feito por seu avô e assim sucessivamente. Sendo os chefes um tipo de pessoa ( $o$ tipo ideal de pessoa) que só pode ser feita a partir de outra semelhante, a hereditariedade surge como um efeito do princípio do aparentamento: aparentar é tornar alguém parecido consigo pela filiação. Isso, por sua vez, não é algo dado: a filiação entre um dono/pai e seu filho só se constrói em oposição à potencial relação de filiação entre outro dono possível (a Placenta) e a criança, fazendo da relação de identificação assimétrica/vertical uma função de outra relação de diferenciação simétrica/horizontal. Reencontraremos a mesma lógica em breve.

\subsection{Esteio de gente}

Qual a necessidade de produzir algumas pessoas como se fossem cópias perfeitas do modelo ideal do humano? Porque os chefes, sobretudo o primeiro cacique, são considerados pais adotivos de "seu pessoal", e como tais têm a difícil responsabilidade de fazer seu povo semelhante a si, por um motivo simples: para que as pessoas possam partilhar um ponto de vista e se produzir como parentes.

Iho significa literalmente arrimo ou esteio, como o poste de madeira no qual uma pessoa amarra sua rede. Mas esta noção também é utilizada para descrever uma série de relações baseadas no cuidado e na nutrição: o dono de uma casa também é iho das pessoas 
que moram nela, pois se espera que ele cuide de seus corresidentes, que os oriente, organize as atividades coletivas da casa, os apoie em seus problemas; um marido também é iho de sua esposa e seus filhos, pois deve provê-los com comida e protegê-los; pelo mesmo motivo, alguém que seja o único homem de uma casa também é iho das mulheres que moram nela. Pode-se dizer que iho, então, se refere a qualquer pessoa que se encontre na posição de protetor e provedor de outros. Talvez pudéssemos dizer que iho é alguém que tem o dever de "dar suporte", pois seria a descrição mais literal da função de um esteio. Um chefe também é chamado de $i h o^{38}$ :

\section{Tipüsusu:}

Kuge iho helei anetüi leha inhügü

Ele é o esteio das pessoas, aquele que já se tornou chefe

Anetü etijipügü

Os filhos dos chefes

\section{Kuge iho, $h m$}

São o esteio das pessoas

Anetü jetsa tisiho, tisanetü

Os próprios chefes são nossos esteios, nossos chefes

Um chefe é "esteio de gente" (kuge iho) porque ele é um pai em relação a seu povo, seus "filhos/crianças" (forma pela qual se refere às pessoas em discursos formais). Ele deve proteger, educar e nutrir seus filhos, orientando-os com o uso da fala verdadeira (akihekugene), sempre oferecendo peixe e beiju no centro da aldeia e nunca negando nenhum objeto que lhe peçam, por mais valioso que seja. Um kuge iho deve cuidar de sua aldeia e seus moradores como o dono de uma casa cuida de todos os que moram nela. Por conta de sua fala boa e sua generosidade, os chefes são vistos como o motivo pelo qual as pessoas vivem juntas em uma aldeia, a única razão pela qual o grupo local não se fragmenta indefinidamente.

\footnotetext{
${ }^{38}$ Muitas vezes sob uma forma do plural, ihoko que, além do próprio chefe, abrange também aqueles de quem ele é esteio (isto é, os moradores de sua aldeia). Quando alguém fala ihoko, portanto, está falando de "um-chefee-seu-povo".
} 
Quando uma aldeia começa a passar por diversas cisões, diz-se que isto se deve à falta de chefes que mantenham seu pessoal unido.

Como já vimos no capítulo 1, aldeias também podem ser iho de outras. Sempre que se conversa sobre aldeias antigas, algumas são frequentemente referidas como "as que se dividiram" (agaketühügü) e outras que são seus iho, sugerindo a existência de assimetria nas relações regionais entre grupos que resultaram de processos de fissão. Por exemplo, durante muito tempo, Kuapügü (a principal aldeia à qual os Kalapalo associam sua “origem”) coexistiu com as aldeias Kalapalo, Apangakigi, Angambütü, Hagagikugu; mas estas aldeias não estavam em pé de igualdade, pois Kuapügü era considerada iho das demais. Uma aldeiaiho tem a capacidade de exercer uma força centrípeta sobre as aldeias que se originaram a partir dela, que limita a tendência a que todo processo de fissão seja um processo de criação de novas identidades coletivas.

Mas há uma questão mais importante em jogo, pois a condição de iho nestas duas escalas (local e regional) está ligada à produção do parentesco e de um ponto de vista coletivo dentro do sistema xinguano. Em uma aldeia (que só pode existir se houver um iho/chefe), a convivência, a partilha de refeições e o exercício da reciprocidade são os responsáveis pela produção de um tipo generalizado de aparentamento: pessoas que vivem em uma mesma aldeia não devem se enfrentar em rituais e, no nível do contraste com outras aldeias, são todos hisuüdaõ ou têm o mesmo "sangue". Em contrapartida, parentes que vivem em aldeias diferentes tendem a se tornar menos parentes, ou "parentes de longe" (Guerreiro Júnior, 2008). Desta forma, se a existência de aldeias de "verdade" (com casa dos homens e capazes de patrocinar rituais) duráveis é a condição para a produção do parentesco, pode-se dizer que a produção do parentesco está condicionada à existência de chefes. Há uma questão a mais, ligada ao vetor que faz da convivência e da comensalidade entre pessoas de origens diversas uma forma de produzir parentes: a paternidade adotiva do chefe. Se a filiação em geral é uma relação de assemelhamento e humanização, o chefe precisa ser um kuge exemplar para que seus filhos sejam também kuge; e na medida em que a humanidade e o parentesco são coextensivos, fazendo gente os chefes criam as condições para o aparentamento em um plano coletivo. Os iho - sejam homens de carne e osso ou aldeias inteiras - oferecem as condições para a identificação e o aparentamento, tanto de um ponto de vista sincrônico quanto diacrônico, local e regional. 
Esta noção de esteio também está ligada aos conceitos mutuamente implicados de tronco e corpo, que nos aproximam da relação entre o egitsü e a chefia. Um esteio de fato (aquele no qual amarramos nossas redes) é feito, obviamente, de um tronco de árvore, e a palavra para tronco ou caule, que é a mesma para corpo, também é utilizada para se descrever os chefes: ihü. Eles são ditos ukugetihü ou katotihü (katote ihü), isto é, "o tronco-corpo das pessoas" ou "o tronco-corpo de todos":

\section{Tipüsusu:}

Katote ihüko leha sakitse leha

O tronco-corpo de todos discursa

Ahütüha ila inhümingo leha

"Não façam desse jeito"

Ahütüha ila inhümingo leha

"Não façam desse jeito"

Nügüha iheke

Ele diz

\section{Katotihü kilü}

O tronco-corpo de todos diz

Sanetunda hegei leha, sanetunda leha

Assim ele está chefiando, ele está chefiando

Estas relações entre chefia e os conceitos de tronco e corpo não são exclusivas aos Kalapalo nem ao Alto Xingu, mas podem ser encontradas alhures na Amazônia indígena. Segundo Costa (2007), como já vimos de passagem no capítulo 1, os Kanamari utilizam uma mesma palavra (-warah) para dizer corpo, tronco, chefe e dono; um coletivo só existe se possuir um corpo/chefe que o sustente, que cuide dele, que o proteja. Os principais corposchefes dos subgrupos kanamari, por exemplo, teriam sido no passado o motivo pelo qual as pessoas viviam próximas e como parentes. Eles teriam a função de reunir as pessoas em sua grande maloca em tempos de rituais e seriam os responsáveis por manter a unidade dos 
subgrupos (sem chefes os subgrupos se diluiriam, e as pessoas teriam que ir viver em outro subgrupo que tivesse um warah): "Um grupo de pessoas só emerge como uma unidade e como um grupo de parentes através de um chefe, que estabiliza aqueles que, os Kanamari nos fazem crer, não poderiam de outra forma viver juntos" (Costa, 2007: 47).

Ao mesmo tempo, o subgrupo é o principal critério pelo qual as pessoas definem quem são seus parentes (ainda que haja diferentes graus de parentesco em seu interior), do que se conclui que o parentesco depende da existência de chefes/corpos/donos que reúnam uma multiplicidade de pessoas, pois eles são o que "estabiliza aquilo que é potencialmente fluido; afirma-se como um em relação àquilo que é (potencialmente) muitos” (id. ibid.). Estabilizar uma multiplicidade, fazer um conjunto de pessoas aparecerem como membros de um grupo, é o que permite que elas se assemelhem enquanto um mesmo tipo de "gente", um mesmo corpo de parentes (ibid: 167-171).

Costa prefere traduzir o -warah kanamari por "corpo" na maioria dos contextos, mas penso que entre os Kalapalo a tradução de ihü como "tronco" parece ter um maior rendimento analítico e etnográfico (principalmente em uma tese sobre um ritual com troncos para chefes). Primeiro porque ela permite realizar uma passagem fácil entre tronco (ihü) e esteio (iho) - já que todo esteio é um tronco - em um contexto no qual não se utiliza a mesma palavra para tudo, como entre os Kanamari; segundo porque as plantas, sobretudo as árvores, são uma metáfora para a continuidade genealógica (e, portanto, para a cognação ${ }^{39}$ ) e para as relações assimétricas implicadas entre chefes e comuns: as raízes são os ancestrais, a base (ena) os chefes principais, o meio do tronco (ihü) os chefes de média importância, a parte superior do caule os chefes pequenos, e os galhos (îkungu) as pessoas comuns ${ }^{40}$. Se eu optasse por privilegiar a tradução de "corpo" em detrimento de "tronco", correria o risco de deixar em segundo plano a "concepção vegetal" que os Kalapalo têm de seus coletivos e do parentesco consanguíneo em geral. Isso não exclui, contudo, o uso de corpo, na medida em que chefes permitem a produção de coletivos como corpos de parentes (pois, no limite, uma aldeia é um "corpo de parentes" face a outras, já que todos podem ter "o mesmo sangue").

A divisão entre "base" e "galhos" também está presente na organização das suítes musicais. Fausto, Franchetto et. al. (2011: 60) mostram que "les Kuikuro distinguent deux

\footnotetext{
${ }^{39}$ Como vimos no conceito de atilü, que designa ao mesmo tempo o crescimento vegetal, as relações de filiação entre os chefes e o parentesco cognático de maneira geral.

${ }^{40}$ Essa anatomia será retomada no capítulo 7, quando discutirmos a produção das efígies.
} 
éléments constitutifs de tous les chants : iina (la « base ») et itsikungu (la « rupture »)". Os autores descrevem estes conceitos da seguinte forma: "le terme iina désigne, par exemple, la base d'un arbre ou d'une fleur (l'endroit d'où sortent les pétales). C'est un mot qui connote quelque chose qui surgit de l'endroit en question. Itsikungu, en revanche, indique une bifurcation, une rupture, un détour" (id. ibid., nota 30). A imagem vegetal tem uma grande capacidade para descrever conjuntos englobantes.

Esteio e tronco-corpo se aproximam de forma interessante: todos são formas pelas quais os Kalapalo descrevem relações assimétricas baseadas no cuidado, na proteção e na alimentação (entre um marido e sua mulher, entre um chefe e sua aldeia, entre uma aldeia ritualmente mais importante e outras menos). Para que haja coletivos nas escalas mais variadas, de um núcleo conjugal a nexos regionais, é preciso que exista uma relação de assimetria entre um tronco/esteio/corpo que unifique e suporte as pessoas que vivem ao seu redor. Um chefe é como um tronco que sustenta o crescimento de um corpo de parentes, assim como é um esteio sobre o qual eles se apoiam.

\subsection{Sentar-se, ser visto e tornar-se conhecido}

Tratemos por fim da questão que nos permitirá passar ao capítulo 3, onde discutirei a noção de dono e a relação dos chefes com a alteridade e a afinidade potencial: para se tornar substitutos de alguém, os futuros anetü precisam ser escolhidos por outros chefes e publicamente exibidos para os chefes estrangeiros nos rituais. Como já mencionei, os chefes associam o começo da chefia ao momento em que "se sentam", isto é, se tornam ugihongo ou ugiho pela primeira vez:

\section{Tipüsusu:}

Uüilü iheke hotugui ugiho Ipatsena, Lahatuana

Primeiro meu pai me fez ugiho em Ipatse, quer dizer, em Lahatua

Kuikuruna

Nos Kuikuro 


\section{Uüilü iheke}

Ele me fez

Tipüsusu se refere a seu pai, que a "fez" (chefe) em uma festa nos Kuikuro da qual ela participou como ugihongo. Mais adiante em sua fala, ela ainda nota que fazer alguém chefe não é um assunto que compete exclusivamente aos pais, mas depende dos outros chefes:

\section{Tipüsusu:}

Inke apa aminga Aru mugu telü ugiho inke

Veja só, outro dia o filho de Aru foi ugiho, veja

Etinenügü hegei ugiho tütelü heke ilá uluki, egena, Nabocana

A sua ida como ugiho nos Yawalapíti, no uluki, foi o começo

Sakanenügü hege iheke anetü hege itsomi

Ele "foi sentado" para se tornar chefe

Anetüha ege itsomi sakanenügü

Para se tornar chefe ele "foi sentado"

Ugiho tisingenügü beja egena hugombonga

Nós somos chamados para ser ugiho no centro

Ekü hekeha, anetü heke beja kuarup entoteha ina etinhü entote

Por um chefe, quando o Quarup vier, quando os mensageiros vierem

Ülegote tisingenügü

Quando isso acontece nós somos chamados

(...)

Ahütü uge uitsomi anetüi tsitsipügühüngü

Não se diz "eu vou ser anetü"

Ukuge heke kukingilü anetü heke

Uma pessoa nos vê, um chefe vê 
Ekü eitsomi ekü anetü ingetomi ingenügü leha

“Será você", ele chama

Ülegote leha ototihü ${ }^{41}$ telü ike leha

Quando isso acontece seu pai vai com ele [para o centro]

Inkeha uegei

"Veja você!"

Koteneki tatanakinhü

"Você é bravo!"

Ngiko kungapala okotui - isi kilü leha iheke leha

"Você nunca deve sentir raiva" - sua mãe lhe diz

Inhalü okotui

"Você não deve sentir raiva"

Inhalü ila ekilü kuge heke

"Você não deve dar ordens às pessoas"

Tütomi ila ekingalü kuge heke? - isi kilü leha

"Por que você daria ordens a alguém?" - sua mãe diz

Waja e Ageu também falam sobre a importância de serem mostrados como chefes aos estrangeiros:

\section{Waja:}

Engü leha, apaju heke uüilü leha anetüi leha

Então, meu pai me fez chefe

Anetüi leha utelü Mehinakuna, ugiho, quarupgote

Eu fui chefiar nos Mehinaku, como ugiho, quando houve Quarup

\footnotetext{
${ }^{41}$ Segundo um colaborador, esta palavra, que foi traduzida como "pai", é formada a partir de oto (dono) e ihü (tronco-corpo).
} 
Apaju heke uïilü

Meu querido pai me fez

Igia leha uitsa leha

Assim [sentado] eu fiquei

Aiha

Pronto

Kotote leha ukuge heke uingilü

Todas as pessoas me viram

Kotote leha ukuge heke uingilü, pessoal, Kalapalo heke leha, haingopeko heke, aiha

Todas as pessoas me viram, pessoal, os Kalapalo me viram, os velhos me viram, pronto

\section{Ageu:}

Üle amileha

Tempos depois disso [de seu pai pedir que ele se tornasse seu substituto]

Kuarup inhügü

Houve Quarup

Ületomi lahale uüitomi iheke ningenügü leha apaju heke

Então para fazer isso, para que ele me fizesse, meu querido pai me levou

Utetomi bejeta hugombonga lahale

Para que eu fosse para a praça

Ugiho leha utetomi lá anetüi kunhügü anügü

Para que eu fosse ugiho, é assim que nos tornamos chefes

Lá uhitsokongohüngü higei anetüi kunhümi

É assim, os que não são procurados não se tornam chefes

Kuarup itsoteha

Se houver Quarup

Kukingenügü 
Nós os chamamos

Kuarup itsoteha ukingenügü anetüiha ukutsomi

Se houver Quarup nós os chamamos para se tornarem chefes

Kutegomi hegei

É para irmos

Tekinhü lombonga kukakandomi

Para nos sentarmos

Anetüi hegei kutsomi

Isto é para sermos chefes

Kukakanügü leha apungu hegei leha

Quando já nos sentamos, está pronto

Tekinhü ngikinhugu ekulü hegei kupehe leha

Nós comemos o beiju dos povos de outras aldeias

Inhalüha atahakilüi sagingohungu atahakilüi

Não se apaga quem é seu semelhante [i.e., semelhante aos chefes]

Inke hõhõ umugu angi

Veja só, meu filho ali

Hasagü angiha tüipügü leha uheke leha uitüpohongoi

Ali está Hasagü, eu já o fiz meu substituto

Hehu leha ugei leha inhalü leha uinhahetungui leha

Eu já estou velho, eu não sou mais forte

Inhalü leha uinhahetungui

Eu não sou mais forte

Hehu leha ugei

Eu já estou velho

Angi leha umugu paki geleha etengalü tekinhüna

Meu filho vai sempre para os povos de outras aldeias 


\section{Ugiho \\ Ser ugiho \\ Umugu tengalü uitüpohongoiha ungüipügü elei \\ Meu filho sempre vai para ser meu substituto, ele é quem eu fiz}

As falas são claras sobre a conexão entre "ir sobre o banco", ser ugiho, e o começo da chefia. Waja nota que parte da importância disso está em ser visto: "Todas as pessoas me viram. Todas as pessoas me viram, pessoal, os Kalapalo me viram, os velhos me viram". Em outra ocasião, conversando sobre o mesmo tema, Waja me disse que quando se leva os jovens para serem ugihongo é quando eles começam a ficar famosos (tuhutinhü, "que é conhecido"). As pessoas sempre se perguntam quem é aquele ou aquela jovem, comentam de quem ele(a) é filho, se é ou não uma boa pessoa, um bom lutador, se é bonito(a), etc. Quanto mais um jovem é feito ugihongo por seus pais, mais ele é visto pelos outros e mais se torna famoso.

Isso não é só com os chefes, mas também com os campeões de luta (ojotse) - o que idealmente, como já foi dito, todo grande chefe deve ter sido. Pouco antes do dono da casa onde eu sempre me hospedo falecer, ele pediu a seu filho caçula (com cerca de 12 anos, prestes a entrar em reclusão) e a seu neto mais velho (por volta dos 15 e já recluso) que se esforçassem para se tornar campeões. Ele dizia que não queria que as pessoas se esquecessem de seu nome, que se eles se tornassem grandes lutadores, se tornariam conhecidos, e assim as pessoas de outras aldeias estariam sempre "mexendo no seu nome" (falando dele) e pensando em como ele deve ter sido um bom professor para seus filhos e netos. Estas situações de exposição pública nos rituais regionais não apenas tornam uma pessoa visível e conhecida, mas por meio dela se produz uma memória genealógica impressionante a respeito dos chefes e campeões de luta que boa parte das pessoas não mantém sequer a respeito de seus parentes próximos. A realização de cada ritual regional envolve a produção de uma memória sobre o passado dos chefes e campeões que, em consequência, os fortalece em suas respectivas posições e amplia as condições pelas quais eles podem produzir filhos semelhantes a si mesmos, seus "substitutos".

Ainda há outro ponto importante, para o qual Tipüsusu chama a atenção: não basta ser exibido como chefe aos estrangeiros, mas é preciso ter sido escolhido por outros chefes, idealmente parentes mais distantes. Um pai não decide se seu filho se tornará ou não 
ugihongo (e, portanto, se terá início o processo de substituição), mas outro chefe precisa sugerir isso. A descendência não é suficiente para levar à chefia: é preciso que outros chefes reconheçam a qualidade do jovem que se tornará anetü, e que algum deles o indique para se tornar ugiho. Se para ser chefe é preciso descender de algum anetü, a decisão de iniciar o processo depende de outros. Isso é um caso particular de uma condição mais geral que reencontraremos constantemente nesta tese: só chefes podem fabricar outros chefes, e a diferença entre os que são fabricados e os que decidem fazê-lo tende a replicar uma oposição entre consanguíneos e afins.

Pela forma como os entrevistados se referem às suas iniciações como chefes, fica clara a importância das relações entre o regionalismo ritual e a chefia. Sem os chefes, as relações regionais rituais são impossíveis, pois os encontros rituais são, antes de qualquer coisa, encontros entre chefes:

\section{Tipüsusu:}

Andeha, ekü, ekü beja, ugihongo enümingo egitsene inha egitsene inha

Aqui... os ugihongo chegarão para a festa, para a festa

Ah, ugiho itã̃ telü

Ah, uma mulher será ugiho

Anetü helei, ugiho oto

Ela é chefe, a dona do banco

(...)

Anetü telüha, ahütüha talokitohüngü, anetüi

É um chefe é quem vai, não é um qualquer, mas quem é chefe

Itaõ anetügü telüha ugiho

A chefe das mulheres vai, para ser ugiho

Ilango hegei

É desse jeito 
Hekine beja isakisü, atütü sakisü

Se seu jeito for bom, se seu jeito for bonito

Tüteha ugiho

Ela será ugiho

\section{Ageu:}

Nago tisugeha ingenalüko, ingenalüko tiha tiheke anetão ingenalü ülegoteha ülegotetsi benaha anügü hale

Nós os chamamos, nós chamamos, quando isto acontece [quando mensageiros chegam] nós chamamos chefes

Hugombongaha, hugombonga

Para o centro, para o centro

Etinhü akandoteha anetüko ingenügü anügü beha kupehe inhalü bahale talokito igitaha

Quando os mensageiros já estiverem sentados, nós chamamos apenas chefes, não se chama um qualquer

Ande tsüha uluki enügü gehale, uluki ülegotetsüha anetã̃ uhijü tiha tiheke

Quando o uluki chega também, se houver uluki nós procuramos os chefes

Uhijü ago tsüha tuhugu geleha

Os procuramos todos

Uhijü tiha tiheke

Nós os procuramos

Ülegotetsüha ẽhẽ nügü tsühi iheke tengikokgi atanini ẽhẽ nügü iheke

Quando isto acontece "Sim”, ele diz, se possuir objetos, "sim", ele diz

Inhalü bahale talokitoko ingenümi anetüko ingenümi bahale

Não se chama mesmo qualquer um, pois só se chama chefes

É interessante a recorrência do termo talokito nas duas falas, usado com frequência para falar dos não chefes. Talokito é uma palavra nominal formada a partir de taloki, "à toa". 
Estar sem fazer nada, é estar taloki; perguntar algo a alguém sem nenhum interesse específico é perguntar taloki; visitar alguém sem querer nada, é taloki. Quando usado para se referir a objetos, talokito pode significar sem valor, frágil, inútil, imprestável ou insuficiente. Também já o ouvi sendo empregado, por exemplo, a pescadores que voltam sem peixe de uma pescaria, ou a cães que afugentam a caça ao invés de persegui-la. Nesta acepção, talokito parece significar “incapaz” ou mesmo “imprestável”, já que tem um sentido pejorativo. É uma palavra polissêmica, mas que parece transmitir a ideia geral de que aquilo a que se aplica (um objeto, uma ação ou uma pessoa) não tem a capacidade de gerar os efeitos que se espera deles: uma flecha talokito não mata, um pescador talokito não consegue peixes, um cachorro talokito não caça nem defende seu dono. Talokito se refere a algo ou alguém sem capacidade de "fazer coisas". Quando aplicado por nobres a não chefes, talokito às vezes aparece em contextos de fala nos quais um chefe comenta sobre a falta de conhecimento dos demais, as restrições ao uso de certos ornamentos ou a impossibilidade de participar nos rituais regionais como dono, homenageado, coordenador, chefe dos convidados ou mensageiro ${ }^{42}$. Já que uma das principais características de um anetü é sua participação diferenciada no sistema de rituais regionais, não é difícil entender porque, de seu ponto de vista, um não anetü é talokito: não faz nada que um anetü faz, seja por não saber, seja por não poder.

Talokito difere de outros termos para não chefe, como anda ("seguidor") ou kamaga (corruptela de "camarada"), usados sempre em suas formas possuídas para designar um coletivo em relação a seu chefe. Mas da mesma forma que os outros, ele não designa uma categoria social, uma "classe" (Carneiro, 1993) ou uma camada social "castelike" (Heckenberger, 2005: 265): é apenas um ponto de vista (pejorativo) dos chefes sobre os outros. Talokito permite pensar os não chefes a partir do que, ao menos do ponto de vista dos anetü, é o que os define: sua falta de valor, sua incapacidade, seu comportamento potencialmente ruim.

Se o parentesco cognático é a via pela qual o potencial da chefia se transmite, a afinidade ritual é condição para que este potencial se atualize. Antes de ser chefe "de alguém", os anetü são chefes para alguém, isto é, para os chefes estrangeiros e os chefes que não fazem parte de sua parentela próxima e dos quais dependem para ser reconhecidos. A

\footnotetext{
${ }^{42}$ Para os Kalapalo, idealmente seria preciso ser nobre para ser mensageiro. Se um não nobre assume esta posição é apenas porque há mais aldeias para serem convidadas do que nobres disponíveis para realizar a tarefa (o que se tornou a situação normal a partir da expansão dos rituais regionais).
} 
partir do próximo capítulo abordarei as formas como o "exterior" e a alteridade são constitutivos da pessoa do chefe, e que ser parcialmente diferente e afim é o que permite a ele ocupar tal posição. O objetivo deste enfoque na nobreza não é reificar a dicotomia entre "interior" e "exterior", mas mostrar como semelhança e diferença precisam ser ativamente gerados em todos os níveis.

O conteúdo dos depoimentos nos permite reavaliar a centralidade atribuída a algumas das questões tradicionais das etnografias da área (como poder, autoridade, formas de controle, hereditariedade), já que o próprio vocabulário usado pelos anetü revela outros aspectos que eles julgam importantes para definir a chefia. Um dos pontos que considero importantes é a reconsideração da hereditariedade a partir da noção kalapalo de "substituto" (itüpohongo). Vemos que a relação vertical de substituição de um chefe de uma geração por outro está condicionada às relações simétricas entre os vários chefes do grupo local e de todos eles com os chefes estrangeiros. A "hereditariedade" exige uma espécie de mediação extra-corporal, que condiciona a ativação da substituição de consanguíneos à relação com afins potenciais (outros chefes do grupo local e chefes estrangeiros). Isso ajuda a entender a necessária existência de vários chefes em um mesmo grupo local, pois sem essa multiplicidade interna a chefia não se transmite. Como discutirei no capítulo 4, todos os rituais de chefia exigem a participação de pelo menos cinco chefes adultos.

Outro ganho diz respeito à compreensão das ideias kalapalo sobre assimetria e parentesco, ligadas à condição de esteio ou tronco-corpo dos chefes em relação a "suas crianças", algo que escapa às simplificações em português feitas por tradutores (kuge iho, ukugetihü ou katote ihü são sempre traduzidos apenas como "cacique"). Nesse ponto, não só damos um passo para compreender melhor como os Kalapalo entendem a assimetria entre chefes e comuns, como se abre um canal entre a ilha ${ }^{43}$ alto-xinguana e outras paisagens etnográficas sul-americanas (aqui exemplificado pela comparação com os Kanamari, mas certamente há outras possíveis). Há décadas o corpo assumiu um lugar saliente na etnologia

\footnotetext{
${ }^{43}$ Digo "ilha" porque o Alto Xingu, mesmo tendo sido objeto de várias descrições, é mantido relativamente afastado das comparações com outros povos sul-americanos.
} 
das terras baixas, dada sua centralidade para o pensamento indígena (Seeger, DaMatta et al., 1979; Viveiros de Castro, 1979). É comum que o foco no corpo recaia sobre suas formas mais, digamos, "óbvias": o corpo pessoal, sua fabricação, a manipulação de suas partes e substâncias e etc. Mas, pelo que vimos, algumas ideias que teriam "corpo" como apenas uma de suas traduções possíveis podem ter sentidos muito mais amplos, como é o caso da noção de ihü.

Muitos mitos falam sobre as primeiras aldeias-iho de nexos regionais, e a etno-história kalapalo está repleta de eventos que narram como o alcance das identidades coletivas se torna cada vez mais restrito com a criação de novas aldeias por seus chefes. Ao produzir chefes, os Kalapalo produzem esteios/troncos/corpos capazes de agregá-los, e geram as condições para produzir parentes. Todas as pessoas, chefes ou aldeias-iho, que possibilitam processos de identificação e aparentamento instauram relações de assimetria próprias a estes processos, homólogas entre si, mas que se realizam em diferentes escalas. E a cada degrau dessa escala encontramos o mesmo tipo de pessoa-relação: um iho ou ihü, uma forma-chefe responsável tanto pelas identificações em si quanto pelas mudanças de escala. Essa forma-chefe se autorreplica desde a família conjugal até um aglomerado de aldeias, funcionando como um “indigenous integrator and scale-shifter" (Wagner, 1991: 171).

Adiantando uma discussão que ocupará os capítulos 3 e 4, os chefes realizam no plano sociológico algo que, no plano cosmológico, só seres perigosos (sobretudo os maiores predadores, como a onça, a sucuri e o gavião) são capazes de fazer: atrair pessoas para um ponto de vista (no sentido de Viveiros de Castro, 1996; 2002d) específico e mantê-las nele, transformando-as em seus parentes (seus "filhos") e parentes de seus semelhantes. No caso dos chefes, o ponto é atrair as pessoas para um ponto de vista específico não no campo das relações interespécies, mas sim no das relações intra-espécie, um ponto de vista de humanos em relação a outros humanos - uma aldeia e um povo em relação a outros no sistema regional. 


\section{Capítulo 3 - $\mathrm{O}$ encontro com a onça}

Você diz que cuida do seu pessoal, mas você os come (Primo cruzado do gavião, provocando-o por sua condição de chefe)

Nos capítulos anteriores, discutimos como a assimetria entre chefes e comuns é parte de processos de aparentamento que fundamentam a constituição de coletivos em diferentes escalas: na diacronia, povos; e na sincronia, aldeias e aglomerados regionais. Mas como argumentei, antes dos chefes se definirem a priori em relação aos não chefes, eles precisam ser feitos e apresentados como tais perante outros chefes de sua aldeia, mas que não sejam seus parentes muito próximos, e perante os chefes de outros povos. Em ambos os casos, a relação entre aqueles que são feitos chefes e seus pares é marcada pela afinidade potencial: os outros chefes são vistos (ao menos temporariamente) como menos parentes, no primeiro caso, ou como inimigos simbólicos, no segundo. Também já comentei de passagem que, não só entre os Kalapalo, a onça, o maior animal predador do ponto de vista humano, é eleita como uma das figuras ideais para simbolizar sujeitos capazes de instaurar relações assimétricas. Agora é preciso abordar diretamente essa questão, investigando as relações entre chefia, afinidade e predação. Enquanto no capítulo anterior focalizei as relações de paternidade adotiva e cuidados entre chefes e seu povo, neste tratarei do lado inimigo/predador dos chefes. Aprendemos que um anetü (chefe) é, metaforicamente, um tipo de "super pai" para seu povo; agora veremos, na mitologia, o caso de um pai que contradiz seu papel e passa a ser chamado apenas de anetü por seus filhos verdadeiros.

Isso será feito por meio de uma análise de três narrativas que os Kalapalo consideram centrais para o ciclo mítico do egitsü, e que nos servirão a (pelo menos) dois propósitos. Sob um aspecto, esses mitos fornecem várias informações sobre os chefes míticos mais importantes e têm nos símbolos da predação/afinidade potencial e da filiação/consanguinidade fictícia - a onça e algumas árvores, respectivamente - o seu foco central, permitindo-nos entender melhor a correlação entres estes diferentes aspectos da chefia. Sob outro ângulo, eles descrevem modalidades distintas de relação que os gêmeos entretêm com animais, peixes e vegetais, nos ajudando a entender como os humanos se posicionam no mundo e qual a 
conexão do egitsü com a perspectiva humana, realizando a passagem para os próximos capítulos, centrados na descrição do ciclo ritual.

A origem do egitsü faz parte da saga dos gêmeos Taũgi e Aulukumã, composta por uma enorme quantidade de narrativas que tratam da origem das características do mundo tal como conhecido pelos humanos. É verdade que nem tudo o que os Kalapalo conhecem se deve aos gêmeos, mas boa parte do essencial é fruto de sua ação deliberada ou acidentes ocorridos durante suas vidas. Entre seus feitos principais (intencionais ou não), estão a criação da diferença entre humanos, espíritos e animais, a captura do fogo, a alternância entre o dia e a noite, o surgimento das araras vermelhas, dos rios, do urucum, do jenipapo, e, entre muitas outras coisas, a realização de um egitsü que ficou conhecido entre os humanos e deu forma ao ritual. Cada elemento do egitsü tem uma origem diversa, e a forma dada por Taũgi e Aulukumã é apenas uma entre as possíveis.

Boa parte do que os gêmeos fizeram ou do que aconteceu com eles é indispensável para a vida humana, mas o egitsü ocupa um lugar especial neste conjunto de eventos. Ele é um ritual que trata da irreversibilidade da morte de sua mãe, "a primeira pessoa que morreu", e com isso marca o início da vida propriamente humana no mundo. Não que antes os itseke não pudessem morrer, mas além de poderem ressuscitar, na maioria das vezes eles apenas sofriam algum tipo de transformação corporal que não implicava em morte, mas em mudança. A morte humana também é uma transformação corporal, causada pela penetração de substâncias não humanas no corpo (feitiços), mas o que diferencia um caso do outro é que enquanto os espíritos podem se transformar à vontade sem perder sua natureza de itseke (a capacidade de transformação é sua natureza), os humanos, ao sofrerem transformações muito grandes, podem perder sua humanidade. A morte da mãe dos gêmeos marca o início da humanidade tematizando o que caracteriza o mundo que se seguiu àquele dominado pelos itseke - um mundo instaurado pela diferença entre "gente" e "espírito", no qual transformarse sem controle passou a significar, para os primeiros, doença e morte, tendo esta se tornado inevitável e irreversível. 
Assim como em outros rituais alto-xinguanos, quase tudo o que se faz no egitsü já está descrito em seu mito de origem, que fornece algo como um script (Menezes Bastos, 1978; 1990). A ordem de execução de cada ato, a origem de cada prática e cada conjunto de conhecimentos (discursos, rezas, cantos), grande parte disso é minuciosamente descrito na mitologia. Mas nem tudo está contido naquele que é considerado pelos Kalapalo como "o" grande mito de origem do egitsü, pois há outros eventos, às vezes sem a participação dos gêmeos, que também estão na origem de elementos importantes desse ritual, sendo alguns anteriores à homenagem à mãe dos gêmeos, outros posteriores, alguns protagonizados por espíritos, outros por humanos. O egitsü não tem uma origem única, mas é, como o próprio Alto Xingu, um complexo quebra cabeças cujas peças têm origens tão diversas quanto os grupos que compõem o sistema regional.

Há uma dificuldade inerente à análise de mitos de um único povo e, mais ainda, de uma única aldeia, que diz respeito ao alcance das comparações, face à sua importância metodológica ${ }^{1}$. Segundo Lévi-Strauss (2004 [1964]), um dos princípios da análise estrutural de mitos é que nenhuma narrativa pode ser analisada individualmente: a armação, o código e a mensagem presentes em cada mito só se tornam inteligíveis quando se compreende suas transformações em relação a outras variantes, isto é, quando os mitos são relacionados por suas diferenças em um grupo de transformações. É a transformação que nos dá acesso às regras da linguagem mítica e seu sentido, pois é por meio de transformações (inversões, correlações, homologias) que os mitos procedem para criar seus códigos e mensagens. A linguagem da mitologia cria um universo saturado de sentido que, aberto por natureza (abertura explicitada desde sempre na fórmula canônica ${ }^{2}$ ), exige a ampliação do horizonte etnográfico do pesquisador que deseje se aventurar por ele.

Levando isso em consideração, o tratamento que posso dar ao material mítico kalapalo é bastante limitado, pois proceder a uma análise desse tipo exigiria dedicação exclusiva ao tema. Uma saída que me parece razoável é me aproximar dos procedimentos usado por LéviStrauss n’A Gesta de Asdiwal (Lévi-Strauss, 1996 [1973]), no qual a análise não procede por meio de comparações entre mitos e a construção de grupos de transformações, mas se baseia na comparação entre diferentes códigos na mesma sociedade: o código mítico é elucidado

\footnotetext{
${ }^{1}$ Mais do que metodológica, na realidade. Lévi-Strauss (2004 [1964]) afirma que os mitos de uma população são sempre construídos tendo em vista mitos de populações vizinhas dos quais tomaram conhecimento. Nesse sentido, a comparação é um movimento próprio ao pensamento mítico.

${ }^{2}$ Almeida (2008); Lévi-Strauss (2008 [1955]).
} 
quando colocado em relação com os códigos sociológicos, ecológicos e históricos. Esse é um tipo de análise pertinente quando lidamos com um único mito ou um conjunto limitado de mitos, e minha intenção no que se segue é tentar me aproximar das relações entre os códigos mítico, sociológico e ritual.

É impossível apresentar e analisar de forma completa as narrativas ligadas ao egitsü, pois além de serem muitas, nem todas são conhecidas em Aiha (e ainda que eu dispusesse de todas, elas teriam de ser objeto de outra tese). Mas três delas podem ser consideradas como as principais $^{3}$, e são estas que vou explorar a seguir. Elas tratam da origem do demiurgo Kuatüngü, o casamento de suas filhas de madeira com Enitsuẽgü (a onça chefe dos animais terrestres), o nascimento dos gêmeos Taũgi e Aulukumã e a realização do primeiro egitsü no formato atual. Elementos de outras narrativas ligados ao ritual são apresentados em linhas gerais nos momentos oportunos.

\subsection{A família do Ipê Amarelo e o Morcego Pescador}

Desde sempre o mundo fora habitado por uma imensa variedade de pessoas que são, simultaneamente, plantas ou animais, e toda a gente antigamente era assim. A princípio, pareceria possível indagar se tratava-se de pessoas com nomes de plantas e animais, ou de plantas e animais com características de pessoas, mas esta é uma falsa questão, pois não se trata nem de uma coisa, nem de outra: eram seres que, quando se apresentavam sob a forma física de seres humanos, tinham nomes de animais e vegetais e (geralmente) apresentavam índices de sua natureza não humana, mas que também poderiam, a qualquer momento, apresentar corpos animais e mesmo assim continuarem sendo (potencialmente) gente - isso é o que caracteriza os itseke, "espíritos”. Naquela época, o Ipê Amarelo era uma pessoa, assim como o Morcego Pescador, a Onça e todos os itseke, que tinham exatamente a forma de um corpo humano. Contudo, era possível diferenciá-los por algumas características específicas, como a capacidade do Morcego Pescador de adquirir forma de animal para voar e a

\footnotetext{
${ }^{3}$ Elas são consideradas assim pelos Kalapalo, e compõem uma sequência (são ordenadas, tinapisinhü, apesar de haver vários outros mitos entre uma história e outra). Entre o nascimento dos gêmeos e a homenagem para sua mãe estão alguns dos episódios mais importantes da modelagem do mundo - inclusive alguns ocorridos no caminho entre sua aldeia e o local da homenagem -, mas que geralmente são deixados de lado ao se contar a origem do egitsü, por não estarem diretamente ligados a ele.
} 
localização celeste de sua aldeia; o hábito da Onça de caçar e comer outras pessoas; a capacidade da Cobra viajar longas distâncias debaixo da terra, e etc. Enfim, eram todos gente, mas possuíam certas características corporais típicas de espécies de animais que permitiam diferenciá-los, e poderiam efetivamente assumir uma forma e um comportamento animal em diferentes situações. A condição geral dessas pessoas era serem ao mesmo tempo potencialmente gente e animais, e uma ou outra condição poderia ser atualizada, isto é, tornada visível e eficaz, dependendo da situação, da intenção do agente e das relações em que ele estivesse envolvido.

O primeiro mito de que trataremos é o do nascimento do demiurgo Kuatüngü, avô materno dos gêmeos:

\section{Mito 4: A filha do Ipê Amarelo fez $\operatorname{sexo}^{4}$ (Jukuku indisü ikupügü)}

Na terra havia uma aldeia do Povo Árvore ( o otomo), chefiada por um homem-árvore chamado Jukuku$^{5}$, o Ipê Amarelo. Ele era um grande anetü que tinha uma filha que acabara de menstruar e, por isso, deveria entrar na reclusão pubertária. Outro chefe de sua aldeia sugeriu ao seu pessoal que eles construíssem o gabinete de reclusão da filha de Jukuku para que ela também se tornasse chefe. Os outros chefes conduziram o pessoal para buscar madeira e, enquanto isso, Jukuku saiu para buscar o peixe que serviria de pagamento pelo trabalho. Os trabalhadores encontraram grande quantidade da madeira tahaku ${ }^{6}$, que usaram para fazer o gabinete da jovem. Pronto o gabinete, a filha de Jukuku entrou na reclusão, cresceu e engordou bastante, ficando muito bonita. Certa vez, quando saiu para dançar em uma festa, como é costume das reclusas, o Morcego Pescador (Ajua Kuẽgü), a viu e ficou admirado com sua beleza.

Um dia sua mãe pediu que ela fosse tomar banho fora de casa ${ }^{7}$. Enquanto ela tomava banho, o Morcego Pescador passou voando bem rápido perto da moça, indo de um lado para o outro rezando, mas a garota não percebeu nada de mais - pensou que fosse apenas um morcego. Algum tempo depois ela ficou sem menstruar, e não entendeu o que poderia ter acontecido,

\footnotetext{
${ }^{4}$ Narrada por Waja, em 29 de junho de 2010.

${ }^{5}$ Agostinho (2009 [1974]: 173), falando dos Kamayurá, afirma que se trataria do jatobá.

${ }^{6}$ Madeira não identificada por mim. A tradução de seu nome (tahaku) é "arco", mas apesar disso ela não é usada para a confecção dessa arma. Ela é a melhor lenha da região, e também é usada na construção de estruturas para nobres, como a casa ou túmulo de um chefe, a casa dos homens ou, como nesse mito, o gabinete de reclusão da filha de um chefe. As qualidades valorizadas para tanto são sua densidade e a retidão de seu tronco.

${ }^{7}$ Enquanto de fato é costume das reclusas tomarem banho dentro de seu gabinete de reclusão, lavando-se com o auxílio de cuias.
} 
pois ela não havia feito sexo com ninguém - ainda era virgem. Sua mãe ficou preocupada, e as pessoas começaram a comentar que a filha de Jukuku estaria grávida. Sua mãe lhe perguntava insistentemente com quem ela havia feito sexo, mas a jovem não sabia o que responder. Sua barriga cresceu e seu pai, envergonhado, disse que as pessoas poderiam desfazer seu gabinete de reclusão ${ }^{8}$. De tanta vergonha, durante a gravidez a jovem nunca mais saiu de casa para nada.

Ela ficou grávida mais tempo do que o normal, e o bebê atrasou um mês para nascer. Ela deu à luz um menino, Kuatüngü, que não chorou quando nasceu. Ele também não se movia, mas todos sabiam que não estava morto, pois seus olhos ficavam abertos. Jukuku estava triste por seu neto, e queria saber quem era o pai dele, para que se casasse com sua filha. Por isso Jukuku resolveu dar uma festa, para ver se a criança daria algum sinal de vida caso reconhecesse seu pai. Jukuku enviou mensageiros para todas as aldeias na terra ${ }^{9}$ e organizou diversas festas seguidas, mas de nada adiantou. Quando os convidados chegavam, o menino não tinha reação alguma, permanecendo imóvel.

Kuatüngü já havia crescido um pouco, tinha cerca de dois meses, e Jukuku estava muito triste por seu neto. Foi então que ele imaginou que um itseke deveria ter engravidado sua filha e resolveu convidar um povo do céu para uma festa. Seus mensageiros foram para o céu e convidaram o Morcego Pescador (que era chefe em sua aldeia) e seu pessoal. Os convidados chegaram ao entardecer do dia seguinte. Quando ainda estavam bem longe da aldeia e gritaram para avisar sua chegada, Kuatüngü mexeu seus olhos para olhar na direção de onde vinha o barulho, e todos se surpreenderam. Quando o povo do céu estava chegando perto da aldeia, eles gritaram novamente e Kuatüngü ficou contente, se mexendo muito. Àquela altura Jukuku já imaginava que o pai de seu neto era o chefe Morcego Pescador, e sua filha se lembrou do morcego que ficara voando ao seu redor enquanto tomava banho certa noite. Quando os convidados entraram na aldeia à noite para buscar o fogo que iluminaria seus acampamentos, Kuatüngü ficou muito alegre, se mexendo e rindo bastante. No dia seguinte, pela manhã, os convidados entraram para lutar, e Kuatüngü estava tão alegre que mesmo com apenas dois meses de idade ele já quase andava. Terminada a luta, Jukuku perguntou quem havia engravidado sua filha. Morcego Pescador admitiu o feito, e foram levar sua rede para a casa de Jukuku para que ele se casasse com a jovem.

\footnotetext{
${ }^{8}$ As jovens não devem fazer sexo durante a reclusão, e engravidar sem um marido é uma grande vergonha para uma mulher e sua família (principalmente a filha de um chefe, que idealmente deve se tornar noiva de alguém). ${ }^{9}$ Para cada tipo de ser, o mundo se divide em terra (lugar onde habitam), céu e fundo das águas. No caso das árvores, há uma semelhança com o ponto de vista humano, pois plantas e humanos veem a mesma coisa como "terra" (diferentemente dos peixes, por exemplo, que veem a superfície da água como o céu, o leito dos rios como terra e têm, em baixo d'água, seus próprios rios).
} 
Ele havia trazido várias plumárias como pagamento para seus sogros e demais parentes de Jukuku, mas, como eles eram muitos, seus objetos não foram suficientes. Dos parentes de Jukuku, os mais conhecidos por terem recebido plumárias do Morcego são Agengi (outro Ipê Amarelo $^{10}$, esposa de Jukuku), Ahisu (uma árvore alta e de flores roxo-avermelhadas ${ }^{11}$ ), Sike (árvore alta de flores vermelhas), Kagate (árvore de flores amarelas, não muito alta) e Anakuãbungu (muito alta e cujas flores, dizem, são tão vermelhas quanto penas de tucano ${ }^{12}$ ). Quando suas plumárias coloridas já haviam acabado, ele deu uma plumária branca, de penas de garça (ugisu), de pouco valor, para Agi (uma árvore bem baixa), que aceitou (e por isso tem flores brancas). Sua esposa o lembrou que ele estava se esquecendo de um "irmão" de Jukuku, o Tracajá. O Morcego Pescador não tinha mais nada para dar, e resolveu oferecer um banco de chefe (ugi), uma coisa sem valor. A mãe da jovem o entregou para o Tracajá, dizendo que ali estava o pagamento de seu sobrinho uterino/genro - mas o narrador observa que o Morcego Pescador não era sobrinho/genro de verdade do Tracajá, que a mãe da moça estava mentindo, pois sua relação de germanidade com Jukuku não era real. Por isso na época da seca o tracajá fica sentado nos troncos da beira dos rios, que são seus bancos.

Este é um dos mitos alto-xinguanos mais reproduzidos na literatura, e em todas as variantes há um núcleo estável: trata-se sempre da procriação não sexual de um homemmorcego com uma mulher-árvore, provocada magicamente pelo primeiro. Em algumas versões, a filha do chefe das árvores é descrita como uma mulher-jatobá, ou menciona-se que se trataria de uma "madeira preta", mas nenhum dos dois corresponde ao caso Kalapalo. Também não encontrei em outras variantes o tema da criança imóvel, que não está nem morta (pois mantém seus olhos abertos) nem viva (não se move nem faz barulho), a não ser em uma versão registrada por Basso (1987b) entre os próprios Kalapalo.

Basso apresenta uma versão contada por um grande mestre de histórias de Aiha (Ulutsi, avô materno do atual segundo cacique), já falecido, muito semelhante à que apresentei aqui e que difere apenas em alguns detalhes. Ela não contém, por exemplo, o episódio da decisão pela construção do gabinete de reclusão da jovem para que ela se tornasse uma chefe. Em compensação, há uma riqueza bem maior de paralelismos, pois o ato de enviar

\footnotetext{
${ }^{10}$ É uma variedade diferente de ipê amarelo. Enquanto jukuku é mais alto, ocorre em matas mais fechadas e em pouca quantidade, agengi é mais baixo, ocorre nos campos e em maior quantidade.

${ }^{11}$ De longe pode parecer um ipê roxo, mas suas flores são bem diferentes em tamanho e forma. Talvez se trate de uma variedade de jacarandá (Dalbergia sp.), árvore frequentemente confundida com o ipê.

${ }^{12}$ Essa árvore não existe na região de Aiha.
} 
mensageiros e convidar estrangeiros é repetido várias vezes (característica de uma história bem contada). Outro detalhe importante da versão de Basso é a forma como se espera que Kuatüngü responda aos estrangeiros, andando para pegar um arco oferecido por eles. $\mathrm{Na}$ versão que apresento aqui o tema da oferta de armas ao bebê está ausente, e as reações de Kuatüngü são condicionadas não por objetos, mas pela própria aproximação dos convidados com gritos e à sua presença no pátio central, durante a noite para buscar fogo e durante o dia para a luta. Por fim, a versão de Basso marca a necessidade da criança andar, que não é o ponto aqui (apesar de ser também o ponto na versão aweti de Figueiredo, 2010). Nesta, a criança não se mexe de forma alguma, e quando ela mexe seus olhos em direção aos gritos do pessoal do Morcego Pescador, já é um sucesso. No limite da alegria, durante a luta, Kuatüngü quase anda, mas não chega a tanto.

Esta história é central porque Kuatüngü é um itseke especial para os humanos, pois é quem se tornará avô materno de Taũgi (Sol) e Aulukumã (Lua). Todos os itseke são tratados como avós dos humanos por sua antiguidade, mas Kuatüngü é uma referência diferente, pois os Kalapalo dizem que quando fazem egitsü eles "se lembram" dele e de sua família materna (ele, sua mãe e Jukuku). O mito mobiliza uma oposição entre terra e céu, que coincide com outra, entre humanos e itseke. É interessante que após fazer várias festas com os povos terrestres Jukuku conclui que o pai de seu neto só poderia ser um itseke - uma perspectiva que só é possível se o Povo Árvore vir a si mesmo e aos outros povos sobre a terra como "gente", da mesma forma que, no futuro, os verdadeiros humanos veriam. Há indícios de que os convidados terrestres são aldeias de outras árvores, pois em outra variante aweti, na qual se convida apenas um povo, este é o "pessoal do Pequi" (Agostinho, 2009 [1974]: 153). Isso é muito curioso, pois os itseke sempre se veem uns aos outros como "gente ${ }^{13}$ ", não havendo ninguém que vejam como "espíritos" em relação a si. Há uma aproximação analógica entre o ponto de vista propriamente humano e aquele das árvores, pois o povo de Jukuku faz uma diferença (gente/itseke) que só viria a fazer sentido, posteriormente, para os humanos.

Esta identificação não é fortuita, pois as árvores são símbolos recorrentes da condição humana (Rival, 2001 [1998]). Entre os Kalapalo, como já vimos, os troncos servem como símbolos tanto para a consanguinidade e a continuidade geracional quanto para as relações de assimetria entre chefes e comuns que as condicionam. Entre os Panará, por exemplo, as árvores simbolizam a dimensão vertical da vida social, "em que se situam os processos de

\footnotetext{
${ }^{13}$ Menos suas eventuais presas, as quais veem como animais.
} 
crescimento, maturação, e a passagem diária e anual do tempo" (Schwartzman, 1988: 167), e que por ser um objeto estático é visto como análogo da identidade clânica (Coelho de Souza, 2002: 239). Entre os Huaorani (Rival, 1993), o ciclo de vida de algumas árvores é um importante símbolo da vida intra-aldeã e da consanguidade. Segundo Rival (ibid: 636), "the Huaorani's conceptualization of their society is informed by their perceptions of differential growth processes in their forest environment (...)”. O lento crescimento da pupunheira (Bactris gasipaes), "which grow and endure on a time scale commensurate with the passage of human generations, parallels that of huaomoni groups [grupos locais autônomos]" (ibid: $648)$.

Em uma análise mais geral sobre o simbolismo ligado a árvores, Rival (2001 [1998]) argumenta que "trees and plants make perfect natural models for genealogical connections" (ibid: 11), citando exemplos dos Beti (Calame-Griaule, 1969) e Ndembu (Turner, 1967), na África, e dos japoneses (Knight, 2001 [1998]). Ainda, "tree symbols materialize the living process at three levels: that of individuals, that of communities and social groups, and that of life itself" (Rival, op. cit.: 24). Em suma, para diversos povos a anatomia de uma árvore "é boa para pensar" as relações de continuidade temporal, permanência, semelhança e parentesco. É portanto compreensível porque o mito kalapalo faz questão de afirmar, entre seres que os Kalapalo consideram todos como itseke, uma diferença entre "Povo Árvore/gente" e "espíritos", associando os primeiros ao ponto de vista que os verdadeiros humanos viriam a ter.

Mas árvores são imóveis e, não por acaso, crescimento e mobilidade são dois dos temas centrais na narrativa. Kuatüngü, de um lado, pertence a um Povo Árvore cujo ponto de vista é análogo ao dos humanos, mas de certa forma não tinha vida, por ser imóvel. Já o Morcego Pescador, com seu voo rápido e que muda constantemente de direção, simboliza uma mobilidade exagerada, e tem uma relação próxima com as árvores, pois a maioria vive nelas $^{14}$. O morcego da história, especificamente, é conhecido como morcego pescador (provavelmente Noctilio leporinus), uma espécie que vive no oco de grandes árvores e se alimenta de pequenos peixes (além de insetos, pequenos caranguejos e escorpiões ${ }^{15}$ ). Provavelmente vem daí a associação entre o seu aparecimento e o banho noturno da jovem,

\footnotetext{
${ }^{14}$ Há espécies de morcego no cerrado que vivem em cavernas, mas não sei se existe alguma delas no Alto Xingu (sobretudo pela raridade de abrigos rochosos).

15 Brooke, 1994.
} 
pois, sendo notívago, o morcego pescador ronda a água à noite. Na nossa versão, a jovem toma banho fora de casa com uma cuia, e na versão de Basso ela se banha, também à noite, na lagoa - local de "caça" dessa espécie de morcego. Ambas as versões associam o aparecimento do Morcego Pescador à presença da jovem perto da água, descrevendo-o como um ser ao mesmo tempo celeste (pois sua aldeia é no céu) e aquático (pois ronda a água em busca de suas presas: pequenos peixes ou jovens reclusas ${ }^{16} \ldots$ ), mas com uma relação especial com as árvores.

É interessante que ele seja carnívoro e um dos maiores morcegos da região, pois assim ele apresenta duas características dos chefes dos animais: são quase todos predadores, e os que não são, são os maiores exemplares de suas espécies. Além disso, o nome desta espécie, ajua, é parte do nome de outro espírito, chamado Ajuaga, uma onça voadora com asas de morcego que vive no fundo dos rios. O próprio chefe das onças, Enitsuẽgü, é descrito dessa maneira, apesar de não se confundir com Ajuaga (Enitsuẽgü é na verdade seu arquétipo, e Ajuaga uma versão enfraquecida daquela onça mítica).

Lévi-Strauss (2004 [1964]: 149-151) nota que em muitos mitos jê os morcegos são vistos como seres capazes de produzir aberturas corporais (fazendo as pessoas rirem ou abrindo-lhes o crânio). Pode-se pensar que o Morcego Pescador promoveu uma dupla abertura no corpo da jovem: engravidando-a sem fazer sexo e fazendo com que ela parisse uma criança enquanto ainda era virgem. Ele não produziu apenas uma abertura corporal, mas também uma "abertura social”, estabelecendo as condições para uma relação de aliança entre dois povos muito diferentes, um povo terrestre e um povo celeste. Os Kalapalo frequentemente associam os seres celestes a diferentes aspectos da afinidade. O hagaka, ritual de confronto entre primos cruzados distantes, é dito ser "festa de passarinho", pois sua origem é celeste e os principais personagens do ritual são pássaros. As aves também são os inimigos tradicionais dos mortos, que os enfrentam em grandes batalhas durante os eclipses, e é do céu que vieram as primeiras esposas de Taũgi e Aulukumã, filhas do chefe Urubu Rei ${ }^{17}$. Além disso, os pássaros são o modelo do cativo/animal doméstico dos Kalapalo, pois, além de constituírem a grande maioria de animais nas casas, qualquer outro animal que se crie (macacos, cachorros,

\footnotetext{
${ }^{16}$ Há uma correlação explícita entre morcegos e sedução (mas não ajua, e sim atsiji, um morcego herbívoro). Na época das cheias, enquanto o morcego come pequenas frutas nas árvores, ele acaba derrubando algumas, que caem na água e são comidas pelos matrinchãs (Brycon $s p$.), e por isso se diz que esse peixe se sente atraído pelo morcego. Quando alguém dá presentes supostamente desinteressados (seja homem ou mulher, mas sobretudo os homens) para alguém do sexo oposto, os Kalapalo brincam chamando a pessoa de "morcego".

${ }^{17}$ Sarcoramphus papa.
} 
gatos, coelhos) é chamado de tolo - pássaro. Há, claro, um ponto crucial a se considerar: o morcego não é um pássaro, apesar de ser pensado como uma criatura celeste. Para os humanos, os pássaros são o modelo ao mesmo tempo do parente que oscila entre a inimizade e a afinidade real (o primo cruzado), do inimigo (os pássaros em relação aos mortos) e do cativo/animal de estimação (pássaros em relação aos vivos), apresentando algumas das principais características da afinidade potencial ameríndia (Fausto, 1999; Viveiros de Castro, 2002c). O Morcego Pescador, celeste, também acaba funcionando como uma espécie de afim potencial das árvores.

Esta história também nos ajuda a entender um pouco do que está por trás da classificação de certas árvores como anetü. Jukuku é uma variedade de ipê amarelo ${ }^{18}$, cuja madeira dura e bonita era antigamente utilizada na confecção dos bancos dos chefes. O ahisu (de flores roxo-avermelhadas), que pode ficar muito alto, também é uma madeira muito dura e resistente, e é a principal madeira usada nos postes de sustentação das casas. As belas flores destas árvores são as plumárias que receberam do Morcego Pescador como pagamento, e que utilizam na época dos rituais regionais - de julho a setembro, sua época de floração e período no qual as árvores "estão alegres", pois também estão fazendo suas festas. O ipê amarelo é o primeiro a florir, seguido por ahisu, agi (de flores brancas) e depois os outros. Onde ocorrem, estas árvores se destacam da vegetação circundante tanto por sua altura quanto por sua floração exuberante, que coincide com o período dos rituais regionais. Muitas vezes estas árvores não ocorrem em grande quantidade em uma mesma área, produzindo um belo contraste entre elas e a vegetação circundante (que nessa época está mais "apagada" em função da seca). A foto de um jukuku abaixo ilustra isso muito bem:

\footnotetext{
${ }^{18}$ Da espécie Tabebuia, pertencente à família das Bignoniáceas, da qual também faz parte o jacarandá.
} 


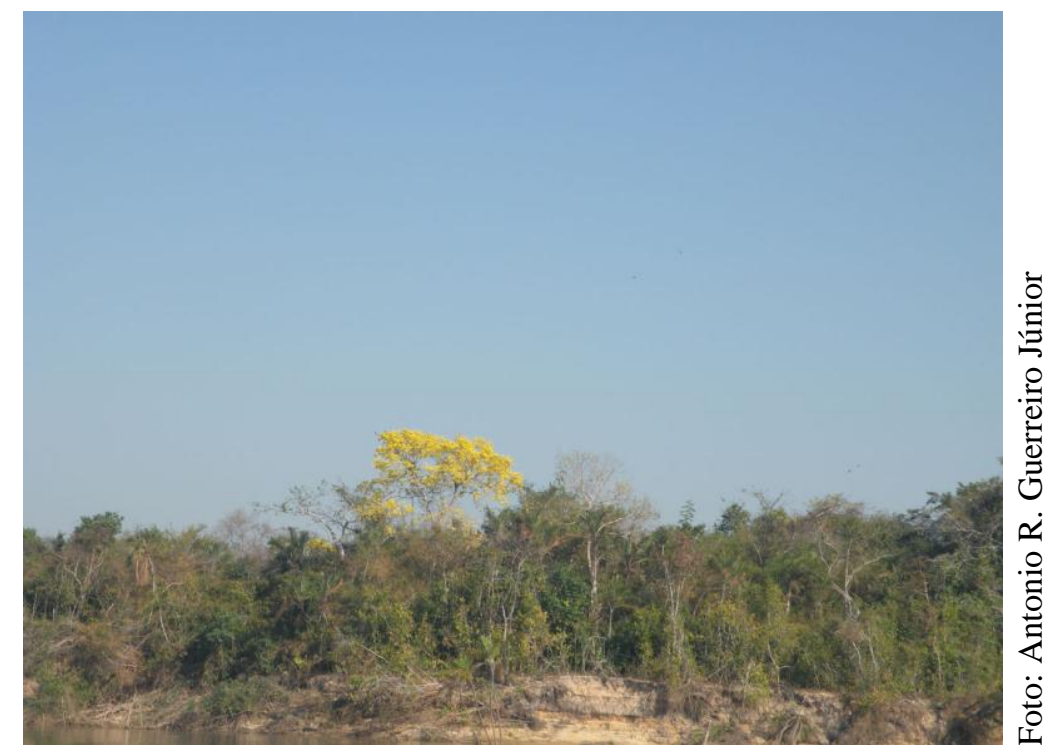

Figura 3.1: um exemplar de jukuku em meio ao "seu pessoal”, às margens do Culuene.

Desnecessário explicar porque ele é um dos chefes das árvores.

Dada a impressão causada pela saliência sensível dos ipês, não é preciso muito para entender porque este é um dos "chefes das árvores": especialmente grande e belo em meio ao "seu pessoal" (lembremos do comentário sobre a lua cheia na epígrafe do capítulo 2: "Ela está chefiando seu pessoal na aldeia de outro povo. Veja como ela está grande e bonita”). Há outras duas características associadas aos ipês (e também, como veremos, à uẽgühi - árvore de que são feitas as efígies), que são a dureza e a durabilidade. O ipê, como se sabe, é uma das madeiras mais duras e resistentes encontradas no cerrado (Jankowsky, Chimelo et al., 1990). São árvores que, segundo os Kalapalo, duram muito tempo e, de fato, o ipê é das árvores mais longevas da região, podendo viver saudavelmente por séculos (Longhi, 1995). A uẽgühi também é muito dura, mas os Kalapalo focalizam sua resistência de outra forma: diferentemente dos ipês, que vivem muito, a uẽgühi é considerada resistente por não apodrecer na água (seu destino após o egitsï). Também é importante notar outra diferença entre os ipês e a uẽgühi: os primeiros são os chefes do cerrado, enquanto a uẽgühi é o senhor da mata alta. De forma geral, grandeza, beleza, dureza e durabilidade são as principais características dos chefes das árvores.

O Tracajá ocupa um lugar complicado nesta trama, e não consigo imaginar porque ele seria tratado como irmão dos chefes das árvores. O próprio mito reconhece que há algo estranho nessa relação, pois o narrador nota que o Morcego Pescador não seria seu genro de 
verdade. Mas é interessante que o Tracajá tenha recebido um banco, feito necessariamente de uma árvore (e, idealmente, feito de jukuku!), um importante índice de chefia ${ }^{19}$ (apesar de ser considerado sem valor como pagamento para os afins). O que vemos como troncos nas margens dos rios são na verdade os bancos dos tracajás, e é por isso que, a partir do final de julho, é possível vê-los sentados em troncos ao longo do rio. Mas há uma semelhança que Jukuku e seus irmãos guardam com o Tracajá. O período de julho a setembro, quando utilizam seus presentes (flores e banco), é justamente o período de reprodução e maior visibilidade de ambos - as árvores têm flores que serão polinizadas, e o tracajá está pondo seus ovos (época do ano em que ele é mais visível ao longo dos rios). Kuatüngü começa a viver de fato (e digo isso dessa forma porque até o reconhecimento de seu pai ele não estava exatamente vivo) no período de reprodução de algumas das espécies de árvores mais exuberantes do cerrado alto-xinguano, que se destacam por seu tamanho e beleza, e do tracajá, cuja carne e ovos são muito apreciados e procurados nessa mesma época, e cuja desova marca o início da época do egitsü. O período da seca e dos rituais regionais, isoã, é talvez o principal marco do calendário anual kalapalo. É nessa época que vive o avô dos gêmeos, é quando se fazem os rituais regionais e é usado como medida de tempo (um ano é isoandühügü, "uma estação seca passada"; hoje, quando se pergunta a idade de alguém, pergunta-se "quantas foram suas estações secas", ũa eisoandühügü?"”).

Um dos principais personagens da mitologia kalapalo é então o resultado da conjunção de uma mulher terrestre, análoga aos humanos (por seu lugar no cosmos e pela distinção que seu povo faz entre eles próprios e itseke) e virtualmente inerte (por sua condição arbórea), com um ser celeste hiper móvel (mas que não é um pássaro). Esta conjunção é transformada em afinidade, mas é importante notar a ausência do sexo nesta relação. Se a mãe de Kuatüngü era uma "mãe sem sexo", a mãe dos gêmeos e suas irmãs são o inverso, pois são o suprassumo da beleza feminina, despertam o desejo de todos e fazem sexo com uma série de animais que encontram no caminho até a aldeia de seu noivo. A mitologia narra como os ancestrais da humanidade vão sendo construídos a partir da combinação de consanguinidade/imobilidade e afinidade/mobilidade, e como o sexo (figurado no primeiro caso, real no segundo) efetua uma mediação entre as duas séries, dando início à formação,

\footnotetext{
${ }^{19}$ Na versão de Basso (1987b), o Tracajá não é um irmão de Jukuku, mas é, curiosamente, um animal alado cujas penas o Morcego Pescador tirou e fez os presentes para seus sogros, e de cujo casco teria feito um banco. Basso explica esta passagem dizendo que os Kalapalo consideram que, há muito tempo, os tracajás eram criaturas dotadas de penas, mas não disponho de informações sobre isso.
} 
como diz Basso (1987b), de um pedigree que dará aos humanos as suas características fundamentais.

Kuatüngü se tornou um itseke muito poderoso, capaz de fazer tudo o que quer. Como seu avô e seu pai eram anetü, e sua mãe uma itankgo, Kuatüngü também se tornou um grande chefe. De sua vida quase nada se sabe a não ser a forma como foi concebido e o episódio em que ofereceu suas filhas ao chefe-Onça (os Kamayurá têm um mito sobre a origem de suas primeiras filhas ${ }^{20}$ ). Ele aparece em outras narrativas, mas que não são exatamente sobre ele ou são sobre Taũgi e Aulukumã, ou sobre outros de seus muitos "netos" (cujas origens também são desconhecidas). Ele é um grande dono de rezas (kehege oto), fórmulas mágicas semimusicais capazes de produzir efeitos sobre as coisas e as pessoas (Franchetto, 1986; Mehinaku, 2010: 108-110). Basso (1987b) nota que a presença de Kuatüngü costuma ser tranquilizante nas narrativas, oferecendo auxílio e conforto a seus netos. Isto é parcialmente verdade, pois apesar dos Kalapalo verem Kuatüngü como uma pessoa boa e um grande chefe, eles também dizem que ele era temido pelos outros itseke por ser um grande feiticeiro.

Ele foi o inventor de um procedimento de criação de pessoas a partir de toras de madeira, e, segundo a mitologia kamayurá, há muito tempo seu método podia ser utilizado para ressuscitar os mortos ${ }^{21}$. Foi por meio deste método de criação de pessoas que Kuatüngü fez as mulheres que ofereceu à Onça, o que foi reproduzido no primeiro egitsü e agora é repetido no ritual.

\subsection{As mulheres mais lindas do mundo}

O mito das mulheres de madeira talvez seja o mais descrito na literatura xinguana, e diversos de seus componentes estão presentes de forma esparsa em mitos de outros povos sulamericanos (Lévi-Strauss, 2004 [1967]; 2004 [1964]; 2006 [1968]; 2009 [1971]). Considerando versões de diferentes povos ou variantes kalapalo, as diferenças do corpo principal da narrativa são, no geral, muito pequenas. Estas variações serão abordadas ao longo

\footnotetext{
${ }^{20}$ Ele nunca se casou, e teria concebido suas primeiras filhas copulando com um cupinzeiro apenas para que elas o ajudassem com o preparo de comida (Agostinho, 2009 [1974]).

${ }^{21}$ Para os Trumai, que não praticam o Quarup, este método ainda é muito perigoso e eficaz. Dizem que, em um dos poucos Quarup dos quais os Trumai participaram como convidados, eles se assustaram por achar que as efígies tinham ganhado vida, e desde então não aceitaram mais convites para estes eventos (à exceção dos rituais realizados para os irmãos Villas Boas).
} 
do texto, mas pode-se delinear uma sequencia bastante regular reproduzida em todas as variantes: 1) Kuatüngü vai buscar algum tipo de fibra na mata e encontra Enitsuẽgü caçando com seu pessoal; 2) em troca de sua vida, o demiurgo chama Enitsuẽgü pelo termo para

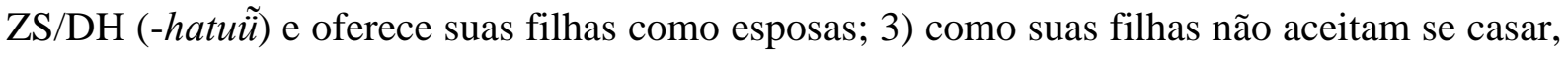
ele fabrica mulheres de madeira para cumprir sua promessa, uma das quais dará à luz os gêmeos Taũgi e Aulukumã e será mortalmente ferida por sua sogra-onça; 4) os gêmeos descobrem o que aconteceu com sua mãe e iniciam uma guerra contra os espíritos na qual criam os humanos (índios e não índios). Mas vamos ao mito ${ }^{22}$. Como a narrativa é muito longa, dividi o mito em cenas, que compreendem grandes momentos da história.

\section{Mito 5: O aparecimento de Taũgi (Taũgi otsogitsügü)}

\section{Cena 1: o encontro com o Onça e a fabricação das anhipe ("The Made Ones ${ }^{23 \text { ") }}$}

Kuatüngü vivia na aldeia Inhatasa, perto do rio Curisevo. Um dia, disse para sua mulher que iria até Iugataha, um lugar próximo ao rio Culuene, buscar fibra de tucum para fazer uma rede de pesca. Enquanto Kuatüngü pegava tucum, um grupo de onças que caçava gente se aproximou. Elas vinham da aldeia Haukugu, e seu chefe era Enitsuẽgü. Percebendo a aproximação das onças, Kuatüngü se escondeu, mas as onças o viram e o cercaram. Enitsuẽgü se adiantou e parou bem perto de Kuatüngü, enquanto as outras se mantiveram longe. Quando o chefe das onças se aproximou mais, Kuatüngü, com muito medo, para evitar ser morto lhe disse:

- Meu sobrinho, não me mate! Eu tenho duas filhas, duas de suas primas, eu as enviarei para se tornarem suas esposas.

Enitsuẽgü aceitou, e disse que arremessaria Kuatüngü de volta para sua aldeia com seu arco especial $\left(\right.$ majahi $\left.^{24}\right)$. Quando chegou em sua casa, Kuatüngü chorava de medo e tristeza. No dia seguinte, ele acordou suas três filhas e contou que havia prometido duas delas para seu primo

\footnotetext{
${ }^{22} \mathrm{O}$ resumo que apresento aqui foi feito a partir de várias versões do mito, mas se baseia principalmente em duas gravações em áudio com o mestre de histórias Ageu, transcritas em karib e traduzidas para o português. A transcrição e tradução de uma versão desta narrativa, gravada por Marina Cardoso, foi feita por Jeika Kalapalo e posteriormente revisada por mim em campo com a ajuda de Ugise Kalapalo. Outra versão, registrada por mim, foi transcrita e traduzida com a ajuda de Ugise e Hüge Hüti "Orlandinho" Kalapalo.

23 Basso, 1987: 24.

${ }^{24} \mathrm{O}$ arco dos chefes, cuja confecção é especialidade dos Wauja e Kamayurá.
} 
Enitsuẽgü em troca de sua vida, e lhes pediu que fossem para a aldeia de seu noivo. "Não vamos, não vamos nos casar com ele", disseram elas, o que entristeceu Kuatüngü. Pensando em como resolveria a situação, ele se lembrou de sua mãe e seu avô materno (que eram árvores), pegou seu machado e junto com seus irmãos Ahinhuka ${ }^{25}$, Atuta (Aranha Caranguejeira ${ }^{26}$ ), Atsiji (Morcego) e Nahangi (Abelha Jatai ${ }^{27}$ ) começou a esculpir mulheres em toras de madeira. Primeiro Kuatüngü derrubou as árvores uãgu e enguhe kuẽgü (não identificadas) para tentar transformá-las em mulheres, mas ficaram mudas. Seus cabelos eram feitos de fibra de abacaxi, quase brancos, e como não eram mulheres de verdade, Kuatüngü não gostou do resultado e resolveu tentar outras madeiras, chamadas hata (não identificada) e uẽgühi (Humiria balsamifera var. floribunda ${ }^{28}$ ).

Ele as fez junto com seus irmãos. Primeiro amarraram suas coxas com fibra de abacaxi, e depois Kuatüngü fez seus dentes com uma pedra preta chamada kugugi ${ }^{29}$. Pediu que as mulheres sorrissem, mas achou muito feio e tirou seus dentes. Depois os fez com sementes de mangaba, o que os deixou bem brancos e bonitos, mas também perecíveis (e por isso os dentes dos humanos estragam). Em seguida, ele fez seu cabelo com fibra de abacaxi e pintou com fuligem para ficar preto, mas quando elas tomaram banho o carvão saiu. Kuatüngü mudou de ideia e resolveu buscar cabelos de verdade com a Hiper Gente (Kuge Kuẽgü), um espírito feminino que vive na água e é a dona do cabelo (pois tem cabelos bem pretos, lisos e longos), o que as deixou lindas. Kuatüngü foi atrás de plantas com as quais pudesse fazer $u l u r i^{30}$ para as mulheres. Primeiro ele foi conversar com o Embira (Hangite Kagahügü), que não concordou: "Eu sou um lutador e não posso ir para junto das vaginas das suas filhas, senão ficarei fraco", disse ele. Em seguida, Kuatüngü pediu à planta Etuĩ, que aceitou. Depois ele foi conversar com a árvore Igigi (árvore não identificada que ocorre na beira de rios) e com o Jatobá Gigante (Uagitsuẽgü, que fica na mata alta), que também aceitaram; depois conversou com Agiti Untukugu. Após isso foi até Hihitse, um pequeno pássaro de asas bem finas que sabe fazer uluri, e até outro pássaro, irmão de Hihitse, mas cujas asas são um pouco mais

\footnotetext{
${ }^{25} \mathrm{O}$ único que não é um animal.

${ }^{26}$ Aracnídeo da família Theraphosidae.

${ }^{27}$ Tetragonista Angustula.

${ }^{28}$ A espécie Humiria balsamifera é popularmente conhecida no Brasil como Umiri, e é abundante na região guianense. Ela também é conhecida como Tauroniro ou Oloroso, na Venezuela. Sua madeira é muito densa e durável, valorizada por sua resistência a fungos e cupins.

${ }^{29}$ A mesma usada antigamente para cortar e furar as conchas de caracol usadas na confecção de cintos e colares. Von den Steinen (1940: 664) identificou esta pedra como quartzo.

${ }^{30}$ Vestimenta das mulheres alto-xinguanas; etuĩ, em kalapalo. Costumava ser usada no cotidiano, mas hoje é usada apenas durante os rituais. Consiste em uma pequena peça triangular, feita da entrecasca de uma espécie de palmeira, colocada sobre o púbis. A peça é presa em um cinto de fios de buriti que contornam os quadris com seu vértice direcionado para baixo, do qual pende um fio que perpassa a região perineal da mulher e junta-se à parte de trás do cinto, sobressaindo uma ponta.
} 
grossas. Os dois passarinhos fabricaram os uluris, e cada um os fez como sua asa, mais fino ou mais grosso. Por fim, Kuatüngü as levou para perderem sua virgindade. A Anta tentou fazer sexo com as mulheres, mas não conseguiu e machucou suas vaginas; em seguida Kuatüngü as levou para a planta Tihigu (uma espécie de planta aérea ${ }^{31}$ ), que foi o primeiro fazer sexo com elas (pois ele tem um fruto cuja ponta é bem fina, e por isso conseguiu furá-las).

Kuatüngü e seus irmãos foram buscar peixe em um lago para as mulheres comerem ${ }^{32}$. À noite, Kuatüngü e Ahinhuka dormiam em redes, mas os outros dormiam como animais. O Morcego dormia pendurado em uma árvore; a Abelha Jataí dormia dentro de um tronco; a Aranha Caranguejeira dormia em sua teia. Lá mesmo, perto do lago, assaram os peixes e os trouxeram de volta. No caminho, desceram até uma praia e viram que Hikuanga (um molusco de água doce) estava parindo um menino, chamado Janama. Quando Hikuanga viu os pescadores, ela correu para a água e deixou seu filho Janama na praia. Os pescadores o viram chorando e rolando na terra, o pegaram e resolveram levá-lo para sua aldeia e criá-lo como um neto, que se tornou o primo cruzado $^{33}$ mais velho de Taũgi e Aulukumã. Quando chegaram em casa, deram peixe para as mulheres feitas de madeira.

O primeiro episódio do mito é o do célebre encontro entre o demiurgo e o chefe dos animais terrestres, Enitsuẽgü. Os Kalapalo têm duas interpretações etimológicas para seu nome: uma delas diz que ele teria se originado de ngene tsuẽgü, "animal terrestre diferente, gigante, distante, perigoso"; outra diz que o Eni- de seu nome viria de "inimigo" (como, por exemplo, em u-eni-sü, 1-inimigo-REL, "meu inimigo"), produzindo assim, com o acréscimo de tsuẽgü, a ideia de "inimigo diferente, gigante, distante, perigoso". No último caso, há uma clara correlação entre diferença e inimizade; mas ela também está presente no primeiro, pois dentre os animais terrestres a onça é considerada o primo cruzado dos humanos, porque "brigam sempre que se encontram". Independentemente da etimologia de seu nome, o chefe das onças ocupa a posição de antípoda arquetípico dos humanos por sua condição de animal, inimigo e afim. Este mito é muito semelhante ao mito bororo sobre o nascimento dos gêmeos

\footnotetext{
${ }^{31}$ Isto é, uma planta epífita, que vive sobre outras plantas.

${ }^{32}$ Depois da primeira menstruação, as mulheres não devem comer peixe, pois podem adoecer. Algum tempo após a menarca, a jovem deve ser "perfumada" com cheiro de peixe assado e seu pai pode pescar para que ela volte à sua dieta normal (sobre o processo, ver Figueiredo, 2010). Comer peixe depois do período de abstinência que se segue à menarca marca o fim do estado de liminaridade da recém-reclusa, que muda de nome e se torna mulher.

${ }^{33}$ Sua identificação como primo cruzado não está relacionada a nenhuma relação genealógica cruzada, e não sei dizer o motivo pelo qual ele se tornou primo cruzado dos gêmeos ao invés de "irmão" (para tanto seria preciso levantar e analisar o conjunto de mitos de Janama, dos quais não disponho).
} 
Bakororo e Ituboré, no qual um homem que está na mata, ao ser acuado pelo jaguar, oferece a ele uma esposa em troca de sua vida. As proximidades não terminam por aí, pois veremos mais adiante que os dois mitos se assemelham no que dizem sobre a morte da mãe dos gêmeos.

Enitsuẽgü não é uma onça comum, mas uma onça preta gigantesca com dois rabos e grandes asas de morcego. Um amigo kalapalo diz já ter visto um desenho de Enitsuẽgü em um livro sobre dinossauros, e sugere que eles devem ter sido os ancestrais dos humanos. Este encontro é central para o desenrolar de toda a história, pois é em função dele que o mito se desenvolve. É interessante que, em várias versões, Kuatüngü está em busca de fibras: para fazer uma rede para peixes, nesta versão, e para fazer corda de arco, em outras versões kalapalo (Basso, 1987b) e kamayurá (Agostinho, 2009 [1974]). Enquanto o demiurgo sai para coletar plantas, o chefe das onças sai para caçar carne. Na versão apresentada, as plantas que o demiurgo procura servem para fazer um utensílio (rede de pesca) para a obtenção do alimento humano por excelência (peixe), enquanto o chefe das onças, armado com um majahi, o melhor dos arcos, caça humanos, evocando a relação entre humanidade/pesca e animalidade/caça que marca o sistema alimentar kalapalo.

Kuatüngü resolve fabricar mulheres para cumprir sua promessa, mas ele não o faz sozinho, e sim com a ajuda de seus irmãos. Quase todos eles são itseke que se comportam como animais a partir do anoitecer (as exceções são Ahinhuka e o próprio Kuatüngü, que se mantêm com forma humana e dormem em redes). Vale notar que este processo de transformação noturna é característico dos mortos, que, ao anoitecer, perdem sua forma humana e se transformam em animais. De acordo com um mestre de histórias, comentando este mito em uma ocasião, Kuatüngü decidiu usar árvores para fabricar mulheres por "se lembrar de sua mãe e seu avô Jukuku", que eram árvores. A relação de Kuatüngü com seu pai Morcego é excluída aqui, e as relações de continuidade geracional passam por um caminho "arbóreo": Jukuku -> filha de Jukuku -> Kuatüngü -> mulheres de madeira. O próximo mito

(Mito 6: A origem do egitsü (egitsü etĩhũtepügü)) deixará ainda mais claro que, além de arbórea, essa continuidade é feminina.

As mulheres são sempre feitas em conjuntos a partir de duas madeiras diferentes (as primeiras são de uãgu e enguhe kuẽgü, e as segundas de hata e uẽgühi). Kuatüngü e seus irmãos não fazem apenas "troncos decorados" (como no ritual) e esperam que se tornem gente, mas eles de fato esculpem mulheres e fazem seus corpos completos. Os detalhes do 
corpo e da ornamentação feminina vão sendo feitos por Kuatüngü por tentativa e erro - como a confecção de dentes de pedra ou semente de mangaba -, e foi preciso mobilizar várias pessoas para que os corpos de suas filhas ficassem prontos. Os Kalapalo dizem que os corpos dos parentes estão todos ligados, e na história das mulheres de madeira vemos este princípio operar em um caso limite, no qual partes de corpos de outras pessoas são intencionalmente manipuladas para se tornarem parte dos corpos, segundo o narrador, "daquelas que serão nossas mães ${ }^{34,}$. Como mostra o mito, os corpos dessas mulheres foram feitos literalmente com partes de corpos de outras pessoas (espíritos), e o episódio envolvendo o Embira sugere que esse processo colocou estes seres e as mulheres em relação permanente - Embira não poderia "ir" para a vagina das filhas de Kuatüngü porque ele se enfraqueceria, já que é um lutador e o cheiro do sexo o enfraquece. Kuatüngü certamente não usaria "o" Embira, e sim uma planta da qual ele é o dono; mas o episódio sugere que exista uma forte relação de contiguidade corporal e identidade entre possuidor e possuído, ao menos nestes casos. A passagem também evoca, de maneira um tanto literal, a ideia de que os pais precisam fazer seus filhos produzindo seus corpos (cf. também Figueiredo, 2010, para uma descrição semelhante desta passagem do mito).

\footnotetext{
${ }^{34}$ Em algumas passagens o narrador se refere às mulheres de madeira como "nossas futuras mães", kuk-isi-ngo (12-mãe-FUT).
} 


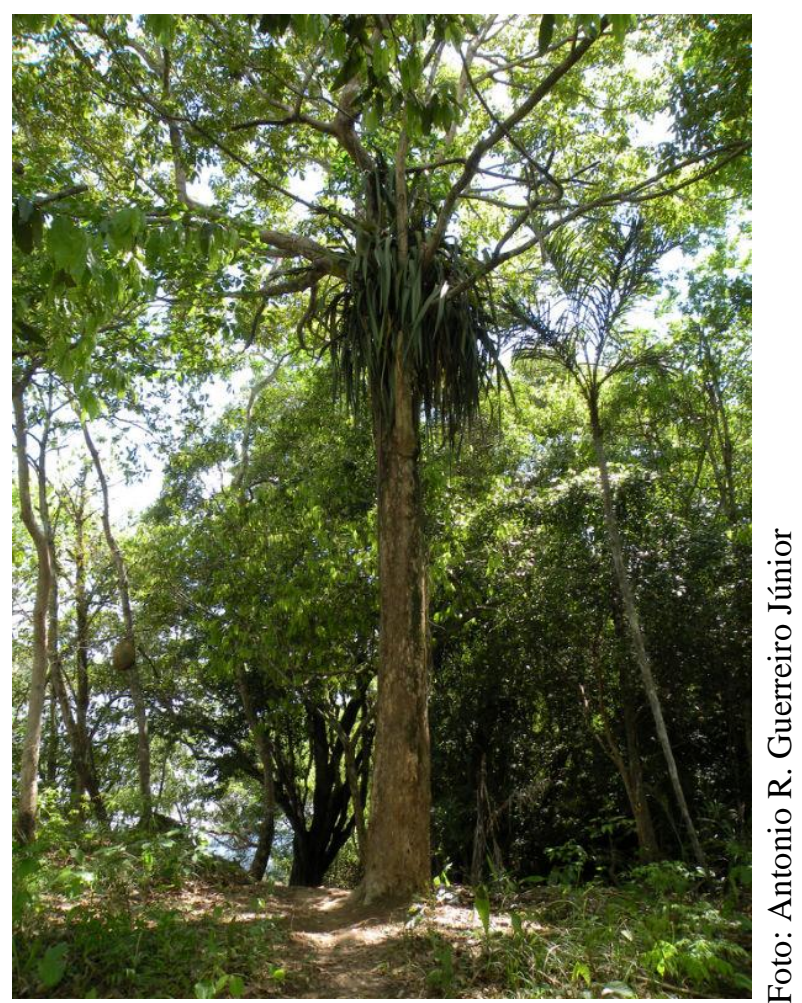

Figura 3.2: uãgu, próximo à antiga aldeia Kahindzu.

Logo atrás desta árvore, descendo um pequeno barranco, ficava o acampamento da Expedição Roncador-Xingu.

Quando os corpos das mulheres mais lindas do mundo ficaram prontos - pernas amarradas para engrossar, dentes brancos, cabelos negros e compridos, e uluri, é chegado o momento de fazê-las se tornarem mulheres de fato, comendo peixe pela primeira vez - como faz uma jovem ao final do jejum parcial que se segue à primeira menstruação, quando ficam proibidas de comer peixe - e sendo "furadas", fazendo sexo pela primeira vez. Prontas como mulheres, estavam aptas a começar sua jornada.

\section{Cena 2: uma viagem alimentar e sexual}

Logo depois, à tarde, Kuatüngü as enviou para se casarem com Enitsuẽgü. Ele pediu que elas cortassem pedaços de bambu e os colocassem dentro de suas vaginas, pois no meio do caminho elas fariam sexo com vários animais e não deveriam engravidar. Antes de saírem, seu pai as orientou sobre os animais que elas encontrariam pescando em seu caminho:

Primeiro vocês encontrarão o Tatu (Kagutaha), que cuida de uma armadilha para peixes; depois o Urubu (Kuguagi ou Sagiku) e em seguida o Urubu de Cabeça Vermelha (Juahula); 
depois encontrarão o Garça (Ugisu); depois o Gavião Belo ${ }^{35}$ (Kuantata); depois vocês encontrarão o Martim Pescador (Ituga); depois o Gaviãozinho (Tete); depois outro Gaviãozinho, menor (Iatalü); depois o Socó (Tsaujaka); depois encontrarão o $\operatorname{Irara}^{36}$ (Akusu), mas seu mel é perigoso e vocês não devem comê-lo; e, por último, vocês encontrarão Egü Ngamanetühügü ${ }^{37}$.

À noite elas ouviram uma coruja dizendo "Vão para Haukugu! Vão para Haukugu!". Antes que elas saíssem, seu pai lhes deu mais orientações: "Quando Enitsuẽgü vier buscar vocês, ele mostrará seu corpo de frente; se seu primo cruzado Suçuarana (Ahua) vier, ele mostrará suas costas. Vocês têm que entender isso para não errar". Pela manhã, após fazerem beiju, elas partiram. Seu pai pegou seu banco e se sentou na porta de sua casa para vigiar, de longe, a jornada de suas filhas.

No caminho, as mulheres viram uma nuvem de fumaça, feita pelo Tatu. Quando elas se aproximaram ele disse: "Minhas primas, vocês estão indo se casar com Anetü?", ao que responderam afirmativamente. O Tatu lhes ofereceu peixe, que elas comeram de bom grado, e quando terminaram sua refeição ele disse que queria fazer sexo com alguma delas como forma de pagamento. As mulheres aceitaram, e disseram que ele deveria fazer sexo com uma das mulheres feitas de hata. Ele até tentou fazer sexo com ela, mas não conseguiu, pois seu pênis não endurecia - ele havia esquecido seu pênis duro em casa guardado com sua mãe. O Tatu correu para buscá-lo, mas as moças não quiseram esperar e seguiram viagem.

A situação se repete de forma idêntica várias vezes, e a cada animal que encontram este faz a mesma pergunta (“Minhas primas, vocês estão indo se casar com Anetü?"), oferece comida (que elas sempre aceitam e consomem) e pede sexo como pagamento. Quando encontraram o Urubu, este lhes ofereceu comida podre e as mulheres disseram que ele poderia fazer sexo com a mulher mais nova feita de hata; ao encontrarem o Urubu de Cabeça Vermelha, este ofereceu mais comida podre, e fez sexo com a mulher mais velha de hata; a Garça lhes ofereceu peixes [não especificados] e também fez sexo com uma mulher de hata; encontraram o Gavião Belo, que lhes ofereceu cobra como se fosse peixe, e também fez sexo com uma das mulheres de hata. Quando avistaram o Martim Pescador, uma das mulheres de uẽgühi logo disse a suas irmãs que ela é quem faria sexo com ele, pois o havia achado muito bonito (ele estava com um belo colar ndihegiku ${ }^{38}$ em seu pescoço) e que ele tinha muitos peixes bons,

\footnotetext{
${ }^{35}$ Busarellus nigricolis.

${ }^{36}$ Eira barbara, conhecido como Papa Mel.

${ }^{37}$ Possivelmente Porzana carolina, uma ave que se parece com o socó e vive perto dos aguapés.

${ }^{38}$ É um colar feito com a concha de um caramujo aquático, toda pintada. É considerado muito mais bonito que os colares convencionais, e também é muito mais valioso. Sua confecção era considerada uma especialidade dos
} 
muitos tucunarés. O Martim Pescador falou mal da comida do Gavião Belo, dizendo que só agora elas estavam comendo peixe de verdade. Quando pediu seu pagamento, Sangitsegu, que era a mulher mais velha feita de uẽgühi e também a mais linda de todas, se ofereceu. Antes de fazer sexo com ela, Martim Pescador virou seu colar para que ela não o danificasse. Quando ele ejaculou, Sangitsegu logo tirou seu esperma com a mão e o jogou nele. Ele ficou com manchas coloridas onde seu esperma caiu, e Sangitsegu rezou para que não saíssem mais. Por isso o Martim Pescador ficou bem colorido e com a marca do colar nas costas, que se tornou sua pintura.

Em seguida, encontraram o Gaviãozinho (Tete), que assava seus peixes e usava uma bela pintura facial. Quando viu sua pintura, a mulher mais nova de uẽgühi, Tanumakalu, disse que faria sexo com ele. Gaviãozinho lhes ofereceu matrinchãs, esnobou a comida estragada oferecida pelos urubus e como pagamento fez sexo com Tanumakalu. Em seguida encontraram outro Gaviãozinho (Iatalï), que também era lindo e tinha muitos matrinchãs. Ele zombou mais uma vez da comida dos urubus, lhes ofereceu peixe de verdade e fez sexo com Sangitsegu (mais uma vez, depois dela própria anunciar seu interesse em pagá-lo). Em seguida, avistaram o Socó, que tinha muitos piaus, e na hora do pagamento as mulheres ofereceram uma das feitas de hata. Mais adiante encontraram o Raposa, que assava um peixe de carne meio vermelhada chamado sotohakegü. Ele desdenhou dos outros peixes que elas haviam comido, lhes ofereceu comida e fez sexo com outra mulher de hata.

Seguindo seu caminho, encontraram o Papa Mel, que tinha um machado bem colorido e uma cuia cheia de mel de jataí, que ele ofereceu e as instruiu a tomarem-no bem devagar, por ser perigoso. Enquanto elas comiam, Papa Mel rezou para que elas se engasgassem, até que começaram a tossir e desmaiaram. Enquanto isso Papa Mel fez sexo com as quatro. Quando elas acordaram ele tentou enganá-las, pedindo sexo como pagamento, mas elas perceberam que ele já havia feito sexo com todas e foram embora. Pensando que este fosse o último animal que encontrariam, tiraram os bambus de suas vaginas, que estavam cheios do esperma dos animais (e por isso hoje esse tipo de bambu tem uma seiva dentro dele). Mas logo em seguida elas viram mais uma fogueira, e se lembraram que ainda encontrariam mais uma pessoa - a ave Egü Ngamanetühügü (“enfraquecido pela vagina”), que assava seus peixes. Ele também desdenhou do alimento do Gavião Belo e lhes ofereceu piaus. Sangitsegu, a anhipe mais linda e mais velha, falou para suas irmãs que faria sexo com ele, mas apenas para empurrá-lo. Ela se ofereceu a ele, mas foi fazer sexo sem o bambu, com sua vagina de verdade. Como Egü Ngamanetühügü encontrou uma vagina de verdade, ele ejaculou muito 
rápido e intensamente; imediatamente Sangitsegu o empurrou e ele saiu voando meio tremendo, ficando assim até hoje.

As irmãs seguiram viagem, até que encontraram um buriti. Uma delas resolveu tirar folhas da planta para fazer um cinto com a fibra, e jogou o espinho da palma do buriti no chão, que caiu e ficou em pé. Kuatüngü, vendo isso de longe, rezou para que sua filha caísse com a vagina bem em cima do espinho do buriti, para que ela morresse (ele queria que apenas as duas mulheres de uẽgühi se casassem com Anetü). Lá mesmo ela foi enterrada e as três irmãs restantes seguiram viagem. Elas ficaram com sede no caminho e encontraram tuã kuẽgü, uma água venenosa. A outra mulher de hata não aguentou de sede e bebeu a água, e Kuatüngü rezou para que ela fosse envenenada. As outras mulheres choraram, sepultaram o corpo da irmã, e seguiram viagem. As duas mulheres feitas de hata morreram, e sobraram apenas as que se chamam Sangitsegu e Tanumakalu, feitas de uẽgühi.

É um procedimento comum que os mitos se iniciem com um estado de indistinção que vai sendo progressivamente desfeito no decorrer da narrativa, cujo trabalho é justamente marcar diferenças, produzir cortes no continuum que caracteriza o estado de coisas inicial do mito (Lévi-Strauss, 2004 [1964]: 76). Inicialmente, a única diferença entre as quatro mulheres é a madeira de que foram feitas; mas, conforme elas vão encontrando os pescadores sobre os quais seu pai as havia alertado, o mito começa a marcar outras diferenças entre as mulheres de hata e uẽgühi. De saída, quando o Tatu pede sexo como pagamento elas logo indicam uma das mulheres feitas de hata, e o mesmo se passa com os dois tipos de Urubu e o Gavião Belo. Tudo que o mito diz sobre estes animais é que seu alimento é inapropriado (peixe ruim, podre ou cobra) ou que o homem é imprestável como amante (caso do Tatu). A situação só muda quando elas encontram Martim Pescador, um homem bonito, enfeitado com seu valioso colar de conchas e de posse de muitos tucunarés: antes mesmo de se aproximarem dele, uma mulher feita de uẽgühi (Sangitsegu), a mais velha e mais bonita, anuncia que será ela a pagálo com sexo por seus peixes. Depois, quando encontram com um Gaviãozinho com muitos matrinchãs, a mais nova feita de uẽgühi (Tanumakalu) também anuncia seu interesse em pagá-lo com sexo. Já quando encontram o próximo pescador (o Socó), que tem apenas piaus (peixes de pequeno porte e com muitos espinhos), pedem que ele faça sexo com uma mulher de hata. 
A forma pelas quais as mulheres se relacionam sexualmente com os animais que lhes ofereceram diferentes tipos de comida (comida podre, cobras, peixes ordinários ou nobres) e que tinham diferentes condições físicas (impotentes como o Tatu, feios como os Urubus, ou belos como o Martim Pescador e o Gaviãozinho), inserem diferenças na série das mulheres correlatas à oposição entre hata e uẽgühi. Ao longo da jornada, às mulheres de hata restam os amantes menos interessantes e os piores pescadores, enquanto às mulheres de uẽgühi são reservados os melhores, mais bonitos e enfeitados. Também há uma diferença entre mais velhas e mais novas: à mais velha de todas, Sangitsegu, cabe o homem mais bonito e o melhor pescador (o Martim Pescador), e à mais nova, um dos mais feios e comedores de comida podre (o Urubu). A distinção entre mais velha e mais nova se reproduz tanto dentro de cada conjunto quanto no total das mulheres, com as mulheres de uẽgühi ocupando a posição de mais velhas em relação às de hata. Se a série das mulheres de madeira era mais contínua no início, os encontros das mulheres com seus "primos" sucessivamente marcam duas diferenças, entre uẽgühi e hata e entre mais velhas e mais novas. Nesta relação também não podemos deixar de notar o anonimato das mulheres de hata, já que apenas Sangitsegu e Tanumakalu (de uẽgühi) são nomeadas, e a diferença de beleza entre as mulheres, pois Sangitsegu é marcada como a mais bonita de todas. Poderíamos resumir as correlações feitas pelo mito na seguinte proposição (lembrando que ela também é válida no interior da série das mulheres de uẽgühi):

uẽgühi/hata :: mais velha/mais nova :: mais bonita/menos bonita :: melhores pescadores/piores pescadores :: pescadores mais bonitos/pescadores feios ou impotentes (Tatu)

Outra coisa que chama a atenção para quem ouve a narrativa em kalapalo (que infelizmente acaba ficando de fora em um resumo) é a repetição formal dos diálogos das mulheres com os animais a cada encontro, pois eles invariavelmente começam com o animal interpelando as mulheres como "minhas primas cruzadas" e perguntando se elas estão indo se casar com Anetü. Os animais não usam o nome de Enitsuẽgü e nem se referem a ele como o chefe de um povo específico, chamando-o simplesmente de "Chefe". Na verdade, não haveria 
necessidade disso, pois ele era $\underline{o}$ chefe de todos os animais, o arquétipo de qualquer anetï, a forma-chefe mais potente (englobante) entre os animais do tempo mítico.

\section{Cena 3: $O$ destino das mulheres e o nascimento dos gêmeos}

Elas chegaram ao lago próximo à aldeia de Enitsuẽgü e ficaram esperando escondidas, até que a Sariema, sua primeira esposa, veio com seu filho Kogokogoti [um pássaro preto que costuma ficar perto de lagos e rios, considerado bem feio] para tomar banho, trazendo uma cabaça para pegar água. Enquanto ela tomava banho, as anhipe colocaram suas lindas pernas brancas e grossas na lagoa, ainda escondidas. Quando a Sariema olhou para a água, viu o reflexo das pernas de uma delas e pensou que fossem suas. Logo pensou: "as pessoas falam mal da mulher do Anetü porque ela é preta e tem pernas finas, mas não é verdade, veja como eu tenho pernas grossas e brancas”. Depois disso ela encheu sua cabaça e já ia para casa, quando as anhipe transformaram suas unhas em mutucas e mandaram que elas picassem a Sariema, que desesperada com as picadas soltou sua cabaça e derramou toda a água. Quando isso aconteceu ela soube que quem estava fazendo aquilo eram as mulheres que vinham para se casar com Anetü.

Ela chegou em casa sem sua cabaça e disse para seu marido: “Anetü, vá lá ver as mulheres que estão vindo casar com você". Enitsuẽgü foi procurá-las e, mostrando a frente de seu corpo, chamou por elas quando chegou na beira da lagoa. Elas ouviram, mas não apareceram para ele, com medo. Ele disse que achava que elas estavam vindo atrás de seu primo cruzado Suçuarana, e foi embora. Elas pensaram em aparecer, mas continuaram escondidas. De volta à aldeia, Enitsuẽgü avisou seu primo que havia mulheres para ele na beira da lagoa. Logo Suçuarana foi buscá-las e as levou para sua casa. Ao chegarem, as mulheres de madeira ficaram tristes, pois viram que a cobertura de sua casa era de palha de buriti (considerada ruim e feia). Já a casa de Enitsuẽgü era diferente, uma grande casa de chefe ( talühe $^{39}$ ) coberta com sapé (a cobertura ideal) e construída pelas formigas Kahagagü e Küaleke, exímias arquitetas.

Depois de três dias, o chefe organizou uma caçada aos humanos que viviam perto dos cupinzeiros, planejando um jeito de roubar as mulheres de seu primo Suçuarana. Saíram pela manhã e, no caminho, Enitsuẽgü fingiu ter machucado seu pé. Anetü pediu que seu primo conduzisse as pessoas na caçada, e seu pessoal disse que ele deveria voltar, por causa de seu pé machucado. Chegando na aldeia ele lançou para o alto duas flechas que assoviam (kaiha), que caíram dentro da casa de seu primo. Sangitsegu e Tanumakalu pegaram essas flechas, que

\footnotetext{
${ }^{39}$ Discutirei a talühe em detalhes no capítulo 4.
} 
seguravam em suas mãos quando Anetü foi buscá-las. Foi aí que elas perceberam que tinham se mostrado para a pessoa errada. Enitsuẽgü se aproximou, agarrou as flechas seguradas pelas mulheres e as arrastou para sua casa.

No dia seguinte os caçadores retornaram com muitos humanos mortos ${ }^{40}$. Suçuarana chegou em casa e foi avisado do acontecido por sua mãe, que estava presente na ocasião, mas não reagiu, reconhecendo que elas não haviam sido enviadas para ele. De manhã cedo Anetü deu uma raiz abortiva para que suas mulheres bebessem, e cada uma abortou um filho de seu primo. Enitsuẽgü começou a fazer sexo com elas e Sangitsegu engravidou, mas Tanumakalu não. Perto da época do parto, Sangitsegu não ia mais à roça e ficava em casa sozinha com sua sogra, Kahisatigo, que, enquanto varria a casa, peidava de propósito para provocar o riso da nora. Enitsuẽgü já havia prevenido sua mulher disso, e a orientou para que não risse de sua mãe. Mas um dia, enquanto Sangitsegu fazia corda para arco e cortava a ponta da fibra de abacaxi com os dentes, cuspindo os pedaços no chão, Kahisatigo achou que seu cuspe fosse uma ofensa. Ela fez aparecer uma unha de onça em seu dedo indicador e cortou o pescoço de Sangitsegu. Quando Enitsuẽgü e sua esposa voltaram da roça, Tanumakalu pediu ajuda para tirar o cesto de mandioca da cabeça, mas sua irmã não respondeu e viu que ela estava caída no chão. Enitsuẽgü procurou sua mãe com a intenção de matá-la, mas ela já havia fugido para uma casa no mato, que ela cercou com marimbondos, cobras e uma planta cheia de espinhos (uma variedade de abacaxi, ahaga kuẽgü).

Sangitsegu não morreu e ficou muito tempo doente, ainda grávida, até o momento do parto. Primeiro nasceu Taũgi, e depois Aulukumã. Eles nasceram com rabo de onça, mas logo Tanumakalu os cortou e jogou fora. Enitsuẽgü veio e perguntou à sua esposa se eles haviam nascido iguais a ele, mas ela mentiu e disse que não. Enitsuẽgü e Tanumakalu se cansaram de cuidar de Sangitsegu, que continuava doente, e por isso Anetü a levou para cima da casa de Atugua, um espírito poderoso e cuja casa é venenosa, para que ela morresse lá. Sangitsegu ficou lá muito tempo, sem que seus filhos soubessem de nada. Devagar eles cresceram, sendo cuidados e alimentados por sua tia materna Tanumakalu, a qual eles chamavam de mãe, pois pensavam que era sua mãe de verdade. Quando ficaram um pouco maiores, seu pai fez pequenos arcos e flechas para eles, que usavam para caçar pequenos lagartos no mato em volta da aldeia. Um dia, brincando, eles encontraram o Raposa, que perguntou se eles tinham nomes. Respondendo que não, ele lhes deu alguns de seus nomes: primeiro chamou o mais

\footnotetext{
${ }^{40}$ Em versões de outros povos (Agostinho, 2009 [1974]), nesse momento as mulheres de Enitsuẽgü se recusam a comer carne humana (mais uma vez, as árvores afirmam um ponto de vista análogo ao dos humanos atuais) e pedem a seu marido que as onças cessem as caçadas.
} 
novo de Sogokohuku (Raposa) e Aulukumã ${ }^{41}$, e depois o mais velho de Anha Heĩgü (Caminho Torto/Esquerdo), e eles se chamaram por seus nomes. Outro dia encontraram Eteüga, o Pequeno Gafanhoto, que fez o mesmo que Raposa, mas primeiro deu nome ao mais velho, que chamou de Giti Taũginhü (Sol Mentiroso), e depois ao mais novo, que chamou de Ngunehuku (Lua), e os gêmeos se chamaram por seus nomes. Taũgi vem de Taũginhü, "Mentiroso", e por ser um trickster é sempre associado à maldade (Caminho Torto/Esquerdo); já Aulukumã é visto como bondoso e correto ${ }^{42}$.

Quando já estavam maiores, seu pai lhes contou sobre a existência do amendoim que ficava perto da casa de uma de suas avós (Intihi, uma ave parecida com o macuco). Ele sugeriu que eles fossem atrás do amendoim, e os alertou de que talvez sua avó tentasse enganá-los. Eles chegaram ao local, tiraram e comeram bastante amendoim, até que Intihi, a dona do amendoim, se aproximou e os gêmeos se esconderam. Quando ela viu que haviam comido seu amendoim ela ficou brava e começou a esbravejar, sem saber que Taũgi e Aulukumã estavam no local: "Ah, quem tirou o meu amendoim? Acho que foram aqueles que não têm mãe, os que falam 'mãe' para a irmã de sua mãe. Seu pai levou sua mãe em cima da casa de Atugua para ser envenenada"! Eles se mostraram, Intihi os chamou de "netos" e os autorizou a colherem seus amendoins. Taũgi perguntou a sua avó por que ela estava dizendo que eles eram sem mãe, até que Intihi, relutante, resolveu contar e mostrar a eles onde era a casa de Atugua, sobre a qual estava sua mãe moribunda.

Eles resolveram ir à casa de Atugua ver sua mãe, e confirmaram o que Intihi havia lhes contado. Voltaram para sua casa em Haukugu e não entraram, ficaram na porta dos fundos chorando. Enitsuẽgü e sua esposa não sabiam onde estavam seus filhos, até que Tanumakalu os viu chorando quando levava massa de mandioca para fora. Ela avisou Anetü, que foi buscálos. Ainda tristes, os gêmeos entraram e foram direto para suas redes dormir, sem dizer uma palavra. Quando acordaram, chamaram seus pais de anetü e itankgo. Discutindo com seu pai, os gêmeos contaram o ocorrido e explicaram que por causa de sua mentira não os chamariam mais de "pai" e "mãe", mas apenas de anetü e itankgo.

Nesta parte, assim como na anterior, o narrador quase não usa o nome de Enitsuẽgü, e só o chama de Anetü. Kuatüngü havia alertado suas filhas sobre a forma como ele e seu primo

\footnotetext{
${ }^{41}$ Segundo Mehinaku (2010: 79), a origem deste nome é “Awaulukuma (wauja) ou Awajulukuma (mehinaku)”, e significa "Hiper Raposa".

${ }_{42}$ Por isso os Kalapalo de Aiha escolheram chamar sua associação de "Associação Aulukumã". Vale notar que a imagem de Sol como o irmão enganador inverte boa parte dos mitos de gêmeos, que geralmente conferem esse papel à Lua (Lévi-Strauss, 1991; 2004 [1967]).
} 
poderiam se mostrar, e que elas deveriam prestar atenção nisso para não errarem. Porém, com medo de serem vistas, ficam escondidas e acabam errando o destino. O mito faz uma importante referência às casas de Anetü e Suçuarana: este último tinha uma casa com cobertura de palha, o que indica ser uma habitação pequena e provisória, construída por alguém sem capacidade de mobilizar o trabalho coletivo necessário para a construção de uma casa "de verdade". Já a casa de Anetü tinha cobertura de sapé, era bem feita e, mais do que isso, era uma talühe, uma "casa de chefe" feita com materiais e decoração especiais (que será abordada em detalhes no capítulo seguinte).

Depois que Anetü recupera suas esposas, mais uma diferença é introduzida na série das mulheres de uẽgühi, pois só Sangitsegu fica grávida do chefe, e por sua condição começa a passar mais tempo sozinha com sua sogra-onça, enquanto seu marido e sua irmã trabalham na roça - uma proximidade letal. Como já notei, há um claro paralelismo com o mito Bororo sobre a esposa do jaguar, cuja armação é muito semelhante à do mito kalapalo:

Um índio deu a filha ao jaguar que tinha salvado sua vida. Ela ficou grávida e, como o dia do parto se aproximava, o jaguar, antes de sair para caçar, recomendou que ela não risse, em hipótese alguma. Logo depois, a mulher ouve a voz feia e ridícula de uma grande larva (mãe do jaguar, em algumas versões), que tenta fazêla rir. A mulher contém o riso o quanto pode, mas não consegue evitar um sorriso. Imediatamente sente dores atrozes e morre. O jaguar volta a tempo de fazer uma cesariana com suas garras. Assim, ele tira do cadáver gêmeos, que serão os heróis culturais Bakororo e Itubore (Colbacchini e Albisetti, 1942: 193 apud Lévi-Strauss, 2004 [1964]: 151)

A diferença é que grande parte das variantes alto-xinguanas (como já notado por LéviStrauss em relação a um mito Kalapalo) transforma o riso em um peido emitido pela sogra (que ou acusa a nora de tê-la desrespeitado peidando em sua presença, ou desencadeia o riso da nora, que leva a sogra a matá-la) - ambos relacionados, no pensamento ameríndio, como Lévi-Strauss (ibid: 160-165) demonstra, à abertura corporal.

O nascimento dos gêmeos é o resultado da conjunção entre o chefe dos animais com mulheres feitas de uma madeira considerada o chefe das árvores, mas esta seção do mito gira em torno de duas disjunções. A primeira é a disjunção dos gêmeos em relação a seu pai, que se dá logo no seu nascimento, quando têm seus rabos de onça cortados por sua tia materna. $\mathrm{O}$ diálogo desta passagem se repete de forma praticamente idêntica em qualquer versão, contada 
por qualquer narrador, com Enitsuẽgü perguntando se eles "são como ele" e sua esposa respondendo que não, pois não têm rabo. A segunda é a dissolução dos laços de consanguinidade entre os gêmeos, seu pai e sua tia materna, provocada pela revelação da mentira dos dois. Ao descobrirem a verdade sobre sua mãe, dizem que, por causa da mentira, eles não poderiam mais chamar Enitsuẽgü e Tanumakalu de pai e mãe, mas apenas de anetü e itankgo, chefe e chefa. No capítulo anterior, vimos que o chefe é um tipo de "pai coletivo"; nesta passagem, que é um dos núcleos duros do mito, vemos que um pai que não se comporte como tal pode ser visto como um chefe, ou, melhor dizendo, que um chefe também pode ser um "não pai" - alguém que mente, engana, que é potencialmente perigoso e do qual é possível querer se separar.

\section{Cena 4: A vingança dos gêmeos}

Taũgi e Aulukumã cresceram mais, se tornaram os itseke mais poderosos do mundo e resolveram se vingar de sua avó-onça. Para chegar até ela, seria preciso desfazer as proteções que ela havia colocado em volta de sua casa. Para isso, os gêmeos chamaram seus avós Anta, para comer todos os abacaxis, as aves Antsatsa Kuẽgü e Tügüju para comerem os marimbondos (que fazem parte de sua dieta) e o Acauã, para comer as cobras (também parte de sua dieta). Vencidos os obstáculos, eles se transformaram em crianças pequenas para enganar sua avó e colocaram pequenas pedras no lugar de suas unhas para matar a velha. Ela recebeu seus netos e ficou brincando com eles na rede sem perceber nada. Taũgi ficou pulando em cima da barriga da velha, até que a rasgou com as pedras sob suas unhas. Quando a velha morreu, saíram várias borboletas de sua barriga que procuraram os gêmeos para cortar seus pescoços, mas eles correram para fora da casa. Quando Aulukumã olhou para trás, uma borboleta cortou seu nariz, e por isso ele tem o nariz pequeno, enquanto o nariz de seu irmão é mais avantajado.

Depois de matarem a avó, resolveram tirar sua mãe de cima da casa de Atugua, e para isso chamaram seu primo cruzado Janama e seu avô Kuatüngü, com todos os seus irmãos. Primeiro, Taũgi rezou para descer sua mãe, depois Aulukumã e depois seus avós, que conseguiram descê-la da casa de Atugua. Sua mãe ficou doente muito tempo, e os gêmeos se cansaram de cuidar dela, pois para não piorar sua doença ficaram sem comer peixe e emagreceram demais. Eles inventaram, com a ajuda de xamãs e rezas, uma pequena cobra para matar sua mãe, que fizeram a partir de partes da corda que amarrava a rede de Sangitsegu. Eles pediram que sua mãe olhasse para essa cobra e, no instante em que o fez, ela morreu. Eles 
também queriam mostrá-la para sua tia Tanumakalu, mas não conseguiram, pois a cobra fugiu. Eles choraram muito, e depois enviaram o Raposa para avisar Kuatüngü em Inhatasa sobre a morte de sua filha. Raposa chegou na aldeia de Kuatüngü gritando, o que assustou as pessoas, que saíram para matá-lo, mas o Raposa conseguiu fugir. Em seguida as pessoas começaram a ir para Haukugu chorar a morte de Sangitsegu. Vieram Sakata (uma ave), o Tatu Canastra e o Tatu, que rezaram Haukugu para que a aldeia se tornasse muito ruim. Sakata tinha o cabelo pintado com urucum e foi o primeiro a chorar; enquanto chorava, rezava para que a aldeia de Enitsuẽgü se tornasse feia. Em seguida veio o Tatu Canastra, rezando para que o pátio da aldeia ficasse cheio d'água. Por último veio o Tatu, que tropeçou na soleira da porta e caiu. Os gêmeos riram do Tatu, e Taũgi disse que eles deveriam rir mesmo, senão morreriam de saudade $^{43}$.

O besouro Heulugi e o marimbondo Tunutunugi, que moravam na aldeia de Kuatüngü, se tornaram coordenadores do enterro de Sangitsegu. Cavaram dois buracos, um a leste e outro a oeste, onde colocaram dois postes de madeira. Entre os dois, cavaram um túnel, onde colocaram a mãe dos gêmeos deitada em uma rede, com a cabeça a oeste e a face voltada para o leste. Em seguida, os dois foram pescar para tirar a tristeza dos gêmeos e, no dia seguinte de manhã, as esposas de Taũgi e Aulukumã prepararam mingau. Bem cedo, um chefe levou fogo na porta da casa dos gêmeos (o fogo de Sangitsegu) imitando uma onça, deixando um tição com fogo na porta de cada casa, que suas mulheres pegaram e levaram para a fogueira da cozinha. Fizeram isso em todas as casas, rodando a aldeia no sentido horário. Depois os coordenadores foram chamar Taũgi e Aulukumã para dar banho neles. Cantaram Jujuagi onde sua mãe foi enterrada, e os gêmeos levaram cintos e colares de caramujo para os cantores usarem, e em seguida cantaram Tühomisinhü.

Eles queriam matar Enitsuẽgü por ter levado sua mãe para cima da casa de Atugua, e fizeram flechas para matar todos os animais terrestres e seu chefe. Quando terminaram de fazer suas flechas, eles colocaram alguns pedaços sobre uma folha de kejite e elas se transformaram em índios bravos (ngikogo). À noite, os índios começaram imitando o grito da raposa, que é um aviso de que os que o ouvirem morrerão. Eles cercaram a aldeia de Enitsuẽgü para matar os animais. Haukugu era enorme, mas os índios também eram muitos e cercaram a aldeia toda. De manhã, atacaram e mataram quase todos, menos uma cutia, que conseguiu escapar. Enquanto isso, Aulukumã se aproximou de Enitsuẽgü e Tanumakalu, e chamando-os novamente de "pai” e "mãe", os escondeu em uma nuvem de cinzas, para que os índios não os vissem, e os arremessou para o céu, salvando-os.

\footnotetext{
${ }^{43}$ E por isso hoje as pessoas aguentam a saudade e conseguem voltar a rir depois da morte de um parente.
} 
Enquanto ainda faziam flechas para matar seu pai, os gêmeos colocaram uma flecha em frente de Tanumakalu, que engravidou quando passou por ela. Dela nasceu Carabina (Kagahina), o ancestral dos brancos. Alguns dizem que ele nasceu com uma flecha de pena de papagaio na mão e outros, que já teria nascido de calça, camisa, chapéu, chinelo e carabina.

A parte final da história reúne uma série de vinganças que os gêmeos empreendem contra sua avó, os animais terrestres da aldeia de Haukugu e, por último, seu pai e sua tia materna. A intenção de Taũgi sempre foi matá-los, mas Aulukumã não permitiu e os arremessou para o céu. Enitsuẽgü pode ser visto até hoje na Via Láctea caçando um veado e uma $\operatorname{anta}^{44}$ (que Aulukumã também jogou para o céu para que seu pai não morresse de fome). Segundo uma narradora, os humanos só morrem por causa dessa guerra e da partida do chefe dos animais para o céu; caso contrário, “ainda seriamos itseke”. Isso porque foi após essa guerra que a diferença entre humanos, animais e itseke começou a vigorar. Mortos todos os animais, Taũgi rezou para ressuscitá-los, mas eles voltaram a viver sob a forma de animais, e só quem continuou se vendo como gente em condições normais foram os índios criados pelos gêmeos. A estes, ele distribuiu objetos que se tornariam suas especialidades ${ }^{45}$ : alguns escolheram a borduna, e se tornaram guerreiros; outros escolheram objetos valiosos e se tornaram "gente" no sentido xinguano do termo: povos que, ao invés de guerrear, fariam festas e trocariam seus objetos entre $\mathrm{si}^{46}$.

Com a morte de Sangitsegu, o mito começa a descrever o passo a passo do egitsü, que começa com a morte: o enterro em uma cova especial e a execução de músicas que só são cantadas na ocasião da morte de um nobre. O egitsü começa aqui - a confecção da efígie e o final do ritual são apenas a ápice do ciclo. Tühomisinhü (que significa "com o bico fechado") é especialmente interessante, pois consiste em um conjunto de pequenas canções que evocam o começo do ciclo mítico, e também pode ser chamado de Jukuku indisü ikupügü (A Filha de Jukuku fez Sexo), tal qual o mito com o qual este capítulo foi aberto. Ele recebe o nome de tühomisinhü porque seus primeiros versos devem ser cantados com a boca bem fechada e em

\footnotetext{
${ }^{44}$ Enitsuẽgü não coincide com nenhuma constelação ocidental, mas, segundo Basso (1987b: 360-361) ele estaria à esquerda de beta Hydra e psi Hydra. Pelo que pude identificar, seus olhos (principais pontos de referência dessa constelação) são Wei ( $\varepsilon$ Sco) e $\mu^{1}$ Sco, que fazem parte da cauda de Escorpião.

${ }^{45}$ Segundo outro narrador, quem teria oferecido esses objetos aos índios foi Janama, o primo cruzado mais velho dos gêmeos.

${ }^{46}$ Segundo Piedade (2004: 22), o termo wauja putakanau, aplicado à humanidade xinguana, significaria "genteque-empresta", ou, segundo Mello (2004: 56), "aqueles que sabem trocar".
} 
voz bem baixa, pois são extremamente perigosos para as crianças, que se os ouvirem morrerão imediatamente. Ele está todo em $\operatorname{arawak}^{47}$, e os três cantores de Aiha que o conhecem não fazem qualquer ideia do que o canto diga; sabem apenas que ele é dividido em 14 partes, das quais sete (dentre as oito primeiras) são sobre personagens da parentela próxima dos gêmeos ${ }^{48}$ :
1) Kuamuti (Kuatüngü) - é a abertura, ou "feito para começar" (inetoho)
2) Jokoko (Jukuku)
3) Jukuna (urucum)
4) Kaminaui (Sol)
5) Keginaui (Lua)
6) Janama (primo dos gêmeos)
7) Sangitse (Sangitsegu)
8) Nitsuma (Enitsuẽgï)

Estes cantos só são executados em sua totalidade se o morto for filho de pai e mãe nobres. Caso seja nobre por apenas uma das vias (materna ou paterna), canta-se apenas sobre Jukuku (canto 2) e pula-se para o nono canto.

Em uma comparação mais geral, este mito pode ser visto como uma variante do conjunto de mitos da esposa do jaguar analisado por Lévi-Strauss no primeiro volume das Mitológicas (Lévi-Strauss, 2004 [1964]). Este conjunto é articulado por um tema central, no qual os humanos estabelecem uma relação com o jaguar através de alguma mulher humana que passa a viver com ele. Nos mitos Kayapó-Gorotire e Kayapó-Kubenkranken sobre a origem do fogo de cozinha analisados por Lévi-Strauss (ibid: 91-93), por exemplo, um jovem abandonado por seu cunhado no alto de um rochedo é convidado pelo jaguar para comer carne assada em sua casa, e o jaguar resolve adotá-lo. O jaguar tinha uma esposa humana que detestava o rapaz e vivia a importuná-lo. Seu pai adotivo lhe ensinou a usar arco e flecha e o

\footnotetext{
${ }^{47}$ Agradeço a Mutua e Jamalui Kuikuro-Mehinaku que se esforçaram para tentar traduzir o que fosse possível desse canto.

${ }^{48}$ As outras são um conjunto de trechos chamados de ihakitoho, "feitos para traduzir", nos quais o cantor alterna algumas frases (em arawak) com a expressão "meu dono disse" (também em arawak, onde "dono" se refere à mãe dos gêmeos). Dois jovens kuikuro que compreendem arawak tentaram, mas não conseguiram traduzir estas partes do canto, a não ser a primeira delas, onde se diz "meu dono disse/meus braços estão no céu" (nimafaji nueketu/uana uana enufaji ijakuji aji).
} 
instruiu a usar suas armas contra a mulher caso seja necessário. O rapaz acaba matando a esposa do jaguar, foge para a floresta e depois retorna para buscar o fogo. Transformações podem ser encontradas entre os Apinayé, Timbira Orientais e Xerente (ibid: 94-98), nas quais varia a forma como o homem vai parar na casa do jaguar e obtém o fogo, mas um modelo persiste: 1) o jaguar já é casado com uma humana; 2) um homem vai viver com eles; 3) a mulher do jaguar não gosta do homem, o irrita e ameaça; 4) o homem mata a mulher do jaguar; e 5) os humanos obtêm o fogo de cozinha.

Homem e jaguar participam de uma relação tensa de oposição: o jaguar é o principal rival do homem na obtenção de caça (em um mito Ofaié ${ }^{49}$, além de ser dono do fogo, o jaguar é o único capaz de prover boa caça em abundância); o homem come cru, enquanto o outro, cozido/assado; e principalmente, o jaguar come o homem, mas o contrário não acontece. Homem e jaguar se encontram em uma relação fundamental de competição, uma relação caracterizada por Lévi-Strauss ao mesmo tempo como assimétrica e de "reciprocidade nula", que só pode ser compensada pela afinidade:

Para que tudo o que o homem possui (e que o jaguar não possui mais) pudesse lhe vir do jaguar (que o possuía antes, ao passo que o homem, não), é preciso, portanto, que surja entre eles o meio de uma relação: esse é o papel da mulher (humana) do jaguar (ibid: 107).

Mas depois de feita a ligação entre humanos e o jaguar, a sobrevivência da esposa humana do jaguar seria contraditória, dada a permanência da relação fundamental de reciprocidade nula entre homens e jaguares, e por isso ela precisa ser eliminada:

(...) as satisfações culinárias provêm do jaguar, mas, para que os homens pudessem aproveitá-las sem risco, foi preciso que a mulher do jaguar fosse eliminada, uma exigência diante da qual o jaguar, nos dois casos, se curva de bom grado e com uma indiferença manifesta (ibid: 109)

Assim, obtido o fogo (e eventualmente tudo o mais de valioso que pertencesse ao jaguar, segundo cada variante), a mulher se torna inútil, tendo cumprido seu papel de condição prévia para a relação entre humanos e jaguares e instaurando, com sua perda, uma

\footnotetext{
${ }^{49}$ Ibid: 108 .
} 
separação definitiva entre humanos e animais (ibid: 108). Inicia-se uma relação com o Jaguar através do casamento, e encerra-se esta relação com a perda desta mulher.

O mito kalapalo também se organiza em torno do tema da esposa humana do jaguar, mas com diferenças importantes. A primeira, mais óbvia, é de que não se trata de uma narrativa sobre a obtenção do fogo, nem de armas, enfeites, nem nada deste tipo, como na maioria das variantes analisadas por Lévi-Strauss. A maior aproximação é com o mito Bororo, não por acaso também um mito de origem de gêmeos transformadores e modeladores do mundo.

Feito o casamento, a temática do desafeto da esposa do jaguar por outro humano, ou da mãe do jaguar por sua esposa humana, é outra constante do grupo. No caso Kalapalo, é a sogra quem mata uma das esposas do jaguar. Segundo uma versão apresentada por Herbert Baldus (1958 apud Lévi-Strauss, op. cit.: 151), a sogra peida e acusa a nora; nas versões de que disponho, a sogra peida, a nora cospe no chão enquanto trabalha e a sogra a acusa de estar zombando dela. Em todo caso, há a ocorrência de um comportamento trivial, porém delicado, na presença de afins de gerações diferentes, e interpretado como ofensivo pela sogra. Os dois gestos, o peido da sogra ou o cuspe da nora, são sobre a saída de substâncias do corpo (gases ou saliva), que podem gerar o riso da nora ou a ofensa da sogra. Há sempre um distúrbio na interpretação dos sons na comunicação: se a sogra peida, a nora ri; se a nora cospe, a sogra se ofende; os dois casos terminam com a mulher humana morta por sua sogra-onça.

Há inúmeros mitos sobre os efeitos da abertura descontrolada do corpo, como seria o caso do peido, do cuspe e do riso (Lévi-Strauss, op. cit.: 163-165). Em qualquer caso, os "excessos de comunicação inadequada" provocados por esses sons têm como efeito ocasionar problemas para seus emissores, que são repreendidos por outros. Aqui, o assassinato da nora pela sogra causa duas disjunções, uma primária e outra secundária: a primária é entre a sogra e seu próprio filho, que tenta se vingar dela; a secundária deriva das atitudes do chefe-onça após o acontecido, que levarão os gêmeos a empreender uma série de vinganças contra os espíritos e definir a posição dos humanos no mundo.

Em uma comparação mais específica, esse mito se liga ao mesmo tempo aos conjuntos de mitos da "noiva de pau ${ }^{50 "}$ e de gêmeos analisados por Lévi-Strauss (2004 [1967]). Os

\footnotetext{
${ }^{50}$ Segundo Lévi-Strauss (2004 [1967]: 201) o motivo da noiva esculpida do tronco de uma árvore é encontrado desde o Alasca, entre os Tlingit, até a Bolívia, entre os tacana. Ainda, o motivo mais geral da estátua ou imagem
} 
Warrau e Macuxi (ibid: 199-205), por exemplo, possuem mitos que contam como um homem fez mulheres a partir do tronco do taperebá. No primeiro caso, um velho solitário fez uma filha para cuidar dele; no segundo, o Jacaré fez uma filha para que se casasse com Sol, a quem havia prometido uma esposa em troca de ter sua vida salva (note-se a semelhança com o mito xinguano).

Esses mitos trabalham com dois tipos de árvores das quais foram feitas as pessoas palmeiras ou taperebá -, e Lévi-Strauss (ibid: 215) observa que elas se opõem em pelo menos dois aspectos: quanto à dureza (o tronco da palmeira é mole, enquanto o do taperebá é duro) e à forma de provisão de alimento (uma contém em seu tronco um alimento interno, e outra tem em seus galhos um alimento externo). É notável que o taperebá seja considerado imputrescível pelos mitos (ibid: 216), pois essa é justamente uma das características que se atribui à nẽgühi. Aparentemente, o taperebá possui uma grande vitalidade e, mesmo desenraizado, volta a brotar e suas mudas se transformam em novas árvores (id. ibid.). É o oposto das palmeiras, que uma vez "derrubadas ou simplesmente privadas de seu broto terminal não voltam a brotar" (id. ibid.).

Também há questões relativas ao comportamento das pessoas feitas de cada tipo de madeira. Lévi-Strauss (ibid: 217) observa que quando é feita de taperebá, a noiva é uma provedora (abastecendo seu cônjuge com polpa); porém, quando é feita de palmeira, a noiva é uma amante (não-provedora), e além do mais uma amante negativa, pois é “impenetrável”. No mito kalapalo, as mulheres são feitas de uma madeira que se aproxima do taperebá quanto à sua dureza e "vitalidade às avessas" (é considerada imputrescível), ao mesmo tempo que se distancia dele, por não produzir frutos comestíveis. Nesse caso, as mulheres resultantes se aproximam daquelas feitas de palmeira, pois não são provedoras e sim "amantes impenetráveis" (fazem sexo com diversos animais em troca de alimento e têm suas vaginas protegidas por gomos de bambu).

Lévi-Strauss (ibid: 217-218) compara esse conjunto de mitos com aqueles da esposa sobrenatural de um mortal. Nos mitos jê da esposa-estrela, ela "acumula em sua pessoa os dois papéis, de amante impenetrável (devido à sua castidade) e de provedora (como introdutora das plantas cultivadas)" (id. ibid.). Como esses mitos são transformáveis em um grupo de mitos tupi-tukuna, "nos quais a esposa sobrenatural provém do fruto, maduro ou

que se anima é amplamente distribuído na América do Norte, como entre os Esquimós do Estreito de Bering, os Micmac, os Iroqueses, e os Pueblo (ibid: 201, nota 10). 
podre, de uma árvore" (ibid: 218), Lévi-Strauss afirma que "existe, portanto, toda uma série de esposas, poder-se-ia dizer, "vegetais"” (id. ibid.).

Lévi-Strauss continua, dizendo que as personagens desse conjunto de mitos são "furadas" (para o bem ou para o mal) por um sariguê ou um pássaro chamado de "catingueiro" (aqui pelo Egü Ngamanetühügü), e nos mitos guianenses se tornam mães de gêmeos - cujas narrativas também têm várias analogias com o mito que estamos analisando. No mito Warrau, os gêmeos Makunaíma e Piá matam sua mãe adotiva, uma rã. A rã é, em outros mitos karib (ibid: 203), mãe do jaguar, de modo que, de alguma maneira, os gêmeos do mito Warrau também mataram uma "mãe de onça".

A morte de Sangitsegu dá início ao processo pelo qual os gêmeos modelarão o mundo para os humanos, tomando dos itseke tudo aquilo que julgarem necessário para uma vida melhor para si. De forma análoga, o fim desse processo (ou pelo menos de seus principais momentos) é marcado pela realização do egitsü da mãe dos gêmeos. E se tudo começa com uma guerra contra os animais terrestres e a separação dos gêmeos de seu pai onça, termina com uma festa (agonística) com os animais aquáticos e a conjunção dos gêmeos com sua mãe árvore/humana.

\title{
3.3 O desafio aos peixes
}

\author{
Mito 6: A origem do egitsï ${ }^{51}$ (egitsü etĩhũtepügü) \\ Quando Taũgi morava em Mügena (confluência dos formadores do Xingu) ele decidiu \\ homenagear sua mãe, em outro lugar, muito tempo depois que ela havia morrido. De Mügena \\ ele e seu irmão levaram polvilho para um local chamado Sagihẽgu, no alto Culuene. Seu corpo \\ estava enterrado em Haukugu, a aldeia de seu pai, mas eles decidiram fazer a festa neste outro
}

\footnotetext{
${ }^{51}$ Síntese de versões narradas por Ageu e Tawana.
} 
$\operatorname{local}^{52}$. Depois que trouxeram o polvilho, foram cortar uma árvore uẽgühi para fazer a efígie (tita) de sua mãe. Foram pescar com timbó em uma lagoa muito distante chamada Naulaja, que fica no ribeirão Sete de Setembro e é habitada por muitos espíritos perigosos. Taũgi fez seu acampamento na mata alta, enquanto seu irmão Aulukumã acampou na mata às margens da lagoa. Antes de começar a pescaria Taũgi matou os espíritos da lagoa, os retirou com uma peneira que as mulheres usam para tirar pequi da panela e pintou sua cabeça com urucum que, junto com uma reza, ajuda o timbó a envenenar os peixes. Eles fizeram uma rede de embira, que puxaram até o final da lagoa cantando para os peixes. Seu pessoal, que eram animais terrestres (o antigo pessoal de seu pai), pescou muito para ele. Depois de dormirem alguns dias no acampamento para moquear os peixes, eles retornaram para Sagihẽgu e, no dia seguinte pela manhã, Taũgi enviou o Cascudo (Kagikagi) como seu mensageiro até a aldeia dos peixes, no rio Amazonas.

Sagihẽgu era uma aldeia de animais terrestres, na qual Taũgi era considerado chefe. Nunca encontrei nenhuma explicação para ele não ter homenageado sua mãe em Haukugu, onde ela foi enterrada ${ }^{53}$, mas me parece que isso está ligado ao processo de diferenciação de Taũgi e Aulukumã em relação a seu pai onça: seus rabos de onça foram cortados logo que nasceram, deixaram de chamar Enitsuẽgü de pai, Taũgi tentou matá-lo e, nesse momento do ciclo mítico, a aldeia Haukugu é deixada definitivamente para trás.

Também há uma relação importante entre os lugares mencionados no mito e a concepção que os xinguanos têm de seu território, cujos limites e extensão são explicitados no movimento norte-sul realizado pelos gêmeos. Os gêmeos moravam em Mügena (região conhecida como Morená), que é a confluência entre os formadores do rio Xingu. Esse ponto marca o limite norte do que os xinguanos consideram como seu território, pois dali em diante, rio abaixo, é "terra de índios", inimigos. Essa diferença é codificada ao mesmo tempo de forma social (nos formadores, povos pacíficos; no rio Xingu, povos guerreiros) e cosmológica, pois se diz que, a partir de Mügena, deve haver espíritos diferentes daqueles que os Kalapalo conhecem, e mesmo diferentes regimes de relações entre espíritos, espaços, plantas e animais - não se sabe quem é dono de que(m) ou de onde. Por exemplo, antigamente

\footnotetext{
${ }^{52}$ Onde dizem que até hoje é possível ver as árvores onde as pessoas limparam o excesso de urucum de suas mãos, que ficaram marcadas para sempre.

${ }^{53}$ Depois da guerra e das rezas, provavelmente Haukugu deve ter sido abandonada.
} 
o bambu usado na confecção das flautas atanga, tocadas durante o ciclo do egitsü ${ }^{54}$, era obtido principalmente abaixo de Mügena, pois dizem que o bambu de lá "não tinha dono", enquanto o dono do bambu alto-xinguano é uma cobra gigante que torna sua obtenção muito perigosa. Sagihẽgu, em compensação, é o limite sul do território xinguano: a partir de lá, no sentido rio acima, não se sabem mais os nomes das partes do rio ${ }^{55}$, e talvez houvesse outros povos naquela fronteira (possivelmente Xavante).

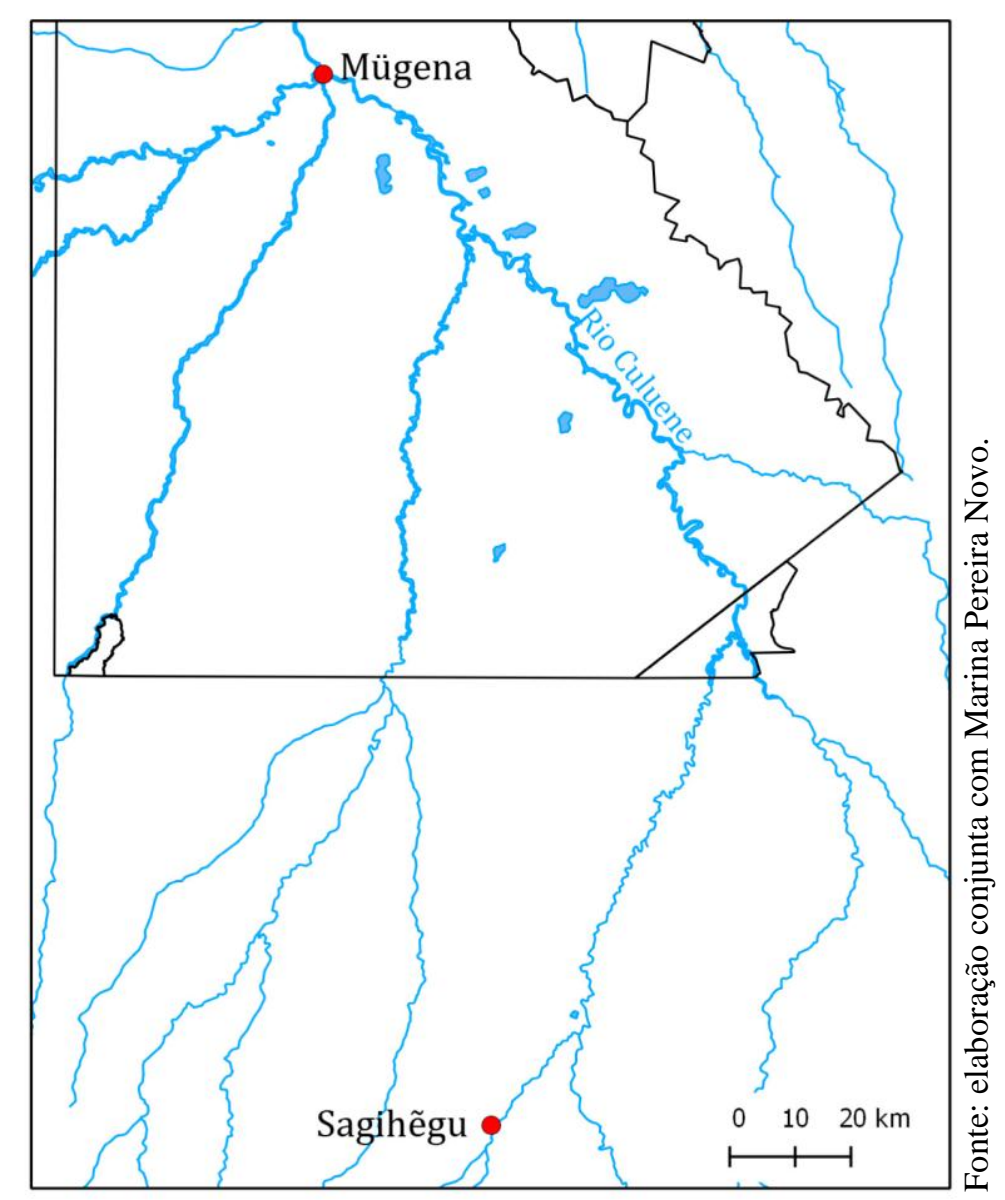

Figura 3.3: mapa do Alto Xingu, com os limites do Parque e a localização de Mügena e Sagihẽgu.

A localização do último está conforme identificação da Documento Patrimônio Cultural (2009).

\footnotetext{
${ }^{54}$ Atanga é um instrumentos musical formado por quatro aerofones divididos em dois pares, cada um manuseado por um músico-dançarino. Este instrumento só é possuído por campeões de luta e filhos de chefes, que não podem comprá-lo nem fabricá-lo para si, mas devem recebê-lo como um presente de seu pai. Ele é executado de forma intermitente durante todo o ciclo do egitsü, a partir do dia da construção do tahiti, e não é utilizado em nenhum outro tipo de ritual.

${ }^{55}$ Dizem que alguns kalapalo mais velhos conheciam os nomes de poucas partes do rio acima de Sagihẽgu, mas hoje não há mais ninguém que os saiba.
} 
A sequência das atividades dos gêmeos delineia mais ou menos a ordem do ciclo ritual: é preciso juntar polvilho, depois organizar uma pescaria coletiva e só então enviar mensageiros para os convidados. Mas no ritual isso acontece de acordo com outro calendário, bem mais longo: junta-se polvilho entre o final de maio e meados de junho (época em que se colhe muita mandioca), e só se organiza a pescaria pouco mais de uma semana antes da chegada dos convidados. O momento de juntar o polvilho é importante, pois é nesta ocasião que se convida um ou mais povos para se tornarem aliados (kataentsokongo ${ }^{56}$ ) do grupo patrocinador. Os grupos aliados chegam cerca de dez dias antes do final da festa e oferecem seus melhores campeões para lutarem ao lado dos anfitriões (relação que será melhor explorada no capítulo 6). Talvez a relação entre Taũgi e Aulukumã neste mito seja análoga a uma relação entre grupos aliados. Os gêmeos representam os dois principais blocos formadores do Alto Xingu, os arawak (na figura de Aulukumã, que fala arawak) e os karib (na figura de Taũgi, que fala karib ${ }^{57}$ ), e sua relação neste mito evoca aquela entre grupos aliados: são diferentes, mas estão juntos. Depois de juntar o polvilho, a pescaria com timbó é o grande momento no qual se marca a relação entre grupos aliados, quando se deve juntar peixe para o dono da festa e, apesar do trabalho conjunto, os diferentes grupos ficam em acampamentos muito próximos, mas distintos. Nesta passagem do mito, chama atenção a localização dos acampamentos dos gêmeos durante a pescaria, onde, por alguma razão, o mito faz a associação Taũgi:mata alta :: Aulukumã:mata ciliar. A cena da pescaria também retrata a situação de conflito potencial entre os donos do egitsü e os donos dos peixes, que podem se sentir "atacados" com a pescaria por timbó e a morte de muitos de "seu pessoal", e por isso tentar matar todos os pescadores.

Na volta da pescaria, Taũgi envia seu mensageiro, o Cascudo, para buscar seus adversários, os peixes. Na verdade, ele enviou três mensageiros, como se faz hoje em dia, mas apenas o Cascudo é nomeado, pois era o mensageiro principal - seu iho.

\footnotetext{
${ }^{56}$ Ataenjü significa "junto", e kataentsokongo talvez possa ser glosado como "os que ficam junto conosco".

${ }^{57}$ Não conheço nenhuma explicação para essa diferença linguística entre os gêmeos (que já foi mencionada por Franchetto 1986), mas os Kalapalo com frequência observam que tudo tem nomes tanto em karib quanto em arawak porque cada um dos gêmeos chamava cada coisa em sua língua.
} 


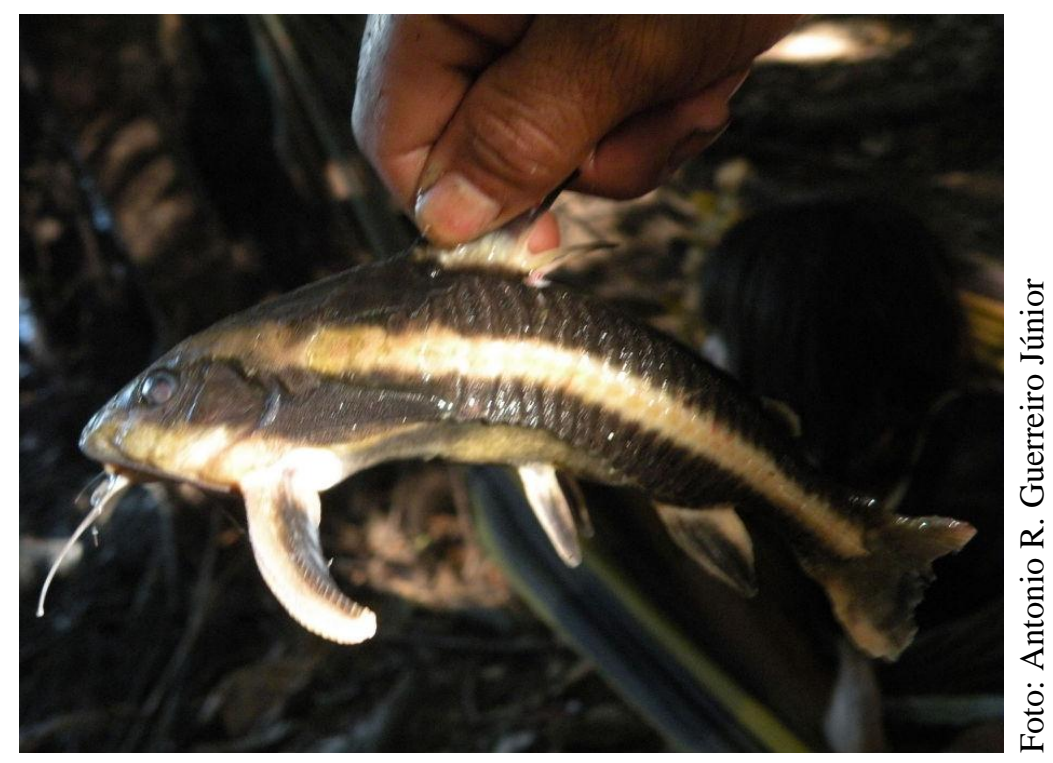

Figura 3.4: Cascudo (kagi-kagi), o mensageiro de Taũgi.

Depois que os gêmeos sobem o rio, é preciso novamente fazer um movimento rio abaixo. Os mensageiros foram enviados para muito longe, seguindo rio abaixo indefinidamente, até chegar, segundo o narrador, no Amazonas:

Depois de viajar durante dias, os mensageiros chegaram e foram sentados no centro da aldeia dos peixes. Seu chefe era o Peixe Cachorra (Ahi Kuẽgü), que assumiu como coordenador (ugihongo) de seu grupo, e os peixes partiram no dia seguinte, rio acima, em direção a Sagihẽgu. Quando chegaram em Cranhãnhã, os peixes fizeram um ensaio da dança de entrada dos convidados na aldeia, e o local onde eles fizeram um círculo se transformou na lagoa Cranhãnhã, onde os Nahukwa pescam hoje em dia. Depois, chegaram em Kasiho [porto da aldeia Aiha], onde encontraram um homem chamado Kangasingi ${ }^{58}$. Ele estava pescando, mas não conseguia peixes, pois todos estavam indo para o egitsü. Eles o convidaram para ir junto, e Kangasingi aceitou. Chegando em Jagije [local que não pude identificar], seu chefe pediu que eles ensaiassem novamente. Fizeram uma fila bem grande, mas faltou um pouco para alcançar o rio Culuene, e para resolver isso completaram a fila com as crianças.

\footnotetext{
${ }^{58}$ Me disseram que Kasiho viria de "Kangasingi iho", traduzido como "o lugar de Kangasingi". O nome deste humano, por sua vez, significaria "atrás dos peixes" (kanga singi).
} 
Seguiram viagem, e no caminho o Peixe Cachorra mentiu dizendo que havia esquecido o objeto que ele deveria levar para a festa ${ }^{59}$. Dois amigos lutadores, os peixes Hugoi (Peixe Sabão ${ }^{60}$ ) e Akutsi, se ofereceram para voltar à aldeia e buscá-lo. Chegaram na aldeia à noite e encontraram as duas filhas do Peixe Cachorra sozinhas; a mais nova era a mais bonita, e as duas usavam duas pinturas de urucum diferentes. Aproveitando que elas estavam sozinhas, eles fizeram sexo com as filhas do chefe, e as marcas das pinturas das mulheres ficaram em seus corpos, e por isso estes peixes possuem suas pinturas atuais.

Quando os peixes chegaram a uma lagoa na margem do Culuene chamada Hihi, ouviram o chocalho do Sapo Boi (Magitahata) e do Tamanduá-Mirim (Kangatakugu), que cantavam em Sagihẽgu, que parecia perto, e ensaiaram mais uma vez. Ali os peixes se dividiram: alguns foram em direção ao som do chocalho achando que encontrariam um atalho, seguindo pelo igarapé Itsundü, e outros continuaram subindo o Culuene. Os que foram pelo córrego chegaram à sua nascente, em Kambügape, e lá pararam, pois não tinham como continuar. Os peixes que sabiam pular deram longos pulos até voltarem para o Culuene, mas outros, como a Corvina e a Pirarara, ficaram lá.

No Culuene, os peixes chegaram em um local chamado Hete Kingoho, onde encontraram uma barragem de pedras feita por Taũgi para impedir a chegada de seus convidados ${ }^{61}$. Aqueles que haviam ido buscar o objeto do Peixe Cachorra os encontraram presos ali, e o chefe pediu que seus campeões empurrassem o obstáculo. Antes de empurrar a pedra, o peixe Hangitse Kuẽgü, que é um grande campeão, rezou sua mão para ter força, e por isso hoje alguns lutadores têm essa reza. Removida a pedra, os peixes continuaram subindo até Koso, onde fizeram outro ensaio. Além de Kangasingi, havia outra pessoa diferente com eles, o Gafanhoto. Eles fizeram um círculo bem grande, mas não conseguiram fechá-lo. Depois apareceram no rio, fizeram um último ensaio já perto de Sagihẽgu e subiram devagar.

O chefe dos peixes é o Peixe Cachorra, que se tornou coordenador (ugihongo). Assim como a onça (o principal predador terrestre) é o chefe dos animais, o peixe cachorra é escolhido para esta função por sua condição de predador e seu aspecto ameaçador. Não sei se ele é de fato o maior predador daquelas águas, mas por sua aparência é fácil entender porque ele pode ser pensado como tal:

\footnotetext{
59 Todo coordenador deve levar algum objeto de muito valor para trocar com o mensageiro que foi até sua aldeia. Voltarei a isso no capítulo 6.

${ }^{60}$ Crenicichla, da família dos ciclídeos.

${ }^{61}$ Segundo outra versão, isso teria ocorrido na cachoeira de Asã Ipügü (local onde foi construída a Pousada Mutum). O leito do rio ali é bastante pedregoso.
} 


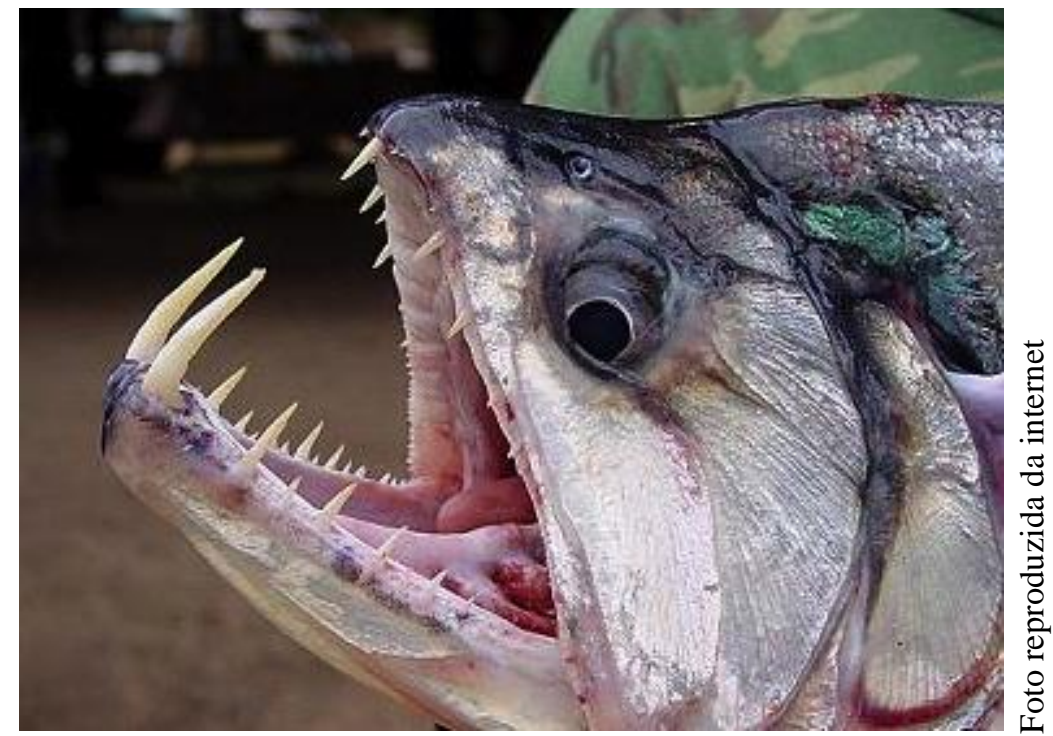

Figura 3.5: peixe-cachorra (Hydrolycus armatus).

A viagem dos peixes é marcada por vários episódios que explicam a origem de elementos da paisagem, como a lagoa Cranhãnhã e outras entradas do rio Culuene na mata, e de características da fauna aquática, como as manchas dos peixes hugoi e akutsi, e a concentração de corvinas e pirararas na nascente do córrego Itsundü. Mesmo vindo de tão longe - do rio Amazonas! - os lugares só começam a ser nominados no médio Culuene, a partir da região do Cranhãnhã, tradicionalmente ocupada pelos Nahukwa (onde também já houve uma aldeia trumai), e o curso dos peixes passa por território tradicional karib (Von den Steinen já havia reconhecido que os karib eram os "senhores do Culuene"). Como já vimos no capítulo 1, a região do alto Culuene é território de ancestrais dos Kalapalo possivelmente ligados ao aglomerado de Akuku. De fato, há outros lugares associados à mitologia do egitsü, mas que não aparecem nessa versão da história, também localizados ao sul, como Hagagikugu e Kaunhe (ligados a mitos de origem de cantos do ritual). Pelo fato de seu repertório ser majoritariamente em arawak (como a maior parte dos repertórios rituais), sua origem costuma ser atribuída aos povos falantes daquela língua, mas é curioso que "geopoliticamente" ele seja totalmente ligado aos karib. Aliás, não só geograficamente, pois a espécie da uẽgühi (Humiria balsamifera var. floribunda) é considerada uma árvore típica da região de origem da família linguística karib, o maciço guianense. Na Guiana Francesa, ela é usada na fabricação de 
esteios de habitações indígenas, e seu nome vulgar, "umiri”, tem origem na língua Garipon (karib), na qual é chamada de houmiri (Emmerich, Emmerich et al., 1987: 389).

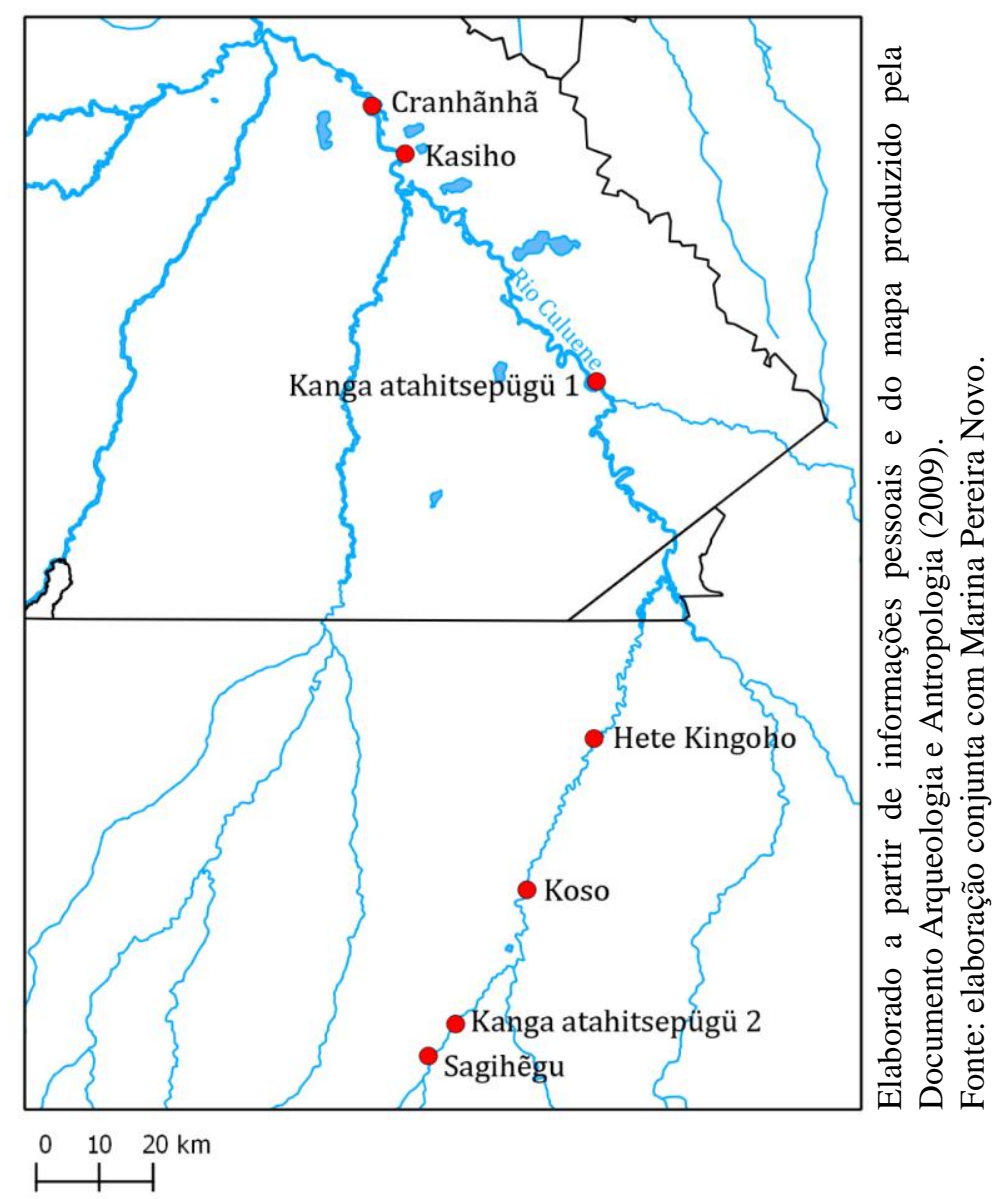

Figura 3.6: alguns pontos do caminho dos peixes até Sagihẽgu.

O ponto “Kanga atahitsepügü 1" (“Onde os Peixes Ensaiaram”) não aparece nesta versão do mito, e fica próximo à aldeia Tankgugu. Decidi marcá-lo por ser mencionado com frequência por outros narradores.

Esta foi a razão pela qual os Kalapalo foram indicados pelos outros alto-xinguanos para trabalharem junto com a equipe que fez os estudos de impacto da construção da barragem da Pequena Central Hidrelétrica (PCH) Paranatinga II, que seria construída no local do Sagihẽgu. Em 2004 foi feito um acordo entre algumas lideranças do Alto Xingu, a construtora e o governo do Mato Grosso, segundo o qual, uma das condições para a construção da barragem seria a garantia de preservação de dois lugares míticos que poderiam 
ser afetados: Sagihẽgu e a caverna de Kamukuaka ${ }^{62}$. Os Kalapalo foram indicados para acompanhar o processo envolvendo Sagihẽgu, e os Wauja aquele envolvendo o Kamukuaka. Houve uma controvérsia sobre a real localização do Sagihẽgu. O laudo da empresa contratada para a realização da pesquisa identificou o local um pouco abaixo da barragem da PCH Paranatinga II (que já estava em construção), e os Kalapalo (cujos chefes e mestres de histórias acompanharam a viagem ao local) parecem concordar que aquele é de fato o lugar do mito. Porém, Fausto (2004b) argumenta que, segundo os Kuikuro, o Sagihẽgu não seria ali, mas seria exatamente no local da barragem. É difícil avaliar a situação, pois ao mesmo tempo em que o trabalho da equipe de pesquisa contratada apresenta falhas técnicas (que não cabem discutir aqui), os Kalapalo com os quais conversei sobre o assunto parecem bastante convencidos sobre a localização do sítio; possivelmente a localização exata desse tipo de sítio varie segundo diferentes tradições orais.

O conhecimento que os Kalapalo têm do alto Culuene, comparado com o de outros alto-xinguanos, criou uma situação curiosa, pois de conhecedores do Sagihẽgu (e da paisagem mítica do primeiro egitsü em geral) se tornaram seus "donos" no processo de identificação e tombamento deste sítio. Apesar de ser um local associado a um ritual realizado por todos os povos do Alto Xingu, o Sagihẽgu se transformou em um patrimônio cultural visto pelos outros alto-xinguanos (e, até onde eu saiba, de forma mais ou menos legítima) como sendo "dos Kalapalo", que já têm planos de aproveitamento do lugar. Eles pretendem construir uma aldeia cenográfica no local, onde realizarão esquetes de festas para turistas, e também planejam realizar rituais mortuários sob encomenda para brancos: quem quiser poderá pagar para homenagear um parente morto no local onde foi realizado o primeiro Quarup.

O caminho dos peixes também é importante porque retrata uma tensão entre os convidados e seu principal anfitrião (Taũgi), que aumenta pouco a pouco até atingir seu clímax no final da luta. Primeiro alguns peixes se confundem com os cantos que ouvem e ficam para trás, e depois se veem presos em uma barragem feita pelo próprio dono da festa, um claro sinal de que as intenções de Taũgi em relação aos peixes não eram as melhores, o que ficará ainda mais claro no trecho a seguir:

\footnotetext{
${ }^{62} \mathrm{O}$ pedido de tombamento de ambos os sítios foi aprovado pelo IPHAN em 24 de junho de 2010.
} 
Os peixes chegaram no rumo de Haukugu (que não fica na beira do rio, mas na mata entre o Culuene e o Curisevo) e seguiram para Sagihẽgu (que fica na beira do rio) sem dormir. Logo cedo eles chegaram gritando. O pessoal de Taũgi era de onças muito gordas e eram todos grandes lutadores, inclusive uma onça branca gigante chamada Kusutse. Havia muitos peixes, e os que haviam sido mensageiros vieram recebê-los e levá-los para o acampamento. Depois todos levaram comida ${ }^{63}$ para seus conhecidos. Os lutadores dos peixes eram o Poraquế ${ }^{64}$ (Ugake), a Cobra (Ekehuẽgü), Hangitse Kuẽgü, o Pintado, o Barbado, a Traíra e o Gafanhoto. Eles comeram muito no acampamento e, depois de um tempo, os ex-mensageiros foram chamá-los para buscar lenha no centro da aldeia. Foram todos (inclusive Kangasingi), menos os lutadores (para evitar se aproximar de mulheres menstruadas da aldeia ou ser alvo de feitiços). Depois os ex-mensageiros foram chamá-los novamente, agora para cantar perto da tita. Em seguida, cantaram kuegitsaha, cantos-rezas que servem para dar força aos lutadores: os peixes cantaram no acampamento e o pessoal de Enitsuẽgü/Taũgi no centro da aldeia. Nem os peixes nem o pessoal de Taũgi dormiram à noite para não sonharem com a derrota, e ficaram rezando suas mãos para ter força.

De madrugada, os peixes se pintaram e logo cedo os ex-mensageiros vieram chamá-los. Primeiro as pessoas da aldeia fizeram uma fila e um círculo ao redor da efígie - eles eram muitos e muito fortes. A Anta estava com eles, ela também era um lutador. Depois, os convidados (que eram tão fortes quanto as pessoas da aldeia) fizeram o mesmo. Eles se juntaram atrás do seu coordenador, e por isso hoje se faz assim. Taũgi chamou seus campeões para se ajoelharem. Primeiro chamou o Sapo Boi (Magitahata), que é gigante e musculoso. Quando o viu, Kangasingi disse para os peixes que lutaria com ele, que ficaram surpresos, achando que ele seria derrotado. Em seguida chamou a Suçuarana, a Onça Preta, o Tatu Canastra, a Anta e, por último, o Esquilo (Ĩgu).

O Sapo Boi e Kangasingi se enfrentaram, e depois de alguma expectativa (Sapo Boi era muito forte e os peixes não acreditavam em Kangasingi), Kangasingi pegou a mão de seu adversário e o derrubou no chão, surpreendendo a todos. Depois, Suçuarana lutou contra o Poraquê, que lhe deu um choque atirando-o em cima da efígie. Em seguida foi a vez da Cobra contra a Onça Pintada, que lutaram e empataram. Depois Hangitse Kuẽgü contra a Onça Preta, e também empataram. Depois o Gafanhoto lutou contra a Anta e venceu [por alguma razão o narrador observa que eles são "semelhantes"]. O Gafanhoto derrubou a Anta, que caiu de bunda no

\footnotetext{
${ }^{63}$ E a comida aqui é... peixe! Paradoxalmente, os peixes são ao mesmo tempo convidados e alimento. Tentando esclarecer isso um rapaz me explicou que nesse mito só os peixes de muito longe são "gente", porque foram convidados para a festa; os peixes da região do Alto Xingu, que não participaram do evento, "ficaram como peixe mesmo", e por isso se tornaram alimento no ritual.

${ }^{64}$ Electrophorus electricus, conhecido como "peixe elétrico".
} 
chão. Quando ela se levantou, Taũgi soprou a terra que havia ficado sobre ela e rezou para que ela ficasse com a bunda fina, como tem hoje. A Cobra lutou com outras pessoas e derrubou todas, pois era um grande lutador. Depois lutaram Esquilo e Traíra (que estava com o cabelo pintado de urucum). Este passou por baixo da perna do Esquilo e o manchou com urucum, e por isso ele tem essa mancha até hoje. Por último lutou o Tatu Canastra contra o Barbado, que derrubou seu adversário e o deixou tonto.

Terminada a luta dos campeões, todos começaram a se enfrentar. Taũgi estava irado porque os peixes estavam ganhando e decidiu lutar, desafiando Cobra, que vencia todos que enfrentava. Taũgi tentou derrubá-lo, mas não conseguiu, até que Cobra o derrubou! Taũgi fingiu ter desmaiado, e enquanto isso Cobra correu para trás dos coordenadores, entrou na terra e fugiu, com medo da revanche de Taũgi. Este foi mexer na terra por onde ele havia entrado, mas não o encontrou. Como Cobra havia espalhado tali $^{65}$ em seu corpo e Taũgi remexeu um pouco a terra, hoje há poucos lutadores em cada aldeia; se ele tivesse mexido mais e espalhado mais tali no solo, haveria mais campeões. Em seguida, ele pegou um cesto de pesca e foi no lago procurar por Cobra, pois queria matá-lo, mas não o encontrou. Ele só conseguiu pegar uma cobra aquática chamada ekeu; com raiva, a soltou dizendo que ela se tornaria alimento dos humanos ${ }^{66}$.

No final das lutas, Cotia queria lutar com Angagu, um peixe que, dizem, também "tem choque", mas ele hesitava em aceitar o desafio dizendo que estava cansado. Depois que outro peixe insistiu para que ele lutasse, Angagu aceitou enfrentar o Cotia. Angagu agarrou seu oponente e segurou seus cotovelos contra o chão para machucá-lo. Taũgi viu os cotovelos do Cotia sangrando e rezou para que ficassem murchos e sem pelos, como são hoje.

Terminada a luta, o dono da festa levou peixe e beiju para os convidados comerem, e alguns campeões dançaram atanga para receberem mais peixes do dono. No fim do dia, quando os convidados estavam na casa dos homens se preparando para dormir, vieram as ariranhas, os "índios dos peixes ${ }^{67}$ ", que chegaram atrasadas e foram direto para a casa de Taũgi, que mandou avisar seus convidados. Os peixes fecharam a porta da casa dos homens e as ariranhas foram até lá. Kangasingi resolveu que iria falar com elas, já que ele não era peixe e por isso não corria perigo. As ariranhas se surpreenderam com a presença dele, e uma delas perguntou pelo seu chefe Peixe Cachorra, dizendo que queria comer sua cabeça, e depois perguntaram

\footnotetext{
${ }^{65}$ Óleo de copaíba, que os lutadores passam sobre o corpo para ficarem fortes (cujo cheiro é perigoso para mulheres e crianças).

${ }^{66}$ Antigamente essa cobra era parte da dieta kalapalo, mas hoje apenas poucos idosos a comem. Ela costumava ser consumida quando a obtenção de peixe era mais difícil e quando ainda se usavam armadilhas de pesca (utu), que também capturavam cobras aquáticas.

${ }^{67}$ São consideradas os ngikogo, "índios ferozes", dos peixes, porque os atacam.
} 
sobre todos os outros peixes, um por um. Enquanto conversavam, Kangasingi peidou escondido no meio deles. As ariranhas adoraram o cheiro, e pediram para Kangasingi que ele peidasse mais. As ariranhas se deliciaram e perguntaram como ele fazia. Ao explicar por onde saia o cheiro, as ariranhas quiseram saber se ele poderia fazer nelas um buraco igual ao seu. Kangasingi as avisou que seria muito difícil e, mentindo para evitar que elas desconfiassem que ele tinha a intenção de matá-las, disse que quase havia morrido quando fizeram com ele. Kangasingi foi pedir o arco do Peixe Cachorra (um majahi), que afiou sua ponta e o entregou pedindo que matasse seus inimigos.

Kangasingi pediu que as ariranhas deitassem de bruços no chão, formando uma fila em frente à casa dos homens, e furou um a um com a ponta do arco do Peixe Cachora. Ele já havia matado quase todas as ariranhas, até que a última desconfiou do que estava acontecendo e fugiu. Kangasingi foi atrás dela e arremessou seu arco na intenção de matá-la, mas a ariranha mergulhou no rio e o arco só entrou um pouco. Os peixes enterraram os corpos das ariranhas e ficaram muitos felizes. De manhã dançaram pela última vez e desceram o rio de volta para sua aldeia. Kangasingi foi junto, mas no caminho retornou para sua aldeia, onde contou sua história, e foi assim que os humanos aprenderam a fazer egitsü.

O clímax do ritual é a luta - o que o mito deixa muito claro com suas descrições detalhadas de como um lutador agarrou o outro, como alguém foi derrubado, quem era mais forte, quais lutadores empataram, qual era a ordem dos lutadores, etc. Não há (ou não encontrei) nenhum mito de origem da luta a não ser esse que acabamos de ver: a luta surge com o egitsü. O mito mal menciona a efígie (a não ser quando Suçuarana foi arremessado sobre ela!), e muito menos toca no assunto de sua detalhada produção. O problema para o mito é a relação de antagonismo entre animais terrestres (sobretudo onças) e animais aquáticos, que apesar de se tratarem com toda a formalidade ritual necessária (a diplomacia entre mensageiros e coordenadores, a entrega ritualizada de alimentos), estão praticamente em guerra: o episódio da barragem deixa claro que Taũgi não quer que os peixes cheguem e, se eles conseguirem, ele quer que eles morram (por suas mãos ou de seus convidados sinistros, as ariranhas).

Há uma série de elementos que permitem pensar as relações entre anfitriões e convidados no egitsü como uma espécie de "guerra mal disfarçada". Os mensageiros, por exemplo, devem pintar seus corpos todos de preto, com fuligem de carvão, antes de chegarem à aldeia convidada, que é a pintura para a guerra. A aldeia convidada deve apresentar um 
“coordenador" (ugihongo) para cada um dos três mensageiros, os quais, após a aceitação formal do convite com o discurso apropriado, passam a se considerar "inimigos" (imütongo). As vocalizações musicais que caracterizam diferentes momentos do ritual, como o aviso de chegada, a entrada na aldeia e, da parte dos anfitriões, a escolha dos lutadores principais, são as mesmas que os narradores reproduzem quando contam histórias de guerras - são vocalizações que antecedem ataques guerreiros. O momento do roubo do fogo do morto, à noite, é especialmente tenso. O principal coordenador de cada grupo de convidados é chamado no acampamento por seu "inimigo" para que aquele grupo pegue lenha dos fogos colocados em frente às efígies, que será usada para fazer fogo no acampamento. Os visitantes pegam o fogo fazendo uma algazarra e, por vezes, fazendo gestos ameaçadores com os tições, enquanto os anfitriões permanecem sérios e atentos, parados em frente à casa dos homens. Os Kalapalo sempre dizem que há chances reais dos convidados agredirem alguém (e por isso mantêm as crianças afastadas), apesar de eu nunca ter ficado sabendo de nenhum caso desse tipo. Por causa da quantidade de turistas na aldeia, nessa ocasião os Kalapalo sempre têm que fazer um "policiamento" dos brancos para evitar que se metam em confusão com os visitantes.

\subsection{Maestria, chefia e predação}

\subsubsection{Humanos e animais}

O ciclo mítico do egitsü lida com três relações de diferença: o primeiro mito, com a distinção povo celeste (morcego)/povo terrestre (árvores); o segundo, com a distinção humanos/animais terrestres; e o terceiro, animais terrestres/peixes. Os três descrevem essas oposições a partir de diferentes formas de lidar com a alteridade: por meio da afinidade real, no casamento entre o Morcego Pescador e a filha do Ipê Amarelo; a inimizade, no caso da guerra entre humanos e animais terrestres; e a sobreposição entre afinidade e inimizade na relação entre animais terrestres e peixes, cujo resultado é o enfrentamento ritualizado.

Seres aquáticos e onças ocupam posições distintas na forma como os Kalapalo veem suas relações com os seres não humanos. A onça é tida como o primo cruzado dos humanos 
porque brigam sempre que se encontram, assim como a cobra e o sapo, a aranha e o rato, e outros animais tidos como inimigos por excelência. O que define a relação de primos cruzados aqui não é nenhuma eventual relação de cognação cross-sex, mas a situação de competição e predação real em que os sujeitos se encontram. Já a relação entre humanos e peixes é o oposto, pois a socialidade aquática talvez seja a mais próxima do ideal kalapalo da socialidade intra-aldeã. Peixes também não caçam, não são guerreiros (sequer se mostram agressivos frente às provocações de Taũgi ou à ameaça de seus inimigos ariranha) e são donos de festas dissociadas do conteúdo agonístico de outros rituais. Rituais aquáticos como o ndühe (tawarawanã) e o kagutu (o ritual das flautas proibidas às mulheres) são festas que se realizam na maioria das vezes apenas pelo grupo local. Quando são realizadas por mais de um grupo, é durante o uluki, a festa de trocas entre dois povos. Esse ritual é referido nos discursos dos chefes como um encontro entre dois "grupos de amigos" (atokondo), no qual o caráter competitivo e a tensão típicos de outros rituais, como o egitsü e o hagaka, são bastante reduzidos (por exemplo, os convidados não dormem nos arredores da aldeia, mas ficam hospedados na casa do chefe principal - como os aliados em um ritual; há combates entre os lutadores, mas que assumem uma proporção bem menor do que as lutas no egitsü - mais uma vez, como as lutas entre grupos que atuarão como aliados). O uluki celebra uma situação de partilha e troca, e a forma adequada para isso é fazê-lo festejando como (e com, na realidade $^{68}$ ) os seres aquáticos.

A origem do ndühe narra relações muito cordiais entre humanos e peixes, protagonizadas por um antigo chefe de Akuku, chamado Jagihunu, e o Peixe Cachorra. Jagihunu fizera um casamento arranjado com a filha de seu tio materno, mas ela não gostou dele e começou a tratá-lo mal. Um dia, triste pela forma como era tratado por sua mulher, Jagihunu saiu ainda de madrugada para pescar, mas não conseguia nada. Até que um peixe ahehi enorme veio até ele (informação que por si só já indicava que o peixe era um itseke, pois o ahehi é um peixe bem pequeno). Ele pediu que não o matasse, pois era uma pessoa, e avisou Jagihunu que ele não encontrava peixe porque todos estavam fazendo a festa ndühe na aldeia de seu chefe Peixe Cachorra. Mais do que isso, ele trazia um recado do próprio Peixe Cachorra que, tocado pela tristeza de Jagihunu, estava oferecendo a ele sua filha em casamento. Jagihunu aceitou e foi com Ahehi até a aldeia dos peixes, onde se casou com a filha do chefe e, durante o tempo que ficou lá, seu sogro Peixe Cachorra lhe ensinou todos os

\footnotetext{
${ }^{68}$ Pois estes seres são "trazidos" para a aldeia durante as performances músico-coreográficas.
} 
cantos do ndïhe. Quando ele voltou à sua aldeia, organizou um ndühe no qual cantou e as pessoas gostaram muito. Tempos depois, convidou um amigo para voltar com ele à aldeia dos peixes, onde ele também se casou, com a filha do Piranha.

Boa parte das pinturas corporais que os Kalapalo usam também têm uma origem aquática. A forma genérica (composta por losangos) do principal conjunto de pinturas corporais kalapalo (tüihitinhü), usada por homens no corpo todo e pelas mulheres da cintura para baixo, foi feita pela primeira vez por Mbabangisu, um espírito aquático (mas que não é um peixe), em seu neto Aulukumã. Após ficar ressentido por Taũgi ter roubado sua esposa, Aulukumã decidiu viver junto de seu avô aquático, que cuidou dele até que ficasse calmo e seu irmão fosse buscá-lo. Esse motivo é o famoso merechu que aparece na obra de Von den Steinen (1940: 229), e sabemos que ele é associado por outros xinguanos aos peixes (Agostinho, 1974: 138; Coelho, 1993: 613; Ribeiro, 1993). A pintura tüihitinhü também pode ser chamada de ingü, "roupa", da mesma forma que as roupas animais que feiticeiros e espíritos utilizam para assumir uma determinada forma e adquirir capacidades de outros corpos. Tal designação confere à pintura corporal um caráter transformativo (mais do que meramente "decorativo"), que permite aos humanos se aproximarem, durante os rituais, ao mesmo tempo de sua socialidade ideal e da socialidade aquática, vestindo uma "roupa de peixe".

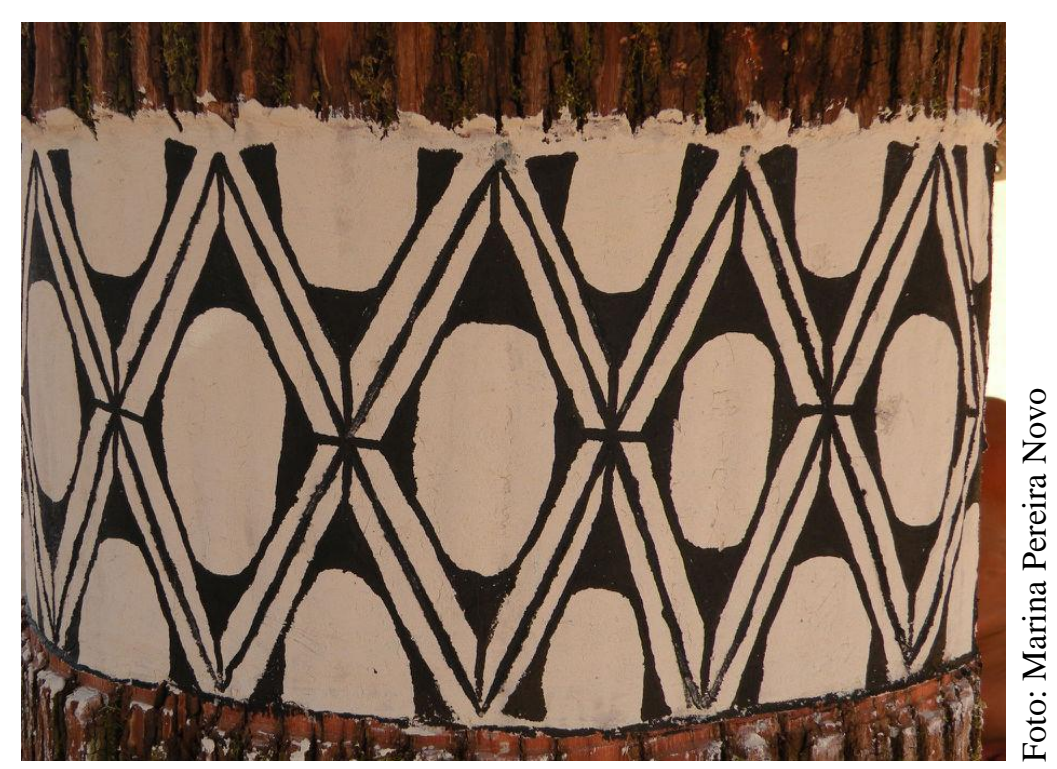

Figura 3.7: motivo tüihitinhü (merechu) aplicado sobre a efígie mortuária de uma mulher. 

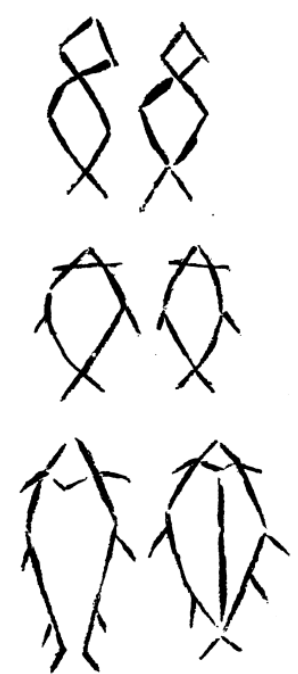

Figura 3.8: transformações de desenhos de peixe, do mais icônico (abaixo) ao mais abstrato (acima), aproximando-se das linhas externas do motivo tüihitinhü (merechu).

Fonte: Schmidt, 1905: 388

Max Schmidt (1905: 384) recolheu dois desenhos interessantes, um de ser humano e outro de peixe, no qual as formas do humano e do peixe são muito parecidas. A forma ideal do humano, o modo como ele se apresenta perante outros como gente, é uma forma aquática (apesar dos humanos comerem peixes - voltarei a isso em breve).
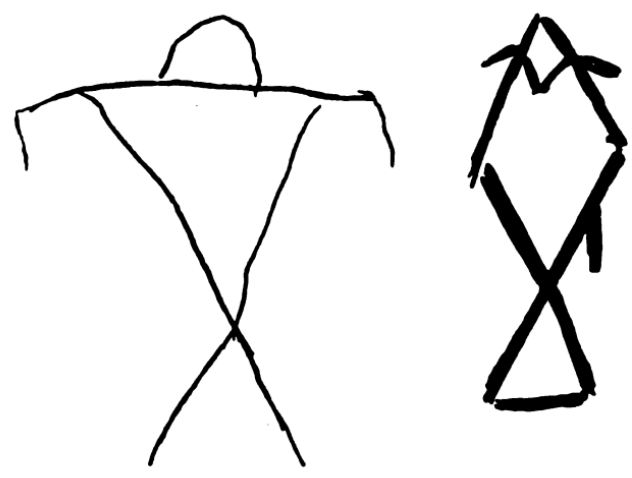

Figura 3.9: desenhos de homem (à esquerda) e peixe (à direita).

Fonte: Schmidt, 1905: 384

Assim fica mais fácil entender a associação entre peixes e um humano no primeiro egitsü, pois a perspectiva humana é uma perspectiva ambígua: sua socialidade ideal é 
aquática, mas vivem na terra e, logo, como antagonistas das onças e outros animais terrestres. Em contraposição à agressividade das onças (e outros animais terrestres chefiados por elas), que simbolizam relações de inimizade, os seres aquáticos parecem ter uma atitude benevolente com os humanos, simbolizando uma socialidade pacífica - a socialidade xinguana ideal $^{69}$.

Isso coloca uma questão ligada ao sistema alimentar kalapalo: por que ele exclui ${ }^{70}$ a caça e o consumo de carne de animais terrestres e se volta quase integralmente para o consumo de peixes? Algumas aves (como macuco, pomba, jacu, papagaio, arara, e outros) e macacos-prego são consumidos quase exclusivamente em situações liminares (reclusão pósparto, couvade, menstruação, após o uso de certos remédios), mas quando os Kalapalo moravam longe das margens dos rios esses animais eram muito mais presentes na dieta cotidiana. Sabemos que essa lógica alimentar está ligada a uma "lógica das substâncias", segundo a qual certos animais não devem ser consumidos por algumas de suas propriedades corporais (Basso, 1973; Viveiros de Castro, 1977). Por exemplo, não se consome animais tidos mais ou menos como "podres", como o jacaré que, apesar de consumido pelos brancos do Posto Leonardo e pelos índios do Médio Xingu, é sistematicamente rejeitado pelos Kalapalo. Como o jacaré come peixes mortos e mesmo em putrefação, consumir este animal seria a mesma coisa que comer uma grande quantidade de comida podre, que deixaria o sangue da pessoa sujo e traria as consequências ruins dessa contaminação.

Outra substância perigosa é o sangue, que pode provocar dores, mal-estar e ainda deixar o corpo da pessoa vulnerável a ataques de espíritos. Viveiros de Castro (1977; 2002b) observa que os Yawalapíti pensam os animais terrestres como "cópias" dos espíritos, e dizem que seu sangue "tem flechas" que podem ser introduzidas no corpo humano pelo consumo de sua carne. Essa associação entre animais e espíritos é importante, porque revela um problema central que o sistema alimentar precisa resolver: a subjetividade dos animais, sua capacidade de aparecerem como pessoas para os humanos. Em outras cosmologias amazônicas que

\footnotetext{
${ }^{69}$ Talvez seja preciso expandir a oposição onças/peixes, pois junto das primeiras está a anta e junto dos segundos estão um humano e um gafanhoto. Anta e gafanhoto se enfrentaram na luta de campeões, e o narrador observa que "eles são parecidos". Talvez ele se referisse à força de ambos, mas eles são parecidos sob outro aspecto, já que os dois não pertencem ao conjunto de que fazem parte nessa história (a anta não é uma onça, assim como o gafanhoto não é um peixe). É preciso notar que os gafanhotos são peixes para os humanos mortos, assim como as antas são peixes para as onças - sob esse aspecto, os dois são semelhantes porque têm capacidade de assumir uma "função peixe-presa" para certos sujeitos.

${ }^{70}$ Melhor dizendo, "evita” a caça. Um homem que tem uma esposa kamayurá, por exemplo, caça pacas, porcos e antas com frequência para sua esposa, pois estes animais são parte importante da dieta kamayurá, e ele próprio se acostumou a comê-los (o que, vale dizer, é motivo de reprovação para a maioria das pessoas).
} 
atribuem aos animais a condição de pessoas, a caça sempre corre o risco de ser vista como uma forma de guerra (Fausto, 2001; 2002; Lima, 1996). Porém, todos os povos caçadores dispõem de formas pelas quais, justamente, fazem da caça uma atividade distinta da atividade guerreira, "anulando" a subjetividade do animal caçado. Para os Kalapalo, isso parece difícil de ser feito com os animais terrestres, mas é mais fácil de fazer com os peixes.

Os animais terrestres são, de modo geral, "mais itseke" do que muitos outros ${ }^{71}$, o que se reflete em sua maior capacidade de aparecer (se tornarem visíveis) como pessoas para os humanos. Quando algo assim acontece é porque o humano (sua alma) foi levado pelo espírito, o que implica em adoecimento e, nos casos mais graves, morte. Um dos problemas da caça é que o ato de matar um animal ativa sua capacidade de aparecer como pessoa ${ }^{72}$ e, logo, de se apoderar da alma do caçador. Nem sempre o próprio animal aparece como gente, e muitas vezes quem se manifesta para o humano agressor é seu dono (o chefe de sua aldeia). Começou a ficar claro para mim como o ato de caçar era um problema a ser levado mais a sério quando um grupo de mecânicos do Posto Leonardo que estavam na aldeia para consertar o caminhão da associação resolveu caçar um veado no final do dia. Várias pessoas disseram que não comeriam a carne, de jeito nenhum, senão correriam o risco de "ficar loucos" e saírem correndo no mato, como veados. Porém, quando o veado já estava limpo e a carne pronta, ela foi consumida rapidamente, inclusive por boa parte dos que disseram que não poderiam comer. Matar o veado seria muito perigoso, porque seu espírito, seus parentes ou seu donochefe poderiam vir se vingar e roubar a alma do caçador. Já comê-lo poderia ou não deixar a pessoa em um estado de vulnerabilidade, e pareceu a muitos Kalapalo que valeria a pena arriscar.

A relação com as cobras revela bem como a agressão pode despertar o "lado humano" de um animal. Certa vez estava na casa do chefe de uma pequena aldeia, quando sua esposa gritou apavorada: havia uma jiboia enrolada na estrutura do teto da casa, próxima da porta. $\mathrm{O}$ dono da casa pegou uma vara bem comprida e empurrou a cobra para fora, através da palha do telhado. Enquanto isso ele perguntava à cobra: "O que é que você veio fazer aqui? Você está assustando seus netos! Por que você quer assustá-los?!”. Ele arremessou a cobra no mato ainda viva, e me disse que não deveria matá-la, pois isso seria perigoso para ele. Pouco

\footnotetext{
${ }^{71}$ Mas nem todos, como por exemplo uma espécie de "taturana" dona do tabaco (tukutinhü), que está entre os itseke mais poderosos, ou o beija-flor (dono do pequi), também muito perigoso.

${ }^{72}$ Como discutirei na sessão seguinte, essa capacidade varia intra e entre espécies.
} 
depois, a cobra voltou, e o dono da casa passou um bom tempo conversando com o animal pedindo que ele fosse embora, até que resolveu ignorá-lo. Ele me contou que aconteceu algo semelhante quando apareceu uma sucuri enorme no córrego perto do local onde as mulheres pegam água: passou três dias conversando com a sucuri para que ela fosse embora. A explicação era simples: cobras são itseke, e quem as mata corre o risco de ter sua alma levada pelo espírito do animal.

Em suma, os humanos reconhecem que a caça coloca em jogo as posições de predador e presa, sujeito e objeto, e que eles são o lado mais fraco dessa relação. Quando alguém mata um animal, o caçador pode se tornar "presa" de um itseke. O grande problema é que os Kalapalo não veem uma forma de contornar isso, fazendo com que a caça inevitavelmente tenda para a guerra - o que eles obviamente não desejam, tanto por uma questão de saúde quanto por seu ethos pacifista (é comum ouvir que "quem caça é ngikogo", índios bravos porque caçar, para os alto-xinguanos, está muito próximo de matar gente). É preciso lembrar que os animais terrestres não são qualquer tipo de gente, mas são o pessoal do pai dos gêmeos, as pessoas das quais a humanidade se separou (por meio, inclusive, de uma guerra), e que talvez por isso eles tenham tanto potencial para capturar os humanos. Nesse sentido, a evitação dessa guerra é a evitação da guerra com aqueles dentre os animais que estão mais próximos dos humanos.

A caça e o consumo do macaco-prego geralmente aparecem como uma "exceção", mas esse não é o ponto de vista dos Kalapalo, para quem ele não é um animal terrestre, e sim arbóreo, e por isso não fazia parte do "pessoal" de Enitsuẽgü. Há ainda a afirmação complexa de que se come macaco-prego porque é um animal "parecido com gente" (ver também Viveiros de Castro, 2002b). A aparência física do macaco, dizem os Kalapalo, é a razão de sua semelhança com os humanos ${ }^{73}$, mas segundo Viveiros de Castro (2002b) haveria mais: para os macacos, os humanos seriam como onças, assim como para as onças os humanos seriam macacos ${ }^{74}$ (ibid: 48). Isso confirma, pela negativa, a ideia de que é impossível fugir da guerra quando se caça: os humanos só comem macacos-prego porque, na relação com eles, conseguem manter a posição de predador e, logo, de sujeito da relação, evitando os perigos da caça de outros animais.

\footnotetext{
${ }^{73}$ Há um mito segundo o qual os macacos-prego teriam se originado dos bebês abandonados pelas mulheres monstruosas (e seriam, portanto, ex-humanos).

${ }^{74}$ Ver a expressão "gente é macaco de onça" usada pelos Yawalapíti.
} 
A situação com os peixes é bem mais simples, apesar de não estar completamente livre de perigos. A pesca, em condições normais, está dissociada da belicosidade, aproximando-se da "coleta 75 ". Quando alguém vai caçar, diz que vai matar algum animal; mas quando alguém vai pescar, diz que vai kangaki (kanga-ki, peixe-INST), "pegar peixe", de forma semelhante ao que diria se fosse buscar mandioca (kuigi-ki, mandioca-INST), buscar embira (oĩ-ki, embira-INST), buscar madeira ( $i$-ki, madeira-INST), buscar pequi (indze-ki, pequi-INST) atividades não predatórias. Obviamente, para pescar é preciso matar os peixes, mas isso não parece representar nenhum perigo na maioria das condições. Talvez porque a maioria dos peixes que se pesca não são "peixes de verdade", mas imitações de peixe (kanga hutoho) produzidas por um tipo de camarão (hüta) para enganar os humanos e evitar que eles matem muitos peixes-pessoa. Como grande parte do que se pesca não são peixes de verdade, excluise dessa atividade o caráter guerreiro que torna perigosa a caça de animais terrestres.

Mas ainda assim, eventualmente, os humanos entram em confronto com os peixes quando a pesca precisa ser feita em grande quantidade, como na pescaria com timbó e rede que antecede todo egitsü. Franco Neto (2010: 29) também menciona um episódio no qual os pescadores, após terem conseguido muitos tucunarés, decidem voltar para casa, com medo de que o dono dos peixes começasse a se irritar com eles e os provocasse algum tipo de mal. Nesses casos, a pesca "ativa" um dono-chefe dos peixes, que é com quem os Kalapalo consideram estar em potencial conflito. Porém, diferentemente do que acontece com os animais terrestres, os humanos conseguem controlar essa relação, oferecendo comida (mingau de pequi e pimenta) e pedindo que os xamãs conversem com o espírito.

Essas pescarias podem ser eventos muito tensos. Em 2010, durante a pescaria para um egitsü em Tankgugu, os Kalapalo quase foram devorados pelo Porco Gigante (Heu Kuẽgü), dono da lagoa onde pescavam (e, é importante notar, chefe dos peixes que pretendiam capturar). Mas eles deram sorte e foram salvos por Atugua, um espírito visível sob a forma de um redemoinho que se formou sobre o lago, que enfrentou o Porco Gigante e o acalmou. No fim das contas, o dono do local aceitou que os Kalapalo pescassem ali e liberou muitos peixes para serem capturados. Em outra ocasião, os Kalapalo decidiram pescar em um lago cujo dono-chefe é uma "sereia” (Kuge Kuẽgü). Decidiram pescar naquele local porque o dono do lago onde havia sido feita a pescaria do ano anterior (uma Onça) havia dito aos xamãs que não

\footnotetext{
${ }^{75}$ Os Kĩsêdjê (jê) também veem a pesca como uma espécie de "coleta" (comunicação pessoal de Marcela Coelho de Souza).
} 
aceitaria a comida que lhe ofereceram (mingau de pimenta e pequi) e não liberaria seu pessoal para a pesca (e de fato a pescaria foi um fracasso, todos reclamaram de ter passado fome). Num dado momento, uma grande panela de mingau de pimenta, deixada na beira da lagoa como oferta para o dono do local (o que serve para agradá-lo e persuadi-lo a liberar seu pessoal para a pesca), tombou para dentro d'água. Todos acharam muito estranho, pois ninguém percebeu nada a não ser um vento que passou de repente (muito fraco para derrubar uma grande panela de alumínio cheia de mingau). Segundo um xamã, a panela teria sido chutada pelo dono do outro lago, que deveria estar com ciúmes do dono do novo local de pesca, e por sorte ele não decidiu tentar matar os pescadores. Em função de tais perigos, os Kalapalo sempre escolhem um lugar cujo dono tenha sido calmo e generoso em pescarias anteriores. O lago da Onça, por exemplo, é onde os Kalapalo pescaram em 2006, 2008 e 2009, e só não pescaram lá em 2010 por causa dos resultados ruins da pescaria do ano anterior, associada ao comportamento egoísta de seu dono. Já para o egitsü de 2011 retornaram a ele, pois agora que a alma de um importante xamã vive lá ${ }^{76}$, consideram que ele pode interceder a seu favor junto ao dono-chefe do local. Se várias pescarias forem bem sucedidas, pode-se estabelecer uma relação de cordialidade duradoura com espíritos específicos.

O volume de uma pescaria coletiva faz com que ela tenda para a guerra, e para evitá-la é preciso mobilizar chefes e xamãs para atuar na pacificação dos donos dos peixes, através de discursos formais apaziguadores (no mesmo molde da fala dos chefes) e da oferta de alimento. Com os animais terrestres a situação estaria perdida, mas com o dono-chefe dos peixes é possível tentar estabelecer uma relação cordial. Como a relação é com um chefe (frequentemente um animal terrestre - voltarei a isso ainda) que assume a posição de sujeito entre os peixes, estes podem ser pescados como objetos sem problemas.

Vê-se então que há uma ligação entre donos, chefes e relações pensadas como guerra: são estas que desencadeiam o aparecimento de tais tipos de agentes.

\footnotetext{
${ }^{76} \mathrm{O}$ destino da alma será discutido no capítulo seguinte.
} 


\subsubsection{Donos de outros, donos para outros}

A noção de "dono" está presente em praticamente todas as cosmologias ameríndias, e, segundo síntese de Fausto (2008: 330),

(...) designa uma posição que envolve controle e/ou proteção, engendramento e/ou posse, e que se aplica a relações entre pessoas (humanas e não-humanas) e entre pessoas e coisas (tangíveis ou intangíveis).

Entre os Kalapalo, um dos sentidos do termo para dono (oto) é o de alguém que possui um objeto qualquer, seja porque o tenha fabricado ou então comprado. Quando se refere a pessoas e objetos tangíveis, oto pode ser entendido simplesmente como aquele que detém a propriedade sobre algo. Eu sou dono de meus cadernos assim como alguém é dono de seu cinto, outro é dono de uma canoa, e etc. Ainda em relação a objetos, oto também tem o sentido de "cuidador" ou "responsável" (esta última palavra é bastante usada para traduzir esta noção). O caminhão e o trator da Associação Comunitária de Aiha, por exemplo, têm donos, que são os responsáveis por guardar suas chaves, autorizar seu uso e pressionar as pessoas para que não os estraguem. O material da escola também tem um dono, que é um os professores; os remédios e o material de primeiros socorros, na falta de uma UBS, ficam com seu dono, o agente de saúde mais velho da aldeia. O rádio é um objeto cuja apropriação é especialmente interessante. Em tese, os rádios foram fornecidos pela FUNASA para viabilizar a comunicação entre as aldeias e a primeira referência de atendimento, o Posto Leonardo, e por isso idealmente deveriam ser alocados na UBS. Mas em todas as aldeias xinguanas que conheci o dono do rádio é sempre o primeiro cacique: toda conversa via rádio deve passar por sua casa. Aiha, por exemplo, não tinha rádio até 2007, quando ganhou um de presente de um visitante alemão, que fora assistir a uma festa, e depois recebeu outro da FUNASA. Os agentes de saúde colocaram um dos rádios na UBS, mas que em pouco tempo foi solicitado pelo chefe, que manteve consigo os dois rádios, um em funcionamento e o outro guardado.

Outro sentido de oto é o de "conhecedor". Alguém que tenha aprendido cantos, histórias e rezas com um mestre se torna seu oto e, por isso, pode executar e transmitir estes conhecimentos a outras pessoas de maneira formal e valorizada, eventualmente demandando pagamento. Esta noção de conhecedor também abrange habilidades manuais, como a 
construção de barragens para a pesca com timbó ou a fabricação de objetos: quem sabe fazer qualquer coisa com destreza é seu dono. Isso é claro no âmbito da especialização produtiva regional, no qual cada povo alto-xinguano é considerado oto de algum tipo de objeto porque sabe produzi-lo: cerâmica, cintos e colares de conchas, arcos especiais, sal. Em alguns desses casos, a noção de oto tem um sentido ainda mais forte, pois torna o conhecimento exclusivo. Por exemplo, um mehinaku que conheci poderia aprender a fazer colares de caramujo com seu sogro nahukwa, mas nunca sequer tentou; a filha de uma mulher mehinaku que nasceu na aldeia kalapalo poderia ter aprendido a arte da cerâmica com sua mãe, o que também nunca lhe interessou (sua própria mãe nunca produziu cerâmica na aldeia). Figueiredo (2010) afirma que entre os Aweti a noção de "donos do sal" não teria nenhuma conotação de exclusividade, mas isso talvez se deva ao fato do sal ser de fato produzido em quase todas as aldeias xinguanas (os Kalapalo mesmo o produzem - com pouca frequência, mas ainda assim o fazem).

Lugares também têm donos, como o caminho de entrada principal (tanginhü) da aldeia e o caminho para a lagoa. É dever de seus donos mantê-los limpos e organizar mutirões quando for preciso refazer algum trabalho coletivo, como construir uma ponte (nos quais deve oferecer comida a todos que trabalharem). O dono do caminho principal (tanginhü oto) em 2007 era, não por acaso, filho do anetü responsável por receber mensageiros de outras aldeias em quase todas as ocasiões; hoje o segundo cacique é quem se tornou o tanginhü oto. A casa dos homens também tem dono, e este precisa ser um anetï. Desde 2006 Aiha teve duas casas dos homens (uma ficou muito estragada e outra foi construída em seu lugar). A primeira que conheci foi cuidada pelo sobrinho uterino do primeiro cacique, e a atual é cuidada por seu filho mais novo, o principal campeão kalapalo. Nestes casos, passa-se da mera relação de cuidado para outra, que é a de patrocinador. Decidido quem será o dono da casa dos homens (um anetü que possa e queira assumir essa posição), será sua responsabilidade organizar pescarias para oferecer comida aos homens que trabalharem em cada etapa da construção, algo parecido com o que se passaria se ele estivesse construindo sua própria casa. Vale notar que espaços ou objetos de uso coletivo não "têm donos" simplesmente, mas precisam ter donos. Não há nenhuma ideia de que algo possa ser "coisa da comunidade" (katutolo engü, lit. "coisa de todos") e cuidada por todos, pois se algo é de todos, significa que não é de ninguém. 
Mesmo o caminhão e o trator da aldeia, apesar de serem ditos "da comunidade" (em português), têm seus donos ${ }^{77}$.

Não são só os espaços da aldeia que têm donos, mas quase toda a paisagem xinguana "pertence" a alguém. Espíritos, por exemplo, possuem alguns lugares porque os escolheram como local de construção de suas aldeias. Trechos do rio, lagoas, espaços na mata e qualquer morrinho de terra no chão podem ser a morada de espíritos, e não há lugares livres desses seres (apesar de haver lugares mais e menos perigosos). Toda a paisagem é social logo de saída e, ao lidar com ela, ao arrancar uma planta, queimar um mato ou derrubar um morrinho, é preciso ter em mente que pode-se estar entrando em relação com seus donos. Um povo também pode ser dono de lugares não habitados, na condição de que lá tenha havido alguma aldeia de seus ancestrais. Em condições ideais, um Kalapalo não abriria uma aldeia onde os Matipu já tenham vivido (a menos que ele seja "meio matipu"), ou que tenha sido uma aldeia wauja, por exemplo (Aiha só foi aberta em território kamayurá por falta de opção, motivo de queixas até hoje).

Outro sentido de dono é "causador" (que muitas vezes aparece associado à ideia de patrocinador). Os donos do trovão e do vento, por exemplo, são espíritos capazes de provocar estes fenômenos, que não existem sem tais seres. Este sentido também é encontrado entre os Trio, que associam o dono, o tronco de uma árvore e os pés das montanhas, que carregam as ideias de "estar na origem de" ou "ser a base de" (Fausto, 2008: 331). O dono e patrocinador de uma festa também é, de certa forma, seu “causador", pois ele é a condição para que a festa aconteça. Sob o aspecto do ciclo de pagamentos dos rituais, fica clara a congruência entre as posições de causador e patrocinador, pois tudo o que as pessoas fazem para uma festa "deixa o dono com vergonha" e o faz retribuir com alimento, o que, por sua vez, "deixa os executantes com vergonha", que se sentem no dever de trabalhar para o dono da festa. Dar envergonha o receptor, cria obrigações e, nesse sentido o patrocínio do dono causa uma festa tanto quanto as atividades dos demais causam, no dono, a obrigação de patrocinar. Uma das capacidades dos donos-mestres é fazer outras pessoas agirem, mas este fazer agir é sempre marcado por uma ambivalência, "pois não se sabe exatamente quem causa a ação e quem está agindo" (ibid: 343).

\footnotetext{
${ }^{77}$ A relação da "comunidade" com recursos dos brancos (objetos ou dinheiro) por meio de seus donos será discutida no capítulo 6 .
} 
O dono de uma festa para espíritos também se torna pai do espírito (uma pessoa) e dono da máscara ou instrumento musical (um objeto) usado para tornar o espírito presente, e esta relação ressalta um dos aspectos da relação de dono, que é sua formulação a partir da linguagem da filiação adotiva (ibid: 333). Isto fica claro na relação das pessoas com seus animais de estimação, também construída como filiação adotiva. Quem tem um pássaro, um cachorro, um macaco ou uma ariranha, tem uma espécie de filho e, quando alguém quiser saber de quem é um animal de estimação, perguntará “tü mukugu igei?", "este é o filho de quem?". Várias vezes fui apresentado a animais de estimação por seus donos me dizendo algo como "Antonio, inke, ande umukugu”, "Antonio, veja, este é meu filho". Longe de ser uma peculiaridade kalapalo, a associação entre a relação dono/animal de estimação e pai ou mãe/filho ou filha pode ser encontrada entre vários povos (Fausto, 1999; 2001; 2008). Aquele que é dono de um espírito também se torna seu pai, e pode se referir ao espírito como seu filho(a). A base desta identificação entre um dono (oto) e aquele que é "possuído" (otondelü) como pai e filho está nos cuidados que o primeiro deve dispensar ao segundo. Oferecendo comida e música aos espíritos, que se alimentam e se alegram nas festas, estes seres são parcialmente domesticados e a relação entre um humano e um itseke, conduzida nestes termos, permite que este tenda para a humanidade (Barcelos Neto, 2008; Franco Neto, 2010). $\mathrm{Na}$ verdade, o inverso seria o processo de adoecimento, no qual a alma do doente é alimentada por um espírito, do qual tende a se tornar como um filho. Ao domesticar alguém, o dono funciona como um vetor de identificação para aquele que é otondelü, que tende a se alterar e se transformar em alguém mais parecido com seu oto. Como já vimos no capítulo anterior, esta relação entre donos e seres dos quais se cuida e a linguagem da filiação está presente também na terminologia de parentesco kalapalo. Um dos significados de oto é pai ou mãe, podendo ser aplicado para qualquer parente de $\mathrm{G}^{+1}$, e seu coletivo, otomo, pode se referir virtualmente a todos os parentes desta geração. Um dono é como um pai, assim como um pai é um tipo de dono.

Sobre os Aweti, Figueiredo (2010: 182) chama a atenção para o fato de que "em uma acepção mais genérica, portanto, a noção de itat [dono] não precisa ser associada a relações de cuidado, domínio ou posse, mas simplesmente à marcação de intensidade na relação entre um sujeito e um objeto, em comparação a outros sujeitos" (grifos no original). A autora argumenta assim que "podemos falar do dono como sujeito cuja potência é tornada aparente pela relação que estabelece com outros sujeitos através de um objeto, na esteira das análises 
de Strathern a respeito da troca na Melanésia como um meio de evidenciação de capacidades internas" (ibid: 183). Dessa forma, ser dono é o que faria de alguém um sujeito aos olhos de outro, com o qual se relaciona por meio daquilo que possui.

Essa talvez seja a característica geral dos donos/chefes: estar no lugar de algo ou alguém para um terceiro. Eles seriam como signos/representamen no sentido mais geral que Peirce dá ao conceito: “A sign, or representamen, is something which stands to somebody for something in some respect or capacity” (Peirce, 1960 [1932], parágrafo 228). Isso é diferente de definir os donos/chefes a partir da relação de "controle", pois esta apareceria somente quando dois donos entram em relação mútua. Se quisermos ficar na linguagem da semiótica de Peirce (id. ibid.), podemos dizer que a relação entre um signo (dono-chefe) e um objeto (um "povo") não pode existir por si só, enquanto uma relação diádica, mas necessariamente deve ser parte de uma relação triádica envolvendo também um interpretant (tudo o que o signo comunica para seu receptor). Ao invés das relações de controle e filiação adotiva definirem a maestria, é a relação entre diferentes donos que instaura aquelas como interpretant - ou seja, a relação de diferença simétrica entre donos é condição para a efetividade de uma relação assimétrica entre um dono e aquilo/aqueles que são "possuídos". Poderíamos dizer que se o dono-chefe é um representamen, a filiação adotiva é a representação, definida por Peirce (1958, parágrafo 540) como “(...) the operation of a sign or its relation to the object for the interpreter of the representation" (grifos no original).

\subsubsection{Afinidade potencial e chefia}

Quando falei sobre os donos dos espaços e estruturas coletivas, deixei propositalmente de lado a ideia de dono da aldeia (ete oto) para abordá-la aqui em mais detalhes, pois ela é uma boa conexão entre os conceitos de dono e chefe. Toda aldeia tem um dono, a pessoa responsável por escolher seu local, organizar o trabalho de limpeza do terreno e, o que é muito importante, construir a primeira casa. Este dono será, idealmente, seu chefe, mas a situação na prática é mais complicada. Aiha, por exemplo, já foi reconstruída em dois lugares contíguos desde a mudança para aquele local no começo dos anos 1960, para comportar o crescimento da população e a falta de lugar para enterrar os mortos. Na última mudança, em 2000, a primeira casa no novo local foi construída por um homem que, apesar de ser anetü, 
não era o primeiro cacique. Ele passou a ser considerado o dono da aldeia, mas nem por isso se tornou o chefe principal, e quando este homem se mudou de Aiha, o então primeiro cacique se tornou automaticamente o dono da aldeia.

De qualquer maneira, deixando de lado essas torções micropolíticas, no modelo indígena as posições de dono de aldeia e chefe se sobrepõem, e isso nos aproxima das concepções kalapalo sobre os “donos dos animais". É comum entre vários povos ameríndios que os animais sejam entendidos como animais de estimação de um espírito referido como seu "dono" ou "mestre". Uma das imagens frequentes é a de um espírito-dono que mantém seus animais de estimação presos em sua casa ou em um cercado, e aqueles que os humanos encontram são apenas os que o dono permitiu que saíssem para passear e eventualmente serem mortos pelos humanos. De fato, para os Kalapalo, qualquer animal (peixe, pássaro ou animal terrestre) faz parte de um coletivo que se vê como gente e vive em aldeias exatamente iguais às dos humanos. Suas aldeias são circulares, possuem casa dos homens, chefes, xamãs e mesmo feiticeiros e, assim como os humanos, também fazem seus rituais. Tudo é exatamente igual. Porém, eles não têm um "dono" do mesmo tipo que, por exemplo, os Runa (Kohn, 2007), que os mantêm em cercados, ou como os Arara (Teixeira-Pinto, 1997: 97), para quem os donos mantêm suas crias dentro de "caixas". Para os Kalapalo é um pouco diferente, pois o que os animais têm de fato é um chefe (que também é chamado de dono pelos humanos - voltarei a isso em breve, pois não é um mero detalhe). Este é sempre um itseke que é dono e chefe da aldeia onde vivem os animais, e a relação entre eles não evoca, até onde eu saiba, nenhuma imagem de continente-conteúdo como as que acabei de mencionar, pois cada animal vive em um casa, com seus parentes e etc., exatamente como em uma aldeia de humanos. Os animais são livres para ir e vir, casar-se com animais de fora e mesmo para mudar de aldeia, se quiserem. Não estão presos a um dono que os domestica, mas apenas, como os humanos, se sentem bem vivendo em uma aldeia onde haja um grande chefe que aglutine pessoas, patrocine rituais $^{78}$, ofereça comida, instrua e cuide bem de seu pessoal.

Mesmo assim, o aspecto de "controle" não está ausente desta relação, pois um donochefe dos animais pode regular as relações entre seu pessoal enquanto coletivo e os humanos. Os animais, individualmente, andam por aí livremente passeando, indo a suas roças, fazendo suas pescarias, encontrando suas namoradas. Porém, quando os humanos intentam interagir com eles enquanto grupo (em grandes pescarias coletivas, mas virtualmente o mesmo

\footnotetext{
${ }^{78}$ Não é à toa que o itseke "menos humano" que se conhece (Ahasa) vive sozinho.
} 
aconteceria em uma grande caçada, caso a praticassem), esta relação depende de seu donochefe. É como se uma função-chefe só fosse ativada, isto é, tornada perceptível, na relação com outros grupos, único tipo de ocasião em que um dono-chefe se apresenta como a “imagem singular de um coletivo" (Fausto, 2008: 335). De fato, porque talvez não exista algo como um "coletivo" fora de qualquer relação com outros grupos de escala equivalente. É como se a relação assimétrica entre um chefe e um povo só se tornasse visível em relações simétricas e potencialmente conflituosas com outras pessoas.

Assim como no mundo dos humanos, entre os animais nem todos têm a capacidade de assumir a posição de dono-chefe. Estas pessoas são concebidas pelos Kalapalo sob a forma de seres considerados "outros" de alguma maneira, e geralmente perigosos. Tomemos os veados como exemplo. No começo dos tempos eles viviam na aldeia de Enitsuẽgü, que era o chefe de todos os animais terrestres, e hoje muitos ainda vivem em aldeias chefiadas por outras onças, mas deve haver, segundo dizem, aldeias formadas só por veados. Nesse caso, seu chefe seria um grande veado com chifres, um as ã kuẽgü, isto é, um veado que, por suas características corporais em relação ao coletivo de veados que chefia, é considerado kuẽgü, “outro, perigoso, grande". O mesmo se passa com os porcos, que podem viver tanto em aldeias chefiadas por onças quanto em aldeias de porcos. Estas provavelmente são formadas ao mesmo tempo por queixadas e caititus, mas elas certamente são chefiadas por um queixada gigante, um heu kuẽgü (novamente, “outro, perigoso, grande”).

Cada animal pode ter aldeias e donos-chefes próprios, mas cada plano de existência (aquático, terrestre e celeste) tem seus grandes chefes, aqueles capazes de chefiar a todos, e estes são, quase todos, grandes predadores. Já vimos que no tempo mítico Enitsuẽgü chefiava $\operatorname{todos}^{79}$ os animais terrestres: outras onças, tatus, antas, veados, porcos. Quando os humanos mataram todos os animais e Taũgi os ressuscitou, eles se espalharam pelo mundo e se dividiram em aldeias próprias ou chefiadas por outras onças. A onça é o maior felino das Américas e o principal predador terrestre da América do Sul. Ataca e é capaz de vencer qualquer animal terrestre (à possível exceção do tamanduá, que, dizem os Kalapalo, dificilmente consegue caçar com sucesso). De forma semelhante ao que Costa (2007) comenta para os Kanamari, no começo quase tudo estava contido por uma forma-onça, e a mitologia

\footnotetext{
${ }^{79}$ Nem todos, na verdade, pois que eu saiba o macaco-prego ainda não existia (e ocupa um lugar especial na relação entre humanos e onças) e o tamanduá talvez não fizesse parte desse grupo, já que ele e a onça são, segundo os índios, amigos, mas que se enfrentam.
} 
narra o enfraquecimento dessa forma e a multiplicação dos seres no mundo. Mesmo os seres aquáticos, que não estavam contidos pela forma-onça de Enitsuẽgü e não passaram pelo mesmo processo de dispersão e multiplicação, estavam contidos em uma estrutura associada a uma onça aquática (Kuakutu, a casa dos homens de Sagankguẽgü, o dono da água e chefe das estrelas $^{80}$ ).

Já no mundo celeste, os pássaros são chefiados pelos gaviões e pelo urubu rei de duas cabeças. Que eu conheça, há cinco tipos de gaviões nomeados pelos Kalapalo, e o gavião real $^{81}$ (Harpia harpyja), a maior ave de rapina das Américas, será sempre o maior chefe onde viver. Porém, o pequeno gavião tete também é anetü, e pode tanto ser um chefe menor na aldeia de um gavião real quanto ser o chefe principal em outra aldeia de pássaros na qual não haja harpias. Se estes gaviões tiverem que se relacionar entre si, eles podem ser hierarquizados em função de seu tamanho, mas isso não faz diferença em relação ao conjunto dos pássaros, para os quais são apenas "gaviões”. Neste nível de contraste, todos os gaviões são tolo kuẽgü, "híper pássaros", "pássaros outros" ou "pássaros perigosos”, considerados como tais por suas capacidades predatórias, já que são aves de rapina que se alimentam de outros pássaros, peixes e pequenos roedores. Outra coisa que aproxima formalmente onças e gaviões é sua relação de inimizade com os humanos. A primeira, como já vimos, é o primo cruzado e inimigo dos humanos na terra, e o segundo é um dos inimigos dos mortos no céu (um de seus chefes). O modelo da relação dos humanos com estes chefes animais, onça e gavião, é a inimizade, forma pura da afinidade amazônica (Viveiros de Castro, 2002a).

Já ouvi dizer que o urubu rei seria chefe de todos os pássaros, mas também já ouvi que em sua aldeia viveriam apenas outros urubus. Sendo um comedor de carne podre, ele é o oposto de um grande predador. E ele é um chefe poderoso, que manda os urubus comuns sobrevoarem a terra procurando carniça para ele: ele não só come podre como ele não vai atrás de sua própria comida. Como se esta condição dúbia não bastasse, o urubu rei também é

\footnotetext{
${ }^{80}$ Os gêmeos roubaram a água de Sagankguẽgü, que ficava guardada em grandes panelas dentro de seu kuakutu (a casa dos homens, que, lembremos, leva o nome de uma onça aquática), e dentro dessas panelas viviam os seres aquáticos. Quando os gêmeos as quebraram, a água caiu nos rios e lagos, junto com os seres que viviam confinados. É considerando a relação entre o kuakutu e o itseke Kuakutu que digo que mesmo os seres aquáticos estavam unificados sob uma "forma onça".

${ }^{81}$ A maioria dos autores menciona a existência, nas aldeias alto-xinguanas, de grandes gaiolas cônicas de madeira, feitas para prender um gavião real. Os Kalapalo dizem que criavam essas aves com o único objetivo de conseguir penas para enfeites, e eu nunca ouvi nenhuma explicação diferente. Hoje, como as espingardas facilitam a captura desse animal, eles preferem caçá-lo ao invés de criá-lo (pois é muito difícil manter um gavião alimentado). Também dizem que decidiram não criar mais essas aves depois de um incidente ocorrido nos anos 1970: uma criança se aproximou da gaiola de um gavião real e teve sua barriga rasgada pelas unhas do animal.
} 
o dono do fogo, e por isso é objeto de algum respeito por parte dos pescadores. Quando saem para pescar, os homens sempre assam alguns peixes para comer antes de voltar pra casa (prática que as mulheres não apreciam nem um pouco), e se houver sobras do que foi assado, raramente um homem as levará consigo, deixando-as no lugar para os urubus comerem, "porque eles são os donos do fogo", me disseram em uma pescaria (ver Schultz e Chiara, 1971, para a mesma atitude entre os Wauja). Mas é preciso reconhecer que, dentre os comedores de podre do céu, o urubu rei é diferenciado não só por sua estética. Onde quer que haja essa espécie de urubus, eles são sempre os primeiros a se servir da carcaça, e outras espécies só se servirão depois do urubu rei (Sick, 1997). Além do mais, ele não procura carniça, mas vigia outros urubus e, quando percebe que estes encontraram algum animal morto, desce para comer, e quando chega, mesmo os maiores urubus se afastam e deixam que o urubu rei termine sua refeição (ele só fica saciado quando já mal consegue se mover). Ele vive solitário, e voa no máximo aos pares, mas na hora da alimentação, é como se ele próprio tivesse organizado uma "caçada". É por isso que o urubu rei e o gavião real disputam a posição de chefes das aves: o primeiro é o maior comedor de podre-predador alado, mas dotado de uma posição distintiva impressionante entre os outros urubus, e o segundo é o maior predador.

Passando para o mundo aquático, já vimos que o chefe dos peixes é o peixe cachorra. Ele é um dos principais peixes carnívoros da bacia do Xingu e se alimenta de qualquer tipo de peixe, além de alcançar um tamanho avantajado. Apesar de haver peixes muito maiores nos rios e lagos, como o jaú, a pirarara e o trairão, o peixe cachorra conjuga tamanho e uma estética ameaçadora, preenchendo requisitos importantes para poder ser visto como um grande chefe. Além do peixe cachorra, outro animal capaz de chefiar embaixo d'água é a sucuri. Esta, além de chefe, é vista como um grande lutador, e uma das coisas que um jovem mais deseja é conseguir uma parceria com um espírito-sucuri que lhe dê força para as lutas. Também há uma peculiaridade no mundo aquático que não encontrei nos mundos terrestre e celeste (o que não quer dizer que não existam), que é a existência de aldeias de animais aquáticos chefiadas por animais terrestres, como o queixada gigante e variedades de onças.

Ainda sobre a vida embaixo d'água, vimos que as ariranhas são "os índios dos peixes”, isto é, são vistas pelos peixes como índios guerreiros. Quando o assunto é capturar peixes, há poucas coisas mais impressionantes do que ver um bando de ariranhas pescando, o que as coloca na posição de grandes predadores. Mas se é assim, inicialmente é curioso que uma 
ariranha não possa ocupar a posição de chefe dos peixes. Mais ainda, as ariranhas não têm chefes, são um bando amorfo. Esta é mais ou menos a forma como os Kalapalo veem povos como os Kayapó, Kayabi ou Kĩsêdjê, pois associam a prática da guerra à ausência de chefes (quer dizer, à ausência do tipo alto-xinguano de chefe). Se tivessem "chefes de verdade" eles não seriam guerreiros, mas seriam pacíficos e fariam festas com seus vizinhos. Tenho a impressão de que isto está relacionado à forma como as ariranhas se alimentam e se relacionam com seus filhotes. Já vi diversas vezes as pessoas comparando alguém tido como egoísta a uma ariranha, principalmente pessoas que comem escondido, pois estes animais devoram sua comida de forma voraz. O pior de tudo é que, de tão egoísta, uma ariranha sequer alimenta seus filhotes. Certa vez um rapaz encontrou um filhote de ariranha perto do lago onde fora pescar e resolveu trazê-lo para casa, para que se tornasse o animal de estimação de seu filho. Um dia fui à sua casa ver o animal, que era a sensação daquela região da aldeia no final da tarde, quando as crianças ficavam brincando com ele. Conversando sobre a ocasião em que ele encontrou o filhote, perguntei, brincando, se a mãe dele não ficaria brava, ao que o rapaz me respondeu sem a menor dúvida: "não, se ele ficasse lá ele ia ficar com fome, pois a ariranha nem divide comida nem com seus filhos”. Por isso a ariranha não pode assumir o papel de chefe dos peixes, apesar de ser um grande predador, pois isso não basta. É preciso ser capaz de oferecer cuidados, dentre eles a nutrição. Se um dono-chefe é alguém capaz de cuidar, alimentar e agregar pessoas, como a ariranha poderia fazê-lo, se não divide sua comida nem mesmo com seus filhos? A ariranha é pura potência predatória, mas sendo tão egoísta ela também é o antípoda da boa vida coletiva. Só sabendo predar e sem a menor capacidade de cuidar e agregar, a única posição que resta às ariranhas é a de "índios dos peixes".

Fausto (2008) afirma que a razão pela qual animais como a onça, a sucuri e o gavião são os seres capazes de engendrar relações assimétricas com outros é que "o dispositivo principal de produção de englobamento, portanto, de magnificação da pessoa, é a incorporação canibal. A predação é um vetor assimétrico de identificação-alteração: quem come contém o outro e a sua alteridade dentro de si ${ }^{82}$ " (ibid: 335). Animais predadores seriam, portanto, capazes de simbolizar o movimento pelo qual uma pessoa assume o lugar de um coletivo, engloba uma coletividade plural para fazê-la aparecer sob sua figura, uma pessoa

\footnotetext{
${ }^{82}$ Figueiredo (2010: 185) descreve o esquema de Fausto como se houvesse "cuidados dentro" e "predação fora". Mas pela citação acima me parece que o autor quer dizer que a capacidade de adotar e cuidar seria fruto da capacidade de comer seus próprios "filhos".
} 
singular (no sentido de Lima, 2005). Mas como Fausto (op. cit.: 332-333) bem observa, para compreender a categoria dono é preciso investigar (todas) as relações que ela implica e como este esquema relacional aparece em contextos variados. $\mathrm{O}$ autor prossegue:

O que estou sugerindo, enfim, é que a relação de maestria opera, à maneira da afinidade simétrica, como um "operador cosmológico" (Viveiros de Castro 1993). Se temos, como propõe Viveiros de Castro, uma afinidade sem afins - intensiva e potencial - temos também um tipo de filiação cosmopolítica e interespecífica (uma metafiliação), na qual a adoção, e não a transmissão vertical de substâncias, é o elemento crucial. (ibid: $348-349$ )

Seguindo a sugestão do próprio autor de investigar as relações que a categoria dono implica, me pergunto se no caso kalapalo seria possível falar da filiação adotiva (assimétrica) e da afinidade potencial (simétrica) como dois "operadores cosmológicos" (id. ibid.) distintos, ou se não se trataria de diferentes aspectos de uma mesma estrutura, uma única forma relacional que implica ao mesmo tempo em simetria e assimetria, consanguinidade fictícia e afinidade potencial, cuidados e inimizade. Pois para quem os chefes mostram sua forma ${ }^{83}$ predadora e em que condições?

Grande parte das vezes que um anetü kalapalo se apresenta como tal (se não todas), ele o faz exibindo insígnias de animais predadores, sendo a mais notória delas os acessórios de partes do corpo da onça. Mas não é o tempo todo que um anetü precisa se fazer visível desta maneira, e as principais situações nas quais isso acontece são os rituais regionais. A condição ao mesmo tempo de super-pai e predador dos chefes evoca a noção de "condensação ritual" de Houseman e Severi (1998), segundo a qual objetos ou sujeitos eficazes em contextos rituais são produzidos pela acumulação de conotações contraditórias ou paradoxais, cujo resultado são figuras que Severi (2004) caracteriza como "complexas". Também evocando Severi (2007) e referindo-se à ambiguidade aparente dos donos/chefes, Fausto (op. cit: 343) observa que "esse caráter paradoxal, em que elementos antagônicos condensam-se na forma de uma imagem ao mesmo tempo singular e múltipla, é a fonte mesma (...) da eficácia ritual desses personagens". Mas o que significa dizer que o espaço desta eficácia é o ritual? Ou melhor, por que é no plano do ritual, quando sobressaem relações de afinidade potencial (e

\footnotetext{
${ }^{83}$ Uso o conceito de forma no mesmo sentido que Strathern (2006 [1988]), entendido como a maneira pela qual uma pessoa torna visíveis/perceptíveis alguns de seus aspectos constitutivos para se apresentar como um agente em uma relação.
} 
não, talvez, nas interações cotidianas entre parentes), que esta "forma complexa", este "sujeito paradoxal" (a forma "ao mesmo tempo singular e múltipla" do dono-chefe), é ativada? Como vimos no capítulo anterior, uma das marcas do chefe kalapalo é que, antes de tudo, ele se apresenta como tal para chefes estrangeiros. Ninguém se torna chefe para os seus em primeiro lugar, e sim para os outros, pois é sendo visto e conhecido por chefes de outros grupos que um jovem é feito substituto de seus pais ou avós.

Em todos os casos, o dono aparece como uma figura de mediação. De fato, talvez fosse mais preciso dizer que aquilo que é possuído por alguém permite a relação de um terceiro com seu dono. Os donos são "ativados" na relação com outros (mesmo que sejam os coaldeões do chefe dono da casa dos homens - é para eles que é preciso cuidar da casa). Independentemente da natureza singular ou coletiva da relação (um lutador com um espírito, ou um chefe-e-seu-povo com outro chefe-e-seu-povo), as relações com donos são sempre entre dois sujeitos. Nos casos das relações entre coletivos, as noções de dono e chefe necessariamente se sobrepõem, e o dono-chefe aparece como uma espécie de condição para a produção de formas coletivas de ação, sempre na relação com outros e, sobretudo, em relações de potencial conflito. Não há ação coletiva "comunitária" no sentido que atribuímos ao termo, mas alguém - um oto - sempre deve ser a sua origem.

Pode-se dizer que, da forma como é mobilizada em contextos de ação pelos Kalapalo, a condição de dono-chefe é uma função das relações de inimizade ritual entre chefes estrangeiros. Quando dois grupos se encontram em um ritual como o egitsü, o fazem por meio de seus chefes, que se tratam reciprocamente como inimigos. $\mathrm{O}$ aparecimento de uma pluralidade de pessoas sob a forma de um coletivo, que se apresenta na figura singular de um chefe, está condicionado às relações de "inimizade simbólica" dos chefes estrangeiros (que por sua vez tornam possível a "amizade" - a não-inimizade prática, real - dos grupos). O mesmo se passa na relação entre os humanos, quando organizam grandes pescarias, e os chefes dos peixes: é somente nessa condição de confronto que a figura dos chefes se faz necessária. A estética predadora/agressiva dos chefes é voltada para estes encontros (intra ou interespecíficos), é direcionada para fora, e não para dentro do grupo (quando isso acontece, é na figura tão comum do chefe acusado de feitiçaria). A assimetria entre um coletivo e seu chefe não é produzida, como sugere Fausto, porque este é capaz de comê-los e, ao fazê-lo, englobá-los em seu corpo, mas porque o aspecto predador que os chefes apresentam de forma recíproca instaura entre eles uma relação de diferença: duas onças podem guerrear, mas não se 
caçam, não se comem e não fazem parte de um mesmo "todo" (não se identificam). O parentesco e todas as formas de assemelhamento resultam de processos de diferenciação, e a forma mais englobante da semelhança - um povo -, que implica na relação de assimetria entre (pelo menos) um chefe e seu pessoal, só existe porque há um plano no qual esse chefe se diferencia de outros sujeitos equivalentes, e é essa diferença que a inimizade ritual entre os chefes instaura. Ao fazê-lo, os chefes criam coletivos, mas com a condição de que eles sejam uma função da afinidade potencial e da inimizade - ainda que ritualizadas. Podemos, enfim, passar ao ciclo do egitsü. 


\title{
Capítulo 4 - Refazendo o parentesco com alguns mortos: a produção de corpos-Casas para chefes
}

\begin{abstract}
Não se trata, contudo, de descrever ou representar os corpos; pois estes já têm suas qualidades próprias, suas ações e suas paixões, suas almas, em suma, suas formas, que são, elas mesmas, corpos. (Deleuze e Guattari, 1995 [1980]: 27)
\end{abstract}

O ciclo do egitsü começa com a morte. Não tratarei das questões ligadas ao processo de adoecimento, pois elas são bastante complexas e já foram discutidas por outros autores (Barcelos Neto, 2006; 2007; 2008; Cardoso, 2004b; 2008; Franco Neto, 2010; Novo, 2010). O objetivo deste capítulo é discutir os destinos da alma após a morte e o tratamento diferenciado que um chefe falecido recebe no mundo dos vivos e na aldeia dos mortos. Na intenção de fazer do chefe morto alguém memorável, os Kalapalo empreendem um processo que tenta assegurar à sua alma alguma humanidade, condição necessária para se criar uma relação de continuidade entre mortos e vivos. Este processo, que pode ser visto como uma "reconstrução do parentesco perdido", gira ao redor da mesma coisa que a produção do parentesco entre os vivos: a fabricação de (novos) corpos.

\subsection{A pessoa dividida}

Todos os seres possuem uma "alma", cujo nome genérico é akuã , frequentemente descrita como um princípio de animação ou princípio vital, cuja falta acarreta a morte. É consenso que nos humanos ela está presente desde a concepção, mas os Kalapalo não parecem se preocupar com sua formação ou origem. Quando eu insistia nessas questões, a única resposta que eu obtinha era que já no ventre materno o bebê em formação tinha akuã. A akuã é intimamente associada à forma daquilo a que está vinculada, e o mesmo termo é utilizado para se referir a um duplo, sombra, imagem e reflexo de alguém ou algo. Os Waiwai, por exemplo, falantes de karib e habitantes da região das Guianas, também utilizam um único termo para falar de "alma", "força vital", "sombra" e "figura" (Rivière, 1997: 140). Para os

\footnotetext{
${ }^{1}$ Basso (1973) traduz o termo como "sombra". A autora também se refere à akuã como "interactive self", por ser a forma pela qual uma pessoa ou um objeto sempre pode aparecer como humano para alguém (Basso, 1987a).
} 
Kalapalo, qualquer forma projetada por um corpo (seja um corpo humano, animal ou um objeto) é sua akuã. Talvez por isso mesmo não haja nenhuma preocupação com qualquer suposta origem da alma humana: ela não é algo que possa ter uma gênese separada do bebê em formação, pois é uma característica de qualquer corpo.

A akuã kalapalo não parece estar localizada em nenhum lugar específico do corpo, sendo, antes de tudo, coextensiva ao mesmo, mas pode se separar dele em diversas situações e em diferentes graus. Sua presença é indispensável, pois quando a alma deixa o corpo por muito tempo é sinal de que a pessoa está gravemente doente (foi capturada por algum espírito), e quando ela o deixa definitivamente, a pessoa morre. Bebês, por exemplo, têm almas muito suscetíveis de serem capturadas por espíritos. Seus corpos são objeto de uma produção cuidadosa fora do ventre materno, até pelo menos os dois anos de idade. Enquanto o corpo da criança não tiver sido totalmente humanizado, sua alma permanece muito próxima de seres que possuem outros tipos de corpos - os espíritos, e particularmente o espírito Placenta, que alimentou e cuidou do bebê durante a gestação, tem um carinho especial por ele e sempre deseja levá-lo para viver consigo (conforme apresentado no capítulo 2). A alma do bebê também é frágil, não suporta força nem os efeitos ruins de comidas gordurosas ou com muito sangue. Por isso seus pais não devem fazer esforço ou comer alimentos inapropriados, pois a alma da criança fica, nestas condições, suscetível a ataques de espíritos (o que permitiria que sua alma fosse levada por esses seres). Já os adultos, em condições normais, têm sua alma bem presa ao corpo, mas ainda assim ela passeia todas as noites durante o sono (estes passeios da alma é que produzem os $\operatorname{sonhos}^{2}$, visões de uma realidade fora do tempo na qual a akuã pode encontrar outras akuã, de humanos ou não). A situação mais complexa é a dos xamãs, que podem "morrer" voluntariamente, ingerindo grandes quantidades de fumaça de tabaco, para que sua alma se desprenda do corpo e possa ver e ouvir espíritos.

Os Kalapalo distinguem ainda uma "alma do olho", ingugu oto, que significa literalmente "dono do olho" 3 ". Ela equivale ao ojutai ogamawato ("alma do - ou no - olho") dos Wauja, que Barcelos Neto (2008: 239) descreve como "a consciência e a memória", e pode ser entendida como uma "substância vital (paapitsi). Como é comum entre outros povos que identificam "almas do olho", esta designa a pessoa que vemos na íris de alguém quando

\footnotetext{
${ }^{2}$ Basso, 1987a.

${ }^{3}$ Não encontrei nenhuma informação semelhante no trabalho de Franco Neto (2010).
} 
olhamos para ela ${ }^{4}$ (nosso próprio reflexo ${ }^{5}$ ), e os Kalapalo dizem que ela é responsável pelos movimentos dos globos oculares. Em relação a este ponto, o dono do olho é aquilo que o anima, assim como a alma de uma pessoa é indispensável para a animação de seu corpo. Falantes de karib de outras regiões, como os Waiwai (Rivière, 1997: 141), os Trio (id. ibid.), os Akawaio (ibid: 145) e os Yekuana (id. ibid.) também reconhecem a existência de almas do olho. A relação entre akuã e ingugu oto é complexa, pois os Kalapalo insistem que, a despeito de seus nomes distintos, elas são "a mesma coisa" ("as duas são o corpo"), e que na verdade todos têm apenas uma alma, uma única akuã. Isso porque elas só aparecem efetivamente como "duas" após a morte, e não faz muito sentido distinguir entre akuã e ingugu oto para alguém vivo.

A presença da akuã no corpo é o que garante a vida de qualquer ser humano. Ela se assemelha a uma ideia de "consciência", pois toda perda dos sentidos é entendida como uma saída da alma (especificamente da alma-sombra; o dono do olho nunca deixa o corpo de um vivo), e desmaiar e morrer são vistos como diferentes graus de um mesmo processo (Basso, 1987a). Uma pessoa que desmaiou "morreu um pouco", mas sua alma deve voltar ao corpo, como indicam sua respiração, o batimento do coração e o pulso (três importantes índices de que a alma ainda está ligada ao corpo). Mas o índice mais importante de todos é a capacidade de reabrir os olhos (a palavra "vivo", tingugingo, parece ser formada a partir da raiz ingu, “olho"): se isso não acontece, é porque o dono do olho já partiu, e a morte se tornou irreversível.

A morte dá início um processo de divisão da pessoa, com a progressiva saída do corpo da $a k u \tilde{a}^{6}$ e do ingugu oto como entidades distintas, e que terão destinos opostos (a primeira se transforma em itseke, e a segunda permanece humana). No exato momento da morte, quando cessam a respiração e o coração, a alma do olho deixa o corpo, vai para a frente de sua casa e começa uma complicada jornada para a aldeia dos mortos, no céu; já a akuã apenas começa a se soltar do corpo, processo que só termina após o enterro. Como ela está ligada à forma do corpo, à sua imagem, parece lógico que ela só se desprenda depois que o corpo desaparece deste mundo - isto é, quando é finalmente enterrado e tornado invisível. Sem algo com forma

\footnotetext{
${ }^{4}$ Lagrou, 2007; McCallum, 1996; Stang, 2009: 71, nota 52.

5 Basso (1987a: 94) já notara que o reflexo que se vê no olho de alguém também é sua "alma", mas sem se discutir sua especificidade.

${ }^{6}$ Ao deixar o corpo, esta passa a ser chamada de akuãpe, "ex-alma" (ou akuãpügü, com o mesmo sentido). Por uma questão de simplicidade, mantenho o uso de akuã.
} 
a que se ater, a alma se solta. Como diz Vilaça (2002) para os Wari, seria mais apropriado dizer que a alma fica livre quando o corpo se ausenta, e o enterro é o caso extremo disso.

Até lá, a akuã fica perto de seu corpo e de seus parentes (ela ainda rondará a aldeia com frequência até que se faça um egitsü para ela). Inconformada com a morte, a akuã chora e tenta o tempo todo se fazer ver e ouvir por seus parentes vivos, querendo chorar com eles, se despedir e, eventualmente, levá-los consigo (não por maldade, mas por apego). Ela dificilmente consegue se fazer perceber, pois a voz dos mortos é muito fraca, e parece que eles só conseguem emitir um único som (algo como um a-ha-ha-ha-ha..., segundo dizem). Raramente alguém vê ou ouve a alma de um morto nessas ocasiões, o que poderia ser letal. A alma do morto sente um forte desejo (hogene) de continuar junto de seus parentes, e esse sentimento pode fortalecê-la e permitir que ela consiga se fazer ver ou ouvir por um vivo. Se isso acontecer, é um sinal de que a alma do morto conseguiu transformar esta pessoa em alguém semelhante a ela, isto é, um morto. Se alguém já estiver um pouco doente e perceber a alma de um morto de alguma maneira, certamente morrerá; se não estiver doente, leva um "choque" no corpo e desmaia, pois sua alma sai temporariamente do corpo por causa do susto. A alma de um morto pode fazer isso quase sem querer, pela simples força da saudade (otonu), um sentimento perigoso que pode conectar pessoas diferentes como um vivo e um morto, ou um humano e um itseke. Saudade e desejo são sentimentos que se cruzam com facilidade, e ambos deixam o corpo fraco e a alma sujeita a se desprender.

Vários povos karib que distinguem entre uma alma-sombra e uma alma do olho também lhes atribuem destinos post mortem diferentes, e há muitas semelhanças entre tais concepções e as dos Kalapalo. Entre os Waiwai, a alma (ekati, durante a vida, ekatïnho após a morte) permanece próxima à cova como um espírito invisível, mas que pode se manifestar sob a forma de animais, enquanto a alma do olho segue para o céu (Rivière, 1997: 140-141). Para os Trio, a alma do olho faz uma jornada rumo a um lugar onde o céu e a água se encontram e no qual ela mergulha e se extingue, ao passo em que a alma (amore) sobrevive por um tempo perto dos vivos e tenta levá-los consigo (ibid: 142-143). Para os Akawaio, sabe-se que uma alma vai para o céu e outra permanece na Terra (ibid: 145), mas não tenho informações suficientes para afirmar se a que vai para o céu seria um equivalente das outras almas do olho 
karib. Os Ye'kuana também afirmam que o destino póstumo da alma do olho é o céu ${ }^{7}$ (id. ibid.).

Logo que deixa o corpo, a alma do olho inicia sua jornada rumo à aldeia dos mortos, que fica em algum lugar do céu a oeste (giti uendoho). Lá não há trabalho, a comida é deliciosa, ninguém é casado (não tem afins, portanto) nem faz sexo, só vive com seus próprios parentes e a aldeia toda está eternamente em festa: é o mundo perfeito, dominado pela consanguinidade. Segundo o único xamã de Aiha que já viu o que acontece com a alma do olho deixando o corpo, ela sai de sua casa e vai até a metade do caminho entre a porta da frente e o centro da aldeia, onde espera que apareça um caminho que desce do céu. Esse caminho nunca toca o chão, e fica em uma posição sempre mais alta do que o morto conseguiria escalar sozinho. Em pouco tempo, a alma do olho começa a avistar pessoas descendo, que são alguns de seus finados parentes consanguíneos mais próximos e queridos (nunca afins), que vêm para buscá-lo e acompanhá-lo até a aldeia dos mortos. É preciso que os parentes do morto venham, pois o morto só consegue subir em direção ao caminho com a ajuda desses parentes, que o erguem.

O caminho até o céu é repleto de dificuldades que podem fazer com que a alma se perca ou "morra de vez" (sendo devorada ou transformando-se em fumaça). No meio do caminho, ao lado da estrada, posta-se um itseke chamado Kainahagü, que fica pedindo aos mortos que olhem para ele. Os parentes do morto devem instruí-lo a não olhar, caso contrário ele inevitavelmente seguirá no caminho deste itseke e viverá eternamente triste em sua aldeia, uma espécie de avesso da aldeia dos mortos: lá ninguém é parente, pois só vivem nela os que preferiram ouvir o chamado de um itseke aos conselhos de seus semelhantes. Depois de passar por Kainahagü, o morto atravessa uma ponte de madeira muito lisa e escorregadia, o que deve fazer com muito cuidado. Caso caia da ponte, a alma desaparecerá para sempre: segundo alguns, ela simplesmente vira fumaça; segundo outros, é devorada pelo Híper Lambari (Tahugi Kuẽgü), que vive no rio embaixo da ponte, e também desaparece.

\footnotetext{
${ }^{7}$ Estes últimos parecem ser os karib que, à moda dos povos de língua pano, reconhecem uma maior quantidade de almas. Segundo Guss (1989), haveria duas contidas no corpo, uma alma do olho (ayenudu akano akato) e uma alma do coração (ayewana akano akato), que são boas, representam a imortalidade, viajam durante os sonhos e se vão para o céu após a morte. Outras quatro, por sua vez, seriam externas ao corpo e, segundo Rivière, teriam um caráter "redentor", pois absorveriam os pecados da pessoa. Seriam elas uma "alma na Lua" (nuna awono akato), uma "alma no Sol" (shi awono akato), uma "alma na água" (tuna awono akato) e uma "alma na Terra" (akatomba).
} 
Depois da ponte, o morto encontrará um grande jatobá (uagi), cujas folhas secas caem em grande quantidade e cobrem todo o chão da estrada. O problema é que o que o morto vê como folhas secas é na verdade lama e, caso escorregue e caia, ficará invisível para sempre. Ele nunca será visto por seus parentes mortos, sendo obrigado a viver em uma eterna situação de tristeza. Ao longo de todo o caminho, a qualquer momento, o morto e seus parentes também podem ser atacados por índios ferozes (ngikogo), que vivem tocando fogo no mato e assustando os mortos. "São os índios deles", como dizem, mas o que os mortos veem como índios ferozes seriam, segundo os vivos, pequenos caranguejos (tühoko).

Após passar por tudo isso, a alma finalmente chega à aldeia dos mortos ${ }^{8}$. Ela está muito fraca, sua carne está "mole", seu sangue tem um cheiro ruim e seu corpo está feio e pálido. Mas ela já não é exatamente uma "alma”, e sim um corpo; ela só é alma para os vivos. Este corpo fraco, pálido e feio precisa ser fortalecido e embelezado, para se tornar novamente um corpo humano. Para isso, o morto vai para a casa de seu pai, se este já tiver morrido ${ }^{9}$, onde entrará em reclusão (assim como uma moça ou um rapaz que entra na puberdade). Esta reclusão não tem uma duração fixa, mas termina caso aconteça um eclipse ou se faça uma efígie para o morto em um egitsü. Durante esse período, o morto será escarificado para retirar o sangue "sujo" (que cheira podre) do cadáver que ele deixou para trás, e trocar sua pele velha por uma nova, mais bonita. Seu pai esfregará remédios de espíritos nas feridas provocadas pela arranhadeira para fortalecer seu filho morto, que deve tomar eméticos para limpar seu estômago e engordar, com o objetivo de voltar a ter um corpo belo, forte e jovem exatamente como se faz na terra. Até sua saída da reclusão, a pessoa deve se comportar tal como jovens durante a reclusão pubertária, deixando de comer certos alimentos que desagradem aos espíritos donos das plantas que está usando como remédios. Rapidamente o corpo do morto se torna lindo (isso é sempre enfatizado) e seu cheiro muda, por causa da comida diferente que passa a consumir e pela ausência de sexo.

A comida na aldeia dos mortos é muito mais saborosa do que aquela consumida na terra, e isso é absoluto consenso. Mas também é consenso que, do ponto de vista dos vivos, a comida dos mortos não é "de verdade", pois enquanto eles pensam que comem peixes,

\footnotetext{
${ }^{8}$ Segundo os Aweti, apenas os chefes tatuados entrariam na aldeia dos mortos, enquanto as pessoas comuns seriam devoradas pelo Urubu Bicéfalo (Figueiredo, 2010: 86). Para estes tupi, a condição de chefe seria, portanto, necessária à continuidade da vida após a morte.

${ }^{9}$ Se a pessoa morrer ainda criança ou muito jovem, e seu pai ainda estiver vivo, sua alma esperará debaixo de uma árvore frutífera chamada $a g o$, em frente à entrada principal da aldeia dos mortos.
} 
estariam se alimentando de gafanhotos. Os mortos veem gafanhotos pequenos como peixes bicuda (Boulengerella spp.) e os grandes gafanhotos como trairões (Hoplias lacerdae). Estes gafanhotos ficam no campo, mas os mortos enxergam tais áreas de vegetação como rios e lagos, e procuram gafanhotos como se fossem peixes. A despeito disso, esses falsos peixes são muito mais saborosos do que os consumidos pelos vivos, e para os mortos são "comida de verdade". É por comerem gafanhotos, insetos "secos", que os mortos não têm cheiro e praticamente não têm sangue. Outra diferença entre os pontos de vista dos vivos e dos mortos é em relação à passagem do tempo, pois enquanto é dia para uns, é noite para os outros.

Enquanto isso, o outro aspecto da pessoa, a akuã (alma-sombra), tem um destino diferente. Por um lado, ela permanece perambulando até o final do egitsü, e até lá, vez ou outra, tenta se comunicar com seus parentes vivos. À noite, os mortos se transformam em animais e podem aparecer aos humanos como tais, frequentemente sob a forma de corujas ou raposas. Certa vez, quando já estávamos todos quase dormindo, um homem se levantou armado e saiu; voltou pouco depois, sem ter dado qualquer tiro. "O que foi?", perguntei. "Fui tentar matar uma coruja, acho que era a alma de um morto", ele respondeu. Na sequência me explicou que teve a impressão de que o animal dizia "keteha!", "vamos!", o que seria um morto, ainda não homenageado, com saudades de seus parentes chamando-os para sua companhia. Caso ele, ou outra pessoa, tivesse ouvido claramente o canto da coruja como uma voz humana (isto é, como “vamos!”), seria um sinal de que lhe restavam poucos dias de vida.

Por outro lado, essa mesma alma-sombra também começa um processo de metamorfose em itseke. Se em vida o morto foi dono de alguma festa para itseke, como uma Onça, um Atugua (espírito do redemoinho) ou uma Arraia, irá se transformar em um itseke do mesmo tipo e viverá em sua aldeia. Caso contrário, nos momentos que antecedem a morte algum espírito invariavelmente se apossará da alma do moribundo, e sua alma-sombra também viverá em uma aldeia de espíritos. O que está por trás disso é uma transformação corporal, pois a alma-sombra passa a ingerir comida de itseke, a ver o mundo como eles o veem e seu corpo começa se assemelhar ao deles. Isso é concomitante ao aparentamento, pois nesse movimento o morto se torna um itseke porque está se tornando seu parente, e viceversa. Mas isso não significa necessariamente uma "desumanização". Ao mesmo tempo em que desenvolve um corpo de itseke, a alma-sombra também fica jovem e bonita, podendo aparecer assim para seus parentes em sonhos. Ainda, a alma-sombra nunca se esquece de seus parentes vivos, e pode visitá-los sob a forma de um animal noturno, ajudar pajés que 
conheceu em vida ou auxiliar em pescarias coletivas. Há casos de três mortos ${ }^{10}$, por exemplo, cujas almas-sombras os moradores de Aiha sabem viver em um lago específico, e que podem ajudá-los em pescarias. Antes de morrer, um pajé sugeriu a seu cunhado, também pajé, que usasse o canto da Onça (o espírito no qual ele se transformaria após a morte) durante suas sessões de cura, pois ele próprio, agora sob a forma de um itseke, viria ajudá-lo. Mais do que desfazer o parentesco, a morte permite que a alma-sombra se torne parente de outros seres ao mesmo tempo, se tornando simultaneamente humana e itseke ${ }^{11}$.

Com o desenvolvimento do conceito de perspectivismo na etnologia americanista (Lima, 1996; 2005; Viveiros de Castro, 1996; 2002d; 2007b), a noção de alma ganhou centralidade e passamos a entender melhor sua relação com o corpo e o parentesco. Como vem sendo mostrado, o mundo ameríndio é habitado por uma infinidade de pessoas, humanas e não humanas, que o apreendem de pontos de vista distintos (Descola, 1994 [1986]; 1998; Viveiros de Castro, 1996; 2002d). Neste mundo, todos os seres possuem alma, que é sua capacidade de participar como pessoa (geralmente sob forma humana) em uma relação, fazendo da humanidade um pano de fundo comum a todos os seres. Se a alma une tudo o que existe no cosmos, o corpo é o responsável por sua diferenciação: diferentes seres possuem pontos de vista específicos porque possuem corpos diferentes. Nas palavras de Viveiros de Castro (2002d: 372), "é sujeito quem tem alma, e tem alma quem é capaz de um ponto de vista".

Corpo e alma não estão em uma relação de continente e conteúdo, nem de aparência e essência. Às vezes podemos ter essa impressão quando o corpo é visto como uma "roupa" ou um invólucro que pode ser vestido e removido, como, por exemplo, os corpos dos animais que ocultam sua alma humana; porém, para o animal, essa alma é na realidade um corpo (seu corpo verdadeiro, cuja forma é humana de seu ponto de vista, enquanto sua aparência animal é apenas uma "roupa"). Mas a alma não é um elemento reflexivo, consciente, acessível ao sujeito, dado que ela só age à revelia da pessoa. "O sujeito e seu duplo se ignoram na mesma medida em que a dimensão 'animal' do animal, fazendo parte da experiência sensível dos humanos, escapa ao animal que se vê como humano" (Santos, 2010: 62). Ou seja, para que

\footnotetext{
${ }^{10}$ Um deles é mencionado por Basso (Becker, 1969) em sua tese (ele já havia morrido à época). Este homem era epilético e teve uma crise enquanto pescava em um lago, sozinho. Ele caiu na água e morreu afogado, e por isso a Onça dona do local ficou com sua alma-sombra.

${ }^{11}$ De forma semelhante ao que ocorre com os xamãs em vida, que também se tornam parentes de itseke.
} 
uma alma se manifeste, é preciso que ela interaja com sujeitos de natureza diferente da sua, isto é, sujeitos com corpos diferentes.

Como já discutimos no capítulo 2, ter um corpo específico é o resultado de um processo de aparentamento: alguém se torna humano porque teve seu corpo fabricado por outros semelhantes; aquele que se torna itseke, é porque começou a se tornar parente destes seres. A morte também implica na transformação das relações de parentesco do morto e de seus corpos. Assim como diz Coelho de Souza (2002: 378) sobre povos de língua jê, "a morte aqui corresponde pois ao aparentamento (...) lá”. A divisão da pessoa em alma-sombra e dono do olho corresponde a aparentamentos distintos: a primeira se torna um ser de outra natureza, um itseke (que, como tal, pode roubar almas de outros vivos, ou ajudar xamãs); a segunda (a menos que olhe para Kainahagü no caminho), não se aparenta de estranhos, mas reforça seus laços de parentesco com os que já morreram. Essa dualidade da alma parece replicar, após a morte, a dualidade corpo/alma: o corpo vivo é a forma que a pessoa assume em meio a seus parentes na terra, e sua existência é simultânea à presença da alma do olho (esta só deixa o corpo na morte); já sua akuã pode se destacar e se unir temporariamente às akuã de outras pessoas (em sonhos) ou a espíritos (tornando-se parcialmente parente destes seres, caracterizando metamorfose e doença). A pessoa é feita, ao mesmo tempo, de dois corpos possíveis: um corpo humano e um corpo-itseke, tanto em vida quanto após a morte. Em vida, o aspecto potencialmente itseke deve ser controlado e, se mantido inerte, é visto apenas como reflexo, sombra ou imagem do corpo humano (manifestando sua capacidade de agência somente quando o corpo sai do estado de vigília).

A alma-sombra e o dono do olho não são, portanto, entidades que alguém "possui", mas diferentes aspectos da pessoa, diferentes formas pelas quais alguém é capaz de se relacionar com outros (espíritos, vivos, mortos). Como é comum na Amazônia indígena, conceitos como "alma", "sombra" e "duplo" nunca possuem sentidos unívocos. Pelo contrário, estão sujeitos a condições pragmáticas de uso da linguagem e de reflexão sobre as relações, tendo seu sentido tanto restringido quanto multiplicado por suas possibilidades de aplicação. Temos dificuldade para definir a "alma" ameríndia porque não se trata de algo ao qual possa ser acoplado um significado, um objeto que possa ser submetido a um esquema de classificação, mas sim da capacidade de se assumir diferentes posições em uma multiplicidade de relações. Como diz Santos (2010: 90), “a alma talvez seja um substantivo sem substância - esse efeito de perspectiva - que busca nomear um estranhamento que se dá 
em toda troca comunicativa (seja exclusivamente entre humanos ou entre humanos e nãohumanos) e em toda delimitação dos contornos da pessoa”. Alma é, antes de qualquer coisa, um ponto de vista em uma relação (o que é diferente, note-se, de dizer "sobre" uma relação). O que é alma-sombra para mim, meus parentes e todas as outras pessoas que chamo de "gente", é corpo para um espírito ou para um morto. O que o conceito de akuã revela não é exatamente uma "dualidade interna" ou uma simples divisibilidade da pessoa, mas sim a capacidade de alguém assumir diferentes pontos de vista por meio de diferentes corpos.

\subsection{O enterro e o começo da organização do ritual}

Acordei com choros. Não consegui entender de onde vinham exatamente, as pessoas estavam se movimentando muito lá fora. Era bem cedo, o sol ainda não havia nascido e de minha rede eu podia ver pela porta que um pouco de neblina ainda encobria a aldeia. Na casa onde fico, uma mulher se dirigiu a seu filho com um choro cantado muito baixo, e lhe disse algo que o fez sentar-se em sua rede e começar a chorar, também de forma cantada. $\mathrm{O}$ choro dentro de casa era diferente do lá de fora, que era bem mais alto, mais cantado e parecia muito mais triste. Alguém parecia ter morrido, mas eu não sabia quem poderia ser, já que não sabia de ninguém que estivesse doente. Me levantei, fui à porta da casa e vi que o foco da movimentação e dos choros era uma casa do outro lado da aldeia. Lá fora, dois rapazes pegavam em pás e começavam a cavar.

Uma mulher bem idosa, a quarta esposa do falecido pai do chefe principal, havia morrido. Ela teve apenas um filho, que faleceu ainda pequeno, e depois disso nunca mais engravidou. A maioria de seus parentes havia morrido no sarampo e ela vivia na casa de sua sobrinha, onde se dizia que não era muito bem cuidada. Como acontece com a maioria dos idosos que já não conseguem mais trabalhar e têm dificuldade para se locomover, esta mulher era muito solitária e a indiferença em relação a ela só era quebrada pelas chacotas e pequenas violências verbais (e às vezes físicas) que sofria diariamente. Isso sempre foi uma das coisas que mais me chamou a atenção no convívio com os Kalapalo, e que sempre pareceu destoar 
de sua alegria e seu interesse em cuidar dos outros: como tantas vezes os velhos eram objeto de pequenas violências e descaso ${ }^{12}$.

Ela era a única pessoa viva a ter visto o Coronel Pierce Fawcett em carne e osso ${ }^{13}$. Como contava, ela "estava desse tamanho" (de uma criança de uns 10 anos, talvez?) quando ele e outros quatro kagaiha chegaram à aldeia. Considerando que Fawcett apareceu para os Kalapalo e desapareceu para o mundo em 1925 e, supondo que na época ela tivesse em torno de 10 anos, quando faleceu em 2007 ela já estaria com cerca de 90 anos. Apesar de ter sido esposa de um importante anetü e ser nobre (seu pai era anetü, lembrado como descendente do primeiro chefe de Kuapügü), ela mesma não era itankgo. Só fui saber disso porque vi que sua cova estava sendo aberta a meio caminho entre a porta da casa onde morrera e o centro da aldeia - bem mais perto da porta da casa do que do centro, na verdade. Me explicaram que se ela fosse uma itankgo ou alguém mais importante (como uma cantora), sua cova teria sido aberta no centro da aldeia.

A aldeia é um cemitério, e os mortos ocupam nela diferentes espaços dependendo de diversos fatores. Chefes, jovens em geral e adultos importantes (grandes cantores e, antigamente, guerreiros) são sempre enterrados no pátio central, no espaço em frente à casa dos homens. Crianças e idosos que não sejam chefes, são enterrados em covas logo à frente de sua casa, e adultos comuns, a meio caminho entre esta e o centro. Fetos abortados, bebês natimortos ou que faleceram antes de completar um ano de vida, são enterrados atrás da casa. Dentre as pessoas enterradas no centro, o que as diferencia é, principalmente, o tipo de sepultura e o tratamento dispensado a seus corpos. Para a maioria, cava-se um buraco cujo fundo é alargado e no qual o corpo é depositado, envolto em sua rede, deitado de lado e com as pernas flexionadas (a cova é chamada de "toca do tatu canastra", aguga ngagü). Se o morto for homem, por cima dele será colocada uma ou mais esteiras feitas de buriti e algodão, para que ele possa guardar as penas dos pássaros que matar quando os mortos entrarem em guerra com eles, nos eclipses. Também pode-se colocar uma grande panela (de cerâmica ou

\footnotetext{
${ }^{12}$ Certa vez presenciei essa mesma mulher chegando em casa com seu cajado e sentando-se ao chão perto da porta (antigamente as mulheres não deveriam se sentar em lugares altos, reservados aos homens, e ela ainda seguia esse costume). Quando chegou um grupo de jovens, um dele chutou seu cajado e, rindo, ordenou que ela o pegasse. A velha, sem escolha, rastejou para pegá-lo e, quando se aproximava dele, outro veio e chutou seu apoio um pouco mais para longe, o que se repetiu ainda uma terceira vez, sempre com muitas risadas e comentários sobre seu corpo debilitado. Quando ela faleceu, havia vários rumores de que ela estaria sem comer há alguns dias, desde que ficara um pouco doente (um dos motivos de suas visitas frequentes à casa onde me hospedo era que a dona da casa, filha de seu falecido marido com outra de suas esposas, era uma das únicas pessoas que lhe dava de comer).

${ }^{13}$ Há uma mulher mais velha na aldeia, mas que não vivia com os Kalapalo à época.
} 
alumínio) sobre o morto, para evitar que a água das chuvas molhe o cadáver e acelere a decomposição. Feito isso, tapa-se a cova e pede-se que os parentes do morto tragam todos os seus pertences. Quase tudo que ele possuía deve ser queimado, caso contrário, a alma tende a permanecer perto de seus objetos, dos quais sente falta. Além disso, tais pertences evocam nos vivos a memória do morto, provocando saudades e colocando-os em perigo. Objetos mais valiosos, como plumárias, cintos e colares de conchas, voltas de missangas, enfeites de couro ou garras de onça, não são queimados, mas os parentes do morto não devem guardá-los. Estes objetos devem ser trocados ou vendidos o mais rápido possível, pois a memória do antigo dono vinculada a eles se dissipa com sua circulação.

No mesmo dia, os enterradores devem pescar e levar alguns peixes até a casa onde o morto vivia, que são moqueados por seus parentes enquanto esperam a vinda de um pajé. Ele reza no local onde ficava a rede da pessoa pedindo que sua alma vá embora, e depois faz o mesmo sobre seu túmulo, onde coloca peixe moqueado com beiju, evolvido em uma esteira. Esta reza difere um pouco da maioria pois se parece mais com um canto, e é toda em arawak, não sendo compreendida pelo único pajé de Aiha que a conhece. Ele diz apenas que a reza serve para pedir que a alma vá embora, e o peixe a alimenta, para que não sinta fome ${ }^{14}$.

Quando se trata de um chefe, este será enterrado em um túnel feito no sentido lesteoeste (esse tipo de sepultura é chamada de tunatatenhü). Em cada extremidade do túnel cavase um buraco fundo o suficiente para se colocar um tronco da madeira uẽgühi, que serão os esteios da rede do morto. Ele deve ser colocado, todo pintado e enfeitado, sobre uma rede feita especialmente para esta ocasião, trançada com o motivo geométrico ingü, formado pelos contornos externos do principal grafismo corporal kalapalo, tüihitinhü (comentado no capítulo anterior). A pintura do morto pode ser feita por algum dos enterradores, um afim ou qualquer parente distante, e deve ser paga com um grande colar de conchas. Geralmente o(a) pintor(a) é alguém que quer demonstrar respeito ou carinho especial pelo morto.

\footnotetext{
${ }^{14}$ Segundo Basso (1985: 105), esse peixe seria para Taũgi, mas nos falecimentos que presenciei, várias pessoas me disseram que ele seria consumido apenas pela alma do morto.
} 


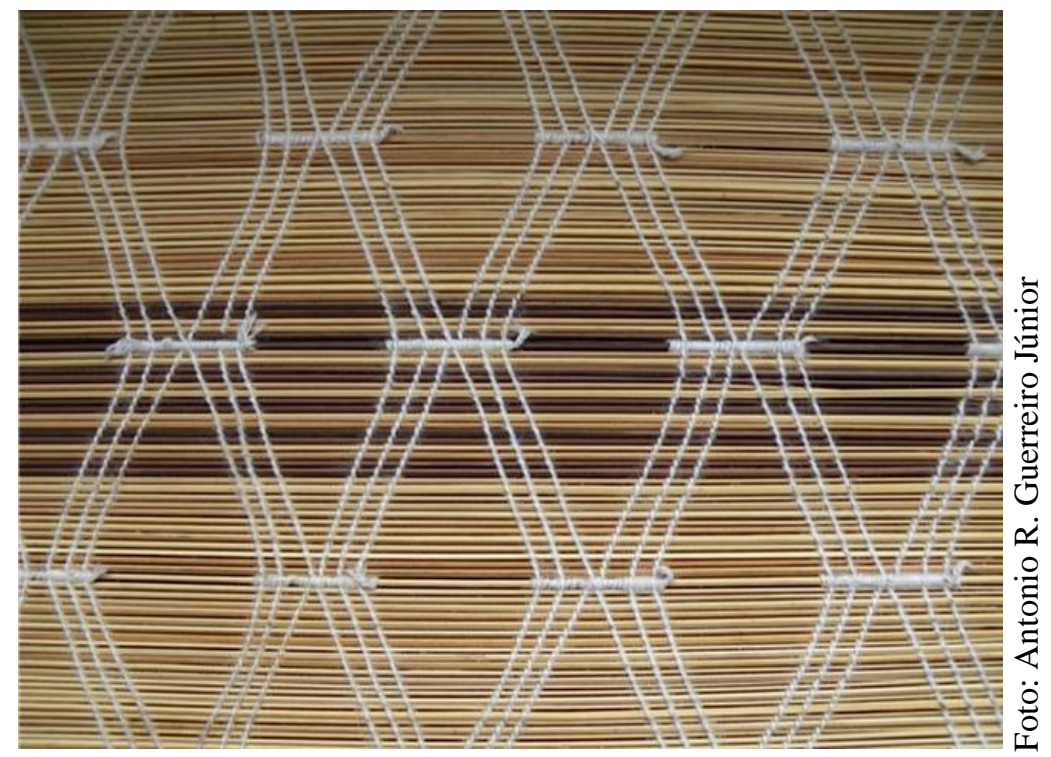

Figura 4.1: esteira de espremer mandioca com o padrão ingü, o mesmo que deve ser trançado na rede de um nobre falecido.

O morto em sua rede, que será amarrada nos seus esteios, é colocado deitado no túnel de barriga para cima e com a cabeça a oeste, de modo que sua face fique sempre voltada para o nascente e ele possa ver o sol nascer todos os dias ${ }^{15}$. A forma do enterro de nobres varia entre os alto-xinguanos, pois outros povos (como os Kamayurá) enterram seus nobres em pé (amarrados em uma estrutura de madeira), ao invés de deitados (mas também com a face para o leste). A aldeia é pensada como um corpo orientado segundo os pontos cardeais: o leste é a parte da frente do corpo, o oeste as costas, o norte a esquerda e o sul a direita. Quando um chefe é enterrado em pé, no centro, e virado para leste, é como se ele fosse "sobreposto" ao eixo central da aldeia, criando uma imagem holográfica interessante: o corpo do chefe e o "corpo" da aldeia são dispostos da mesma forma. No caso do enterro deitado, também há um simbolismo relevante. O chefe é enterrado no eixo leste-oeste, que simboliza a passagem do tempo pelo movimento do sol. O tempo que passa também é pensado pelos Kalapalo a partir da imagem do crescimento vegetal, sobretudo das árvores, o que nos permite especular que o eixo leste-oeste é, de certa forma, "arbóreo". Ora, como vimos no capítulo 2, o crescimento das árvores está associado à consanguinidade, à reprodução intergeracional da chefia, à

\footnotetext{
${ }^{15}$ Segundo Franco Neto (2010: 264, nota 150), essa forma de enterro seria exclusiva para os "donos de aldeia". Este não me parece ser o caso, pois o chefe que faleceu em 2009 não era o "dono da aldeia" e foi enterrado segundo este modelo.
} 
continuidade da vida coletiva, e os chefes são, eles mesmos, chamados de "troncos"; desse ponto de vista, o eixo leste-oeste é o eixo da chefia.

Uma pessoa comum tem dois enterradores, que não devem ser parentes próximos o suficiente para ficar de luto. Em um cenário ideal, as pessoas são enterradas por seus genros ou outros afins, em sinal de respeito. $\mathrm{O}$ enterro marca assim uma diferença entre parentes próximos que ficam de luto, e afins ou parentes distantes que conduzem o enterro. Já no caso dos nobres, são necessários quatro enterradores, que também devem ser anetü. Esta é uma ocasião na qual muitos chefes aproveitam para apresentar seus filhos como futuros anetü, colocando-os na posição de enterradores (eles os colocam como seus substitutos, assim como quando são "sentados" e feitos ugihongo). Em 2009, por exemplo, três chefes colocaram seus filhos como enterradores, todos jovens em preparação (um deles, que havia saído da reclusão há pouco tempo, começou a ser chamado de "caciquezinho" depois disso). Quando se coloca jovens nesta função é para que eles sejam vistos, seus nomes ganhem fama e que sejam reconhecidos como futuros chefes. São eles que, a partir de então, serão chamados de tajope ("que gritam") ou tagi oto ("donos da fala"), que os Kalapalo traduzem como coordenadores $^{16}$, os responsáveis por organizar as atividades do egitsü-mas, na prática, seus pais é que atuarão de fato como tais, já que os jovens não sabem organizar as atividades. Eles recebem esses nomes porque sua atuação mais marcante é justamente gritar no centro da aldeia chamando as pessoas para o trabalho e organizando as atividades (obviamente não se trata de um gritar qualquer, mas de chamados ritualizados com gritos semi-musicais).

Cada um dos quatro tajope deve ser pago pelo enterro, enquanto os enterradores de pessoas comuns não recebem nada. Tradicionalmente, paga-se cada um com um grande colar de placas de concha, mas hoje alguns têm cobrado objetos dos brancos. Um dos enterradores do anetü morto em 2009 cobrou dos filhos deste uma espingarda calibre 32 (que custou cerca de $\mathrm{R} \$ 3.000$, todo o dinheiro que seu falecido pai havia conseguido guardar com sua aposentadoria rural) e outro cobrou um pequeno gerador a gasolina com partida elétrica, que custa em torno de R $\$ 1.500$. Para piorar a situação, o tajope que pediu o gerador é sogro de um dos filhos do chefe morto e, por respeito e vergonha, não haveria chance de se negociar outro pagamento. Os filhos do morto ficaram bastante chateados com isso, e várias pessoas comentaram comigo que achavam um absurdo o que aqueles tajope haviam feito. Segundo dizem, entre outros povos a prática de se cobrar objetos dos brancos pelo enterro de nobres já

\footnotetext{
${ }^{16}$ Quando italicizada, designa especificamente os tajope.
} 
se tornou comum, e as pessoas se queixam de que isso encareceu demais os enterros (além de ser desrespeitoso querer sair ganhando com a morte de alguém).

Os parentes do morto ainda podem ser obrigados a fazer pagamentos aos chefes de outras aldeias, que após o falecimento de um nobre normalmente vêm chorar ao lado dos enlutados. Eles entram na aldeia realizando o mesmo discurso feito pelos tajope para chamar os enlutados para tirar a tristeza (que analisarei mais adiante), e são encontrados no centro pelos parentes do morto, onde ficam um tempo chorando ao lado da sepultura. Nesse caso, os chefes visitantes devem ser pagos com colares de conchas.

Pessoas comuns não recebem nenhum tipo de atenção depois de enterradas, mas os nobres logo começam a receber um tratamento diferenciado. No dia seguinte ao enterro, antes do sol nascer, os tajope fazem uma pequena fogueira no centro da aldeia (considerada o "fogo do morto"). Ela não pode ser feita com qualquer madeira, mas apenas com tahaku ${ }^{17}$, a melhor madeira para lenha ${ }^{18}$ (também usada na construção de partes da casa do chefe e da cerca de sua sepultura - voltarei a isso). Depois que o fogo é aceso, os parentes do morto devem levar ao centro uma panela de mingau de pequi para cada tajope e bastante pirão (uma ou duas panelas grandes). O homem mais importante dentre os donos do egitsü oferece uma panela de mingau individualmente a cada tajope, que a recebe e a carrega mais para perto da casa dos homens. Entregue o mingau, as pessoas começam a beber, enquanto os tajope cortam pedaços de beiju que colocam no chão, sobre esteiras ou lonas, e dividem o pirão, de modo que cada pessoa da aldeia receba uma porção. O que sobra nas panelas pode ser comido à vontade.

Depois que todos já tiverem comido, um dos tajope precisa se enfeitar com adornos de onça (cinto, braçadeira ou coroa de couro, e/ou colar de garras). É importante que o tajope só se enfeite depois de ter acabado de comer, pois é perigoso comer ou beber qualquer coisa usando enfeites daquele animal. Se alguém comer ou beber algo usando uma coroa de couro de onça, seu cabelo cairá e nunca mais crescerá; se estiver usando braçadeiras ou um colar de garras, seus braços ou pescoço ficarão doloridos. Segundo um cantor, é porque "a onça te come!". O chefe, paramentado como onça, fica proibido de exercer a maior capacidade daquele animal: comer. Depois de enfeitado, o tajope pega um pedaço de lenha com fogo e leva para a casa do morto, andando um pouco curvado, jogando o corpo para os lados e

\footnotetext{
${ }^{17}$ Madeira não identificada.

${ }^{18}$ Quando um homem se casa ele deve buscar tahaku para seu sogro regularmente. Ele também deve oferecer um grande pedaço de tahaku para os irmãos e primos de seu sogro, como um sinal de que os reconhece como afins de $\mathrm{G}^{+1}$.
} 
imitando o esturro da onça no caminho. Ele deixa o fogo na porta da casa e volta para o centro da aldeia, ainda imitando o esturro do felino. Uma mulher da casa pega o pedaço de lenha e o leva para o fogo da cozinha, enquanto o anetü se dirige para a próxima casa com outro pedaço de lenha, fazendo a mesma coisa, casa por casa, em sentido horário. Neste momento do ritual, o chefe aparece como uma onça dona do fogo de cozinha, algo que não se encontra nos mitos alto-xinguanos (que conferem este papel ao Urubu Rei, conforme apresentado no capítulo 3). O fogo de uma pessoa parece estar relacionado à sua permanência entre os vivos: quando a efígie ficar pronta, em frente a ela será feita outra fogueira com tahaku (também chamada de "fogo do morto"), que deverá ser mantida acesa a noite toda (enquanto o morto está entre os vivos) e enterrada no amanhecer do último dia do ritual (quando sua alma parte definitivamente).

Terminada a distribuição do fogo, os tajope vão, em grupo, do centro da aldeia até a casa dos parentes mais próximos do morto. Quando chegam na porta, começam a fazer um discurso, no gênero de fala específico dos chefes, para cada um dos homens enlutados, a começar pelo filho mais velho. O discurso não é exatamente em uníssono e, apesar dos tajope começarem mais ou menos juntos, cada um faz um discurso um pouco diferente e parece não se importar com o que os outros estão dizendo. Segundo o melhor conhecedor dos discursos em Aiha, se diz o seguinte:

\section{Konkginge ikatigi 19 ("convite para o banho")}

1 ah muke ngapa higei uãke

2 ingila muke ngapa higei uãke

3 ah üngele muke gele higei uãke

4 ah ijatsiteganügü muke gele higei uãke

5 ah kunginginu heke muke gele higei uãke

6 üngele ijatsiteganügü muke gele higei uãke

7 ah kunginginu heke muke gele higei uãke

$8 \quad$ ingila muke ngapa higei uãke

9 tuitunguki muke gele uãke

10 ah üngele muke gele higei uãke [sem elementos lexicais]

desde muito antes

ah, aquele que morre

ah, é feito um coitado

ah, por aquele que nós não vemos [um feiticeiro]

aquele que morre é feito um coitado

ah, por aquele que nós não vemos

desde muito antes

ficamos com saudades

daqueles

\footnotetext{
${ }^{19}$ Executado por Ageu em 02 de julho de 2010, em sua casa na aldeia Aiha.
} 
11 otoganügü muke gele higei uãke

12 ah üle kae muke gele akangaba kungonditanügo muke [gele higei uãke] que morrem

ah, pois assim somos abandonados

Isto é um chamado para que os enlutados se dirijam ao centro para tomar banho e "tirar a tristeza". O banho limpa da tristeza pois considera-se que, com a morte, o corpo fica sujo com as lágrimas e o catarro expelidos pelo choro ${ }^{20}$ (como também nota Basso, 1985; 1987b). Este é apenas o primeiro banho, para tirar "um pouco" da tristeza, que só vai sair completamente com um último banho dado pelos tajope no final do egitsü. Os enlutados saem em fila e cobertos, os homens na frente e as mulheres atrás, com o parente mais importante encabeçando a fila. Parentes residentes em outras casas fazem o mesmo. Chegando ao centro, sentam-se no banco em frente à casa dos homens, de cabeça baixa, enquanto dois homens se posicionam atrás dos enlutados e começam a cantar.

Há duas músicas para essa ocasião, uma para pessoas comuns (tinhakuhongo) e outra específica para os nobres. A segunda é o canto do Urubu Rei (Uguhu Igisü), executado pelo Morcego no funeral de sua sogra. Resumidamente, Morcego cortou o clitóris gigantesco de sua sogra para transformar seu sangue em urucum, e enganou sua esposa dizendo que ela havia se engasgado com um espinho de peixe e morrido sufocada. Ele próprio cantou no funeral, porém disfarçado de outra pessoa. Enquanto cantava, Morcego cometeu uma gafe: pronunciou o nome de sua sogra. Sua esposa, achando isso estranho, foi ver o cantor de perto e reconheceu seu marido, do qual se divorciou ${ }^{21}$. O canto é em arawak e incompreendido, mas o cantor de Aiha diz que ele é dividido em três partes que recontam brevemente o que aconteceu com a sogra do Morcego.

Terminada a música, os tajope dão banho nos filhos do morto, e pedem que outras pessoas de seu grupo doméstico deem banho nos demais. Homens dão banho em homens e mulheres dão banho em mulheres. Os viúvos recebem um tratamento especial, pois obrigatoriamente devem ser banhados por um cunhado ou uma cunhada. Em seguida, os enlutados também devem banhar aqueles que os lavaram primeiro, "para que eles também não fiquem tristes" (a tristeza é um estado corporal que pode passar de uma pessoa a outra nessa ocasião). Terminados os banhos, os tajope mandam alguém buscar vários ramos da planta

\footnotetext{
${ }^{20}$ Mesmo parentes distantes de outras aldeias ficam "sujos".

${ }^{21}$ Para uma versão completa desse mito, ver Basso (1985: 108-125).
} 
kejite e pequenos bambus para se fazer uma flautinha tihehe (uma espécie de "flauta de pan", feita de quatro pedaços de bambu de tamanhos diferentes, geralmente usada no aprendizado de músicas das flautas takuaga e atanga).

Enquanto isso, os enlutados se dirigem a suas casas para buscar pequenos pagamentos para os que lhes deram banho, como anzóis, conchas de caramujo, sabonetes, fósforos, fios de algodão. Todos (menos os enlutados) se pintam e se preparam para uma festa, que acontece no começo da tarde, no horário no qual geralmente o jovens fazem seus treinos de luta. Nesta festa os grupos domésticos dos tajope devem se mobilizar para fazer uma série de pequenas "brincadeiras" coreografadas em volta do túmulo do morto (assoviar, bater pedaços de cerâmica com as mãos, tossir, soprar as flautinhas tihehe, rindo muito). Basso (Becker, 1969: 327) nota que a coreografia deste ritual reproduz a forma da cerca que será construída ao redor do túmulo, o tahiti (do qual tratarei na seção seguinte). Digo brincadeiras porque o clima no qual as coisas são feitas é o de absoluta jocosidade, uma alegria que contrasta com o luto no qual se encontram os parentes do morto. Tudo o que é feito é para que o morto fique alegre - pois todo o ciclo é um longo processo que tem como um de seus objetivos principais acabar com a perigosa tristeza dos vivos e do morto.

\subsection{Corpos-casas}

- Há algum tempo atrás eu sonhei com meu pai.

- Ah é, e ele disse alguma coisa pra você?

- Disse sim. A voz dele estava diferente, ele não falava bem, porque o feiticeiro usou um pedaço de cigarro dele para matálo e isso afetou sua língua. Antes de morrer ele não conseguia falar direito.

- Mas você conseguiu entender o que ele dizia?

- Consegui. Ele disse que estava muito feliz com a casa nova dele. Ele disse: "Nossa, filho, você tem que ver a casa que o pessoal construiu pra mim. Ela é bem grande, bem bonita. Ela

é toda pintada e os pilares da porta são 'deste tamanho.".

- Quem construiu essa casa pra ele?

- O pessoal dele na aldeia dos mortos, eles fizeram uma talühe pro meu pai, porque ele era um grande cacique. Outro dia o seu tio disse que sonhou com ele também. 
- Disse que meu pai contou para ele que o filho daquele chefe famoso estava bravo, com inveja dele.

-Como assim, por que ele estava com inveja do seu pai? Na aldeia dos mortos?

- Isso, ele estava com inveja do meu pai porque o pessoal não construiu uma talühe pra ele.

- Mas ele não era cacique, filho daquele grande chefe kalapalo?

- Era, mas como o filho dele não aceitou homenageá-lo, ele ficou sem tahiti e ficou sem talühe.

$* * *$

Um dos momentos mais importantes do ciclo do egitsü é a construção do tahiti do morto, uma espécie de cerca feita ao redor da sepultura com pequenos pedaços de ẽ gühi (lembrando: a madeira com a qual foi feita a mãe dos gêmeos e da qual são feitas as efígies). Essa construção aparece em uma ilustração no segundo livro de Von den Steinen.

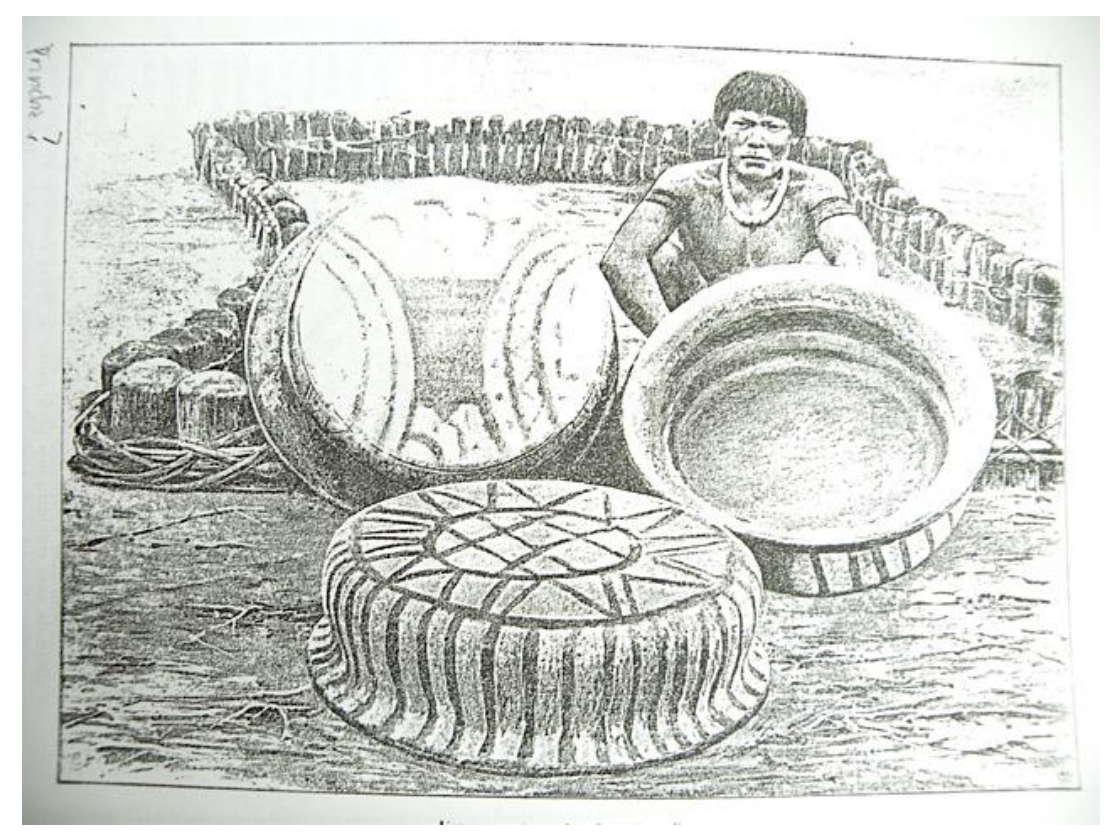

Figura 4.2: sepultura em uma aldeia Aweti, retratada pela expedição de Von den Steinen (1940: 356). 
Os Kalapalo dizem que o tahiti é a "casa do morto". Mais especificamente, ele é uma talühe, uma casa de chefe, construída ao mesmo tempo para o morto (pelos vivos) e para o dono do olho (pelos mortos). Na ocasião da construção do tahiti (de um a três meses após a morte, pelo que observei), ao mesmo tempo os mortos constroem, em sua aldeia celeste, uma talühe para o morto, onde ele irá morar quando sair de sua reclusão. Morar em uma talühe é um grande prestígio para um chefe, pois isso significa não apenas que ele é "reconhecido" como tal, mas é um investimento do grupo voltado para a sua permanência e de sua família na aldeia. Quando se constrói uma talühe para alguém é por que "seu pessoal" não quer que o chefe e seus filhos se mudem dali, é um investimento na reprodução de uma parentela de chefes. Como o tahiti é feito de uẽgühi, uma árvore que tem um dono poderoso (o chefe das árvores), ele é perigoso para crianças, que não devem ir ao local onde a madeira será cortada nem se aproximar do tahiti depois de pronto, para evitar eventuais ataques do espírito da árvore. Homens com filhos pequenos também não devem participar do corte da madeira pelo mesmo motivo (se forem atacados, seus filhos se sentirão mal também).

Uma nota sobre a aldeia dos mortos. Há visões diferentes e igualmente recorrentes sobre haver uma ou várias aldeias dos mortos. Segundo a primeira ideia, haveria uma única aldeia gigantesca composta pelos mortos de todos os povos alto-xinguanos; já de acordo com a outra, cada povo teria sua própria aldeia dos mortos. Em qualquer caso, o chefe principal da aldeia dos mortos não é um homem, mas sim uma mulher: Sangitsegu, a mãe dos gêmeos. Não parece estranho a ninguém que o "primeiro cacique" dos mortos seja uma mulher, pois as pessoas sempre me deram duas justificativas que tratam como óbvias: primeiro, como ela foi a primeira pessoa (kuge) que morreu e foi homenageada em um egitsü, ela é a dona da aldeia; segundo, ela não só é uma grande chefe, como é considerada anetü bama, uma espécie de atualização perfeita do chefe ideal. Bama é uma palavra que pode ser aplicada a alguém que domina algo com perfeição. Por exemplo, um bom mecânico pode ser um mecânico hekugu, "verdadeiro", mas um mecânico infalível, que conserta qualquer coisa, é um mecânico bama; um bom chefe é um anetü hekugu, mas um chefe excelente, muito calmo e muito generoso, que conhece com maestria mitos e discursos cerimoniais, é um anetü bama. A chefia entre os vivos é algo eminentemente masculino (pois a chefia feminina, apesar de importante, é eclipsada pelos homens), mas o que unifica todos os humanos mortos em uma única aldeia (ou várias - a multiplicidade de Sangitsegu não é um problema para os partidários dessa visão) é uma mulher. No limite, a mãe dos gêmeos é a chefe que deu origem à humanidade, 
talvez ela seja a pessoa mais antiga que se possa chamar de "parente", e sua preeminência na aldeia dos mortos deixa claro como a consanguinidade é vista como um princípio feminino. Segundo Basso (1987b), ao chegarem no céu os mortos devem beber do leite de Sangitsegu para começarem a ficar fortes novamente. Um tema semelhante reaparece entre os Aweti, segundo os quais, para poderem entrar na aldeia dos mortos, as pessoas devem beber o leite ${ }^{22}$ de uma mulher que guarda a entrada da aldeia - à exceção dos chefes (Figueiredo, 2010: 86). No céu, onde a consanguinidade, a beleza, a alegria, a fartura e a tranquilidade atingem seus pontos máximos, a chefia não cabe a um homem-animal predador, mas a uma mulher-árvore nutriz. É somente no mundo dos mortos que pode haver alguém que chefie todos os humanos e cuja posição independa dos rituais guerreiros, onde a assimetria entre um chefe e seu povo dispense a inimizade ritual.

A posição de Sangitsegu na aldeia dos mortos está ligada à forma como o primeiro egitsü é visto pelos Kalapalo. Vejamos um trecho da fala de Ageu sobre isso (em resposta a uma das perguntas mais bobas, porém honesta, que eu poderia ter feito: "por que se faz egitsü?'):

\section{Ageu:}

Taũgi heke tütipe engü beha înũtepügü atehe egea ukunhalü beha

Nós ficamos assim porque Taũgi ancestralizou sua mãe

Taũgi heke tüti hunügü tunatate beha

Taũgi sepultou sua mãe em uma cova de dois buracos

Ülepe tahititselü iheke

Depois ele fez um tahiti para ela

Anetüi beha tüti tüilü iheke, ülepeti higei

Ele fez de sua mãe uma grande chefe, daí a sua origem [do egitsü]

Tinhuhinhalüi geleti higei tisitsipügü

É isso que nós procuramos para os nossos mortos

\footnotetext{
${ }^{22}$ Que, do ponto de vista dos vivos, é pus.
} 
Engü tiha tinhuhinhalü anetãopetse beha uhitsekela gehale anetãopetse beha tüi

É isso que procuramos quando chefes morrem, também não é qualquer um, é só quando chefes morrem

Inhalü talokitope tsüha talokitope tüilü takandibüngüpe tüilüi, inhalüha

Não se faz isso com um qualquer, não se faz isso com alguém que não se sentou

Egea tüilüi anetãopetse beha egea tüi kupehe

Nós fazemos assim, nós fazemos isso para chefes mortos

Kuarup tüitohoi beha kupehe

É pra isso que o Quarup serve

Ülepea tiha Taũgi heke tüti hutühügüpea tiha ülepea kuguha

É porque Taũgi fez uma imitação de sua mãe, é por isso de verdade

Igei egitsü inhatohoi tsühigei

O egitsü é feito pra isso

(...)

Ukailohoi beja itsomi, ukailohoi

Para que seja algo que serve para dançarmos, que serve para dançarmos

Tapogingo bena hegei egitsüi, tapogingo

O egitsü é muito divertido, muito divertido

Üle atehe hegei

É por isso

Ülepea betsüha ĩhũtepügüpea geleha

Para ancestralizar alguém grande que morreu

Tüti hutühügüpea beha iheke

Ele [Taũgi] fez uma imitação de sua mãe

Îhũtelü (origem-VBLZ-PUNCT) é uma palavra verbal cuja raiz, îhũ é a mesma usada na produção da palavra "ancestral", îhũgu (origem-REL). Ela é muito usada em sua forma 
reflexiva, etĩhũtelü (REFL-origem-VBLZ-PUNCT), com o sentido de "origem”: egitsü etĩhũtelü, "a origem do egitsü", ndühe etĩhũtelü, "a origem do ndühe", etc. Há também outra forma nominal feita a partir da mesma raiz que se refere a um lugar onde uma espécie ocorre com muita frequência, ou o local de origem de algo ou alguém, que é îhũtegoho (origemVBLZ-INSTNR). Por exemplo, um lago ou região do rio onde uma espécie de peixe ocorre em abundância é seu ĩhũtegoho. Mas me parece que a forma verbal transitiva formada a partir de îhu (ĩhũtelü) não tem o sentido de "dar origem (a algo ou alguém)", pois eu não poderia usá-la para dizer, por exemplo, que Kuatüngü deu origem a suas filhas, ou que Taũgi deu origem ao egitsü. Segundo a tradução de um rapaz, a passagem acima quer dizer que Taũgi “transformou sua mãe em îhũgu". Uma glosa possível seria "colocar na origem" ou, retomando a tradução que os Kalapalo fazem de îhũgu como ancestral, îhũtelü talvez seja "ancestralizar". Mas na origem de que/quem? Ao desconstruir a relação de parentesco com seu pai onça e reafirmar a relação com sua mãe, Taũgi colocou Sangitsegu como a principal ancestral da humanidade e, por isso, a pessoa a ter sua primeira casa construída na aldeia dos mortos.

Observando o começo da mesma fala, vemos que o "colocar na origem" veio junto com a confecção de um tahiti (o cercado da sepultura de um nobre) para Sangitsegu e que, assim, ela "foi feita chefe". Há então alguma relação a especificar entre ancestralidade, chefia e a construção do tahiti. A questão da natureza das relações entre mortos e vivos na Amazônia é antiga e é muito difícil falar sobre ancestralidade na região (Chaumeil, 2007; Erikson, 2007). Pelo menos desde os trabalhos de Hélène Clastres (1975) sobre os Guayaki e de Carneiro da Cunha (1978) sobre os Krahô, sabemos que para vários povos ameríndios, de formas variadas, “os mortos são outros” e que há um esforço para afastá-los da sociedade dos vivos. Perigosos para os humanos e objeto de necessário esquecimento (caso contrário, podem capturar os vivos), uma separação radical entre vivos e mortos comum a várias cosmologias sul-americanas seria uma das razões pelas quais é difícil encontrar ideias muitos fortes de ancestralidade ou o desenvolvimento de "linhagens" entre os povos ameríndios (Carneiro da Cunha, 1978). E mesmo onde os mortos não são vistos nem como muito perigosos, nem completamente como "Outros", sua humanidade é sempre corrompida por um retorno à condição de animal (Viveiros de Castro, 2007b). Em cosmologias desse tipo, como a ancestralidade, isto é, o reconhecimento socialmente eficaz de relações de continuidade entre vivos e mortos, poderia operar? 
Philippe Erikson (2007) descreve entre os Matis, um povo de língua pano da Amazônia Ocidental, os mariwin, seres que evocam uma ideia de ancestralidade ao mesmo tempo que se nega com eles relações de parentesco. Os mariwin são considerados muito antigos, encarnam os valores matis da durabilidade, da generosidade, possuem uma grande quantidade de "energia" (sho) e exibem uma ornamentação corporal hiperbólica que os humanos tentam imitar ${ }^{23}$. Por isso Erikson (ibid: 227) diz que os mariwin "represent a model that contemporary generations strive in vain to equal", e que eles simbolizam a fertilidade sênior e a super-humanidade (ibid: 229). Além disso, algumas propriedades dos mariwin seriam metáforas de um passado idealizado, que Erikson chama de "imagens de ancestralidade" (ibid: 230). Os mariwin são mortos ${ }^{24}$, apesar de anônimos, e se assemelham aos fundadores míticos das seções dos Marubo, vizinhos dos Matis. Eles também são descritos como um "exoesqueleto que anda", "a motif that, even in Amazonia, is not without echoes of intergenerational continuity" (ibid: 231). Os mariwin também são ligados aos velhos, pois estes são pensados como "mais próximos" dos mariwin (só o homem mais velho do grupo pode chamar os mariwin através do canto, e só velhos podem comer carne de arara, o alimento favorito daqueles seres). Na síntese de Erikson (ibid: 232):

Belonging to the category of tsusi - which, depending on the context, means 'shadow' or 'spirit' or 'elder' - the mariwin are intimately associated with themes of death, ancient times, and the perpetuation of collective identities by way of imitating a highly respected primogenitors.

Mas, ao mesmo tempo, os mariwin são chamados de tawari, um termo que designa "a close relationship between people who resemble and respect each other, but without being related as kin" (ibid: 233). Esse conceito é traduzido como "amigo", mas só se aplica a pessoas sem relações prévias (isto é, que não são parentes) e que pertencem a grupos diferentes. Quando os mariwin aparecem para o açoite ${ }^{25}$ ritual das crianças, através do qual transferem energia para os Matis, os homens que os interpretam evitam açoitar parentes próximos, concentrando-se em seus parentes cruzados. Alguns açoites específicos feitos em

\footnotetext{
${ }^{23}$ Já outros espíritos, os maru, seriam maus, pouco enfeitados e isso os tornaria invisíveis. É interessante que eles lembram o Ahasa, um espírito da mata que os Kalapalo descrevem como canibal, incapaz de aprender a se enfeitar e mal-humorado, cujos ossos têm o poder da invisibilidade.

${ }^{24}$ Os Matis dizem que os mortos não viram mariwin hoje em dia, mas que antigamente viravam (Erikson, 2007).

${ }^{25}$ Com varetas cobertas por inúmeros espinhos.
} 
adolescentes e adultos (principalmente mulheres na menopausa), que se destinam a aumentar a fertilidade, são "as a general rule, administred by affines, in particular the maternal uncle" (ibid: 233). Desta forma, vê-se que os mariwin estão ligados tanto à consanguinidade e à ancestralidade quanto à afinidade. A partir disso, Erikson sugere que a relação dos mariwin com os Matis seja vista como uma forma de "ancestralidade mediada ${ }^{26 "}$ (ibid: 237), "that, in a typically Amazonian fashion, is defined less in terms of descent than of cerimonial friendship and alliance".

Chaumeil (2007) observa que as formas sul-americanas de lidar com a memória dos mortos são bem variadas, e que o panorama das concepções ameríndias sobre o tema "does not really conform, to put it mildly, to the single model of a radical discontinuity between the living and the dead" (ibid: 248). O autor nota a existência de diversas práticas que podem ser vistas como maneiras de produzir relações de continuidade entre vivos e mortos. Ele cita, entre alguns exemplos, a interpretação de McCallum (1996) do endocanibalismo kashinaua como parte do processo de constituição do parentesco entre o morto consumido e seus parentes vivos, e o caso analisado por Graham (1995) dos "imortais" no sistema de classes de idade xavante.

Haveria, para o autor, uma diferença entre sociedades que tratam seus mortos como estranhos (e os apartam completamente dos vivos) e aquelas que procuram "conservar seus mortos em casa" (Chaumeil, , op. cit: 275), pois estas últimas teriam "a more cumulative conception of time” (ibid: 272). Segundo Chaumeil (ibid: 274), “(...) relations to time and history among societies that conserve their dead or reembody them in ritual objects are different from those relations among societies that strive to make the dead vanish as quickly as possible". O autor nota que muitos dos processos voltados para "relembrar" dos mortos e viabilizar sua continuidade no mundo dos vivos são geralmente dirigidos a pessoas eminentes: "the chiefs, shamans, great warriors, or combatants felled in foreign lands" (ibid: 275). Citando os casos dos Xavante, dos Yagua e do Alto Xingu, Chaumeil (ibid.) nota que fenômenos que podem aparecer sob a forma de "ancestralidade" parecem ser diferentes modos de se perpetuar a memória de (alguns) mortos, o que o leva a sugerir que "it perhaps makes more sense to qualify these figures as 'immortals' rather than 'ancestors"' (ibid: 275).

\footnotetext{
${ }^{26} \mathrm{O}$ autor também sugere as interessantes expressões "ancestors-in-law" e "ancestor by adoption" (Erikson, 2007: 234).
} 
O ponto seria investigar que lugar a memória desses homens eminentes ocupa nesses regimes de reprodução social.

Não bastaria, portanto, dizer que o egitsü transforma alguém em "ancestral", pois os sentidos dessa palavra no contexto ameríndio estão longe de ser claros. Se um chefe vivo já é, ao mesmo tempo, super consanguíneo e predador/afim potencial, cabe perguntar em que ele se transforma após a morte e como o ritual lida com isso. A construção da cerca da sepultura de um chefe (tahiti) é muito ilustrativa de como esta complexidade começa a ser trabalhada no egitsï.

O tahiti tem uma forma encontrada em várias pinturas alto-xinguanas, que é a de dois arcos em elipse com as aberturas voltadas para fora ${ }^{27}:$ ) (. Há indícios de que, para os altoxinguanos, esta seja a forma básica de um corpo humano, os traços mínimos de uma pessoa. Segundo Coelho (1993: 611), os Wauja sempre desenham o tronco de uma figura antropomorfa com esse motivo. Entre eles, o motivo é chamado de atirruá, que seria uma "pintura de borboleta" ou a pintura de um peixe parecido com o acari (ele reproduziria as listras que aparecem em seu dorso), uma espécie de cascudo que teria sido mensageiro no Quarup mítico (possivelmente o mesmo que aparece na mitologia kalapalo). Coelho (ibid.) nota que esse mesmo motivo é pintado com urucum nas costas dos mensageiros quando uma aldeia aceita formalmente o convite para um Quarup. Entre os Kalapalo também se faz o mesmo desenho nas costas dos mensageiros e no mesmo contexto, mas a despeito de sua forma idêntica, dizem que é "outro desenho", chamado de urubu ${ }^{28}$ (kuguagi).

Barcelos Neto (2008: 212-213) também afirma que, além de ser um motivo gráfico, essa forma visual é um esquema alusivo à antropomorfia, no qual "os arcos configuram o tronco dos seres antropomorfos" (ibid: 213). O autor nota que os arcos em elipse estão presentes em diversos artefatos wauja, como as grandes máscaras atujua (atugua, em kalapalo), as pás de virar beiju, as grandes panelas de cerâmica e todas as máscaras de tipo

\footnotetext{
${ }^{27}$ Segundo Agostinho (1974: 28-29), os Kamayurá fariam esse desenho no teto da casa do chefe principal da aldeia, "e só nela, distinguindo-a das demais" (ibid: 28).

${ }_{28}^{2}$ Isso talvez possa ser explicado pela associação dos urubus aos bancos rituais dos chefes, pois a imagem "clássica" do urubu rei, um dos chefes das aves, é sentado em seu banco enquanto ressuscita pássaros derrotados em batalhas com os mortos. Pintar os mensageiros "como urubus", seria um sinal para os chefes que os enviaram de que eles "se sentaram" e que o convite foi aceito. Isso estaria em consonância com o nome kamayurá dessa pintura segundo Agostinho (ibid: 29), apikap, que significa "banco".
} 
Sapukuyawá. Não conheço uma máscara equivalente entre os kalapalo ${ }^{29}$, mas entre eles também é possível encontrar esse motivo em outras máscaras, como na kuambü, usada por seres aquáticos:

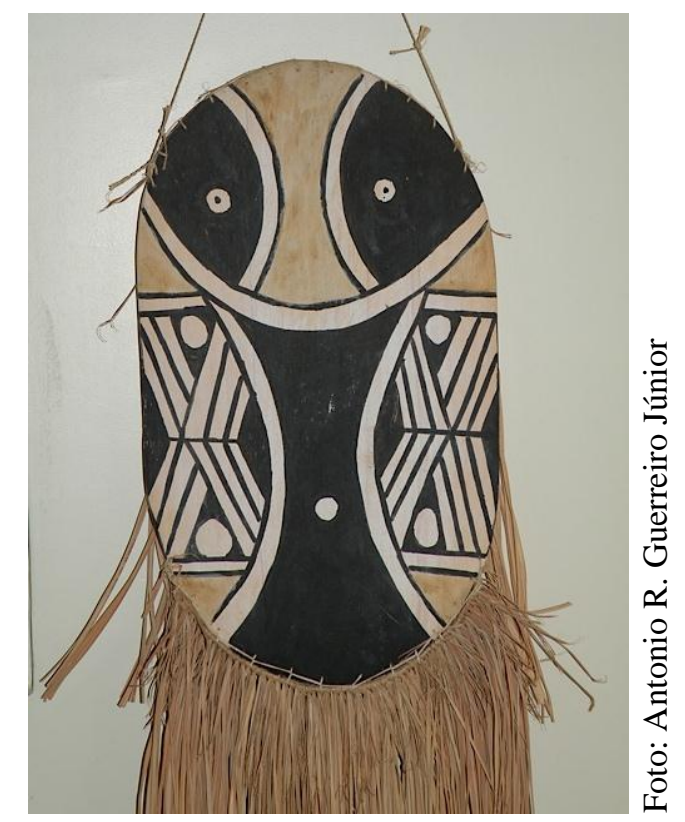

Figura 4.3: kuambü, máscara usada por seres aquáticos quando aparecem para os humanos.

A maior área na qual se aplica o motivo é descrita como o corpo/tronco (ihü) da máscara, e na área externa, à esquerda e à direita (suas "laterais do tronco", ijatü), aplicam-se padrões típicos da pintura corporal xinguana. Na parte superior da máscara o motivo reaparece, delineando seu "rosto", uma relação também presente nas máscaras atugua (o motivo também é chamado de "rosto de atujua" pelos Wauja quando aplicado no fundo de panelas; Barcelos Neto, 2008: 216). Ainda segundo Barcelos Neto (ibid), a questão seria saber porque um mesmo esquema seria aplicado a objetos aparentemente tão diferentes, ligando

\footnotetext{
${ }^{29}$ Há um certo consenso entre os Kalapalo de que os Wauja "têm muito mais festa", por causa da quantidade de máscaras de espíritos de que dispõem, muito mais do que os Kalapalo. Essa discrepância também se reflete nas poucas pessoas em Aiha que são donas de máscaras. Se entre os Wauja quase todo mundo é dono de um espírito e muitos são donos de máscaras/flautas (Barcelos Neto, 2008), entre os Kalapalo de Aiha poucas pessoas são. A maioria dos ataques de itseke é atribuída à feitiçaria e, na maior parte das vezes, as pessoas atacadas não se tornam donas de espíritos e suas festas, indicando dinâmicas diferentes nas relações dos Wauja e Kalapalo com os espíritos. Vale notar que essas diferenças podem ter seus reflexos na organização social. Os Kalapalo, que vêm se dividindo com frequência, atribuem isso à feitiçaria, enquanto a aldeia Wauja é, de longe, a maior aldeia alto-xinguana (cerca de 520 pessoas, segundo dados da FUNASA). Como Barcelos Neto (2003; 2008) já argumentou, os rituais de máscaras são um dos elementos que compõem e fortalecem a chefia, o que é uma das condições para a existência de grandes aldeias.
} 
todos ao corpo humano. Isso estaria associado à condição ambígua de objetos e espíritos que são, ao mesmo tempo, coisas e pessoas, ou animais e pessoas. O "lado pessoa" destes objetos e animais é necessariamente ligado ao corpo (alguém aparece como pessoa na medida em que tem um corpo humano), e os arcos em elipse traduziriam a ideia de antropomorfia em uma forma visual, efetuando uma "síntese formal" (ibid: 217) entre um conjunto de artefatos:

(...) é por meio de uma esquematização, expressa por determinados motivos gráficos ou formas plásticas, que yerupoho/apapaatai ["espíritos", itseke], objetos e pessoas adquirem uma continuidade que é pensada como antropomorfia. Ou seja, o conceito de antropomorfia seria dependente da sua possibilidade de ser visualmente sintetizado. (ibid: 215).

Também é possível especular que essa forma geométrica seja a mesma a partir da qual é feita a "moldura" básica da pintura corporal masculina, tal como delineada no tronco humano:

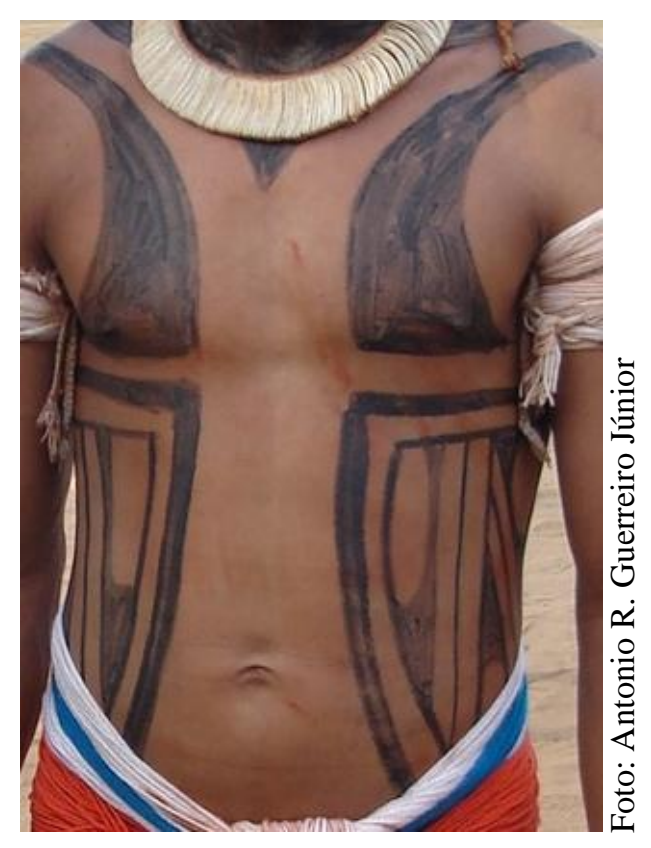

Figura 4.4: pintura corporal masculina, cujos contornos básicos evocam o motivo das elipses.

Não são só espíritos e objetos que precisam ter sua faceta humana tornada visível, mas também os humanos em situações rituais. Afinal, se um corpo não se apresentar como 
humano, que tipo de pessoa poderia ser? Segundo Von den Steinen (1940), os Mehinaku tatuavam esse motivo em alguns homens (acompanhando o bordo interno da omoplata) e mulheres (nos braços). Agostinho (1974: 29) diz ter ouvido dos Kamayurá que

(...) em tempos antigos os chefes tatuavam esse desenho sobre o peito, verticalmente: os dois arcos aproximavam-se a meio do esterno, deixando os mamilos de fora, e iam das clavículas quase à cintura, sem que linhas os unissem em cima e embaixo, limitando o espaço circunscrito. A tatuagem era conhecida como ìrìvutsi(n)ng ara(n)ngap, 'figura de urubu-rei' (...). (grifos no original)

Nenhum kalapalo pôde confirmar essa informação, e dizem nunca terem ouvido falar de tatuagens semelhantes (mas a semelhança entre a descrição de tais tatuagens e a moldura da pintura corporal masculina, como aparece na Figura 4.4, é digna de nota, bem como sua associação ao urubu rei). Sabe-se, contudo, que entre os Mehinaku (assim como entre os Kamayurá e Aweti) é comum tatuar mulheres nobres usando um motivo de três linhas horizontais paralelas dispostas no braço, um pouco abaixo do ombro, ou no pulso. Se a tatuagem mehinaku contemporânea está associada à chefia, é possível especular que as tatuagens observadas por Von den Steinen também estivessem. Se assim fosse, novamente esse motivo gráfico apareceria ligado à condição de pessoa, pois, como já vimos, comparados às pessoas comuns, somente os chefes são efetivamente kuge, gente (e talvez fosse isso que as tais tatuagens marcassem).

Voltando especificamente à sepultura nobre, vemos que o tahiti é de fato concebido como uma espécie de corpo, que possui orelhas (ihangagü), testa (ihinitü) e laterais do tronco (ijatï). As orelhas são feitas com pedaços um pouco mais grossos de uẽgühi, enquanto as outras duas partes são feitas de tahaku, uma madeira mais clara, com o objetivo de provocar contraste: 


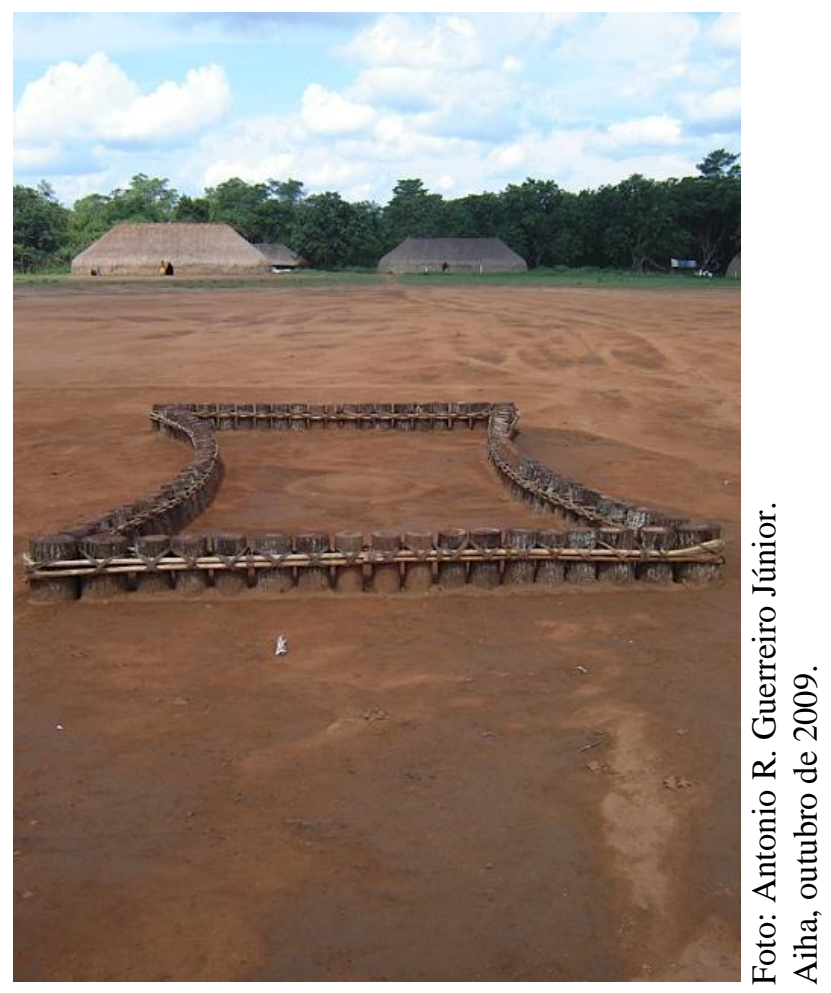

Figura 4.5: tahiti, a casa nobre do morto.

Em seu interior nota-se a cobertura de uma cova de um único buraco, pois a pessoa homenageada não era nobre, mas sim o maior cantor da aldeia.

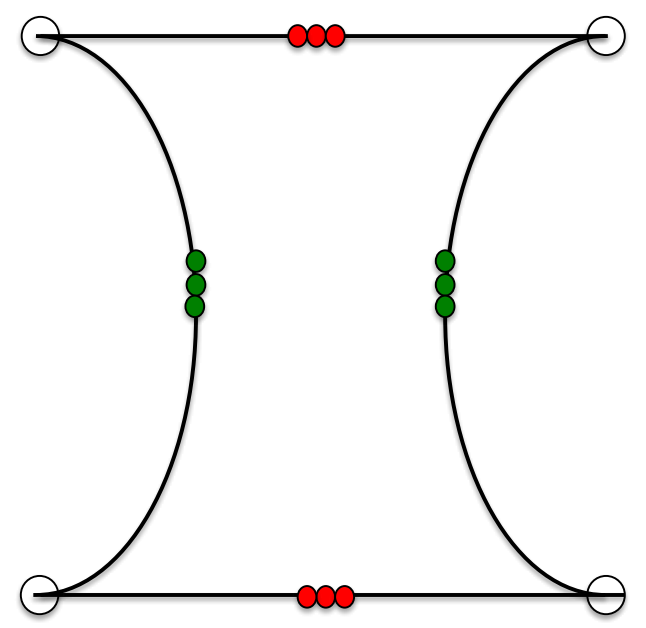

Orelhas (ihangagü)

- laterais do tronco (ijatü)

- Testa (ihinitü)

Figura 4.6: anatomia do tahiti.

É como se essa forma humanizasse aquilo sobre o que se aplica - objetos, máscaras, e mesmo os corpos humanos teriam, com ela, sua condição de Pessoa tornada manifesta. Não 
por acaso esta também é a forma do campo no qual se praticava um antigo jogo de bola ${ }^{30}$, cujo dono é uma Onça-chefe (redundância...) que, de todos os seres, é o único que consegue estar sempre na posição de Pessoa.

Cabe perguntar, portanto, a que estaria relacionada a forma com função humanizadora do tahiti. Por um lado, ele torna manifesto que ali está uma Pessoa, um(a) kuge. Mas ele não apenas "representa" o morto, pois sabe-se que uma das marcas da arte xinguana é que ela tem a capacidade de tornar atual, presente, aquilo cuja forma se constrói (Barcelos Neto, 2008). Fazer uma máscara é trazer um espírito para o convívio dos humanos, desenhar uma anta é atrair este animal para as roças. Nessa mesma lógica, fazer um corpo-casa é como refazer o corpo do morto e colocá-lo para habitar o centro da aldeia. Mas por que refazer o morto por meio de um processo que lembra a confecção de máscaras? Talvez porque, assim como um espírito familiarizado, o morto também é meio itseke, meio humano. Sua alma-sombra já está junto a um espírito e, vivendo como tal, seu corpo já não é mais completamente antropomorfo (do ponto de vista dos vivos).

O tahiti tem a capacidade de manter o chefe morto ligado a seus parentes de forma segura. O morto ganha uma casa, mas não no círculo da aldeia, e sim no centro, lugar próprio aos espíritos - o lugar no qual a alteridade pode aparecer de forma controlada e produtiva. A alimentação desempenha um papel importante nisso, assim como em qualquer processo de aparentamento. Enquanto o tahiti for mantido, geralmente até pouco tempo antes da festa para juntar polvilho ${ }^{31}$, os parentes próximos do morto devem depositar, periodicamente, uma pequena panela com mingau de pequi sobre o buraco a oeste (isto é, aquele que corresponde à cabeça na cova de dois buracos ${ }^{32}$ ). Esse mingau serve para matar a sede do morto mas, mais do que isso, serve para atrair sua alma-sombra para sua nova casa junto aos humanos. Como já mencionei, a proximidade entre mortos e vivos é perigosa, pois quando alguém vê ou ouve a alma de um morto, é porque já está se transformando em um. As atividades rituais progressivamente ajudam a eliminar a tristeza e a saudade, tanto da alma-sombra quanto de seus parentes vivos. Junto a isso, alimentar um espírito é humanizá-lo, é atraí-lo para o ponto

\footnotetext{
30 Agostinho (1974: 29) diz o mesmo para os Kamayurá, acrescentando que o nome deste motivo seria “'caminho da mangaba', ou campo do jogo de bola".

${ }^{31} \mathrm{O}$ tahiti é desfeito algum tempo antes da festa porque o centro será ocupado com outras atividades, e sua madeira se tornará lenha. De fato, esse corpo ambíguo do chefe será substituído por um corpo menos ambíguo, a efígie.

32 No caso do cantor, enterrado em uma cova comum, sua panelinha de mingau era colocada sobre o único buraco da cova.
} 
de vista dos humanos, o que, como já foi discutido, é aparentá-lo (uma lógica semelhante à dos rituais de máscaras). Ao invés de permitir que o morto, triste e com saudades, venha buscar seus parentes (e faça deles parentes de espíritos), são estes que alegram e alimentam o morto e que de certa forma "vão buscá-lo", mas o fazem a uma distância de segurança - a distância do ritual. Citando Chaumeil (2007: 275), "in sum, it is more a question of creating an adequate distance from or relation to the dead than of systematically obliterating them via a collective amnesia". Nesse sentido, a sepultura faz para um chefe morto algo semelhante ao que uma máscara faz para um espírito. A construção do tahiti é uma forma de domesticar a alma-sombra do chefe e mantê-la humana por um tempo, e se um ritual de máscara marca uma relação entre um itseke e uma pessoa, a construção do tahiti marca uma relação coletiva entre um chefe e seu povo.

Mas por que manter a alma do morto por perto, ao invés de deixá-la se distanciar de seus parentes de uma vez por todas? Aqui é preciso lembrar que este esforço só é desprendido para os nobres, pessoas que, assim como a mãe dos gêmeos, serão "colocadas na origem", transformadas em ancestrais. Se o parentesco e a condição humana são coextensivos, para transformar um chefe morto em ancestral é preciso mantê-lo como parente e, para isso, é preciso mantê-lo humano, ainda que de forma reconhecidamente temporária. Como entre outros povos ameríndios, a ancestralidade aqui é embebida em diferença e a estética do tahiti, seu local de construção e seus propósitos tornam isso evidente.

\subsubsection{Do céu à terra}

Há ainda outro procedimento para manter a alma do morto por perto até o final do ritual por meio da alimentação. No final da um dia qualquer, antes do anoitecer, um cantor experiente vai à casa do dono da festa, acompanhado de outros homens (geralmente outro cantor menos experiente, ou um aprendiz, e vários outros interessados em aprender o canto ou apenas ouvir a música e dançar). A música é cantada dentro de casa, na porta da frente, repetindo-se algumas vezes. Se o cantor souber só um pouco, o ritual será rápido, durando menos de cinco minutos; se o cantor for bom, após o começo, algumas mulheres virão acompanhar, cantando em coro e dançando. Terminado o canto, os donos da festa devem oferecer pirão como pagamento aos cantores e às mulheres (que o levam ao centro e o 
redistribuem). Depois do anoitecer, os cantores e as mulheres retornarão e farão a mesma coisa, mas dessa vez indo de casa em casa em sentido anti-horário. Quando completam uma volta na aldeia, cantam e dançam uma última vez na casa do dono da festa, e então todos se dispersam.

Este ritual musical se chama ohogi, e está relacionado à capacidade dos mortos retornarem ao mundo dos vivos. Segundo os Kalapalo, há algum lugar do rio Curisevo, não muito longe da aldeia wauja atual, onde o rio se encontra com a Via Láctea (o rio celeste). Por isso é muito perigoso pescar à noite naquela região, pois os pescadores podem se confundir e acabar indo parar no céu, como já aconteceu há muito tempo (antes mesmo do primeiro egitsï). Conta-se que alguns pescadores wauja teriam se dado conta de que haviam chegado ao céu. Lá eles foram atacados por índios bravos (caranguejos, do ponto de vista dos vivos), e quase todos morreram. $\mathrm{O}$ único sobrevivente foi um homem que tinha tido um periquito de estimação, do qual havia cuidado muito bem e que já havia morrido. A alma desse periquito veio e lhe ensinou o ohogi e, enquanto cantava, o pescador conseguiu fugir dos índios bravos. Sempre acompanhado da alma de seu periquito, o pescador passou por várias aldeias ao longo do curso da Via Láctea cantando essa música, até que conseguiu retornar à sua aldeia na terra. Ele contou sua história, ensinou a música que aprendera com a alma de seu periquito e, depois de cinco dias, morreu. Taũgi, quando homenageou sua mãe, decidiu que esta música deveria fazer parte do ritual, e por isso é cantada durante sua preparação (uma vez, no centro, um dos cantores - que também era tajope - apressava os outros homens para terminarem de se arrumar, dizendo que naquela noite ainda tinham de fazer “a coisa dos Wauja”, “Auga engü”).

Assim como outras inúmeras músicas, os Kalapalo não entendem o que se diz no ohogi, que está todo em arawak, mas o chamam de kanga engetoho ("que serve para comer peixe") e ànha akuãpe (“alma do morto"). A primeira designação é porque deve-se oferecer aos cantores uma grande panela de pirão e beiju, que será levada ao centro e distribuída entre os homens pelos tajope. Os coordenadores sempre avisam a família do dono da festa um dia antes da realização de um ohogi, para que os homens possam pescar e as mulheres tenham tempo de preparar o pirão. A segunda designação é mais difícil de interpretar. Ela tem uma ligação óbvia com o mito resumido acima e, nas vezes que perguntei a alguém o porquê do ohogi ser a "alma do morto", a única explicação que consegui foi a repetição da história. Sobre a possível presença da alma do morto durante os cantos, dizem que, como sua almasombra "está andando por aí" e como as festas "servem pra alegrar o morto", é provável que 
sua alma acompanhe o ohogi. Mas me parece haver mais. No campo do ritual (sejam os rituais públicos, sejam as práticas ocultas dos feiticeiros), todo "desenho" é uma imitação e toda imitação é uma atualização daquilo que se imita. Não seria possível pensar o mesmo de uma música? Basso (1985) já havia notado que, para os Kalapalo, cantar é uma faculdade dada a seres superpoderosos, e quando os humanos cantam o fazem com a intenção de reproduzir o que estes seres fizeram nos mitos. Cantar uma música é replicar a ação de um itseke tendo em vista menos o sentido referencial da canção (incompreensível), mas seu contexto e seus efeitos. Desse ponto de vista, dizer que o ohogi é a "alma do morto" pode significar que é o feito do pescador wauja que se tenta reproduzir, o retorno da alma de um morto ao mundo dos vivos, uma tentativa de driblar a morte. Assim como a construção do tahiti e a oferta de bebida ao morto enquanto durar seu túmulo-casa, a musicalidade do ohogi e a oferta de comida que o acompanha focalizam o retorno e a permanência do morto entre os vivos por mais algum tempo. O que se obtém fabricando corpos (sejam sepulturas, sejam máscaras) para espíritos que se quer aparentar e humanizar, também pode ser feito com a música, e a alimentação desempenha um papel central em ambos os casos.

\subsection{Casa, corpo e pessoa}

Além de efetuar a "síntese formal" entre as qualidades dúbias de itseke e humano que a alma-sombra assume, o tahiti também torna visíveis algumas relações entre casa, corpo e pessoa. Levei um grande susto em 2009 quando dois rapazes que estavam em Brasília me disseram que, depois da saída de algumas pessoas de Aiha, a aldeia agora estaria com apenas “17 pessoas". Lembrando do que diz Lima (2005) sobre como os Yudjá contam as pessoas $^{33}$, imaginei que este número pudesse se referir aos homens adultos da aldeia, mas ainda assim me parecia muito pouco. Quando cheguei em Aiha, vi que a aldeia estava cheia, não parecia ter se esvaziado tanto, e havia muito mais do que 17 homens adultos. Havia, porém, apenas 17 casas. O leitor deve se lembrar que no capítulo 1 já encontramos uma identificação entre aldeia e pessoa, quando citei a narrativa de um chefe jagamü sobre a antiga

\footnotetext{
${ }^{33}$ Segundo ela, quando os Yudjá dizem "uma pessoa" eles estão se referindo a alguém que assume a posição de sujeito de um grupo e aqueles que são "eclipsados" por sua posição (Lima, 2005: 76). Por exemplo, "uma pessoa" pode significar um-homem-e-sua-família, situação na qual apenas o homem é contabilizado como sujeito.
} 
aldeia Timpa. Como ele dizia, "havia cinco pessoas ao redor da praça": esta "praça" (sua aldeia-esteio) era a aldeia Timpa, e as outras "cinco pessoas" eram suas aldeias satélites. Considerando a contabilidade dos habitantes de Aiha que os Kalapalo fizeram, poderíamos trazer esse tipo de relação para o grupo local, e teríamos então a casa dos homens no centro e as demais "casas de verdade" como as pessoas da aldeia.

As casas alto-xinguanas típicas são grandes estruturas ovaladas feitas a partir de diferentes tipos de madeira, bambu, embira e sapé. Segundo medições de Heckenberger (2005: 257) na aldeia kuikuro Ipatse, o comprimento das casas varia entre 11 e 35 metros, sua altura entre 3,5 e 7 metros, e sua largura entre 6 e 14 metros. Toda casa tem um dono, necessariamente um homem, que foi o responsável por decidir sua construção e organizar o trabalho para tal. Isso só muda quando o genro organiza a construção da casa de seu sogro, caso more com ele, o que é mais ou menos frequente quando o sogro já está muito velho ou não conta com parentes suficientes para ajudá-lo. Nessas condições, é obrigação do genro construir sua casa e a condição de dono se torna ambígua: algumas pessoas dirão que o dono é o genro, porque organizou o trabalho, mas a maioria dirá que o dono é o sogro.

Toda casa é construída em duas metades: a da esquerda deve ser feita pelo dono e seus parentes masculinos, e a da direita é construída com a ajuda de todos os homens da aldeia. Erguer uma casa é muito trabalhoso, e fazê-lo por conta própria levaria tempo demais, a ponto de parte do sapé e da madeira utilizados começarem a estragar antes mesmo da casa ficar pronta. Isto aconteceu em Aiha com a casa de um rapaz. A casa não faria parte do círculo principal de casas, nem seria uma "casa de verdade" (não seguiria o padrão tradicional, seria uma casa mais simples), e por isso a construção ficou toda a cargo da família. Ainda assim, ela era consideravelmente grande e o envolvimento dos parentes do jovem com o patrocínio de dois egitsü dificultou sua construção. Em 2009 sua estrutura já estava pronta; em 2011, ela estava sendo coberta pela segunda vez, algumas madeiras do telhado precisariam ser trocadas e ela ainda estava longe de ficar pronta.

Tratando-se de uma casa de verdade, o dono não pode construí-la sozinho e, assim como a construção de uma pessoa exige parentes e afins, a relação entre o dono-da-casa-comseus-parentes e os trabalhadores tem traços de afinidade. Um dia de trabalho coletivo em uma casa é uma oportunidade para primos cruzados entrarem em relações ao mesmo tempo tensas e cooperativas. Nessas ocasiões, qualquer primo cruzado do dono da casa em construção pode pedir um pagamento adicional por seu trabalho. Quando uma pessoa faz isso, aproveita para 
pedir pagamentos médios ou mesmo coisas complicadas para o dono ${ }^{34}$, como uma espécie de desafio a seu primo (que não pode, em hipótese alguma, recusar). Em contrapartida, espera-se que estes primos trabalhem duro e ajudem na coordenação do trabalho (dizem que eles ficam "igual a tajope"). Como qualquer pessoa, uma casa é o produto da relação entre consanguíneos e afins (ainda que nesse caso se trate dos afins terminológicos).

Assim como a casa é uma pessoa, ela também é/tem um corpo (masculino): possui tronco, costelas, axilas, pescoço, cabeça, colar, plumária, e está armada de uma lança de pesca. Vista de fora, ela é análoga ao corpo de um pescador paramentado para a festa, reunindo os dois elementos que os xinguanos consideram como seus diferenciais: a prática de seus rituais e a centralidade dos peixes em seu sistema alimentar.

\subsubsection{Casas nobres}

Um dos principais índices de que alguém é um grande chefe é que ele viva, ou já tenha vivido, em uma talühe. Esta casa tem um papel importante para a planta da aldeia, pois ela divide o círculo de casas - do ponto de vista de quem a olha de frente a partir da praça - em esquerda (iheĩgü inhongo) e direita (oto inhongo ${ }^{35}$ ). Seu local ideal de construção é à leste, de frente para a casa dos homens e para a entrada principal da aldeia; quando é construída nesse polo, a oposição entre esquerda e direita se sobrepõe àquela entre norte e sul. Uma casa como essa nem sempre existe em toda aldeia o tempo todo, mas há um ideal de que, tendo a aldeia um grande chefe (seu primeiro cacique), este deveria morar em uma talühe. Aiha contava com 25 casas em agosto de 2011; contudo, não há nenhuma talühe nesta aldeia atualmente, e a última foi destruída em 2007, quando já estava muito velha. Mas já há planos para que uma nova seja construída em breve para o sucessor do chefe principal, seu sobrinho uterino.

Como já foi discutido, os chefes estão intimamente ligados à onça e, se recordarmos o capítulo 3, a talühe aparece pela primeira vez no mito de origem da humanidade como a casa

\footnotetext{
${ }^{34}$ Um homem foi pescar com seus três filhos e seu genro para pagar a comunidade pelo trabalho em sua casa. Eles passaram a noite pescando, pois o trabalho começaria de manhã. Logo cedo, enquanto cobriam a casa com sapé, um primo cruzado do dono da casa gritou e pediu... peixe! O dono ficou bravo, mas sem manifestar isso, aceitou - não havia alternativa. Naquele mesmo dia ele teve que ir pescar novamente e trazer peixe exclusivamente para seu primo cruzado. Tempos depois, comentando o ocorrido comigo, desabafou: "nossos primos cruzados são loucos".

${ }^{35}$ Lit. "em direção ao dono".
} 
de Enitsuẽgü. Quando os gêmeos se mudaram para sua aldeia em Mügena, Taũgi construiu para si uma casa como a de seu pai-onça, e esta é a origem das casas dos chefes. Diferente de uma casa comum, um chefe jamais pode decidir pela construção de sua própria talühe. Isso deve ser uma sugestão de outros chefes que, se for aceita pelos demais, ainda pode ou não ser aceita pelo chefe que viverá na casa. Quatro chefes (como em outras atividades direcionadas aos nobres ${ }^{36}$ ) se tornam responsáveis por coordenar a construção da talühe e transformam o chefe principal em dono de uma festa, que será realizada praticamente todos os dias até o final da construção; ao efetuar pagamentos pela realização da festa, sob a forma de peixe, beiju e mingau, o chefe paga pela construção de sua casa. Segundo o primeiro cacique, ele nunca passou por nada tão desgastante como quando construíram sua talühe. Pescava todos os dias, com a ajuda apenas de seus dois filhos homens e seu único genro à época, e só contava com uma filha adulta. Sua mulher me contou ter sugerido que ele arranjasse uma segunda esposa, pois ela não aguentava mais trabalhar. Nas palavras do chefe, hoje: "eu não quero mais saber de talühe!".

Essa casa é sempre um investimento do coletivo em uma pessoa que se espera que permaneça chefe ou que se torne um grande chefe. Em Aiha, o atual chefe principal só teve sua talühe construída em uma situação política potencialmente tensa: quando um importante chefe se mudou para outra aldeia e outro chefe se mudou para Aiha, a pedido dos próprios Kalapalo, para se tornar o "dono dos brancos". Construindo uma casa para ele, os Kalapalo afirmaram sua posição como primeiro cacique em uma conjuntura política em transformação. Atualmente, este homem está sendo substituído por seu jovem sobrinho uterino, para quem a aldeia já planeja construir uma talühe em breve. Ou seja, ao construírem uma talühe, os Kalapalo também estão construindo um chefe - outro corpo de chefe, em outra escala.

A expressão "construir" não está aqui à toa. As qualidades e capacidades das pessoas são o resultado da longa e intencional construção de seus corpos, e a talühe é pensada justamente como um tipo de corpo que tem várias analogias com o modelo de corpo de um

\footnotetext{
${ }^{36}$ É importante notar a recorrência do número de tajope: quatro para enterrar um chefe, quatro para construir o tahiti, quatro para coordenar o egitsü, quatro para construir uma talühe. Haveria qualquer relação entre este número e a forma mínima de uma aldeia circular? O mínimo para que uma aldeia tenha um centro e uma casa dos homens são quatro casas (e já notei como a aldeia é um tipo de corpo). Se o chefe é, ao menos em alguns momentos, uma espécie de "centro" da vida social (como a própria praça da aldeia), o mínimo para a produção desse(s) centro(s) também são quatro pessoas. Outra coisa interessante é a distribuição dos tajope, no enterro, na construção do tahiti e na construção de uma talühe, em dois grupos de dois: nos dois primeiros casos, são dois enterradores para o leste e dois para o oeste; no caso da talühe, são dois responsáveis pela metade da esquerda (idealmente norte), e dois pela metade da direita (idealmente sul).
} 
grande chefe - que precisa ser deliberadamente construído ao longo da vida e, mais ainda, sempre a partir da sugestão e sob a coordenação de outros (quatro) chefes. As principais marcas de nobreza exibidas pelos chefes em seu corpo, em diferentes contextos ao longo de toda uma vida de participação em rituais, são sintetizadas na talühe e tornam visíveis, em diferentes escalas, uma dualidade fundamental entre super-consanguinidade e afinidade potencial.

Assim como as outras casas kalapalo, a talühe é pensada segundo o modelo do corpo humano masculino, mas que, assim os corpos dos chefes, é um corpo diferente dos demais. De saída, uma talühe pode ser identifica pela exibição de raízes de árvores nas extremidades externas do teto ${ }^{37}$, que são suas orelhas ou brincos, um índice de que a casa foi construída coletivamente e por vontade da comunidade. Dizem que isso serve para que qualquer pessoa que venha de fora saiba logo onde vive o chefe principal. Além da talühe, apenas a casa dos homens possui esse tipo de adereço. Ela tem orelhas porque "o chefe tem que escutar as pessoas", e sua casa é um lugar onde se deve falar de coisas sérias. O chefe principal de Aiha repete com frequência que seu trabalho é muito difícil porque as pessoas sempre o procuram em sua casa para falar sobre acontecimentos desagradáveis, conflitos, pedir coisas, pedir ideias para atividades coletivas, etc. Uma vez um rapaz me disse que a casa do futuro chefe, apesar de ser uma casa comum, "já é uma talühe, você vê que as pessoas vão lá o dia inteiro pra conversar".

Também já me disseram que estes brincos seriam como os brincos de rabo de rei congo, de uso exclusivo dos chefes em contextos rituais (usados obrigatoriamente pelos donos do egitsü, e feitos pelos tajope). Versões invisíveis de tais brincos também são usadas por itseke e grandes xamãs, e é o que lhes confere a capacidade de escutar a longas distâncias. A meu ver, a relação entre chefes e as "orelhas" de suas casas especiais, ou brincos que, em outras pessoas, conferem capacidades auditivas extraordinárias, é algo ligado ao uso ritual da fala e à obrigação de ouvir os outros. Os chefes são os que discursam em encontros rituais com os estrangeiros, e eles não apenas falam, mas também ouvem discursos dos chefes visitantes, mesmo que não os compreendam.

Esta correlação entre a capacidade auditiva do chefe e adornos exclusivos dele e de sua casa evoca a discussão de Seeger (1975) sobre o tema, segundo a qual a ornamentação do

\footnotetext{
${ }^{37}$ Isso é feito amarrando nas extremidades do teto parte de alguma árvore de tronco bem fino com suas raízes.
} 
corpo estaria ligada à importância simbólica de certas faculdades corporais. Ele argumenta que, para os homens Suyá, suas orelhas seriam ornamentadas com alargadores e seus lábios com botoques porque estes são os órgãos ligados às principais faculdades de um homem, a audição e a fala. Estes ornamentos seriam "physical representations of the conceptual elaboration" (ibid: 218) de tais capacidades:

Lip discs and ear discs are clearly associated with the cultural importance of hearing and speaking as they are defined by the Suya. (...) They maintain that the ear is pierced so that people will 'hear-understand-know'. They say the lip disc is symbolic of, or associated with, belligerence and bellicosity, which are correlates of masculine self-assertion, oratory, and song. (ibid: 217)

Vista de fora, a talühe é como um homem xinguano portando brincos que, em contextos rituais, são insígnias da posição de chefe e estão ligados a uma capacidade auditiva exacerbada. A talühe também apresenta, sobre o teto, um friso externo com pinturas, no qual se aplica (pelo menos) um desenho que representa a junção das asas de uma borboleta a seu corpo (hototo ijatagü, "axila de borboleta"). Este desenho pode ser combinado a outros, como o principal padrão da pintura corporal (tüihitinhü) e o motivo da efígie masculina (outro tipo de "axila de borboleta"). Dois frisos idênticos são colocados no interior da casa sobre as portas frontal e traseira, ao longo de todo o seu comprimento. Abaixo, um friso desse tipo no teto da casa dos homens: 


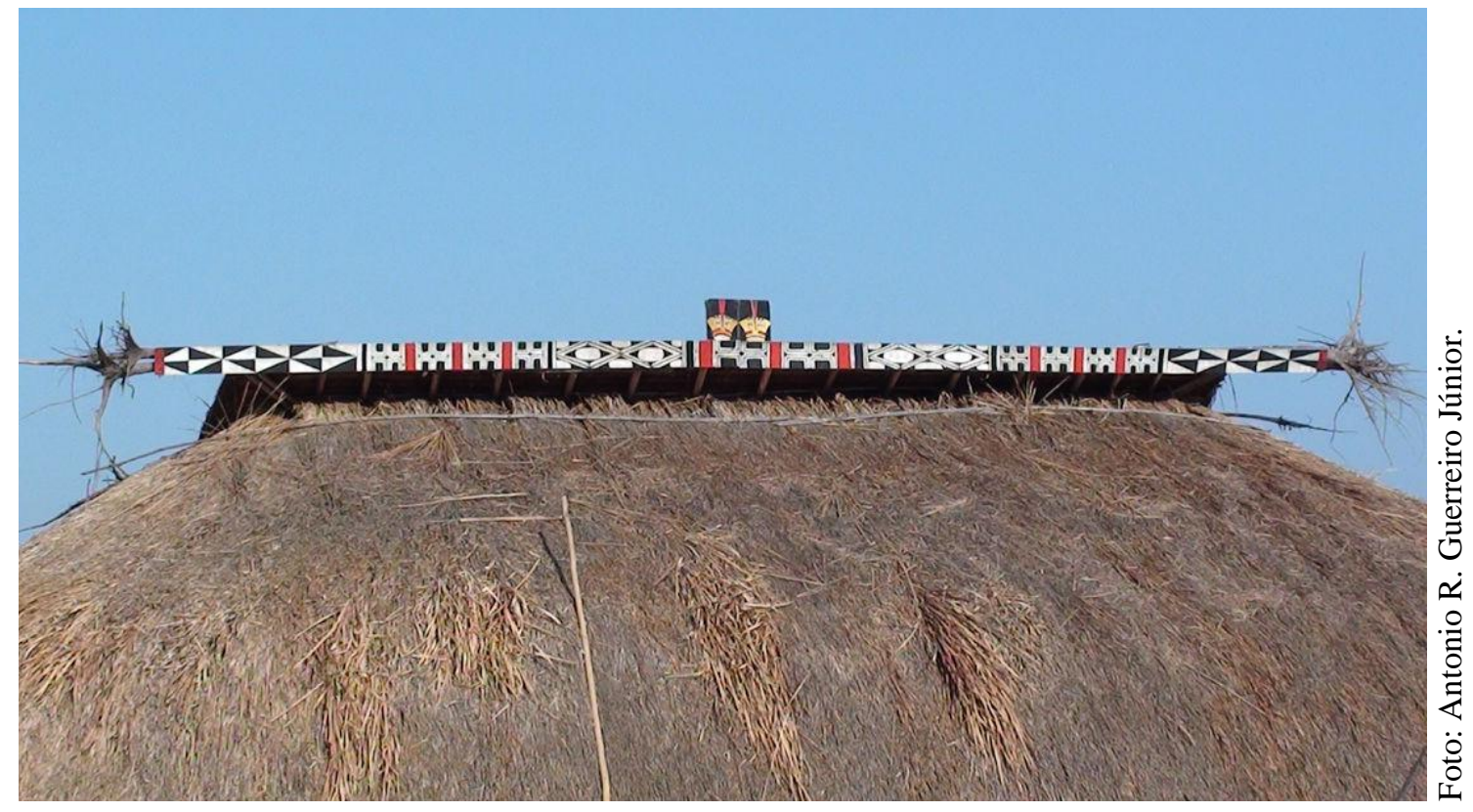

Figura 4.7: friso externo da casa dos homens, semelhante aos colocados na talühe por fora (no teto) e por dentro (sobre as portas).

Nas extremidades foi pintado um motivo hototo ijatagü (“axila de borboleta"); ao lado deles, outro motivo hototo ijatagü, a pintura da efígie masculina; em seguida, vem o motivo tüihitinhü, pintura corporal típica (também usada em efígies de mulheres). No centro, repete-se o padrão usado nas efígies masculinas. As duas plumárias no topo "representam" Taũgi e Aulukumã, e as raízes nas extremidades são as "orelhas" ou "brincos" da casa dos homens.

É difícil saber o porquê de tais desenhos, e os Kalapalo não possuem uma "história geral dos grafismos" como, por exemplo, os Wauja (Barcelos Neto, 2002; 2008). Para estes arawak, todos os grafismos seriam desdobramentos de um motivo infinito presente na roupa de cobra que um homem, após ter cometido incesto, fabricou para se transformar em uma serpente gigantesca. Mas as únicas racionalizações dos Kalapalo sobre essas pinturas são que "é para ficar bonito" ou que "a casa do pai de Taũgi era assim". Por alguma razão, outra forma pela qual os Kuikuro (Franchetto, 2003a: 19) chamam o motivo "axila de borboleta" é "boca de animal terrestre" (ngene hotagü).

Outros aspectos da talühe remetem mais diretamente às relações dos anetü com os seres míticos. Os pilares de sustentação da casa do chefe, seus mourões e os batentes das portas só podem ser feitos de uẽgühi - a mesma madeira da qual foram feitas as esposas de Enitsuẽgü, da qual são feitos os esteios do túmulo dos chefes, seu tahiti e as efígies mortuárias. Os dois pilares centrais, inclusive, recebem a mesma pintura das efígies 
mortuárias masculinas. Só o chefe das árvores pode ser usado para produzir pessoas - foi assim no tempo mítico, é o que se tenta reproduzir no egitsü e talvez as analogias corporais do tahiti e da talühe autorizem a dizer que algo no mesmo sentido se passa nesses casos.

O interior da talühe é diferenciado das demais casas pela presença de certos elementos decorativos, também ligados aos corpos dos chefes, às insígnias que eles exibem e aos chefes míticos. Talvez sua peculiaridade mais notável seja a presença de duas esculturas de barro ${ }^{38}$ com formato de onça em frente à porta principal, uma de cada lado dos postes centrais da casa. Já ouvi dizer que, idealmente, a da direita seria uma onça pintada, enquanto a da esquerda seria uma onça parda; contudo, a talühe que havia em Aiha e fora destruída em 2007 contava com duas onças pintadas. Também já me disseram que além das onças, pode-se fazer um veado no centro, ou apenas uma onça de um lado e um veado do outro, com a explicação de que "é porque a onça come o veado". Heckenberger (2005: 258) nota que, para os Kuikuro, a escultura da direita seria uma onça, a da esquerda uma sucuri ou outro tipo de cobra e, entre as duas, um sapo ("food for the anaconda", como o veado na talühe kalapalo).

Estas esculturas servem para dizer aos que entram na talühe que ela deve ser respeitada: são titsangitsoho, literalmente "que servem para provocar respeito". Respeito (itsangi) é o que se deve ter, de maneira geral, por sujeitos classificados de alguma maneira como outros, principalmente os afins e os espíritos, marcando uma relação como potencialmente perigosa. Desrespeitar um afim provocaria extrema vergonha (até mesmo divórcio compulsório, se um genro ou uma nora desrespeitar seu sogro ou sogra), e desrespeitar um espírito pode significar adoecimento ou morte. Em certo sentido, desrespeitar significa se aproximar demais de uma figura de alteridade sem os devidos cuidados, tratar indevidamente um Outro como se fosse alguém com quem as relações são muito relaxadas.

Um chefe kuikuro disse a Heckenberger (ibid: 257) que antigamente a talühe era objeto de um respeito especial por parte de seus afins ${ }^{39}$, que não passavam perto dela. $O$ filho do último grande chefe nahukwa, que vive em Aiha, me disse que seu pai sempre viveu em talühe, e que ele nunca construiu uma casa (o que outros confirmam). Segundo ele, ninguém ia ou saia da casa de seu pai "sem nada nas mãos": quando iam até ela, as pessoas sempre

\footnotetext{
${ }^{38}$ Um barro vermelho que se obtém ao cavar o chão da casa a certa profundidade.

${ }^{39}$ Nas palavras deste chefe, "(...) in-laws passed farther from it, spoke more softly, and respected it with the utmost sanctity" (Heckenberger, 2005: 257). Mas quais ideias estão sendo traduzidas por "utmost sanctity"? Isso seria a tradução de alguma expessão em karib ou o chefe teria utilizado a palavra "sagrado" em português? Seria importante que o autor detalhasse os sentidos dessa ideia para os Kuikuro.
} 
levavam peixe, e às vezes pediam objetos, que seu pai nunca negava. Também se diz que é preciso ter respeito em relação aos chefes, mas não sei precisar o que isso significa na prática (tenho a impressão de que aqui esta palavra se refere a algo mais próximo do que nós mesmos chamamos de respeito, algo como "formalidade"). Dizem que, até não muito tempo, não se pronunciava os nomes dos chefes, chamados apenas de tongisa ${ }^{40}$ (Ageu diz ter vivido isso enquanto ainda era jovem, antes do sarampo). A evitação dos nomes dos chefes evoca a proibição de se pronunciar os nomes dos afins, e é um indício de que, além da chefia estar fundada em uma diferença (do chefe como predador), ela pode ser vista como uma relação de afinidade. No caso da talühe, as figuras titsangitsoho parecem indicar que, de alguma maneira, o dono daquela casa é alguém diferente e potencialmente perigoso, que se deve tratar com cuidado.

Também há referências a serpentes na talühe, pois duas grandes sucuris são pintadas nas madeiras que escoram o "peito" da casa (proteções contra vento). Penso que as serpentes podem estar ligadas ao ideal de que todo grande chefe deve ter sido um grande lutador. Para isso, é necessário incorporar substância-força de espíritos que darão ao pretendente a campeão força e habilidade - processo que coloca o lutador e o espírito em um devir (no sentido usado por Viveiros de Castro, 2007a) que faz dos lutadores (e de qualquer pessoa, de fato), um pouco itseke, alguém diferente de si mesmo (assim como faz do espírito um pouco humano). Um dos principais espíritos lutadores é justamente a Sucuri, cuja força de ataque é capaz de derrubar qualquer adversário. Para conseguir sua força, um lutador precisa cortar o rabo de uma sucuri viva, retirar sua carne, deixar a pele secar e usá-la para cobrir uma peça de madeira, de uns $90 \mathrm{~cm}$ de comprimento, cortada no formato de um rabo de cobra. Esse objeto se chama hũbongo ("que fica sobre as costas"), e é usado como enfeite pelos homens quando tocam as flautas do egitsü (atanga), e também takuaga ${ }^{41}$. Esse enfeite é associado sobretudo com a atanga, pois antigamente era usado apenas por grandes campeões quando dançavam no egitsü (mas hoje imitações do enfeite original são usadas por qualquer homem). Este objeto é um enfeite "inalienável", pois não pode ser dado nem vendido. Caso seu dono o desse ou trocasse, ficaria seriamente doente, pois seria agredido pelo espírito da Sucuri (um espírito escolhe dar força para um lutador por suas qualidades físicas e morais, e o desrespeito a essa escolha é perigoso).

\footnotetext{
${ }^{40}$ Vocativo para anetü. Nunca consegui uma tradução dessa palavra que não fosse "chefe". Ela ainda é usada nos discursos ligados à festa de trocas (uluki), que serão analisados no capítulo seguinte.

${ }^{41}$ Antes das lutas ele também pode ser esfregado nos braços dos lutadores para que fiquem fortes (Costa, 2011).
} 


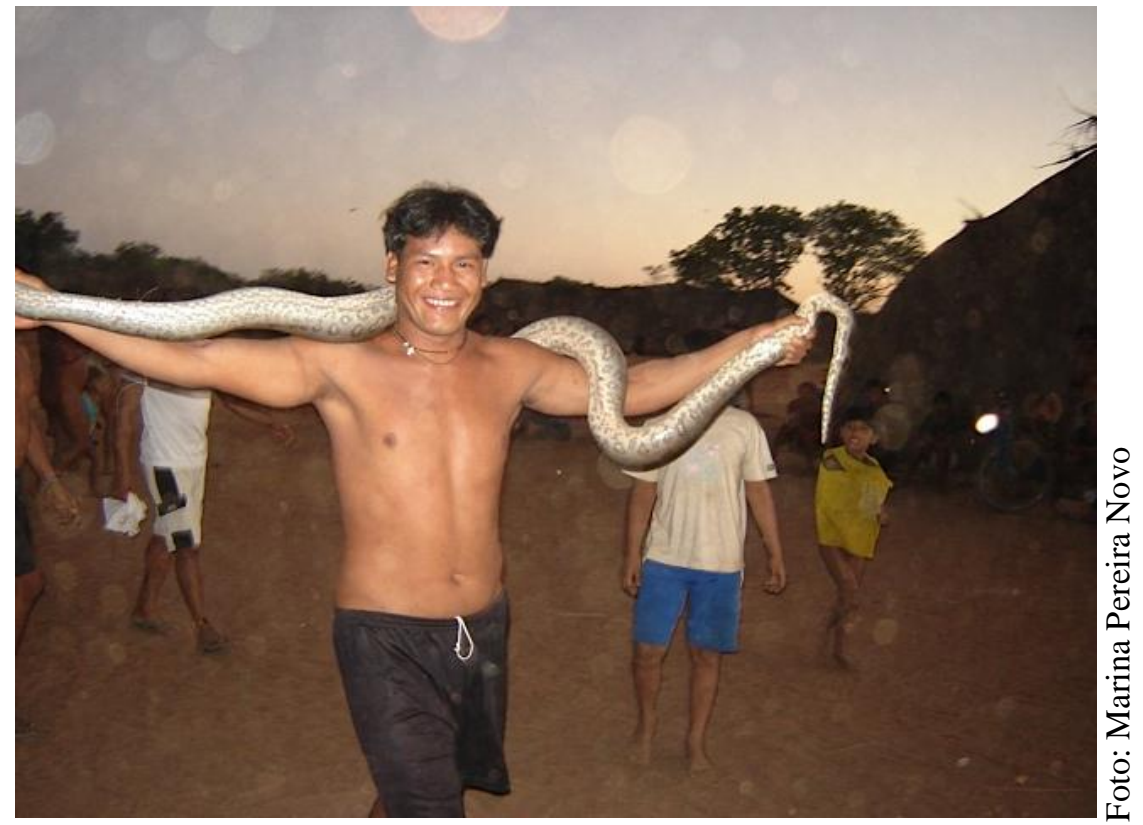

Figura 4.8: jovem lutador exibindo uma sucuri que utilizaria para fazer um hũbongo.

A talühe está repleta de elementos associados ao mundo dos espíritos, tanto ao chefe das árvores quanto a espíritos de animais predadores. Essa dualidade se replica, de forma um pouco diferente, no tahiti, que também está ligado ao chefe das árvores (foi feito pela primeira vez para a mãe dos gêmeos e é feito de sua madeira) e, por sua forma, à condição dúbia de itseke e humano da alma-sombra do morto. Em uma aldeia onde todos se consideram parentes e partilham um mesmo sangue, mora alguém que ao mesmo tempo é seu pai e seu não pai, humano e não humano.

Já que estamos falando de casas de nobres, cabe a pergunta: isso poderia ter alguma relação com o conceito de Casa (Lévi-Strauss, 1986 [1984]; 2004 [1979])? O conceito de "sociedades de casas" (sociétés à maisons) surgiu tardiamente na obra de Lévi-Strauss (2004 [1979]) como uma tentativa de preencher uma lacuna em sua teoria do parentesco: os sistemas cognáticos ou de filiação indiferenciada. Ele parte das descrições de Franz Boas sobre o numaym entre os Kwakiutl da América do Norte, e da dificuldade para caracterizar esse tipo 
de organização. O material etnográfico indicaria a coexistência de princípios antagônicos de pertencimento, como filiação patri e matrilinear, que dificultavam sua identificação aos tipos de grupos tradicionalmente descritos pela antropologia:

(...) ce type d'institution ne coincide avec aucun des trois modes de descendance unilinéaire, bilinéaire, indifférenciée - qu'on a trop tendance à traiter comme des catégories séparées, alors que les institutions de type numayma les recoupent. (Lévi-Strauss, 2004 [1979]: 148)

A coexistência de duas regras de pertencimento por descendência se combinaria ainda com a possibilidade de entrada em um numaym por aliança: um homem casado entraria para o numaym de seu sogro. Esse tipo de instituição também teria riquezas materiais e imateriais como nomes, cantos, títulos, prerrogativas rituais, e se reproduziria por meio de sua transmissão. Como tanto a consanguinidade quanto a afinidade poderiam servir de meio a essa transmissão, o parentesco ficaria sujeito à subversão por interesses políticos e econômicos, pois as pessoas poderiam "travestir toutes sortes des manoeuvres sociopolitiques sous les oripeaux de la parenté" (ibid: 149). Em vista disso, Lévi-Strauss propõe uma analogia entre estes agrupamentos e as Casas nobres da Europa Medieval, definindo a Casa como uma

(...) personne morale détentrice d'un domaine composé à la fois de biens matériels et immatériels, qui se perpétue par la transmission de son nom, de sa fortune e de ses titres en ligne réelle ou fictive, tenue pour légitime à la seule condition que cette continuité puisse s'exprimer dans le langage de la parenté ou de l'alliance, et, le plus souvent, de deux ensemble. (Lévi-Strauss, 2004b: 151-152).

E, por sua capacidade de reunir princípios antagônicos para sua constituição e reprodução, a Casa representaria

(...) un effort pour transcender, dans tous les domaines de la vie collective, des principes théoriquement inconciliables. En mettant, si l'on peut dire, 'deux en un', la maison accompli une sorte de retournement topologique de l'intérieur en extérieur, elle remplace une dualité interne par une unité externe. (ibid: 161). 
Em suas primeiras ocorrências na obra de Lévi-Strauss, as "sociedades de casas" aparecem como um "tipo social", um modelo de sociedade que estaria a meio caminho (em termos lógicos, e não evolutivos, como Lévi-Strauss faz questão de enfatizar ${ }^{42}$ ) entre as estruturas elementares e as estruturas complexas de parentesco. Diferentemente das primeiras, nas sociedades de casas a política e a economia seriam realidades mais descoladas das relações de consanguinidade e afinidade, mas cuja autonomia ainda incipiente as obrigaria a se expressar na única linguagem disponível, subvertendo-a: a linguagem do parentesco. Mas justamente por isso elas também não se confundiriam com as estruturas complexas, nas quais a política e economia formariam sistemas com linguagens próprias.

O conceito de Casa geralmente não é considerado muito rentável para descrever os povos ameríndios (eles sequer são mencionados por Lévi-Strauss em seus textos sobre o assunto, e no livro organizado por Janet Carsten e Stephen Hugh-Jones ${ }^{43}$ há apenas três artigos que contemplam a América do Sul). A maioria apresenta sistemas de aliança de tipo dravidiano operando de forma ego-centrada, local e, consequentemente, aberta, o que dificultaria a cristalização de unidades sociais do tipo Casa (Viveiros de Castro, 2002c: 96). Como observa Gordon (1996: 194), a associação entre Casas, hierarquia e perpetuação no tempo, dificultaria a aplicação do modelo em sociedades igualitárias e com organizações fluidas do ponto de vista da morfologia social. Mas o próprio Lévi-Strauss chama a atenção para formas mais efêmeras da casa (Lévi-Strauss, 1984), como as que existem em Bali, o que permitiria relativizar o argumento acima.

Alguns americanistas vêm utilizando esse conceito em diferentes contextos etnográficos, com rendimentos descritivos e explicativos variados. Provavelmente a primeira tentativa é a descrição que Vanessa Lea (1986; 1993; 1995) faz dos Mebengokre (Kayapó). Segundo ela, a sociedade mebengokre seria formada por um conjunto de Casas, cada qual "uma unidade exogâmica representada por $n$ habitações nas aldeias existentes atualmente" (Lea, 1995: 322), e cujo pertencimento seria transmitido pela via materna. Cada Casa ocupa um lugar específico no círculo residencial, tem sua distinção assegurada por um "patrimônio de nomes pessoais e de prerrogativas (nekrets)" (id. ibid.) e é qualificada por epítetos referentes aos principais itens que compõem seu patrimônio (ibid: 323). Apesar de serem

\footnotetext{
${ }^{42}$ Lamaison e Lévi-Strauss, 1987: 3.

${ }^{43}$ Carsten e Hugh-Jones, 1995.
} 
unidades exogâmicas, as Casas não estariam ligadas entre si por nenhuma regra prescritiva de casamento.

De fato, a posse de riquezas materiais e imateriais é uma das características "clássicas" das Casas, como Lévi-Strauss aponta ${ }^{44}$, e isso torna a aproximação do contexto mebengokre com o conceito de Casa tentadora. Mas o fato do pertencimento a uma Casa mebengokre ser exclusivamente matrilateral e das Casas serem exogâmicas coloca uma questão importante, já levantada por outros pesquisadores (Coelho de Souza, 2002; Gordon, 2006): o que faz desses grupos Casas, no sentido lévi-straussiano, e não "grupos de descendência unilinear", linhagens, no sentido clássico? Como Lévi-Strauss enfatiza, o conceito de Casa só pode render onde não há formas claras de descendência (uni ou bilateral); além do mais, ao invés de se definirem como grupos exogâmicos, as Casas combinariam os princípios de endogamia e exogamia tendo em vista questões políticas e/ou econômicas. Coelho de Souza (2002: 631633) argumenta que o tratamento das Casas mebengokre por Lea se mantem preso a uma visão das funções dos grupos corporados na esfera político-jural: "seus horizontes continuam sendo, de um lado, as 'corporações' intrinsecamente parciais que são as matricasas e, de outro, a totalidade constituída por sua reunião" (ibid: 632). Para ilustrar seu argumento, a autora cita uma passagem de um trabalho de Lea que reproduzo aqui:

As casas são privadas, não somente porque o acesso a elas é restrito a indivíduos específicos, mas também porque constituem o domínio das particularidades bens simbólicos, interesses políticos, dever masculino de vingar homicídios praticados contra seus membros... $O$ patrimônio cultural da sociedade mebengokre é segmentado pelas Casas cujo conjunto forma uma totalidade. Esta idéia é exemplificado [sic] pela associação de cada porção da carne de anta [...] a uma determinada Casa, cujos membros detêm o direito de consumi-la. A soma de porções produz uma totalidade - o corpo da anta ou a soma das Casas que constituem a sociedade Mebengokre. (Lea, 1993: 275)

Não me parece haver espaço na descrição de Lea para o que, segundo entendo (e como também argumenta Coelho de Souza, 2002: 632), parece ser a principal característica das Casas enfatizada por Lévi-Strauss nas poucas, porém densas, páginas dedicadas ao conceito em Paroles Données (Lévi-Strauss, 1984): o mascaramento de uma dualidade interna sob a forma de uma unidade externa.

\footnotetext{
44 "Européenne ou indienne, la Maison possède un domaine qui consiste en richesses tant immatérielles que matérielles" (Lévi-Strauss, 2004 [1979]: 153-154).
} 
A aplicação do conceito à organização social tukano feita por Hugh-Jones (1993) me parece mais próxima das formulações de Lévi-Strauss. Como ele nota, o conceito de “descendência" é muito importante para as descrições que os antropólogos fazem desses grupos, enfatizando a patrilinearidade e a hierarquia em sua composição; Hugh-Jones argumenta, porém, que a situação é complexa, e as relações sociais seriam concebidas de duas maneiras complementares, das quais a descendência seria apenas uma. Esta seria pertinente em contextos míticos e rituais, que enfatizam a hierarquia; já as relações da vida cotidiana seriam concebidas segundo um ideal mais igualitário e cognático. Por esse motivo, HughJones sugere que o conceito de Casa descreveria com mais acuidade a organização social destes grupos do Noroeste Amazônico, pois as casas tukano combinariam dois princípios "normally taken to be mutually exclusive" (ibid: 98) e mascarariam essa dualidade sob a forma da unidade da casa. Segundo o autor, "these two conceptualizations correspond to two different, gendered readings of the house as a physical structure” (ibid: 97). Hugh-Jones lembra que, em sua discussão sobre sociedades de casas, Lévi-Strauss está mais preocupado com grupos do que com edifícios, mas observa que "though there is no necessary correlation between the two, the salience of the House as a social institution is frequently reflected in architectural elaboration" (id. ibid.).

A comunidade da maloca, a grande unidade residencial tukano, se identifica com a casa, pensando e agindo como uma única família e segundo uma ideologia de consanguinidade e princípios de igualdade (ibid: 100). Mais ainda, a noção de comunidade seria transposta para a representação de uma casa feminina pensada como um útero, "a womblike, female house" (id. ibid.). Às vezes os Tukano falam da casa como uma mulher (ibid: 102), com cabeça (o fundo arredondado da casa), vagina (a porta de entrada frontal) e útero (seu interior). O modelo da casa se replicaria em diferentes escalas, além do edifício da maloca. Os grupos territoriais tukano (conjuntos formados por malocas vizinhas pertences a dois ou mais diferentes grupos exógamos) se juntam, de tempos em tempos, em festas chamadas de "casas", nas quais a casa é colocada, metonimicamente, no lugar das pessoas dentro dela (ibid: 101). Nestes eventos, o grupo territorial se apresenta como se fosse uma mesma família comensal, os convidados agindo como maridos provedores de carne e os anfitriões como as esposas cozinheiras (id. ibid.). As relações entre anfitriões e visitantes são lidas ao mesmo tempo como relações de gênero cruzado e de afinidade, exibindo as relações 
entre homens e mulheres ou entre consanguíneos e afins como relações entre pessoas que são “iguais-mas-diferentes" (“equal-but-different”; ibid: 105).

A maloca também replicaria a estrutura do cosmos, sendo seu chão como a terra e seus pilares como as montanhas que suportam o céu (ibid: 102). No plano das relações entre os grupos Tukano, os ancestrais de cada um teriam habitado uma casa ancestral diferente na região do rio Vaupés, ocupando territórios específicos e de posse de diferentes línguas e riquezas (materiais e imateriais), elementos que funcionam como emblemas grupais. Neste nível, a mitologia enfatizaria as relações de equivalência e diferença entre os vários grupos tukano.

Nos níveis da maloca, das festas de oferta de comida envolvendo grupos territoriais, e da constituição de cada grupo tukano, a diferença entre consanguíneos e afins, anfitriões e visitantes, um grupo e outro, é expressa pelo idioma da afinidade, ao mesmo tempo em que é complementada pela ideia de que essa diferença supõe relações de igualdade:

Affinity, as a 'between' relationship, is expressed in relational terms - in the relative placing of individuals within the house or in that of houses within a given area. Consanguinity, as a 'within' relationship, receives concrete expression in the womb-like interior of the maloca. Depending on context, the family contained in this womb may be the nuclear family in its compartment, the community in the maloca, the territorial group at a dance house, or the whole of humanity inside the house-as-cosmos. (ibid: 106)

A definição da organização social a partir da noção de hierarquia estaria restrita a outros contextos, notadamente os rituais de iniciação, o que proporciona uma aproximação com um dos aspectos mais importantes do conceito de casa: sua reprodução através da transmissão de suas riquezas, materiais ou imateriais. Cada grupo tukano descende de um ancestral anaconda de mesmo nome, ocupa um território tradicional em uma determinada porção do rio e está dividido internamente em um ou mais conjuntos de sibs, hierarquizados como mais novos e mais velhos. Idealmente, seriam cinco conjuntos de sibs, tal como na casa primordial, cada um com papeis rituais especializados (do sib mais velho para o mais novo: chefes; cantores-dançarinos; guerreiros; xamãs; e servos). Há histórias que narram como, na jornada da anaconda ancestral rio acima, cada grupo obteve diversos objetos cerimoniais, cantos e encantamentos, "posses" cuja transmissão é uma das coisas que os perpetua. Do 
ponto de vista das diferenças ligadas às prerrogativas rituais e ao território, o cosmos também é visto como uma casa, mas uma casa completamente diferente: ao invés de ser um útero feminino englobante, ela é vista como uma anaconda masculina e linear (ibid: 108). "In one grand fusion of group, space and time, body, house and cosmos coincide, the present becomes the past, individuals become whole sibs, and the group becomes one with its ancestor" (ibid: 111). Aqui sim estamos diante de uma série de elementos que marcam o conceito de Casa: princípios femininos e masculinos de concepção das relações sociais, igualitários e hierárquicos, cotidianos e rituais, englobantes e lineares - princípios antagônicos reunidos e mascarados sob a forma da Casa (em seus diversos tamanhos, da maloca ao cosmos).

Também há uma tentativa de interpretar o Alto Xingu como uma "sociedade de casas" (Heckenberger, 2005; 2011), mas que me parece pouco adequada ao material etnográfico de que disponho e opera certas distorções do conceito. Contudo, isso não significa que este não seja aplicável; pelo contrário, com algumas adequações talvez possamos reencontrar algo como uma Casa (como as descrições do tahiti e da talühe já devem ter dado as pistas) em um dos objetos mais caros à etnologia americanista: o corpo. Mas o façamos com cuidado, pois como questiona Gordon (1996: 195) a respeito da correlação entre corpo e Casa na América do Sul, "caberia perguntar, enfim, se isto nos conduziria além ou aquém de Lévi-Strauss".

Heckenberger (2005: 258) sugere que as parentelas dos chefes alto-xinguanos poderiam ser vistas como Casas, cuja disposição no círculo da aldeia seria uma expressão de suas diferenças hierárquicas: "The cardinal houses - the tajïfe (when present) and its oppositional counter-part - are thus the 'heads' of the major village factions, social segments, what amount to the kindreds of the major village chiefs, or 'Houses' (...)". Cada Casa de chefe seria formada por um conjunto de diferentes habitações: além da habitação do chefe, as casas de sua parentela ao redor formariam com ele uma facção politicamente coesa. Nos Kuikuro, as Casas dos dois chefes principais (do antigo dono da aldeia e do "dono do centro ${ }^{45}$ ") teriam ocupado os polos norte e sul das duas últimas grandes aldeias ${ }^{46}$ há cerca de 30 anos (ibid: 273), enquanto as casas de outros chefes menos importantes teriam ocupado as regiões leste e oeste. Além disso, o autor afirma que "Casas Menores" ("Minor Houses"), situadas a leste e oeste, seriam parte das Casas do sul e do norte: "Minor Houses (high-ranking but

\footnotetext{
${ }^{45}$ Esta figura não existe entre os Kalapalo. Entre os Kuikuro, o atual dono do centro também se tornou o dono da aldeia, depois que a pessoa que ocupava esta posição se mudou.

${ }^{46}$ Lahatua e Ipatse.
} 
subordinate chiefs) are situated at easterly or westerly side of the village. They are also part of larger northern and southern Houses, through kinship and alliance (i.e., their kindreds or 'Houses' are nested within those of their older brothers)" (ibid: 258). A principal aldeia Kuikuro atual (Ipatse) seria assim, composta de duas Casas de chefes, cada uma "a larger, usually multihouse dwelling place and also a kin group" (ibid: 259), capaz de englobar as casas dos chefes menos importantes.

Há várias coisas a se considerar. Primeiro, a relação das casas (habitações) com o espaço da aldeia e sua permanência no tempo. A disposição das casas dos chefes principais no eixo norte-sul não me parece ser uma "regra de morfologia" geral das aldeias xinguanas pois se é uma regra para os Kuikuro, não é para os Kalapalo. Em Aiha, por exemplo, a casa do chefe principal fica a leste, quase de frente para a casa dos homens, o que é considerado pelos Kalapalo o "lugar certo" de uma talühe. Na aldeia dos Yawalapíti, observei algo semelhante, pois lá o chefe vive em uma talühe perfeitamente alinhada, a leste, com a casa dos homens e com a entrada principal da aldeia. Contudo, em 1978, Sá (1983: 109) registrou a casa do chefe yawalapíti disposta a oeste. Em 1968, Basso (1973: 143) também registrou as casas dos dois chefes principais de Aiha dispostas a oeste, uma de cada lado da entrada principal da aldeia. Ou seja, além da possível existência de diferentes modelos espaciais entre os povos, a disposição de casas de chefes em um lugar ou outro parece ser mais ou menos contingencial, um resultado da história das relações de parentesco e dos lugares nos quais os chefes puderam/quiseram construir suas casas, mais do que uma fórmula rígida de ocupação do espaço.

A disposição das casas no círculo da aldeia certamente se dá de acordo com relações de parentesco e afinidade entre seus donos, mas daí à identificação de várias habitações a uma Casa englobante há um salto indutivo cuja validade é preciso avaliar etnograficamente. Muitas vezes, quando um genro sai da casa do sogro, ele constrói sua primeira casa um pouco atrás de onde vivia, fora do círculo principal, e a grande maioria das casas do segundo círculo de Aiha são casas de genros. Apenas uma pertence a um rapaz que saiu da casa de seu irmão mais velho, e foi construída como forma de pressionar a família do sogro do rapaz a autorizar uma residência virilocal para o casal logo após o casamento. Parece haver de fato uma tendência às casas do segundo círculo serem pensadas como partes de alguma "casa verdadeira", o que ganha forma na maneira pela qual os Agentes Indígenas de Saúde contam as casas, com a finalidade de manter um censo. Até onde sei, em todas as aldeias a "casa 1" é 
sempre a casa do primeiro cacique, e a contagem prossegue de forma crescente em sentido horário (como em um ritual de flautas, no qual os primeiros a dançar iniciam suas voltas na aldeia pela casa do dono da festa e seguem em sentido horário). Todas as casas cuja frente é voltada para o centro recebem um número, enquanto as casas do segundo círculo são tomadas como "parte" das casas principais.

Mas a relação de englobamento de uma casa por outra para por aí, pois as casas do círculo principal não se encontram englobadas pelas casas dos chefes, como Heckenberger afirma sobre os Kuikuro. Desde 2006, eu pude acompanhar mudanças significativas na disposição das casas de várias pessoas em Aiha, e não me parece haver nenhum "atrelamento" delas com a casa de nenhum chefe. Os dois genros mais novos do chefe principal (dois irmãos), por exemplo, construíram em 2011 uma casa do outro lado da aldeia, pois um homem que deixou Aiha e queimou sua antiga casa deixou um lugar vago no círculo. Um homem que tinha uma casa pequena no sul da aldeia agora se mudou para o leste, onde pôde construir uma casa maior (ao lado, inclusive, da casa de um homem acusado de ser um dos feiticeiros responsáveis pela morte de seu irmão mais novo). A disposição das casas no círculo certamente reflete preferências de proximidade com parentes, mas também a necessidade (ou o desejo) de mais espaço, ou mais privacidade, maior proximidade com a lagoa, distância da pista de pouso, etc.

Essa variabilidade acaba erodindo a ideia de que haveria "facções espacializadas" (o que me parece que é uma das ideias que Heckenberger (2005: 258) tenta exprimir com seu uso do conceito de Casa: “(...) major village factions, social segments, what amount to the kindreds of the major village chiefs, or "Houses"'. Da forma como Heckenberger descreve, é como se qualquer casa que não fosse de chefe não pudesse ser mais do que uma "casa satélite". Cada casa que faz parte do círculo principal é considerada uma "pessoa", e cada uma delas pode ter casas "anexas", que quase sempre são casas de genros, mas cada casa é tanto uma pessoa quanto a casa de um chefe (seja ela ou não uma talühe), não havendo motivo para que as casas de não chefes ou chefes menores sejam englobadas pelas casas dos anetü mais importantes. Também não conheço termo ou expressão em kalapalo que possa ser usado para se falar de uma Casa tal como definida por Heckenberger (uma parentela distribuída em um conjunto de habitações), e valeria a pena investigar se há algum conceito indígena que dê conta de tal agrupamento (que desconheço). 
Supondo que fosse possível identificar tais Casas de chefes, restaria a questão de sua permanência em um local específico da aldeia, que ocupa um lugar importante no argumento do autor: “(...) Houses (...) are more enduring as composite persons than individual chiefs (...). In part, major Houses are fixed in place and it is this physical immobility that cements their continuity" (ibid: 275). Em Aiha, o filho mais velho do chefe principal ocupa uma casa a norte, enquanto seu sobrinho uterino vive em uma casa ao sul. Os dois são chefes, o primeiro foi feito substituto de seu pai e o segundo substituto de seu avô materno. Qualquer um deles que assumisse o lugar do primeiro cacique faria a suposta Casa "mudar de lugar". E quem foi escolhido pelo primeiro cacique para ser seu sucessor, por indicação do segundo e com total aprovação da comunidade, foi seu sobrinho uterino. O espaço não parece ser relevante na determinação de quem será substituto de tal ou qual chefe.

Minha impressão é que, para o autor, a Casa funciona como um conceito de grupo corporado na falta destes. Isso fica claro em algumas passagens, como na afirmação de que apesar dos xinguanos não terem grupos de descendência linear ou metade nomeadas, "they do not lack lineality, in the form of 'House' groups, ancestrality, genealogy, castelike organization, and social hierarchy" (ibid: 265). Heckenberger faz uma aproximação clara entre Casas e grupos corporados, pois ainda que não utilize essa terminologia e não recorra à descendência como princípio de pertencimento, ele não deixa de definir as casas como unidades que agem como grupos coesos, que formariam um "voting block" (ibid: 266) para os assuntos públicos.

Há também a questão das propriedades imateriais:

Considered historically, and in terms of indigenous social models, it is the sitting chief's sons, daughters, and grandsons that tend to, or ought to, ascend to office by replacing their parents in one of the enduring Houses, particularly the major Houses, north and south, through the inheritance over time, of 'sacred' things. (ibid: 279; grifos meus)

Nos depoimentos analisados no capítulo 2, os chefes ressaltam a importância de sentar-se para o começo da chefia, mas não mencionam a herança de "coisas sagradas" como critério de substituição. O que seriam essas coisas? Segundo Heckenberger, seriam nomes, "títulos" e objetos rituais. As casas xinguanas não têm nomes, mas Heckenberger considera que os nomes de chefes, transmitidos em gerações alternadas, cumpririam esse papel. De fato, 
os Kalapalo têm um discurso explícito de que não se quer perder "nomes bonitos", o que, em alguma medida, também significa "nomes famosos", ou seja, nomes de grandes campeões ou chefes. Quando um pai ou mãe tem a expectativa de que um filho se torne um chefe, reserva para ele, após a reclusão, algum nome famoso, um nome que pertenceu a alguém conhecido. Mas isso não é algo que conforme "grupos". Ao contrário, a circulação de nomes entre aldeias permite que diferentes chefes, de diferentes povos, se considerem descendentes de ancestrais comuns. Há, ainda, o caso de nomes partilhados entre parentelas de chefes de aldeias diferentes que vivem em conflito. A situação é muito diferente dos nomes masculinos mebengokre analisados por Lea $(1986 ; 1993)$, que permanecem nas casas maternas. Os nomes Kalapalo não, eles circulam muito, pois uma pessoa sempre recebe nomes de parentelas diferentes e os redistribuirá a seus netos que não se sabe onde vão nascer. Ter um nome de chefe - qualquer chefe - é um índice de nobreza, mas não é um "mecanismo de pertencimento" a nenhum grupo. Heckenberger também trata posições como "dono do centro" e "dono da aldeia" como títulos que poderiam ser transmitidos e mantidos por uma Casa, reproduzindo-a no tempo. Mas considerando que tais posições circulam e são atribuições pessoais, como elas poderiam ser "posses" de "grupos"?

A situação de objetos como flautas e máscaras é igualmente complicada. Tais objetos podem, de fato, ser transmitidos de pais para filhos, ou mesmo entre irmãos, mas não conheço casos nos quais eles tenham durado mais do que duas gerações. Outro problema é entender isso como "propriedade ${ }^{47}$ ". A relação entre uma pessoa e suas flautas não é de posse, mas de parentesco: as flautas kagutu do falecido xamã de que venho falando eram suas filhas, e não suas riquezas. Elas foram enterradas com ele pois nenhum de seus filhos quis ficar com elas, mas, caso alguém ficasse, continuaria se relacionando com elas como se fossem parentes. A aldeia também é parte constitutiva da relação entre uma pessoa e uma máscara ou flauta, o que não pode ser desconsiderado. Quando uma mulher, dona de kuambü, se mudou de Aiha, ela propôs deixar a máscara com seu irmão, que não aceitou. A mulher não pôde levar sua máscara para a nova aldeia e teve de queimá-la; ninguém hoje em Aiha é dono de kuambü. O mesmo aconteceu com o dono do tolo que, depois de ter deixado a aldeia, não é mais seu dono no lugar onde foi viver. Estas "coisas sagradas" ("sacred things"; Heckenberger, 2005: 279) não são uma propriedade de grupos, mas são a forma material assumida por duas relações de parentesco: do dono com o espírito, e deste com a aldeia. Se faltar um dono (por

\footnotetext{
${ }^{47}$ Isto é, como uma relação entre sujeitos e objetos, pessoas e coisas.
} 
sua morte), ou se faltar a aldeia (no caso da mudança do dono), esses objetos devem ser destruídos. Mesmo o mais importante chefe não pode levar consigo suas flautas caso venha a se mudar. Sendo assim, ao menos entre os Kalapalo, é difícil dizer que chefes substituem uns aos outros "through the inheritance over time, of 'sacred' things" (id. ibid.). Qualquer pessoa, chefe ou não, pode herdar festas de pais e irmãos, pode recusar sua herança e, caso se mude, as perderá.

Peço desculpas ao leitor pela delonga, mas era preciso avaliar ponto a ponto o uso desse conceito feito até o momento para mostrar que o que está por trás dessa confusão é a insistência em descrever a chefia com referência a "grupos". No capítulo 2 argumentei contrariamente à fixação da antropologia pela tentativa de definir a nobreza xinguana como uma espécie de grupo, como algo que se transmite ou como algo que, na relação com os não chefes, teria a ver com poder, autoridade, ordem, ou ideias do tipo. Aqui nos deparamos mais uma vez com esse tipo de fixação, pois a descrição de Heckenberger da chefia segmenta a aldeia em grupos - as Casas -, elas mesmas passíveis de serem decompostas em casas cada vez "menores" ou ampliadas para o plano da aldeia, "the Great House". O autor sugere que grupos "above the family" (sic; o que é "the family"?), seriam formados em três níveis institucionais básicos: “(1) house or household; (2) suprahousehold interest groups, generally conforming to the chiefly kindreds of minor and major Houses; and (3) the village (or galactic cluster), the 'Great House' in regional systems" (ibid: 265). Essa diferença de níveis seria acompanhada de uma replicação auto-similar de um mesmo tipo de pessoa, a Casa, evocando o conceito de pessoa fractal (Heckenberger, 2005; 2011; Wagner, 1991). Porém, é curioso que, depois de fazer uma revisão bibliográfica sobre fractalidade, ele acaba ilustrando seu argumento com uma estrutura hierárquica de tipo segmentar:

It is also combined with that of chiefliness, which, through ranked systems of consanguinity and affinity, positions all member of Xinguano society in an overarching hierarchical structure, that turns family and household members into house heads, house heads into chiefs (the primary villages chiefs or anetï, the heads of chiefly kindreds or Houses), and notably the community into one or a few ranking 'great chiefs' (anetï ekugu, or in certain contexts, high-ranking female chiefs, tango). (Heckenberger, 2005: 262)

É exatamente contra esse tipo de estrutura que se volta, segundo entendo, o conceito de Wagner (1991). Um fractal não pode ser formado por unidades cada vez mais englobantes; 
por definição, ao sair de um ponto ínfimo de um fractal e passar para uma visão mais ampla da mesma figura, não vemos outra coisa senão a mesma figura. Isso talvez seja a forma visual mais clara da ideia, associada aos fractais, de que "as relações externas são internas" (id. ibid.): quando se olha para fora, vê-se o que já se via dentro. É diferente de dizer que há grupos menores englobados por outros maiores (casas menores englobadas pelas "Major Houses", até culminar na aldeia como uma "Great House").

A noção de Casa oferece uma alternativa não só à ideia de grupo de descendência unilinear, mas à própria noção de grupo corporado, e é aí que deve-se procurar seu rendimento. Coelho de Souza (2002: 631) argumenta nesse mesmo sentido, observando que o conceito de Casa, "além de pretender completar uma tipologia - a do próprio Lévi-Strauss, para a qual os sistemas pós-elementares de descendência cognática punham problemas consideráveis - ele se desenvolve também como resposta crítica às teorias britânicas da corporação".

Uma aproximação tentativa pode ser feita retomando as leituras que Lévi-Strauss (1986 [1984]) faz de materiais indonésios e melanésios. Nelas, o autor retém um aspecto que já fazia parte da definição original, que é a capacidade da Casa para transformar uma dualidade interna em uma unidade externa. Contudo, a Casa deixa aqui de ser uma "instituição" (uma pessoa moral, como nas primeiras formulações), um "substrato objetivo" (Gordon, 1996: 192), para se tornar a objetificação, ou reificação, de uma relação tensa.

Lévi-Strauss argumenta que, na impossibilidade de recorrer aos critérios de filiação, propriedade ou residência na descrição de alguns grupos da Indonésia, "surge um critério que não fora percebido, o da aliança, já que os fatos atestam que, tanto em Bornéu como em Java, o casal conjugal forma o verdadeiro núcleo da família e, de modo mais geral, do parentesco" (Lévi-Strauss, 1986 [1984]: 190). Nos casos indonésios, há uma diferença de status entre doadores e tomadores de esposas, com os primeiros ocupando uma posição superior. A arquitetura indonésia revela que a aliança aparece ao mesmo tempo como um "princípio de unidade" e um "princípio de antagonismo" (id. ibid.). Uma casa abriga diversas famílias ligadas por afinidade e, logo, com status diferentes, mas há um esforço para fazer com que, na disposição dos cômodos, essa diferença seja compensada (por exemplo, a família mais importante ocupa um dos lugares mais quentes da casa, para privar os demais desse desconforto; a família menos importante, por sua vez, ocupa o cômodo superior da casa, que é o menor mas também o mais agradável). “Acreditamos, ao contrário, que é preciso passar da 
idéia de um substrato objetivo para aquela da objetivação de uma relação: relação instável de aliança, que, enquanto instituição, a casa tem a função de imobilizar, ainda que sob uma forma fantástica" (ibid: 191).

O conceito se transforma de maneira ainda mais interessante quando o autor investiga se na Melanésia haveria formas institucionais do tipo "casa", que ele define como aquelas

(...) que resultam do parentesco cognático, ou ainda do conflito entre dois modos concorrentes de descendência e, portanto, da necessidade de dar à ordem social um fundamento que não o genealógico, de escapar da realidade ou do mito dos 'laços de sangue' em proveito da resistência ou desse ou daquele modo de determinação do status. (ibid: 198)

No caso da Nova Guiné, o próprio corpo humano aparece como um tipo de Casa:

Com efeito, por toda parte, trata-se de transcender um conflito entre duas preeminências, de mascarar o que as opõe e, se possível, de confundi-las, com o risco de cindir, nos limites da 'casa', os domínios com os quais seus constituintes se identificavam anteriormente. Crise social ao mesmo tempo inevitável, desejada e temida, da qual a Nova Guiné teria a originalidade de oferecer uma versão fisiológica, dando-lhe o corpo individual como cenário infinitamente multiplicado. (ibid: 204).

Os ecos com o material kalapalo são óbvios, mas uma ressalva que deve ser feita diz respeito ao atrelamento da noção de afinidade com a aliança matrimonial de fato, que faz parte do pensamento lévi-straussiano. Como comenta Michel Bergès (2008: 28), a Casa "permet d'immobiliser, d'hypostasier, de fétichiser sous forme fantasmatique les relations d'alliance entre preneurs et donneurs de femmes". Fica claro que a afinidade em foco é somente a afinidade real. Contudo, na nobreza kalapalo, a tensão entre consanguinidade e afinidade não se reduz à aliança matrimonial de fato, mas está vinculada aos papeis que esses dois tipos de relação desempenham na produção do ponto de vista dos humanos no mundo. Como venho argumentando, os chefes reúnem, ao mesmo tempo, as facetas de protetor e inimigo, consanguíneo e afim potencial. Esta dualidade não é apenas "conceitual”, restrita aos mitos, mas é objetivada (precisa se objetivar) nos corpos dos chefes, seja sob a forma do corpo individual, da casa ou da sepultura. Ela é de fato constitutiva de qualquer corpo, pois 
todos têm um potencial humano/parente e um potencial animal/diferente, mas apenas os corpos dos chefes são feitos intencionalmente para tornar essa dualidade visível (pois só um chefe precisa aparecer como pai para os seus e inimigo para os estrangeiros. Quando uma pessoa comum torna visível essa dualidade entre seus próprios parentes, ela se aproxima de outra figura que é ao mesmo tempo parente e predador: o feiticeiro).

É essa mesma tensão que está presente na necessidade de um futuro anetü ser indicado e feito por outros chefes, atraídos para o polo da afinidade potencial: o filho de um chefe precisa ser feito por seus "não-parentes" ou afins, sempre por meio de processos corporais: reclusão, furação da orelha, enterro, construção de uma casa, homenagem póstuma. O corpo nobre explicita sua multiplicidade constitutiva ao mesmo tempo que a mascara na ficção de uma unidade complexa. É esse corpo que transmite nomes bonitos e famosos para corpos de mesmo tipo, seus substitutos; é esse tipo de corpo-pessoa que pode ser dono de espaços, estruturas e conhecimentos exclusivos. A nobreza não é um grupo ao qual as pessoas possam pertencer, mas é uma síntese tensa entre consanguinidade e afinidade, que se objetiva no corpo e se replica em diferentes escalas: uma casa, mas em uma "versão fisiológica", tal qual o corpo melanésio na leitura de Lévi-Strauss. Reunir questões de parentesco, política e economia em sistemas não elementares de aliança: essa é uma das potências do conceito de Casa, e por isso tratar os corpos nobres a partir dele permite vê-los como algo mais do que corpos.

$* * *$

Neste capítulo vimos que as primeiras atividades do egitsü elaboram a questão da morte de um nobre como um problema de "(re)familiarização" do morto: para que um nobre possa ser "ancestralizado", ele precisa ser mantido como parente e como humano mesmo após a morte. Isso é feito pela construção do tahiti, que alimenta a alma-sombra e a mantém entre os vivos, e desencadeia a construção de uma talühe para a alma-do-olho na aldeia dos mortos. Além de evitar os perigos da alma-sombra transformada em itseke, a construção do tahiti faz da alma do olho um grande chefe no céu. A partir da discussão sobre o tahiti e a talühe como corpos e de uma análise de suas características, pudemos ver a nobreza kalapalo como um corpo multiplicado que objetiva, sob a forma de uma unidade, a convivência dos aspectos 
paradoxais de super-consanguíneo/protetor e afim potencial/predador do chefe descritas nos capítulos 2 e 3.

Na sequência apresentarei outras formas pelas quais essa dualidade é manipulada pelo ritual até culminar na produção da efígie. No capítulo seguinte apresento o conjunto de discursos cerimoniais associados ao egitsü a fim de investigar como as performances oratórias dos chefes são parte dos processos pelos quais alguns homens são colocados "no lugar do coletivo", ensaiando também comparações com variantes de outros povos karib (Kuikuro e Matipu) e outros tipos de discursos rituais kalapalo. 


\section{Capítulo 5 -Akitsene: o sistema de discursos rituais dos chefes}

Em diversas ocasiões mencionei os discursos dos chefes como uma das principais marcas do exercício da chefia no Alto Xingu e, no capítulo 2, vimos que dois dos entrevistados mencionam o seu aprendizado como parte de sua fabricação como chefes. $\mathrm{O}$ objetivo deste capítulo é apresentar e analisar o conjunto de discursos ligados ao egitsü, a fim de compreender que ideias eles veiculam e como atuam na construção das posições ocupadas pelos chefes ao longo do ciclo do ritual.

Os discursos dos chefes compõem um amplo gênero verbal conhecido em karib xinguano como anetü itaginhu, "fala do chefe" ou "conversa de chefes" (Franchetto, 1986; 1993; 2000). Eles também podem ser chamados de akitsene, que poderíamos glosar como "prática do discurso" 1 ". Não há encontros rituais sem discursos trocados entre chefes, fazendo deles performances indispensáveis para a política regional alto-xinguana ${ }^{2}$. Este é um gênero de fala bastante formalizado que pode ser facilmente reconhecido em qualquer aldeia xinguana, falante de qualquer língua, pois o que mais "salta aos ouvidos" é sua musicalidade típica. Com "formalizado" quero dizer que cada discurso é constituído de um conteúdo que muda muito pouco de uma versão a outra ${ }^{3}$, cujas sentenças completas devem ser divididas em linhas ordenadas segundo um estilo paralelístico preciso, e entoadas com uma mesma estrutura rítmica e melódica ${ }^{4}$ - algo semelhante à recitação de salmos (Franchetto, 2000: 485; Monod-Becquelin, 1975: 70). Quem ouve uma fala destas, não importa em qual língua, sabe que se trata de conversa de chefes e, em grande medida, é na sua musicalidade, seu caráter de "fala cantada" (Franchetto, 1993; 2000), que reside sua eficácia como meio de comunicação nos encontros rituais, que quase sempre envolvem grupos falantes de línguas mutuamente ininteligíveis (Franchetto, 2000: 486). Não que não haja diferenças melódicas e ritmicas entre as versões conhecidas, e análises acústicas feitas por especialistas seriam muito reveladoras.

\footnotetext{
${ }^{1}$ Aki-tse-ne (palavra-VBLZ-NMLZG), formada a partir de aki-tsu (palavra-VBLZ, "discurso"). O nominalizador genérico -ne é concatenado acima de uma raiz verbal já categorizada (Santos, 2007: 211), e pode-se entender que ele dá nome a "práticas", como em ikindene (luta, raiz ikindu), hetene (gritaria, raiz hetu), atakanene (troca, raiz $a k a)$.

${ }^{2}$ Com efeito, entre vários povos sul-americanos a prática de discursos rituais é muito comum, principalmente em encontros potencialmente hostis. Para discussões mais gerais sobre o tema, ver por exemplo Rivière (1971), Urban (1986), Monod-Becquelin e Erikson (2000), e Beier, Michael e Sherzer (2002).

${ }^{3}$ Levando em conta tanto várias execuções de um mesmo chefe quanto execuções de chefes diferentes (inclusive de outros povos karib).

${ }^{4}$ As exceções são as falas de abertura (etinetoho) e encerramento (upüitoho) de alguns discursos, que possuem estruturas formais e rítmico-melódicas diferentes do corpo das falas (mas sempre idênticas entre si).
} 
A fala dos chefes compreende subgêneros que se distinguem "non par le style, mais selon des critères qui vont de la fonction et du contexte d'éxecution aux différences de contenu thématique et de type de compétence qui est exigé de la part de l'exécutant" (Franchetto, 2000: 483). Assim, há diferentes conjuntos de discursos apropriados para cada situação, com conteúdos diversificados e que empregam vocabulários específicos. Uma das marcas desse gênero de fala é o uso de um vocabulário complexo, uma "linguagem figurativa metafórica e erudita, típica de um registro muito especial e restrito a poucos especialistas" (Franchetto, 1986: 365). Os Kalapalo dizem que muitas das palavras e expressões usadas no anetü itaginhu são "língua dos antigos" (ngiholo akisü) ou "língua de chefes" (anetü akisü), e o uso desse tipo de fala formal confirma a ligação entre seus praticantes - os chefes vivos - e os chefes do passado, de quem são considerados substitutos (itüpohongo).

Basso (2009: 255) observa que uma das principais características do anetü itaginhu "is the multivocal, dialogical nature of the genre", também notada por Ball (2007: 37) e Franchetto (2000). Apesar da fala do chefe parecer um monólogo, é mais apropriado pensá-la como um "diálogo" (mediado pelo chefe) entre várias coletividades. Segundo Ball (op. cit: 32), a fala do chefe é ao mesmo tempo uma "representação e encenação (enactment)" da comunidade que constrói "a web of numerous speaking subject and addressee positions" (ibid: 37); um processo que, ao produzir uma identidade coletiva por meio do discurso,

(...) necessarily invokes this identity in relation to the identities of specific others construted in the same moments. These may be ancestors, spirit-monsters, other Upper Xinguan groups, other indigenous groups beyond the social exchange network of the Upper Xingu proper, Brazilians, etc. (ibid: 32-33).

É possível dividir os discursos em, pelo menos, dois grandes grupos: aqueles realizados para estrangeiros e aqueles realizados para coaldeões (mas os Kalapalo não fazem essa distinção; tudo é akitsene ou anetü itaginhu). No primeiro grupo, estão os conjuntos de discursos para cada ritual regional, designados pelo nome do ritual seguido de itagimbakitoho 5 ("feito para cumprimentar"), como egitsü itagimbakitoho ("feito para cumprimentar no egitsü"), uluki itagimbakitoho ("feito para cumprimentar no uluki") e

\footnotetext{
${ }^{5}$ Franchetto (2000: 495-496) traduz esse termo como "feito para recepcionar", mas optei pelo uso de "feito para cumprimentar" pois, além dos discursos de recepção, ele também pode ser aplicado aos discursos de despedida.

${ }^{6}$ Festa de trocas entre aldeias.
} 
hagaka itagimbakitoho ("feito para cumprimentar no hagaka”). Há também discursos que devem ser executados na ocasião da recepção de mensageiros de outras aldeias, chamados etinhü itagimbakitoho ("feito para cumprimentar mensageiros"), que apresentam variações dependendo do ritual para o qual a aldeia está sendo convidada.

No segundo grupo (discursos para coaldeões), há um tipo de fala pública não cerimonial ligada ao jogo político (Franchetto, 1986: 378) e, ao menos entre os Kalapalo, um conjunto de dois discursos que idealmente deveriam ser executados diariamente (ou ao menos com alguma frequência) pelo maior chefe de uma aldeia. Um deles, realizado antes do amanhecer, é o Ugonhi akitsu, "discurso do Gavião ugonhi",; o outro, realizado após o pôrdo-sol, é Ekege akitsu, "discurso da Onça”.

Franchetto (1986; 1993; 2000), Ball (2007), Basso (2009) e Mehinako (2006) são os únicos pesquisadores que até o momento registraram, apresentaram e analisaram peças deste gênero de fala no Alto Xingu. O trabalho de Franchetto é o mais completo, seguido pela tese de Ball, por um artigo de Basso e pelo trabalho de Mehinako (sendo que os dois últimos apresentam apenas pequenos trechos de discursos). Todos eles trabalharam com o discurso para a recepção de mensageiros no egitsü (e, no caso de Franchetto, 2000, com seus discursos correlatos), o mais longo e elaborado de todos (e também considerado o mais importante pelos Kalapalo). Mehinako (op. cit.) também apresenta trechos de discursos ligados ao ritual de trocas.

O núcleo deste capítulo também será uma análise do conjunto de discursos do egitsü. Porém, minha intenção é tentar fazer uma análise mais ampla deste gênero de fala entre os Kalapalo, utilizando também os discursos do uluki, que mobilizam ideias diferentes das presentes no conjunto do egitsü, e os discursos do Gavião e da Onça. Estes dois são especialmente interessantes, pois além de ainda não terem sido discutidos na literatura, oferecem exemplos de como a alteridade do chefe pode se atualizar no interior do grupo local independentemente das relações com estrangeiros, apresentando o chefe ora como Gavião (chefe dos pássaros), ora como Onça (chefe dos animais terrestres). Além disso, onde for pertinente, apontarei comparações iniciais com versões de outros grupos karib, a fim de

\footnotetext{
${ }^{7}$ Ritual de arremesso de dardos entre primos cruzados distantes, também em homenagem a um chefe ou grande cantor falecido.

${ }^{8}$ Mensageiro, "convidador". Literalmente, "buscador".

${ }^{9}$ Pequeno gavião não identificado.
} 
mostrar que tais discursos formam um sistema bastante regular em termos das imagens mentais que mobilizam.

Trabalharei com versões recolhidas por mim entre os Kalapalo de Aiha, versões kuikuro registradas e analisadas por Bruna Franchetto, uma versão kalapalo de Tanguro, registrada pelo Coletivo Kuikuro de Cinema $^{10}$, e uma versão matipu, registrada por mim e Aline Varela ${ }^{11}$. Quase todos os discursos kalapalo utilizados neste capítulo foram gravados por mim e a pedido meu (à exceção da variante de Tanguro já mencionada), para que pudéssemos ter a maior qualidade sonora possível e ouvir interpretações dos chefes. Dois deles, o discurso do Gavião e da Onça, foram gravados enquanto um mestre os ensinava a seu sobrinho uterino, com autorização de ambos (de fato, o jovem aproveitou que eu estava interessado em gravar discursos e usou isso como pretexto para pedi-los ao seu tio). Os discursos foram transcritos, traduzidos e interpretados com a ajuda de vários colaboradores indígenas $^{12}$.

\subsection{O aprendizado}

Como o próprio nome deixa claro: a "conversa de chefes" não é um gênero de fala que pode ser utilizado por qualquer pessoa, mas apenas por homens reconhecidos como anetü. Aprendê-lo e dominá-lo nunca é algo fortuito, mas parte de um projeto consciente para dar continuidade a uma parentela de chefes, projeto que, para dar certo, precisa ser compartilhado por pais (ou avós) e filhos. Como diz Franchetto (1986: 366), o interesse de um chefe em aprender o anetü itaginhu "é consequência de um projeto consciente para alcançar e garantir o reconhecimento da força e coesão de seu grupo doméstico e de aliados. O aprendiz explicita a determinação de perpetuar uma tradição que o liga à linhagem de chefia”.

Isto não significa que pessoas comuns não conheçam estes discursos parcial ou mesmo integralmente, mas de nada adianta "saber" os discursos se a pessoa não for um anetü reconhecido para executá-los publicamente. Estes discursos, junto com uma série de adereços,

\footnotetext{
${ }^{10}$ Cuja cópia me foi gentilmente cedida por Bruna Franchetto.

${ }^{11}$ Mestranda no Programa de Pós-Graduação em Linguística da UFRJ.

12 Agradeço a Ugise, Hüge Hüti “Orlandinho", Sapuia, Kamankgagü "Viola”, Tawana, Kapuringa e Jeika pela ajuda em diferentes momentos do processo de transcrição, tradução e interpretação dos discursos.
} 
pinturas e objetos, são tai ${ }^{m}$ pane, tabu ${ }^{13}$, para não chefes, e seu uso inapropriado pode gerar provocações jocosas por parte de outros e, consequentemente, vergonha (um estado emocional e corporal que se busca evitar sempre que possível).

Mulheres, via de regra, não discursam (nem mesmo no ritual feminino jamugikumalu), mas muitas conhecem bem os discursos, na íntegra. Sabendo que eu estava tentando aprender os discursos (discutirei isto adiante), algumas itankgo me procuraram para recitar as versões que conheciam, e uma delas (filha de um falecido chefe da antiga aldeia jagamü ${ }^{14}$ ) me ofereceu o que é, sem dúvida, uma das melhores execuções do discurso de recepção de mensageiros que ouvi ${ }^{15}$ (mas que infelizmente não pude gravar, foi uma execução espontânea). Certa vez, cheguei a presenciar na aldeia de outro grupo karib, uma chefe "soprando" para seu marido as linhas que ele deveria dizer, enquanto era gravado. Um dia, quando eu estava na casa de Ageu, uma de suas sobrinhas veio pedir que ele lhe ensinasse algumas rezas. Depois disso ele pediu que ela "pegasse" o discurso de recepção de mensageiros ("etinhü itagimbakitoho itse ${ }^{16 ", ~ e l e ~ d i s s e ~ a ̀ ~ s u a ~ s o b r i n h a), ~ p a r a ~ q u e ~ p u d e s s e ~}$ ensiná-lo a seus filhos. Mesmo que itankgo não discursem, elas podem ter um grande domínio sobre este gênero de fala.

Executar um discurso é uma verdadeira performance que, como tal, deve observar procedimentos específicos, precisa produzir certos efeitos e está sujeita ao julgamento daqueles que a presenciam. Grosso modo, toda fala de chefe "funciona" (isto é, uma performance não muito boa não cria nenhum tipo de problema para o desenrolar do ritual), e ninguém que não saiba um discurso em sua forma mínima o executará. Mas há uma diferença de grau entre uma performance e outra, podendo haver discursos mais ou menos bonitos - e certamente os melhores (assim como seus executores) serão objeto de comentários, principalmente de outros chefes. Em 2010, um dos comentários após o egitsü de Aiha era como o discurso feito por um velho chefe havia sido belo, fato comentado pelos chefes locais e pelos chefes Kuikuro e Yawalapíti. Comentava-se também que já seria de se esperar uma performance tão boa, pois seu pai (Sagagi) é considerado o maior chefe Kalapalo desde a década de 1940. A primeira vez que gravei este gênero de fala, um chefe me deu de bom

\footnotetext{
${ }^{13}$ Tai $^{m}$ pane é tudo o que é perigoso para alguém, e por isso se torna "proibido" (daí a escolha de sua tradução como "tabu"). Alimentos proibidos em certas ocasiões, músicas que não podem ser ouvidas por crianças, objetos que não podem ser vistos pelas mulheres, etc., são todos tai ${ }^{m}$ pane.

14 Nahukwa.

${ }^{15}$ Em termos da completude e da fluência do discurso.

16 "Pegue o etinhü itagimbakitoho".
} 
grado o discurso de recepção de mensageiros, mas só depois de cinco dias de espera, pois nos dias anteriores ele estivera com tosse e dor de garganta, e me disse que não poderia correr o risco de interromper o discurso, que para ser bonito precisa ser executado "direto" (titage), em um ritmo constante. Não seria aceitável gravar um discurso executado "mais ou menos", ainda mais sabendo que outras pessoas (os que me ajudariam na transcrição e tradução) o escutariam e o comentariam.

O tom de voz, o ritmo e a melodia devem ser controlados, a respiração deve ser regular, o corpo deve estar posicionado de maneira correta, a cabeça, os olhos e as mãos só se movem segundo um código de respeito e vergonha. Ao falar com um chefe estrangeiro, a cabeça deve estar baixa, pois não se deve olhar outro chefe nos olhos para discursar; quando chefes de uma mesma aldeia conversam neste gênero de fala, as mãos são levadas frequentemente à cabeça para mexer no cabê-lo ou coçá-la, índice de vergonha e humildade; a fala deve ser feita no tom apropriado, geralmente baixo, e cada linha, executada após uma breve pausa para a respiração (uma das piores coisas que se pode fazer é interromper a execução de uma linha). Discursar é uma performance ritual completa, cuja estética, tudo aquilo que a audiência percebe, envolve a fala e o corpo do executor em todos os seus aspectos. O que se apresenta em uma ocasião como esta não é apenas uma fala, mas uma pessoa por inteiro, alguém que, no que diz e na forma como se porta, se coloca como uma pessoa não trivial - um chefe-grupo, homem vivo e porta-voz dos ancestrais, grande homem e homem modesto; alguém que é, ao mesmo tempo, a encarnação do grupo, mas cuja elipse no discurso e retraimento corporal são condições para a aparição do coletivo (Ball, 2007; Franchetto, 2000: 483). 


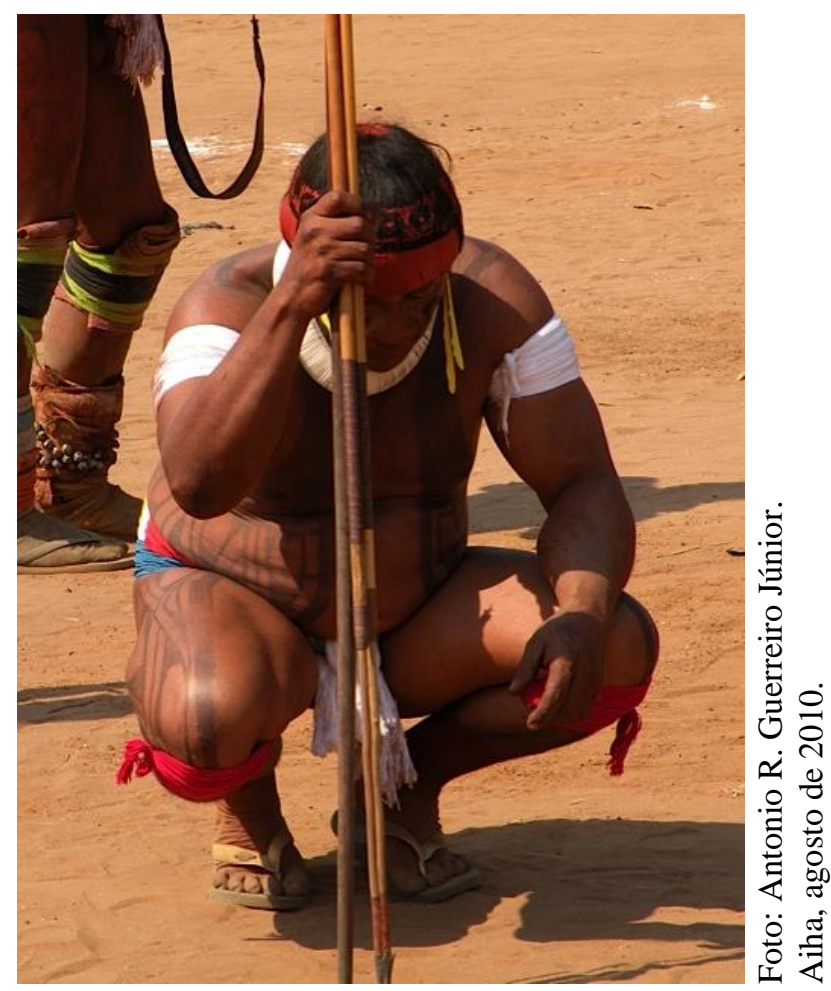

Figura 5.1: dono do egitsü discursando para se despedir dos chefes aliados.

Aprender tais discursos deve ser uma iniciativa do aprendiz, que precisa perguntá-los a seu mestre (de preferência seu pai, avô ou outro parente). Mesmo que um pai queira que seu filho aprenda os discursos, ele não os ensinará caso o jovem não pergunte. O desinteresse do filho por esse tipo de conhecimento já é um índice de que ele não teria a personalidade ideal de um chefe, que deve ser uma pessoa interessada nos costumes e nos rituais. Nada impede que um anetü pergunte algum discurso a um não parente, ou mesmo a um chefe de outro povo (como aconteceu recentemente, quando um kalapalo foi procurado para ensinar um homem que assumira a chefia de outro grupo karib), mas isto não é nada prestigioso (afinal, não ter um parente próximo para tomar como mestre é reconhecer uma condição precária de chefe).

Ageu, reputado como o maior conhecedor deste gênero verbal, acabou se tornando meu "professor" 17 ", - ele dizia que não adiantava nada eu apenas gravar os discursos se eu não os entendesse (pois ninguém além dele saberia explicar direito), e queria que eu os aprendesse da melhor forma possível. Durante quase três meses, em 2010, todos os dias nos encontrávamos para gravar histórias e rezas, mas antes de começarmos ele sempre pedia que

\footnotetext{
17 K-ingu-he-ni (GEN-olho-quebrar/abrir-AGNR), "aquele que nos abre os olhos", termo usado para quem ensina qualquer coisa a alguém (inclusive para os professores da escola indígena).
} 
eu executasse o discurso de recepção de mensageiros, me corrigindo e executando novas versões. Certo dia, seu filho estava nos observando de sua rede, interessado na forma como eu havia executado o discurso e prestando atenção nas correções que seu pai me fazia:

- Você já tem este discurso? - perguntei a Hasagü

- Não

- Não, ele não perguntou!, disse Ageu em voz alta e em tom de reprovação

- Por que não?

- Diga a ele: "pergunte ao seu pai”!

- Sim, pergunte ao seu pai, só ele os conhece bem!

- Está bem, eu vou perguntar. Mas eu preciso gravar e depois escrever, para aprender bem.

- Pergunte mesmo! Nós podemos escrever juntos, mas você precisa perguntar.

- "Pergunte ao sei pai", diga a ele! Para que se torne sua posse [ingipingo itsomi]!

O rapaz em questão é o filho mais jovem de Ageu e, de seus três filhos homens, é o único "que se sentou" (foi feito chefe), pois só ele apresenta o temperamento esperado de um anetü, além de ser um bom lutador. O rapaz ficou um pouco envergonhado quando me disse que ainda não tinha o discurso, reconhecendo que não havia perguntado. Seu pai, por outro lado, mostrou uma grande empolgação, aproveitando a oportunidade para pedir que eu fizesse ao seu filho uma cobrança que ele próprio aparentemente não se sentia confortável para fazer sozinho (pois se espera que chefes não reclamem nem cobrem nada de ninguém), para que ele aprendesse os discursos em versões que todos confirmam que são exclusivas de seu pai. Ageu é bastante orgulhoso deste fato, e não foram poucas as vezes que ele fez questão de deixar claro que não adiantava eu perguntar (como ele sabia que eu andava fazendo) estes discursos para outros anetü: "Só anetü tem, só eu tenho. Eles não têm, os que moram em outras casas não têm, só eu tenho. Etinhü itagimbakitoho, só eu tenho o suficiente (uge tsügü ngipi anügü), os outros não".

Sua insistência na exclusividade de seu conhecimento me parece ligada à sua posição complicada na chefia. Ele foi escolhido e intensamente preparado por seu pai para substituí- 
lo, mas quem acabou assumindo a chefia foi seu irmão mais novo, escolhido pelo então diretor do Parque Indígena do Xingu, e que não foi tão preparado por seu pai (conforme relatado no capítulo 1). Este foi o começo da primeira conversa que tivemos antes de começarmos a gravar os discursos:

- Você já gravou o etinhü itagimbakitoho? - Ageu me perguntou

- Já gravei com seu irmão.

$-\mathrm{Hm}$.

- O que foi?

- Será que ele falou bem?

- Eu não sei, acho que falou.

- Hm. Será que ele tem [o discurso] bonito?

- Não sei. Será?

- Não, ele não tem bonito, só eu tenho bonito.

Há uma diferença clara entre ter um discurso bonito ou não. Na verdade, me parece que é a diferença entre "saber", em um sentido geral, e ter. Alguém que é dono (oto) de um conhecimento é alguém que não erra, que sabe bem e, o que talvez seja o mais importante, é capaz de ensinar os outros (já que o dono é uma figura de mediação). Para isso, é preciso ter entrado em uma relação de mestre e aprendiz, na qual é papel do mestre avaliar quando o aluno pode ser "solto". Estes cuidados são importantes para a reputação de um mestre, pois caso seu aluno não aprenda bem, o professor pode ser visto como "mentiroso" (t-aũgi-nhü, ANA-mentir-PTP-PATNR; "mentir" aqui significa fazer algo com imperfeição ou de maneira improvisada; talvez fosse melhor traduzir como "enganador"). Esta insistência em sua especialidade foi muito enriquecedora, apesar de ter me deixado várias vezes em posições desconfortáveis em relação a seu irmão. Meu "mestre" insistiu que eu deveria ser capaz de executar pelo menos o principal dos discursos, pois assim não poderiam dizer que ele estava "mentindo" para mim (como ele mesmo dizia que outros estavam mentindo ao me oferecer versões incompletas ou "feias" dos discursos, e sem se preocuparem se eu estava entendendo ou aprendendo). 


\subsection{Os que foram conduzidos pelo pulso}

O principal discurso é o etinhü itagimbakitoho, "que serve para cumprimentar mensageiros". Ele é considerado o "primeiro" de todo o gênero anetü itaginhu, ihotugu, que significa literalmente "sua ponta", como a ponta de uma flecha, a proa de um barco ou o banco do motorista de um carro. No caso de qualquer ritual interaldeias, o discurso de recepção é "primeiro" em relação a um "segundo", ou literalmente a um "outro" (otohongo, "segundo" ou "outro igual"), que serve para o chefe se despedir de seus convidados. Ele é o primeiro porque é o mais importante, o mais longo e o que idealmente só pode ser executado em sua completude (voltarei a isso adiante) pelo chefe principal.

Atualmente, a chegada de mensageiros é sempre um evento esperado e programado com bastante antecedência, pois a comunicação via rádio permite que os convites para as festas sejam bem acertados para evitar sobreposição de datas e resolver questões logísticas (das quais a principal é o transporte, que deve ser garantido pelo dono da festa). Contudo, mesmo a chegada dos mensageiros estando prevista para um determinado dia, não deixa de haver alguma tensão em torno disso. Em 2010, os Kuikuro anunciaram que fariam um hagaka em junho e um jamugikumalu em setembro. Desde praticamente o começo do ano este hagaka já tinha data marcada, os Kalapalo estavam cientes do evento, haviam sido avisados que seriam convidados para serem aliados dos Kuikuro, mas, ainda assim, quando eu perguntava se iriam ou não para a festa, sempre me respondiam que "se os mensageiros vierem, nós iremos". Convites informais não têm valor algum e, a menos que os mensageiros venham para oficializá-los, não se pode ter certeza de nada.

Isso ficou ainda mais claro para mim às vésperas do jamugikumalu de 2010, para o qual os Kalapalo não foram convidados. Faltando mais ou menos um mês para a festa, vários jovens, homens e mulheres já estavam muito ansiosos e todos diziam que, se convidados, certamente iriam para a festa. Contudo, os chefes eram mais cautelosos: "não sei se os Kuikuro nos enviarão convidadores. Se os enviarem, nós iremos, mas vamos ver ainda". Os convidadores não vieram, e muitas pessoas tiveram seus planos frustrados.

Eu só presenciei a recepção de mensageiros uma vez, em junho de 2007, quando os Kalapalo foram convidados pelos Kuikuro para um hagaka. Nas minhas demais estadias 
sempre vi os Kalapalo enviando mensageiros de suas festas, mas nunca recebendo, infelizmente. Quando eles novamente receberiam mensageiros kuikuro (para o hagaka de 2010), para a surpresa de todos, o destino dos mensageiros foi mudado. Ao invés de se dirigirem para Aiha, eles foram enviados para Tanguro. Em um domingo, o chefe kuikuro havia dito ao chefe de Aiha, via rádio, que os mensageiros iriam para sua aldeia na terça-feira; contudo, na segunda-feira à tarde, ouviram no rádio os Kuikuro dizendo que, na verdade, os mensageiros seriam enviados a Tanguro e não Aiha, o que criou uma grande tensão em torno da viagem para a festa. Receber mensageiros é um privilégio que uma aldeia e um chefe importante não gostam de perder. Os chefes de Aiha ficaram muito ofendidos com a "surpresa" e o primeiro cacique não só não foi à festa como pediu que toda sua família ficasse (o que só foi respeitado pelas mulheres, pois seus dois filhos homens acabaram indo).

- Por que os Kuikuro mudaram de ideia? - indaguei curioso. Waja respondeu deixando transparecer que estava muito chateado com o fato:

- Eu não sei, eles tinham dito que os convidadores viriam pra cá! Aí ontem à tarde eu os ouvi no rádio, avisando o cacique de Tanguro que eles podiam esperar convidadores para amanhã de manhã. Eu não entendi.

- E agora, o que vocês vão fazer? Vocês vão pra festa?

- O pessoal vai, mas eu não vou. Se o cacique de Tanguro tivesse me chamado para ser ugihongo, pra levar o pessoal junto com ele, eu iria, mas como ele não me convidou, eu vou ficar aqui, junto com minha mulher e minhas filhas.

O chefe principal só aceitaria ir a uma festa para a qual sua aldeia não foi diretamente convidada na condição de ugihongo, "chefe dos convidados", e não na posição de anda, "seguidor", dos chefes de Tanguro. Aiha se considera, e em grande medida também é considerada, iho (esteio; cf. Capítulo 2) em relação às outras aldeias Kalapalo, mas esta posição vem se transformando rapidamente com o aumento das atividades rituais em Tanguro. Uma aldeia iho é onde idealmente se realizam os rituais regionais de um povo, é onde estão seus ancestrais em relação aos quais se definem como coletivos e é, logo, para onde se enviam mensageiros. As aldeias que não os recebem são aquelas vistas como "sem chefes", "pequenas" ou "sem lutadores", o que é obviamente bastante ofensivo para uma aldeia 
grande. Geralmente, nos rituais que Aiha patrocina ou para os quais é convidada, os principais chefes de Tanguro sempre assumem algum papel importante, quase nunca participando como anda, e a possibilidade do chefe de Aiha ter que participar como "seguidor" destes outros chefes lhe pareceu absurda.

Idealmente, os quatro tajope (coordenadores) da festa é que deveriam ser os mensageiros. Antigamente, dizem, convidavam-se apenas quatro aldeias, uma por tajope, mas depois da criação do Parque e o aumento das proporções do egitsü, há muitas aldeias para convidar e por isso é preciso que outras pessoas assumam essa posição ${ }^{18}$. Para cada povo vão sempre três mensageiros, sendo um principal (ihoko ${ }^{19}$ ) e dois acompanhantes (ikongo); o principal fica sempre no meio dos outros dois, hierarquizados em "segundo" (à sua esquerda) e "terceiro" (à sua direita). É importante entender a designação do mensageiro principal como ihoko. O sufixo - ko é uma forma do plural que, em muitas situações, não indica a mera soma de indivíduos (Franchetto, Santos et al., 2007: 15): "plural in Kuikuro means a group, a collective, in the sense that it exists because of the network of relations that tie its members". Por exemplo, uma constelação pode ser referida pelo nome de uma estrela, acrescido do sufixo -ko, como Tuteko, "the stars of the constellation of Aldebaran" or "the people of the star(s) (of Aldebaran)" (ibid: 16). Ainda, se vejo um menino kalapalo passar correndo com várias crianças e alguém me perguntar “quem era?", posso responder apenas "Atchünho-ko", isto é, Atchünho-e-os-que-estão-com-ele. Nos dois casos, um único elemento do grupo (uma estrela ou uma das crianças) é tomado como referência. Essa forma do plural também é comum no tratamento entre afins, que sempre usam o plural para falar uns dos outros. Como dizem Franchetto, Santos et al. (id. ibid.), "affines treat each other as a group".

No caso do mensageiro principal, a que se referiria este $-k o$ ? Em uma tradução inicial sugeri que ele talvez se referisse aos outros mensageiros, ideia que me pareceu plausível e foi acatada por alguns tradutores. Contudo, certa tarde, enquanto eu revisava a tradução de algumas palavras, um homem me chamou a atenção dizendo que este $-k o$ se referia não aos acompanhantes, mas a todos os Kalapalo, e era uma forma de "respeitar". "Respeitar o mensageiro?", perguntei. "Não, quando dizemos ihoko estamos respeitando a "comunidade"”. Assim, o mensageiro principal não é apenas um chefe, nem um chefe-com-seus-

\footnotetext{
${ }^{18}$ E não necessariamente nobres como os tajope.

${ }^{19}$ Iho-ko, esteio-PL.
} 
companheiros, mas um chefe-com-seu-povo, uma "pessoa plural”, alguém que está no lugar de um coletivo.

Quando o final da festa se aproxima, as pessoas já começam a conversar sobre quem gostaria de ir a qual aldeia. Muitos se prontificam a ir a tal ou qual povo, interessados nas trocas que poderão fazer, pois os mensageiros e os coordenadores do grupo convidado devem trocar objetos valiosos ${ }^{20}$. Outros são solicitados pelos tajope, principalmente quando é preciso enviar alguém para muito longe, aonde ninguém quer ir (como para os Mehinaku ou Aweti). Dois dias antes da chegada dos convidados (i. e., um dia antes da saída dos mensageiros ${ }^{21}$ ), ao entardecer, os tajope chamam os donos da festa e colocam um banco em frente à casa dos homens para que se faça a escolha formal dos mensageiros. Nesse ponto, geralmente, os destinos de cada um já estão decididos, mas é preciso discutir para saber com certeza quem irá para onde. Confirmada a decisão sobre cada destino, o dono principal se aproxima do mensageiro que será ihoko, o segura pelo pulso direito, o conduz até o banco e o senta. Feito isto, o chama pelo termo de parentesco apropriado e pergunta, em tom baixo, olhando para baixo ou para longe, para onde ele iria (sinais de respeito e vergonha, assim como o uso do modo hipotético e do plural na pergunta: “[termo de parentesco], unama eteholüko?”, "para onde vocês iriam"?). O futuro mensageiro responde, as pessoas gritam de alegria e o chefe novamente conduz o mensageiro pelo pulso direito, agora para que ele se levante. Isso é repetido para cada ihoko. Esta imagem da condução pelo pulso é central, e veremos que ela aparece em vários discursos.

Pouco antes de chegar ao seu destino, os mensageiros pintam o corpo todo com carvão (a pintura apropriada para a guerra ${ }^{22}$ ), e quando avistam a aldeia em seu caminho começam a gritar, como uma forma de avisar sua chegada. No caso do egitsü, há um grito específico e, antigamente, só de ouvi-lo já se sabia para que festa seriam convidados. Os mensageiros entram pelo caminho principal e vão direto para o centro. Quando chegam, podem ter de esperar que alguém venha sentá-los, enquanto aquele que deve recebê-los formalmente não chega (ou os faz aguardar de propósito). Na recepção que presenciei, os mensageiros esperaram quase uma hora até que o chefe voltasse de sua roça. Quando retornou, foi tomar

\footnotetext{
${ }^{20}$ A questão das trocas será abordada em detalhes no capítulo 6.

${ }^{21}$ Antes dos caminhões, tratores, motos e barcos a motor o intervalo entre a partida dos mensageiros e o final da festa era, logicamente, muito maior.

${ }^{22}$ Esta também é a pintura que a alma de um xamã usa quando conversa com um itseke que roubou a alma de alguém e pede que a devolva (pois dizem que o xamã "briga" com o itseke).
} 
banho, pôs um cinto simples e ainda passou um bom tempo observando os mensageiros de dentro de sua casa - como se sua demora fosse parte importante da recepção. Caso o ihoko seja um chefe importante, ele pode chamar cada anetü da aldeia, também no registro do anetü itaginhu:

[Com o corpo virado para a casa de cada chefe, o braço direito erguido à altura da cabeça com a mão aberta, e em voz alta $^{23}$ ]

$\begin{array}{ll}1 & \text { Itsanginhü higü } \\ 2 & \text { Uge utsakugatiga } \\ 3 & \text { Ahangahitigi } \\ 4 & \text { Agingo heke uahekehetühügü atehe } \\ 5 & \text { Ahangahitigi utsakugatiga }\end{array}$

$1 \quad$ Itsanginhü higü

Neto de respeitável

Eu estou correndo

Para contar algo no seu ouvido

Porque fui conduzido pelo pulso por seu semelhante

Eu estou correndo para contar algo no seu ouvido

No convite que presenciei, este chamado não aconteceu, e parece que ele só é feito por um chefe que "não tenha vergonha" de fazê-lo (um chefe mais velho, por exemplo). O chefe então se prepara para receber os mensageiros. Como me explicou o primeiro cacique Waja, antes de começar a executar o discurso ${ }^{24}$, o chefe deve pegar um arco majahi e um flecha, que deve portar enquanto discursa. $\mathrm{O}$ arco em questão é feito de uma madeira bastante dura e bonita, também chamada majahi, e é uma especialidade produtiva dos Wauja e Kamayurá (uma verdadeira obra de arte; valoriza-se muito os arcos mais lisos, sem sinais de ferramentas de corte e poucas marcas de lixa). Este arco geralmente é chamado de "arco de madeira preta" na literatura, mas trata-se na verdade de uma madeira de um marrom bem claro quando nova, que vai ficando preta ao longo do tempo, com a oxidação (possivelmente ipê). A flecha é uma hüge tahekinhü, "flecha com asas", feita sempre com uma pena de rabo de gavião (o chefe dos pássaros) e outra de rabo de arara vermelha (tahitse kuẽgü, a arara feita do sangue de Aulukumã). Este conjunto de arco e flecha chama-se anetü akitsoho, "que serve para o chefe discursar":

\footnotetext{
${ }^{23}$ Executado por Waja em 2010, enquanto ensinava seu sobrinho uterino.

${ }^{24} \mathrm{Na}$ maior parte das vezes que vi alguém ensinando algo (discursos, cantos ou rezas), o conhecimento é passado após uma descrição detalhada de seu contexto e forma de execução.
} 


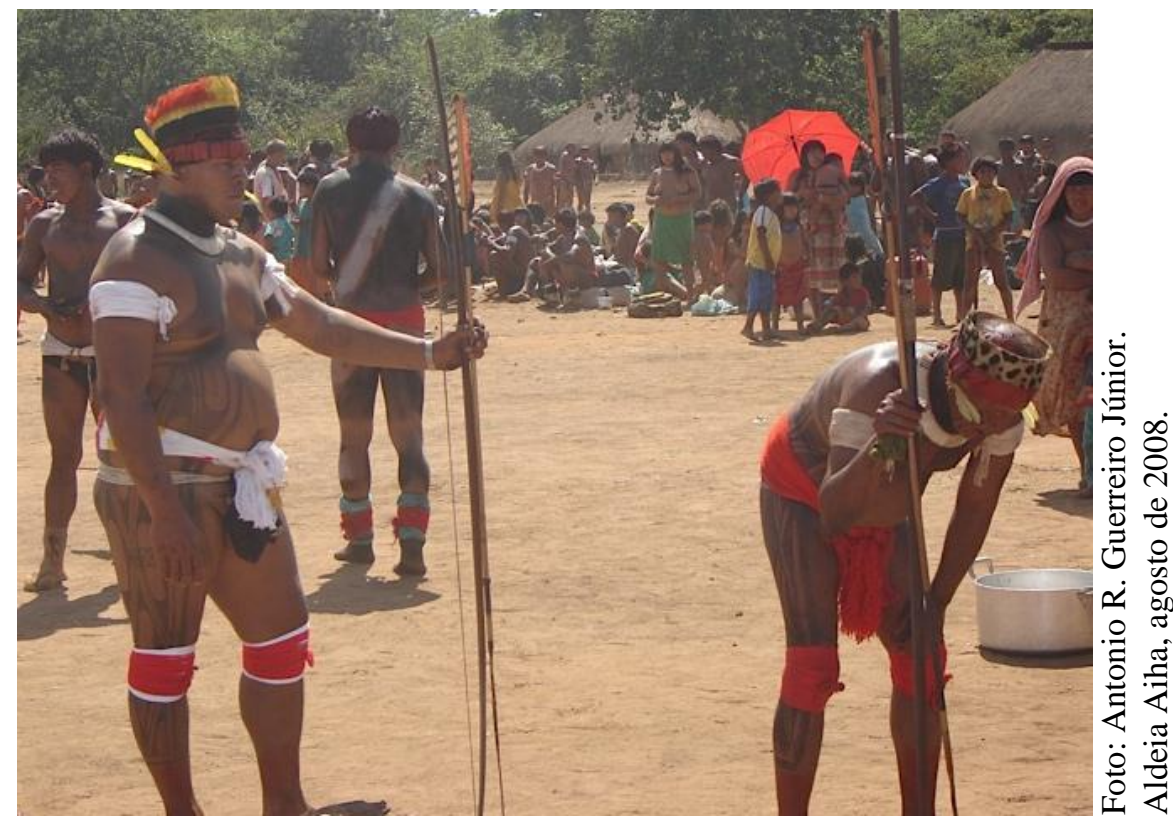

Figura 5.2: donos do egitsü com seus akitsoho se despedindo formalmente dos convidados.

Em seguida, depois de algum tempo, o chefe aparece em frente à sua casa e começa a discursar:

(1)

Executado por Waja, em 11 de novembro de 2009

[Em voz alta, para toda a aldeia ouvir. O chefe porta poucos enfeites, em sinal de humildade e vergonha]

1 Ailitüe, ailitüe, ailitüe, ailitüe

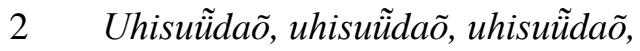

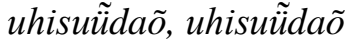

3 Ailitüe, ailitüe, ailitüe, ailitüe

4 Ukotohoko ngengokugu, ailitüe, ailitüe, ailitüe, ailitüe
Alegrem-se, alegrem-se, alegrem-se, alegrem-se

Meus irmãos, meus irmãos, meus irmãos, meus irmãos, meus irmãos

Alegrem-se, alegrem-se, alegrem-se, alegrem-se

Mensageiros dos nossos donos/pais, alegrem-se, alegrem-se, alegrem-se, alegrem-se 
Alegrem-se, mensageiros dos nossos donos/pais

Este trecho é chamado de "início" (inetoho, "que serve para começar") ou "base" (como a base de uma árvore, ena) do discurso. Seu ritmo, sua melodia e sua métrica são bastante diferentes de seu "tronco" ou "corpo" (ihü), pois ele foge ao tipo de paralelismo que marca a maior parte da fala. Ainda parado, antes de começar uma caminhada entre a porta de sua casa e o centro da aldeia, o chefe exorta "seus irmãos" e os mensageiros a se alegrarem. Diferentemente do que se encontra em outros discursos (kalapalo ou não), nos quais o chefe se refere ao seu pessoal como "crianças" (kangamuke), neste ele os chama de "meus irmãos"

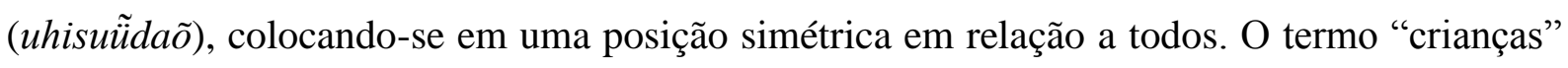
é utilizado nas versões do mesmo discurso registradas por Franchetto (1986; 2003b) entre os Kuikuro e por Basso (2009: 257) entre os Kalapalo. No registro dos discursos, os mensageiros não são chamados de etinhü, mas de ngengoku, que os Kalapalo traduzem como "empregado" ou "funcionário" (também aparece como ngingoku nos discursos kuikuro; Franchetto, op. cit.). Qualquer pessoa que seja mandada para fazer algo, como buscar um objeto, dar um recado, fazer uma viagem, fazer um trabalho, é um ngengoku da pessoa que o mandou. Esse termo é usado com bastante frequência para falar dos funcionários de órgãos do governo, todos entendidos como, em última medida, ngengoku de quem ocupa a presidência da república.

É interessante analisar a expressão ukotohoko ngengokugu (linhas 4 e 5), "mensageiros de nossos donos/pais". A palavra ukotohoko é formada a partir da raiz oto, “dono", também utilizada para se referir a parentes de $\mathrm{G}^{+1}$ (cf. capítulo 2). Basso (2009: 257) traduz o termo como "nossos parentes", em consonância com sua definição de otomo (coletivo de oto) como o universo dos parentes em geral (Basso, 1973). Contudo, eu não pude confirmar este uso de otomo em Aiha, e me parece que a palavra geralmente utilizada para esse universo é

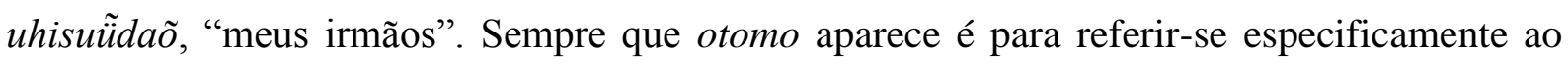
conjunto de parentes de $\mathrm{G}^{+1}$ de alguém, e tenho a impressão de que essa assimetria geracional pode ser relevante. Um indício disso é o uso, por um chefe de Tanguro, de uma expressão que, se não indica uma assimetria geracional como ukotohoko (e otomo), indica uma diferença de idade relativa: ele diz kupinhanoko ngengokugu, "mensageiros de nossos irmãos mais velhos". 
A primeira expressão evoca a consanguinidade putativa entre chefes e "suas crianças", entre uma pessoa e seus animais de estimação, um espírito e a alma de um humano. As relações entre esses tipos de sujeitos frequentemente são vistas como relações de "domesticação" (um chefe que alimenta suas crianças, um dono que protege seus animais de estimação, um espírito que alimenta e oferece companhia a uma alma humana), a forma “canônica" das relações assimétricas (cf. Fausto, 1999; 2008). Caso seja a esse tipo de relação que a assimetria geracional no discurso se refere, talvez o envio de mensageiros possa ser visto como uma tentativa de colocar os convidados na posição daqueles que têm dono, isto é, que são capturados e domesticados (ou pelo menos que se tenta capturar e domesticar) por aqueles que convidam. Isso fica ainda mais instigante quando lembramos que a pintura dos mensageiros (o preto) é uma pintura de guerra.

Na versão de Basso (executada nos anos 1980 pelo irmão mais velho de Waja, cuja versão estou analisando), há um trecho praticamente idêntico ao que acabamos de ver (cito da forma como está no artigo da autora, incluindo suas glosas e traduções):

[em Basso, 2009: 257]

$1 \quad$ kangamuke, kangamuke, kangamuke, kangamuke, kangamuke, kangamuke children, children, children, children, children

2 ah uk-oto-ko-ingo-kugu muke ali-tu-e, ali-ta-i, aili-ta-i, EXP dual-parent-PL-POT-INT EM cheer-Vi-I, cheer-CI-CL, cheer-CIL-CL, ali-ta-i, ali-ta-i, aili-ta-i, aili-ta-iii $\ldots$ cheer-CI-I, cheer-CI-CL, cheer-CI-CL, cheer-CI-CL...

Believe me, though they may not want to, both our relatives are coming, so cheer, cheer, cheer, cheer, cheer...

Quando comparamos com a versão de Waja, vê-se que algumas das transcrições de Basso precisam ser revistas. Ukotokoingokugu (Basso, linha 2) talvez seja ukotoko ngengokugu, equivalente a ukotohoko ngengokugu (linhas 4 e 5). O plural dual não aparece aqui para dizer que há dois "pais" ou "parentes", mas sim para criar um efeito de inclusão dos ouvintes do chefe (suas "crianças") em sua fala. Trata-se, portanto, de "mensageiros dos 
nossos pais" (não faria sentido falar dos mensageiros como "both of our relatives", já que eles são três). E o que Basso transcreve como ailitue, ailitai ou alitai talvez seja alitüe, cuja glosa me parece ser alegria-IMP, apenas.

Em seguida, o chefe começa a caminhar em direção ao centro, discursando. No que se segue, não há sentenças completas em nenhuma linha, pois elas são quebradas em versos, nos quais há poucos elementos lexicais. Estes elementos são seguidos pelo uso regular e formalizado de várias partículas de sentido complexo, algo comum a todo o anetü itaginhu entre os falantes de karib. A mais recorrente é, sem dúvida, a partícula inferiorizadora muke (Franchetto, 2000: 496), que faz parte das formas de fala autoderrogatórias, uma das principais características do gênero de fala dos chefes. Ela inferioriza o falante e reduz a importância do que ele diz, produzindo o que Basso (2009) chama de "efeito de humildade" (humbling effect). Outra das mais utilizadas é o dêitico ige, uma partícula evidencial que indica proximidade/presença/existência, fixado à cópula - $i$ (Franchetto, 2000: 492). Vejamos seu uso combinado na prática:

$\begin{array}{lll}6 & \text { Hesinhü ihatigila muke ngapaha igei } & \text { Não deve ser para contar algo ruim } \\ 7 & \text { Ukotohoko ngengokugu mukeha igei } & \text { [Que] os mensageiros dos nossos donos/pais } \\ 8 & \text { Atsakutanügü mukeha igei } & \text { Correm } \\ 9 & \text { Ukutsatohokona mukeha igei } & \text { Para o lugar onde ficamos }\end{array}$

Uma mesma partícula final, ou conjunto de partículas, é geralmente repetida em uma série de linhas que aparentemente conformam blocos no interior dos discursos, que se distinguem, em uma observação inicial, pela temática e por referências temporais. Veja-se por exemplo o uso de igei entre as linhas 6 e 9, formadas com a repetição de mukeha igei (muke ngapaha igei, no caso da linha 6). Sendo uma partícula evidencial de proximidade, com o seu uso, o chefe chama a atenção de todos para a chegada dos mensageiros ali, naquele momento. Encontra-se o mesmo uso de igei na versão Matipu do mesmo trecho:

[Executada pelo chefe matipu Jamatua, em 26 de outubro de 2009, em sua casa na aldeia Küngahünga] 
1 He, kupisuügü ngengokuguko muke ngapaha igei

2 He, telindikijü heke mukeha igei

3 He, kukatundani mukeha igei

$4 \quad$ He, kupangahitigini mukeha igei

5 Kupisuügüko ngengokuguko atsakutanügü mukeha igei
Os mensageiros dos nossos irmãos

Erram o caminho

Vindo atrás de nós

Para nos contar algo no ouvido

Os mensageiros dos nossos irmãos correm

Nos trechos acima, os chefes falam sobre a chegada de mensageiros que correm (em direção a chefes de outros povos), uma "imagem mental" que perpassa todas as variantes. Entre os Kuikuro, o correr assume um lugar central, pois é utilizado praticamente em todo o discurso (Franchetto, 1986; 1993; 2000). Igei é precedido, na primeira linha das versões Kalapalo e Matipu pelo epistêmico ngapa, que marca algo como uma suposição não confirmada, uma probabilidade (Franchetto, 2007a: 192). Na variante Kuikuro, na primeira linha na qual o chefe fala sobre os mensageiros, apesar de não termos igei, também temos ngapaha (o epistêmico ngapa acrescido do intensificador -ha), seguindo de pohese (uma partícula cujo sentido é desconhecido ${ }^{25}$ ): ngingoku ngapa pohese (Franchetto, 2000: 489). Ngapa é uma partícula frequentemente utilizada quando se conta algo sobre ações, estados, pensamentos ou intenções não expressos (mas prováveis) de um terceiro. Aqui ela é usada porque o chefe não tem como ter certeza sobre as intenções dos mensageiros - só eles mesmos as conhecem. Veremos que ela também aparece abundantemente no restante do discurso, tendo a função de indicar que a fala do chefe é desprovida de autoridade, que o que ele diz talvez possa ser desmentido por outros (mais um dos recursos de autodepreciação desse gênero de fala).

Basso (2009) cita uma linha muito semelhante à linha 6 da versão de Waja, mas com um sentido distorcido pela tradução:

[em Basso, 2009: 257]

$$
\begin{array}{rlllll}
3 & \text { ah } k \ddot{t} \text { tï } & \text { i-fati-gi-la-muke } & a-k a-m b a & \text { igey } & m u . . . \\
\text { EXP ugly } & \text { 3-send-ADV-NEG-EM } & \text { 3.-seated-Vi DEM } & \text { EM }
\end{array}
$$

\footnotetext{
${ }^{25}$ Franchetto, comunicação pessoal.
} 
Believe me, though they may not want to, sending no old and useless people (others will be) seated here...

Há alguns problemas aqui, como por exemplo na glosa de ihatigila (ifatigila na grafia de Basso). Basso considera hati a raiz para "enviar", enquanto de fato a raiz aqui é iha, "contar/mostrar" (a raiz para enviar é humi). Também em akamba, Basso identifica ka como a raiz da palavra, com o sentido de sentar. Contudo, a raiz para "sentar" é $a k a$, como em $(i) s$ $a k a-N-d a$ (3-sentar-CONT), “ele(a) está sentado(a)”. Akamba é recorrente nos discursos cerimoniais, mas apesar de Basso tratá-la como uma única palavra ela é descrita pelos Kalapalo como uma forma contraída dos marcadores epistêmicos aka ("confirmation de l'expérience visuelle de l'autre"; Franchetto, 2007a: 198) e ngapa. Em outras versões, encontramos akangaba exatamente no mesmo tipo de construção da seção de partículas que encerra uma sentença nos discursos: muke akangabaha igei. E os colaboradores são assertivos ao dizerem que as "palavras de verdade" seriam aka e ngapa, mas que elas devem ser juntadas nos discursos: faz parte da sonoridade deste gênero de fala, de sua métrica. Talvez fosse possível transcrever o trecho de Basso como "ah kütsü ihatigila muke akangaba igei muke", exatamente com o mesmo sentido da linha 6 da fala de Waja: "não é para contar algo ruim" (um dos significados de kütsü é ruim, além de ser também uma interjeição de nojo).

Voltemos ao discurso de Waja, que prossegue:

10 Tü kaenga hogima gitse ate?

11 Igehungugote gitse ate?

12 Ngengoku mukeha gitse ate

13 Eti ${ }^{m}$ begalüha gitse ate

14 Inde muke lengapa gitse ate

15 Kutelüko atehe muke lengapa gitse ate

16 Ngengoku elimotanügü muke lengapa gitse ate

17 Ukutsatohokona muke lengapa gitse ate

18 Igehunguki muke geleha gitse ate

19 Kutengatanini muke geleha gitse ate
Para ir ao encontro de quem?

Quando algo assim acontece?

Mensageiros

Chegam

$\left[\right.$ Pois $^{26}$ ] aqui

Nós vamos

Mensageiros erram o caminho

Vindo para onde estamos

Deste jeito

Nós todos vamos indo

\footnotetext{
${ }^{26}$ Este "pois" aparece entre colchetes porque ele seria a tradução de atehe, que só aparece na linha seguinte.
} 
20 Nhunkgulu tohoila mukeha gitse ate

21 Kutelüko atehe mukeha gitse ate

22 Inde muke lengapa gitse ate

23 Kutelüko atehe muke lengapa gitse ate
[Pois] sem fazer barulho

Nós vamos

[Pois] aqui

Nós vamos

A partir deste trecho, encontram-se três conjuntos de partículas: mukeha gitse ate; muke lengapa gitse ate; e muke geleha gitse ate. $\mathrm{O}$ inferiorizador muke é sempre a primeira partícula, e isso em todos os discursos kalapalo que conheço. Em sua forma mínima, ela é seguida das partículas gitse e ate, que fornecerão a rima da maior parte da fala daqui em diante. Gitse significaria, segundo Basso (2009: 256), “pobremente”, “incompleto”, e é usada sempre que o chefe fala do presente em sua aldeia; já ate permanece não identificada ${ }^{27}$. $\mathrm{O}$ final gitse ate também é recorrente na variante matipu. $\mathrm{O}$ outro conjunto mais comum inclui lengapa, que escrevi assim por insistência de meus colaboradores kalapalo, mas que penso ser a junção de leha (“já”) com ngapa. Outra forma substitui lengapa por geleha, onde gele tem o sentido de "ainda" e - ha uma função enfatizadora (Franchetto, 2000).

Nesse momento do discurso, o chefe não é mais alguém que fala para seus irmãos, mas desaparece para dar lugar a um sujeito coletivo, um "nós". O chefe utiliza bastante a forma mais inclusiva do plural ${ }^{28}$, como em "os donos/pais de todos nós" (ukotohoko, linhas 4, 5 e 7), “o lugar onde todos nós estamos" (ukutsatohoko ${ }^{29}$, linha 9), "nós todos vamos" (kutelüko, linhas 15, 21 e 23), "nós todos vamos indo" (kutengatanini, linha 19). Mas apesar desta capacidade de falar pelo grupo, o uso de partículas de inferioriedade, dúvida e incompletude, fazem com que a fala do chefe seja desprovida de qualquer conotação ostensiva de autoridade. Enquanto o chefe fala, parado, de sua casa, nota-se uma diferença entre ele e aqueles para os quais ele discursa (principalmente nas versões nas quais os chama de "crianças"), mas quando ele se move em direção ao centro, começa a se fundir com sua aldeia. A transformação do chefe em um "nós" é expressa tanto pela fala quanto por um deslocamento no espaço, de sua casa na periferia para o centro.

\footnotetext{
${ }^{27}$ Não a encontrei nos trabalhos de Franchetto (1986; 1993; 2000; 2007a) e Santos (2007), que também afirmaram nunca tê-la ouvido em kuikuro (comunicação pessoal). Vale notar que ela nunca aparece sem ser precedida de gitse, apesar desta partícula aparecer sozinha em outras ocasiões.

${ }^{28} \mathrm{O}$ uso do plural inclusivo neste gênero de fala é uma forma de neutralização do enfrentamento entre o Eu e o Tu, uma técnica de dissolução ou elusão da individualidade (Franchetto, 1986).

${ }^{29}$ A glosa literal seria "que serve para todos nós ficarmos" (12-ficar-INSTNR-PL).
} 
O trecho acima pode ser considerado um bloco temático, que mobiliza ideias presentes nos trechos correspondentes em todas as variantes. No começo do bloco, entre as linhas $10 \mathrm{e}$ 13, o chefe questiona seus irmãos sobre quem os mensageiros haveriam de encontrar após correrem tanto, e passagens muito semelhantes aparecem nas variantes de Tanguro, dos Matipu e dos Kuikuro (nota-se que a variante kuikuro é a que mais se distancia, pelo conteúdo, pela forma e pelo vocabulário, das demais):

\section{[Kalapalo de Tanguro]}

$1 \quad$ Tü kaenga hogima gitse ate?

Para ir ao encontro de quem?

$2 \quad$ Ngengoku etimbegalü mukeha gitse ate?

Mensageiros chegam?

\section{[Matipu]}

$1 \quad$ Tü kaenga muke manaha gitse ate?

Para ir ao encontro de quem?

$2 \quad$ Ngengoku etimbegalü mukeha gitse ate?

Mensageiros chegam?

[Kuikuro - conforme Franchetto, 2000: 490]

1 Tüheke osima ngingoku kugingitomi ngingoku atsakugatai geleha ige uãke?

"pour qui alors voudrait/pourrait accueillir les messagers, les messagers doivent courir encore comme toujours?"

2 Taloki geleha ngingoku atsakugatai kangamuke

"pour rien les messagers courent encore maintenant comme toujours"

A partir da linha 14, a forma como o chefe fala do lugar onde eles vivem sugere uma carência, ou uma decadência em relação a um passado melhor/ideal - e por isso o chefe diz que os mensageiros "erram o caminho" (linha 16) neste lugar onde os Kalapalo vão vivendo “sem fazer barulho" (linhas 12 a 20). "Errar o caminho" é outra imagem mental que reaparece em todas as variantes. "Sem fazer barulho", segundo meus colaboradores, significa duas coisas: que não há festas (e portanto as pessoas vivem tristes), e que isso se deve à falta de 
chefes que as patrocinem ${ }^{30}$. Nesta passagem, o chefe ao mesmo tempo oferece uma visão pessimista a respeito de sua aldeia e se apresenta como um falso chefe.

A passagem que se segue gira em torno de outro tema invariante: a preocupação com a posse de objetos de valor que permitam aceitar o convite para o ritual.

24 Kutaũpüaõko engikogupe itsanügü muke Os antigos objetos dos nossos avós lengapa gitse ate

25 Tühogisila mukeha gitse ate

Não são encontrados

26 Kupeheni muke lengapa gitse ate

Por nós

27 Ünago muke ata itsüale [jetsü hale] uãke

Mas eles

28 Igehungugote muke ata itsüale [jetsü hale] uãke

Se algo assim acontecesse

29 Tengikoguko muke ata itsüale [jetsü hale] Seus objetos uãke

30 Igelü heke muke ata itsüale [jetsü hale] Levavam uãke

31 Sagingoila mukeha gitse ate

32 Kutelü tikungu mukeha gitse ate

33 Igehungugote mukeha gitse ate

$34 \quad$ Ngengoku heke mukeha gitse ate

Levavam

Não é igual

Por isso nós vamos

Quando algo assim acontece

[Por esse motivo ${ }^{31}$ ] mensageiros

35 Ukakijüko tikungu mukeha gitse ate

Nos fazem hesitar

36 Inde muke lengapa gitse ate

[Pois] aqui

37 Kutelüko atehe muke lengapa gitse ate

Nós vamos

38 Ünago ngigihukipügütela muke ngapaha gitse ate

[Pois] em um lugar que não foi aberto por eles

39 Kutelüko atehe muke lengapa gitse ate

Nós vamos

40 Kutaũpüaõko engikogupe itsanügü muke leha gitse ate

41 Hangapola muke leha gitsa te

Os antigos objetos dos nossos avós

42 Kupeheni muke lengapaha gitse ate

Não são mais furados

Por nós

Os objetos dos quais o discurso trata são os cintos e colares feitos a partir da concha do caracol inhu (Megalobulimus sp.), e "furar" (linha 41) é a linguagem para se referir à sua confecção, especialidade dos karib xinguanos (segundo os Kalapalo, sua especialidade - os

\footnotetext{
${ }^{30}$ Os Kalapalo dizem que algumas aldeias são "silenciosas", com a intenção de ofendê-las e criticar seus chefes.

${ }^{31}$ A expressão aparece entre parênteses porque traduz tikungu da linha seguinte.
} 


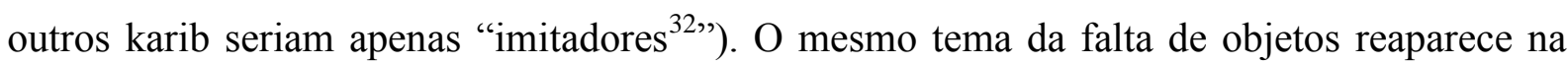
versão mehinaku ${ }^{33}$ (Mehinako, 2006: 17-18) e no discurso wauja apresentado por Ball (2007: 46), no qual o chefe menciona que eles não saberiam mais "trabalhar a argila" como seus ancestrais (referindo-se aos objetos de cerâmica, a especialidade wauja). A incapacidade de encontrar/fabricar estes objetos aparece como um tema importante do discurso, porque eles são indispensáveis para se aceitar um convite, já que os ugihongo dos convidados deverão oferecer, na ocasião da festa, cintos ou colares como presentes para aqueles que foram convidá-los. Ninguém que não disponha destes objetos pode ser ugihongo, e uma tensão entre a aceitação ou não do convite em função da capacidade dos chefes encontrarem os objetos valiosos de que precisam, é algo que persiste até o momento em que os ugihongo se ajoelham perante os mensageiros para discursar e aceitar o convite formalmente. Sabendo da vinda dos mensageiros, os chefes interessados já separarão seus objetos, mas assim como o convite não está certo até a chegada dos convidadores, também não se pode ter certeza se alguém aceitará ou não se desfazer de seus objetos valiosos até que execute a fala e o gesto apropriados.

O chefe constrói uma oposição nostálgica entre o passado e o presente, dizendo que "eles" (os chefes do passado), tinham objetos de valor e podiam aceitar de prontidão um convite, mas que hoje não, seu povo hesita em aceitar um convite porque não dispõe mais dos objetos de seus antepassados. Há, na verdade, duas oposições, uma entre um "aqui" e um "não aqui", e outra entre "nós" e "aqueles" (ünago, a forma mais comum de falar dos chefes do passado no anetü itaginhu). Como Franchetto (2000: 493) comenta, hipérbole e contraste são características centrais do anetü itaginhu e do pensamento alto-xinguano de maneira geral, que podem ser entendidas a partir "de la tension permanente entre une matrice modèle et son " devenir » dans la dimension du réel toujours actualisé”. O presente nunca é mais do que uma atualização imperfeita de um passado construído como grandioso e mesmo excessivo (na medida em que esta grandeza pode significar perigo, como no caso dos espíritos).

As linhas 27-30 são construídas utilizando o contrastivo hale (para marcar a diferença entre o passado e o presente) e uãke, elemento da categoria dos mediativos ou marcadores epistêmicos (Franchetto, 2000: 492). Esta última partícula não apenas atua na construção do

\footnotetext{
${ }^{32}$ Alguns dizem que conseguem saber se um colar foi feito por um kalapalo ou por um kuikuro, pois haveria pequenas diferenças técnicas.

${ }^{33}$ Segundo Mehinako (2006: 17-18), os "objetos" de que fala o chefe (colares de conchas ou de garras de onça) são, na verdade, formas de se referir aos lutadores: os primeiros seriam "apelidos" dos jovens campeões, e os segundos dos campeões veteranos. Quando o chefe mehinaku diz que não tem objetos, ele na realidade diz que não tem lutadores hábeis para levar à aldeia que o convida.
} 
tempo passado, mas indica que o falante o presenciou ou tem autoridade para falar sobre ele. Aqui, o uso de uãke dá autoridade ao chefe porque o conhecimento que exibe chegou até ele passando diretamente entre chefes legítimos (Franchetto, 2000: 492). Sagingoila (linha 31), "não se parece", é recorrente em todo o anetü itaginhu kalapalo imediatamente depois de blocos construídos com $u \tilde{a} k e$, e antes de retomar uma fala sobre o presente, construída com gitse, gitse ate ou igei. Ao menos nas variantes kalapalo, as partículas finais estão organizadas em pares de oposições associados a tempos dotados de valores diferentes, com uãke referindo-se a um passado grandioso e gitse ou gitse ate referindo-se a um presente imperfeito.

$\begin{array}{ll}43 & \begin{array}{l}\text { Unago akuãpütegohotela muke } \\ \text { lengapaha gitse ate }\end{array} \\ 44 & \text { Kutelüko atehe muke lengapa gitse ate } \\ 45 & \text { Igia mukeha gitse ate } \\ 46 & \text { Ngengoku muke leha gitse ate } \\ 47 & \text { Ukakijüko tikungu muke leha gitse ate } \\ 48 & \text { Igehunguki muke leha gitse ate } \\ 49 & \text { Kutengatanini muke leha gitse ate }\end{array}$

Nós não homenageamos/substituímos
mais aqueles que morreram
Pois nós seguimos
Assim
[Por esse motivo] mensageiros
Nos fazem hesitar
Deste jeito
Nós todos vamos seguindo

Nós não homenageamos/substituímos

Pois nós seguimos

Assim

[Por esse motivo] mensageiros

Nós todos vamos seguindo

Antes de concluir e chegar ao centro da aldeia, o chefe reafirma, de forma diferente, algo que já havia dito: que não há mais chefes em sua aldeia. Mas enquanto na abertura falase sobre a falta de barulho e, consequentemente, de festas e chefes, agora no final o chefe se refere ao (falso) abandono do egitsü, que chama de akuãpütegoho ("feito para homenagear/substituir" - este conceito será objeto do último capítulo). Este termo é uma palavra nominal cuja morfologia descreve a finalidade do egitsü (akuãpütelü, imitar/reanimar o corpo provisório do morto ${ }^{34}$ - a efígie), mas aqui predomina a linguagem metafórica do anetü itaginhu. Quando o chefe diz que não se homenageia mais os chefes mortos, ele

\footnotetext{
${ }^{34}$ Akuã-pü-te-lü (alma/imagem-ex-VBLZ-PNCT). Esta palavra tem um duplo sentido. Por um lado, como akuã é a imagem de alguém, e akuãpügü é a imagem de alguém morto, a forma verbal akuãpütelü significa "construir uma imagem de alguém que morreu". Ao mesmo tempo, construir certas imagens implica em personificar os seres imitados, e pode ter o sentido de "animar" (dotar de alma/agência) - neste caso, o morto, que revive temporariamente em sua própria imagem (a efígie do egitsü). Esta interpretação é corroborada pelo sentido de akuãtelü (alma-VBLZ-PNCT), o procedimento pelo qual os pajés devolvem a alma de um doente ao seu corpo. Akuãtelü e akuãpütelü têm, ambas, o sentido de "animar": no primeiro caso, dotar um vivo de sua alma; no segundo, dotar a alma de um morto de um corpo/imagem provisório. O foco da ação é distinto nos dois casos, mas o objetivo é o mesmo.
} 
também diz que não há descendentes destes mortos que possam fazê-lo e substituí-los (por isso os Kalapalo insistiam que akuãpütelü, neste caso, significa substituir). O objeto da fala não é o egitsü enquanto evento, mas seus efeitos sobre a continuidade da chefia. Sem objetos de valor, sem chefes e, portanto, sem ninguém apto a aceitar o convite, "mensageiros/nos fazem hesitar" (linhas 34 e 35; 46 e 47). Contudo, é preciso notar que todas estas afirmações negativas são uma forma irônica de discurso antinômico: quando um chefe afirma não haver algo (como chefes ou rituais), quer dizer justamente o contrário.

Depois que o chefe chega no centro, ele começa a chamar todos os outros anetü:

[Em voz alta, com o corpo virado em direção à casa de cada anetü, em tom de voz descendente]

$1 \quad$ Untsi $^{35}$, ilanha etete, ilanha etete, ilanha etete, uinha

Meu filho/sobrinho, venha para cá, venha para vá, venha para cá, para mim

2 Ukotohoko ngengokugu taloki muke kundzuginhitomi muke hõho

Os mensageiros dos nossos donos/pais, vamos recepcioná-los à toa

3 Tükaenga hogima gitse ate?

Para ir de encontro a quem?

$4 \quad$ Igehungugote gitse ate?

Quando algo assim acontece?

$5 \quad$ Ngengoku eti ${ }^{m}$ begalüha gitse ate

Mensageiros chegam

$6 \quad$ Ünago kaenga muke hale gitse ate

Mas para junto daqueles

$7 \quad$ Ngengoku etimbetanügü mukeha gitse ate

Mensageiros chegavam

$U_{n t s i}{ }^{36}$ tem o mesmo sentido de ipü, um vocativo que pode se usado para parentes masculinos de geração inferior à de Ego, como S, ZS, BS ou ChCh. É considerado um termo de karib antigo, chamado de "língua dos de antes", ingilango akisü, ou "língua de chefes", anetü akisü. As duas tendem a se confundir, pois os principais chefes se orgulham de usar um vocabulário "fundo", às vezes inteligível apenas para algumas pessoas - seus próprios

\footnotetext{
${ }^{35} \mathrm{O}$ vocativo muda de acordo com o tipo de parente chamado pelo chefe. No caso de cunhados, o chefe usaria amago, "vocês", e, no caso de sogro ou genro, usaria tecnonímias (como "pai do meu neto", por exemplo). Vale notar que o vocativo usado para chamar um neto nessa ocasião é apitsi, "vôvô", promovendo uma identificação entre parentes de $\mathrm{G}^{+2} \mathrm{e} \mathrm{G}^{-2}$.

${ }^{36}$ Mehinaku (2010: 141) diz que os Kuikuro chamam jocosamente os Kalapalo de "untsi", porque eles seriam os únicos karib xinguanos que usariam esse termo. Na mesma página o autor nota que os Kalapalo também são chamados de ngagupohongo, "outro povo, povo de fora (lit. aquele que fica do outro lado da fronteira com outro povo/cultura" (id. ibid.).
} 
parentes -, um importante índice de (suposta) "pureza". Como uma mulher me disse uma vez, “eu falei assim com você e você entendeu, mas quando usei a verdadeira língua kalapalo você não entendeu. Que horror, você só sabe palavras feias, porque está aprendendo com os outros, que são misturados com matipu, kuikuro, nahukwa. Eu tenho as palavras verdadeiras, as palavras dos meus antepassados, as palavras de Kahagahü e Kambetse [sua avó e avô maternos, falecidos chefes kalapalo]". O gênero de fala dos chefes usa um conjunto de palavras que, de certa forma, colocam o chefe na posição de "ancestral" em relação aos demais.

Os outros chefes já esperam o momento em que deverão aparecer, mas só o fazem depois da convocação do principal. Eles saem de cabeça baixa pela porta da frente de sua casa e vão, um a um, até o centro, ouvindo o chefe repetir parte daquilo que ele já havia dito. Os que souberem o anetü itaginhu caminharão respondendo ao chamado do chefe, também falando sobre o erro dos mensageiros por terem vindo até ali, a falta de chefes e de objetos para aceitar o convite. Agora os Kalapalo como um todo não são mais os interlocutores do chefe, mas apenas os outros anetü. As pessoas comuns saem da cena poética e a fala do chefe se torna um diálogo exclusivo entre nobres.

Quando cada chefe chega ao centro, aquele que está executando o discurso lhe diz:

$1 \quad$ Untsi

2 Ingike muke taloki

3 Ukotohoko ngengokugu kunhini
Meu filho/sobrinho

Dê uma olhada à toa

Vamos ver/recepcionar os mensageiros dos nossos donos/pais

O chefe dirige esta fala a cada anetü, no intuito de saber quem vai aceitar o convite e se tornar ugihongo. O chefe questionado responde reafirmando que já não encontram mais os objetos de seus avós, isto é, não dispõem dos objetos valiosos necessários para aceitar o convite: 
(4)

$\begin{array}{ll}1 & \text { Enẽ, enkingale } \\ 2 & \text { Inde muke leha gitse atehe } \\ 3 & \text { Kutelüko atehe mukeha } \\ 4 & \begin{array}{l}\text { Kutaũpüaõko engikogupe itsanügü muke } \\ \text { gitse ate }\end{array}\end{array}$

$5 \quad$ Tühogisila gitse ate kupeheni muke leha
Sim, de fato

[Pois] aqui

Nós vamos

Os antigos objetos de nossos avós

Nós já não os encontramos

Esse momento da recepção dura bastante tempo, pois o chefe fará essa pergunta um a um, e ninguém aceita um convite imediatamente - é preciso negar primeiro. Depois que todos negaram, o chefe tornará a perguntar, um por um, se eles dispõem de objetos, até que alguém aceite (é preciso que três pessoas o façam, pois deve haver um ugihongo/coordenador para cada mensageiro). Aqueles que aceitarem devem dizer que mentirão para os mensageiros, apenas para poderem levar seu povo à festa. Como não encontram seus objetos e não há mais verdadeiros anetü, a única chance do convite ser bem sucedido é a mentira despretensiosa de alguém que se passará por chefe:

(5)

[Termo de parentesco], taloki muke apa ũaũgudani kulimo nhigetani

[Termo de parentesco, referindo-se ao chefe que coordena a recepção], com a melhor das intenções eu vou mentir para levar os nossos filhos

Que o ugihongo vá "mentir" para o mensageiro é uma forma do sujeito, ao mesmo tempo, se afirmar chefe (ele será ugihongo) e diminuir sua condição. Todos sempre enfatizavam para mim durante a tradução: "Ele está dizendo que não é chefe, mas é, só que no discurso ele precisa mentir". Mentira aqui não tem um sentido necessariamente "ruim", pois como eu já disse, mentir também significa fazer algo de improviso. O que o futuro ugihongo diz é que, na falta dos grandes e ricos chefes do passado e de seus descendentes, alguém sem importância e pobre como ele terá de bastar. Pode parecer que não há chefes para atender ao convite, mas o sentido antinômico do discurso deixa claro que há. 


\subsection{Os que foram abandonados no caminho}

Depois do aceite dos ugihongo, o chefe responsável pela recepção deve dar seu akitsoho para eles discursarem, um a um, perante o mensageiro que se tornará seu "inimigo" (imütongo, "que fica face a face"), também dentro do gênero da "conversa de chefes" (o primeiro ugihongo se tornará inimigo do ihoko, e assim por diante). Muitas vezes os ugihongo não sabem esse discurso, e o chefe que recepcionou os mensageiros é quem o executará, ao lado dos primeiros. Esta parte da fala possui uma linha de abertura e outra de encerramento cuja musicalidade é peculiar, aplicada de forma muito semelhante a todas as linhas de abertura e encerramento de conversas diretas entre dois chefes de grupos distintos (diferente da fala de abertura que vimos na seção anterior). Esta musicalidade diferenciada é fundamental para o desenrolar da conversa, pois ao fim da abertura o mensageiro deve responder ao ugihongo. Porém, dado que frequentemente ele e o ugihongo falam línguas mutuamente ininteligíveis, como poderá saber que seu interlocutor terminou sua fala e é sua hora de responder? É em parte neste registro que a musicalidade opera. Como Menezes Bastos (1978) já apontou, a música é a língua franca do Alto Xingu, que viabiliza a comunicação entre os grupos, independentemente da compreensão verbal mútua. Mesmo sem entender nada de wauja ou kamayurá, por exemplo, um chefe kalapalo sabe perfeitamente quando o outro terminou sua fala e ele deve responder.

$\left(6^{37}\right)$

[Em voz baixa e em tom descendente, com os olhos virados para o chão, apoiando-se no akitsoho]

$\begin{array}{ll}1 & \text { Ngengoku, ngengoku } \\ 2 & \text { Uege kana etibegatiga } \\ 3 & \text { Üngele higümbügü katundalüa }\end{array}$

Mensageiro, mensageiro

Você que está chegando

No caminho dos netos daqueles que já morreram

\footnotetext{
37 Aqui optei por usar uma versão do discurso executada por Ageu, irmão mais velho de Waja. Eles são praticamente idênticos no que toca ao vocabulário e à forma, mas a versão que escolhi apresentar é mais completa, pois menciona mais chefes e faz referência ao tempo de Angahuku (algo que falta na versão de Waja).
} 
Este é o bloco de abertura da fala do ugihongo, dirigida ao mensageiro com o qual ele estabelece uma relação de inimizade ritual. Não mais irmãos, não mais os outros chefes kalapalo: o interlocutor agora é um estrangeiro considerado um tipo de inimigo. Na terceira linha, o ugihongo usa o pronome livre anafórico ${ }^{38}$ üngele (“aquele") que, assim como ünago, se refere aos chefes do passado (neste trecho outros chefes dizem ünago ao invés de üngele). Optei traduzir üngele higümbügü por "netos daqueles que já morreram”, pois o sufixo (m)bügü, que se segue a higü, "neto", indica que os avós em questão já faleceram. Na última linha, aparece pela primeira vez a palavra katundalüa ${ }^{39}$, que será recorrente de agora em diante. Ela significa "no caminho que leva a algo ou alguém" e tem um sentido muito forte. Não se diz que alguém "vai no caminho que leva a outro", a menos que seja algo muito sério e urgente. É depois deste cumprimento inicial que o mensageiro responde:

[Resposta do mensageiro, sentado, olhando para o chão e com a voz baixa]

$1 \tilde{E}$, uge utsakugatiga

2 Agingo heke uahekehetühügü hütiseke, utsakugatiga

3 Ai muke gele jakuãke

$4 \quad$ Uenügü tikungui muke gele aka uãke

$5 \quad$ Agingo heke muke gele aka uãke

$6 \quad$ Uahekehetühügü hütiseke muke gele aka uãke

$7 \quad$ Egea muke gele aka uãke

$8 \quad$ Akatunda muke gele aka uãke

9 Uenügü tikungui muke gele aka uãke

10 Uaũgu tikungui muke gele aka uãke

11 Egea muke gele aka uãke

12 Üngele ingugikügü beke muke gele aka uãke
Sim, eu estou correndo

Pela vergonha de ter sido conduzido pelo pulso por seu semelhante, eu estou correndo

[sem nenhum elemento lexical]

Por isso eu vim

Por seu semelhante

Eu fui conduzido pelo pulso e envergonhado

Assim

Por isso no seu caminho

Eu vim

Por isso eu menti

Assim

Durante a decisão sobre aquele morto

\footnotetext{
${ }^{38}$ Santos, 2007: 56.

39 A palavra vem de katunda, "caminho", como por exemplo em Ete katunda, "o caminho que leva à aldeia", ou Canarana katunda, "o caminho que leva a Canarana”. Waja usa katundagügüa, que tem o mesmo sentido.

${ }^{40}$ Esta é uma típica frase formulaica que aparece nos discursos, formada a partir da concatenação de diversas partículas, mas sem nenhum elemento lexical.
} 
13 Ah, üle hütiseke muke gele ngapa igei uãke

14 Üngele heke muke gele ngapa uãke

15 Ah, titsatinhü muke gele aka uãke

16 Uahekehetühügü hütiseke muke gele aka uãke

17 Egea muke gele aka uãke

18 Akatunda muke uãke

19 Uenügü tikungui muke gele aka uãke
Ah, como isso me envergonhou

Por aquele

Ah, por aquele que está festejando

Eu fui conduzido pelo pulso e envergonhado

Assim

Por isso no seu caminho

Eu vim

O mensageiro corre porque foi "conduzido pelo pulso" (lembremos da descrição no começo do capítulo) por um semelhante daquele que o recebe, e por "semelhante" deve-se entender anetü. Hütiseke ${ }^{41}$ (linhas 2, 6, 13 e 16) pode ser traduzido como "por vergonha", e é uma maneira significativa de expressar o sentimento de obrigação que a condução pelo pulso provoca em um mensageiro. $\mathrm{O}$ mensageiro também afirma ter mentido durante a decisão sobre o morto (momento no qual se decide sobre fazer ou não um egitsü), pois para ser tajope e mensageiro é (teoricamente) preciso ser anetü, e nessa passagem ele nega sua condição de chefe. Em seguida, o ugihongo retoma a palavra:

$1 \quad$ Ah uhitseke geleha etibegake ngengoku

2 Ah itsuginhikügü tohoila etibegake ngengoku

3 Etibegoki jetü hale igei uãke

$4 \quad$ Ngengoku jetü hale igei uãke
Ah, você chega sem saber de nada, mensageiro

Ah, você chega sem uma recepção, mensageiro

Mas para eles [antigos chefes] é que chegavam

Mensageiros

Nestas linhas, estão algumas das ideias centrais do discurso que serão repetidas de formas variadas. A ideia fundamental é que os mensageiros chegam "sem saber de nada", isto é, sem saber que não há descendentes de chefes capazes de recebê-los. As linhas 3 e 4, que são sempre repetidas em conjunto, produzem um contraste com o passado: "mas para eles [antigos chefes] é que chegavam mensageiros”. Em seguida, nomeiam-se então alguns chefes

\footnotetext{
${ }^{41}$ Hütise-ke (vergonha-TEND).
} 
cujos descendentes, caso houvessem, poderiam oferecer uma verdadeira recepção aos mensageiros.

É especificamente o trecho seguinte do etinhü itagimbakitoho que Franchetto descreve como uma "celebração da história" (1993) entre os Kuikuro, por se tratar de uma "métaphore épique de l'idéntité du Lahatuá ótomo, les Kuikúro" (Franchetto, 2000: 502), uma sequência de enunciados que seriam "une chronologie et une gallerie des grands chefs anciens, histoire célébré d'une identité collective en relation de contrast avec les autres ótomo [povos]" (id. ibid.). As versões kalapalo de que disponho também evocam antigos chefes, o que parece ser o objeto central desta fala (uma característica saliente em todas as versões karib disponíveis, mas que não se encontra na versão wauja, apresentada por Ball, 2007, nem no trecho de uma versão mehinaku apresentada por Mehinako, 2006). As variantes kalapalo deste trecho tratam dos mesmos temas que a variante kuikuro - a ausência de chefes para receber adequadamente os mensageiros -, mobilizando expressões e ideias semelhantes. No que toca ao conteúdo, uma semelhança específica salta aos olhos: a referência a um mesmo momento histórico no qual os karib viviam em uma região chamada Angahuku ("Buritizal”), às margens do rio Buriti (oeste). Como veremos, o discurso funciona como um index histórico. Cada nome e lugar tem alguma explicação histórica (por menor que seja), isto quando não se liga a narrativas completas.

Os chefes mencionados pelos Kalapalo são reconhecidos como muito antigos e "grandes", mas, segundo me explicaram, não é sua antiguidade que os faz ser lembrados no discurso (afinal, há incontáveis grandes chefes antigos deixados de fora), e sim algo marcante na trajetória de todos eles, que faz a história imbricada no discurso extrapolar as fronteiras do mundo xinguano: eles próprios (ou seus filhos, segundo diferentes interpretações) foram roubados ou mortos por “espíritos” - os brancos, na linguagem do anetü itaginhu.

1 Ah üngele higümbügü katundalüa etibegake ngengoku

2 Ah itsuginhikügü tohoila etibegake ngengoku

3 Ah uĩhũguha tühigümbükila ngengoku

4 Eusaguha tühigümbükila ngengoku
Ah, você chega no caminho dos netos daqueles que estão mortos, mensageiro

Ah, você chega sem uma recepção, mensageiro

Ah, não há netos de meu ancestral, mensageiro

Não há netos de Eusagu, mensageiro 
5

Eusagu higümbügü katundalüa etibegake ngengoku

6 Ah uhitseke gekeha etibegake ngengoku

$7 \quad$ Etibegoki jetü hale igei uãke

$8 \quad$ Ngengoku jetü hale igei uãke
Você chega no caminho dos netos de

Eusagu, mensageiro

Ah, você chega sem saber de nada, mensageiro

Mas para eles é que chegavam

Mensageiros

Este bloco se repete outras quatro vezes, cada uma mencionando o nome de um chefe diferente, sempre na mesma ordem: Kanutagi, Kamankgagü, Aküana e Akügagi. Depois dos chefes homens, é a vez das mulheres: Sakuãgu, Ahua e Kasima. Os blocos sobre as itankgo são praticamente idênticos aos blocos sobre os homens, a não ser pela substituição regular de "üngele higümbügü" ("netos daqueles que estão mortos") por "itankgo higümbügü" ("netos das mulheres chefes que morreram"). Há uma ambiguidade central nesse discurso, que é a afirmação da inexistência de descendentes de chefes, associada ao uso do termo uĩhũgu (1-ancestral-REL, "meu ancestral") pelo ugihongo: como é possível que o chefe diga que "não há netos de meu ancestral"? Ao mesmo tempo que afirma não haver netos dos chefes nomeados, o ugihongo se apresenta como descendente de cada um deles! Esta passagem talvez seja a que mais ressalte a dinâmica complexa entre passado e presente, chefes vivos e ancestrais, evocada pelas antinomias do discurso.

Há ainda outros nomes de chefes que, segundo me disseram, poderiam ser incluídos no discurso, mas não foram mencionados em nenhuma das versões que obtive. A ordem dos chefes nomeados não deve ser alterada em hipótese alguma (quando eu errava a ordem de um ou outro era imediatamente corrigido, e meu professor sempre o fazia em tom de reprovação), mas ela não se refere necessariamente a uma sucessão cronológica, nem significa que eles façam parte de uma "linhagem" ou algo do tipo. Estes nomes são considerados especialmente bonitos por serem muito "famosos" (tuhutinhü, conhecidos) e, não por coincidência, parte deles pertence a parentes muito próximos do atual chefe principal. Alguns destes nomes também circulam entre chefes matipu que herdaram a chefia de uma ancestral kalapalo, e nomes mencionados pela filha de um chefe jagamü circulam hoje entre itankgo nahukwa. Nomes bonitos e famosos são como riquezas, e dá-los a pessoas específicas faz parte de projetos conscientes de perpetuação do prestígio de uma parentela nobre. 


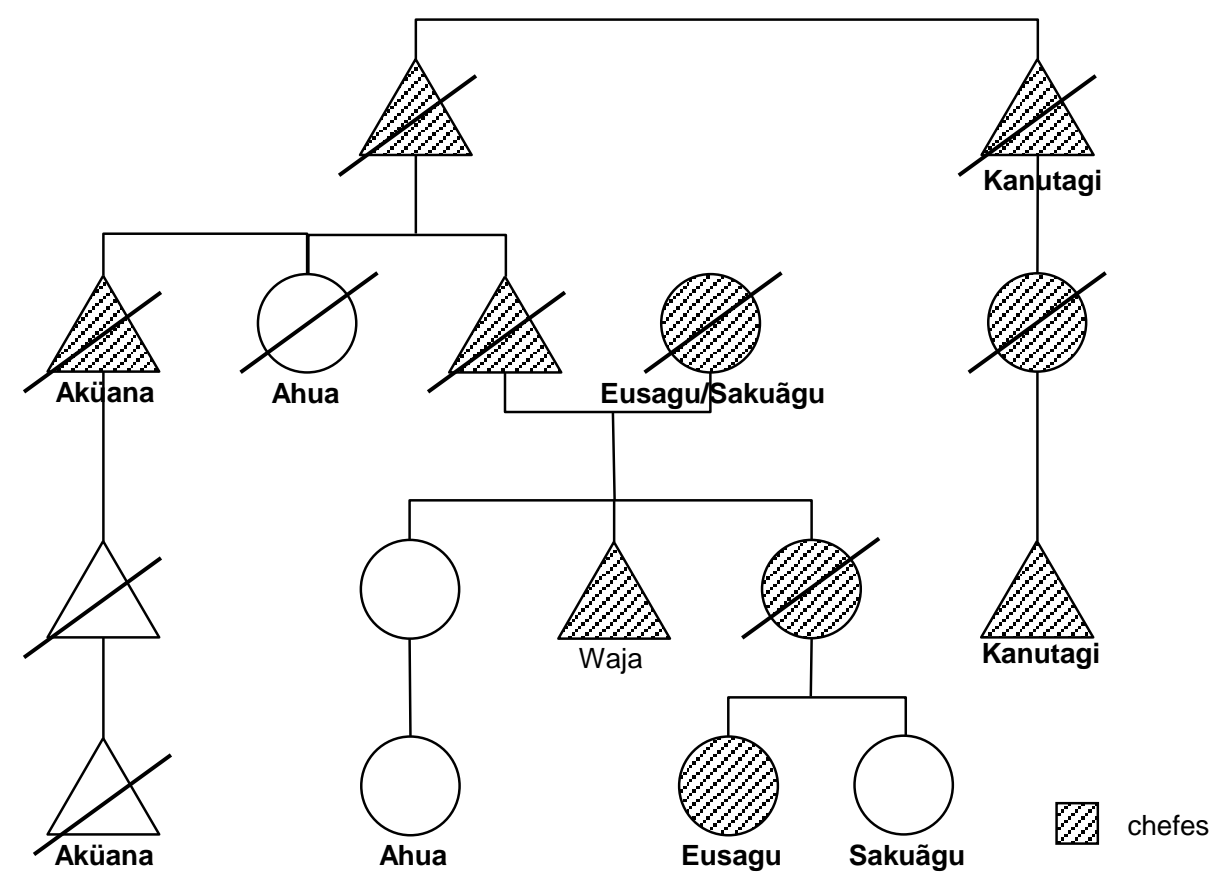

Figura 5.3: diagrama mostrando a transmissão de nomes de chefes mencionados no etinhü itagimbakitoho (em negrito).

Note-se que estes nomes têm sido usados por parentes próximos do chefe principal Waja. No discurso, Eusagu é um homem, mas este nome tem sido usado por mulheres (os Kalapalo possuem diversos nomes unissex).

Até pouco tempo eu imaginava que todos os anetü kalapalo nomeassem os mesmos chefes em seus discursos, pois os três chefes com quem gravei o etinhü itagimbakitoho o fazem. Mas Ageu me corrigiu sobre isso quando perguntei sobre a razão da filha do chefe jagamü incluir outros nomes em sua versão: “é porque esses são os ancestrais dela”. Ele em seguida me explicou que outro chefe de Aiha nomeava em seus discursos Atakuma, um antigo chefe mehinaku, e Sesuaka, uma itankgo kalapalo, porque eles eram seus ancestrais; e outro chefe (sogro do chefe yawalapíti sobre o qual falamos no capítulo 2) mencionava o anetü Saganaha e a itankgo Kaigu. Ageu contou ainda que, quando um chefe matipu pediu a ele que lhe ensinasse o etinhü itagimbakitoho, ele negou dizendo que não poderia: "como eu saberia quem são os ancestrais dele?!", me disse.

Como Franchetto $(1993 ; 2000)$ mostra, a menção a estes chefes faz o grupo aparecer como um povo com uma histórica específica, cuja identidade coletiva atual é inseparável da referência histórica de seus chefes do passado: é porque descendem de certos chefes, e não de outros, que os Kalapalo são quem são (cf. discussão do capítulo 1). No caso Kuikuro, Heckenberger e Franchetto veem os chefes evocados nos discursos como os "fundadores" do 
grupo, sugerindo uma relação geral entre estes chefes e os Kuikuro como um todo. De fato, muitos dos nomes mencionados ali também figuram no mito de origem daquele povo. Entre os Kalapalo, as informações de Ageu sugerem que a situação é diferente, pois, na realidade, cada chefe tem seus próprios ancestrais, e ao evocá-los não só se apresenta como seu descendente, mas se diferencia de outros chefes. A imagem da personificação do grupo pelo chefe parece ainda mais "literal", pois naquele momento do discurso, os Kalapalo são personificados por aquele chefe que diz descender daqueles ancestrais específicos, e não de outros.

A recorrência ou divergência dos nomes citados nas variantes de diferentes povos também são índices das relações históricas entre os karib xinguanos. No subsistema karib, os Kalapalo e Kuikuro são os que se consideram mais distantes e não é à toa que nos respectivos discursos nenhum nome de chefes se repete. Em compensação, na variante matipu, um povo "mais próximo" dos Kalapalo, o único chefe mencionado (Aküana) também é citado na variante kalapalo. Não pude registrar nenhuma variante nahukwa, mas é curioso que na versão que ouvi da filha de um chefe jagamü, ela apenas acrescente alguns nomes à lista dos Kalapalo (e os Nahukwa são justamente os karib mais próximos - geográfica, social e historicamente - dos Kalapalo).

Mas por que não há descendentes destes chefes?

\begin{tabular}{|c|c|c|}
\hline & Ünago itsopügü muke geleha igei uãke & Aqueles estariam \\
\hline 2 & Ngengoku etibetoho muke geleha igei uãke & No lugar de chegada dos mensageiros \\
\hline & Ah itseke heke muke akangabaha igei uãke & Ah, os espíritos \\
\hline & Tüanhagü apogui muke geleha igei uãke & Os abandonaram em seu caminho \\
\hline & $\begin{array}{l}\text { Ngengoku etibetoho itsopügü muke geleha } \\
\text { igei uãke }\end{array}$ & $\begin{array}{l}\text { Haveria um lugar de chegada para } \\
\text { mensageiros }\end{array}$ \\
\hline & Ah itseke heke muke akangabaha igei uãke & Ah, os espíritos \\
\hline & Tüanhagü apogui muke geleha igei uãke & Os abandonaram em seu caminho \\
\hline & Apegutigatühügü muke geleha igei uãke & Para que morressem \\
\hline & $\begin{array}{l}\text { Enongo kae muke gele akangabaha igei } \\
\text { uãke }\end{array}$ & [Enquanto] na outra margem \\
\hline & Ah kutelüko hata muke geleha igei uãke & Ah, nós íamos \\
\hline & Angahuku kae muke geleha [igei uãke] & [Enquanto] no Buritizal \\
\hline & Ah kutelüko hata muke geleha igei uãke & Ah, nós íamos \\
\hline
\end{tabular}


13 Enongo mütü muke geleha igei uãke

14 Ah kutelüko hata muke

15 Ngengoku, ngengoku, ngengoku
[Enquanto] na outra margem

Ah, nós íamos

Mensageiro, mensageiro, mensageiro

Quando ainda viviam na região de Angahuku (Buritizal), especificamente em Kuapügü, os ancestrais dos Kalapalo tiveram os primeiros contatos com os brancos. $\mathrm{Na}$ versão kuikuro, há um trecho praticamente idêntico, que também menciona as mortes dos chefes em Angahuku (Franchetto, 2000: 499), apontando para um tempo no qual os karib talvez vivessem ainda mais próximos. Nesta e em outra versão de que disponho, este trecho é executado no final do discurso, mas na versão kuikuro ela aparece imediatamente antes da recordação dos antigos chefes (id. ibid.). Levando em conta esta preocupação das duas variantes, somos levados a ver a falta de chefes verdadeiros não apenas como um recurso da retórica autoderrogatória dos anetï, mas também como um testemunho histórico do impacto das mortes pelo contato (violentas ou causadas por doenças).

Na realidade, sabe-se muito pouco sobre o destino destes chefes. Alguns estão ligados a histórias, como Sakuãgu e Kosimo, duas jovens itankgo de Kuapügü que, ainda adolescentes, foram sequestradas pelos kagaiha enquanto iam sozinhas até o rio e nunca mais retornaram (seus parentes pensavam que elas haviam sido roubadas pelo Híper Veado, que faz as pessoas se perderem na mata). Saganaha, que aparece na versão da filha do chefe jagamü, era neto de um grande chefe de Kuapügü, foi sequestrado, teve filhos entre os brancos, retornou e depois se tornou um grande chefe - um épico das narrativas históricas kalapalo (Basso, 1993; 1995: 41-61). Ahua seria irmã do grande chefe Kapita, um dos primeiros chefes da aldeia Kalapalo e cuja história de encontro com um branco (Õdoni) vimos no capítulo 1; Aküana é o chefe da aldeia Kuakutu, cuja narrativa também foi apresentada naquele capítulo. De outros, em compensação, não se sabe quase nada: de Eusagu, diz-se que teria se tornado um grande chefe enquanto ainda era uma criança bem pequena, mas não se sabe onde; Sanguku, que aparece em apenas uma versão, teve uma grande festa exclusivamente para furar sua orelha (tiponhü) - um importante índice de chefia ${ }^{42}$-, mas sua aldeia também é desconhecida. De Kanutagi, Kamankgagü e Akügagi não consegui saber nada, mas alguns

\footnotetext{
${ }^{42}$ Só se faz esse tipo de evento para chefes muito grandes. A maioria dos tiponhü acontece depois de um egitsü, e ter uma festa exclusiva é vista como um "algo a mais".
} 
especulam que devem ter sido chefes em Kuapügü/Kalapalo, já que o discurso trata daqueles que viveram no Buritizal (à exceção de Aküana).

Assim como a variante kuikuro, o discurso kalapalo também é uma "celebração da história" (Franchetto, 1993). A lembrança de chefes e lugares antigos situa os Kalapalo em relação aos demais grupos karib e outros xinguanos, de modo que a história adquire uma importância crucial nos encontros rituais, ocasiões em que a condição para a celebração do pertencimento a um mundo comum - o mundo alto-xinguano - parece inseparável da celebração das diferenças entre os grupos. Mas o discurso também é um lamento por essa história, um lamento por todos os chefes roubados e mortos pelos kagaiha: se eles não tivessem sido raptados e assassinados, talvez ainda houvesse grandes chefes, grandes recepções e o presente, quem sabe, estivesse mais próximo do passado. Estes discursos mostram como lugares, ancestrais e características linguísticas são mobilizados em um magnífico jogo poético de produção de sujeitos coletivos de magnitude variada (o chefe e sua aldeia, os Kalapalo como um povo, os karib), colocados em relação dialógica por meio do aparente monólogo do chefe, um sujeito constantemente feito e desfeito nesse processo.

\subsection{Netos de respeitáveis}

No egitsü, os ex-mensageiros (ngengohupe) são responsáveis por recepcionar os chefes da aldeia que foram convidar, que chegam sempre ao entardecer do penúltimo dia antes do final da festa. Eles são os responsáveis por abrir acampamentos na mata onde os convidados dormirão, e no dia de sua chegada deixam um banco em frente ao acampamento aguardando os chefes. O ugihongo principal vê o iho dos ex-mensageiros e vai até ele, seguindo à frente de seu povo como "sua ponta" (ihotugu) ou "seu nariz" (inatagü). Quando se aproxima, o ex-mensageiro o toma pelo pulso direito e o conduz até o banco para se sentar. As pessoas ficam nas margens do caminho, ocupado apenas pelos chefes. $\mathrm{O}$ ex-mensageiro então agacha, se ajoelha ou se curva diante do chefe dos convidados e, em voz baixa e com os olhos voltados para o chão, o cumprimenta com o hagito itagimbakitoho ("feito para cumprimentar convidados"): 
[Executado por Ageu em 07 de setembro de 2010]

$1 \quad$ Itsanginhü higü

2 Uege kana etimbegatiga

3 Üngele heke üngele akuãpütegohona

$4 \quad$ Ah, muke gele akangabaha igei uãke

5 Ahangahitigi muke geleha igei uãke

6 Ah, utelü tikungu muke geleha igei uãke

7 Ah, üngele heke muke gele akangabaha igei uãke

8 Ah, uahekehetühügü atehe muke gele akangabaha igei uãke

9 Ahangahitigi muke geleha igei uãke

10 Ah, utelü tikungu muke geleha igei uãke

11 Ah, tuãgisütihü muke ata hale igei uãke

12 Ah, igatitsatinhü heke muke ata hale igei uãke

13 Ah, tüngengokugui muke ata hale igei uãke

14 Taheketati muke ata hale igei uãke

15 Ah, ukulimo heke muke gele akangabaha igei uãke

16 Ah, tütehopügüko muke geleha igei uãke

17 Opitsomi muke gele akangabaha igei uãke

18 Itsanginhü higü
Neto de um respeitável

Você que está chegando

Para a homenagem que ele [o dono da festa] faz àquele morto

[sem nenhum elemento lexical]

Para te contar algo no ouvido

$\mathrm{Ah}$, por isso eu fui

Ah, pois por aquele

Ah, fui conduzido pelo pulso

Para te contar algo no ouvido

Ah, por isso eu fui

$\mathrm{Ah}$, aquele que tem muita comida

Ah, aquele que está festejando

Ah, seus mensageiros

Conduziu pelo pulso

Ah, nossos filhos

Ah, aqueles que iriam

Para voltar

Neto de um respeitável 


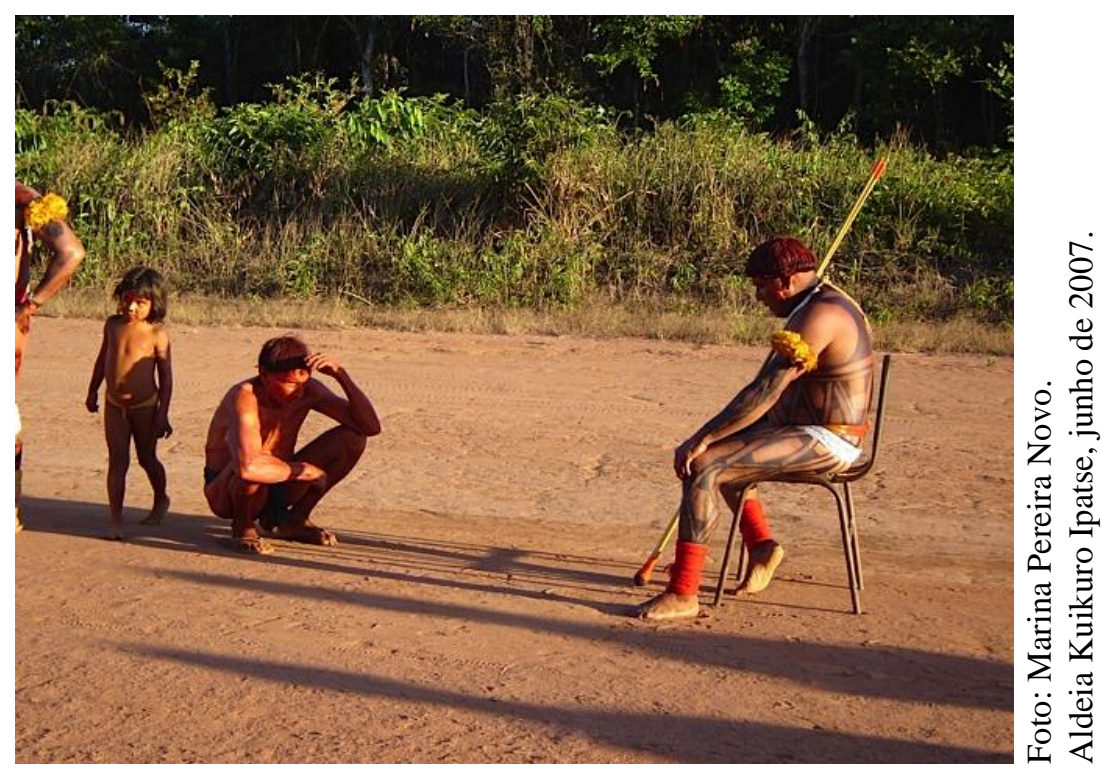

Figura 5.4: ex-mensageiro kuikuro recebendo ugihongo kalapalo para um hagaka.

Itsanginhü higü, "neto de respeitável", é uma forma de dizer anetü ou, como prefere um chefe matipu, de dizer "neto de anetü". Todos a quem perguntei, me disseram que itsanginhü vem de itsangi, respeito, o que permitiria traduzir o termo como "respeitável" (itsangi-nhü, respeito-AINR). Esta noção de respeito pode ser utilizada para se referir a situações sérias ou, em contextos rituais, a coisas perigosas das quais as pessoas devem manter alguma distância. Uma canção que não deve ser ouvida por crianças é titsanginhü ${ }^{43}$ ("que se respeita", em sua forma reflexiva) ou titsangitsoho ("feito para provocar respeito por si"); objetos rituais dos quais crianças não podem se aproximar, como os tronquinhos empregados na construção da sepultura de um chefe (tahiti), são designados da mesma maneira; as flautas kagutu, proibidas aos olhos das mulheres, são titsanginhü para elas; uma canção que não pode ser cantada errada, com perigo de morte para o cantor que o fizer, também é titsanginhü. Tudo o que é "respeitável" em contextos rituais é algo intimamente ligado ao mundo da diferença (como espíritos e afins) e, por isso, representa perigo (de doença, no primeiro caso, e de vergonha, no segundo). Os ugihongo visitantes são marcados, na abertura e no encerramento do discurso de recepção, como respeitáveis porque são diferentes, estrangeiros, e reconhece-se neles algum perigo potencial (não é à toa que são chamados de inimigo), mas que deve ser neutralizado pela refinada etiqueta ritual.

\footnotetext{
${ }^{43}$ T-itsangi-nhü (ANA-respeito-AINR). A maioria dos que me ajudaram nas transcrições dizem que essa seria a forma correta, e que "só para o discurso" usa-se itsanginhü, com o mesmo sentido.
} 
Novamente, a imagem de "conduzir pelo pulso" aparece como o motivo pelo qual o mensageiro foi atrás do outro chefe, "para contar algo no seu ouvido" (ahagahitigi, também traduzido pelos Kalapalo como "contar um segredo").

Terminado o egitsü, o principal dono da festa deve se despedir, primeiro dos convidados e, por último, de seus aliados. Os chefes usam um mesmo discurso para ambos, chamado tagihongo tundoho, "que serve para entregar tagihongo" (nome dado ao alimento oferecido pelos donos da festa aos chefes convidados, em sua despedida). Mulheres da família dos donos carregam grandes cestos ou panelas com peixe para os convidados, mas somente o peixe entregue diretamente aos chefes é tagihongo, um conjunto de peixes moqueados embrulhados em beiju e amarrados com fibra de buriti. O sentido geral deste discurso é basicamente o mesmo do executado na recepção dos convidados:

[Executado por Ageu em 07 de setembro de 2010]

1 Itsanginhü higü

2 Uege kana etimbegatiga

3 Üngele akuãpütegohona uheke

$4 \quad$ Ah muke gele akangaba higei uãke

$5 \quad$ Akatundaje akangaba higei uãke

6 Ah ungengokugu muke gele higei uãke

7 Ahekehenügü muke gele higei uãke

$8 \quad$ Ah uheke muke gele higei uãke

9 Ah etepo muke gele akangaba higei uãke

10 Ah ukanügüko atehe muke gele akangaba higei uãke

11 Ah ungengokugu muke gele higei uãke

12 Akatunda higei uãke

13 Ünago muke gele higei uãke

14 Ahekehenügü muke gele higei uãke

15 Ah uheke muke gele higei uãke

16 Angoloa muke gele akangaba higei uãke

17 Ah üngele muke gele higei uãke

18 Akuãpütelü talüa atehe muke gele akangaba higei uãke

19 Akatunda higei uãke
Neto de um respeitável

Você que está chegando

Para a homenagem que faço àquele morto

[sem nenhum elemento lexical]

Atrás de você

Ah, meu mensageiro

Foi conduzido pelo pulso

$\mathrm{Ah}$, por mim

Ah, [porque] em aldeias próximas

Ah, nós ficamos

Ah, meu mensageiro

Atrás de você

Aqueles

Foram conduzidos pelo pulso

Ah, por mim

[Para que] de verdade

$\mathrm{Ah}$, aquele

Você ouvisse a homenagem àquele morto

Atrás de você 
20 Ungengokugu muke gele higei uãke

21 Ahekehenügü muke gele higei uãke

22 Ah uheke muke gele uãke

23 Itsanginhü higü
Meu mensageiro

Foi conduzido pelo pulso

Ah, por mim

Neto de um respeitável

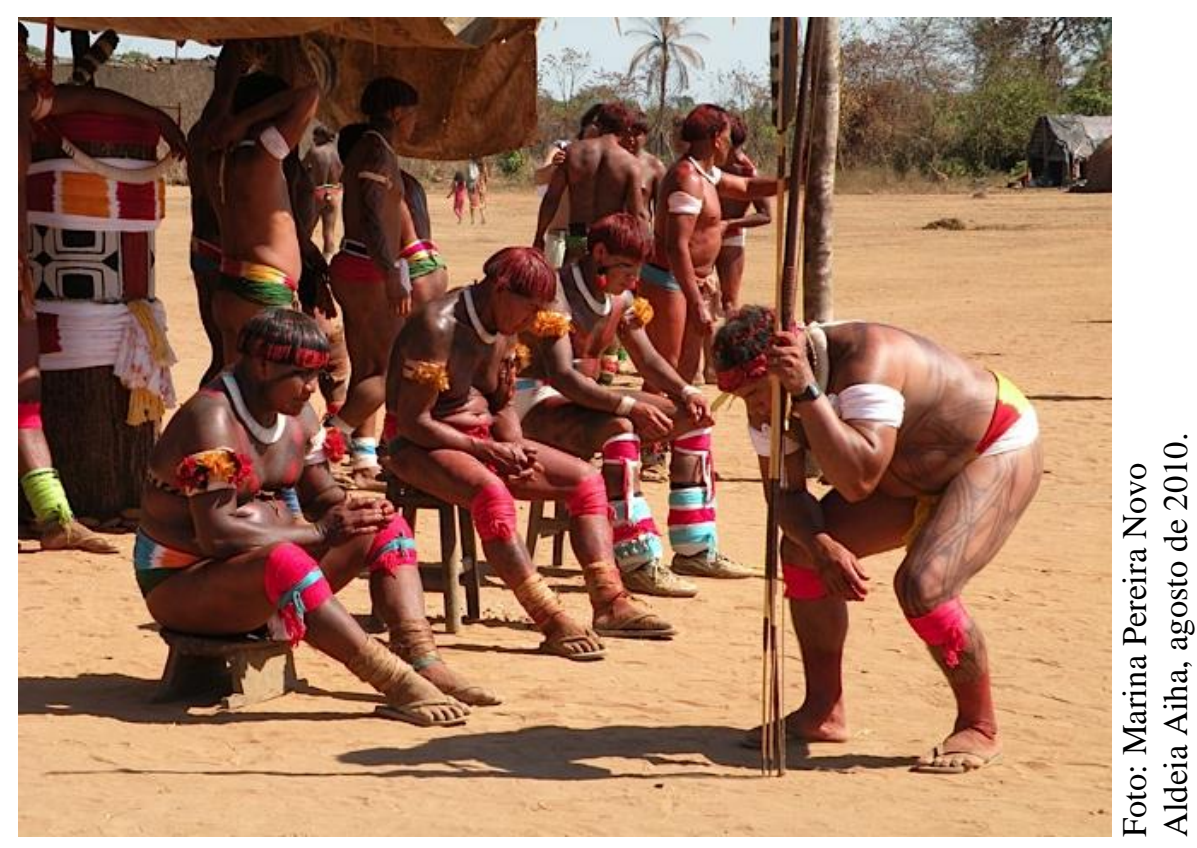

Figura 5.5: um dos donos do egitsü se despedindo dos chefes aliados.

Em todos os discursos, as mesmas imagens se repetem: "ir no caminho", "conduzir pelo pulso", "chegar" - as principais imagens mentais mobilizadas são de movimento. As imagens novas que aqui aparecem referem-se à proximidade das aldeias e ao "ouvir de verdade" a homenagem. Segundo jovens que me ajudaram na tradução, as pessoas que não são convidadas para uma festa ficam "ouvindo" de longe, com inveja e tristes e, por isso, os que moram em aldeias próximas devem ser convidados. Isso provavelmente fazia mais sentido quando nem todas as aldeias eram convidadas, mas apenas aquelas mais próximas de fato.

É digno de nota que em nenhum momento fale-se da luta, enquanto ela é claramente o momento mais esperado do egitsü. Mesmo que o foco do ritual seja a tensão da inimizade ritual, as falas dos chefes estão repletas de cortesias, como se tentassem tornar uma relação potencialmente tensa em uma relação pacífica. Como Basso (2009) mostra, o uso de técnicas autoderrogatórias e de sentido figurado não são exclusivas do anetü itaginhu, mas também 
estão presentes no dia a dia, nas falas entre afins. Discutindo o que chama de affinal civility (Basso, 1975), Basso argumenta que estas estratégias discursivas são comuns em situações nas quais pessoas consideradas diferentes e que se devem respeito precisam interagir. Olhando por este ângulo, as relações rituais entre os chefes no egitsü se aproximam do campo da afinidade - mas da afinidade sem afins, a afinidade potencial (Viveiros de Castro, 2002a).

\subsection{Breve excurso comparativo: de respeitáveis a irmãos}

Tendo abordado o conjunto de discursos do egitsü, vale fazer um sobrevôo sobre os discursos próprios a outro grande ritual regional: a festa de trocas $\left(u l u k i^{44}\right)$. Ela acontece entre os meses de dezembro e fevereiro, geralmente envolve apenas dois povos, e dura três dias, durante os quais as pessoas negociam objetos e fazem festas ligadas ao mundo aquático (ndühe e kagutu). Desde Turner (1995 [1969]), reconhece-se que um ritual é sempre parte de um sistema de rituais, cada qual responsável por efetuar diferentes leituras da vida social. No Alto Xingu isso é bem saliente, e algumas peculiaridades dos rituais são transpostas para o sistema de discursos.

\section{Uluki itagimbakitoho}

[Executado por Ageu em 04 de setembro de 2010]

[O chefe vai à frente de seu povo, entrando na aldeia anfitriã, dizendo em voz alta]

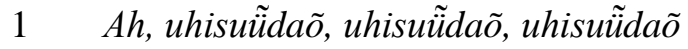

2 Ah, uge muke akangaba egei muke

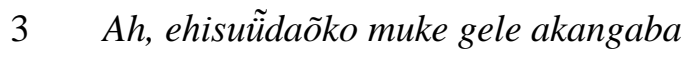
higei uãke

$4 \quad$ Atokondu inkgatitanügü muke gele akangaba higei uheke

$5 \quad$ Ünago nigihukipügüna muke gele uheke
Ah, meus irmãos, meus irmãos, meus irmãos

Ah, eu

Ah, trago um grupo de amigos formado por seus irmãos

Para o lugar que foi aberto por aqueles

\footnotetext{
44 Palavra com possível origem no arawak ulutsi, “andorinha”. Talvez haja alguma relação entre os deslocamentos dos grupos para os rituais de troca no verão e andorinhas que voam em bando na mesma época.
} 
6 Ehisuãdaõko muke gele

$7 \quad$ Atokondu inkgatitanügü muke gele igei uheke

$8 \quad$ Ah, ünago muke gele akangaba higei

9 Apüngeke muke gele akangaba higei

10 Ehisuũdaõko muke gele higei uãke

11 Atokondu inkgatitanügü muke gele higei uãke

12 Ah, uheke muke gele higei uãke

13 Ah, kutaũpüaõko muke ata hale igei uãke

14 Etijipügüko etinhahikitsügü muke ata hale igei uãke

15 Einkgatilü heke muke ata hale igei uãke

16 Ah, isagingoila muke gele akangaba higei uãke

17 Ehisuũ̃daõko muke gele higei uãke

18 Atokondu inkgatitanügü muke gele higei uheke

19 Ünago muke gele akangaba higei uãke

20 Apüngeke muke gele akangaba higei uãke\}

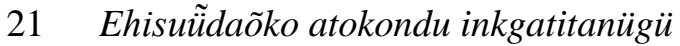
muke gele higei uheke

22 Kutaũpüaõko muke ata hale igei uãke

23 Etijipügüko muke ata hale igei uãke

24 Etinhahikitsügü inkgatilü heke muke ata hale igei uãke
Formado por seus irmãos

Um grupo de amigos eu trago

$\mathrm{Ah}$, na falta daqueles

Eu trago um grupo de amigos, formado por seus irmãos

Mas nossos avós

Quando seus filhos já tinham força nas mãos

Traziam

Ah, não é igual

Eu trago um grupo de amigos, formado por seus irmãos

$\mathrm{Na}$ falta daqueles

Eu trago um grupo de amigos, formado por seus irmãos

Mas nossos avós

Seus filhos

Traziam, quando eles já tinham força nas mãos

Este discurso é feito pelo chefe dos visitantes enquanto ele e seu grupo entram na aldeia e se dirigem para o centro, onde serão formalmente recebidos. Antes de mais nada, o uluki dispensa o envio de mensageiros e não é realizado a convite dos anfitriões. Hoje ele é combinado pelo rádio, e espera-se que a iniciativa de ir a outra aldeia seja do grupo visitante. Todo uluki demanda uma visita de retribuição, então as pessoas sempre esperam visitantes em potencial a cada ano, dependendo de quem visitaram no ano anterior. Ele não é apenas um contexto para se fazer trocas, mas o próprio ritual funciona como uma dádiva, que precisa 
sempre ser retribuída ${ }^{45}$. Diferentemente dos outros rituais, ele é o único realizado apenas na estação chuvosa (preferencialmente entre dezembro e fevereiro, quando as chuvas estão mais fortes).

A tônica é bastante diferente do egitsü, em certos aspectos, e semelhante em outros. Primeiro, a fala é dirigida aos chefes anfitriões, e quando o chefe começa dizendo "ah, meus irmãos, meus irmãos, meus irmãos" (linha 1) ele se coloca em uma relação de parentesco simétrica com os chefes de outra aldeia. Em outras passagens, ele se refere a seu pessoal como "irmãos" dos anfitriões (linhas 3, 6, 10, 17 e 21). Logo a partir da linha 2, é enunciada uma ideia que se repetirá no decorrer da fala, a de que o chefe visitante traz "um grupo de amigos". Estamos longe das referências ao respeito e à inimizade simbólica entre os chefes no egitsü, assim como da consanguinidade assimétrica entre donos da festa e convidados expressa nos discursos de recepção de mensageiros (nos quais os convidados tratam os anfitriões como "pais/donos" ou "irmãos mais velhos"). Tanto a consanguinidade assimétrica quanto a afinidade potencial parecem estar de fora aqui.

Se no etinhü itagimbakitoho o chefe lamenta que ele e seu povo não vivam em um lugar aberto por seus antepassados, neste discurso ele enaltece o povo que visita, dizendo que leva um grupo de amigos "para o lugar que foi aberto por aqueles" (i.e., chefes do passado; linha 7). Mas o que não muda é a autodiminuição do chefe em sua fala, como nas linhas 8-9 e 19-20, nas quais ele se coloca como apenas uma versão imperfeita daqueles que deveriam conduzir seu povo. Nos blocos formados pelas linhas 13-15 e 22-24 vemos novamente o uso do contrastivo hale para falar do passado, acompanhado de uma hipérbole: os chefes eram verdadeiros, e seus filhos que eles traziam "tinham força nas mãos" - eram grandes lutadores. Pelo uso de sagingoila ("não se parece") na linha 16, cria-se também a ideia de que o grupo de amigos atual não é, como os antigos, um grupo de grandes lutadores.

O chefe da aldeia anfitriã vem então, sentar e recepcionar o chefe visitante:

[Chefe anfitrião agachado, olhando para o chão, em voz baixa]

\footnotetext{
${ }^{45}$ No $u l u k i$, a principal festa é o ndühe, que é de dois tipos: um "de peixes" e um "de cobras". Se em uma festa for feito o ndühe de peixes, na festa de retribuição, quando ocorrer, deverá ser feito um ndühe de cobras, e assim por diante.
} 
1 Tongisa, uege kana etibegatiga ünago nigihukipügüna

2 Ah, muke ata hale igei uãke

3 Ünago muke ata hale igei uãke

4 Tongisa toho mukata hale igei uãke

$5 \quad$ Ataginhombalü heke igei uãk

6 Ah, isagingoila muke gele akangaba higei uãke

$7 \quad$ Egea muke gele higei uãke

$8 \quad$ Ünago muke ata hale igei uãke

9 Ataginhombalü heke igei uãke

10 Ah, tongisa toho muke ata hale igei uãke
Chefe, você que chega no lugar aberto por aqueles

\} Mas aqueles

Que são chamados de tongisa

Conversariam com você

Ah, não é igual

Deste jeito

Aqueles

Conversariam com você

Ah, mas os que são chamados de tongisa

Tongisa é um sinônimo de anetü, e só é usado no uluki itagimbakitoho. O chefe anfitrião honra o chefe visitante chamando-o de tongisa, ao mesmo tempo em que nega ser um. Registrei uma versão matipu desse discurso que também usa tongisa e, segundo o chefe daquele povo, diferentemente deles e dos Kalapalo, os Kuikuro diriam anetü em suas execuções. Ainda segundo o chefe matipu, anetü é uma palavra que se usa para falar dos chefes "à toa", enquanto itsanginhü higü e tongisa são as formas respeitosas (é como se, para os Kalapalo e Matipu, anetü fosse apenas um termo de referência, e os outros fossem vocativos). Enquanto no egitsü os chefes se tratam como "respeitáveis" e inimigos rituais (ou seja, afins potenciais), no uluki eles se tratam como irmãos ${ }^{46}$.

\subsection{O Gavião e a Onça: quando o chefe precisa ficar invisível}

Até agora vimos o anetü itaginhu tal como executado na presença de estrangeiros (os itagimbakitoho, "feito para cumprimentar"), mas vamos passar aos discursos feitos por chefes para seus coaldeões. Neste conjunto, está o que Franchetto (1986: 378) chama de oratória

\footnotetext{
${ }^{46}$ Haveria ainda uma terceira forma de ler as relações regionais, pelo viés do hagaka. Não há espaço para isso, mas vale notar que, na abertura da versão matipu, o coordenador dos convidados diz: "Sim, eu trago nossas irmãs atrás de seu polvilho". Se o egitsü trata da afinidade potencial desvinculando-a da troca de mulheres, o hagaka o faz levando em conta a tensão entre primos cruzados ligada ao sistema de aliança. Já a versão kalapalo é diferente, e o coordenador diz a quem o recebe: "Sim, eu chego para a queima do arco daquele que morreu".
} 
política (que os Kalapalo chamam de akitsene $e^{47}$ ), a fala pública não cerimonial, ligada ao jogo político da aldeia, que pode ser feita por chefes e homens mais velhos:

Saber falar e se expor aos ouvidos e comentários da aldeia são disposições que caracterizam certos indivíduos e constituem fina estratégia pela qual se consolida força política, procura-se influenciar, mudar os rumos de uma determinada conjuntura, defender-se de acusações. (id. ibid.)

Esse tipo de oratória lida com acontecimentos na vida da aldeia e, por isso, o falante “constrói seu discurso se valendo de uma relativa criatividade a serviço de seus propósitos e de um contexto particular" (id. ibid.). Como consequência, "a língua dessa oratória se diferencia muito menos do registro cotidiano do que a língua cerimonial” (ibid: 382), e a menor ritualização da oratória ficaria evidenciada pelo alongamento dos versos e pela redução dos paralelismos e da repetição.

Ainda no grupo de falas para coaldeões, ao menos entre os Kalapalo, há dois discursos que se enquadram no subgênero da oratória política, mas são mais formalizados do que os analisados por Franchetto (1986), e sua execução é restrita a grandes chefes. Seu espaço de execução e sua audiência são os mesmos - o chefe fala para seu povo a partir do centro da aldeia -, mas seu conteúdo é fixo e sua forma constante, aproximando-os mais dos itagimbakitoho que da oratória pessoal. É destes dois discursos que trato nesta parte do capítulo.

Hoje, o único anetü que conhece esses discursos é Ageu. Ele os aprendeu com seu pai, mas nunca chegou a executá-los em público ${ }^{48}$. De fato, pelo que os Kalapalo dizem, há décadas esses discursos têm sido executados por cada vez menos chefes, e parecem estar desaparecendo em todas as aldeias. Em Aiha, o último chefe que o fazia parou em meados dos anos 1980, quando já estava muito velho; entre os Matipu, como me contou o chefe da aldeia Küngahünga, eles não são ouvidos desde meados dos anos 70. Ainda segundo este chefe, hoje em dia não se discursa porque as pessoas não se interessam mais pelo que os chefes têm a

\footnotetext{
${ }^{47}$ De fato todos os tipos de discursos são akitsene, mas, quando usam esse termo, os Kalapalo geralmente se referem àqueles feitos para a aldeia.

${ }^{48}$ É digno de nota que este homem nunca executou estes discursos em público, mas pôde recitá-los com uma incrível maestria quando seu sobrinho pediu a ele que o ensinasse (ocasião na qual pedi autorização para registrar o discurso - para mim e para o aprendiz).
} 
dizer: enquanto suas falas são sobre práticas e valores tradicionais, as pessoas têm se interessado cada vez mais pelos costumes dos brancos.

Entre os Kalapalo, o fim dos discursos parece ligado ao deslocamento forçado para Aiha após a criação do Parque (conforme descrito no capítulo 1). Ageu conta que ele cresceu ouvindo chefes discursarem em Nhagü Hatoho, aldeia onde os Kalapalo viviam na época da criação do PIX. Um destes chefes era seu próprio pai, que nunca mais discursou desde a mudança para Aiha. Ele dizia que estes discursos só devem ser feitos onde estão enterrados os ancestrais de um chefe, "no local onde seus avós discursavam, onde seus avós orientavam seu povo $^{49}$ ", e, como Aiha era um território kamayurá, não haveria sentido discursar ali. Nos passos de seu pai, Ageu também optou por nunca discursar em Aiha, mas enfatiza que se ainda vivessem na região de sua antiga aldeia, ou eventualmente voltassem para lá, ele discursaria.

Esses discursos são associados a dois animais definidos como seus donos (oto), uma espécie de pequeno gavião (ugonhi ou kakahuẽgü) e a onça ${ }^{50}$ (ekege). Eles formam um conjunto ordenado (tinapisinhü), no qual o discurso do gavião ocupa a posição de "primeiro" (ihotugu; lit. ponta, proa, frente, bico) e o discurso da onça de "segundo" ou "seu outro igual" (isotohongo).

\subsubsection{Ugonhi akitsu: o Discurso do Gavião}

O Discurso do Gavião deve ser feito ainda de madrugada, antes do sol começar a se levantar. É o horário em que o pássaro ugonhi acorda e começa a cantar - quer dizer, discursar, pois aquilo que os humanos percebem como o canto de um pássaro é, do ponto de vista das aves, a fala que o gavião faz para despertar e orientar seu povo. Como diz Ageu, "ele sempre discursa, pois ele é chefe" (sakitsunalü, anetü helei).

O chefe deve discursar no centro da aldeia, de pé e com o corpo virado para leste (de frente para o nascente). Ele não precisa usar qualquer enfeite, mas pode portar, se quiser, seu

\footnotetext{
${ }^{49} \mathrm{Na}$ viagem a uma região de antigas aldeias kalapalo, Ageu disse: "apitsiko akitsundahügü higei, apitsiko andagü apetatühü higei" ("aqui é onde meus avós discursavam, aqui é onde meus avós orientavam seu povo").

${ }^{50}$ Segundo a mulher chefe mais importante de Aiha, este discurso não é de "qualquer onça", mas de Enitsuẽgü, o pai dos gêmeos (o que, contudo, não foi confirmado por Ageu).
} 
akitsoho (o conjunto de arco e flecha portado por chefes quando aparecem em público nos rituais e quando discursam). Diferentemente dos discursos que os chefes fazem uns para os outros nos encontros rituais, em voz baixa, este deve ser feito em voz alta, para ser ouvido por todos e acordar toda a aldeia. Antes de começar o discurso, Ageu deu uma breve explicação:

$1 \quad$ Tsakeha

2 Andeha ankgilü kupehe, kukakitsu ankgilü künga oto kaenga

3 Künga oto beja, ünagohungu, üngelehungu inha ankgilü kupehe

$4 \quad$ Ankgilüha, ukakitsu ankgilü

5 Egehungu tsale aküngingohüngü bale egei

$6 \quad$ Kakitsüi opisale opisale, la kukita, ipü

$7 \quad$ Kukita tsüha

$8 \quad$ Kandagü apeta hegei kupehe
Ouça

Nós passamos, passamos nosso discurso para os pais dos rapazes

Para os pais dos rapazes mesmo, como aqueles, como aquele, para eles nós passamos

Passamos, passamos nosso discurso

É assim, não é muito

Nosso discurso se repete, se repete, assim nós dizemos, filho ${ }^{51}$

Nós dizemos assim

Nós estamos orientando nosso povo

É interessante o uso de ankgilü ("passar") entre as linhas 2 e 4, pois este verbo também é usado para se referir à transferência de um objeto para um novo dono, ao ato de mudar algo de lugar ou passar algo de um recipiente a outro. Na linha 8 , o chefe chama sua audiência de kandagü ${ }^{52}$, "nosso pessoal" ou "nosso povo". Andagü é a forma possuída de anda, palavra de difícil tradução e que não parece ser aplicada fora do contexto da chefia. Ela não tem plural e se refere, por definição, a um conjunto de pessoas. Ela também só aparece sob sua forma possuída, precedida pelo nome de alguém e seguida do sufixo - gü (X andagü, onde $\mathrm{X}$ é sempre alguém considerado chefe). A expressão indica, portanto, uma relação assimétrica entre uma pessoa nomeada (individualizada) e um coletivo indiferenciado - entre alguém que possui palavras para orientar e um povo que precisa ser ensinado. Traduzi apeta (linha 8) como "orientando" porque a raiz ape significa literalmente "dar direção" (a algo ou alguém). Por exemplo, se vou disparar uma flecha e alguém mexe nela para que ela vá para outro lugar, posso dizer que "uhügi apelü iheke", "ele desviou/orientou minha flecha". Se

\footnotetext{
${ }^{51}$ Enquanto eu gravava, o narrador ensinava seu sobrinho uterino, por isso o vocativo ipü.

${ }^{52} \mathrm{~K}$-anda-gü (12-pessoal/seguidores-REL).
} 
dizemos "vá para a direita", "vá para a esquerda", ou se apontamos o arpão para um peixe, tudo isto é "orientar" (apelü), "dar direção" a algo ou alguém.

O discurso começa:

\section{Ugonhi akitsu ${ }^{53}$ (Discurso do Gavião ugonhi)}

[Em voz alta, para ser ouvido por toda a aldeia]

1 Kamaĩ, Kamaĩ, Kamaĩ, Kamaĩ, Kamaĩ, Kamaĩ

2 Ah, luale muke ata itsange

3 Ah, etijipügüha gitse itakeingakeha gitse

4 Ah, kutaũpüaõ muke geleha gitse, ah, uitunguki muke geleha gitse

$5 \quad$ Etijipügüha gitse itakeingakeha gitse

6 Inke ande efisuündaõ itsa

7 Ah, itsasüfa engifisatanümingo

8 Ah, kingakefa gitse etijipügü hekeha gitse

$9 \quad$ Ah, muke geleha gitse

10 Ah, igehunguki muke geleha gitse

11 Ah, kutengatanini muke geleha gitse

12 Ah, isekalu tohoila muke geleha gitse

13 Ah, itseke tologu heke muke geleha gitse

14 Ah, kutekaginetatanini muke geleha gitse

15 Ah, muke geleha gitse

16 Ah, itseke tologu heke muke geleha gitse

17 Ah, kutekaginetatanini muke geleha gitse
Meu irmão, meu irmão, meu irmão, meu irmão, meu irmão, meu irmão

Por favor, é assim que deve ser

Tirem seus filhos de suas redes

Do sono de nossos avós

Tirem seus filhos de suas redes

Vejam, aqui estão seus irmãos

Eles mexerão em seus trabalhos

Diga a seus filhos

[sem nenhum elemento lexical]

Desta maneira

Nós vamos indo

Sem fazer barulho

O pássaro dos espíritos

Está nos assustando

[sem nenhum elemento lexical]

O pássaro dos espíritos

Está nos assustando

O chefe se refere à sua audiência como kamaĩ (linha 1). Quando transcrevi e traduzi esse discurso, nenhum de meus interlocutores conhecia essa palavra e até achavam que pudesse ser arawak ou tupi ${ }^{54}$. De acordo com o dono dos discursos, ela significa "meu irmão"

\footnotetext{
${ }^{53}$ Executado por Ageu em 19 de agosto de 2010.

${ }^{54}$ Uma mulher que entende Yawalapíti e um pouco de Mehinaku (além de karib) disse que nunca ouviu esta palavra em nenhuma dessas duas línguas. Sobre seu possível parentesco com o tupi, não tenho nenhuma informação, a não ser a de um rapaz - monolíngue - que disse que "parece kamayurá".
} 
e é "língua dos antigos", ngiholo akisü. Segundo o chefe matipu, que também abre sua versão com uma linha idêntica, ela é um sinônimo para anetü. O orador se dirige a seus semelhantes, outros chefes, a quem pede que acordem seus filhos. De acordo com a interpretação do chefe matipu, os "filhos" de que o discurso fala são filhos de chefes, jovens em preparação para se tornarem mestres da luta (kindoto ou ojotse) e futuros anteã̃. Antigamente, os campeões eram acordados muito cedo e deveriam passar horas sentados em suas redes, em silêncio, pensando na luta, em seu comportamento e ouvindo orientações de seu pai. Ainda de acordo com o chefe matipu, cuja fala transcrevo abaixo, isso era para que estes campeões pudessem se tornar mensageiros (ngengoku) de outros chefes quando houvesse rituais:

[Fala do chefe matipu Jamatua]

Ojotse helei inhukugu kindoto beha

Üle atehe itsaenga eteta

Itaginhunda, egea ta tohoi iheke

Kindoto helei egea ta tohoi iheke

Anetü ngengoku helei

Eteta hegei egitsote - küjüou! - atsakuta leha
Os filhos deles são campeões, grandes mestres da luta

Por isso é sobre eles que ele discursa

Quando ele [o chefe] está falando, é isso que ele está dizendo

Eles são mestres da luta, por isso ele está falando assim

Eles são mensageiros dos chefes

Se houver um egitsü eles vão - [interjeição] - , eles correm

Nas passagens das linhas 11 e 12 o chefe toca no tema da falta de "barulho" (festas e chefes que a patrocinem) em sua aldeia, que já vimos aparecer no discurso de recepção de mensageiros. "O pássaro dos espíritos" de que se fala entre as linhas 13 e 17 é a galinha e os espíritos são, de acordo com o narrador, os brancos (assim como na passagem final do etinhü itagimbakitoho). Esta passagem também me parece ligada à ausência de "barulho", à falta de rituais. Em época de festa, desde muito antes do sol nascer, é comum os homens darem longos gritos agudos logo ao acordar, que são respondidos por outros em suas próprias casas. $\mathrm{O}$ objetivo disso é alegrar-se, alegrar os outros e fazer toda a aldeia despertar com alegria. A imagem que o chefe passa é de que, infelizmente, seu povo não desperta mais com gritos de alegria, mas acorda assustado com o canto do "pássaro dos espíritos". 
A passagem a seguir traz um termo fundamental para a descrição da chefia kalapalo, já discutido no capítulo 2 - akihekugene, ou "prática das palavras verdadeiras/boas":

\begin{tabular}{|c|c|c|}
\hline 18 & Ah, kutaũpüaõko muke ata hale igei uãke & Nossos avós \\
\hline 19 & $\begin{array}{l}\text { Akihekugeneki higei uãke, } \\
\text { etijipügüko muke ata hale igei uãke, } \\
\text { ifijü heke muke ata hale igei uãke }\end{array}$ & $\begin{array}{l}\text { Com a prática das palavras verdadeiras, } \\
\text { em seus filhos, } \\
\text { eles mexeram }\end{array}$ \\
\hline 20 & $\begin{array}{l}\text { Ah, üngelepe entanügü muke gele higei } \\
\text { uãke }\end{array}$ & Aqueles que já morreram vinham \\
\hline 21 & Akihekugeneki higei uãke & Com a prática das palavras verdadeiras \\
\hline 22 & Ah, tifisatühügü muke gele higei uãke & ora fazer aguilo gue lhes foi ensinado \\
\hline 23 & Ah, tüilüinha muke gele higei uãke & Para razer aquiro que ines lor ensinado \\
\hline 24 & Ah, tüadagü muke gele higei uãke & Para seu povo \\
\hline 25 & Ah, upetegijüinha muke gele higei uãke & Orientar \\
\hline 26 & Akihekugeneki higei uãke & Com a prática das palavras verdadeiras \\
\hline 27 & $\begin{array}{l}\text { Ah, tifisatühügü tüilüinha muke gele higei } \\
\text { uãke }\end{array}$ & Para fazer o que lhes foi ensinado \\
\hline 28 & Ah, kutaũpüaõko muke ata hale igei uãke & Nossos avós \\
\hline 29 & Akihekugeneki higei uãke & Com a prática das palavras verdadeiras \\
\hline 30 & $\begin{array}{l}\text { Tetijipügüko hijü heke muke ata hale igei } \\
\text { uãke }\end{array}$ & Mexeram em seus filhos \\
\hline
\end{tabular}

As linhas deste trecho terminam com $u \tilde{a} k e$, que já vimos ser uma partícula usada em falar sobre o passado e indicam que o falante tem autoridade sobre o que diz, seja por ter conhecimento direto ou, como é o caso aqui, ter recebido a informação de pessoas com autoridade para transmiti-la - isto é, os chefes antes dele. Desta forma, o orador acopla em sua fala toda a cadeia de chefes pela qual o conhecimento da akitsene foi transmitido até ele. $\mathrm{O}$ trecho é justamente sobre a prática dos discursos pelos chefes do passado, chamados de "nossos avós" (linhas 18 e 28) ou pelo pronome anafórico üngelepe $e^{55}$ (linha 20), que traduzo como “os que já morreram”.

Akihekugene, como já foi discutido no capítulo 2, é a "prática das palavras verdadeiras", que, nas palavras de Franchetto (1986: 381), é "uma fala 'boa', 'verdadeira', uma espécie de anti-fofoca que tenta suturar as fissuras do tecido social da aldeia". Os chefes

\footnotetext{
${ }^{55}$ Üngele-pe (ele/aquele-ex).
} 
do passado são ditos terem feito o que lhes foi ensinado, "mexido" em seus filhos com a fala verdadeira. "Mexer" é um eufemismo para trabalhar ou fazer (muito comum nas conversas entre afins ${ }^{56}$ ), e a relação entre pais e filhos é de fato concebida como uma relação de fabricação na qual o filho é o resultado de esforço intencional e contínuo do pai (Viveiros de Castro, 1977). Mas esta não é apenas uma descrição do passado, e sim um recurso complexo pelo qual o passado serve de exemplo, ao mesmo tempo em que contrasta com o presente como o uso do contrastivo hale nas linhas 18, 19, 28 e 30 deixa claro. O chefe constrói uma oposição entre o passado e o presente na qual este não é mais do que uma forma empobrecida de um antigo tempo idealizado como grandioso: havia chefes que, com sua fala boa, “mexeram" em seus filhos, mas hoje não mais. Ora, ao discursar, o chefe está justamente "trabalhando suas crianças", mas ele deliberadamente tenta se anular e inferiorizar sua fala, como nos discursos feitos para estrangeiros.

$\begin{array}{ll}31 & \text { Ah, luale muke ataitsüha } \\ 32 & \begin{array}{l}\text { Ah, etijipügü̈ko tehugu igakanügü muke } \\ \text { ataitsüe kangamuke hekeni muke }\end{array} \\ 33 & \text { Ah, luale muke ataitsüha } \\ 34 & \begin{array}{l}\text { Ah, etijipügügüko tehugu igakanügü } \\ \text { muka tsitsü ehekeni }\end{array} \\ 35 & \text { Ah, ukugepeki manga ige uãke } \\ 36 & \text { Angaüpüaõko muke gele igei uãke } \\ 37 & \text { Etuatanügü muke gele igei uãke } \\ 38 & \text { Ah, ukugepeki higei uãke } \\ 40 & \text { Angaüpüaõko muke gele higei uãke } \\ 41 & \text { Etuatanügü muke gele higei uãke } \\ 42 & \begin{array}{l}\text { Ah, kohinhandu hüngüki, ah, } \\ \text { kuminhangokiha uketuanalü }\end{array}\end{array}$

Por favor, é assim que deve ser

Crianças, guardem comida para a barriga de seus filhos

Por favor

Guardem comida para a barriga de seus filhos

Com aquele que já foi gente

Seus avós

Se exauriam

Com aquele que já foi gente

Seus avós

Se exauriam

Aquele que não é mato, nosso alimento nos exaure

Esta passagem é sobre a importância do cultivo do milho, metaforicamente chamado de "aquele que já foi gente" (ukugepe, linha 35; referência à origem desta planta, resultado da transformação de uma pessoa em milho no tempo mítico) e "aquele que não é mato" (kohinhanduhüngü, linha 42). O milho é colhido na estação das chuvas, período em que não

\footnotetext{
${ }^{56}$ Por exemplo, um genro não diz que vai "trabalhar para seu sogro", mas que vai "mexer nas coisas de seu sogro".
} 
se colhe mandioca. Nem sempre os Kalapalo conseguiam estocar polvilho para as chuvas como fazem agora e, por isso, as roças de milho tinham uma importância muito grande. Hoje a situação é bastante diferente, pois com a introdução de sacaria se tornou possível armazenar polvilho em grande quantidade e quase ninguém planta milho em Aiha. Quando alguém o faz, é em pequena quantidade e para ter uma alimentação mais variada.

A parte final do Discurso do Gavião é sobre o cultivo de outra planta central da dieta xinguana - a mandioca - e os perigos da feitiçaria:

\begin{tabular}{|c|c|}
\hline 43 & Ahütü muke ataitsüha \\
\hline 44 & Ah, engihitsügüko ukukijila ehekeni \\
\hline 45 & Ah, ingike mukeniha gitse \\
\hline 46 & $\begin{array}{l}\text { Ah, tekundipüngü hüngü ekutanügü muke } \\
\text { geleha gitse kupeheni muke geleha gitse }\end{array}$ \\
\hline 47 & Ah, muke geleha gitse \\
\hline 48 & $\begin{array}{l}\text { Ah, ige hunguki muke geleha gitse } \\
\text { kutengatanini muke geleha gitse }\end{array}$ \\
\hline 49 & Ah, isekalu tohoila muke geleha gitse \\
\hline 50 & Ah, kutengatanini muke geleha gitse \\
\hline 51 & Ahütü ataitsü \\
\hline 52 & $\begin{array}{l}\text { Ah, engihitsügüko ukukijüla ehekeni, } \\
\text { kangamuke }\end{array}$ \\
\hline 53 & Ingike mukeniha gitse \\
\hline 54 & $\begin{array}{l}\text { Ah, ande tekundipüngü hüngü ekutanügü } \\
\text { kupeheni muke geleha gitse }\end{array}$ \\
\hline
\end{tabular}

\author{
Não se deve \\ Esfregar aquilo que foi mexido \\ Veja \\ Nós não estamos comendo comida ruim \\ [sem nenhum elemento lexical] \\ Assim nós todos vamos indo \\ Sem fazer barulho \\ Nós todos vamos indo \\ Não se deve \\ Esfregar aquilo que foi mexido, crianças \\ Veja
}

Nós não estamos comendo comida ruim

Nas linhas 44 e 52 ukukijila, forma negativa de ukukijü, “esfregar", é uma metáfora para "enfeitiçar". Engihitsügüko significa literalmente "que foi mexido/trabalhado por vocês", e se refere especificamente às folhas de mandioca derrubadas dos pés. Um feitiço sobre estas folhas pode estragar a plantação de mandioca de alguém, e é sobre este perigo que a passagem fala. "Não é um alimento ruim o que estamos comendo" (linhas 46 e 54), diz o discurso, mas fica claro que este é um risco caso se pratique feitiçaria - um risco que a fala do chefe pretende evitar. Há de fato em Aiha, uma ideia de que se há muita feitiçaria em uma aldeia é em parte porque os chefes não estão orientando bem seu pessoal. Idealmente, em uma aldeia onde os chefes são respeitados, as pessoas não procuram fazer mal umas às outras, nem fazer 
feitiços que estraguem uma aldeia toda. Já onde a chefia está enfraquecida, o perigo da feitiçaria aumenta, pois deixadas sem orientação, as pessoas tendem a ficar mais egoístas, enlouquecer e "se esquecer" de seus parentes (o primeiro passo para a produção de um feiticeiro $^{57}$; para uma discussão sobre feitiçaria e "anti-parentesco" entre os Aweti ver Figueiredo, 2010).

A tônica do discurso é um tanto pessimista: as pessoas não acordam mais com alegria, existe o risco de feiticeiros estragarem o trabalho de seus irmãos, não há mais chefes que pratiquem as palavras verdadeiras para "trabalhar seus filhos". Mas, apesar disso, o chefe exorta suas crianças ao trabalho, pede aos pais dos jovens (outros chefes, na interpretação matipu) que orientem seus filhos como os chefes do passado o fizeram, com o uso das palavras verdadeiras, para que eles tenham comida e não façam feitiçaria. Mas nada em sua fala pode caracterizá-la como um discurso autoritário, muito pelo contrário; o chefe pede humildemente, e não entoa uma única linha sem incluir partículas que inferiorizem ele e sua fala.

\subsubsection{Ekege akitsu: o Discurso da Onça}

O Discurso da Onça também deve ser feito no centro e em alto e bom som, mas após o por do sol (o mesmo período das oratórias políticas pessoais). O chefe também deve estar virado para o leste, mas desta vez precisa discursar agachado e olhando para o chão, como se estivesse perante um chefe estrangeiro, em posição de respeito e vergonha. A diferença das posições remete às posturas corporais dos animais donos dos discursos: pela manhã, deve-se dispor o corpo como o do gavião em repouso - em pé sobre um galho de árvore -, e à noite, como o da onça, um quadrupede. Os horários dos discursos também remetem aos períodos de atividade destes animais, sendo o gavião um caçador diurno e a onça um animal de hábitos noturnos.

Esta fala tem uma tônica bastante pessimista. Findo o dia, o chefe fala sobre as dificuldades do presente, a falta de chefes para orientar seu povo e sobre as mortes

\footnotetext{
${ }^{57}$ Segundo os Kalapalo, logo no início de seu treinamento os feiticeiros pingam em seus olhos uma substância amarga, encontrada em um órgão interno do peixe traíra (do gênero Hoplias), que os faz esquecer quem são seus parentes.
} 
provocadas pelos espíritos e pelos brancos. É como se, confrontando com uma situação difícil, o chefe se perguntasse: como é possível seguir em frente? A resposta dada no próprio discurso é uma só: com alegria.

\section{Ekege akitsu $^{58}$ (Discurso da Onça)}

[Em voz alta, para ser ouvido por toda a aldeia]

1 Ah, kangamuke, kangamuke, kangamuke

2 Ah, luale muke ataitsüha gitse

3 Ataipanenatüeha gitse

$4 \quad$ Ah, tü akisü kae manga gitse kutengalüko egea gitse

$5 \quad$ Ah, ukugetihü akisü kae muke ata hale gitse

6 Ah, kutehotanünkgo muke ata hale gitse

7 Ah, muke geleha igia kutengatanini muke geleha gitse

8 Tetihoi muke geleha gitse

9 Ah, kutengatanini muke gele higei

10 Ah, itseke heke muke gele higei, ah, tünotohokoki muke gele ah ukinahanetatanini muke
Ah, crianças, crianças, crianças

Por favor

Festejem

Com a fala de quem nós seguimos assim?

Com a fala de um chefe

Nós seguiríamos

Mas nós seguimos assim mesmo

Sem um chefe

Nós vamos indo

Os espíritos estão nos matando com seus objetos mortais

Enquanto o Discurso do Gavião é aberto com uma exortação aos “irmãos” do chefe, aqui ele é aberto com a palavra "crianças". Se no primeiro o chefe trata seus interlocutores de forma simétrica, aqui ele se dirige a todos de forma assimétrica. "Crianças" é, como tenho dito, a forma mais comum pela qual um chefe se refere a seu povo, para quem ele é como um pai adotivo, que protege, educa e alimenta. Também como já vimos, a posição do chefe como pai adotivo está diretamente ligada à produção do parentesco em uma aldeia, algo evidenciado pelo uso, na linha 5, de um termo interessante para chefe que até hoje só ouvi em discursos rituais, ukugetihü. Os Kalapalo, quando tentam segmentar esta palavra, a dividem em kuge, "gente", e ihü, "corpo", o que permitiria glosar ukugetihü como "corpo das pessoas". Isso evoca as discussões do capítulo 2 sobre o chefe como "tronco-corpo" das pessoas,

\footnotetext{
${ }^{58}$ Executado por Ageu em 19 de agosto de 2010.
} 
fundamentos das relações de parentesco e das ideias de continuidade genealógica e consanguinidade. O mesmo tema aparece na linha $8 \mathrm{com}$ a expressão tetihoi, traduzida como "sem chefe", que talvez seja formada a partir da raiz iho. Mais uma vez, o chefe nega sua condição.

Os "objetos mortais" dos espíritos evocados na linha 10 são feitiços, mas obtive diferentes interpretações deste trecho: segundo um chefe, os espíritos aqui são os brancos, cujas doenças/feitiços acreditava-se que eram transmitidas por seus objetos; já segundo um rapaz que me ajudou na tradução, seriam espíritos "de verdade", inimigos da Onça. O tema do perigo dos brancos também está presente em uma oratória analisada por Franchetto (Franchetto, 1986: 140-148, Anexos), na qual o chefe fala dos brancos como "nossos avós" (outra forma de dizer espíritos), cujas doenças hão de chegar. E, assim como o chefe kalapalo, ele pede que seu povo festeje (id. ibid.). Ageu prossegue:

11 Ah, luale muke ataitsü egekaluko, kangamuke

12 Ataipanenatüe ataitsü hetsange

13 Indegela muke gele akangabaha igei gitse

14 Ah, kutelükohata muke geleha gitse

15 Ah, kutaũpüaõko muke geleha gitse, ah, engikapügütela leha gitse

16 Ah, kutelüko hata muke leha gitse
Por favor, façam barulho, crianças

Festejem mesmo

Não é aqui

Que vamos seguindo

Não é em uma aldeia aberta pelos nossos avós

Que vamos seguindo

Mais uma vez o chefe exorta seu povo a fazer barulho e festejar, pois a condição em que vivem não favorece a alegria - já não vivem mais em uma aldeia aberta por seus avós, mas na aldeia de outros (lembremos do etinhü itagimbakitoho, onde este tema reaparece). É difícil interpretar essa passagem. Como já mencionei, desde que se mudaram para Aiha. os Kalapalo vivem em território kamayurá, ao norte de onde viviam, e até hoje os Kamayurá os provocam dizendo que eles não vivem em uma aldeia onde estão enterrados seus avós (os mais velhos dizem que a hostilidade era muito grande no começo). Se fôssemos interpretar a passagem acima de forma literal, poderíamos ser levados a pensar que ela se refere a essa situação específica, e que teria sido incorporada ao discurso em algum momento nos últimos 50 anos. Mas a situação se complica se lembrarmos que o chefe que ensinou esse discurso a 
seu filho nunca o executou em Aiha, mas apenas na antiga aldeia Kalapalo. Toda aquela região foi densamente ocupada pelos Kalapalo desde, pelo menos, a primeira metade do século XVIII e é considerada sua "terra verdadeira" (ngongo hekugu). Em uma viagem que os Kalapalo fizeram à região durante a execução de um projeto de documentação ${ }^{59}$, Ageu se referiu à região como "onde seus avós discursavam", onde eles "orientavam seu povo". A meu ver, a ideia de que não se vive em um lugar aberto pelos ancestrais é equivalente às afirmações recorrentes de que não há mais chefes: caso o falante afirmasse viver em um território ancestral, isso seria o mesmo que dizer que ele está no lugar dos antigos chefes, o que, pela lógica da fala ritual, deve ser sistematicamente negado.

$\begin{array}{rll}17 & \begin{array}{l}\text { Ah, luale muke ataitsü ataipanenükgo, } \\ \text { kangamuke }\end{array} & \text { Por favor, festejem, crianças } \\ 18 & \begin{array}{l}\text { Sekalu tohoila mukeha kutengataniniha } \\ \text { gitse }\end{array} & \text { Sem fazer barulho nós vamos seguindo } \\ 19 & \begin{array}{l}\text { Tü akisü kaemana gitse kutengalükoha } \\ \text { gitse }\end{array} & \text { Com as palavras de quem nós seguimos? } \\ 20 & \begin{array}{l}\text { Ah, ukugetihü akisü haindipügü kae muke } \\ \text { ata hale gitse }\end{array} & \begin{array}{l}\text { Mas com as palavras de um chefe } \\ \text { envelhecido }\end{array} \\ 21 & \begin{array}{l}\text { Ah, kutehotanünkgo muke ata hale gitse } \\ 22\end{array} & \begin{array}{l}\text { Ah, isekalu tohoila muke geleha gitse } \\ \text { kutengatanini muke geleha gitse }\end{array} \\ 23 & \begin{array}{l}\text { Ah, luale muke ataitsüha gitse } \\ \text { Ataipanenatüe }\end{array} & \text { Ah, por favor barulho nós vamos seguindo } \\ 24 & \text { Festejem }\end{array}$

O discurso se encerra retomando o problema da falta de "barulho" (festas/alegria; linhas 18 e 22) e da falta de um chefe (linhas 19 a 21: “Com as palavras de quem nós seguimos? Mas com as palavras de um chefe envelhecido nós estaríamos indo"). Faz todo o sentido que este discurso seja feito no crepúsculo: não é apenas o fim de mais um dia, mas o crepúsculo de um povo que vive triste, sem um tronco-corpo-esteio com cujas palavras poderiam seguir, fora da terra de seus antepassados e ameaçados pelos objetos mortais dos espíritos (sejam os feitiços dos "espíritos de verdade", sejam as mercadorias dos brancos).

\footnotetext{
${ }^{59}$ A viagem foi uma atividade do Projeto Kalapalo, integrante do Programa de Documentação do Museu do Índio/FUNAI, e um de seus objetivos era registrar os conhecimentos etnohistóricos sobre uma série de sítios importantes.
} 
Diante dessas dificuldades, o chefe conclui com um singelo pedido (linhas 23 e 24): “Ah, por favor/Festejem".

Desde pelo menos a obra de Clastres, a "fala do chefe" é objeto de atenção dos etnólogos preocupados com formas indígenas de chefia. Em Troca e poder, Clastres (2003b [1974]) utiliza um exemplo retirado da etnografia de Quain (Murphy e Quain, 1955), a fala de um chefe Trumai (provavelmente alguém que praticava discursos no estilo alto-xinguano atual) e que era completamente ignorado enquanto falava (ou assim parecia). A questão de Clastres era saber se as palavras dadas pelo chefe eram ou não capazes de alimentar um circuito de dons, o que ele concluiu de forma negativa - o chefe ameríndio dá palavras mas não é ouvido nem respondido, e a doação de palavras "ao vento" seria uma das formas de excluí-lo (ou melhor, excluir o potencial de coerção que ele encarna) dos circuitos de dádivas que costuram a sociedade.

Os alto-xinguanos parecem estar envolvidos em um cabo de guerra, no qual, de um lado, estão eventuais manifestações de poder coercitivo, como as histórias de algumas cisões e acusações de feitiçaria deixam claro; de outro lado, há uma clara necessidade de "caciques grandes", "pessoas bonitas", sem os quais um povo não consegue se relacionar enquanto grupo com outros povos xinguanos nos rituais regionais. $\mathrm{O}$ fundamento dessas relações, tal como discutido até agora, é a simetria tensa entre chefes, que aparecem uns para os outros como predadores/inimigos simbólicos - condição para assumirem a posição de sujeitos.

Isso contrasta com os discursos do Gavião e da Onça, nos quais o chefe precisa estar invisível: ou ele fala antes do sol nascer, enquanto as pessoas ainda estão em suas casas, ou depois do sol se pôr, quando todos já se recolheram. Mas ainda assim ele deve se comportar como um animal predador, o que se evidencia em seu corpo: em pé como o gavião, ou agachado como a onça. Percebe-se que a associação entre chefes e predadores é indispensável mesmo nesses casos: os Kalapalo só aparecem como um coletivo de parentes ocupados com o trabalho, o preparo de seus filhos e o respeito mútuo (evitando a feitiçaria), perante um chefe que discursa como certos animais predadores. Mas essa faceta predadora do chefe só deve ser feita visível para os estrangeiros: quando a posição de chefe se manifesta no grupo local, o 
corpo do chefe-gavião e do chefe-onça precisa ser mantido invisível. Os Kalapalo reconhecem o perigo que esse tipo de pessoa representa, e não querem que sua capacidade predatória se volte para dentro. Este é um risco presente nas relações com os chefes, pessoas que precisam ser deliberadamente "amansadas" para se comportar bem com seu pessoal (Figueiredo, 2010). Não é à toa que dizem que enquanto o gavião discursa, seu primo cruzado (um pássaro semelhante ao bem-te-vi) o questiona em frente à sua casa: "Você diz que cuida de seu pessoal, mas você nos come".

Estes grandes homens personificam o grupo, não como uma entidade dada, pronta, mas como o resultado momentâneo de certas relações: dos chefes atuais com os do passado, dos Kalapalo com seus vizinhos karib, dos alto-xinguanos com os brancos e, nos discursos matinal e vespertino, de um conjunto de coaldeões com seu chefe. É porque não há nada que possa, de antemão, ser chamado de "sociedade", que um movimento de construção da "identidade coletiva" (na falta de termo melhor) é necessário. A poética do anetü itaginhu está voltada para isso, para esta construção. O que chama a atenção é como o chefe pode personificar o grupo em sua voz e, ao mesmo tempo, desaparecer em seu próprio discurso. Clastres talvez estivesse equivocado ao achar que "os ameríndios" não dariam importância ao que o chefe fala (os Kalapalo dão e não é pouca - sem isso eles não existem enquanto grupo nos encontros rituais, e os bons discursos são valorizados). Mas ele parece correto ao dizer que o poder é tornado visível para ser cercado, vigiado, negado, pois se o chefe kalapalo pode personificar o grupo em sua fala, é sob a condição de esvaziar dela sua própria individualidade.

No capítulo seguinte passo a outro elemento central para o desenrolar do egitsü: a troca de dons. Apesar de muitos autores focalizarem a importância da economia ritual na política das aldeias e do lugar diferenciado dos chefes nos sistemas de trocas, pouco foi produzido sobre as relações entre dádiva e chefia. No capítulo 6 discutirei estas relações a partir de três pontos: 1) os "rituais de acumulação" por meio dos quais o alimento para o egitsü é reunido; 2) as trocas obrigatórias de objetos de luxo entre ex-mensageiros e chefes estrangeiros; e 3) a entrada dos brancos e seus recursos nos circuitos de pagamentos dos rituais. 


\title{
Capítulo 6 - Algumas formas xinguanas da dádiva
}

\author{
O problema do Xingu é o feitiço. Os feiticeiros estão \\ matando nossas lideranças para que aconteçam \\ festas e os kagaiha kuẽgül tragam dólares. \\ (fala de um ex-membro do Conselho Local de Saúde)
}

Organizar e patrocinar um egitsü dá muito trabalho a muita gente, e custa caro $^{2}$. A quantidade de comida, objetos de luxo e combustível que precisa ser posta em circulação é exorbitante, e exige um planejamento cuidadoso. Se a pescaria para a festa for feita muito cedo, centenas de peixes podem estragar; se for feita muito tarde e for mal sucedida, pode ser que falte peixe e não haja tempo para organizar outra. Se os donos da festa não estiverem em boas relações com seus cunhados e genros, conseguir peixe com a frequência necessária para pagar pelos trabalhos da comunidade se tornará muito mais difícil. Coordenadores, mensageiros e chefes estrangeiros também precisam ter certas preocupações, pois para eles é indispensável dispor de objetos valiosos. E para completar, há o transporte dos mensageiros e dos convidados, que fica por conta do dono da festa (para o egitsü de 2010, os donos da festa conseguiram mais de 2.000 litros de gasolina e em torno de 1000 litros de diesel: não sobrou nada).

Essa complexa logística envolve, obviamente, a mobilização adequada de relações pessoais, o que a torna tão política quanto qualquer outro aspecto do ritual. Isso fica especialmente claro nas relações com os não índios convidados para assistir às festas, que se tornam objetos de disputa entre os chefes, e fontes de complicações envolvendo mercadorias, dinheiro, prestígio e a "ficção da comunidade" criada para interagir com estes agentes e seus recursos. Neste capítulo, abordo a rede de trocas que compõe o egitsü, focalizando a forma pela qual dádiva e dívida atuam nos processos de coletivização voltados para o ritual.

Todavia, antes é preciso é esclarecer alguns conceitos utilizados ao longo do capítulo, a começar pela noção de "dádiva”. Seguindo as definições de Marx - da mercadoria - e de Mauss - da dádiva -, Gregory (1982) formulou um contraste entre "economias da mercadoria" e "economias do dom" segundo o qual, as primeiras estabeleceriam relações objetivas e quantitativas entre os objetos transacionados, enquanto as segundas estabeleceriam

\footnotetext{
${ }^{1}$ Expressão em karib alto-xinguano para não índios de outros países.

${ }^{2}$ No egitsü de 2011 foram usados cerca de 3000 litros de gasolina, 1000 litros de diesel e 600 rolos de algodão, o que, em cálculos grosseiros, não sai por menos de $\mathrm{R} \$ 15.000$.
} 
relações pessoais e qualitativas entre os sujeitos que trocam (ibid: 41). Como sintetiza Yan (2005: 254) a respeito desse argumento, "the real distinction between gifts and commodities, therefore, lies in the different orders of social relations that are constructed and mediated through the exchange of objects".

Na década de 1980 esta distinção foi objeto de críticas por diversos autores (Appadurai, 1986; Basso, 1993; Damon, 1980; 1982; Morris, 1986; Parry, 1986; Parry e Bloch, 1989), que argumentaram que tal oposição seria demasiadamente marcada pela ideologia moderna e que, na prática, todas as formas de troca teriam ao mesmo tempo "aspectos de dom" e a "aspectos de mercadoria". Appadurai (1986: 13) sugere que deveríamos procurar "the commodity potential of all things rather than searching fruitlessly for the magic distinction between commodities and other sorts of things". Ou como Andrew Strathern e Pamela Stewart (2005: 234) colocam, “(...) if we make an analytical distinction between trade and gift exchange, then we will find both categories at work in empirical cases, and what is of interest is to see how they articulate with, or relate to, each other".

Pode-se dizer que tais autores possuem um enfoque "fenomenológico" do dom, pois parecem enfatizar a capacidade dos objetos apresentarem, em cada relação, características de dons e mercadorias. Carrier (1993), por exemplo, argumenta que além de cada transação acoplar características de um ou de outro tipo, haveria ainda vários casos nos quais mercadorias são transformadas em dádivas, como ocorre com a grande maioria dos presentes ofertados no Ocidente. Strathern (1992) critica tal visão do contraste, argumentando que todos estes autores insistem em pensar dom e mercadoria como aspectos de objetos ou transações específicas, enquanto na realidade eles correspondem a diferentes formas sociais nas quais vigoram concepções distintas acerca das relações entre pessoas e coisas.

O problema, segundo Strathern (ibid), é que nas economias capitalistas, pessoas e coisas são vistas como entidades distintas de saída e, portanto, podem dispor de quaisquer objetos para a troca. Isso produziu interpretações das economias não capitalistas na quais

(...) the principles by which comparability is established between the things themselves invariably remains the analytical focus, whether these things are material or metaphysical in nature, and whether the transactions are balanced or unequal. The procedure incorporates what one could call a barter model of value. (ibid: 169) 
Tais análises situam "social interest in terms of the respective values that persons exchange with one another, measured through the worth of what they transfer, in the same way as bartered items are measured against one another" (ibid: 170). Mesmo no modelo de Gregory (1982), para quem as pessoas medem a si mesmas durante as transações, a análise permaneceria centrada nas ideias de comparabilidade entre unidades pré-existentes (neste caso, pessoas), as mesmas que norteariam a visão sobre as trocas utilitárias. Como diz Strathern (op. cit.: 170), "donors and recipients are regarded as measuring one another, 'bartering' prestige (say), insofar as the transaction rests on establishing equivalences". $\mathrm{O}$ problema de tal perspectiva, diz a autora, é que nas economias do dom, a existência de unidades comparáveis, sejam elas objetos ou pessoas, não é algo dado - separar pessoas e coisas e torná-las comparáveis é, justamente, um dos efeitos da dádiva (ibid: 188).

Em sociedades onde o dom vigora, a investigação do potencial das coisas serem transacionadas "must take into account the equivalences between what we would otherwise separate as persons and things" (ibid: 177). Strathern (2006 [1988]: 267) argumenta que a dádiva está atrelada a uma forma social na qual os objetos assumem a forma de pessoas, isto é, na qual as coisas são vistas como "partes" de pessoas que precisam ser extraídas delas para se tornarem transacionáveis. Em tais regimes, um objeto só se torna transacionável porque pôde ser destacado de alguém (ibid: 270). Mas este procedimento só pode acontecer se o doador tiver um receptor em potencial e possa prever qual será seu ponto de vista sobre ele enquanto doador; ou seja, a separação entre uma pessoa e algo que ela possa transformar em objeto de troca só ocorre se o doador for capaz de antecipar a reação futura do receptor (um contra-dom): "without the recipient, the donor would have no objects at his/her disposal (...). The donor only has objects at his or her disposal because he/she can anticipate the extractive perspective of the recipient" (Strathern, 1992: 178).

Desse ponto de vista, o receptor pode ser visto como a causa das ações do doador, e a troca de dons como um tipo de relação baseada "on the capacity for actors (agents, subjects) to extract or elicit from others items that then become the object of their relationship" (ibid: 177). Toda dádiva é sempre um "teste" de capacidade de elicitação (ibid: 186). Disso resulta que nem os objetos trocados, nem os agentes trocadores, existem enquanto tais antes da relação de troca: é por meio da dádiva que pessoas constituídas por múltiplas relações destacam algo de si para produzir um efeito sobre outrem e se tornam agentes, o que só são capazes de fazer porque cada um projeta uma imagem de sua contra-parte ("one entity is 
elicited by another"; ibid: 178-179). Por isso mesmo, as posições sociais dos trocadores não podem ser dadas de antemão, e posteriormente medidas pela dádiva, como para Gregory, mas devem ser vistas como o resultado das operações envolvidas nas transações.

O que se segue é uma tentativa de aplicar tais considerações sobre a dádiva à organização socioeconômica do egitsü, a fim de extrair suas consequências para a conceituação da chefia: como a circulação de alimentos e riquezas específica dos rituais da nobreza transforma algumas pessoas em chefes?

\subsection{Tipos de troca}

Colares de miçangas, cintos e colares de conchas, panelas, machados, facões, roupas, sabonetes, braçadeiras, brincos, pilhas, penas e objetos feitos com elas - praticamente tudo o que se tem pode ser trocado. As principais exceções são as casas, que não se troca de forma alguma $^{3}$, e objetos ligados a espíritos, como máscaras e instrumentos musicais. Esses objetos são as formas materiais assumidas por espíritos que se tornaram "parentes" de seus donos, seus filhos adotivos. Eles objetivam e permitem reproduzir relações de troca entre humanos (ex-doentes) e espíritos e, por esse motivo, não podem ser convertidos em objetos de troca entre humanos: a passagem de uma máscara por seu dono a um não parente, seria vista pelo espírito como "abandono".

Não consegui que ninguém me desse uma palavra em karib para "presente" (muitos diziam que não havia uma palavra específica, outros que eu poderia dizer simplesmente ngiko, “coisa"). Contudo, eles frequentemente usam o verbo ngikombalü para dizer "presentear", referindo-se à oferta "espontânea" de um objeto a alguém. Mas tal espontaneidade é apenas aparente, ngikombalü traz consigo a ideia de que aquilo que foi dado precisará ser retribuído no futuro. Como estamos alertas desde o Ensaio sobre a Dádiva (Mauss, 2003 [1925]), a espontaneidade do dom não exclui interesses pessoais ou a obrigatoriedade da retribuição, mas pelo contrário, os pressupõem. Quando alguém retribui algo, esse objeto, escolhido pelo doador de acordo com suas possibilidades ou interesses, é chamado de opijü, literalmente

\footnotetext{
${ }^{3}$ Mas podem ser "dadas" quando alguém se muda da aldeia. Um homem que deixou Aiha em 2006, por exemplo, autorizou que outro homem se mudasse para sua antiga casa, e este agora é considerado seu "dono" (oto).
} 
"volta", "retorno" ou "resposta" - "retribuição", se quisermos ficar no vocabulário da dádiva. É importante notar que essa retribuição deve ser demorada. Quando alguém vai a uma festa em outra aldeia, por exemplo, sempre espera receber presente de parentes ou amigos (discutirei em breve a amizade xinguana); estes, por sua vez, esperam receber algo em troca somente quando forem (e se forem) em uma festa na aldeia daqueles que presenteou. Essa necessidade de tempo para a retribuição fica clara quando os Kalapalo presenteiam os brancos: espera-se que os objetos dados como presentes sejam retribuídos no futuro, mas no devido intervalo de tempo - retribuir um presente logo após recebe-lo pode ser ofensivo. A troca de presentes deve parecer espontânea (apesar das retribuições serem sempre esperadas), e para isso o intervalo de retribuição precisa ser longo, caso contrário ela se aproxima de uma forma específica de relação que os Kalapalo traduzem como "venda".

$\mathrm{Na}$ "venda" (akanene; raiz aka) a troca não é espontânea e a retribuição é, na maioria das vezes, estipulada pelo doador. Tal retribuição, ao invés de ser tratada como volta/resposta (opijü), é chamada de "pagamento" (hipügü) e encerra a transação ${ }^{4}$. Esse tipo de relação quase nunca é iniciada pelo "vendedor", mas por alguém que precisa de algo e pede a seu dono que o venda (a não ser no uluki - voltarei a isso em breve). Se um homem precisa, por exemplo, de uma calça jeans para o trabalho na roça e tem um amigo que dispõe de uma, ele pode pedir a ele que a venda; mas é muito improvável que alguém que tenha coisas que deseja vender as ofereça a outras pessoas. Nesse caso, a saída da qual a pessoa dispõe é organizar um uluki.

Há várias atividades que requerem pagamentos (hipügü) sob a forma de objetos valiosos, como o enterro de um nobre, o trabalho dos pajés e o ensino de cantos. Na maioria dos casos, o pagamento não é negociado entre os trocadores, mas é estipulado "tradicionalmente" (sempre se sabe com que tipo de objeto essas pessoas podem ser pagas de forma adequada): paga-se com os objetos da mais alta categoria de valor, como colares de conchas, plumárias, enfeites de garra ou couro de onça. O trabalho das pessoas na construção de uma casa, abertura de uma roça ou realização de rituais também exige hipügü; mas, nesses casos, o pagamento assume a forma de alimentos e é chamado de endu (o que nada mais é do que um tipo de hipügü).

\footnotetext{
${ }^{4}$ Hipügü é a forma como se chamam os pagamentos em dinheiro feitos no comércio.
} 
A principal diferença entre opijü e hipügü parece ser que, no primeiro caso, a retribuição deve parecer espontânea e pode ser feita de acordo com as possibilidades de quem a faz; no segundo, a retribuição é reconhecidamente obrigatória e deve-se constituir de algo previamente combinado ou tradicionalmente esperado. Há também uma diferença quanto à temporalidade das modalidades de retribuição: um opijü deve demorar; um hipügü pode levar algum tempo, mas deve ser dado o quanto antes (o único tipo de hipügü que não admite espera são os pagamentos em comida, feitos sempre no dia do trabalho).

Deixando de lado, por enquanto, os pagamentos rituais, aparentemente as trocas "espontâneas" e as "vendas" ocupam lugares distintos nas relações entre as pessoas em função de diversos fatores. Parentes próximos e afins teoricamente não "trocam", pois os Kalapalo dizem que não há necessidade de retribuir objetos recebidos dessas pessoas. Se alguém quer algo de um parente próximo pode simplesmente pedir e o dono do objeto dificilmente vai negar - mas ambas as partes sabem que nenhuma retribuição específica é devida. É claro que as pessoas elaboram estratégias para negar pedidos, mas isso as deixa com vergonha e é muito raro ver alguém negar qualquer coisa a um parente próximo. Afins raramente pedem objetos uns aos outros por uma questão de respeito. O solicitante teria vergonha de pedir e o solicitado ficaria ofendido porque, também por vergonha, não poderia dizer não ou mesmo negociar. Ainda assim, cunhados costumam ofertar objetos uns aos outros eventualmente, como uma forma de agradar e mostrar respeito. É claro que essa situação não configura "partilha", mas uma situação de "reciprocidade generalizada" (Sahlins, 1972): aquele que deu um objeto hoje, mesmo contra sua vontade, no futuro acabará se vendo na posição de pedir um objeto a outro parente; um cunhado, para o qual não se faz propostas de troca, ainda assim deve ser presenteado, pois sua transformação em parente (o objetivo do "respeito" na afinidade xinguana) exige sua inclusão nesse circuito de intensa reciprocidade.

Várias vezes ouvi algo interessante sobre as trocas entre parentes: se meu irmão me dá um objeto, eu não só não preciso retribuí-lo como eu não devo retribuí-lo, pois seria ofensivo. O mesmo vale para as pequenas curas operadas pelos pajés. Todo pajé que não seja parente próximo deve ser pago, geralmente com objetos de pouco valor; já os pajés aparentados não devem ser pagos (e, logicamente, não podem cobrar). A situação só muda se for necessário ao pajé entrar em transe, o que é considerado muito caro e invariavelmente deve ser pago com 
algo muito valioso ${ }^{5}$. É como se um pagamento explícito instaurasse uma distância entre os trocadores, contradizendo sua relação de parentesco próximo.

Saindo do núcleo da parentela, os principais parceiros de troca são os amantes e amigos. Os rapazes costumam dar pequenos presentes a suas namoradas, tratados jocosamente como "pagamento pela vagina" (egü hipügü). As mulheres fazem o mesmo, dando a seus namorados colares e pulseiras de miçangas (mas que não são, até onde sei, tratados como "pagamento" por nada). Estes objetos não costumam ficar muito tempo com seus receptores, que rapidamente os colocam em circulação, a fim de evitar que as pessoas descubram suas relações amorosas.

A amizade xinguana é uma relação que reúne elementos tanto da consanguinidade quanto da afinidade, sem contudo, se confundir com nenhuma das duas (Coelho de Souza, 1992; 1995). Antes de mais nada, ela é uma relação entre pessoas de mesmo sexo e não ocorre no núcleo da parentela - não se é amigo dos parentes com os quais se convive de perto. Uma pessoa começa a fazer amigos em sua própria aldeia ainda criança, mas entre parentes mais distantes ou pessoas com as quais não reconhece laços específicos de parentesco. Nestes casos, a amizade é uma relação afetiva muito forte ${ }^{6}$ que pode se estender por toda a vida: quando crianças, amigos brincam juntos, frequentam as casas uns dos outros para comer e, na adolescência, começam a andar juntos atrás de namoradas. Muito frequentemente, as parceiras favoritas de um rapaz são as irmãs de seus amigos, com os quais se pode contar para incentivar as jovens, facilitar a entrada em sua casa à noite, passar recados, entregar presentes e até convencer seus pais a aceitá-lo como genro ${ }^{7}$.

A amizade com pessoas de outras aldeias também pode começar na infância ou na juventude, durante viagens e festas, e se estender por uma vida toda. Mas muitas vezes, principalmente entre pessoas de povos diferentes, ela pode começar com uma troca ${ }^{8}$, que

\footnotetext{
${ }^{5}$ Dizem que este pagamento é pelo tabaco consumido pelo pajé. Um único pagamento cria uma relação duradoura entre o curador e os parentes do doente, pois o pajé deve entrar em transe sempre que necessário sem necessidade de novos pagamentos. Essa relação é frequentemente fonte de desentendimentos, pois alguns pajés são acusados de cobrarem "caro demais" por seus serviços.

${ }^{6}$ Que se manifesta com uma grande liberdade corporal, principalmente entre os homens: amigos andam de mãos dadas, deitam juntos na mesma rede e fazem várias brincadeiras que envolvem contato corporal.

${ }^{7}$ Em Aiha há dois irmãos casados com duas irmãs de seu melhor amigo, e agora o cunhado mais novo desses homens está interessado em uma de suas irmãs.

${ }^{8}$ Comecei a perceber essa relação entre troca e amizade quando, durante minha primeira viagem a campo em 2006, um jovem me procurou com um objeto na mão (não me lembro o que era) e perguntou: "Você quer ser meu amigo?". Sem entender direito respondi que sim, e o rapaz prosseguiu: "Isso é pra você, agora você já é meu amigo. Sempre que você vier você tem que trazer alguma coisa pra mim". Poucos dias depois ele veio com
} 
tende a se desenvolver em outras relações no futuro. Se alguém negocia algo com uma pessoa de outra aldeia, é provável que eles venham a fazer várias outras trocas no futuro. Isso pode ou não levar a uma relação afetiva como a amizade entre pessoas de um mesmo povo (sejam ou não da mesma aldeia), mas de qualquer forma, ela ressalta um componente que está presente em todas as formas da amizade, que é a troca (de objetos e, eventualmente, irmãs). Quando alguém precisa de qualquer objeto que não possa ou não queira pedir a um parente, ela procurará um amigo disposto a trocá-lo. Amigos não têm vergonha uns dos outros, como se fossem parentes próximos, mas ao invés de partilhar ou ceder de forma aparentemente espontânea, trocam e "vendem". É uma forma de relacionamento paralela ao parentesco, mas que combina aspectos tanto da consanguinidade quanto da afinidade (ver a discussão de Viveiros de Castro, 2002c, sobre as figuras de "para-parentesco" nas terras baixas). Ela tem inclusive o potencial para o aparentamento, pois há diversas pessoas que são chamadas de "irmãos" ou "primos" por causa de suas relações de amizade: amigos de uma mesma aldeia podem se tornar "irmãos" de tanto andarem juntos e trocarem, e amigos de outras aldeias podem passar a se considerar “primos cruzados” (Guerreiro Júnior, 2008: 111).

A única situação na qual as trocas independem de qualquer relação prévia entre os trocadores é o uluki. Quando alguém tem objetos que deseja trocar e decide fazer um uluki, primeiro procura-se um chefe, que chamará as pessoas para a casa do idealizador e coordenará as trocas (ele será "esteio", iho, dos participantes, ou "tronco/corpo", ihü, do uluki). Estes são eventos genderizados, pois quando uma mulher organiza um uluki, só outras mulheres participam e, quando um homem o faz, só homens participam (a exceção é o chefe coordenador que, no caso do uluki feminino, pode ser tanto uma mulher quanto um homem). O dono da casa deve colocar um banco em sua casa, no espaço próximo à porta da frente, para que o chefe se sente. Quando bastante gente já se encontra reunida ali, as pessoas da casa (começando por quem idealizou o evento) entregam ao chefe cada objeto que desejam trocar e dizem o que querem em troca. O chefe então exibe o objeto, comenta sobre suas características e provoca as pessoas para que alguém aceite a proposta de troca. $\mathrm{O}$ uluki passa de casa em casa até completar uma volta na aldeia, mas ele só entra onde haja alguém interessado em oferecer objetos.

sua esposa procurando minha companheira de pesquisa, para quem ela também deu um presente. O rapaz então explicou a situação a ela: "Ela está dando um presente pra você. Agora vocês são amigas pra vida toda". 
Eu precisei participar de muitos uluki (e sair no prejuízo em todos eles) para começar a entender a lógica por trás dessas situações. O uluki é uma espécie de "jogo"; os visitantes estão sempre curiosos para saber o que as pessoas de uma casa têm que possa ser trocado, e as provocam para trocar o máximo possível, enquanto estas se empenham em fingir (ou esclarecer) que não têm nada. No vai-e-vem de objetos do uluki, as pessoas medem umas às outras o tempo todo. Quando os visitantes julgam que as pessoas da casa estão oferecendo muito pouco, as veem como egoístas (tuitunkginhü); já os que ofertam objetos, procuram fazê-lo sem deixar transparecer que possuem muito para trocar, pois sabem que, nesses casos, as pessoas evitam aceitar seus pedidos como forma de obrigar o "vendedor" a pedir objetos menos valiosos, ou a exibir objetos mais valiosos para conseguir o que pretendia. O objeto de negociação não é o pagamento por cada coisa (isso simplesmente não ocorre no uluki), mas a imagem de cada participante. Quando alguém percebe que está sendo visto como sovina, deve se mostrar desprendido, pedindo objetos de pouco valor ou ofertando coisas que a maioria das pessoas desejaria guardar (como enfeites especialmente belos, por exemplo). De forma semelhante ao que diz Strathern (1992) sobre as trocas melanésias, a equivalência ou possibilidade de substituição entre os objetos resulta de relações nas quais as pessoas tentam coagir umas às outras a oferecer algo.

Como em toda economia do dom, todos os tipos de transações são condicionadas, ao mesmo tempo, pelas relações entre os trocadores e pelas relações que elas são capazes de reproduzir ou criar. Mesmo quando alguém quer vender algo de forma impessoal, a única situação para tanto, assume a forma pública e ritualizada do uluki. A impessoalidade destas relações é tão ilusória quanto a espontaneidade dos presentes, pois os participantes avaliam uns aos outros o tempo todo e tais avaliações variam conforme a capacidade de uma pessoa trocar muitos objetos. Strathern (ibid.) diz que um dom é sempre uma forma de extrair algo de outra pessoa, antecipando o ponto de vista do receptor sobre o doador e a coisa dada. O uluki brinca com essa necessidade (e por isso se parece mais com um jogo do que com um mercado ou uma feira), pois a simulação de "falta de objetos", tanto pelos participantes, quanto pelas pessoas de cada casa, cria uma situação na qual é mais difícil efetuar a "troca de pontos de vista" entre doador e receptor que, segundo Strathern (ibid.), está no centro do funcionamento da dádiva. A necessária intervenção de um chefe torna isso evidente, pois o doador oferta um objeto sem ter um receptor em vista - o chefe aparece como um mediador perante um receptor incerto, que pode ou não existir. Mas a forma silenciosa da negociação revela porque 
mesmo essas trocas são parte de uma economia do dom: tanto os sujeitos trocadores quanto a equivalência entre os objetos trocados resultam das tentativas mútuas de extrair um objeto de alguém por meio da extração de um objeto de si mesmo.

\subsection{Reunindo alimento}

Na preparação de qualquer ritual, muitas coisas precisam ser pagas, o que é sempre uma responsabilidade do dono da festa. Nesses contextos, existem basicamente dois tipos de relações de troca: de serviços por alimento e serviços por objetos de valor. Estes dois tipos de transações podem ser diferenciadas segundo o destino final de cada pagamento: no primeiro caso, o dono da festa oferece comida e bebida para os tajope, que os redistribuem para todos (mais frequentemente apenas para os homens); no segundo caso, a relação é apenas entre o dono e os tajope, que recebem objetos de luxo como pagamento por algumas atividades.

No egitsü, as despesas com os tajope começam logo após o enterro do morto, quando os donos devem dar um grande colar de conchas (inhu aketühügü) para cada enterrador, considerado pagamento (hipügü) pelo enterro. Muitas vezes, os donos da festa não dispõem dos colares necessários, mas eles podem mobilizar seus parentes para obtê-los. Se conseguirem os colares com parentes próximos, pode ser que não precisem retribuir; mas caso precisem pegar colares com parentes distantes, deve-se combinar algum tipo de pagamento. Os enlutados também deverão pagar os tajope quando forem lavados por eles para "tirar a tristeza" e quando forem finalmente pintados no penúltimo dia da festa. O primeiro banho, dado aos enlutados quatro dias após a morte, pode ser pago com objetos pouco valiosos, como anzóis, sabonetes, conchas ainda não trabalhadas (assim como outros banhos que acontecem ao longo do ciclo). Os enlutados serão banhados novamente no penúltimo dia antes do final e, nessa ocasião, os tajope devem ser pagos com objetos um pouco mais valiosos (como por exemplo miçangas, pequenos colares de conchas ou penas). $\mathrm{O}$ último pagamento feito aos tajope é o da pintura corporal, que suspende definitivamente o luto e permite aos donos aparecer em público para os convidados. Estes pagamentos devem ser feitos com objetos valiosos e, nos egitsü que presenciei, eles sempre foram feitos com colares de concha médios (uguka). Mas nem sempre os tajope são bons pintores e eles podem chamar outras pessoas para cumprir sua tarefa. Nesse caso, as pessoas responsáveis pela pintura é que devem ser 
pagas, mas elas, por sua vez, deverão procurar um pagamento (menos valioso do que o que ele próprio recebeu) para dar ao tajope que a convidou.

Mas o que mais demanda esforços do dono da festa e sua família é a distribuição de alimentos (afinal, é preciso muito mingau de pequi, peixe e beiju para pagar dançarinos e cantores ao longo de todo o ciclo, e distribuir aos convidados no final). Entretanto, os donos não reúnem esses alimentos sozinhos, contando com o trabalho da aldeia em grandes eventos destinados à reunião de comida, que põem em movimento um grande circuito de dons e contra-dons. Tratarei agora dos três principais eventos desse tipo: a reunião do pequi, do polvilho e do peixe. Minha intenção é mostrar que eles não têm apenas um objetivo "utilitário" (reunir comida), mas que a forma pela qual os alimentos circulam nesses contextos é uma das maneiras pelas quais se produz deliberadamente uma assimetria entre o povo anfitrião e os donos do egitsü.

Como o pequi começa a cair em setembro, antes das primeiras chuvas, e o egitsü termina no auge da seca, esse fruto é sempre o primeiro alimento a ser reunido. Assim, entre a morte de alguém importante e seu egitsü, é preciso que haja uma estação do pequi para que se possa juntar sua polpa. Foi assim em 2009 e 2010: um homem falecido no primeiro semestre de 2009 só pôde ser homenageado em 2010, e sua esposa, falecida em janeiro daquele ano, só teve seu egitsü em 2011. Para juntar a polpa de pequi é preciso fazer uma festa, chamada indze tundomi (lit. "para dar pequi”). Acompanhei este evento para o egitsü de 2010 (que teve dois homenageados principais), ocorrido na terceira semana de outubro de 2009. Apresentarei aqui uma descrição o mais detalhada possível do seu desenrolar, para que o leitor tenha uma ideia do trabalho que se dedica a um evento como esse e para salientar a forma básica que a troca de dons entre chefes, tajope (coordenadores) e trabalhadores, assume nessas ocasiões.

A festa para juntar pequi é uma festa exclusiva do grupo local, da qual não participam nem mesmo outras aldeias kalapalo, com duração de três dias. No dia 20/10/09, umas 5:00 da manhã, o principal tajope (o segundo cacique) pedia a todos que fossem buscar pequi, para entregá-los no dia seguinte. Dia 21 bem cedo, os tajope chamaram os homens para ir buscar lenha. Trouxeram muita madeira (tahaku, a melhor lenha), encheram a carreta do trator, e logo que souberam de sua chegada, os donos da festa começaram a levar panelas de mingau de pequi para o centro, uma para cada tajope, que distribuíram o mingau entre todos. Se por acaso sobrar mingau na panela de algum tajope, este lhe pertence e ele o levará para sua casa. 
A lenha é para o cozimento do pequi que será reunido, um trabalho pesado e demorado que cabe às mulheres das famílias dos tajope.

Por volta das 15:00, enquanto cantores se pintavam dentro da casa dos homens, os donos responsáveis por cada um dos dois chefes homenageados levaram para o centro um arco, um chocalho, um cinto e um conjunto de plumárias (é obrigação dos donos fornecer os enfeites e instrumentos para os cantores). Pouco depois, os cantores apareceram e começaram a entoar a suíte Hagagikugu ${ }^{9}$, que sempre marca a abertura das festas para reunir alimento. Era a segunda vez que se executava cantos desse gênero musical desde a morte dos homenageados; a primeira havia sido no dia da construção do tahiti (cercado sobre a sepultura de um chefe, discutido no capítulo 4). Enquanto isso, homens e mulheres também começavam a se enfeitar, pois no final da tarde dançariam aũguhi:

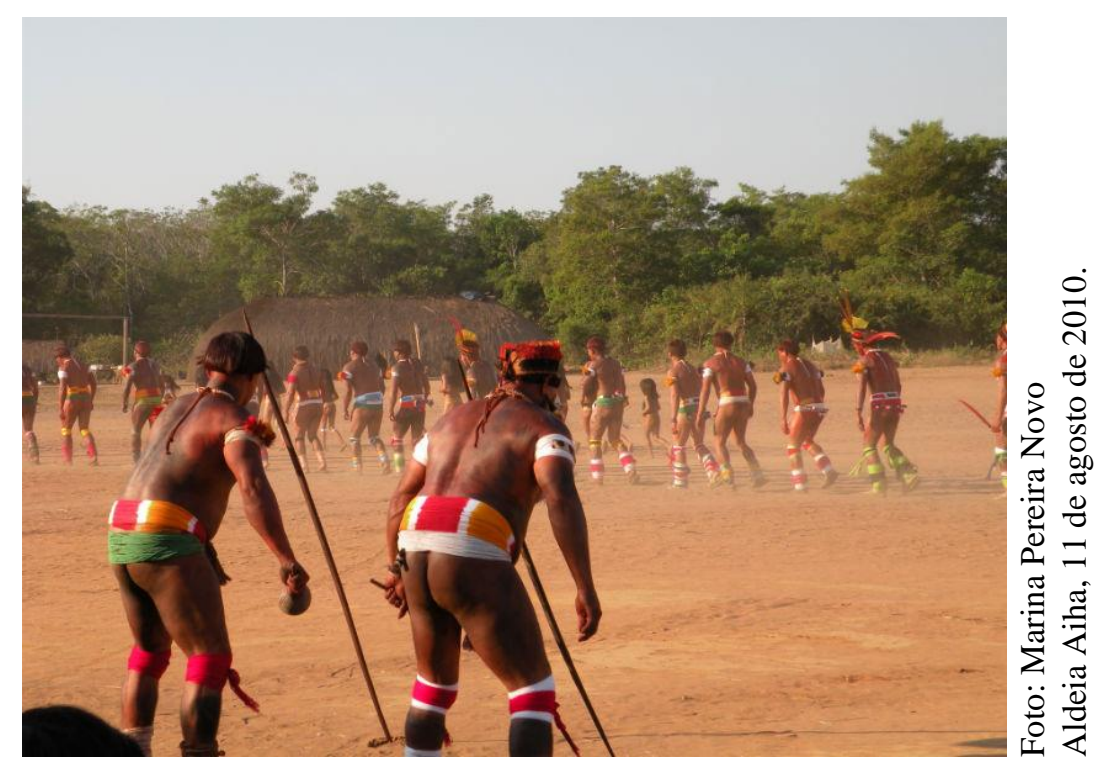

Figura 6.1: aũguhi, em frente à casa dos homens.

\footnotetext{
${ }^{9}$ Essa suíte é cantada do ponto de vista do morto, que em algumas partes pede a confecção de seus enfeites: braçadeiras, cintos, plumárias. Essa suíte é quase toda em arawak e, pelo pouco que os cantores sabem, ela parece ser uma evocação de cada parte do processo de fabricação da efígie. Apenas os primeiros versos são em karib, nos quais o morto pede que sejam feitos os buracos onde será colocada sua efígie. A predominância do ponto de vista do morto provavelmente está ligada ao mito de origem da suíte. Um homem que morava na aldeia Hagagikugu (antigo sítio karib) a aprendeu na aldeia aquática de sua esposa Cobra, para onde havia decidido se mudar. Antes de partir definitivamente para o mundo dos espíritos, ele fez sua própria efígie e cantou essa suíte, como uma forma de se despedir de sua mãe.
} 
Terminado esse momento músico-coreográfico, faltando mais ou menos meia hora para o sol se pôr, os donos da festa levaram várias panelas enormes para o centro e as dispuseram enfileiradas em frente à casa dos homens. Como havia dois homenageados principais, o responsável por cada um levou suas próprias panelas. Um deles levou oito panelas grandes, e o outro levou sete. Os tajope começaram a gritar pedindo o pequi, e as mulheres foram saindo de suas casas trazendo bacias e panelas com o fruto (menos as mulheres enlutadas). Quando as panelas já estavam cheias, os tajope gritavam pedindo ainda mais. A maior parte do pequi foi entregue descascado (como é o ideal), mas também foram trazidos muitos pequis ainda com casca, sobretudo após a insistência dos tajope. Conforme as pessoas traziam pequi com casca, as mulheres das famílias dos tajope eram incumbidas de descascá-los, ao lado da casa dos homens. No final do dia, todas as panelas estavam muito cheias, e havia ainda mais pequi espalhado pelo chão.
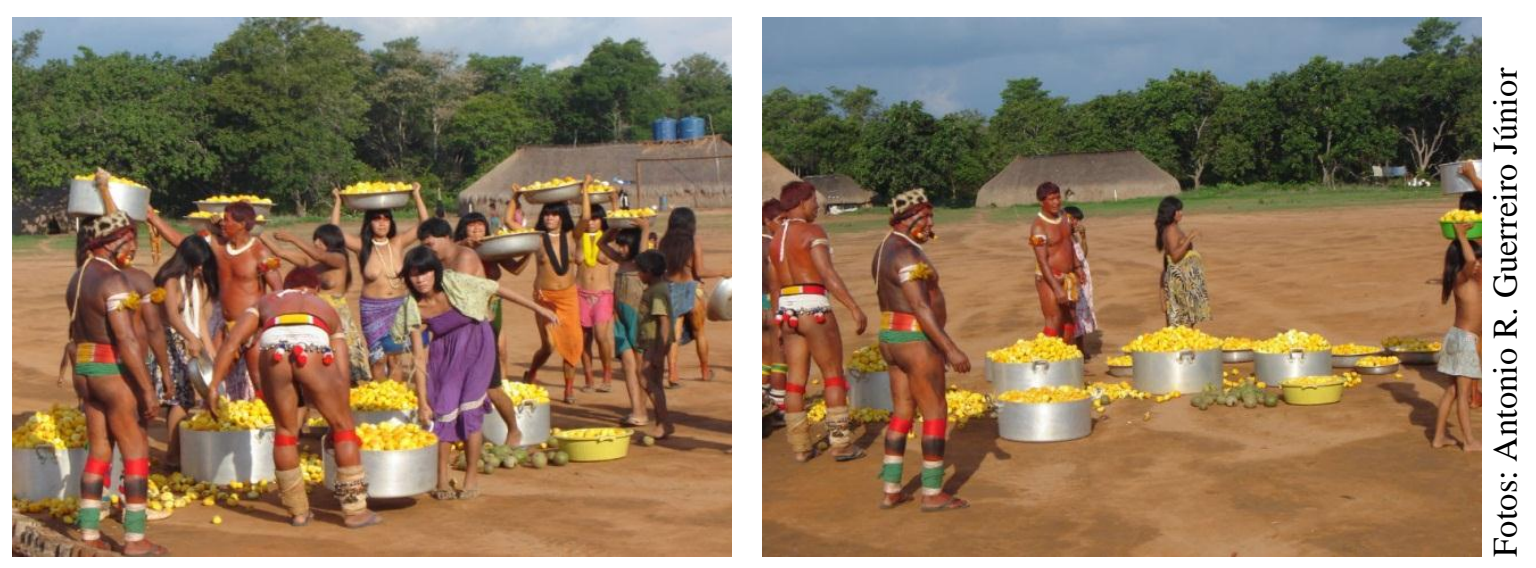

Figura 6.2 e Figura 6.3: imagens do indze tundomi.

Um dos tajope (à esquerda, com coroa de couro de onça) convoca as mulheres para trazerem pequi. 


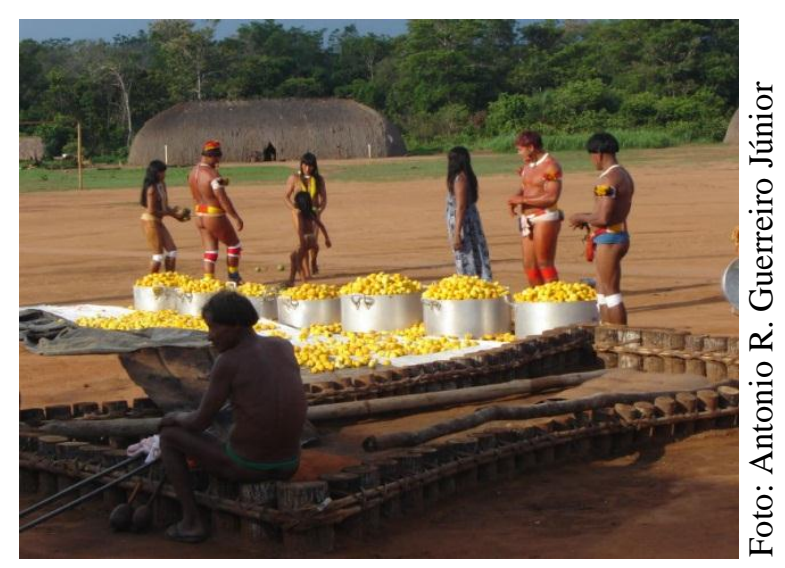

Figura 6.4: vê-se o total de pequi reunido apenas para um dos donos.

O segundo rapaz da direita para a esquerda é um jovem anetü colocado como tajope por seu pai; à frente, um homem sentado sobre o tahiti de um dos mortos.

Por volta das 2:00 da manhã, as mulheres da família dos tajope começaram a cozinhar o pequi perto do centro. O cozimento precisa ser feito à noite para que a polpa possa ser retirada e armazenada ao longo do dia seguinte. Enquanto isso, dorme-se pouco, pois os tajope passam a noite chamando os homens para ficar no centro conversando e tomando café (cujo suprimento também é uma obrigação dos donos da festa). Os cantores de aũguhi também cantam durante essa noite, para manter as pessoas alegres e acordadas. Perto do amanhecer, os tajope começaram a gritar pedindo que as pessoas acordassem e que as mulheres fossem ao centro trabalhar. Todas as mulheres da aldeia, menos crianças, reclusas e mulheres menstruadas ${ }^{10}$, foram para o centro tirar a polpa do pequi. As mulheres, em geral, trabalham em um grande grupo coordenado pelas mulheres dos tajope, um pouco distantes da casa dos homens. As mulheres das famílias dos dois homenageados também trabalharam, mas ficaram em um grupo separado das outras mulheres. Me disseram que elas não precisariam trabalhar, mas elas haviam decidido ajudar ${ }^{11}$.

\footnotetext{
${ }^{10} \mathrm{O}$ sangue menstrual contaminaria o alimento. Caso uma mulher menstruada se aproximasse do pequi, tudo deveria ser jogado fora.

${ }^{11}$ Como os enlutados não devem ser vistos em público (muito menos no centro!), uma situação dessas só foi possível pelo uso de roupas. Para manter sua relativa "invisibilidade", as enlutadas se cobriram ao máximo com vestidos, toalhas e camisetas.
} 

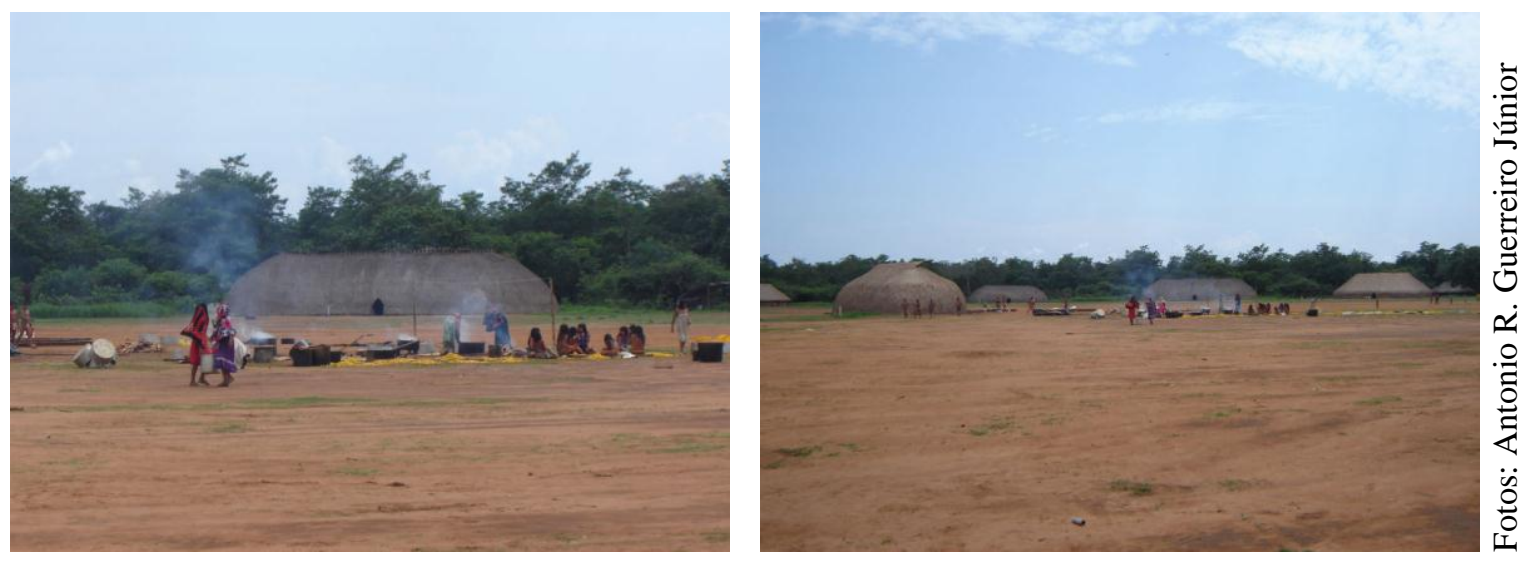

Figura 6.5 e Figura 6.6: mulheres cozinhando pequi no centro da aldeia.

Na foto à direita é possível ver a disposição das trabalhadoras em relação à casa dos homens.

Logo que as mulheres deram início ao seu trabalho, os donos do egitsü começaram a levar uma grande quantidade de alimento para o centro: mingau de pequi, peixe assado, beiju e pirão. Enquanto isso, dois homens começaram a se preparar na casa dos homens para dançar com as flautas atanga. Foi estendida uma grande lona e, sobre ela, todo o beiju foi dividido em vários pedaços pelos tajope, que em seguida colocaram uma quantidade de pirão sobre cada pedaço. É preciso que haja pelo menos um pedaço de beiju com pirão para cada homem e menino presente no centro. O peixe assado também foi dividido, para garantir que não faltasse para ninguém. O que sobra pode ser comido à vontade, e os homens aproveitam para levar um pouco de comida para suas casas. O que mais me impressionou foi a quantidade enorme de mingau de pequi. Cada dono levou muitas panelas com mingau para o centro (preparadas pelas mulheres de sua família). Um por vez, os donos chamavam cada homem adulto da aldeia da maneira apropriada:

\section{[Termo de parentesco], ilanha etete, ilanha etete, ilanha etete uinha!}

[Termo de parentesco], venha para cá, venha para cá, venha para cá, para mim!

O homem recebia sua panela das mãos dos donos, a levava para casa e, em seguida, trazia a panela vazia, para que pudesse ser reaproveitada. Depois que todos os homens foram chamados foi a vez das mulheres, que fizeram o mesmo (com a diferença que elas receberam seu mingau um pouco ao lado do centro, onde trabalhavam, e não em frente à casa dos homens). 
Só a distribuição dos pagamentos levou quase quatro horas: começou pouco depois das 6:00 da manhã e terminou por volta das 10:00. Certamente, não é preciso mencionar a quantidade impressionante de trabalho despendido pelas famílias dos donos: tiveram que pescar na noite anterior e, desde a madrugada, suas mulheres limparam, cozinharam e assaram peixes, e prepararam quantidades indescritíveis de mingau de pequi. Logo após esses pagamentos, os tajope deram mais um banho nos enlutados para tirar "um pouco" de sua tristeza. À tarde, depois que toda a polpa do pequi já havia sido retirada, apenas as mulheres das famílias dos donos permaneceram no centro, cozinhando doce de pequi (parte foi consumida ali mesmo pelos homens e outra foi guardada pelos donos para o dia seguinte). Ainda houve mais festa: outra dupla de flautistas se preparou, e houve canto e dança no final da tarde.

No dia seguinte o trabalho continuou. De manhã bem cedo, os tajope foram sozinhos para o mato buscar embira para a confecção de grandes silos usados para guardar a polpa do pequi. Eles saíram logo que o dia clareou e não demoraram mais do que uma hora. Quando chegaram, os donos novamente levaram mingau de pequi, peixe e beiju para o centro - mais trabalho para os homens, que pescaram à noite, e para as mulheres que prepararam o peixe e o mingau. No mesmo lugar onde as mulheres trabalharam no dia anterior, foram erguidos quatro silos bem altos (dois para cada dono), com uma estrutura de madeira, trançados com embira e forrados com grandes folhas verdes de uma planta específica, usadas por seu tamanho e resistência, dentro dos quais a massa do pequi foi depositada. Ao longo do dia, os donos ofereceram mingau algumas vezes, sempre entregue ritualmente aos tajope e depois redistribuído. No final do dia, os donos ainda ofereceram mingau e doce de pequi (uma panela de cada para cada tajope). Quando os cestos ficaram prontos, foram levados até um córrego não muito longe da aldeia, onde foram enterrados. Esta técnica conserva o pequi até o ano seguinte sem que ele fermente, pois a água o mantém resfriado. Ainda assim, toda essa massa de pequi não será suficiente, e os donos sempre acabam usando seus estoques particulares. A maior parte dela (senão toda) será usada na pescaria coletiva que antecede a chegada dos convidados no final da festa.

Nota-se que os tajope desempenham um papel especial na mediação deste vai e vêm de serviços e alimentos. Na prática, eles são os únicos parceiros de troca dos donos, é sempre para eles que se oferecem os pagamentos, e são sempre eles que entregam aos donos os produtos do trabalho, cujo processamento é coordenado por suas esposas, filhas e irmãs. Na 
verdade, pode-se dizer que as pessoas não trabalham para o dono, mas para os tajope: é para eles que as mulheres trazem todo o pequi, são suas mulheres que as outras ajudam a cozinhar e tirar a polpa da fruta, e é para os tajope que elas entregam a polpa para ser armazenada nos cestos. Os tajope, por sua vez, são os responsáveis por entregar os produtos em sua forma final aos donos e coordenar o seu armazenamento.

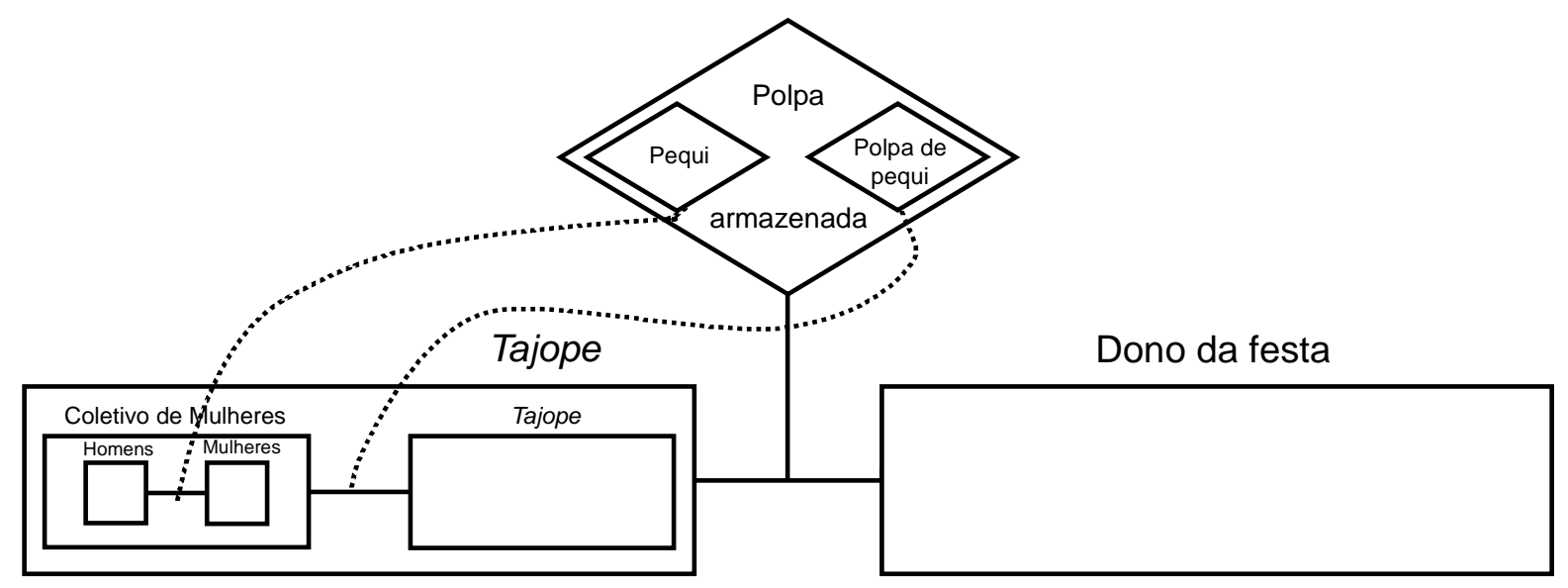

Figura 6.7: diagrama com as relações envolvidas na reunião da polpa de pequi.

Os diagramas deste capítulo se baseiam no trabalho de Gell (1999), onde quadrados e retângulos representam termos, linhas representam relações, losangos representam objetificações, e o englobamento de relações por um termo representam hierarquia.

A festa do polvilho (kuiginhu tundomi, lit. "para dar polvilho") e a pescaria coletiva seguem a mesma lógica básica. Do ponto de vista da relação entre donos, tajope e trabalhadores, tudo se passa da mesma forma: as pessoas fazem festa e trabalham; os donos pagam os tajope com comida, que redistribuem para os trabalhadores; por fim, os tajope entregam o produto final para os donos. A principal diferença é a progressiva inclusão de outras aldeias nos eventos. Na festa do polvilho, é quando os anfitriões escolhem pelo menos mais um povo como seu "aliado" (kataentsokongo) e, na grande pescaria, é quando as outras aldeias kalapalo (e eventualmente os aliados) se reúnem na aldeia patrocinadora. A cada novo passo, o ritual incorpora novos agentes na composição do grupo patrocinador que, apesar de sua natureza compósita, aparecerá como uma unidade perante os convidados.

A festa do polvilho acontece entre a segunda metade de maio e meados de junho, no auge da colheita da mandioca; a partir de julho já se colhe menos mandioca e tem início a fase 
de abertura e plantio de novas roças. Eu não consegui acompanhar essa festa na preparação de nenhum egitsü, mas acompanhei uma na preparação de uma takuaga ${ }^{12}$ em 2007, cuja estrutura básica é a mesma (muda-se a festa, mas não a forma das relações ${ }^{13}$ ): os convidados chegam no fim da tarde, são recepcionados pelos ex-mensageiros e lutam com os anfitriões. Terminada a luta, os donos da festa levam comida para os chefes dos convidados e, em troca, recebem polvilho, que eles devem ter reunido em sua aldeia. Os aliados então se dirigem para a casa do ex-mensageiro, onde se hospedam, e os homens se preparam para dançar. As mulheres anfitriãs só dançam com homens aliados e vice-versa. Há festa a noite toda e, no dia seguinte, as mulheres da aldeia entregam polvilho para os tajope, que então ficam responsáveis por construir a estrutura de madeira, embira e folhas onde ele será armazenado, no centro da casa do dono. O polvilho conseguido só será utilizado para preparar alimento para a grande pescaria coletiva (obrigação das mulheres da família dos tajope) e para os dois últimos dias da festa (responsabilidade das mulheres da família do dono).

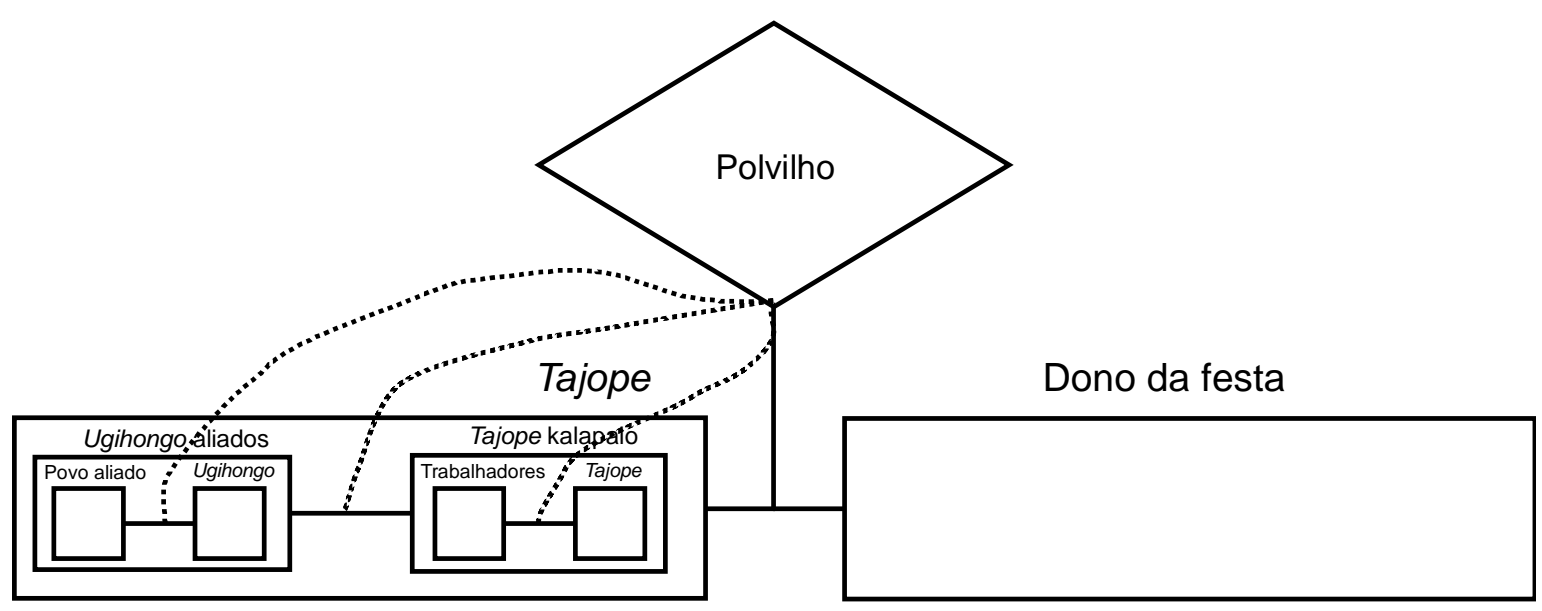

Figura 6.8: diagrama das relações entre aliados e anfitriões mediadas por polvilho.

\footnotetext{
${ }^{12}$ Grande festa para um espírito materializado sob a forma de um conjunto de cinco aerofones (takuaga), que pode possuir um momento interaldeias. Quando uma takuaga é feita pela primeira vez para o doente que se tornará seu dono, a festa é realizada apenas no grupo local e visando a melhora do doente. Contudo, espera-se que o dono patrocine, alguns anos depois, uma takuaga interaldeias, criando um ciclo que, de forma parecida com o egitsü, dura cerca de um ano e exige a reunião de alimento ritual para o dono. Mas um "dono de takuaga" só pode patrocinar um ritual desse tipo uma vez, pois logo após o término da festa, sua takuaga deve ser queimada.

${ }^{13}$ Porque a forma de organização do egitsü é a matriz dos outros rituais regionais. Os Kalapalo dizem que festas como o hagaka e a takuaga são introduções relativamente tardias; a primeira foi aprendida pelos Kamayurá, com os Trumai, e a segunda pelos Bakairi, com os Juruna. Ao serem introduzidas na região, assumiram a forma do egitsü no que diz respeito à duração do ciclo, à reunião de alimento e à diplomacia entre as aldeias.
} 
Os aliados em um egitsü são um ou mais povos escolhidos pelos donos (e não pelos tajope). Com a festa do polvilho, esses outros povos passam a ser como coaldeões: hospedamse na aldeia (e não na mata ao redor, como os adversários), lutam juntos contra os convidados e podem aproveitar para homenagear seus mortos (mas apenas como isandagü, "seguidores", do morto principal). Mas há algumas coisas que marcam a heterogeneidade dos aliados em diferentes momentos do ritual. A obrigatoriedade dos homens de um grupo dançarem com as mulheres do outro até a chegada dos adversários, por exemplo, traduz a diferença irredutível entre os grupos sob a forma da afinidade potencial (uma "troca de mulheres" coreográfica). Antigamente, quando ainda se tocava e dançava atanga ${ }^{14}$ após as lutas, essa diferença era anulada e homens aliados só poderiam dançar com mulheres dos adversários e vice-versa. Os chefes dos convidados também têm uma posição marcada (apesar de passiva) durante a festa, permanecendo o tempo todo sentados em frente às efígies, de frente para os adversários. Essa unidade englobante gerada na festa do polvilho, apesar de tentar parecer um coletivo unificado, tem modos necessários para manter visível sua composição heterogênea para diferentes audiências - o englobamento dos aliados pelos anfitriões nunca é "total".

Eu nunca vi um egitsü ou qualquer outro ritual regional patrocinado por um grupo sem aliados. Mas em que se baseia tal necessidade? Por que um povo não pode enfrentar sozinho seus adversários? Pensando em questões econômicas, a contribuição de polvilho dos aliados geralmente é insignificante perto do que a aldeia anfitriã consegue reunir; em 2010, por falta de combustível os Mehinaku, que se aliaram aos Kalapalo, sequer participaram da festa do polvilho, o que não foi problema algum. O peixe a mais que eles podem proporcionar (mas só no caso de também homenagearem alguém) é sempre bem vindo, mas se não houvesse aliados também haveria menos pessoas para alimentar entre a pescaria e o final da festa. Aliados em uma pescaria só significa mais trabalho para as mulheres dos donos, que precisam pagar os coordenadores aliados com mingau de pequi.

Uma vantagem explícita para os Kalapalo é poder reunir os melhores lutadores de cada aldeia. Quando os chefes selecionam seus lutadores principais, escolhem sempre os melhores dentre os de seu povo e de seus aliados, aumentando as chances de se conseguir uma boa seleção. Mas isso deve ser considerado em paralelo com a dinâmica concêntrica das

\footnotetext{
${ }^{14}$ Depois das lutas, os maiores campeões de cada grupo dançavam atanga durante a tarde e só partiam no dia seguinte pela manhã. Os Kalapalo dizem que essa prática acabou porque, de um lado, não haveria mais grandes campeões como os antigos e, de outro, porque as pessoas sempre querem ir embora tão logo a festa acabe, o que era impossível antes de terem à disposição motos, camionetes e barcos a motor.
} 
classificações de parentesco: não se deve enfrentar os parentes próximos do morto, que se identificam como parentes do grupo anfitrião como um todo.

Os Kalapalo sempre convidam os Matipu e Nahukwa para serem seus aliados por uma questão de proximidade geográfica e, principalmente, social. Mas o inverso nem sempre é verdadeiro: quando os Matipu fazem rituais eles muitas vezes se aliam aos Kuikuro, tratando os Kalapalo e Nahukwa como um único grupo de adversários (isso em função da relação histórica entre os Kuikuro e Matipu, que eram um grande grupo antes de se dividirem ${ }^{15}$ ); o mesmo costuma acontecer quando os Kuikuro são os patrocinadores.

É digno de nota que os Kalapalo nunca convidam seus vizinhos mais próximos como "dois" povos: dependendo de onde o dono da festa tiver mais parentes próximos, ou se convida os Nahukwa, ou se convida os Matipu, que se juntam como se fossem um único povo. Os Kalapalo dizem que é porque suas aldeias são muito pequenas, mas há também que se considerar a história peculiar desses grupos, cujos sobreviventes foram obrigados a se juntar em uma única aldeia (Magijape) na criação do Parque, cuja divisão, no final dos anos 1970, deu origem à aldeia matipu Küngahünga. Essa situação criou uma proximidade muito grande entre os Matipu e os Nahukwa, fazendo com que eles ajam como um único povo em boa parte dos rituais regionais, principalmente quando os patrocinadores são os Kalapalo. Quando os Kuikuro são os patrocinadores, eles fazem algo semelhante com os Kalapalo, que sempre atendem aos convites junto com os Nahukwa como se fossem um único grupo. Diferentes grupos podem aparecer como unidades discretas ou englobantes dependendo daqueles com os quais entram em relação (de enfrentamento ou aliança), o que pode variar em função de onde o chefe patrocinador tiver mais parentes e reconhecer a existência de chefes dignos de receber mensageiros.

Em 2010, além dos Matipu e Nahukwa, os Kalapalo se aliaram aos Mehinaku (o que é bastante incomum), em função das relações de parentesco próximas entre o morto e algumas pessoas daquele povo. Quando souberam do egitsü do xamã de Aiha, os próprios Mehinaku disseram via rádio que deveriam ficar junto dos Kalapalo, pois como o morto "era meio mehinaku" eles não poderiam se comportar como adversários. O xamã era neto de um homem mehinaku casado com uma mulher kalapalo, e seus parentes naquela aldeia ficaram muito sentidos com sua morte. Ele era um cantor e xamã respeitado, foi convidado várias vezes a se

\footnotetext{
${ }^{15}$ Franchetto, 1986; 1998.
} 
mudar para a aldeia de seu avô e algumas pessoas de lá gostariam que um de seus filhos (que se tornou chefe em Aiha) se casasse com uma mulher mehinaku. Mas seria possível perguntar: por que os Mehinaku como um todo e não apenas os parentes que o morto tinha naquele povo ${ }^{16}$ ? Ora, porque as relações rituais só se dão entre chefes, pessoas que estão "no lugar" do grupo como um todo: quando os chefes donos da festa se relacionam com os coordenadores mehinaku, isso só pode implicar na relação entre dois grupos inteiros. Ainda, como o morto era um chefe, por definição um super-parente, um consanguíneo de todos, ao reconhecer a condição nobre de um parente morto, um povo antes autônomo se coloca na posição de seus “seguidores”, seu "pessoal”.

As alianças rituais obedecem ao mesmo princípio gradativo e hierárquico operante nas classificações de parentesco: a proximidade geográfica e social atrai as pessoas para o polo da consanguinidade, enquanto os demais são empurrados para o polo da afinidade potencial e, assim, da inimizade ritual (Viveiros de Castro, 2002c). Logo, povos muito próximos não podem se enfrentar, pois no nível das relações regionais, são como parentes. Isso é algo que parece fazer parte da dinâmica básica desses rituais, mas passou relativamente despercebido nas etnografias ${ }^{17}$. Para que um grupo enfrente outro, ele deve ter escolhido pelo menos um povo para ser seu aliado, o que faz com que as relações de enfrentamento entre dois povos sejam, pelo menos, uma relação a três (evocando a afirmação de Lévi-Strauss, 1958, de que talvez a troca restrita seja um caso particular da troca generalizada, além do tema da oscilação entre dualismo e ternarismo nas comoslogias ameríndias ${ }^{18}$ ). Esse "dualismo em perpétuo desequilíbrio" mostra que a identificação ou diferenciação dos grupos é relativamente flexível e está submetida ao esquema gradativo do parentesco, neste caso, em um plano coletivo e centrado no chefe morto.

O ritual oculta parcialmente as diferenças entre os grupos e transforma um esquema gradativo (minimamente ternário, portanto) em um esquema dual, reunindo dois, três ou até quatro povos para se opor a outros xinguanos como se fossem um grupo só (como em 2010, quando o grupo de anfitriões foi formado pelos Kalapalo, Matipu, Nahukwa e Mehinaku -

\footnotetext{
${ }^{16}$ Tal alternativa seria impossível em condições normais, mas Agostinho (1974: 134) narra um episódio curioso no qual apenas parte dos Kamayurá se aliou aos Kalapalo. Segundo ele, no egitsü que os Kalapalo patrocinaram em 1966, os Kamayurá enfrentavam uma disputa política interna e havia muita tensão na aldeia. Chegando à festa, parte dos Kamayurá, que eram parentes de alguns Kalapalo, decidiu se aliar aos anfitriões, junto aos quais lutaram contra os Kamayurá que permaneceram como adversários.

17 À exceção do trabalho de Agostinho (1974).

${ }^{18}$ Lévi-Strauss, 1991.
} 
quatro povos reunidos como "pessoal" do morto). Essa parece ter sido a lógica original do ritual, antes de sua hiperexpansão após a criação do Parque. Os Kalapalo dizem que antigamente só convidavam para o egitsü os outros karib e que sempre se aliavam com os Jagamü (Nahukwa) e convidavam os Kuikuro como adversários que, por sua vez, vinham com os Uagihütü (Matipu) como seus próprios aliados. No fim das contas, uma relação entre quatro grupos era conduzida durante o ritual como se fosse uma relação a dois (como no próprio mito de origem do egitsü, analisado no capítulo 3, quando a aldeia das onças enfrenta a aldeia dos peixes).

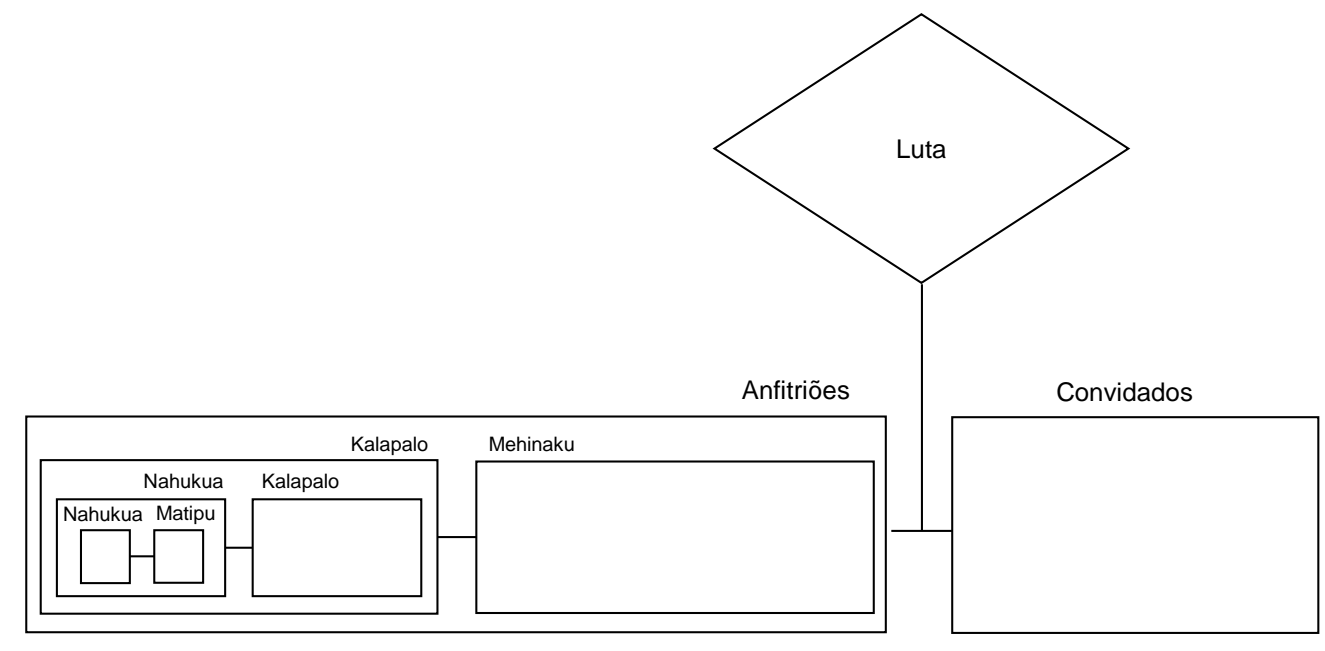

Figura 6.9: diagrama das relações eclipsadas na produção do grupo anfitrião no egitsü de 2010.

A pescaria, por fim, é um grande evento que mobiliza a aldeia toda, homens, mulheres e crianças. Ela funciona basicamente da mesma forma que as festas do pequi e do polvilho: festa, trabalho e pagamento. A diferença é que dela devem participar todas as aldeias do povo patrocinador e, se os povos aliados também estiverem aproveitando a festa para homenagear alguém, eles devem participar da pescaria como todos os outros. É nessa ocasião que se usa a maior parte do pequi reunido pela aldeia, pois é preciso muito, mas muito mingau: 


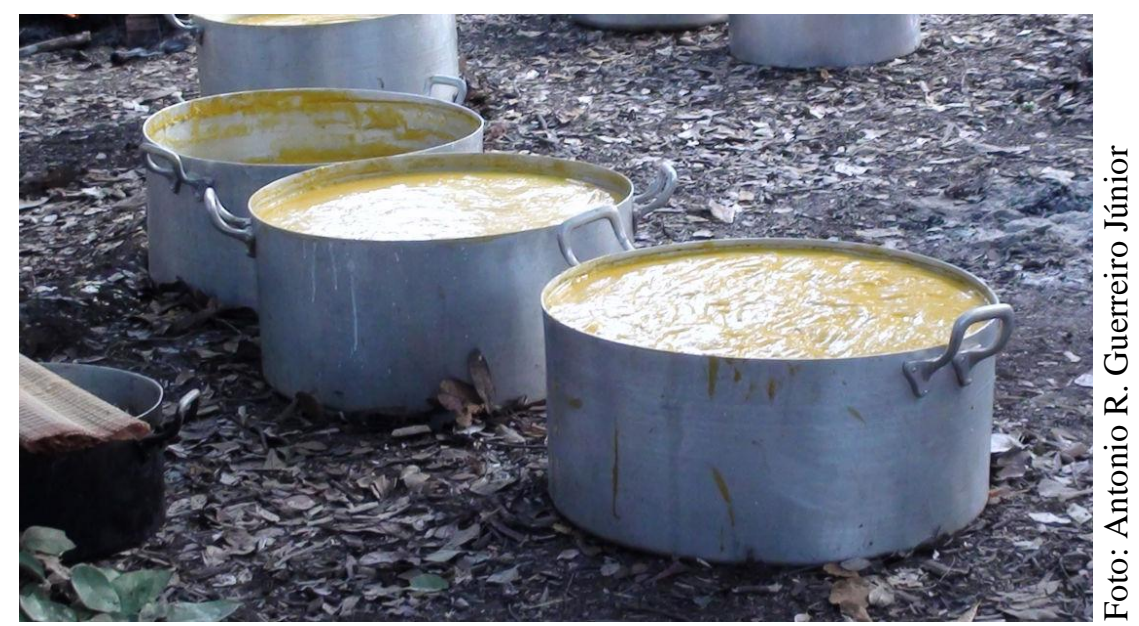

Figura 6.10: grandes panelas com mingau de pequi preparadas por um dos donos.

Vê-se apenas três, mas foram necessárias quatro panelas, uma para cada tajope; o outro dono preparou outras quatro panelas como essas.

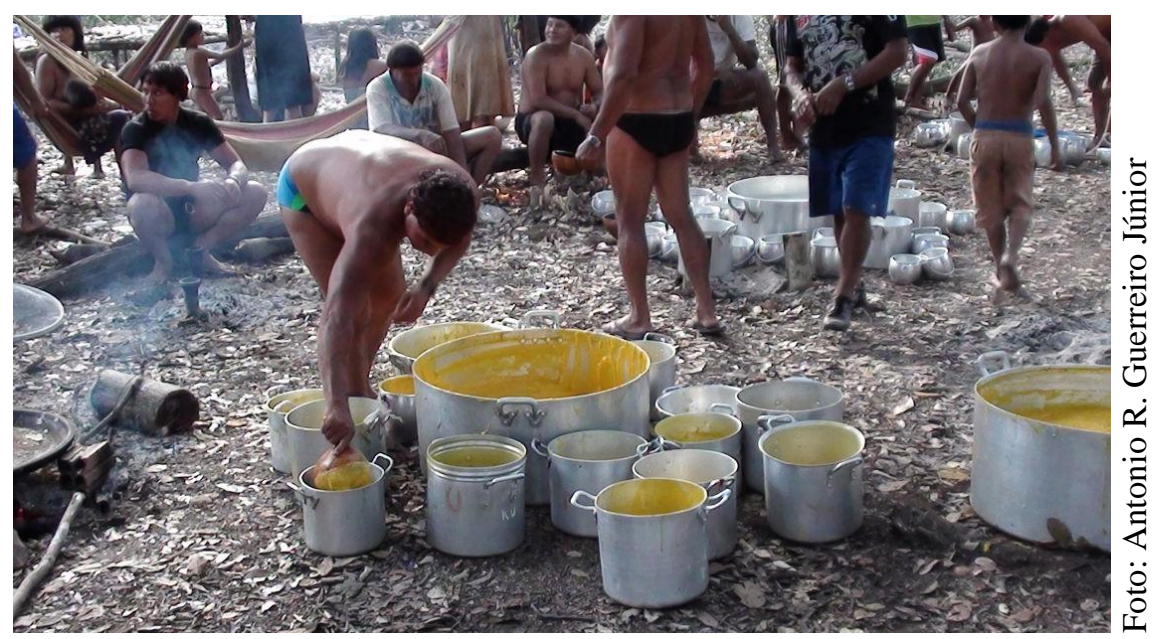

Figura 6.11: um dos tajope distribuindo o mingau que recebeu nas panelas levadas pelos pescadores.

Note-se a quantidade de panelas ao fundo, ainda vazias.

Os espíritos também entram nessa fase do ritual. Como já discuti no capítulo 3, quando fazem uma pescaria desse porte, os Kalapalo precisam se relacionar bem com o dono/chefe dos peixes para ser bem sucedidos e, por isso, os xamãs assumem um papel importante de mediação. Não entrarei aqui nos detalhes deste evento, pois é desnecessário; o ponto relevante no momento é que ele funciona exatamente como os outros: terminada a pescaria, cada pessoa oferece parte de seu peixe para o dono, a pedido dos tajope, que deve recolhê-lo, limpá-lo e começar a moqueá-lo ainda no acampamento. Na volta para a aldeia, é 
responsabilidade do dono manter os peixes no moquém até os dois últimos dias de festa, quando serão entregues aos convidados.

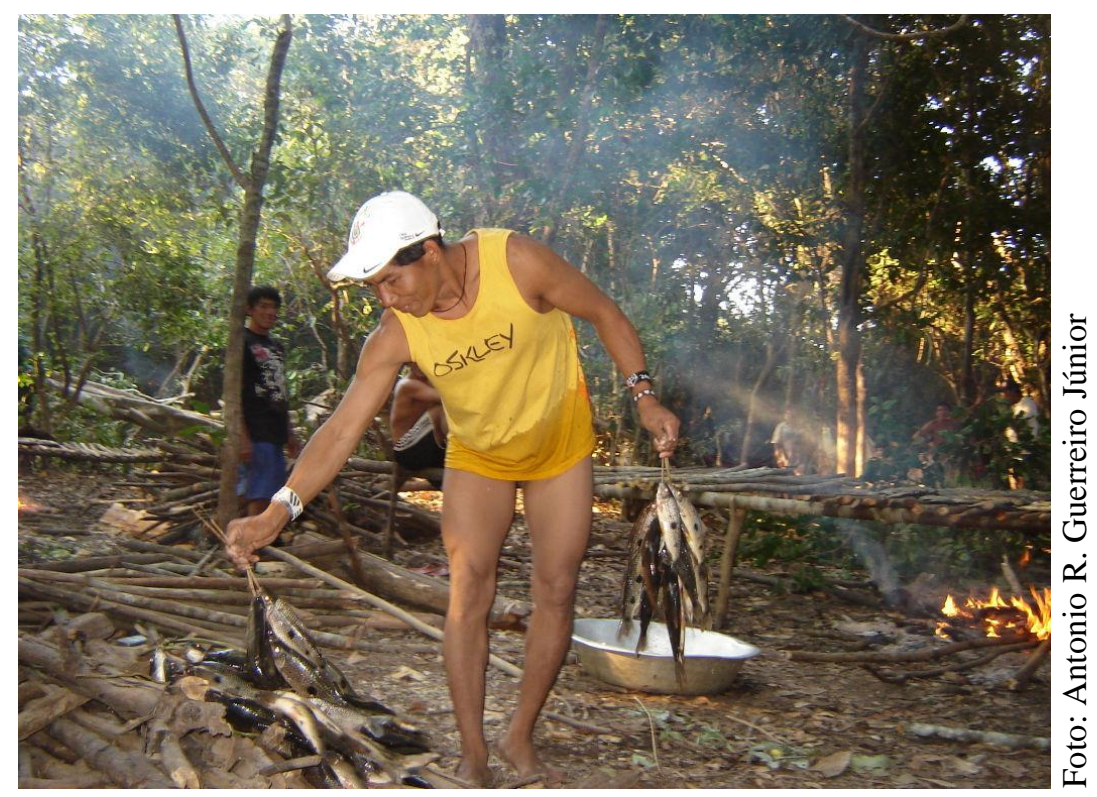

Figura 6.12: homem kalapalo entregando peixes.

$* * *$

No caso dos Kalapalo (e, até onde vejo, de todo o Alto Xingu), a dádiva desempenha um papel fundamental na produção da assimetria entre chefes e comuns - que é também uma questão cosmológica, como tenho insistido. As duas coisas são inseparáveis: para que haja um grupo de pessoas que se veem mutuamente como gente, é preciso chefes que são, ao mesmo tempo, provedores (de uns) e inimigos rituais (de outros); e a realização na prática de tal dualidade depende de uma sócio-lógica centrada na troca de dons. A participação diferenciada dos chefes nos circuitos de dádivas dos rituais regionais é uma questão ao mesmo tempo ontológica e política.

Nos grandes rituais de redistribuição, está em jogo a produção de um tipo de pessoa que não existe em outros contextos, o chefe acumulador-distribuidor. Este tampouco é um tipo de pessoa que pode se fazer sozinha, mas precisa ser ativamente produzida pelo grupo, por meio de uma lógica de endividamento mútuo (na qual a noção de "vergonha", ihütisu, 
desempenha um papel central): ao fazerem festa e trabalharem, as pessoas "deixam o dono com vergonha" e o obrigam a oferecer comida, o que "deixa as pessoas com vergonha" e realimenta o ciclo de obrigações recíprocas. É como se a tão falada generosidade do chefe não fosse espontânea, mas, pelo contrário, fosse preciso provocá-la com coisas que envergonhem (isto é, que endividem o dono da festa), e a dádiva é o meio para tanto. É preciso intencionalmente extrair a generosidade do chefe pela dádiva o que produz, ao mesmo tempo, a relação de assimetria entre ele e o grupo. Como diz Strathern (1992: 177), em uma economia do dom, os receptores são vistos como a causa da ação do doador, e a oferta de uma dádiva é uma forma de extrair algo de quem o recebe. Ao trabalharem para o dono da festa, os Kalapalo intencionalmente tentam extrair do chefe mais alimentos, ao mesmo tempo em que criam as condições para que ele possa dispor de grande quantidade de comida para os chefes convidados.

Formalmente, o dono da festa nunca dá nada para os trabalhadores, assim como as pessoas não trabalham diretamente para ele: chefes (o dono e os tajope) trocam entre si, enquanto os tajope trocam com os trabalhadores. Aqui, talvez o conceito de "eclipsamento" de Strathern (2006 [1988]) possa ser útil. Ele está relacionado à passagem de bens da esfera de sua produção para a de sua transação como dádivas. Considerando que a redistribuição de mercadorias em uma economia capitalista oculta o processo de alienação do trabalho, Strathern (ibid: 237) se pergunta se "a dádiva, uma apropriação de itens produzidos pelo trabalho doméstico, também oculta a natureza dessas relações produtivas".

Strathern (ibid: 234) deixa claro que o eclipsamento está longe da ideia de "alienação", pois esta supõe algo estranho às economias do dom: a possibilidade de separação completa entre um trabalhador e seu produto. Em sistemas não capitalistas, contudo, os produtos sempre permanecem indicativos de suas origens sociais (ibid: 235). Quando um homem melanésio se apropria de um porco produzido com o auxílio de sua esposa para colocá-lo em circulação no moka, ele faz sobressair apenas um elemento da relação de produção: o elemento masculino. Porém, isso não implica na alienação dos produtos domésticos para a troca nem na desvalorização do trabalho do casal, mas no ocultamento parcial e momentâneo das relações envolvidas na produção (inclusive a participação do homem no processo):

Homens e mulheres são ambos produtores; é no contexto retórico de valorizar as transações que os homens distinguem a transação "masculina" da produção 
"feminina", feminizando com isso seus próprios esforços produtivos. Eles eclipsam suas próprias atividades produtivas da mesma forma que as das mulheres. (ibid: 239; grifo no original).

O trabalho feminino e o trabalho criativo (masculino e feminino) de produzir porcos não são negados, mas plenamente reconhecidos (ibid: 240). “(..) Como num eclipse lunar” diz Strathern - "para que os efeitos sejam registrados, é preciso que haja um encobrimento apenas parcial, e não uma obliteração" (ibid: 241). O reconhecimento das relações domésticas de produção se dá não no momento da doação, mas da recepção de outro porco. Quando um homem recebe de volta um porco como retribuição a seu investimento anterior, ele e sua mulher o comem, e o fazem porque aquele porco está ali para saldar uma dívida não apenas ao homem enquanto trocado, mas ao casal enquanto produtores. "Qualquer que tenha sido o trabalho envolvido na produção dos porcos, outros não podem apropriar-se dele como trabalho; estes recebem a dádiva como uma dívida a ser paga" (ibid: 240). O marido continua obrigado a devolver à sua esposa a parte que lhe cabe, seja sob a forma de carne de porco ou sob a forma de um porco vivo.

A produção de porcos para serem trocados resulta de uma série de relações de troca (não mediadas) entre marido e mulher: a mulher alimenta o porco com comida cultivada na terra do clã do marido, preparada por ele e semeada por ela, de modo que não há nada que dê a um ou outro a "propriedade" exclusiva sobre o porco. Uma relação desse tipo só é reivindicada pelo marido perante outros agentes equivalentes (outros maridos), na esfera da troca cerimonial (ibid: 251). Ao usar um porco para a troca, um homem produz uma imagem sobre si mesmo na intenção de extrair outro porco de outro homem que realizará um procedimento semelhante. Eclipsar uma relação de produção é uma operação que os homens realizam sobre si mesmos, remodelando suas qualidades visíveis (ibid: 255).

Assim como o eclipsamento descreve a passagem de objetos da esfera da produção para a da circulação, ele ocorre na passagem de um modo de relação associado à primeira a outro associado à segunda. Segundo Strathern (ibid: 270-271), haveria dois modos de relação de troca: relações mediada e relações não mediadas. As primeiras são aquelas nas quais as pessoas se relacionam por meio da circulação de bens, criando uma mútua vinculação. Tais bens não são objetos no sentido ocidental, mas são partes de pessoas que elas são capazes de destacar de si mesmas em seu relacionamento com as outras (ibid: 289). Como nota a autora, 
estas partes não são apreendidas como "representantes" de pessoas, mas "são apreendidos como extraídos de alguém e absorvidos por outrem" (ibid: 270), criando uma distinção entre doadores e receptores pela maneira com que são extraídos de um e apropriados por outro. As trocas mediadas, assim, qualificam o processo de transação.

Já as relações não mediadas qualificam o trabalho de produção. As pessoas não se afetam umas às outras por meio de "partes" que circulam, mas o fazem diretamente como, por exemplo, no trabalho mútuo dos cônjuges. Suas relações não são produzidas pela circulação de coisas, mas são tornadas visíveis por aquilo que produzem: alimento, filhos, etc. A ausência de objetos que circulam pode criar uma imagem distinta daquela reproduzida a partir da visão maussiana sobre a troca, mas mesmo nesses casos, as relações assumem "a forma de uma 'troca', na medida em que cada pessoa é afetada pela outra” (ibid: 271). Todos os tipos de troca na Melanésia operam no contexto de um único sistema conceitual (uma certa forma de conceber as relações entre pessoas e coisas) e, por isso, não pode haver algumas relações que são "de dádiva" e outras que não são: "o modo não mediado retira sua força da presença do modo mediado, e vice-versa" (id. ibid.: 271).

Assim, no processo que transforma bens produzidos por relações não mediadas em objetos de relações mediadas "as relações sociais são alternadamente eclipsadas e reveladas, mas a ocultação parcial resultante faz um drama de sua visibilidade potencial" (ibid.: 257). Se olharmos para a forma das relações de troca nos rituais de acumulação, veremos que há em jogo algo semelhante ao "eclipsamento" para que o dono do egitsü possa aparecer como um doador de alimentos, ao mesmo tempo aos olhos dos chefes convidados e de seus coaldeões.

Tratemos primeiro da festa do polvilho, que parece ser a que se aproxima mais do modelo melanésio, antes de passarmos às diferenças mais marcadas nas outras. $\mathrm{O}$ polvilho é um dos produtos obtidos no processamento da mandioca, uma atividade feminina por excelência (as mulheres são as responsáveis por colher, descascar e processar a mandioca). Mas a própria mandioca é o resultado da cooperação entre marido e esposa, cabendo ao homem escolher, preparar e plantar as roças onde sua esposa colherá mandioca. Essa relação de produção assume claramente um caráter semelhante às relações não mediadas descritas por Strathern, nas quais os agentes se afetam diretamente e suas relações são objetificadas sob a forma de bens - neste caso, polvilho. 
Parte considerável do polvilho produzido por cada casal no período que antecede a festa sai da esfera doméstica, onde seria consumido, e passa para uma esfera ritual na qual circula (com o objetivo de ser armazenado). Mas, para tanto, é preciso que haja canto e dança, uma incumbência masculina. É como se homens, sob a forma de cantores e dançarinos, e mulheres, sob a forma de produtoras de polvilho, entrassem em uma nova relação não mediada de "produção", pois o polvilho que circula publicamente (um polvilho diferente daquele que se consome em casa) só é produzido pelo coletivo de mulheres quando o coletivo de homens desempenha seu "trabalho" ritual. Isto é uma especificidade da dádiva altoxinguana em relação à melanésia, pois aqui a transformação de um produto em objeto de circulação depende da criação de uma esfera parecida com a doméstica (marcada por relações não mediadas) em nova escala (uma escala coletiva). Ao invés de o produto de uma relação não mediada de sexo cruzado ser logo transposto para uma relação mediada entre pessoas de mesmo sexo, para que ele possa parecer um produto coletivo, é preciso criar novas relações não mediadas de sexo-cruzado no plano ritual.

Os primeiros receptores desse polvilho (assim como de qualquer outro alimento) são os tajope. Eles são os responsáveis por reunir o polvilho, construir o silo no qual ele será armazenado (o que fazem sem a ajuda de outras pessoas, a não ser filhos ou genros) e finalmente entregá-lo ao dono do egitsü. Ao entregarem polvilho reunido e armazenado ao dono da festa, os tajope se apresentam como chefes (substitutos de um coletivo) doadores perante outro chefe receptor (o dono). Neste movimento, os tajope agem como os maridos em Hagen: eles são os "representantes" da comunidade masculina e, ao receberem o produto das relações de produção doméstica (cultivo e colheita de mandioca) e pública (preparação de polvilho para o ritual), eclipsam as relações que o produziram.

"Eclipse" é um termo apropriado porque as relações de produção não são negadas, mas tornadas visíveis pelas contraprestações que os tajope distribuem às trabalhadoras e aos dançarinos e cantores. A cada etapa do trabalho, os tajope recebem alimento do dono e os dividem com os trabalhadores. Por um ângulo, podemos ver todas essas trocas como relações mediadas por alimentos: o polvilho produzido por homens e mulheres passa para os tajope, que repassam às pessoas o peixe, beiju e mingau recebido dos donos. Nas contraprestações do dono, o trabalho de cada um é levado em conta. Outro ponto que favorece a imagem de que, na entrega do polvilho armazenado, apenas os tajope e o dono da festa são os reais parceiros de troca, é a relação dos primeiros com o mingau de pequi: o mingau recebido do dono é seu, 
e sua redistribuição é outra dádiva - tanto que no momento da distribuição o dono sai de cena, se recolhendo novamente para sua casa. Ainda, o alimento entregue aos tajope é "pagamento", hipügü, que se torna endu no momento de sua distribuição, quando entra em outro circuito. Os tajope e o dono são os únicos que conseguem provocar efeitos nas pessoas por meio da dádiva: os primeiros são capazes de extrair produtos tanto dos trabalhadores quanto do dono, e este, a seu turno, consegue extrair produtos dos tajope.

Processos semelhantes ocorrem no núcleo da família do morto, para que o dono possa se apresentar em público como doador de alimento. O dono não só eclipsa o trabalho feminino como o trabalho de seus outros parentes masculinos. O coletivo de homens "donos" (cinco, se houver apenas um morto importante) é sempre suplantado nessas ocasiões por um único homem, que chama os tajope e lhes paga publicamente. Em alguns egitsü que presenciei, patrocinados por homens muito jovens, eles sempre recorreram a parentes mais importantes que pudessem aparecer em público nessas ocasiões (em 2010 os dois donos trouxeram, cada um, um parente importante da aldeia Tankgugu para lhes “ajudar" - isto é, ocuparem a posição pública mais importante).

$\mathrm{Na}$ festa do pequi há uma diferença nas relações objetivadas. Diferentemente do polvilho, que é o produto do trabalho de um casal, o pequi pode ser visto como a objetivação das relações das mulheres com seus pais e avôs. Todo pequizal tem um dono ou, mais frequentemente, uma dona; mas plantar pequi é uma tarefa masculina, que os homens fazem "pensando em suas filhas, pensando em suas netas", como dizem, para que elas tenham pequi para colher no futuro. Apesar de uma relação como essa não parecer do mesmo tipo que a cooperação entre um marido e uma esposa, ela também assume a forma da troca porque "uma pessoa afeta diretamente a disposição de outra em relação a si própria" (Strathern, 2006 [1988]: 271) - como no exemplo dado por Strathern da mãe que faz o bebê crescer dentro de si, enquanto a criança também “faz crescer" a mãe (id. ibid.). Um pai, quando planta pés de pequi para suas filhas, é feito agir como pai pela antecipação das relações delas com a fruta nos mantemos no universo da troca não mediada.

Na festa para juntar pequi, mais uma vez, como na festa do polvilho, antes da oferta do alimento ao dono há uma etapa de troca não mediada entre homens e mulheres no plano coletivo, que trabalham para o cozimento do pequi e a separação de sua polpa: os homens pegam lenha e realizam as performances músico-coreográficas que marcam o evento, enquanto as mulheres processam o pequi. Somente depois dessa etapa que os tajope (e, mais 
uma vez, somente eles, contando apenas com a ajuda de filhos ou genros) constroem os silos de armazenamento e os guardam para os donos.

As relações de troca entre os chefes ativos no ritual eclipsam momentaneamente as relações dos tajope com as pessoas comuns que, por sua vez, eclipsam relações domésticas de produção. É óbvio que, na prática, todos veem essas relações em cada transação (uma das premissas do conceito de eclipsamento), mas o ritual impõe uma forma que faz relações entre três termos (dono da festa, coordenadores e "o pessoal”) assumirem momentaneamente uma aparência diádica. $\mathrm{Na}$ passagem de um ternarismo a dois dualismos (donos/tajope; tajope/trabalhadores) uma relação é necessariamente englobada por outra, pois como comenta Gell (1999: 41), "the principle governing relations between relations is hierarchy". Tem-se então pelo menos quatro relações envolvidas, do mundo doméstico de homens e mulheres à praça exclusiva dos chefes masculinos e, a cada movimento nessa direção, uma relação é eclipsada: das mulheres com seus maridos (polvilho) ou pais/avôs masculinos (pequi); do coletivo de mulheres com o coletivo de homens; dos trabalhadores em geral com os tajope; e dos tajope com o dono (que, para aparecer como tal, também deve ter eclipsado as relações de produção de seus parentes próximos). O que as mulheres produzem em casa, por relações não mediadas entre pessoas de sexo oposto, elas devem processar em conjunto com outras mulheres e outros homens, da mesma maneira; por fim, todo o produto, a objetificação dessas duas relações, é transformado pelos tajope em objeto de troca em uma relação mediada entre pessoas de mesmo sexo.

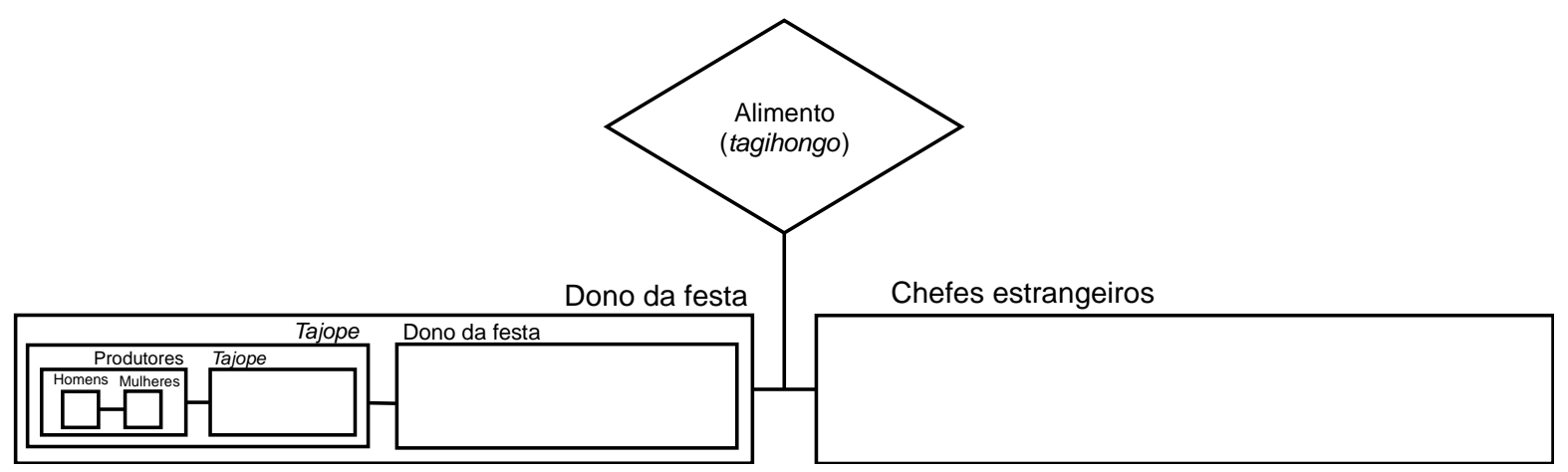

Figura 6.13: diagrama com as relações eclipsadas pelo dono da festa na entrega do alimento ritual aos chefes estrangeiros. 
A pescaria coletiva é a situação mais diferente, pois o peixe obtido é fruto do trabalho masculino e não carrega marcas do trabalho feminino, como o polvilho e o pequi. Apesar das mulheres irem em massa à pescaria coletiva, sua participação é pequena, ficando restrita à preparação de mingau a partir da massa de pequi fornecida pelo dono e ao preparo de peixe para consumo no local (já que o evento dura em média três dias - e deveria durar muito mais quando não havia transporte nem redes de pesca industrializadas). Mas isso não muda em nada a forma da reunião do alimento: os tajope pedem peixe aos pescadores, que os levam até eles; quando ninguém mais tiver nenhum peixe pra trazer, aí sim os donos os recebem e se responsabilizam por limpá-los e começar a moqueá-los, ainda no local.

O produto da pescaria não é o resultado exclusivo da ação dos homens, mas é a forma objetiva da relação entre os pescadores e o espírito dono/chefe dos peixes, por intermédio do dono da festa e dos xamãs. A relação com o espírito é ambígua, pois é preciso negociar com ele e agradá-lo para que autorize um "massacre" de seu povo. No amanhecer do segundo dia da pescaria, as mulheres da família do dono preparam uma grande panela com mingau de pimenta. Ela é levada para perto da beira do lago, para onde o dono se dirige e começa a falar com o espírito em um registro de fala que mistura elementos da forma como os pajés falam com estes seres e elementos da "conversa de chefes" (anetü itaginhu). No registro da fala dos pajés, ele pede que o espírito venha beber mingau, o que é dito por alguns pajés que se juntam ao redor do dono; no registro de fala do chefe, ele pede que ele não faça mal a seus netos. Em seguida, o dono da festa sobe em uma canoa com uma panela de mingau de pequi e percorre todo o lago, jogando mingau para o espírito e pedindo que ele venha bebê-lo.

Quando todo o mingau já foi jogado no lago, o dono retorna e é a hora de começar a puxar a rede que delimitará a região onde o timbó será usado. Essa rede só pode ser colocada por lutadores, pois eles estão confrontando os peixes (eles várias vezes emitem os gritos de “hi-ou!" usados no momento da apresentação dos campeões aos adversários). Antigamente, quando se usava uma rede de embira, havia cantos que "faziam os peixes morrer" (mas que hoje desapareceram, apenas um homem em Aiha conhece um desses cantos). Essa é a única situação em que uma pescaria se assemelha a uma guerra entre humanos e peixes, na qual seus campeões são vistos como guerreiros e seus cantos como armas letais; mas ela também é uma relação de troca mediada entre o dono da festa e dono/chefe dos peixes. Se o acordo entre o dono da festa, os xamãs e o dono/chefe dos peixes não for bem conduzido, e se os lutadores não fizerem seu papel, a pescaria será um fracasso. 
Enquanto nas festas do polvilho e do pequi produtos resultantes de trocas não mediadas entre homens e mulheres são transformados em objetos de trocas rituais pelo eclipsamento, na pescaria coletiva o produto de uma relação mediada entre homens (dono da festa e dono/chefe dos peixes) é transformado em objeto de novas trocas pela predação. $\mathrm{O}$ processo de captura dos peixes deve ser, ao mesmo tempo, um processo de transformação dos peixes em objeto da ação kalapalo. Como foi discutido no capítulo 3, os seres com a maior capacidade de se apresentarem como sujeitos em uma relação com outros são aqueles com capacidades predatórias. Ao aparecer como um predador para alguém, este último se torna sua presa e, logo, objeto de sua ação (Lima, 1996; 2005). Partindo da ideia de que os peixes também são gente, para transformá-los em objeto de troca, os Kalapalo precisam aparecer como predadores, o que fazem enviando seus campeões (suas "onças" e "sucuris") para capturá-los.

A relação entre o dono e os tajope também será eclipsada quando o alimento for oferecido aos convidados: quando os chefes estrangeiros recebem formalmente o tagihongo (alimento ritual) das mãos dos donos, após a luta, é como se todo o trabalho coletivo necessário para a produção e armazenamento ficasse parcialmente oculto no gesto do dono da festa. Aparentemente o tagihongo entregue pelos ex-mensageiros aos coordenadores convidados na ocasião de sua chegada seria diferente. De um lado, ele aparece como o dom de um ex-mensageiro para um chefe estrangeiro; mas, de outro, o doador explicita em seu discurso cerimonial (hagito itagimbakitoho) que aquele alimento não foi produzido por ele, quando diz: "ah, aquele que tem muita comida/ah aquele que está festejando" (ver capítulo 5). O dono da festa é quem "tem muita comida", sua família é que a produziu; o ex-mensageiro apenas a entrega.

No capítulo 3, argumentei que a relação de assimetria entre um dono/chefe e seus "filhos adotivos" só se realiza, se torna visível e eficaz, na relação do dono/chefe com outro sujeito equivalente (outro dono/chefe de fato ou em potencial). Pela análise dos rituais de acumulação, vimos que a produção de ambas estas relações depende da dádiva (os trabalhadores reúnem alimento que o chefe entregará aos chefes convidados). Mas qual o sentido de trocar comida por comida? O que se troca não é tão relevante aqui quanto a forma das relações: reunindo alimento, os trabalhadores e os tajope extraem do chefe a obrigação de alimentá-los e lhes dão a condição para alimentar os estrangeiros, criando ao mesmo tempo, a figura do chefe doador e do homem que personifica o grupo nas relações regionais. 
Sahlins (1972) argumenta que a imagem do chefe generoso seria uma ideologia, no sentido marxista do termo: ela obscureceria as relações reais por trás da suposta generosidade do chefe, somente viabilizada pelo fluxo de objetos e alimentos em direção a ele - isto é, a aparente generosidade não seria mais do que simples redistribuição. Discordo do uso de "ideologia" para descrever situações como desse tipo, pois o conceito implicaria na existência de alguma realidade objetiva "mascarada" pela noção de generosidade, enquanto não me parece haver nada mascarado aqui - lembrando novamente Strathern (2006 [1988]), eclipsar não é a mesma coisa que ocultar. Sempre se sabe o que está em jogo, as pessoas sabem que a diferença entre elas e o dono da festa é produzida por relações de troca que são, ao mesmo tempo, recíprocas e hierárquicas - como todas as relações mediadas em economias do dom. $\mathrm{O}$ uso da noção de vergonha deixa isso muito claro: dar envergonha (i.e., endivida) e obriga, e as distribuições de alimentos pelo dono da festa são vistas como pagamento. Ser generoso não é só dar involuntariamente, mas dar quando solicitado, provocado.

Assim como na Melanésia, entre os Kalapalo a dádiva também é a responsável pela identificação temporária entre um homem e um grupo, e o englobamento é produzido quando um termo de uma relação eclipsa o outro para participar de uma terceira relação (Gell, 1999). No caso do moka melanésio, um homem se apropria dos porcos criados por sua esposa para oferecê-los, como se fossem seus produtos, a outro homem. A cada passagem de uma relação de sexo-cruzado não mediada para uma relação mediada de mesmo sexo, ocorre um englobamento e, logo, uma mudança de escala. Algo semelhante acontece nos rituais kalapalo de acumulação: na passagem das trocas entre homens e mulheres, trabalhadores(as) e coordenadores, coordenadores e dono e, por fim, donos e chefes estrangeiros, há sempre um englobamento de uma relação por um termo, que se efetua pela apropriação do produto da relação englobada (alimento em seus diferentes estágios de preparação).

Estas são as formas sociológicas da coletivização na preparação do egitsü. Como mostra Strathern (2006 [1988]: 189), “a coletivização é efetuada por meio da associação daqueles do mesmo sexo" e esta seria a forma pela qual se alcança o efeito de "multiplicação" das pessoas e seu mútuo reconhecimento na imagem de outros semelhantes (id. ibid.). Por isso só tajope e dono trocam; é preciso eclipsar as relações produtivas masculinas e femininas para transformar seus produtos em objetos transacionáveis somente por homens ${ }^{19}$. O dono só

\footnotetext{
${ }^{19}$ No capítulo seguinte discutirei como o chefe morto participa desse processo de coletivização: para que ele seja capaz de unificar toda a humanidade xinguana momentaneamente em uma aldeia, ele precisa tornar visível um
} 
eclipsa os tajope no último dia do ritual e só aí ele aparece como um agente que eclipsa todos os demais. Isso porque "the external relationship unifies the internal lower-level groups in respect of one another" (Strathern, 1992: 183). Como em qualquer troca, é preciso no mínimo dois parceiros em potencial, cada um elicitando a transformação do outro em agente: “A collectivity or multiplicity of units can always be represented as a single unit, insofar as its unity is elicited in turn by other social identities" (id. ibid.; grifos meus). Esta forma única (um homem) não é uma peculiaridade da chefia, mas é a forma pela qual todo agente se apresenta em uma economia de dons, seja ele um agente singular ou coletivo: “(...) what people exchange is always a totality: one perspective for another; your view of my assets for my view of yours. Thus are persons and objects created. And thus the only possible quantity at issue is one" (ibid: 188).

Não se trata aqui de reduzir a chefia à dádiva, mas de elucidar os processos sociológicos pelos quais a dualidade interna à chefia, seu caráter paradoxal (protetor e predador, super-consanguíneo e afim potencial), opera nos rituais. É impossível separar os aspectos simbólicos dos aspectos econômicos que produzem a assimetria temporária entre o dono da festa e seus coaldeões. A forma assumida pelas dádivas de alimentos não são nem a solução para um problema utilitário, nem um mero "reflexo" de alguma assimetria anterior, uma eventual infraestrutura hierárquica da qual as trocas de alimentos seriam um fenômeno superestrutural. Ao contrário, são as próprias trocas que constituem a diferença entre dono, tajope e trabalhadores, e que viabilizam as relações dos chefes de uma aldeia com chefes estrangeiros. Os agentes envolvidos e os objetos que trocam não existem enquanto unidades ou termos fora dessas relações, mas resultam delas, de suas respectivas posições no sistema de dívidas/vergonha criado no ritual.

\subsection{Inimigos que trocam}

Já mencionei em vários momentos que os ex-mensageiros ficam obrigados a trocar presentes com os coordenadores (ugihongo) do povo que convidaram, e que eles se chamam

traço partilhado por todos; este traço é a consanguinidade, e sua forma visível é a da imagem feminina (por isso sua efígie imita a mãe dos gêmeos). O limite do englobamento é a consanguinidade feminina, que só se realiza após a morte, pois o reconhecimento da semelhança total inviabiliza os processos de diferenciação a partir dos quais os vivos produzem o parentesco. 
de "inimigos" ou "adversários" (imütongo). Essas trocas são as que mais se aproximam da imagem clássica de uma troca de dádivas: trocas aparentemente desinteressadas, marcadas pelas três obrigações de dar, receber e retribuir. Elas configuram um circuito restrito, pois idealmente, apenas chefes poderiam ser mensageiros ${ }^{20}$ (ver capítulo 5) e só se pode trocar objetos de grande valor. Não quaisquer objetos valiosos, mas idealmente apenas aqueles associados às identidades coletivas de cada povo, artigos de luxo dos quais são "donos", especialistas em sua produção. Assim, os Kalapalo só deveriam dar cintos ou colares de conchas; os Wauja, grandes cerâmicas ou arcos de madeira especial; os Kamayurá, donos do mesmo tipo de arco, também só deveriam oferecê-los; os Matipu, colares de conchas coloridas.

Caso não possua nada desse tipo, um ex-mensageiro ou coordenador pode fazer seu pagamento com alguns outros objetos. Em primeiro lugar, vêm os principais (e mais valiosos) enfeites corporais depois dos cintos e colares de conchas, que são as plumárias e, como se trata de chefes, colares de garras de onça e cintos ou coroas de couro desse animal. Dentre as plumárias, a mais valiosa e mais efetivamente posta em circulação nessas ocasiões é o kahokohugu (faixa frontal que cobre a coroa do cocar; é conhecido como tucanapi), feito com penas de tucano e de mutum. Além do valor intrínseco ao objeto como adorno corporal, ele também é valioso pela dificuldade de se obter o material para sua produção (para se fazer um kahokohugu apropriado, belo o suficiente, são necessários cerca de 30 tucanos). Em segundo lugar vêm objetos industrializados, como bicicletas, espingardas e grandes panelas de alumínio $^{21}$ (nada de objetos talokito, imprestáveis).

O fluxo de objetos é enorme. Um egitsü do qual participem todos os povos xinguanos, obrigatoriamente põe em circulação pelo menos 42 objetos da mais alta categoria de valor ${ }^{22}$, sem contar as trocas de todo o tipo em que a maioria das pessoas acaba se envolvendo. As trocas acontecem depois que o ritual termina e, na maioria das vezes, não se quitam imediatamente. Formalmente, quem precisa ter um objeto disponível para a troca são os

\footnotetext{
${ }^{20}$ Essa exclusividade parece ser ainda mais marcada entre os Wauja. Segundo Barcelos Neto (2008: 311), apenas pessoas que passaram pelos rituais pohoká (para furar as orelhas dos futuros chefes) e kaojatapá (para tatuar os braços de futuras mulheres chefe, uma exclusividade dos grupos arawak) podem assumir o papel de "dono do pagamento" e participar dessas trocas.

${ }^{21}$ Que em Canarana não custam menos de $\mathrm{R} \$ 400$. Dizem que antigamente os chefes também se presenteavam com espingardas.

${ }^{22}$ São 7 grupos (seriam oito, mas os Matipu e Nahukwa sempre participam das festas kalapalo como um só), cada um com três ugihongo e três ex-mensageiros trocando presentes (seis objetos circulando por grupo convidado, portanto). Barcelos Neto (2008: 312) estima em 70 o número de objetos que circulam nessas ocasiões.
} 
ugihongo dos convidados, que devem chamar os ex-mensageiros e entregar seus objetos. Já estes, nem sempre têm algo para pagar seus "inimigos" no ato e é normal que fiquem devendo. O pagamento pode ser feito em qualquer ocasião, mas não deve atrasar mais do que um ano (e de fato não me parece atrasar). A expectativa geral é que a dívida seja saldada na próxima estação seca, quando os parceiros de troca se encontrarem em outros rituais. Caso isso não aconteça, ninguém será cobrado (não é do feitio dos xinguanos), mas o exmensageiro se sentiria envergonhado. Apesar do caráter obrigatório, essas trocas não são desvinculadas de interesses utilitários: cada coordenador oferecerá um objeto do qual possa se desfazer e pelo qual possa pedir algo que precisa ou deseja. Muitos mensageiros vão a outras aldeias procurando algo específico e, se tiverem a oportunidade, negociarão com seus adversários o que irão trocar. Mas não necessariamente a negociação tem lugar nessa ocasião e os coordenadores são livres para levar o que quiserem - afinal, é deles a prerrogativa de dar primeiro.

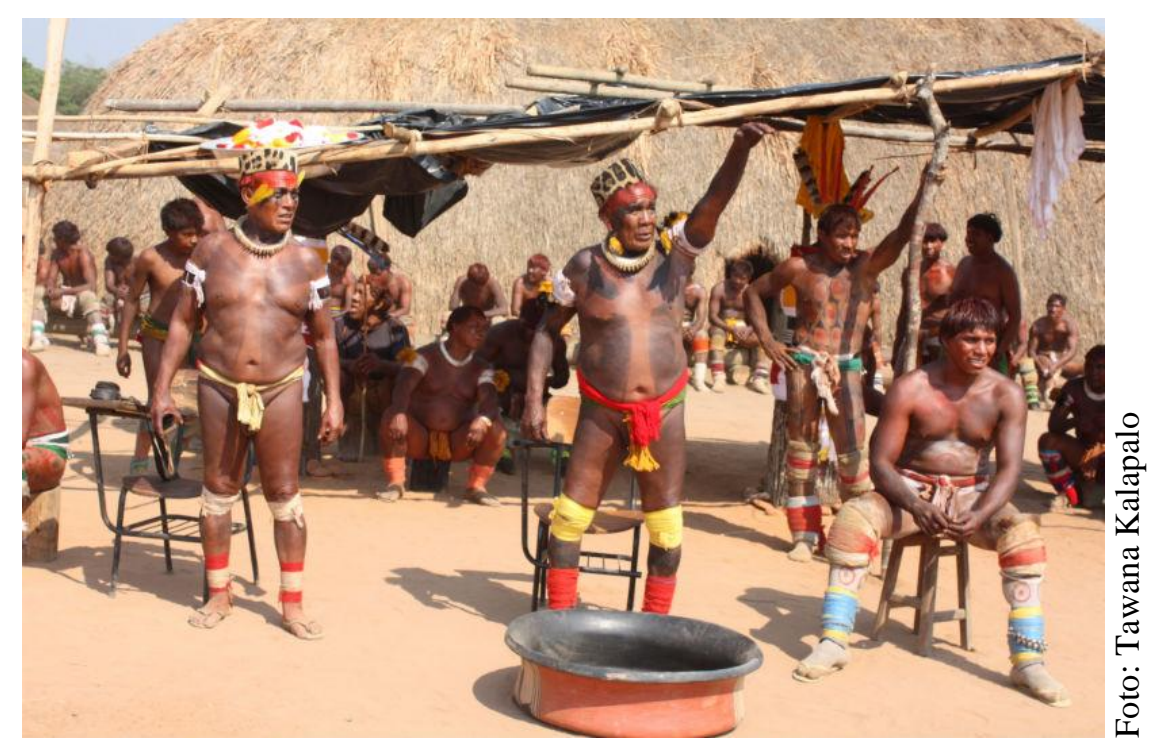

Figura 6.14: ugihongo mehinaku (aliados dos Kalapalo no egitsü de 2010) chamando seu "inimigo" para lhe entregar uma grande panela de cerâmica (especialidade produtiva arawak).

As trocas entre esses inimigos rituais, junto com as especialidades produtivas, constituem uma "esfera de troca" (Bohannan, 1959; Bohannan e Bohannan, 1968), isto é, uma esfera de circulação na qual apenas certos objetos de valor especial são considerados intercambiáveis: 
In calling these different areas of exchange spheres, we imply that each includes commodities that are not regarded as equivalent to those commodities in other spheres and hence in ordinary situations are not exchangeable. Each sphere is a different universe of objects. A different set of moral values and different behavior are to be found in each sphere. (Bohannan e Bohannan, 1968: 227-228)

Segundo Gregory (1994), isso estaria ligado à hierarquia (ranking) dos objetos de valor nas economias do dom. Um caso exemplar é o dos objetos trocados no kula trobriandês tal como descrito por Campbell (1983). A autora descreve cinco categorias nomeadas de braceletes que se distinguem por sua história, seu nome, cor e tamanho, e os colares seriam diferenciados segundo os mesmos princípios. Consequentemente, braceletes da mais alta categoria só são trocados por colares da categoria equivalente, e assim por diante. Não entram em jogo nessas trocas questões de quantidade, mas de qualidade (Gregory, 1994: 918), além da política das quais geralmente fazem parte: "the ranking of gifts is a serious matter of politics rather than a mere game" (ibid: 919).

As trocas entre ex-mensageiros e coordenadores são feitas dois a dois e são "equilibradas", troca-se artigos equivalentes na hierarquia de valores dos objetos. Mesmo assim elas têm um potencial agonístico latente que eventualmente pode se manifestar, deixando mais claro porque esses agentes se tratam como "inimigos". Em 2007 fui a um hagaka na aldeia kuikuro Ipatse, no qual o principal ugihongo kalapalo era o filho mais novo do chefe Ageu. Como o rapaz ainda era muito jovem e não sabe nada dos discursos rituais, Ageu é quem desempenhou de fato as funções de coordenador, apesar de seu filho ter "se sentado" e sido visto como ugihongo. Isso significa que Ageu também era o responsável por trocar com o ex-mensageiro kuikuro. Quando os Kalapalo chegaram em Ipatse pelo caminho principal, Ageu carregava um cabo de madeira comprido no qual estavam amarrados vários colares de conchas. Ele não soltou esse cabo de madeira um segundo sequer e dançou com ele no dia da chegada (no "ensaio") e no dia da festa. 


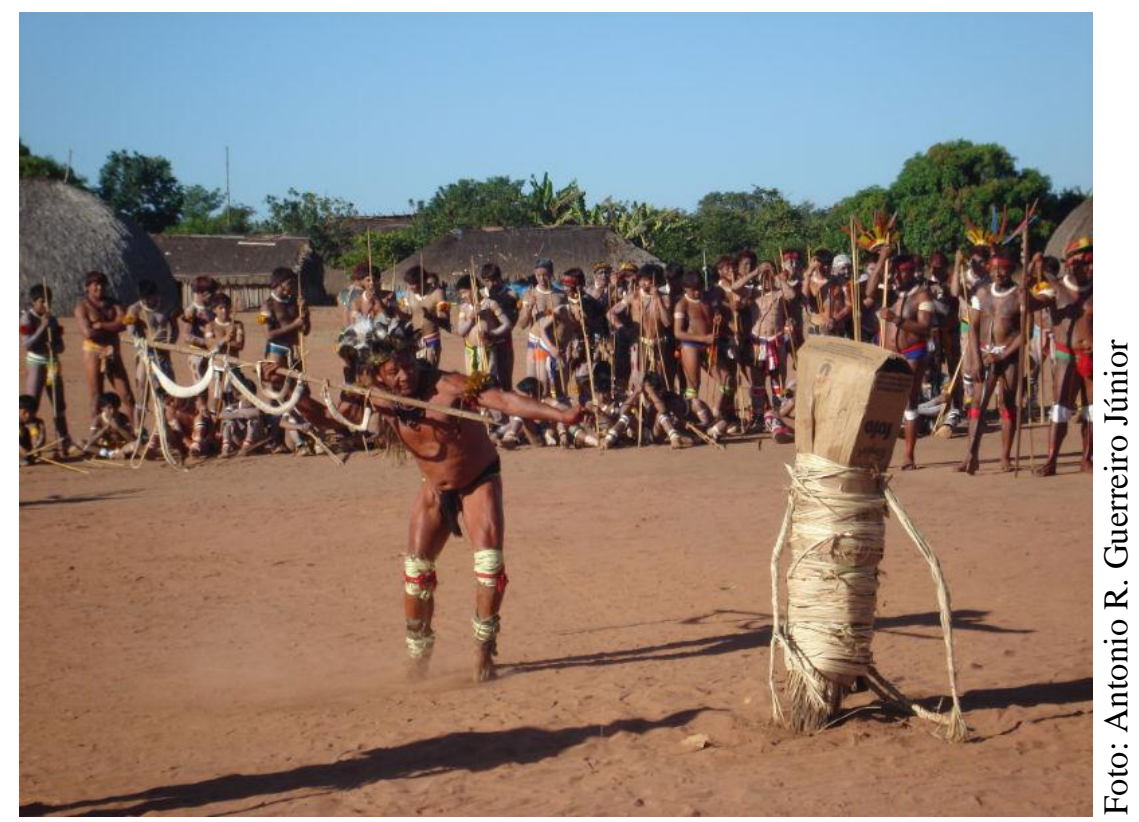

Figura 6.15: pai de ugihongo kalapalo exibindo sua riqueza durante o hagaka (vejam os colares pendurados em sua "lança").

Eu não vi mais ninguém exibindo objetos e fui perguntar por que ele estava fazendo aquilo: ele queria mostrar para seu adversário (o ex-mensageiro kuikuro) como ele era um homem muito rico. A troca entre ele e seu adversário assumiu uma certa "aura" de potlatch: Ageu não queria apenas trocar, mas exibir sua riqueza e envergonhar seu adversário. Diante de tantos objetos valiosos, seria humilhante se o ex-mensageiro não dispusesse de nada equivalente para oferecer. Uma exibição desse tipo só deve ter acontecido porque se tratava do hagaka, um ritual tratado explicitamente como "guerra" (mais do que o egitsü) e temido pelos jovens por sua violência, mas penso que é tudo uma questão de grau: essa competitividade também está lá no egitsü, e talvez só não tenha a oportunidade de vir à tona pela seriedade do evento.

Apesar da possibilidade de entrada de objetos industrializados e da escassez de coisas de valor, nos egitsü que presenciei todos os ex-mensageiros kalapalo receberam objetos tradicionais de seus "inimigos". Dizem que um povo como os Yawalapíti, que não tem nenhuma especialidade produtiva, oferecia objetos dos brancos na época em que eles eram seus principais intermediários e podiam obtê-los com facilidade, mas hoje procuram cerâmicas junto a seus parentes arawak, cintos e colares com seus parentes kuikuro ou arcos com seus parentes kamayurá. Os Aweti, que também não possuem nenhuma especialidade 
"tradicional", têm levado muito sal para trocar nas festas, objeto do qual acabaram se tornando donos mais recentemente por produzirem-no em quantidade (Figueiredo, 2010: 104105). Ou seja, privilegia-se objetos associados às identidades grupais e, depois deles, objetos de grande valor como plumárias ou enfeites de onça - objetos não indígenas vem em último lugar nessa escala.

A versão mais comum sobre como os povos adquiriram suas especialidades produtivas é a de que Taũgi e Aulukumã as teriam distribuído, dizendo que os alto-xinguanos deveriam trocar seus objetos em suas festas ao invés de guerrear ${ }^{23}$. Outra, diz que o responsável por essa distribuição teria sido Janama, primo cruzado mais velho dos gêmeos. De qualquer maneira, a dádiva entre chefes está nas origens do sistema alto-xinguano e, assim como os rituais regionais, também é vista como um substituto da guerra. Como já chamei a atenção, isso não necessariamente significa que a troca se oponha à guerra. No clássico Guerra e comércio entre os índios da América do Sul, cujas primeiras páginas são em boa parte dedicadas ao Alto Xingu, Lévi-Strauss (1943: 127) sugere que "les oppositions guerrières ne sont que la contrepartie de relation positives, et que celles-ci présentent un caractère à la fois économique et social”. As "oposições guerreiras" das quais Lévi-Strauss fala são as tensões ao mesmo tempo expressas e limitadas pela luta xinguana, e as "relações positivas" são as trocas de especialidades produtivas. Ele conclui o texto dizendo que “(...) les conflits guerriers et les échanges économiques ne constituent pas seulement, en Amérique du Sud, deux types de relations coexistantes, mais plutôt les deux aspects, opposés et indissolubles, d'un seul et même processus social" (ibid: 138; grifos meus).

Se troca e guerra podem ser vistas como diferentes aspectos de uma mesma relação, isso significa que a troca pode fazer, de uma maneira própria, algo que a guerra faz ao seu modo. Gow (2002: 162) argumenta que guerra e troca acabaram se transformando em formas antagônicas de relação na antropologia, em parte, pela forma como foram tratadas por Sahlins (1972) em sua sociologia primitiva. Essas relações se tornaram os polos de uma escala que ia da "reciprocidade generalizada" (no campo do parentesco) à "reciprocidade negativa" (a guerra). Nesse processo, "Lévi-Strauss's key insight, that trade and war are at some level the same thing in indigenous Amazonia, was unfortunately lost within this concern for reciprocity" (Gow, 2002: 162).

\footnotetext{
${ }^{23}$ Os caracóis dos quais os Kalapalo produzem cintos e colares foram feitos da mama direita de Taũgi e de sua mama esquerda saíram os caramujos usados pelos Matipu para a fabricação de colares.
} 
Os Piro e os Apurinã (arawak do Peru) são um bom exemplo de como estas podem ser de fato duas modalidade de uma mesma relação. Gow (ibid: 162-163) escreve que as principais diferenças na forma pela qual os Piro e os Apurinã se relacionavam com seus vizinhos na segunda metade do século XIX é que os primeiros preferiam o comércio, e os segundos, a guerra. Ele observa que, apesar da aparente diferença radical, esses dois modos de relação seriam análogos e suas semelhanças teriam sido mascaradas pela lógica do pensamento ocidental:

Because the Piro preferred to trade with their neighbours, their 'foreign policy' seems to us more social than that of the Apurinã, who preferred to raid theirs. Here, the profound analogies of Piro and Apurinã 'foreign policies' are masked under an alien logic that equates positive reciprocity and the social (id. ibid.).

Retomando argumentos de Viveiros de Castro (1993), Gow lembra que os povos amazônicos não se constituem enquanto unidades a priori que, enquanto tais, entrariam em relação com outras unidades equivalentes. Segundo o autor, “(...) the key relation to distant and often hostile others that exists before and above the constitution of the local social order and gives the later its form. (...) It is the global relation to the other that constitutes the self" (Gow, 2002: 163). A forma geral dessa relação seria uma economia simbólica da predação, na qual "predation-prey relations are the cosmological model of all social relations" (id. ibid.). O autor aplica essa lógica às trocas dos Piro com seus vizinhos Campa e Conibo. Os Piro consideram que tudo o que seus vizinhos conhecem ou produzem é de melhor qualidade, e que eles precisam entrar em relação com eles para obter o que consideram adequado para a produção de sua vida. À primeira vista, seria possível pensar esses grupos como povos independentes uns dos outros que poderiam ou não entrar em relação, ou como partes de um todo maior, integrado por alguma forma de divisão do trabalho. Mas o argumento de Gow é que "(...) it is the fact that the Campa and Conibo exist as trade partners that constitutes the Piro, and reciprocally" (id. ibid.). O autor vai adiante, afirmando que a forma como os Piro concebem a troca é semelhante a uma relação entre predador e presa, pois veem seus vizinhos como uma espécie de fonte de recursos para a produção de sua vida social: "From this point of view, therefore, interethnic trading in southeastern Peru does not take the form of an organic regional division of labor, but rather a series of predatory relations on the specialist knowledges of neighboring peoples" (ibid: 163-164). 
A predação seria o modelo da relação global de diferença a partir da qual as identidades podem se constituir (Gow, 2002; Viveiros de Castro, 2002c). A pertinência desse modelo é mais evidente entre povos que conferem à guerra um lugar importante, como o caso dos Apurinã descrito por Gow, mas é mais obscura quando se considera povos que escolheram a troca para se relacionar com os outros. Quando se leva em consideração o papel que as trocas têm na produção (ou objetificação, se preferirmos) de relações de diferença, é possível perceber analogias entre modos de relação aparentemente incompatíveis.

Concordo com o argumento de Gow, mas é preciso notar que a relação predadorpresa, enquanto o modelo cosmológico de todas as relações sociais, tem uma forma peculiar de se atualizar no Alto Xingu. Aqui, ela também é o pano de fundo lógico por trás de qualquer relação: vê-se como sujeito quem assume a posição de predador. Tal ideia está por trás dos encontros rituais entre diferentes povos, pois, caso contrário, não haveria motivo para os chefes se apresentarem como predadores. Mas a especificidade xinguana é que os chefes estão mais para "anti-presas" do que para predadores de fato. Na atualização da relação virtual de predador-presa, os chefes, quando competem, talvez se vejam sob esta ótica, mas a forma dos cumprimentos de chegada e despedida e toda a etiqueta ritual em geral, são esforços no sentido de fazer das relações entre grupos (chefes) relações do tipo "predador-predador". Apesar de estar virtualmente dada em qualquer relação, a posição de presa é intencionalmente obviada na produção de grupos autônomos que não guerreiam entre si. É a mesma lógica da predação que instaura uma relação de diferença a partir da qual as unidades do sistema começam a se constituir, mas na condição de que cada unidade (podemos dizer "povo", mas na prática deveríamos dizer chefes) se apresente como predador e ninguém seja presa de ninguém. É, ao mesmo tempo, uma questão de autonomia e pacifismo: só a relação simétrica entre predadores pode produzir e manter relações de diferença entre coletivos, impedir o englobamento de um povo por outro e, ainda, viabilizar a produção da polity xinguana.

Há uma diferença crucial entre a forma como a relação entre guerra e troca é pensada pela filosofia política ocidental e pela filosofia política xinguana. Do ponto de vista moderno, a supressão do estado de guerra e competição para o qual tenderia naturalmente o homem só seria possível pela criação do Estado e do comércio: com alguém para defender a propriedade privada, as relações sociais poderiam se basear na troca justa (Macpherson, 1962). O ponto de vista xinguano é radicalmente diferente. Primeiro porque a troca é que está associada à competição, seja porque ela é conduzida por "inimigos" em rituais cujo foco é esportivo, seja 
porque ela tem uma tendência agonística apenas parcialmente suprimida pela etiqueta dos encontros. Segundo, porque a troca não promove uma articulação orgânica de unidades previamente existentes (os indivíduos da teoria liberal do Estado), mas cria tais unidades a partir de relações de diferenciação mediadas por objetos. Idealmente só se trocam especialidades e não qualquer artigo de valor, porque a intenção dos trocadores é materializar seu grupo sob a forma de um objeto, marcando diferenças entre os trocadores. Mais do que marcar, a troca instaura tais diferenças. A prática do egitsü define a extensão da humanidade xinguana, e as trocas de objetos emblemáticos são uma das formas pelas quais os chefes tiram seus coletivos desta situação de indiferença no seio de uma humanidade genérica, reencenando o processo mítico de instauração das diferenças que permitem a retomada do processo do parentesco (Coelho de Souza, 2002: 637). Assim como a guerra, a dádiva apresenta uma capacidade diferenciante.

$$
* * *
$$

A dádiva no egitsü pode ser então, classificada em pelo menos dois tipos: as trocas de alimentos, ligadas à produção assimétrica da identidade coletiva no contexto do ritual; e as trocas de objetos de luxo, que atuam na diferenciação simétrica entre os povos. E o que acontece quando dinheiro e mercadorias entram nesses circuitos? Convidados para assistir às festas, os kagaiha acabam entrando na política do ritual como aliados privilegiados de certos agentes e fonte de recursos (materiais e imateriais), cuja partilha com a "comunidade" pode aguçar ou criar tensões envolvendo sobretudo os chefes.

\section{4 "Aqui está parecendo um aeroporto": os brancos nos rituais}

Já mencionei na introdução desta tese que os rituais regionais, principalmente o egitsü, se tornaram uma forma peculiar de relacionamento com os kagaiha. Desde a criação do PIX, pelo menos, os não índios têm sido incorporados a esses rituais de formas variadas: como turistas, convidados de honra, parceiros comerciais, aliados políticos e alguns inclusive, como "homenageados". Hoje ninguém pensa em fazer uma festa sem brancos e, mais ainda, muitas 
vezes os brancos são usados como pretexto para se fazer festas que, em outras condições, não seriam feitas (ou pelo menos não tão cedo). Com essa incorporação dos brancos no processo, os dois últimos dias do egitsü (os dias da produção da efígie e das lutas) acabaram se transformando no "emblema" mundialmente conhecido deste ritual e o que é o final de um longo ciclo foi fetichizado sob o nome aportuguesado "Quarup".

Para os Kalapalo, a participação de brancos nos rituais cria espaços de negociação e possibilidades de construção de alianças, e tem sido uma importante fonte de recursos ${ }^{24}$. Por meio de seus convidados, eles obtêm pagamentos em dinheiro, negociam presentes caros (já conseguiram um caminhão, dois motores de popa, rádios de comunicação, geradores e placas solares, por exemplo), apoio das prefeituras do entorno para projetos de agricultura e transporte, e criam as condições para que os brancos que frequentam suas festas se sintam à vontade para voltar à aldeia quando quiserem: seja para passear, fazer suas pesquisas, fotografar, filmar, etc - contanto que levem seus pagamentos e presentes. Mas dificilmente os brancos vão à aldeia por conta própria e em qualquer ocasião; eles precisam ser "levados", formalmente convidados em momentos nos quais as atividades coletivas estão aceleradas, isto é, durante as festas. Obviamente os Kalapalo conhecem o poder de atração de sua estética ritual e o usam conscientemente para "mostrar sua cultura" para os brancos (isto é, atraí-los intencionalmente $\left.{ }^{25}\right)$. E não é qualquer um que pode sair por aí arranjando brancos, isso é algo que cabe aos donos da festa ou ao "dono dos brancos", o relações públicas perante os kagaiha (discutirei essa posição adiante) - e a relação destes agentes com o coletivo e com os não índios e seus recursos pode ser uma grande fonte de complicações.

\section{$* * *$}

Há alguns anos, os Kalapalo andaram às voltas com a possibilidade de realizar um Quarup em homenagem ao falecido presidente Tancredo Neves, situação que trouxe à tona

\footnotetext{
${ }^{24}$ Os Kalapalo convenceram Ugise a patrocinar um hagaka para seu pai em 2012 porque, como ele mesmo disse, "a comunidade está precisando de muita coisa".

${ }^{25}$ Presenciei uma conversa no centro da aldeia sobre o crescente uso de roupas, na qual um jovem dizia que gostaria de voltar a andar apenas com enfeites. Logo depois de dizer isso ele completou: "Se ficarmos todos vestidos, perdermos nossas pinturas, os brancos não vão mais querer ver nossas festas". Certamente esse é um discurso exagerado e a primeira preocupação dos Kalapalo em uma situação dessas seria com a opinião de seus vizinhos, mas a fala do rapaz não deixa de mostrar o grau de consciência que eles têm do poder de sua estética ritual na atração dos brancos.
} 
questões relativas à política imbricada no sistema ritual. Pelo que sei, parentes do expresidente teriam pedido esta homenagem aos Kalapalo já há algum tempo, em $2006^{26}$. Naquele ano, aconteceu um Quarup em Aiha, mas parece que, por falta de tempo e pelo fato de uma rede de TV britânica estar filmando um reality show ${ }^{27}$ durante o evento, a homenagem não pôde acontecer. Em 2007, os Kalapalo não fizeram nenhum Quarup e, em 2008, os planos foram frustrados porque eles não conseguiram entrar em acordo com os interessados sobre os pagamentos e a compra de recursos para a festa (principalmente combustível e rolos de algodão).

No final daquele ano, porém, parecia estar tudo arranjado para que a homenagem ocorresse em 2009, durante um Quarup que seria realizado em Tankgugu em homenagem ao falecido neto, ainda bebê, de um dos chefes daquela aldeia ${ }^{28}$. Havia muitos rumores sobre esta festa e os Kalapalo estavam maravilhados com a quantidade de pessoas importantes que participariam do evento, a visibilidade que teriam na TV e nos jornais, com o dinheiro e os presentes que receberiam e com a fama que o dono do ritual ganharia em todo o Alto Xingu. Segundo um kalapalo que comentou o assunto comigo, "Os Kalapalo vão ficar muito mais famosos do que os Yawalapíti, vai ter muito mais autoridades que no Quarup do Orlando Villas Boas. Orlando era cacique pequeno, este que nós vamos homenagear é que era cacique de verdade, porque era um presidente do Brasil!".

Como tenho discutido, fama, grandeza e beleza são elementos centrais da política alto xinguana. Um chefe é considerado "grande" quando é amplamente visto como bom e generoso, e fica ainda "maior" quando seu nome se torna famoso, amplamente conhecido entre os estrangeiros (índios e kagaiha). Quem é homenageado em um ritual de nobreza contribui não só para sua própria grandeza (pois seu nome será lembrado durante muitas gerações), mas também para a fama dos patrocinadores (como fica claro na fala acima). Homenagear um grande chefe, ou uma grande autoridade, é um elemento importante do processo de produção dos chefes-patrocinadores vivos. Neste caso, a equiparação entre as

\footnotetext{
${ }^{26}$ Isto foi o que me disse um homem kalapalo que estava em Brasília mediando as relações com os interessados, mas que não soube me dar nomes. Segundo ele, certamente só um parente próximo poderia desejar a homenagem, mas quem - e porque - efetivamente estava programando a festa eu não saberia dizer - só imaginar.

${ }^{27}$ Voltarei a isso adiante.

${ }^{28}$ Um dos homens responsáveis por mediar as negociações com a família do homenageado estava diretamente interessado na possibilidade de obter ajuda dos parentes do ex-presidente na demarcação do território de um antigo grupo karib próximo dos Kalapalo, os Angaguhütü (os Naruvüte ou Anaravuto da literatura). O processo de demarcação foi concluído recentemente, em outubro de 2011.
} 
autoridades e os grandes chefes faz com que a sua atração para um Quarup, a incorporação dos brancos no ritual, tenha efeitos diretos sobre a política nativa. Patrocinar um grande ritual é uma grande fonte de fama e se o ritual for considerado um sucesso (tiver bons cantores, dançarinos animados, muitos expectadores e muita comida e bebida), o chefe-patrocinador será muito bem visto entre os demais, assim como sua aldeia. E então, um dos objetivos do ritual terá sido plenamente cumprido - produzir beleza e grandeza.

Isso ficou claro no hagaka que os Kalapalo organizaram para Orlando Villas Boas em 2011. Ouvi falar desse hagaka desde meados de 2010 e, naquele ano, seu idealizador me disse que teve essa ideia para "conseguir algumas coisas pra comunidade" (ele já teria negociado um motor 40HP, um barco e uma camionete com a família do homenageado). Passado algum tempo, já em 2011, ele me ligou para fazer o "convite formal” para o evento, pedindo que eu levasse 100 rolos de algodão, que seriam distribuídos aos convidados para fazerem seus cintos. Pelo que ele dizia, a festa teria uma proporção gigantesca:

Aqui vai ficar muito cheio, não vai ter lugar pra todo mundo direito, por isso você tem que decidir logo. Eu vou enviar convidadores pra todas as aldeias do Xingu, não só do Alto, mas vou convidar Ikpeng, Suyá, Kayabi, Juruna, e até os Kayapó! Virão o presidente da FUNAI, a família do Orlando, todos os prefeitos, fotógrafos, jornalistas, muita gente!

A lista ainda foi completada com os nomes de vários amigos pessoais que ele costuma levar às festas: fotógrafos, artistas plásticos, documentaristas e donos de lojas de artigos indígenas. Espantado com a proporção que a festa teria, exclamei ao telefone: "Nossa, a festa será enorme!", ao que ele replicou: "A festa vai ser muito grande, e eu também vou ficar grande. Eu vou ficar famoso, todo mundo vai saber meu nome no Xingu, no Brasil e no mundo!”.

Voltando à homenagem de Tancredo. O Quarup de Tankgugu, em 2009, aconteceu, mas sem a homenagem ao ex-presidente, pois a entrada de não índios no Xingu havia sido vetada para evitar uma possível epidemia de gripe A H1N1. Contudo, a possibilidade de que a homenagem acontecesse fez com que a organização deste ritual se tornasse palco de disputas envolvendo os chefes das duas maiores aldeias kalapalo e outra pequena aldeia, criada na virada de 2007 para 2008. Antes de mais nada, é preciso entender o contexto político de Tankgugu. Na época, um dos chefes principais ocupava também a posição de "dono do 
branco" (kagaiha oto, o responsável por intermediar o contato - abordarei este tipo de agente com mais detalhes adiante) e vinha sendo constantemente acusado de se apropriar do dinheiro destinado para a comunidade. Ele também já não residia mais em tempo integral na aldeia, como se espera de um chefe importante e, do ponto de vista de algumas pessoas, o exercício da chefia tradicional havia se tornado inviável para ele.

Nesse contexto, seu irmão começou a ascender e muitos rumores começaram a circular. Já em 2007 vinham me dizendo que lá estava "uma confusão", pois o "terceiro cacique" estaria assumindo a posição de "primeiro". Este tipo de coisa é sempre motivo de discussões e preocupações, pois os Kalapalo definitivamente não gostam da ideia de que uma aldeia tenha mais de um anetü "muito grande". Sempre há vários anetü em cada aldeia, mas apenas um pode ser o "primeiro", caso contrário as disputas e "mentiras" podem correr soltas e fazer a aldeia se dividir.

O chefe em ascensão do qual falei é que se tornaria o dono do Quarup de 2009. O fato deste chefe fazer questão de realizar a festa em sua aldeia, e não em Aiha, foi um ponto importante de disputas. A grande maioria dos Quarup kalapalo acontece em Aiha, considerada a principal aldeia kalapalo (iho, esteio, das demais) e, até então, apenas um ou dois Quarup haviam ocorrido fora (segundo me disseram em Aiha). Como venho argumentando, é muito importante para um grupo alto-xinguano ter seus nobres enterrados e homenageados em sua própria aldeia, pois o patrocínio da festa é parte da produção dos parentes do morto como seus substitutos e desempenha um papel na produção da memória sobre um lugar (apenas lugares onde há chefes enterrados são lembrados como "aldeias de verdade"). Os moradores de Aiha estavam inconformados com a realização de uma festa de tal magnitude em uma aldeia considerada "periférica”. Realizando um Quarup de forma autônoma, o chefe em ascensão não só dava um passo importante para legitimar sua posição em um contexto tenso, como afirmava a independência ritual de sua aldeia. Isso incomoda Aiha, pois a outra aldeia só cresceu após uma grande divisão ligada a uma acusação de feitiçaria, e a parentela de chefes que se mudou para lá é considerada por muitos como mehinaku (e, logo, inapta para a chefia kalapalo). Apesar disso, eles agora "competem" com Aiha por convidados indígenas $e$ não indígenas.

Muitos dos argumentos contrários à festa evocados em público pelos moradores de Aiha se referiam à distância daquela aldeia, que poderia dificultar ou impedir a viagem dos convidados indígenas, ao seu tamanho (é uma aldeia pequena, com pouco mais de 100 
pessoas) e à sua "falta de beleza" (do ponto de vista de alguns). Mas, em particular, não foram poucas as vezes que ouvi queixas de jovens ou lideranças mais velhas de Aiha sobre os chefes da outra aldeia não quererem dividir "seus caraíbas" com Aiha. Com isso, queriam dizer que Aiha não receberia os dividendos da relação com estas pessoas: compra de artesanato, presentes e pagamentos pela estadia na aldeia, alianças para possíveis projetos, ajuda no patrocínio de festas no futuro. As pessoas em geral, diziam que não iriam comparecer ao ritual de forma alguma (uma grande desfeita), e o chefe principal de Aiha deu início a uma verdadeira campanha para convencer os chefes de outros povos a não irem à festa caso ela não fosse feita em Aiha.

Ao mesmo tempo, o chefe de uma outra aldeia kalapalo criada recentemente participou duplamente da disputa, se posicionando contra Aiha (de onde havia saído) e a favor do chefe de Tankgugu (seu primo cruzado e aliado político). Ele se posicionou contra Aiha, onde antes desempenhava a função de "dono dos brancos", a fim de levar seus aliados kagaiha exclusivamente para a outra aldeia, no intuito de não "dividi-los" com Aiha e contribuir para o prestígio de seu primo. Como ele mesmo me disse: "Eu não vou levar meus amigos lá pro Kalapalo [leia-se Aiha] não. Eu consegui tudo pra eles, professor, antropólogo, caminhão, trator, barco, motor, mas eles não gostaram, não sei porquê. Eles me expulsaram. Tem que fazer o Quarup lá na aldeia do meu primo”. Um jovem de Aiha me disse algo no mesmo sentido: "Aquele homem não quer que a festa seja no Kalapalo [Aiha]. Ele quer fazer a festa naquela aldeia porque ele só quer levar os amigos dele pra lá”.

E isso não se resumia à essa festa. Quando se mudou, ele disse que levaria todos os brancos de Aiha para sua aldeia, e ele tem se esforçado para fazer isso. Em 2011 ele se envolveu em outra tensão em torno de um Quarup. Seu pai, um homem jagamü já muito idoso, faleceu no começo do ano. Ele não era anetü, mas foi casado com uma importante itankgo kalapalo, falecida já há muitos anos. Fiquei sabendo da história por acaso: quando eu conversava com uma idosa sobre este homem ela me disse que ele havia morrido. Ela também me contou que seu filho levara o corpo para ser enterrado em uma aldeia próxima, onde já está se formando uma praça, e que ele próprio havia anunciado que faria um Quarup lá para seu pai em 2012. "E você vai?", perguntei ao pressentir que havia algo estranho em seu tom de voz; "Não, por que eu iria? Lá não é uma aldeia de verdade, e ele não era chefe. Ele está fazendo isso pros brancos, só pra conseguir dinheiro". Quando toquei no assunto com outras pessoas, todos manifestaram a mesma opinião, de que seria um Quarup "de mentira" para 
atrair brancos e conseguir dinheiro, e alguns repetiram a ideia de que não se poderia fazer um Quarup naquela aldeia, já que ela não era uma "aldeia de verdade".

Essas situações mostram que o local de realização de um ritual e os aliados não índios que o acompanham podem se tornar objetos de disputa, envolvendo o faccionalismo entre os chefes, o controle de aliados e seus recursos, e o prestígio regional das aldeias. No caso do Quarup de Tancredo, que não aconteceu, as possibilidades de aliança com autoridades e seus benefícios potenciais (tanto materiais quanto políticos e simbólicos) colocaram em jogo a hierarquia entre os chefes da aldeia anfitriã e entre as próprias aldeias; no caso do Quarup em planejamento para o jagamü falecido, os brancos aparecem como único motivo do ritual, o que parece incomodar os moradores de Aiha. Por trás de um ritual que muitas vezes tende a ser lido na chave da "comemoração" de um "sentimento de unidade" (Junqueira e Vitti, 2009), há complexas redes de alianças e conflitos (Harrison, 1992) subestimadas nas etnografias.

\subsubsection{Os brancos também precisam de um dono}

Barcelos Neto $(2003 ; 2008)$ conta uma história interessante sobre os Wauja. Um homem que era o responsável pelas relações com os brancos na aldeia Piyulaga (seu "dono dos brancos") ficou muito doente e se tornou dono de vários apapaatai (palavra wauja para “espíritos”, itseke). Algum tempo depois, a FUNAI manifestou o interesse em adquirir uma grande quantidade de máscaras rituais dos Wauja para serem vendidas em sua loja de artesanato indígena (ARTíNDIA). Para os Wauja, as máscaras não poderiam ser feitas “à toa”, pois fazer uma máscara não é apenas confeccionar um objeto, mas tornar um apapaatai presente - e fazê-lo sem alimentá-lo e alegrá-lo é certamente muito perigoso ${ }^{29}$. Por isso, alguém deveria patrocinar um ritual para o qual as máscaras seriam devidamente fabricadas, enfeitadas, alimentadas e alegradas e, só depois, vendidas para a loja da FUNAI ${ }^{30}$.

\footnotetext{
${ }^{29}$ Tal perigo se mostrou real durante uma exposição de máscaras wauja no Musée du Quai Branly, em Paris. Em 2005, os Wauja viajaram ao museu a fim de participar de uma exposição de máscaras do espírito atujuwa (atugua, em kalapalo) e apresentar esquetes de seu ritual. Os Wauja consideraram que estavam sendo mal alimentados pelos organizadores do evento, o que foi visto como uma ofensa não só a eles mesmos, mas ao espírito atujuwa. Bravo por não poder fumar nem beber refrigerante, o espírito poderia atacá-los e deixá-los doentes (Ball e Fiorini, 2006).

${ }^{30}$ Os Kalapalo, por sua vez, parecem fazer máscaras para a venda sem qualquer preocupação.
} 
Como ninguém mais quis festejar suas próprias máscaras, ele foi levado a patrocinar um enorme ritual para seus apapaatai, do qual participaram quase 40 personagens (um evento consideravelmente raro), cujas máscaras foram posteriormente vendidas. Segundo Barcelos Neto (2003: 82), ele "soube explorar com maestria seu espetacular excedente de apapaatai, vinculando a realização do ritual e a venda das máscaras ao compromisso da ARTÍNDIA em auxiliar a abertura de uma pista de aterragem em Piyulaga". Tempos depois, os Wauja construíram para ele uma enorme casa de chefe, indicando sua ascensão política. Mas tal ascensão, diz Barcelos Neto (id. ibid.), “de um 'nobre' de 'terceira classe' para um 'nobre' de 'primeira classe' (amunaw-iyajo) não deve ser vista como um resultado direto e/ou exclusivo da sua excelente habilidade em representar os Wauja perante os brancos; há uma outra dimensão que também concorre para isso: o ritual de apapaatai (...)”. De fato, sua ascensão deve ter tido os brancos e os apapaatai como um duplo fundamento, tendo resultado da "mistura adequada de agências internas e externas de poder" (id. ibid.).

Esse caso é exemplar para pensarmos possíveis entradas dos brancos na economia de prestígio alto-xinguana, sobretudo a partir dos rituais, pois a condição de chefe daquele homem foi ampliada por suas relações ao mesmo tempo com os apapaatai e com os brancos, que viabilizaram o patrocínio de um grande ritual, renderam um bom dinheiro à aldeia e ajudaram a engrandecer um chefe antes pequeno. Assim como os itseke e seus rituais ajudam a "enobrecer" seus donos, como bem mostra Barcelos Neto, algo semelhante pode acontecer com os kagaiha e seus objetos - que são eles mesmos uma variedade de itseke.

Há elementos tanto na mitologia quanto no discurso cotidiano que enfatizam essa condição dos kagaiha. Em suas primeiras aparições, eram vistos exatamente como itseke, já que o que faziam era tido como um análogo dos raptos de almas e doenças causadas por estes seres: quando os kagaiha apareciam era para sequestrar e matar, e algumas pessoas desaparecidas que se acreditava terem se tornado itseke hoje são vistas como vítimas dos sequestros dos kagaiha. Na história de Saganaha (já mencionada no capítulo 1), um jovem kalapalo raptado pelos kagaiha (segundo se pode especular, por uma bandeira de Antônio Pires de Campos, na primeira metade do século XVIII), aparece um personagem aterrorizante que tortura índios que tentavam fugir do cativeiro: é o Avô-dos-Brancos, um itseke cruel que produz objetos de metal a partir de sangue indígena coagulado ${ }^{31}$. No mito de origem da humanidade xinguana, discutido no capítulo 3, o ancestral dos brancos nasce de uma irmã da

\footnotetext{
${ }^{31}$ A mesma relação entre sangue e metal aparece em Basso (1993; 1995) e Mehinaku (2010: 151).
} 
mãe dos gêmeos, que engravidou de uma flecha, e é ele mesmo um itseke, assim como seus primos paralelos: este é Kagahina, ou Carabina, que já nasce um assassino e cheio de objetos.

Por sua violência típica, a capacidade de transformar sangue coagulado em metal, originada de seus ancestrais, e seu duplo potencial destrutivo-criativo, diz-se que os kagaiha e seus objetos são dotados de itseketu, o mesmo conjunto de capacidades de agressão e transformação/invenção que caracteriza os seres não humanos. Desde uns três ou quatro anos, um homem nahukwa que se tornou xamã tem como seus itseke auxiliares o Facão, a Espingarda, a Lima, o Anzol, entre outros ${ }^{32}$. Atualmente, com a progressiva aquisição de tecnologia, os Kalapalo têm confirmando essa identidade dos kagaiha e seus objetos com os itseke, para eles claramente manifesta nas curiosas capacidades dos computadores, MP10 Players, softwares de edição de vídeo, etc.. Assim, mesmo sendo visivelmente gente, kuge ${ }^{33}$, os kagaiha não deixam de ser itseke - o que não é problema algum para o pensamento kalapalo, já que os itseke também são, do ponto de vista deles mesmos, gente.

Quando um humano vê um itseke, é porque já começou a transformar-se em um. Este processo não só deve ser interrompido pelo xamanismo como deve ser revertido, através da familiarização do itseke por meio de um ritual patrocinado pelo ex-doente, que passa a ser dono do espírito, uma forma de humanização desse ser perigoso. Se os kagaiha também são itseke, o que garante aos Kalapalo que, em seus tantos encontros com estes seres, eles não se transformem em pessoas parecidas com eles? Na relação com os itseke-kagaiha, os Kalapalo tanto correm o risco de "virar brancos" - como de fato temem estar virando ${ }^{34}$ - quanto os brancos podem ser amansados e familiarizados pelos índios, assim como eles fazem com os itseke. Análogos dos itseke, os kagaiha também precisam de cuidados, precisam ser "familiarizados" e, por isso, precisam de um dono (um kagaiha oto, “dono dos brancos”).

No Alto Xingu, praticamente se institucionalizou a existência de chefes cujo papel é “cuidar dos brancos" (recebê-los, alimentá-los, mediar suas relações com a aldeia, ajudá-los

\footnotetext{
${ }^{32}$ Os espíritos destes objetos foram responsáveis por seu adoecimento e, por isso, se tornaram seus espíritos auxiliares. Mas é bom notar que esse homem foi curado e treinado por um xamã apontado por muitos como feiticeiro e "charlatão", e nem seus "espíritos" nem sua capacidade de cura são levados muito a sério pelos Kalapalo.

${ }^{33}$ Utilizado aqui no seu sentido mais abrangente, pois no limite todo ser com forma humana é kuge.

${ }^{34}$ Esta é uma preocupação explícita de muitos velhos e jovens, que frequentemente incide sobre transformações corporais (a redução dos períodos de reclusão, os novos cortes de cabelo, o uso de roupas e acessórios industrializados) e a relação com os conhecimentos e práticas rituais. Mas também é sobre estes dois pontos que incidem formas de resistência, por meio das quais os jovens vêm progressivamente se interessando em retomar o uso de enfeites "tradicionais" no dia a dia e registrar, de todas as formas possíveis, suas festas, cantos e histórias.
} 
em seus trabalhos, etc.). Geralmente, são homens que têm ascendência nobre para utilizar o título de "chefe", mas que normalmente não são os primogênitos dos grandes anetü e, eventualmente, nunca foram preparados para se tornar chefes tradicionais. Entretanto, estas pessoas apresentam o diferencial de falarem um português acima da média dos mais velhos (dos quais alguns sequer entendem essa língua) e terem experiências mais longas de relacionamentos com os brancos, seja trabalhando para eles em fazendas, na cidade ou tendo feito boas relações em viagens, encontros com autoridades em eventos, reuniões, etc. Estes chefes dedicam boa parte de suas vidas a criar e manter relações com não índios e revertê-las para a aldeia, procurando tornar coletivamente valiosas suas conexões com os kagaiha. Fazer viagens frequentes às cidades, conversar com conhecidos ou pessoas potencialmente interessantes, oferecer presentes, hospitalidade, fazer "grandes amigos", trazê-los para a aldeia e, finalmente, procurar contrapartidas para o grupo (como pessoas dispostas a assessorar projetos, dar aulas na escola indígena, comprar grandes quantidades de “artesanato", ou então pagar em dinheiro pela estadia), é o seu trabalho.

Desde a chegada dos irmãos Villas Boas à região, agentes desse tipo têm sido intencionalmente preparados, por índios e brancos, para desempenhar papéis de mediação. Veja-se por exemplo a política de Orlando Villas Boas, que levava filhos jovens de chefes importantes para passar temporadas junto a ele (dentro e fora do Parque) aprendendo a entender os costumes dos brancos, seus interesses e formas de negociar ${ }^{35}$. Enquanto os primogênitos dos grandes chefes continuaram sendo preparados por seus pais para aprenderem os conhecimentos que são suas prerrogativas e assumirem suas responsabilidades rituais, seus filhos mais novos foram progressivamente ocupando o papel de mediadores com o mundo não indígena, o que também passou a lhes render prestígio e novas possibilidades de inserção na economia política local.

Esta figura do "dono dos brancos" é importantíssima para os Kalapalo de Aiha, pois foi por meio de seu kagaiha oto que fizeram a maioria das alianças que mantêm atualmente e os contatos por meio dos quais obtiveram a maior parte do dinheiro que entrou na conta de sua associação (Associação Aulukumã) nos últimos anos. Ele é neto de um importante chefe kalapalo, que já não vivia entre eles desde a década de 1970, quando se casou com uma mulher yawalapíti e se mudou para a aldeia de seu sogro. Nos anos 1990, após a morte de sua

\footnotetext{
${ }^{35}$ Isso era parte da estratégia de devolver às famílias dos chefes sua autoridade, enfraquecida com a emergência de mediadores do contato não necessariamente ligados à nobreza.
} 
mãe (uma itankgo que vivia em Aiha), os Kalapalo o convidaram para se mudar para Aiha, onde abriram sua roça e construíram sua casa, para que ele se tornasse os dono dos brancos. Eles se sentiam meio impotentes por não ter ninguém que falasse um bom português (ainda) e, logo, que pudesse representá-los bem perante os kagaiha. Como ele mesmo me disse várias vezes, ele só foi levado para Aiha para se tornar "funcionário" do primeiro cacique e ajudá-lo a cuidar dos brancos.

Em um momento em que associações de outros povos do Alto Xingu estão desenvolvendo projetos com os quais têm conseguido suprir uma série de necessidades, os Kalapalo de Aiha têm mantido uma política de obtenção de recursos muito centrada na figura do kagaiha oto e seus aliados pessoais. De fato, o chefe que até o final de 2007 desempenhava este papel, fora também o escolhido para presidir a Associação Aulukumã, o que em parte fez com que as atividades desta associação ficassem atreladas às suas iniciativas. A associação passou a funcionar mais como uma espécie de conta conjunta da aldeia, cuja renda vinha exclusivamente dos contatos pessoais deste homem, o que lhe valeu uma trajetória ambígua marcada pela aquisição de muito prestígio, seguida de um período de fortes desconfianças, que levaram à sua saída da presidência da associação e da aldeia.

Ele levava muitas pessoas à aldeia e, para manter sua rede de relações, fazia frequentemente um percurso entre Aiha e várias cidades brasileiras: Canarana, Cuiabá, Brasília, Uberlândia, São Carlos, São Paulo, Salvador, Fortaleza. O circuito era sempre o mesmo e tinha como objetivo fazer visitas sociais aos seus "amigos" e negociar coisas para ele e para a aldeia. Este processo começou a criar vários problemas em Aiha, principalmente com o dono da aldeia. O dono dos brancos mantinha boas relações de troca com seus amigos kagaiha, que frequentemente lhe davam presentes, dinheiro, passagens de ônibus - o que ele retribuía com convites para passarem temporadas em Aiha. Mas, chegando lá, estes amigos geralmente ficavam hospedados na casa do dono da aldeia, que esperava presentes caros também para si, o que nem sempre acontecia. Como resultado, muitos dos presentes que estes visitantes levavam "para a comunidade" eram então apropriados pelo dono da aldeia que, como tal, se sentida no direito de receber presentes especiais dos visitantes. As pessoas começaram a falar mal do dono da aldeia e o prestígio do kagaiha oto só crescia em função dos brancos que ele havia conseguido (que compravam artesanato, organizavam excursões para a cidade, pagavam pela estadia, por fotos, apresentações). A tensão entre os dois ficou 
insuportável, com o dono da aldeia se queixando que o outro não desempenhava papeis de chefe tradicional e vice-versa.

A situação atingiu o limite quando começaram a correr rumores de que o dinheiro da associação estaria acabando por causa das viagens do dono dos brancos. Algumas pessoas argumentavam que ele estaria fazendo estas viagens em proveito próprio, que estava se beneficiando sozinho da rede de amigos que mantinha ativa com dinheiro da associação. Como ele podia continuar fazendo tantas viagens e a aldeia sem ganhar nada? - era o que se perguntavam. Ele, entretanto, se explicava dizendo que este era o trabalho dele, que ele não poderia ir à cidade atrás de amigos ou em reuniões sem usar o barco da aldeia, o motor, a gasolina. Depois de muita confusão, ele acabou sendo removido da presidência da associação e foi obrigado a deixar Aiha no final de 2007.

Enquanto circulavam os rumores de que o dono dos brancos estava se aproveitando da presidência da associação, havia um curioso "clima de feitiçaria" em Aiha, mesmo sem ninguém estar doente ou ter morrido. Toda noite ouviam-se apitos de feiticeiros, viam-se vultos atrás das casas ou na região da lagoa, trancavam-se as portas e os homens saiam armados para fazer "rondas" (um clima que eu só vi novamente em 2009, quando uma acusação de fato estava em curso). É impossível dizer se a tensão em torno do kagaiha oto tinha ou não algo a ver com isso, mas é significativo que os rumores sobre enriquecimento e egoísmo tenham sido acompanhados de um clima de feitiçaria que se desenvolvia num crescendo, pois a ganância e o egoísmo são justamente duas das principais características de um feiticeiro. No ano seguinte, não houve nenhuma acusação em Aiha e é curioso que o clima de feitiçaria e os rumores sobre o dono dos brancos tenham aparecido e desaparecido juntos.

A noção de "cuidar", junto com a forma pela qual os Kalapalo se referem a "seus caraíba”, é importante para entender os conflitos em jogo. Os não índios com os quais eles mantêm alianças mais ou menos duradouras são chamados de "Kalapalo kagaihagü", "caraíba dos Kalapalo". Poderíamos nos perguntar: seriam estes não índios, de alguma maneira, "possuídos" pelos Kalapalo enquanto grupo ou pelos chefes responsáveis pela criação de alianças com eles? Essa é uma falsa questão, diante da forma como chefes e grupos estão relacionados no pensamento kalapalo. A produção da unidade, do coletivo, passa necessariamente pela agência de um anetü - no caso do Quarup, pela agência do chefe/dono da festa, em outros casos, pelo “dono dos brancos”. Os Kalapalo só se relacionam enquanto grupo - seja com outros índios no ritual, seja com os brancos - por meio de seus chefes que, 
ao se colocarem na posição daqueles que "cuidam de seu pessoal”, entram em uma relação assimétrica que faz com que o grupo só exista mediante sua ação e apresentação públicas. Ao menos temporariamente, os chefes/donos encarnam o grupo, são o próprio coletivo personificado.

O questionamento a respeito da eficácia ou legitimidade de um chefe só se torna possível quando, por alguma razão, ele não consegue mais ser o grupo (isto é, construir legitimamente a sua assimetria em relação aos demais). Nestas condições, outro chefe necessariamente chama para a si a responsabilidade (e o privilégio, pois a condição de chefe é dotada de grande valor) de ser o grupo. No caso dos recursos oriundos dos brancos, a condição para a construção e manutenção da assimetria é a sua coletivização: a obtenção de objetos de uso comum, de dinheiro que será revertido a favor de toda a aldeia, ou devidamente distribuído pelas redes de parentesco e afinidade. Quando um chefe não consegue realizar plenamente estas formas de distribuição, nada mais sustenta a assimetria entre ele e seu "pessoal": eles vão procurar outra pessoa que possa cuidar deles.

$* * *$

Aconteceu uma situação desse tipo relacionada à distribuição dos recursos recebidos por Aiha como pagamento por um reality show filmado por uma rede britânica de televisão, um caso interessante para pensarmos sobre como a assimetria entre chefes/donos e pessoas comuns pode incidir sobre os circuitos de dádivas. Em 2006, Aiha recebeu a equipe de filmagem durante o Quarup, por uma soma considerável em dinheiro mais alguns presentes, e o destino destes pagamentos foi objeto de uma acalorada discussão entre 2006 e 2007. Idealmente, os acordos dos Kalapalo com agentes dispostos a pagar grandes quantias em dinheiro para assistirem às festas são firmados pela Associação Aulukumã. O dinheiro proveniente dos pagamentos é depositado na conta bancária da associação e previsto para ser utilizado na aquisição ou reparo de bens de uso comum - como foi o caso da compra de uma camionete, um trator e uma carreta. Objetos valiosos, como motores de popa, placas solares e geradores de energia elétrica também costumam ser prometidos como parte dos pagamentos "para a comunidade". Entretanto, entre a alocação dos recursos para a associação e sua efetiva distribuição pelas redes internas, há uma distância considerável. Não havendo um coletivo $a$ 
priori (o que os discursos indigenistas imaginam como sendo "a comunidade"), independentemente da "função-Eu" (Lima, 2005) desempenhada pelos chefes e donos, estas pessoas podem reivindicar para si os pagamentos (idealmente) destinados à "comunidade ${ }^{36}$ ".

Além do pagamento em dinheiro, os Kalapalo também pediram um gerador caríssimo, que a produção havia levado para seu próprio uso. Depois de muita negociação, a equipe concordou em deixar o gerador como parte do pagamento, desde que ele fosse instalado no posto de saúde local, pois era um "pagamento para a comunidade". Entretanto, logo após a equipe ter deixado a aldeia, o dono da festa (um jovem anetü, pai de um menino morto que havia sido o homenageado principal na festa) reivindicou o gerador para si. Um gerador de partida elétrica, capaz de produzir energia para uma grande equipe de filmagem, passou a ser utilizado para ligar uma TV e um aparelho de DVD, durante cerca de uma hora no começo da noite, em sua casa. Isso certamente não foi bem visto pelos demais, mas foi considerado legítimo em alguma medida. No ano seguinte, os Kalapalo conseguiram comprar um trator e uma carreta, sobrando ainda algum dinheiro. Naquela ocasião, o mesmo dono do Quarup de 2006 reivindicou, no centro da aldeia, que o trator, a carroceria e o dinheiro restante eram seus de direito, e não "da comunidade".

O dono argumentou que estas coisas eram devidas a ele porque seriam pagamento (hipügü) por todo o peixe pescado e pelo mingau preparado para a festa, sem os quais a festa não teria acontecido (e, logo, não haveria filmagem, nem "amigos" dispostos a pagar por um ritual pobre). $\mathrm{O}$ chefe principal argumentou, junto com outros homens, que o que ele dizia não fazia sentido, pois o peixe e o mingau que ele fornecera já haviam sido pagos com dança e música e, portanto, o pagamento pelo Quarup deveria ser revertido em favor "da comunidade". Por causa desta situação, o rapaz se envolveu em um conflito com o chefe principal, que era absolutamente contrário a essa apropriação do pagamento, e isso determinou que ele e sua família saíssem de Aiha. De fato, ele já estava planejando se mudar para uma nova aldeia desde antes do Quarup de seu filho, em função de conflitos envolvendo ele e sua parentela próxima e, certamente, estes recursos seriam úteis para ele. Mas o que importa aqui não são tanto as possíveis motivações do dono da festa e sim a linguagem na qual os seus interesses foram traduzidos e considerados: seus interesses assumiram a forma de

\footnotetext{
${ }^{36}$ Em 2011, um homem que insiste em se dizer anetü, apesar de não ser reconhecido, me disse que quer "ganhar em cima da comunidade", que não é certo ele conseguir coisas para a aldeia e não pegar a parte dele. Isso explica porque ele continua sem ser visto como anetü.
} 
exigência de pagamento por seu trabalho como dono do ritual. Isto é, que o pagamento da equipe de TV fosse "para a comunidade" não era, de modo algum, uma coisa óbvia, pois pareceu possível a este homem, exigir que, de fato, o pagamento era devido a ele. E não só argumentou como, em parte, a própria aldeia concordou: mesmo negando a concessão do caminhão e da carreta, optaram por tirar da conta da associação parte do dinheiro que havia sobrado (quase metade) e dar a ele como pagamento, indicando que havia alguma legitimidade na sua exigência.

A reação do chefe principal pode ser pensada de duas maneiras. À primeira vista, poder-se-ia dizer que o dono da aldeia invocou o conceito de "comunidade" porque estaria se referindo exatamente a uma ideia de "coletivo igualitário", a qual, por alguma razão, defenderia. Talvez o chefe estivesse preterindo o modo nativo de coletivização em favor de um "modelo exógeno" de coletivo (oriundo de certo imaginário a respeito dos povos indígenas amplamente difundido em meios indigenistas). A princípio, parece ser isso o que vemos na fala do chefe; mas não estaria também sua posição de chefe principal, dono da aldeia, ameaçada por um jovem chefe que reclamava para si todos os pagamentos feitos aos Kalapalo? Afinal, quando este jovem exigia estes pagamentos, estava tentando ocupar o lugar do grupo: os pagamentos foram feitos aos Kalapalo em sentido abstrato, mas dado que aquele coletivo só existiu no ritual por causa de sua ação como chefe patrocinador, foi possível para ele usar, com alguma legitimidade, um argumento do gênero "os Kalapalo sou eu". Como ficaria o chefe principal nessa condição? Reduzido à posição de "ajudante", "companheiro" ou "camarada" - o que certamente lhe pareceu absurdo (e é preciso ter trabalhado no Xingu para ter uma real ideia de como os chefes se sentem ofendidos quando são rebaixados ou têm sua posição posta em dúvida). Exigindo que o pagamento fosse revertido para "a comunidade", o chefe principal pôde continuar em seu lugar, na posição de responsável por personificar o coletivo kalapalo. Um chefe pode obter esta posição distribuindo comida e objetos, ou pagamentos - a lógica de produção de assimetria pela dádiva é a mesma.

\subsubsection{Assimetria e coletivização}

Segundo Harrison (1992: 236), os rituais, suas condições de execução e o desempenho de certos papéis são sempre elaborados tendo em vista relações que existem fora do contexto 
ritual. A modificação de um papel no ritual, a inclusão de novos participantes, ou a criação de novas relações, serão sempre objetos de disputa pelos agentes que fazem os rituais, mas cujas relações estão referenciadas em outros contextos. Ou, na formulação de Tambiah (1985), o que este autor chama de inner frame do ritual, seu esquema simbólico de execução, é uma reutilização de elementos situados no outer frame, seu contexto de significação e para onde sua eficácia é dirigida. Se levarmos a sério que é preciso pensar os rituais como eventos cujas funções simbólicas e pragmáticas são indissociáveis, que ao mesmo tempo se fundamentam e repercutem fora do ritual, somos levados a pensar que a inclusão dos kagaiha em certos rituais como espectadores (e, num certo sentido, como consumidores/devedores) também pode ser uma forma de incluí-los na política local, simultaneamente pressuposta e (contra)produzida nos rituais.

Pelos casos discutidos acima, vemos que não há uma situação na qual os kagaiha interajam com "o ritual” enquanto um objeto passível de ser simplesmente visto, mas há uma incorporação dos não índios e seus recursos nos esquemas internos de organização do ritual, indissociáveis da política alto-xinguana. Não há uma separação entre o ritual e aqueles que (supostamente) apenas o assistem, pois estes são subordinados à sua lógica e postos a serviço das máquinas de produção indígenas: produção de beleza e alegria, produção de grandes chefes e coletivos. Tendo isso em conta, vê-se que não se trata simplesmente de produzir "festas bonitas para o branco ver", isto é, produzir uma objetivação (estética) da socialidade indígena, sem efeitos sobre os índios ou os brancos. Não seria possível imaginar semelhante movimento no mundo ameríndio, nem em lugar algum. Aqui, agora, como em outros lugares e tempos (Gell, 1998), toda objetificação é, ao mesmo tempo, índice e causa de relações entre sujeitos (Barcelos Neto, 2008, p. 34; Lagrou, 2007): toda objetificação exibe, de alguma maneira, as relações que a produziram, enquanto cria ou afeta outras relações (pois só se objetifica algo a fim de exibi-lo ou oferecê-lo para alguém que se deseja afetar).

Entre os Kalapalo, os donos de rituais e os nobres (e, no caso dos rituais regionais, estas duas categorias se sobrepõem - seus donos sempre são nobres) são centrais tanto para os processos de produzir coletivos como sujeitos (isto é, coletivos-sujeitos da perspectiva de outros xinguanos que participam dos rituais como convidados), quanto de produzir rituais como "cultura" (i.e., como um certo tipo de objeto de consumo para os brancos). Mais do que a objetificação temporária de uma ideia abstrata de "cultura indígena", os rituais altoxinguanos podem aparecer como uma forma de estender aos não índios os modos kalapalo de 
se relacionar com o estrangeiro e, ao mesmo tempo, de produzir pessoas e coletivos tipicamente xinguanos por meio destas relações - mas não sem suas repercussões no sistema nativo.

É impossível separar os rituais regionais da política, seja no sentido de "política nativa", seja no sentido de "política cultural" - no contexto da preparação, execução e exibição do ritual, ambas são uma coisa só. Os não índios podem fazer parte do sistema de pagamentos dos rituais (como no caso do reality show), incrementar o prestígio de um "dono dos brancos" ou lhe causar problemas, e podem até mesmo colocar em jogo a relação centroperiferia no sistema regional. Em qualquer um desses casos, os não índios se tornaram parte do duplo processo de produção de coletivos e, sua condição e contrapartida, de produção de nobres, homens eminentes, "caciques grandes". 


\title{
Capítulo 7 - Imagens Multiplicadas
}

\author{
Portanto, a filosofia indígena adota resolutamente o partido \\ dos vivos: \\ "A morte é dura; mais dura ainda é a tristeza".
}

Claude Lévi-Strauss, O Pensamento Selvagem (2008 [1962]:

O leitor certamente está impaciente, querendo saber sobre as famosas efígies. Deixei para tratar delas e do que as acompanha no último capítulo porque julguei ser necessário tentar abrir a "caixa preta" da chefia antes de passar para o "arroz com feijão" do ritual mortuário. Como tratar das efígies sem primeiro entender o conceito kalapalo de substituição, ou sem passar pelo destino dos mortos? Como entender sua ligação com o mundo vegetal sem compreender a analogia entre troncos, chefes, continuidade temporal, consanguinidade e identidade? Como entender a necessidade do confronto, ainda que esportivo, sem discutir as associações simbólicas entre chefia, predação e autonomia?

Se eu tivesse começado esta tese escrevendo sobre as efígies, correria o risco de reproduzir, logo de saída, muitos dos lugares-comuns sobre o egitsü. O primeiro deles seria a visão fetichizada da exibição das efígies como "o ritual", o que não passa de uma visão mais ou menos "turística" da coisa. É esse tipo de visão que faz proliferar abordagens deste ritual que pretendem explicá-lo recorrendo às funções dos "sentimentos de unidade", "diminuição de tensões", "reafirmação de vínculos entre os povos" (Carneiro, 1993; Junqueira e Vitti, 2009; Zarur, 2003) - elas desconsideram todas as premissas que desencadeiam o ciclo ritual como uma necessidade, bem como todos os estágios que permitiram chegar até ali (além do que, veremos, trata-se mais de fazer emergir o conflito e produzir diferenças do que reafirmar qualquer unidade).

Diferentemente, venho tentando discutir as ideias kalapalo sobre a chefia e a forma como aparecem em diferentes elementos do ritual (mitologia, enterro, fala cerimonial, reunião de alimento), no intuito de mostrar como a produção de uma forma-chefe se liga ao processo do parentesco em várias escalas e momentos. A produção das efígies é o ápice desse processo, mas só porque leva às últimas consequências a produção do chefe como agente capaz de reunir momentaneamente toda a heterogeneidade alto-xinguana em sua aldeia, da forma mais 
paradoxal possível: após a morte, com sua transfiguração em um ancestral sem nome ${ }^{1}$ (uma forma sem conteúdo) e a transformação de seus parentes vivos em onças.

\subsection{Afinal, o que é uma "homenagem"?}

O leitor deve se lembrar que, no capítulo 5, vimos o uso do termo akuãpütegoho (“feito para homenagear", akuãpütelü) como uma referência ao egitsü e à perpetuação da chefia entre gerações, e ele será o objeto deste capítulo. Como já foi dito na introdução, os Kalapalo propagam a ideia de que o egitsü é uma "homenagem a pessoas importantes"; contudo, apesar de variantes do ritual terem sido exaustivamente descritas, documentadas, comentadas e exibidas de todas as formas imagináveis, ainda não sabemos que ideias os xinguanos tentam traduzir com o conceito importado de "homenagem" com o qual tentam descrever o ritual para os kagaiha (brancos).

Akuãpütelü se refere basicamente ao processo de produção e exibição de (pelo menos) uma efígie mortuária, chamada $t i t{ }^{2}$. As efígies também são chamadas de "desenho de gente" (kuge hutoho), ou "imitação de gente" (já que o sentido da raiz hu é imitar). Ao produzirem tais imagens, os Kalapalo põem em movimento um complexo jogo de pontos de vista sobre a dualidade corpo/alma, fazendo dos chefes vivos, ao mesmo tempo, uma alma/imagem dos chefes mortos e um corpo coletivo para os vivos, sem o qual não é possível viver em grupo nem produzir parentes. Isso só se viabiliza pela associação do chefe morto ao arquétipo mítico dos chefes - Sangitsegu, a mãe dos gêmeos. Um ancestral/consanguíneo coletivo perfeito é (ao menos parcialmente) feminino.

Akuãpütelï ${ }^{3}$ é uma palavra verbal formada a partir da raiz akuã ("alma", "sombra" e “imagem"; cf. capítulo 4) que, grosso modo, se refere à produção da imagem de um morto que, tal como toda imagem, pode ser chamada de akuã. Várias vezes me disseram que os brancos têm o seu equivalente de akuãpütelü no hábito de construir estátuas ou expor fotos

\footnotetext{
${ }^{1}$ Após o ritual, o nome do morto pode voltar a ser pronunciado e retransmitido para seus netos. Neste processo, o morto muda de nome, mas não se sabe como ele passa a ser chamado. É nesse sentido que digo que os mortos, após serem homenageados, se tornam pessoas "anônimas".

${ }_{2}^{2}$ Carneiro (1993: 413) registra a mesma designação da efígie entre os Kuikuro. Franchetto (comunicação pessoal) afirma desconhecer o uso deste termo entre os Kuikuro e diz que eles utilizariam a expressão kuge hutoho ("desenho - ou imitação - de gente"). Os Kalapalo também usam esta expressão com um sentido mais descritivo, mas tita é, sem dúvidas, o termo mais comum.

${ }^{3}$ Akuã-pü-te-lü (alma-PASS-VBLZ-PNCT).
} 
em lugares públicos de pessoas importantes já falecidas, como, por exemplo, ex-presidentes. No caso alto-xinguano, a forma canônica de produção destas imagens é por meio das efígies de madeira do egitsï ${ }^{4}$.

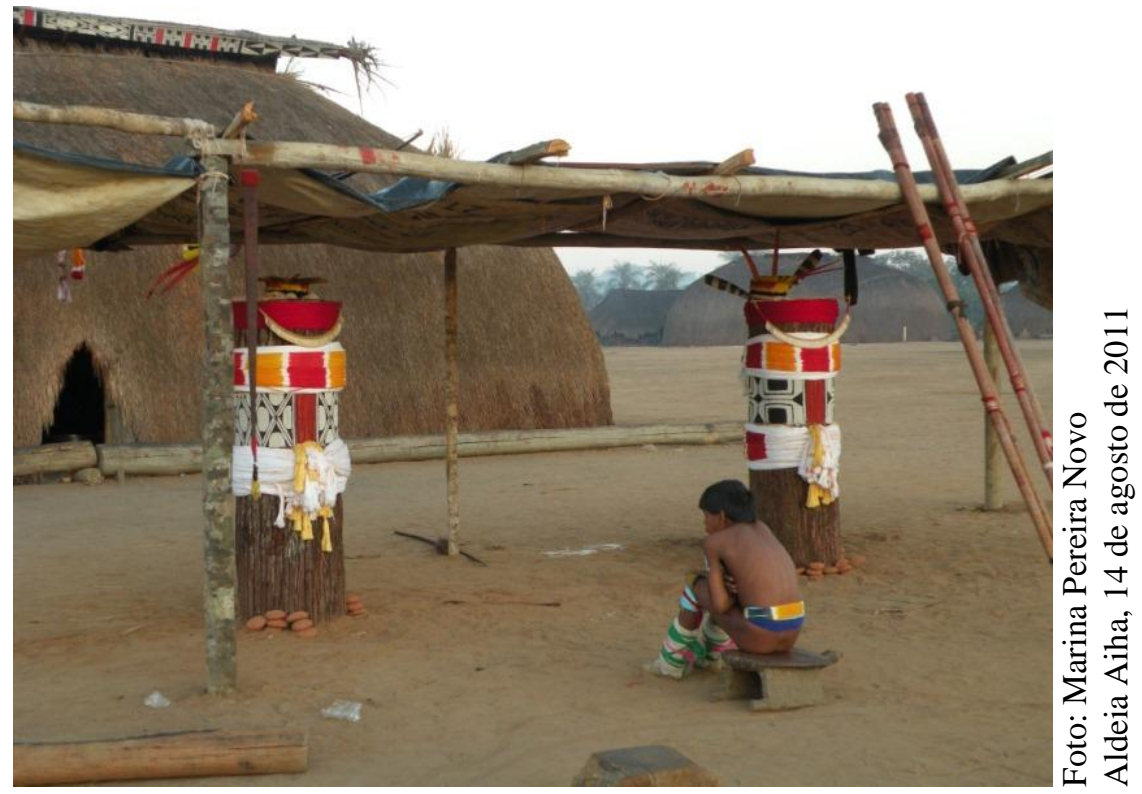

Figura 7.1: duas efígies mortuárias na manhã antes da luta.

À esquerda, uma efígie feminina; à direita, uma efígie masculina (de um menino falecido com menos de um ano de idade).

Um dos objetivos explícitos do egitsü é cortar os laços que ainda prendem a alma aos vivos. Mas qual alma? No capítulo 4, mostrei que, após a morte, a pessoa se decompõe em uma alma do olho (ingugu oto) e uma alma-sombra (akuã), com diferentes características e destinos pós-morte (a primeira vai para a aldeia dos mortos, onde permanece humana e a segunda vai para a aldeia de algum itseke, no qual se transforma). Com a construção da efígie, a dualidade da alma é temporariamente anulada: a "alma do morto" volta pela última vez para os vivos sob uma forma única (uma só akuã).

Outro efeito da fabricação da tita é "lembrar do morto". Como a alma do morto se desprende de uma vez por todas do mundo dos vivos ${ }^{5}$, o egitsü é a última chance que as

\footnotetext{
${ }^{4}$ Certamente não podemos nos esquecer dos "desenhos de gente" que também são feitos no hagaka (Jawari), o ritual de arremesso de dardos entre primos cruzados. Nesta ocasião também se produz uma efígie, mas muito diferente daquelas produzidas no egitsü: enquanto estas não tem forma humana e são objeto da mais rica ornamentação, a efígie do hagaka é humanoide e não tem ornamentação nenhuma; pelo contrário, é feita de palha ou qualquer outro material, sem qualquer preocupação com sua beleza.
} 
pessoas têm de estar em contato (de forma segura) com a pessoa querida, pensar fortemente sobre ela e chorar por sua partida. No momento que antecede a suspensão definitiva do luto, o sentimento de tristeza é trazido à tona de forma pública e exacerbada - os parentes do morto choram intensamente por sua perda no centro da aldeia, durante um dia e uma noite -, mas a tristeza e a saudade deixam de ser algo perigoso, pois são manifestadas no contexto controlado do ritual. Isso é igualmente válido para o morto, que também tem uma última oportunidade de estar junto a seus entes queridos (pois também sente muitas saudades). Ainda, o morto poderá ser lembrado pela futura circulação de seu nome, pois é somente após o egitsü que ele pode voltar a ser pronunciado e dado a algum de seus netos.

Mas esses dois aspectos do ritual, a lembrança e a despedida, só são possíveis porque, de alguma maneira, o morto é tornado presente (os Kalapalo dizem que quando a efígie fica pronta, o morto "fica por perto", acompanhando o ritual). Como? Akuãpütelü tem um claro parentesco com o termo akuãtelü, que designa o procedimento pelo qual os xamãs retomam de um espírito a alma roubada de um doente. Após negociarem com o espírito a devolução da alma, esta é recolocada no corpo do doente, para que melhore. Se akuãtelü é uma forma de trazer a alma de um vivo, akuãpütelü é a forma de trazer a alma de um morto; no primeiro caso é a alma que é devolvida a seu corpo, enquanto no segundo é preciso produzir um corpo, ainda que temporário, para a alma do morto - a efígie.

\subsection{Cortando a uẽgühi}

Já observei diversas vezes que as efígies são feitas de uẽgühi, o chefe das árvores, a mesma madeira de que foram feitas as esposas de Enitsuẽgü. Por se tratar de um espírito muito poderoso, o corte da árvore exige cuidados. Primeiro, é preciso encontrar um exemplar de uẽgühi apropriado. Uma árvore desse tipo nunca está isolada na mata e, mais ou menos perto dela, sempre há outras. A maior é dita ser o chefe das demais, enquanto as menores são seus "colegas", titaginhokongo (“com quem ela conversa"; essa é uma maneira comum de se

\footnotetext{
5 A alma do olho costuma descer à terra quando ocorrem eclipses, para buscar enfeites junto a seus parentes vivos (os mortos usam tais enfeites nas guerras que travam com os pássaros). Por isso, nessas ocasiões, as pessoas expõem vários objetos fora da casa, como cintos, colares e plumárias, e os oferecem a seus parentes mortos, que se apropriam da "alma" das coisas.
} 
descrever as relações entre os chefes de um mesmo grupo local quando não se quer fazer referência às distinções hierárquicas entre eles).

Lembremos que as grandes uẽgühi são vistas como árvores especialmente belas por sua altura, pelo diâmetro do seu tronco e pela homogeneidade de sua circunferência. A grandeza e a beleza da árvore estão obviamente associadas à beleza e à grandeza dos chefes, já que uma tita deve ser a imitação de um nobre. As maiores quase sempre são perfeitamente cilíndricas e os Kalapalo as acham lindas, mas elas não são utilizadas no ritual, pois seria impossível carregar suas toras (é uma madeira muito pesada e mesmo as de tamanho médio precisam ser carregadas por, pelo menos, seis homens fortes); as menores e as que apresentam deformações no tronco (ainda que sutis) também não servem.

Eventualmente, os tajope podem optar por usar troncos maiores do que a média para os chefes mais importantes. Em 2011 a principal homenageada teve a maior efígie que já vi, com cerca de $1,60 \mathrm{~m}$ de altura e $60 \mathrm{~cm}$ de diâmetro. Ela ficou tão pesada que, para carregá-la, foram necessários 13 homens. Conta-se que já aconteceu, há muito tempo, do dono de um egitsü se sentir ofendido pelos tajope terem escolhido uma uẽgühi muito fina, pois considerava o morto um grande chefe; para compensar, os tajope escolheram uma árvore enorme, quase impossível de carregar. Hoje, as toras são trazidas para os arredores da aldeia de trator, mas imagine-se o quão honroso era quando, apesar da dificuldade de se carregar a tora a pé por longas distâncias, ainda assim os tajope escolhiam honrar um chefe com uma tora especialmente grande. 


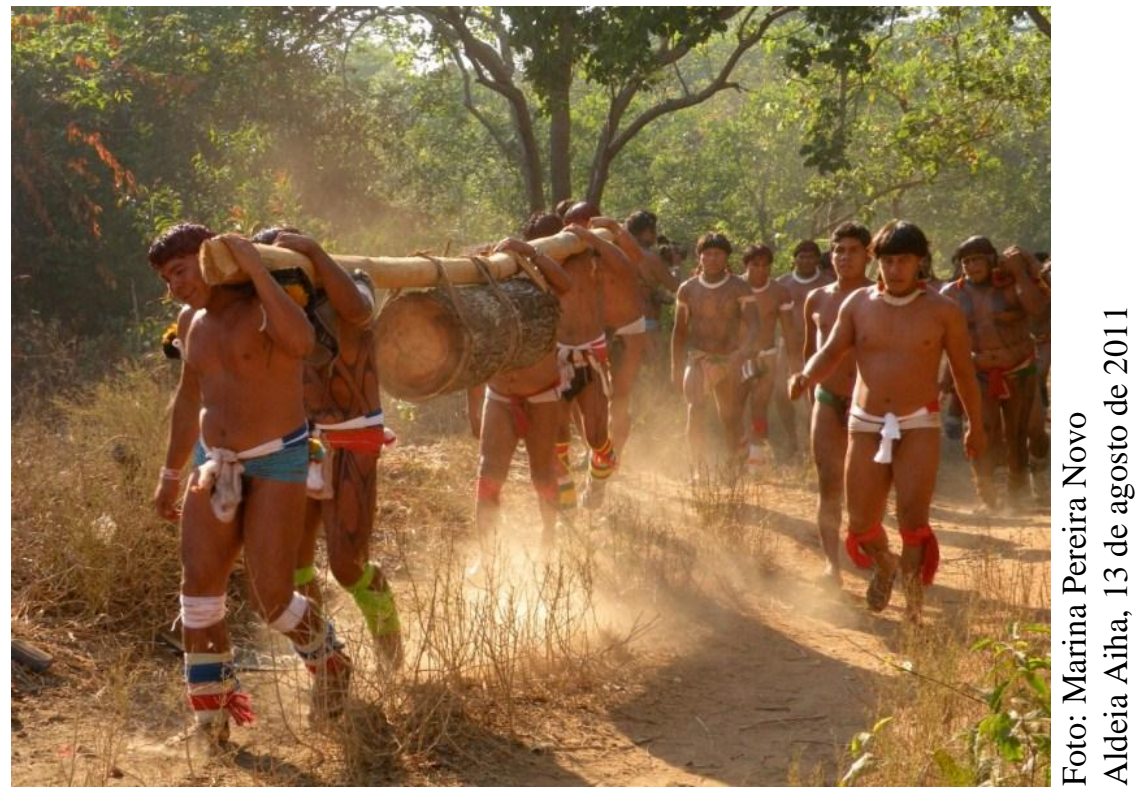

Figura 7.2: homens carregando uma tora de uẽgühi.

À direita, um dos tajope coordena a atividade.

Como a uẽgühi ocorre em matas altas e nos arredores de Aiha predomina o campo, ela só pode ser encontrada longe da aldeia. Desde a decisão por realizar o ritual, as pessoas já começam a ficar atentas para o caso de se depararem com uma uẽgühi de tamanho interessante na mata. Encontrada uma árvore com o tamanho adequado, os tajope programam o dia de sua derrubada, mais ou menos uma semana antes da chegada dos convidados. Todos os homens (jovens e adultos) partem bem cedo para o local onde está a árvore, devidamente enfeitados (os enlutados vão cobertos com roupas, pois em tese precisam estar "invisíveis"). Mulheres não vão porque o cheiro do sexo e do sangue menstrual poderiam irritar o espírito da árvore, e crianças também permanecem na aldeia por estarem especialmente sujeitas a ataques sobrenaturais. Pelos mesmos motivos, os homens devem evitar relações sexuais na noite anterior e aqueles que têm filhos pequenos só participam como espectadores (sua participação ativa na derrubada da árvore poderia afetar seus filhos pequenos, que teriam diarreia ou outros pequenos males).

Este evento deve ser tratado como um encontro ritual (o que ele é de fato - um encontro entre o dono da festa e o espírito da árvore) e, por isso, os homens chegam ao local do corte enfeitados e gritando de alegria (com vocalizações típicas do egitsü). É preciso alegrar o espírito, para que ele não se sinta ameaçado e não ataque ninguém ali presente. 


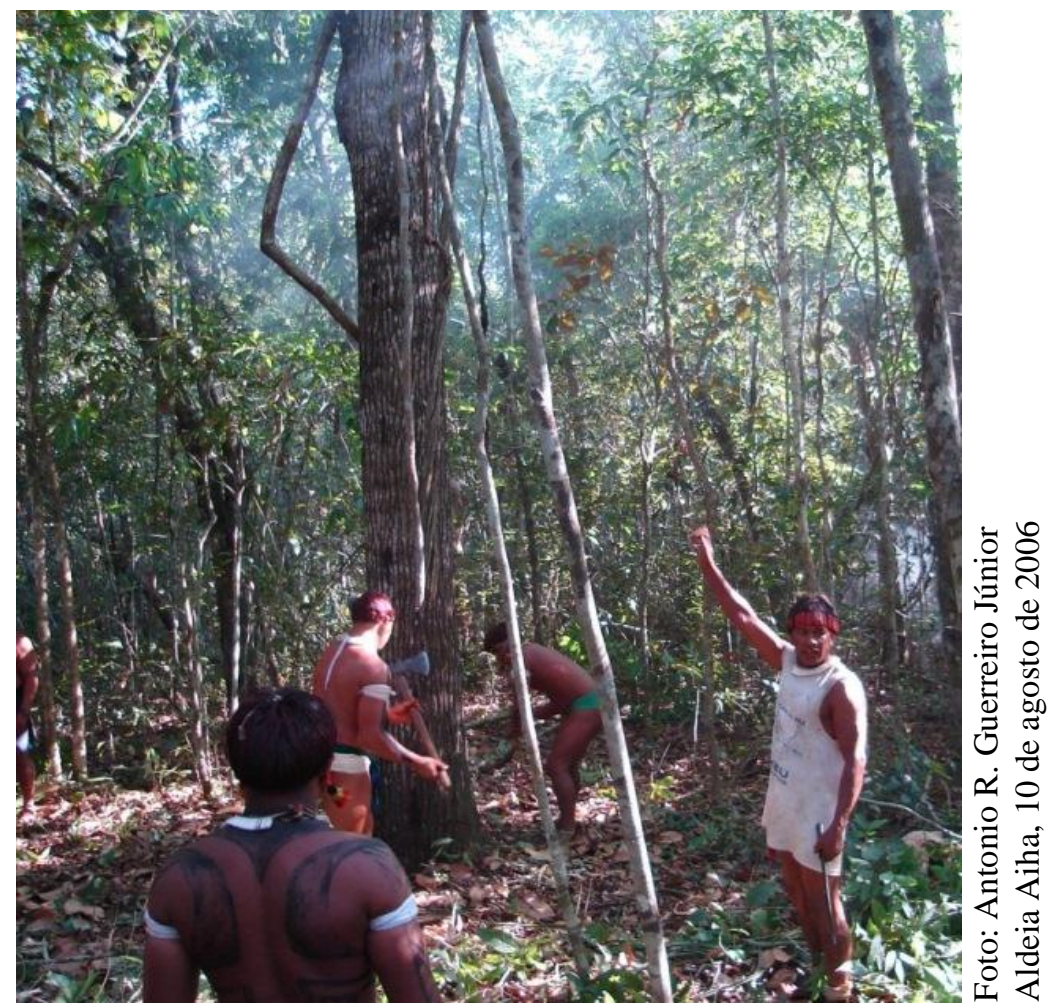

Figura 7.3: começo do corte de uma uẽgühi.

Os pajés e os donos da festa realizam tarefas específicas para acalmar o espírito. Chegando ao local, os pajés escolhem um lugar não muito longe da árvore onde se sentam, preparam suas longas cigarrilhas e começam a fumar. A fumaça é para agradar o dono da árvore, para quem o tabaco é um dos alimentos prediletos. Os pajés fumam durante um bom tempo, enquanto os tajope se preparam para a derrubada da árvore, o que só deve ser feito quando o espírito já tiver tido tempo suficiente de se alimentar da fumaça dos cigarros dos pajés. Se entre estes houver algum capaz de entrar em transe (o que só poucos pajés conseguem), ele fuma até desmaiar ("morrer um pouco") e ouvir o que espírito da árvore tem a dizer. O pajé pede a ele que não faça mal a "seus netos" e que dê força aos lutadores durante o confronto com os adversários. A resposta é sempre positiva (o espírito da uẽgühi é uma boa pessoa e um grande mestre da luta), mas sempre que possível, é importante perguntar, pois quanto mais respeitoso for o tratamento dedicado a ele, maiores são as chances de tudo correr bem.

Em 2006, o espírito da árvore se manifestou de forma peculiar: fez alguns comentários a respeito de uma equipe de esportistas britânicos e americanos que participavam do reality show que estava sendo filmado na aldeia e que lutariam no egitsï, ao lado dos Kalapalo. Um 
dos pajés entrou em transe e, quando retornou, trouxe um recado do espírito para um dos lutadores. Todos pararam para ouvir (à exceção de um rapaz que estava muito empenhado em seccionar o tronco com uma serra elétrica...). Aparentemente, o espírito estava feliz com a presença dos lutadores estrangeiros ali, mas deixou um aviso de que apenas um deles (eram seis) conseguiria vencer seus adversários ${ }^{6}$. Havia muita tensão em torno de sua participação na festa, pois os Kalapalo não tinham esperança de que eles fossem capazes de aprender a lutar e acabariam envergonhando-os perante os estrangeiros. O recado do espírito os animou, pois se dirigiu ao mais forte dentre os lutadores do reality show, em quem passaram a confiar um pouco mais.

Logo cedo, antes da saída dos homens para o corte, as mulheres da família dos donos da festa devem ter preparado para o espírito da árvore uma pequena panela com "mingau de pimenta", que ele vê como mingau de beiju. É importante que a panela seja de cerâmica e esteja envolvida em uma trança de palha de buriti (confeccionada por um homem), pela qual é transportada (isso serve para deixar a panela "mais bonita" e agradar mais o espírito).

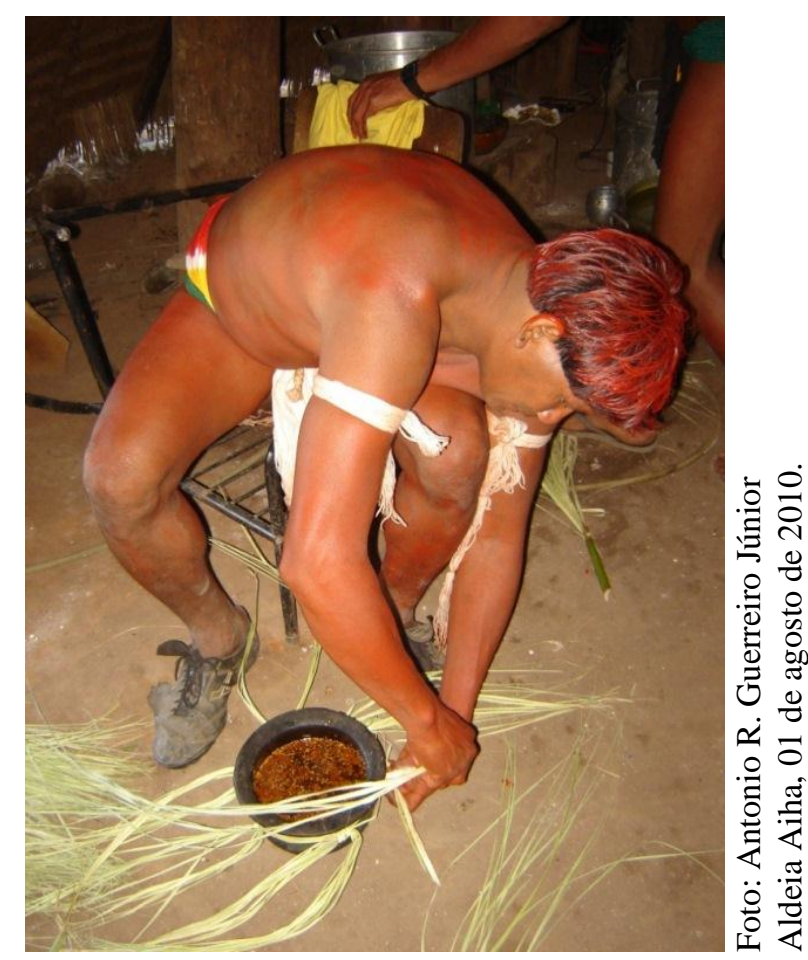

Figura 7.4: homem confeccionando o suporte da panela de mingau do espírito com palha de buriti.

\footnotetext{
${ }^{6}$ Certamente o pajé disse muito mais, mas além de eu não entender nada de kalapalo à época (minha primeira viagem a campo), a gravação que tentei fazer foi inutilizada pelo empenho do rapaz da serra elétrica.

${ }^{7}$ Água e pimenta, apenas, sem qualquer preparo especial.
} 
Imediatamente após a derrubada da árvore, um homem da família do morto deve colocá-la perto da base cortada, para que o espírito beba e fique calmo. Caso haja mais de um homenageado principal, cada dono deve oferecer uma panela de mingau de pimenta.

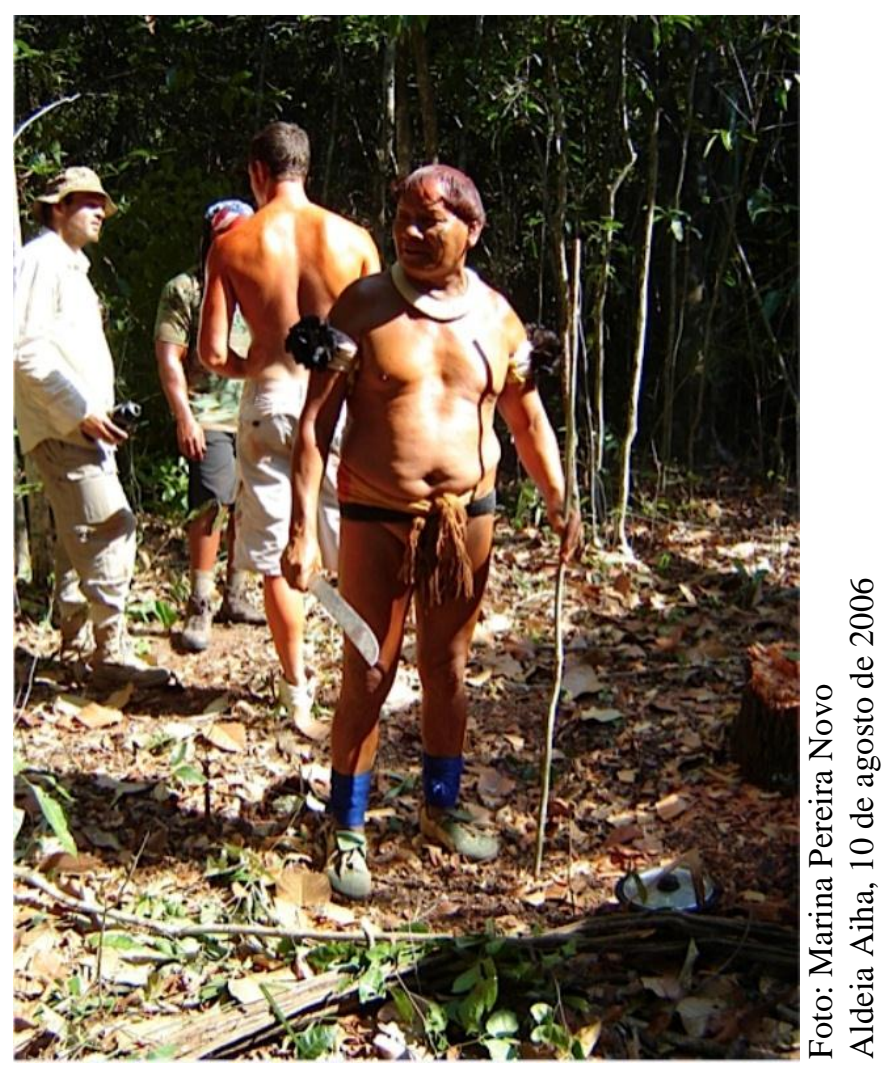

Figura 7.5: o chefe Waja entrega uma panela de mingau de pimenta ao espírito da árvore.

Ao fundo, a equipe do reality show filmado nos Kalapalo.

Chega o momento de cortar o tronco em toras. Os coordenadores escolhem um pedaço de madeira do tamanho apropriado para servir como régua, a fim de cortar todas as toras com o mesmo tamanho. Há uma ordem específica para se escolher de que partes da árvore serão feitas as tita de cada homenageado. A árvore é dividida em base (ena), tronco/corpo (ihü) e galhos (îkungu). O homenageado principal terá sua efígie feita sempre a partir da base da árvore e, se houver mais alguém homenageado como chefe, sua efígie será feita da parte que se segue à base. Já os outros homenageados terão suas efígies feitas das partes do tronco cada vez mais distantes da base, conforme sua importância relativa em vida. 


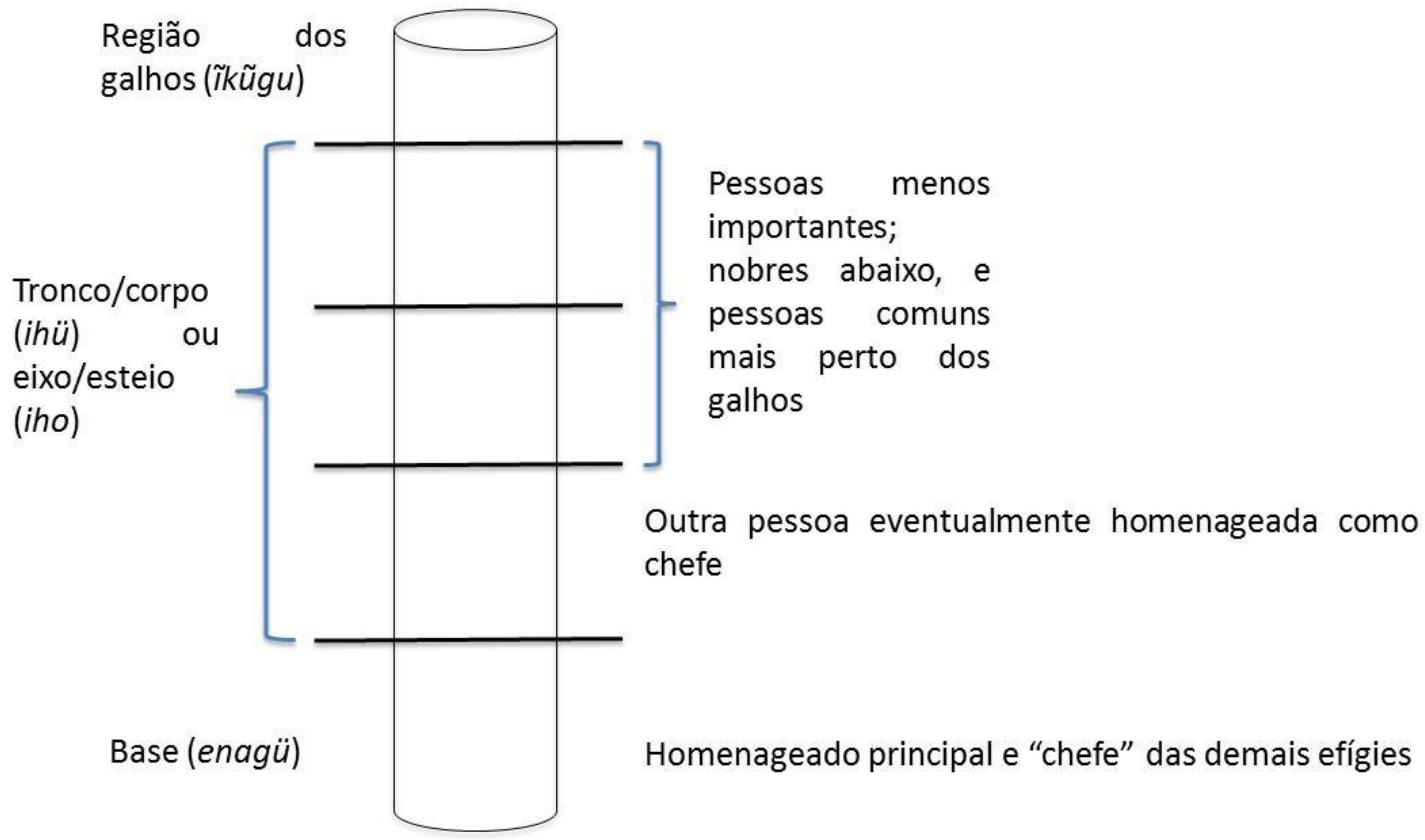

Figura 7.6: "anatomia social" da uẽgühi.

A uẽgühi oferece um modelo assimétrico de relações, que começa com os chefes mais importantes na base (oferecendo suporte ao crescimento do grupo) e vai até a região dos galhos, com a progressiva diminuição da "importância" relativa das pessoas. A anatomia da uẽgühi deixa clara a correlação entre crescimento vegetal, consanguinidade e assimetria já discutida e pode-se dizer que ela é um modelo da socialidade intra-aldeã. Este "dualismo concêntrico" entre chefes e não chefes expresso na uẽgühi evoca alguns dualismos encontrados entre povos de língua jê. Os Panará, por exemplo, dividem-se em quatro grupos nomeados e exógamos, dois dos quais são chamados de Kwakjantêra ("gente da raiz da palmeira buriti”) e Kwasôtantêra ("gente de folha da palmeira buriti”), associados respectivamente ao leste (base) e ao oeste (topo) (Schwartzman, 1988: 106-109). Segundo a descrição de Veiga (1994: 162-176), os Kaingang do Xapecó celebram um ritual pósmortuário chamado ou Kikikoi ("comer o kiki”, uma bebida fermentada à base mel e água), que reúne diversas aldeias. A cerimônia era realizada anualmente, ou a cada três anos, para todos os kaingang falecidos naquele intervalo, a fim de alegrá-los, separá-los definitivamente dos vivos e recuperar seus nomes, proibidos até então (três pontos semelhantes aos efeitos do egitsï). O ritual envolve o corte de um tronco, dividido em base, pé ou raiz, e topo, que é comparado a um morto e colocado na praça da aldeia na mesma posição que o cadáver na 
sepultura, com a "cabeça" para o nascente e os "pés" para o poente (Veiga, 1994: 169; 2000: 235). A orientação da disposição do morto (com a "cabeça" no nascente ou no poente) parece variar de comunidade a comunidade e mesmo em função da metade a que pertencia o morto (Veiga, 2000: 236). O convite às aldeias era feito por dois mensageiros enviados pela família do morto, um de cada metade cerimonial (Kamé e Kaĩru).

Entre os Kĩsêdjê (Seeger, 1981; 1987), na corrida de toras, a metade cerimonial Ambàn-yi é associada ao leste e à base do tronco, e a metade Kren-yi, ao oeste e ao topo do tronco. Segundo Turner (1984: 353), os Kayapó também possuem duas metades conhecidas como "de baixo" e "de cima", associadas ao lado oriental e ocidental da praça, onde se situavam duas casas dos homens ${ }^{8}$ (a primeira dita "da raiz/base" e a segunda "da ponta/topo"). Turner (id. ibid.) sugere que a imagem do crescimento vegetal estaria associada à irreversibilidade do tempo, opondo-se à reversibilidade que marca o modelo da alternância sazonal. Os Apinayé (DaMatta, 1982), apesar de não apresentarem nenhum "dualismo arbóreo" mobilizando a oposição entre base e topo, associam os chefes ao leste e os seguidores ao oeste, replicando a correlação entre chefes/base e comuns/topo que descrevo entre os Kalapalo.

Segundo Coelho de Souza (2002: 309), a oposição entre base e topo está ligada a vários outros dualismos entre os Jê, como as oposição sol/lua, leste/oeste, traço/círculo e, o que é interessante aqui, relacionados a "uma hierarquia de sensitividade/poder místico associada aos nomes e/ou ao contato com o exterior (mortos, outros grupos) (...)". Ora, os chefes alto-xinguanos estão justamente nessa categoria de "pessoas da base", ligadas ao exterior e que são especialmente sensíveis por estarem sujeitas ao ataque de feiticeiros (pela inveja que eles têm de sua grandeza, correspondente à fama de seu nome entre os estrangeiros). O regionalismo cerimonial alto-xinguano (focalizado na diferença entre povos) e a forma de chefia a ele associada, ao invés de corresponder exclusivamente a outras configurações regionais de influência cultural arawak, apresenta vários traços comuns com o

\footnotetext{
${ }^{8}$ Segundo Franchetto (comunicação pessoal), os Kuikuro dizem que, no passado, as aldeias possuíam duas casas dos homens. Questionei alguns kalapalo a esse respeito, mas nenhum confirmou a informação dos Kuikuro. A existência de duas casas dos homens seria mencionada no mito do ndühe kuẽgü, um antigo ritual abandonado há muito tempo. Registrei uma versão kalapalo desse mito, mas nela menciona-se uma única casa dos homens. Segundo o narrador, Tühoni, o ndühe kuẽgü era uma reclusão coletiva dos rapazes na casa dos homens, que durava uma década. Durante todo esse tempo, a aldeia deveria ficar isolada, ninguém poderia ir a outra aldeia e ninguém de outro grupo poderia entrar. Quem desrespeitasse essa proibição, seria enterrado vivo. Para isso, eram construídas grandes cercas de madeira, que avisavam aos estrangeiros que um ndühe kuẽgü estava em curso (essa é a forma como os Kalapalo interpretam os vestígios de paliçadas descobertos pelas pesquisas arqueológicas).
} 
cerimonialismo jê (focalizado nas diferenças entre metades), o que permite situar estes sistemas rituais em relações de transformação estrutural. Além disso, não deve-se descartar a hipótese de influências oriundas do contato entre os alto-xinguanos e outros povos centrobrasileiros.

Voltando ao egitsü, as toras dos homenageados principais recebem um tratamento especial após o corte. Um pajé que conheça as fórmulas adequadas pega folhas de um arbusto chamado kejite, cujas folhas têm um cheiro forte que lembra a menta, as mergulha no mingau de pimenta oferecido pelos donos da festa e as esfrega em uma das faces da madeira expostas pelo corte transversal da árvore, soprando fumaça de tabaco sobre ela. Essa operação será repetida na outra face da tora. Por meio da repetição desse gesto, o pajé literalmente faz o espírito da árvore beber o mingau e assim o deixa mais amigável.

Logo que começa a fazer isso, o pajé executa uma "reza" (tita egikuhitsoho). É interessante que esta não é uma reza comum, como as kehege que se usa para as mais variadas finalidades (atrair amantes, espantar chuva, fortificar uma casa, proteger uma pessoa, ou fazer cair os cabelos de algum desafeto), e sua musicalidade lembra os hitsindzoho ("rezas de batismo") que os chefes executam para garantir uma boa produção de milho ou pequi (Fausto, Franchetto et al., 2011). Parte dela é feita nos moldes da fala dos chefes (ver capítulo 5), pois a enunciação de linhas, a construção de paralelismos e a prosódica são idênticas às que os chefes usam em seus discursos. Para uma árvore-chefe, nada mais apropriado que um discurso de/para chefes:

\section{Aiha}

2 Atütü ihetsange akisü itsomi

3 Atütü, atütü, atütü, atütü

4 Ah, ahütüha ehijaõ ahulahanenümingola eheke muke

$5 \quad$ Sagingoi muke akangabaha igei

6 Anügü akela uãke igei muke

$7 \quad$ Ehijaõ enügü ekujetigiha igei uãke

8 Ah, ehijaõ inginügü tikungu mukeha igei uãke

$9 \quad$ Ah, ehijaõ heke muke geleha igei uãke
Pronto

Isso é para que seu jeito fique realmente bonito

Bonito, bonito, bonito, bonito

Ah, você não deve avisar seus netos sobre a morte deles

Não é com aquele que morreu que você se parece

Seus netos vieram para te cortar

$\mathrm{Ah}$, para isso eu trouxe seus netos

Ah, seus netos o farão

\footnotetext{
${ }^{9}$ Lit. "feito para rezar" (Franchetto, 2011a, Anexo 1).
} 
10 Ahütü ehijão ahulahanenümingola eheke

11 Atütü ihetsange akisü itsomi

12 Atütü, atütü, atütü, atütü
Você não deve avisar seus netos sobre a morte deles

Isso é para que seu jeito fique realmente bonito

Bonito, bonito, bonito, bonito

À reza, seguem-se duas outras fórmulas que servem para deixar o tronco mais leve. Terminado o processo, o dono da festa coloca algodão nas faces expostas para evitar que o tronco "chore". Não muito tempo depois de cortado, o tronco começa a perder água para o ambiente (o que acontece com qualquer madeira exposta), e essa água é vista como lágrimas, um sinal de que o espírito da árvore está chorando. Nesse estágio, o tronco começa a passar por uma transformação: ele começa a se sentir como parente dos donos da festa, e sente compaixão por eles. Como os espíritos podem saber qualquer coisa, o espírito da uẽgühi sabe se algum dos donos da festa irá morrer logo e, por isso, pode chorar de tristeza. Agora que o espírito começou a se aparentar aos donos, ele sofre um luto antecipado por saber quando seus novos "parentes" morrerão. No discurso acima, o pajé pede que o espírito guarde segredo (linhas 4 e 10), pois o anúncio de mais uma morte entre os enlutados só traria mais dor. É interessante que só se observa esse procedimento para o tronco principal (ou principais, quando for o caso). As outras toras perderão água da mesma forma, mas não importa - a água que elas expelem não são lágrimas, apenas água. Somente as partes-chefe da árvore tem/são espírito e, por isso, só elas são tratadas como agentes (uma parte-chefe assume a posição de sujeito em relação ao todo da árvore).

Feito isso, os troncos estão prontos para ser levados até os arredores da aldeia, e cada tora é amarrada com embira a um tronco comprido que será usado para carregá-la. Apena em 2011 vi outro tipo de estrutura para o transporte (feita com vigas de madeira), por causa do tamanho do tronco. 


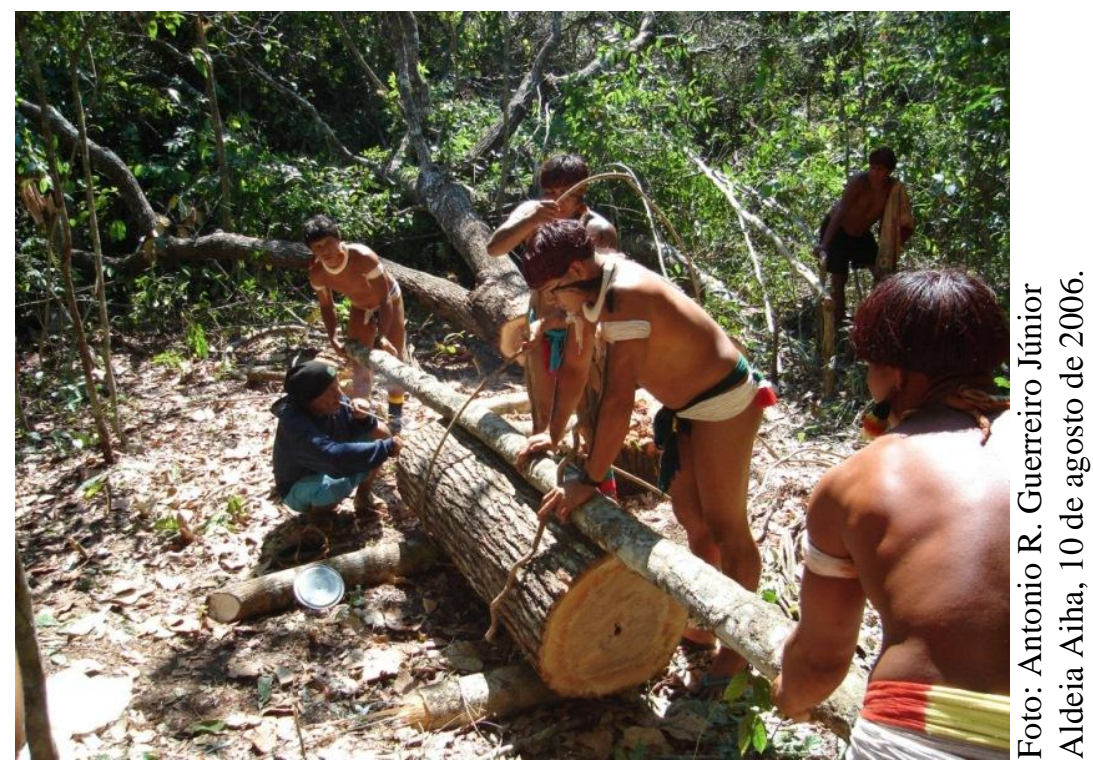

Figura 7.7: enquanto Ageu (agachado) reza para acalmar o espírito e deixar a tora mais leve, jovens a amarram a um tronco que usarão para carregá-la.

Hoje, carrega-se o tronco a menor distância possível até a carreta do trator, e é difícil imaginar como isso era feito antes. Nas duas vezes que acompanhei o corte dos troncos, este se deu a cerca de $2 \mathrm{~km}$ da aldeia, talvez um pouco mais, e carregar as toras essa distância, à pé, certamente demandaria um esforço sobre-humano. Chegando perto da aldeia, as toras permanecem fora do círculo das casas até o dia da chegada dos convidados. Nesse período, os troncos principais precisam ser alimentados diariamente com mingau de pimenta por seus respectivos donos, para que não chorem nem fiquem com sede (o que deixaria o espírito irritado e potencialmente agressivo). Como nessa fase o espírito já está se "humanizando", ele suporta sem problemas a presença de mulheres (o cheiro de sexo não o incomoda mais), que na maioria das vezes ficam responsáveis por levar mingau até o tronco.

O ritual de derrubada da árvore e os cuidados com o tronco que começa a se transformar em tita evidenciam que está em jogo uma tentativa de transformar um espírito em (imitação de) um parente. É exatamente o inverso do que faz um espírito quando captura a alma de um humano: o espírito alimenta e alegra um humano para que ela se torne um itseke, enquanto aqui são os donos do egitsü que alimentam (com fumaça de tabaco e mingau de pimenta) e alegram o espírito (com enfeites e gritos de alegria) a fim de humanizá-lo. Mas a situação é mais complexa: todos estão cientes de que a efígie não se transformará no morto, que ela não recebe sua alma e que ela nunca deixa de ser um espírito. Isso fica claro na fala 
do pajé, ao afirmar que "não é com aquele que morreu que você se parece", uma maneira de dizer que a tita não pode ser mais do que uma imitação; com efeito, o único chefe com quem a uẽgühi se parece é a mãe dos gêmeos, que foi feita dela e é de quem os alto-xinguanos se lembram quando homenageiam um nobre.

Mas a compaixão da árvore pelos donos do egitsü (e só por eles), que pode chorar por saber quando um deles morrerá, é um indício de que a uẽgühi está se transformando em alguém ligado de forma especial aos enlutados. Ela pode não ser seu parente, mas começa a se ver como um. A árvore experimenta um estado no qual ela é, ao mesmo tempo, itseke e humano, um ser potencialmente agressivo (pois pode atacar as pessoas se não for adequadamente tratada) e o duplo de alguém de quem os humanos sentem saudade, alguém que está no lugar de um parente sem, contudo, se confundir com ele. Para transformar o tronco no duplo de um parente só há um método, o mesmo pelo qual se produz qualquer relação de parentesco: a fabricação do corpo.

\subsection{A preparação dos troncos}

Chegado o dia de confecção das efígies - o dia em que chegarão os convidados -, os tajope cavam um buraco para cada tronco bem em frente à casa dos homens, com não mais do que 30 ou $40 \mathrm{~cm}$ de profundidade. Há várias disposições possíveis das efígies, todas obedecendo a um princípio hierárquico. Se, por exemplo, houver um chefe homenageado e duas pessoas tratadas como isandagü ("seus seguidores"), a efígie do chefe fica ao centro; se houver dois homenageados, um chefe e uma pessoa comum, o chefe fica à esquerda (de quem olha a casa dos homens de frente); se dois chefes estiverem sendo homenageados, aquele cuja morte desencadeou o ciclo ritual fica à esquerda, mesmo que o outro tenha sido alguém mais importante. 


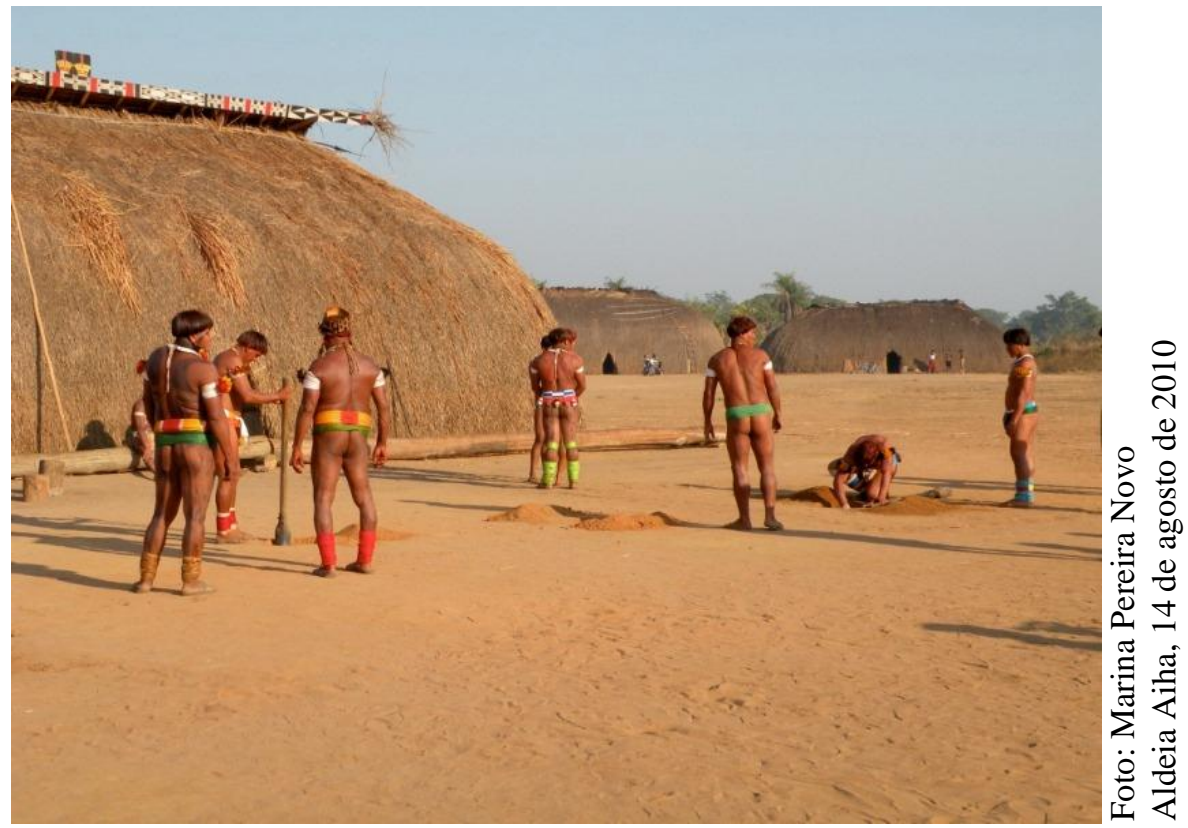

Figura 7.8: homens cavando os buracos onde serão instaladas as efígies.

Depois que os buracos ficam prontos, todos os homens adultos se dirigem até onde estão os troncos e algumas pessoas se preparam para carregá-los, erguendo-os sobre os ombros. Feito isso, os tajope iniciam os gritos típicos do egitsü, e dão o sinal para que comece um pequeno cortejo. À frente vão os tajope e outros chefes, seguidos dos troncos - o mais importante primeiro, e assim sucessivamente. 


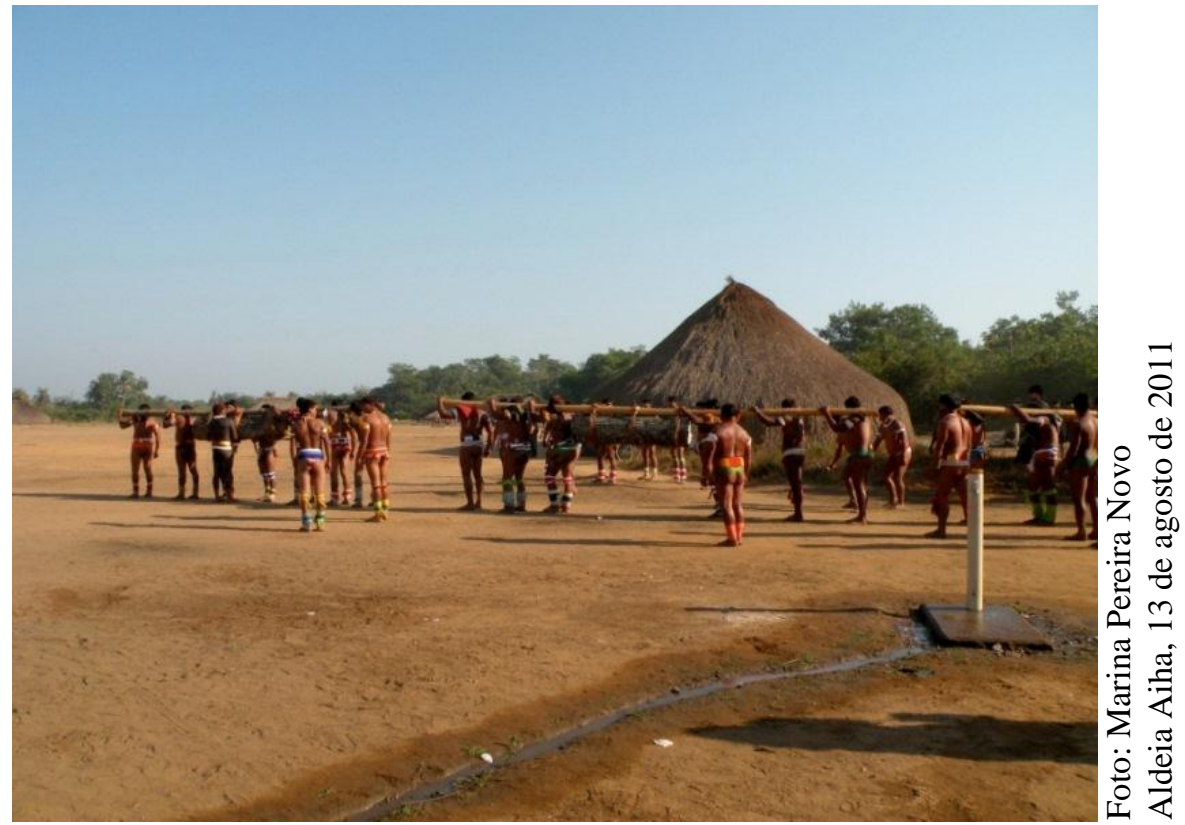

Figura 7.9: troncos prestes a serem carregados para o centro da aldeia.

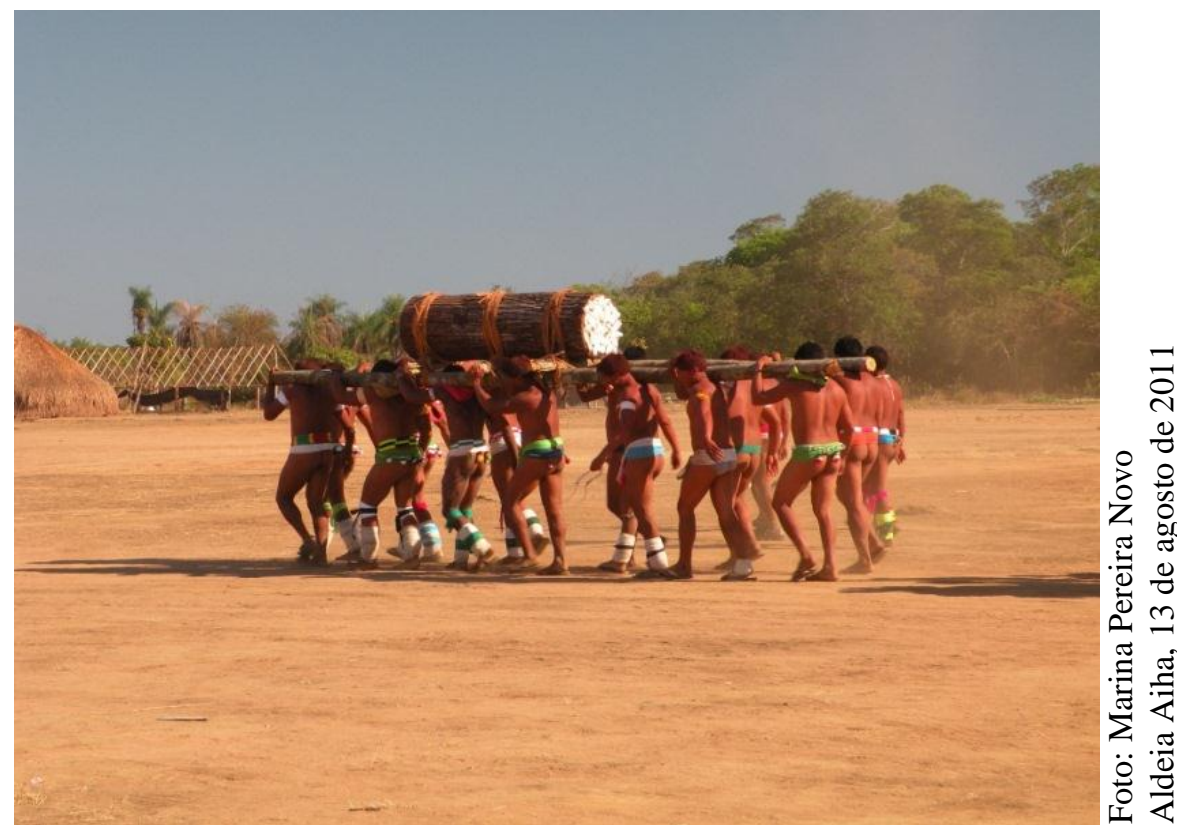

Figura 7.10: grupo de treze homens carregando para o centro da aldeia, em um suporte especial, o grande tronco usado para a efígie da irmã do primeiro cacique.

Dois homens com chocalhos de cabaça rezam todos os troncos, dando voltas ao seu redor durante todo o percurso, até que as toras cheguem ao centro. Os dois rezadores se colocam então na posição dos cantores, em frente à casa dos homens, onde executam a parte final da reza; após finalizarem-na, jogam os chocalhos no chão e os quebram com os pés. 
Enquanto isso, os troncos são tirados de seus suportes, erguidos e suas bases são fixadas em seus respectivos buracos.

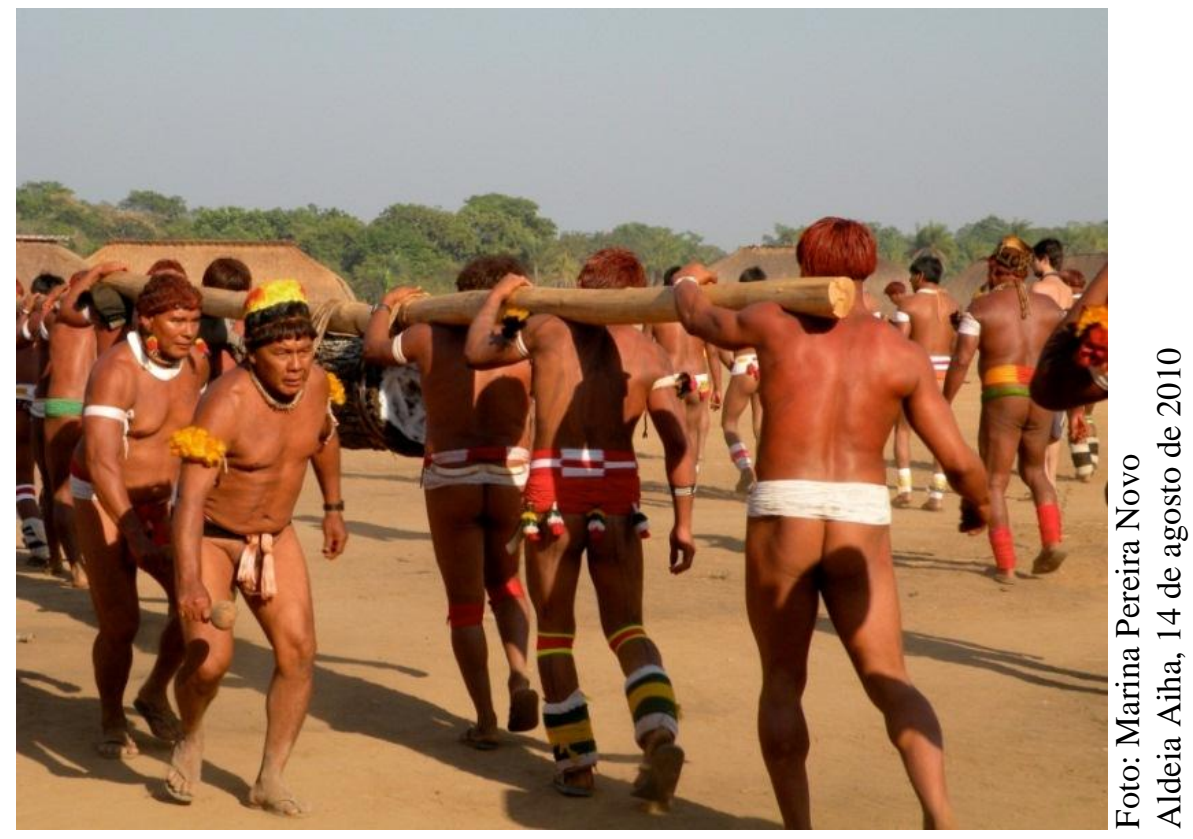

Figura 7.11: os irmãos e anetü Kurikage (à frente) e Ulehe (atrás) rezando ao redor dos troncos enquanto são levados até o centro.

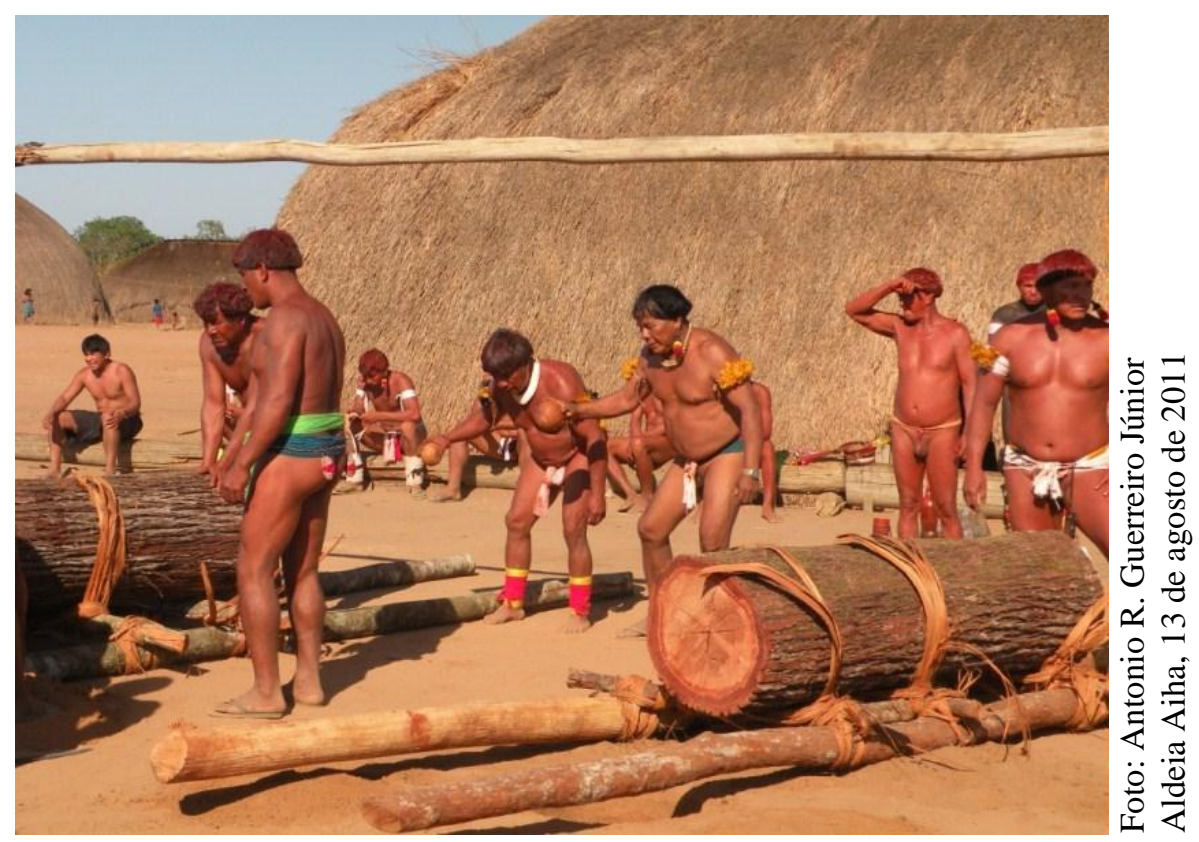

Figura 7.12: troncos no centro, pouco antes de serem colocados em pé.

Ao centro, dois rezadores (Kurikage à direita, como rezador principal, e Lapitsuma, à esquerda). 
Essa reza, que por sua coreografia e melodia mais parece um canto, é a reza do marimbondo (tunu-tunugi) que carregou o corpo da mãe dos gêmeos até sua cova, e é a mesma que se faz quando se leva o corpo de um chefe para ser enterrado e quando os homens trazem a madeira para a confecção do tahiti (ver também Agostinho, 1974: 58, que diz o mesmo sobre os Kamayurá). Ela também está toda em arawak, e os homens que a conhecem não a entendem. A reza do marimbondo é executada cada vez que o corpo de um chefe morto precisa ser publicamente colocado no centro, independentemente da forma que seu corpo assuma em cada ocasião: seu cadáver, seu túmulo-casa (tahiti) ou sua efígie. Os chocalhos precisam ser quebrados por uma questão de segurança, uma vez que se tornam objetos perigosos, capazes de deixar outras pessoas doentes, principalmente crianças (assim como as cabacinhas usadas nos rituais para alegrar a alma-sombra do morto no dia seguinte ao enterro; ver capítulo 4). É como se os chocalhos ficassem "contaminados" pelo morto, podendo produzir uma aproximação exagerada (e, logo, perigosa) entre as pessoas que entram em contato com eles e o mundo não humano.

Tão logo os troncos são erguidos, os tajope começam a prepará-los para serem pintados. Primeiro, descasca-se uma parte próxima ao topo da tora, que servirá de suporte à pintura. A casca não é removida por completo (não se atinge o alburno da madeira), mas apenas o suficiente para se chegar a uma superfície lisa. Os tajope usam duas varas de madeira (uma mais baixa e outra pouco mais alta) para medir, em cada tronco, os limites inferior e exterior das superfícies que serão pintadas, a fim de deixá-las perfeitamente alinhadas em todas as efígies. Com algumas tiras de embira ou palha de buriti, definem os limites da área que será descascada. 


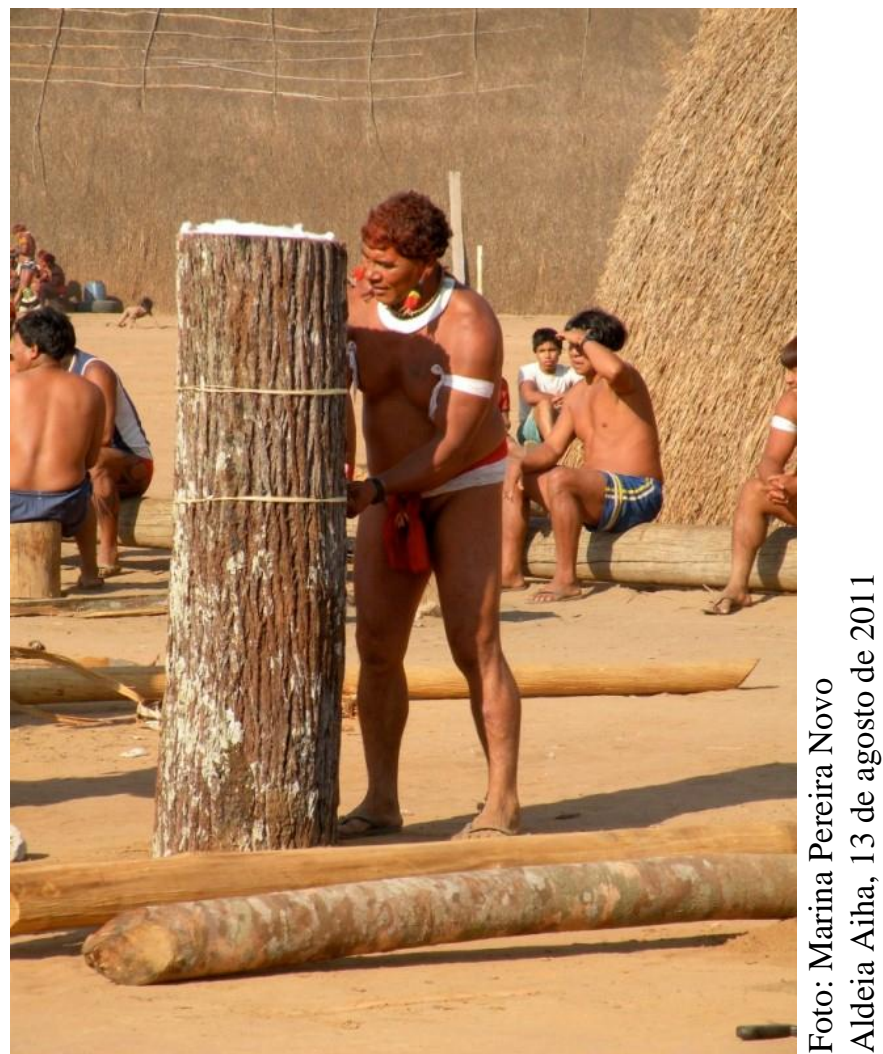

Figura 7.13: o tajope Ulehe delimita, com palha de buriti, os limites inferior e superior da superfície de pintura da efígie do grande pajé e cantor Enumü.

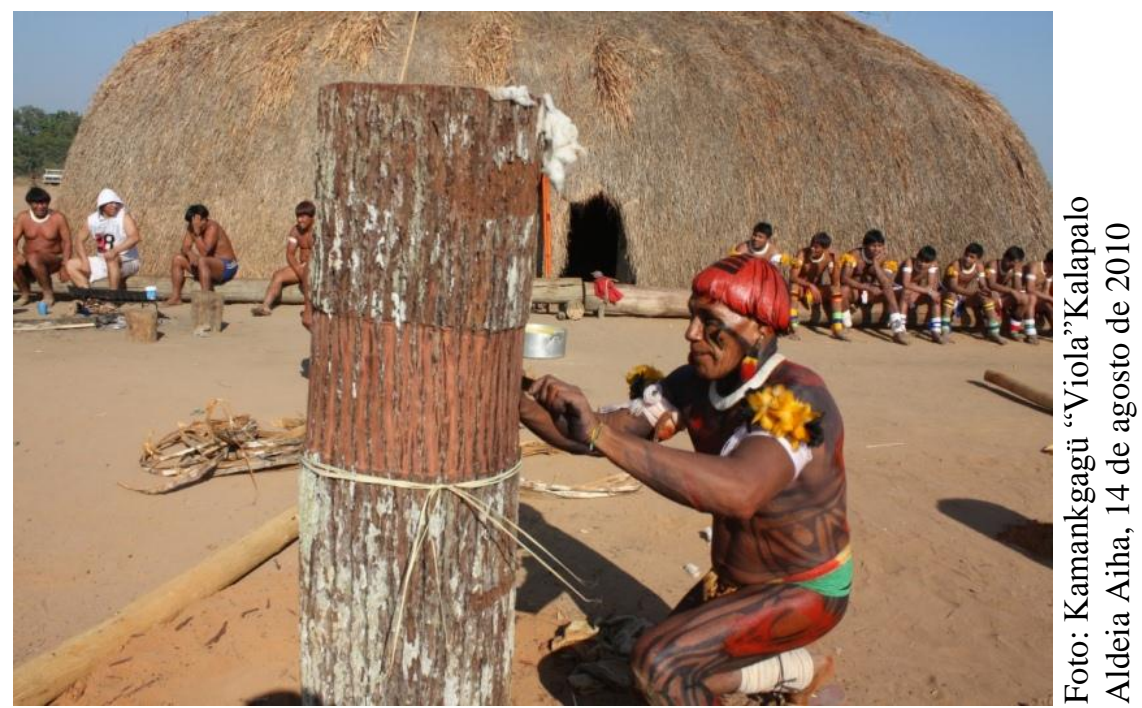

Figura 7.14: o tajope Jaua raspando a casca da tita de Enumü.

A delimitação da área de pintura começa a imprimir no tronco uma morfologia humana: abaixo dela está a cintura e acima está a cabeça. A área é pintada toda de branco com 
tabatinga (um tipo de argila, encontrada no fundo da lagoa de banho), misturada com água. De acordo com os mais velhos, tradicionalmente, a pintura com tabatinga não deveria ser usada por qualquer pessoa, apenas campeões de luta e grandes arremessadores de dardos (hoje, contudo, todos os homens a utilizam em diferentes rituais). Na luta, ela é uma referência a Kusutse, uma grande onça branca que lutou no egitsü da mãe dos gêmeos e, na festa de arremesso de dardos (hagaka, uma festa de aves), ela é uma referência à harpia, a grande ave de rapina que usa o branco em sua pintura. Ou seja, a pintura corporal branca é associada a dois grandes predadores, um terrestre e um celeste e, no mundo humano, está ligada às figuras que mais se aproximam deles - os melhores na luta e no arremesso de dardos. Como todo chefe idealmente foi um grande lutador e, no passado, também um grande arqueiro, a tabatinga adiciona um elemento à imitação do morto. É fato que todas as efígies são pintadas com tabatinga, pois são cópias de um mesmo modelo.

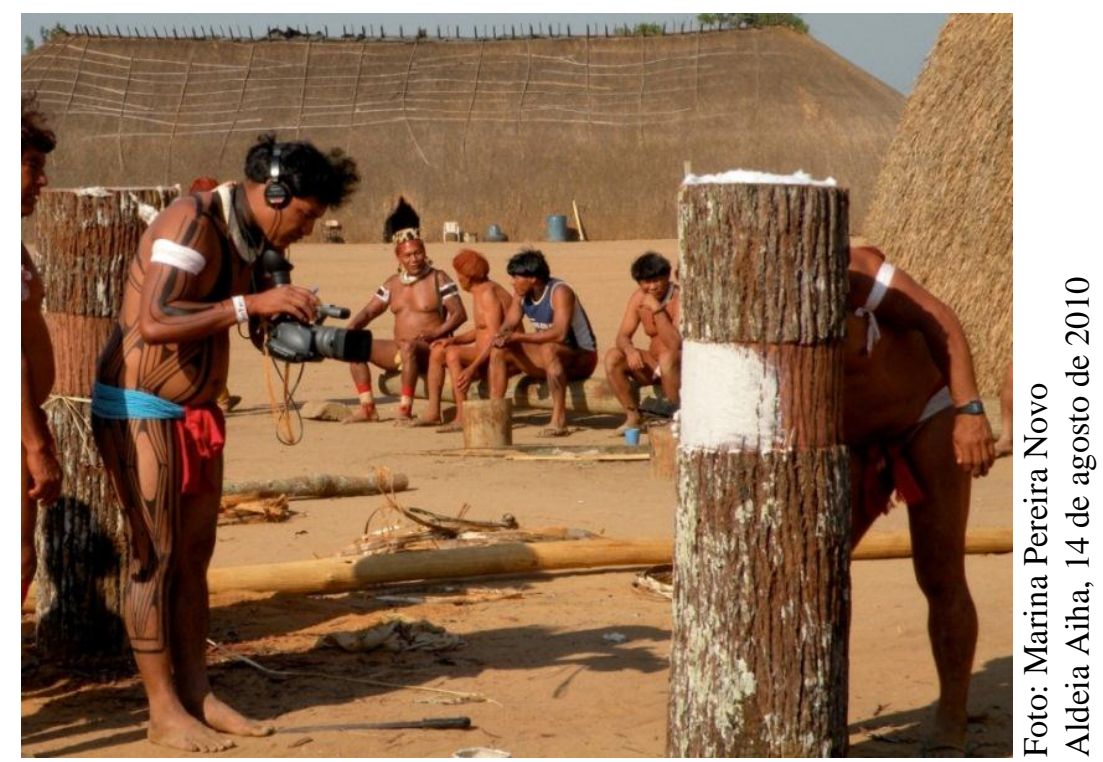

Figura 7.15: o cinegrafista Tawana registra a pintura da efígie de seu pai com tabatinga.

Em seguida, os pintores definem duas áreas retangulares transversais às bordas externas da superfície de pintura, uma na frente e outra atrás do tronco. Essas áreas são chamadas de ihonihisügü, "seu umbigo vermelho", e definem os limites de aplicação dos grafismos que conferem gênero à efígie, indicando se o homenageado é um homem ou uma mulher. Tal limite dá um passo a mais na humanização do tronco, dividindo-o ao meio e 
distribuindo sua pintura em duas metades idênticas, assim como cada lado do corpo humano é pintado com motivos simétricos.

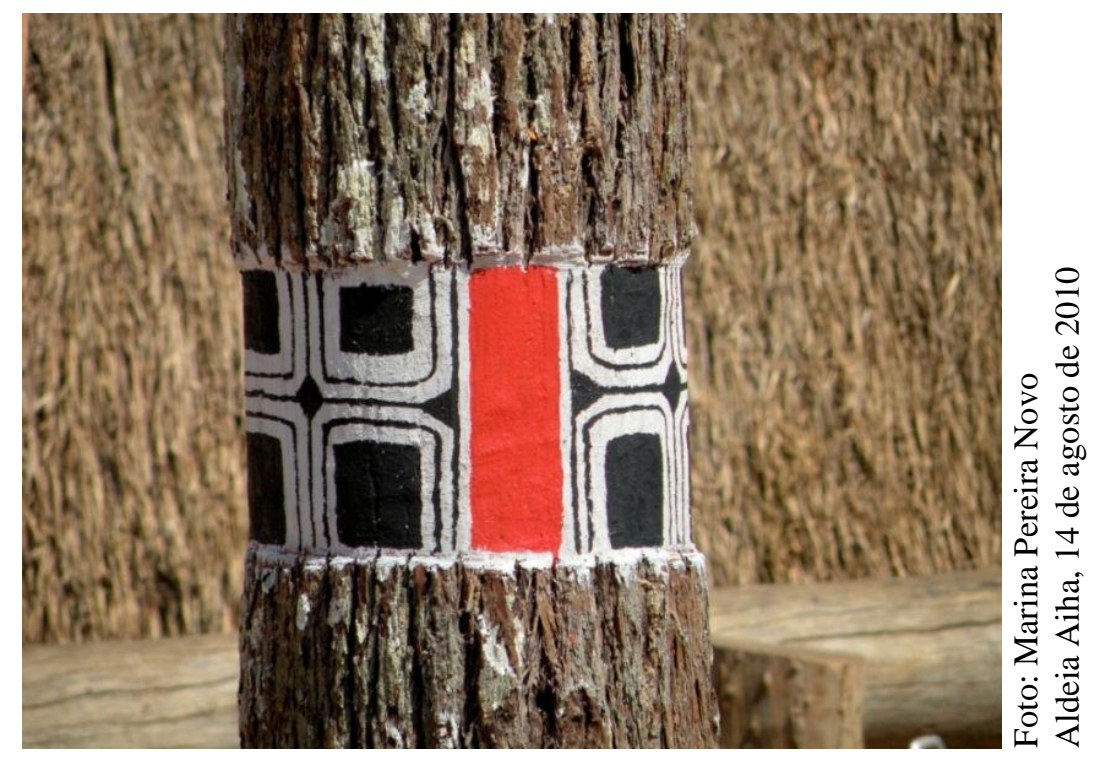

Figura 7.16: o "umbigo vermelho" de uma efígie vista de frente.

A marcação do umbigo na efígie me parece relacionada às "bolinhas" de barro (una) que devem ser dispostas ao longo da base da efígie, mas cuja "função" é ignorada por todos com quem conversei. Elas foram usadas por Taũgi na efígie de sua mãe e isso basta para que elas sejam indispensáveis. Sua confecção é responsabilidade das mulheres das famílias dos tajope, e devem ser feitas um dia antes da chegada dos convidados. Em 2009, no egitsü de Tanguro, em cima da hora os tajope perceberam que não haviam pedido para as mulheres prepararem as una no dia anterior, e houve uma grande correria para que elas ficassem prontas sem atrasar a festa. $\mathrm{O}$ chefe principal de Aiha foi quem me contou o episódio e disse ter dado uma bronca nos tajope, dizendo que não tinha como fazer tita sem una. 


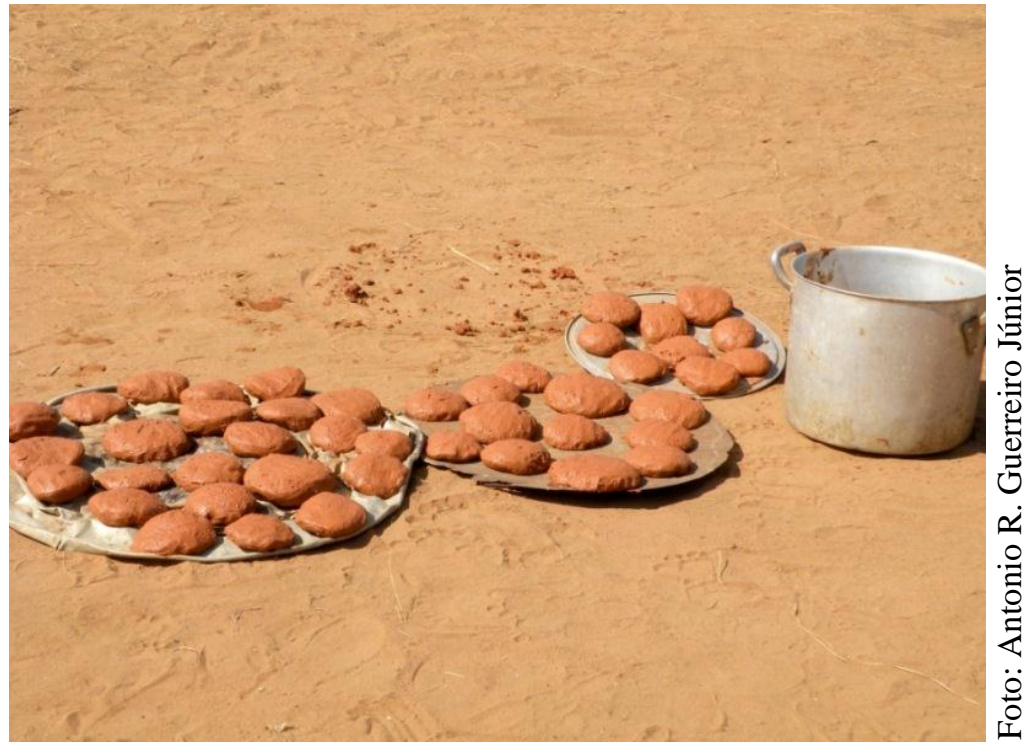

Figura 7.17: una de uma das efígies dispostas no centro, próximas à casa dos homens.

Penso que as una podem ter algo a ver com o nascimento. Ou melhor, se a produção completa da efígie for vista como algo análogo a um nascimento, talvez o papel das una seja facilitar esse processo. Em 2010, enquanto eu andava pelo centro da aldeia vendo as mulheres fazerem una, vi um balde de metal com água e raízes de uma planta dentro. As raízes eram, vez ou outra, espremidas pelas mulheres para misturar seu extrato na água que era usada para umedecer o barro a partir do qual faziam as bolinhas. A planta em questão é hõ, cuja seiva diluída em água pode ser administrada a mulheres em trabalho de parto, ou nas últimas semanas da gravidez, como um remédio para facilitar o nascimento do bebê. Quando soube disso, questionei se esse poderia ser o efeito da una, ajudar a efígie a "nascer", e ninguém me respondeu nem que sim, nem que não. Mas me pareceu curioso que essa seiva (e não qualquer outra) precise ser misturada ao barro.

A única pessoa que se arriscou a dar alguma interpretação sobre as una disse achar que elas são "a comida do tronco". É provável que se elas fossem de fato "alimento", isso fosse do conhecimento de todos, já que a alimentação do tronco com tabaco e pimenta é sempre descrita nestes termos; qual seria o motivo de dois tipos de alimentação serem tão marcados e outro ser largamente ignorado? Mas mesmo que as una não sejam exatamente "comida" do mesmo tipo que o tabaco e a pimenta, talvez elas sejam o veículo de algum tipo de substância que, na minha interpretação, pode ser a seiva, que facilita o parto. A produção do duplo do morto exige o estabelecimento e manutenção de relações de maestria entre os donos da festa e 
o tronco/espírito; dado que o modelo dessas relações é a filiação adotiva, não seria absurdo imaginar que a completude do processo exigisse um nascimento ritual.

Voltemos à ornamentação do tronco. Efígies de homens e mulheres recebem grafismos distintos (apesar de Agostinho, 1974, e Carneiro, 1993, afirmarem que não). As segundas usam o motivo tüihitinhü, que é o principal motivo de pintura corporal tanto de homens quanto de mulheres; já as efígies masculinas são marcadas pelo uso do tema "axila de borboleta" (hototo ijatagü). Este é outro tema difícil de entender. A origem do motivo coincide com o primeiro egitsü (Taũgi teria apresentado essa pintura para os homens, e ela teria sido usada na auto-homenagem de Kumagisa - voltarei a esse mito adiante) e a única explicação que consegui sobre ele é que serve "para embelezar" (atütü itsomi). Mas como já discuti nos capítulos 2 e 4, ele também aparece associado à chefia nos bancos de chefes, nos postes e frisos da casa do chefe e no friso da casa dos homens.
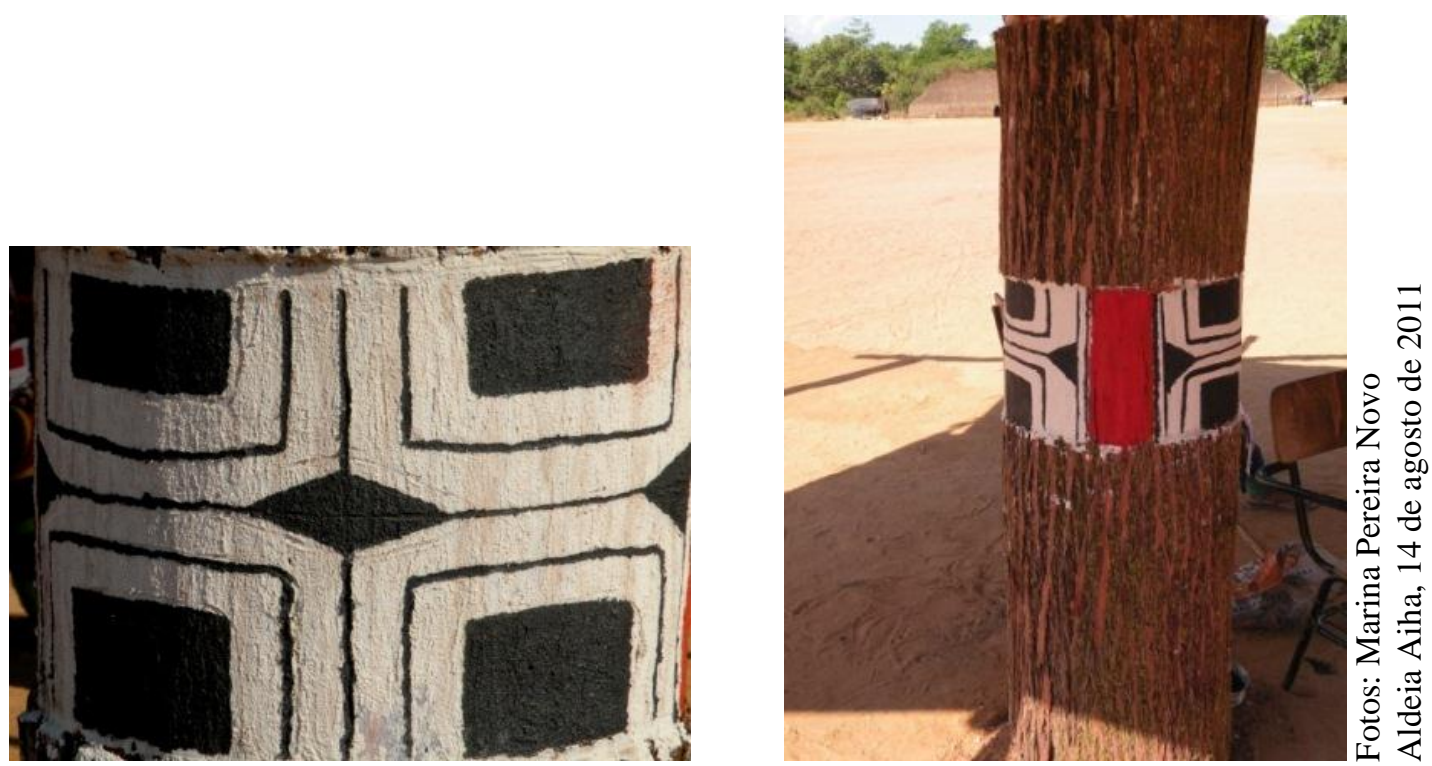

Figura 7.18 e Figura 7.19: à esquerda, o motivo hototo ijatagü, executado apenas em efígies masculinas (vista lateral). À direita, efígie masculina vista por trás. 

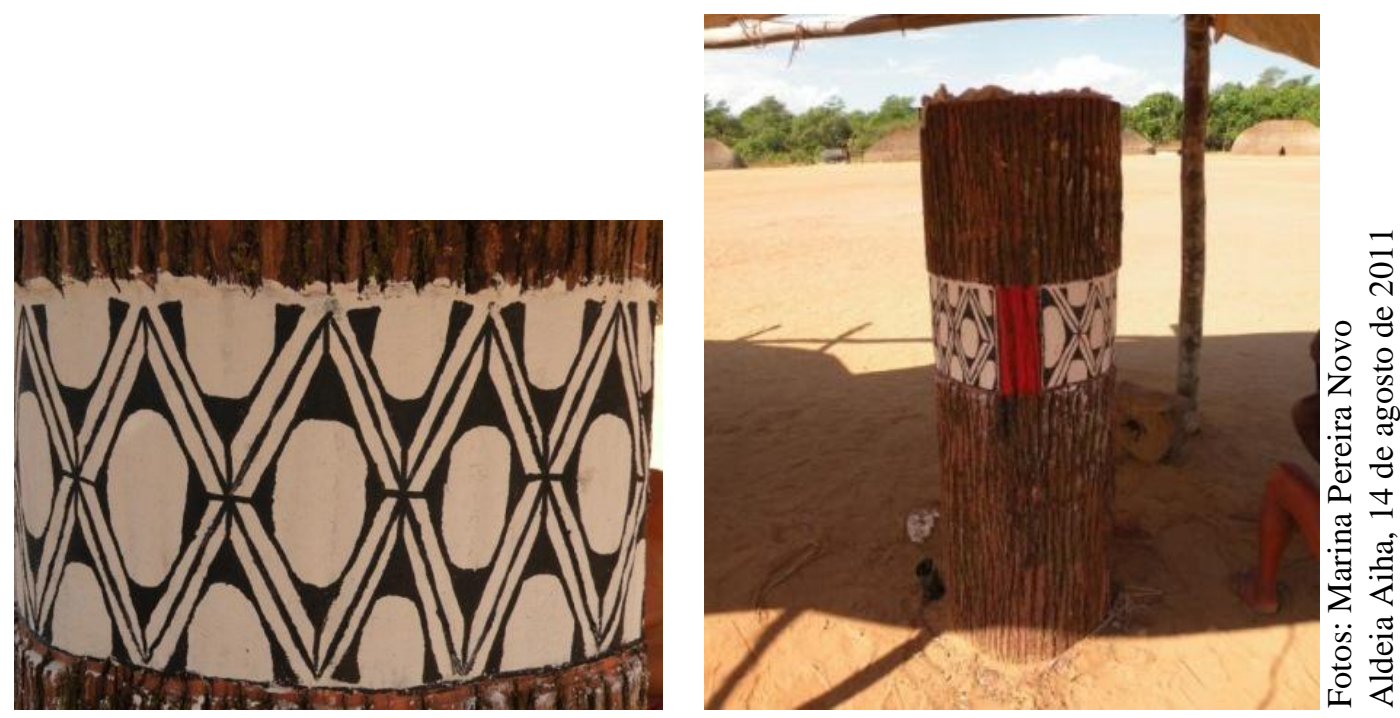

Figura 7.20 e Figura 7.21: à esquerda, o motivo tüihitinhü, aplicado em efígies femininas. À direita, a mesma efígie, vista por trás.

Esse é o fim do primeiro estágio da produção da efígie, que descrevi tal como o observei, em frente à casa dos homens, mas parece que ele costumava ser diferente. Os Kalapalo dizem que, até não muito tempo (época da criação do Parque, talvez?), as efígies eram pintadas dentro da casa dos homens, longe dos olhos de mulheres e crianças. Eles teriam começado a fazê-lo na praça apenas em função do interesse dos brancos em acompanhar e registrar o processo. Outros grupos xinguanos também preparam os troncos longe das vistas de todos, como os Kamayurá (Agostinho, 1974) e Yawalapíti (comunicação pessoal de João Carlos Almeida), que o fazem nos arredores da aldeia. A antiga preparação da efígie na casa dos homens é mais um elemento que evoca uma analogia com a produção de máscaras de espíritos, discutida no capítulo 4. No caso das máscaras, está em curso a materialização/visibilização de um espírito que se tornará "mais humano" (parente do doente) a partir de sua festa; no caso da efígie, também é a conversão de um espírito em alguém como um parente (há uma diferença importante aqui, pois já mencionei que a efígie não se transforma completamente no morto), o que é feito, assim como no caso das máscaras, pela fabricação de um corpo específico.

O estágio seguinte corresponde à colocação dos enfeites, mas só ocorre após a suspensão definitiva do luto. Os tajope chamam os enlutados, que vêm de suas casas até o centro (homens e mulheres; estas param um pouco antes de chegarem à frente da casa dos homens). Lá os homens enlutados são banhados pelos tajope, e as mulheres banhadas pelas 
mulheres das famílias dos tajope. O tratamento dos viúvos é diferente: eles só podem ser banhados por um cunhado, no caso dos homens, ou uma cunhada, no caso das mulheres. Após o banho, os parentes do morto voltam a suas casas para cortar o cabelo e, em seguida, retornam ao centro para serem pintados pelos tajope (homens pintam homens, e mulheres pintam mulheres).

Homens e mulheres são pintados com uma tinta à base de jenipapo ${ }^{10}$ (fruto do jenipapeiro, Genipa americana) usando o motivo tüihitinhü (nas mulheres a pintura só é aplicada da cintura para baixo), têm seus pés e tornozelos pintados com bastante urucum (Bixa orellana), e os homens recebem, também com urucum, uma pintura de cabelo, que entre os Kalapalo é feita com o motivo anetü gikohitügü (ver também Franchetto, 2003a).

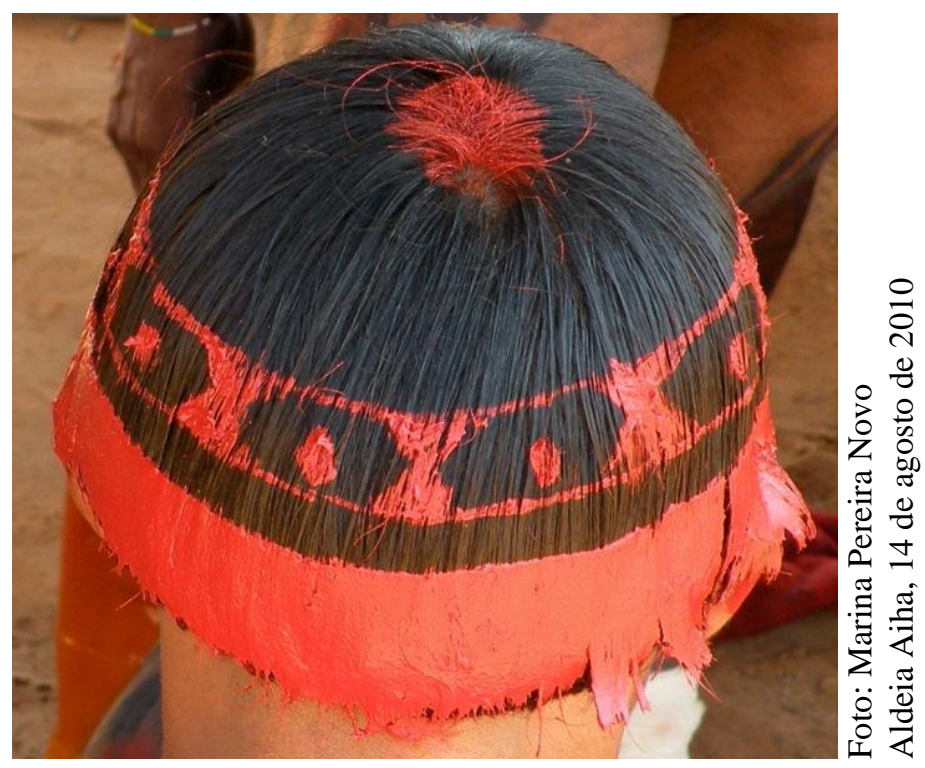

Figura 7.22: pintura de cabelo de chefe com urucum (anetü gikohitügü).

As bolinhas são "esteios" (iho) e o formato de ampulheta em vermelho lembra o tahiti.

Agostinho (1974: figura 14) apresenta a foto de um kamayurá usando como pintura de cabeça o desenho de um tahiti, mais uma analogia entre esta forma e a condição de chefe. Gregor (1982: 154) também apresenta uma pintura de cabeça com o formato do tahiti no centro, que diz ter sido a pintura de cabelo do Sol (mas ele a associa aos xamãs e não aos chefes). Após a pintura de todos os parentes dos mortos (que leva bastante tempo, cerca de duas horas), o luto está definitivamente suspenso e os ex-enlutados podem aparecer em

\footnotetext{
${ }^{10}$ A planta, seu fruto e sua tinta são chamados de anga.
} 
público e participar da festa. Terminada a pintura dos donos da festa, eles recebem de um tajope um par de brincos feito com penas de rabo de rei congo ${ }^{11}$ (küngüa igokugu) que, em tese, só pode ser usado por aqueles que serão publicamente apresentados como donos do egitsü (mas é comum ver chefes de outros povos usando tais brincos, já que são um índice de chefia).

\subsection{A ornamentação das efígies}

É chegado o momento final de preparação da efígie, concomitante ao aparecimento dos ex-enlutados como donos de egitsü: o processo de exibição da imagem do nobre morto só se completa com a exibição de seus donos. Os enlutados vão para suas casas, comem um pouco e trabalham preparando os alimentos que serão servidos aos convidados; procuram os pagamentos que devem aos tajope, reúnem todos os enfeites do tronco e então se agrupam na casa do dono principal, onde esperam. Quando percebem que falta pouco para serem chamados pelos tajope, começam a entoar um choro ritual, em voz alta, no qual "cantam" o termo de parentesco pelo qual eram ligados ao morto, seguido às vezes de partículas que indicam inconformidade ou antecipados de jatsi, "coitado(a)". O choro é musical e ritual ${ }^{12}$, mas o envolvimento emocional das pessoas é enorme e, em pouco tempo, todos estão aos prantos. Apesar disso, os parentes do morto só começam e param de chorar ao comando dos tajope. Os coordenadores fazem um sinal para que os enlutados venham até o centro, um dos momentos mais emocionantes do egitsü. $\mathrm{O}$ dono principal sai sempre à frente dos demais, acompanhado dos outros homens donos e seguidos por seus demais parentes (homens à frente e mulheres atrás). As pessoas saem correndo, mas não muito rápido, chorando em voz alta e carregando os enfeites do tronco.

\footnotetext{
${ }^{11}$ Psarocolius decumanus.

${ }^{12} \mathrm{O}$ choro ritual é chamado de atahisu, diferente do choro comum, honu.
} 


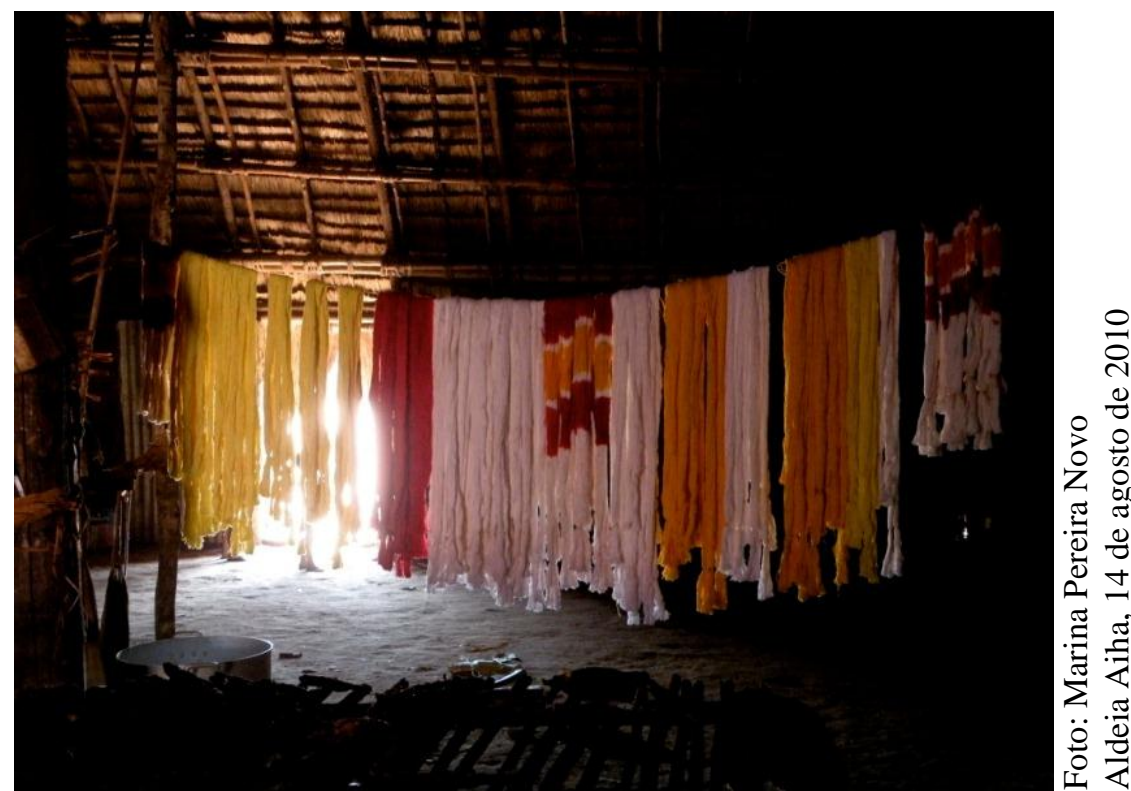

Figura 7.23: cintos da efígie principal.

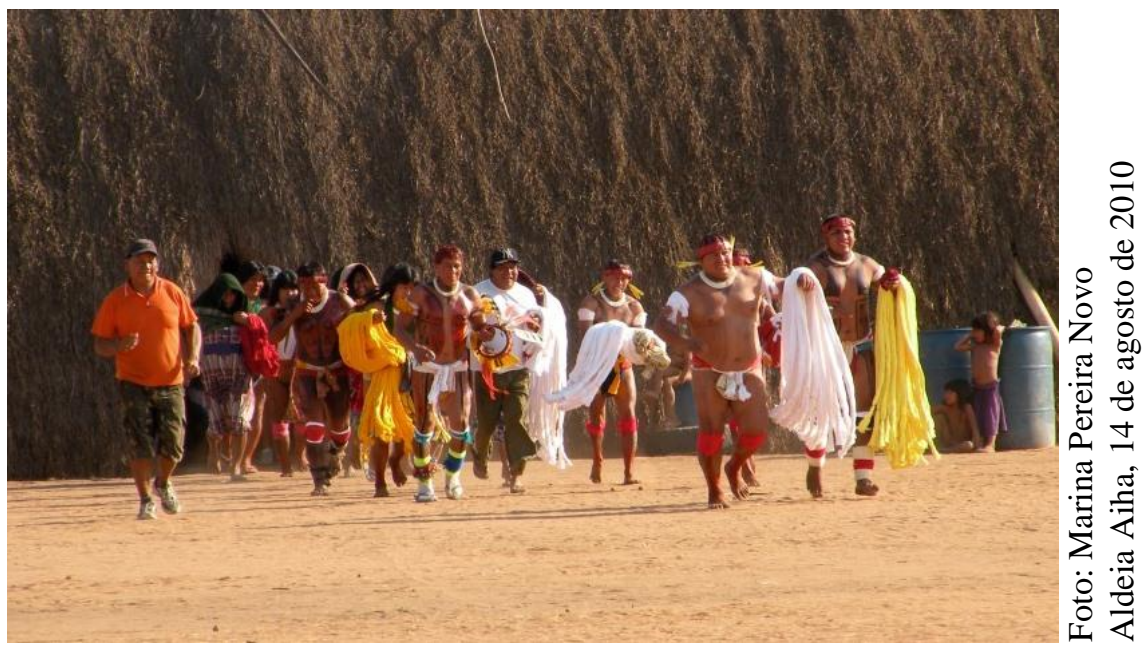

Figura 7.24: donos do egitsü correndo para o centro, chorando e carregando os enfeites da efígie.

À frente segue Ugise, o dono principal.

Chegando ao centro, os donos entregam os enfeites aos tajope, se reúnem agachados ou sentados ao redor da efígie e choram ainda mais alto. Quando os donos já chegaram ao centro, os parentes dos mortos homenageados como isandagü ("seguidores" do homenageado principal) também entregam aos tajope os enfeites que prepararam para as efígies de seus mortos e se põem a chorar da mesma forma. Não só os parentes que estavam de luto choram pelos mortos, mas também seus parentes distantes, afins e amigos - todos aqueles que se sentirem emocionalmente ligados ao morto (quando um não parente chora por um morto 
nesse momento do ritual, é um grande sinal de respeito e consideração). O barulho é enorme, e os agudos cortantes do choro das mulheres, cujo ritmo e intensidade se alteram bastante, produz um contraste marcante com o grave do choro masculino, executado de maneira bastante regular. Fica difícil suportar a posição de expectador diante de um envolvimento emocional coletivo tão intenso.

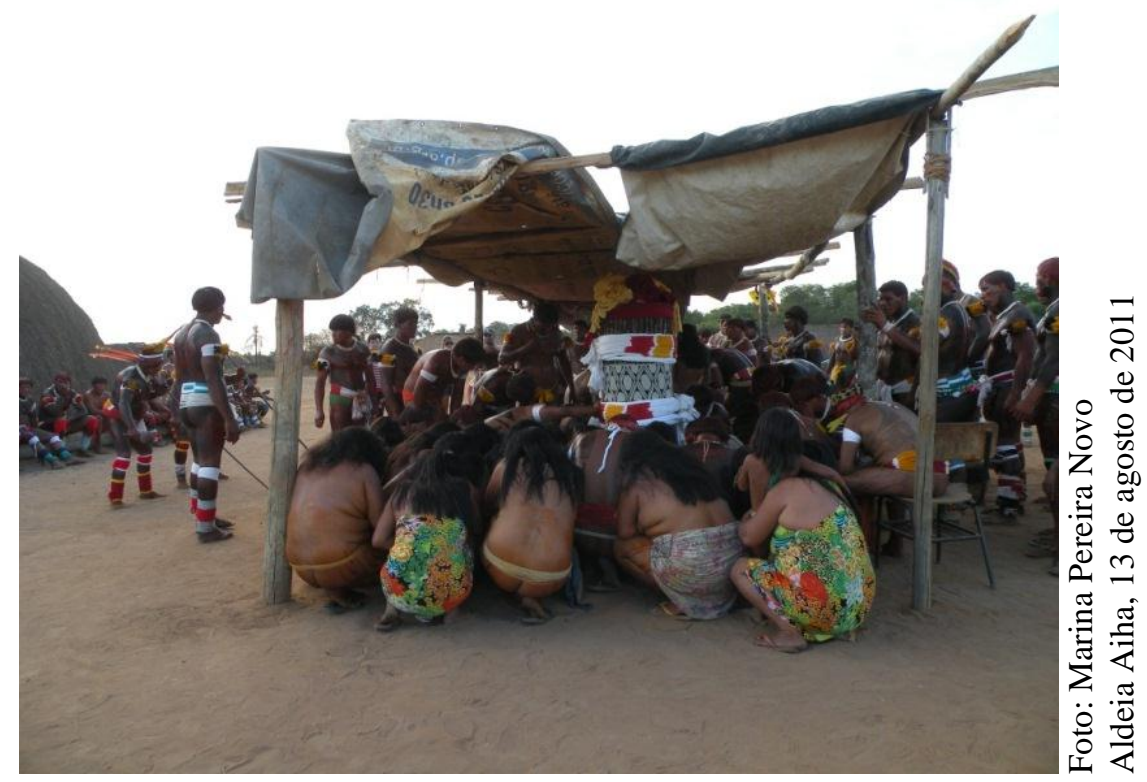

Figura 7.25: parentes chorando ao redor da efígie.

Os tajope são os únicos que, mesmo que sintam vontade, não podem participar do choro coletivo, pois enquanto os parentes se lamentam, eles devem começar a colocar os enfeites nas efígies. Primeiro são colocados os cintos: os de baixo conformam a cintura da efígie, e dividem o tronco em "tronco" (ihui) e "membros inferiores" (ena; lit. "base"); os enfeites de algodão colocados acima do "umbigo" da efígie também são chamados de cintos e não têm nenhuma correlação anatômica exata com o corpo humano; por fim, no topo, são colocadas largas faixas de algodão vermelho que representam a pintura de cabelo do tronco. 


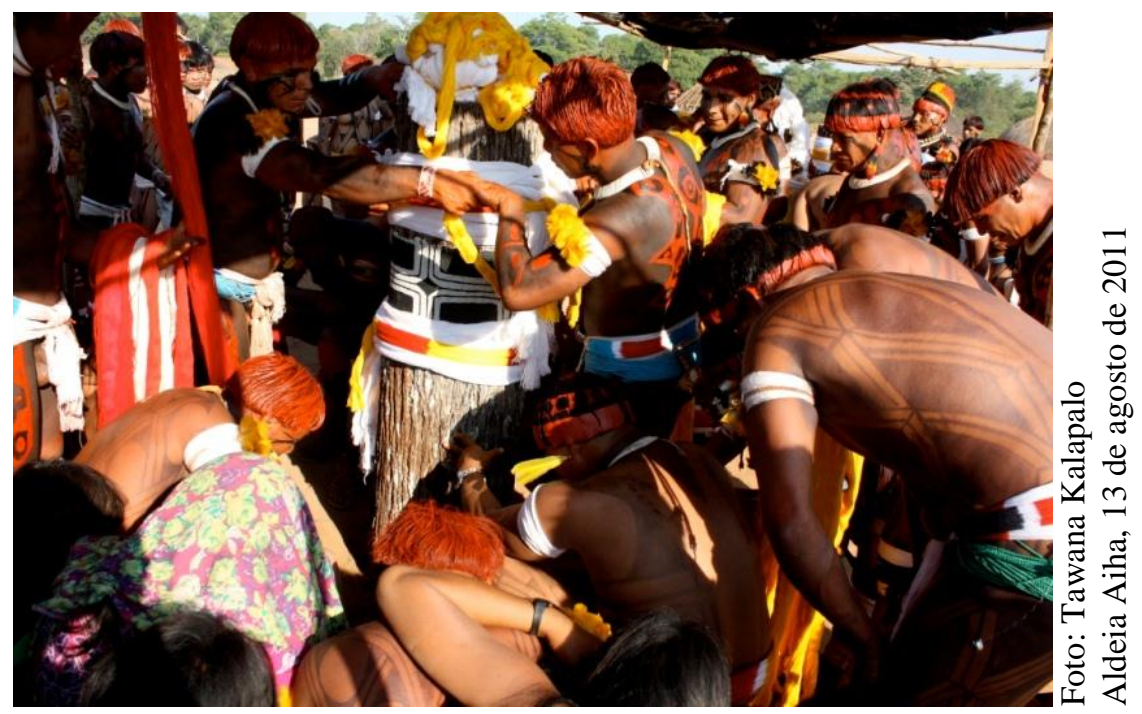

Figura 7.26: enquanto os chefes coordenadores do ritual enfeitam a efígie, seus parentes choram ao seu redor.

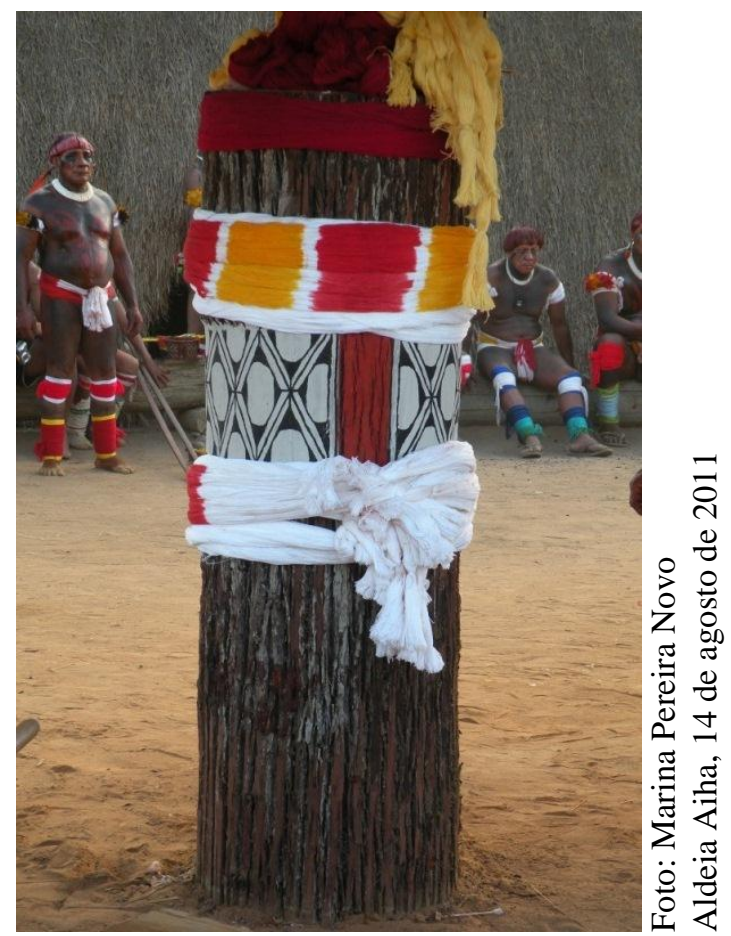

Figura 7.27: efígie feminina sendo adornada com enfeites de algodão.

Abaixo e acima da área da pintura estão seus cintos (sendo que os primeiros conformam a "cintura" do tronco). O enfeite vermelho colocado no topo representa sua pintura de cabelo.

A quantidade de cintos colocados em uma efígie é um dos sinais pelos quais se distingue entre a imitação do homenageado principal e outras, pois a primeira sempre deve ter muito mais cintos. Por um lado, isso está associado a um "excedente de beleza", já que todos 
gostariam de colocar sobre as efígies o máximo possível de cintos. Ainda, os grandes cinturões de algodão branco, os primeiros colocados sobre as efígies, em tese, só podem ser usados por grandes campeões ativos e filhos de chefes (o que só vi ser seguido à risca pelos Mehinaku). Por outro lado, alguns destes cintos serão dados pelo dono principal aos maiores campeões dos povos adversários no momento em que entram na aldeia pela primeira vez, à noite, para pegar o "fogo do morto" (discutirei isso adiante).

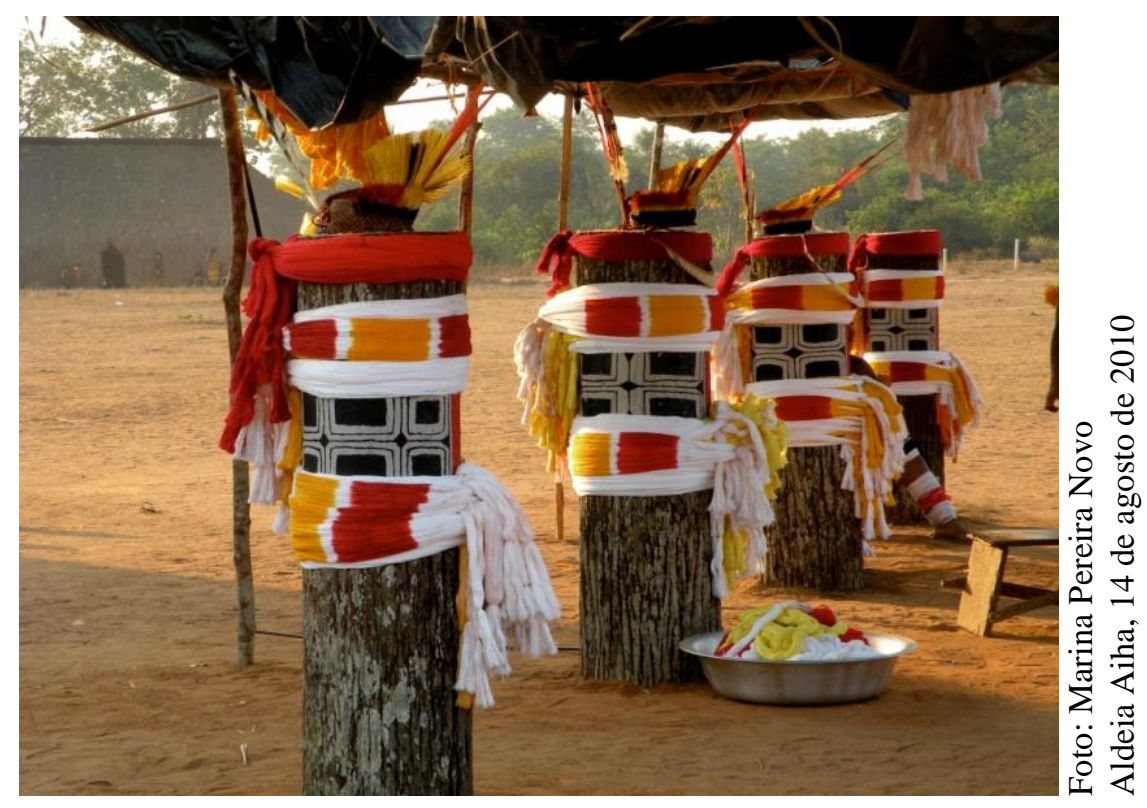

Figura 7.28: efígies de homens, as duas do centro são os homenageados principais.

Note-se a presença de colares especiais e a abundância de cintos de algodão. Em frente a uma delas é possível ver uma bacia de cintos sobressalentes, que seriam entregues aos cantores convidados. A efígie ao fundo, do homem menos importante, sequer possui uma plumária.

Em seguida, a efígie principal recebe um oĩlapi, grande colar de conchas trançadas sobre um pedaço de madeira esculpida em arco. Caso haja algum chefe homenageado como isandagü, sua efígie também pode receber um oĩlapi. Efígies de mulheres dificilmente recebem um, a menos que a homenageada tenha sido uma grande cantora ou mesmo uma grande lutadora (pois as mulheres lutam no ritual feminino jamugikumalu). Esse colar é tai ${ }^{m}$ pane $\left(\operatorname{tabu}^{13}\right)$, e só pode ser usado por grandes chefes (homens), grandes campeões de luta e grandes cantores. Grandes cantoras de jamugikumalu também podem usar um colar como esse quando cantam, a única ocasião em que ele é portado por mulheres. Ninguém que possa e

\footnotetext{
${ }^{13}$ Conforme discutido no capítulo 5.
} 
queira usar um colar desses pode fabricá-lo para si, mas deve recebê-lo de presente de algum parente. Cantoras de jamugikumalu também não podem optar sozinhas por usar esse colar, mas dependem de sua oferta pelo dono da festa. Usar um oĩlapi é um índice de grandeza inquestionável, e por isso mesmo, dizem que as pessoas "não têm coragem" ou "têm vergonha" de fazê-lo - a grandeza de alguém sempre pode ser colocada em dúvida. O futuro primeiro cacique tem um, que ganhou de seu pai, e o usou apenas uma vez há mais de dez anos, época em que era considerado o maior lutador kalapalo.

Por último, as efígies recebem plumárias, e as dos homens sempre ostentam um diadema formado por duas penas de rabo de arara vermelha no centro e duas penas de rabo de harpia nas laterais (este adorno não é usado por mulheres e não é colocado em efígies femininas). As últimas, são um símbolo de grande domínio sobre o arco e uma referencia ao chefe máximo dos pássaros, enquanto as primeiras remetem a Aulukumã, de cujo sangue foi criada a arara vermelha.

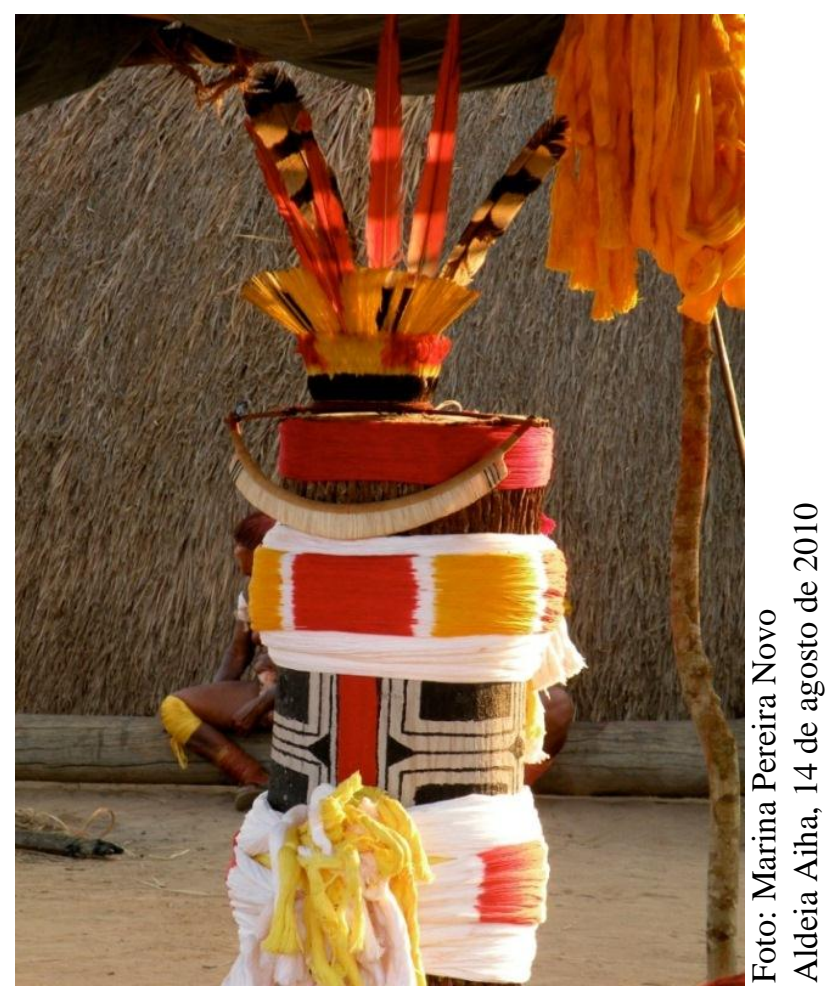

Figura 7.29: efígie masculina adornada com um oĩlapi e plumárias.

Enquanto a efígie é enfeitada pelos tajope e os parentes dos mortos choram ao seu redor, dois grandes mestres do gênero vocal aũguhi executam um canto específico para esse 
momento, chamado tita egikaginetoho. Mais uma vez: não se entende nada, mas os cantores sabem que o canto diz sobre a efígie que "a sua pintura é bonita". É um momento muito perigoso, e se um dos cantores errar qualquer parte do canto, certamente morrerá em breve. O pajé homenageado em 2010, que também era um grande cantor, errou este canto no egitsü de 2008 e faleceu em 2009. Lembro-me da grande tensão que tomou conta das pessoas quando ele errou a música: todos começaram a comentar o ocorrido, e outro cantor rapidamente correu para seu lado a fim de lembrá-lo da letra (cantando bem baixo em seu ouvido) e evitar mais erros. De fato, não há nada no ato de errar a música, que seja letal. O problema é que quem erra uma canção muito séria (titsangitsoho, "feita para respeitar") fica em um estado de vulnerabilidade (kahujehetilü), assim como quem sente saudades ou desejo alimentar (exatamente como o witsixuki wauja, descrito por Barcelos Neto, 2007), e está sujeito a ataques mágicos de espíritos e, principalmente, feiticeiros. Após um cantor errar esta música, algum espírito pode tentar roubar sua alma ou lançar dardos sobre seu corpo. Tal situação poderia ser resolvida por um pajé, sem maiores complicações, mas o problema é que os feiticeiros ficam à espera de descuidos como esse para lançar seus dardos invisíveis sobre suas vítimas. Esses dardos são muito "duros" (o contrário dos dardos dos espíritos, que são “moles") e não podem ser removidos, pois se reproduzem no corpo, levando a pessoa à morte. As pessoas sempre se lembram do episódio de 2008 como o momento crucial no qual o feiticeiro que desejava o mal do pajé/cantor se aproveitou para feri-lo mortalmente.

$$
* * *
$$

Enfeitada a efígie e terminada a canção, os tajope pedem aos parentes dos mortos que parem de chorar. As tita agora estão todas prontas e já podem ser chamadas propriamente de kuge hutoho, "imitação/desenho de gente". 


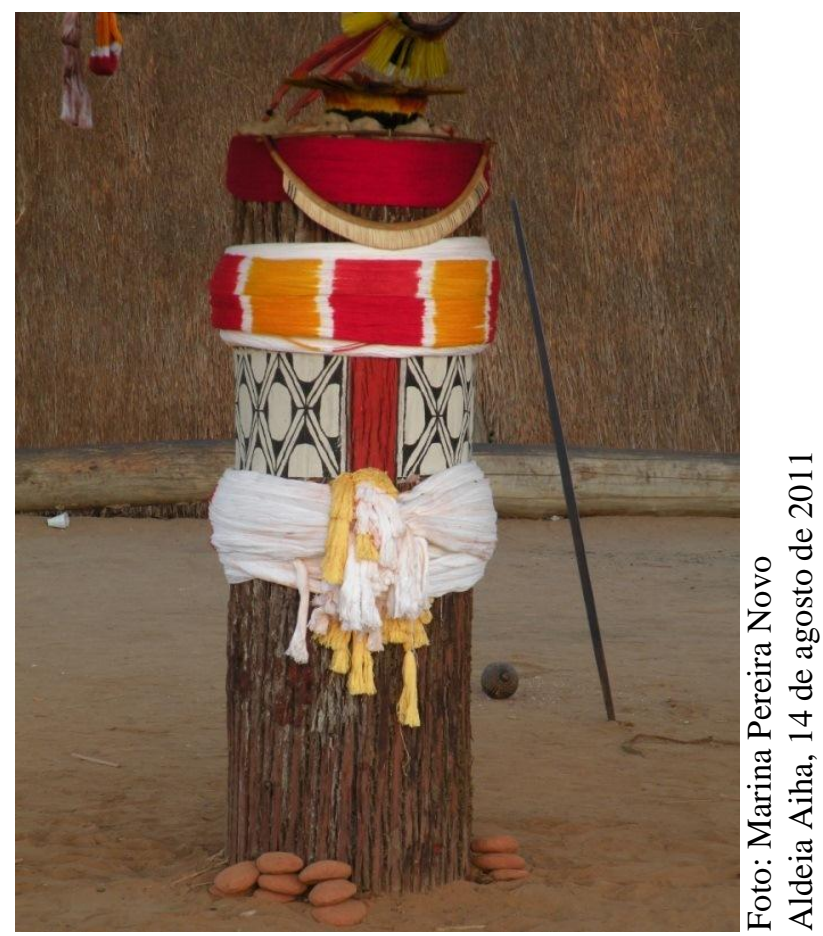

Figura 7.30: efígie feminina pronta, com cintos, colar de conchas e plumária.

Note-se as una dispostas aos pés da efígie. Ao fundo, um arco e um chocalho (no chão) usados pelos cantores.

Mas, pelo que vimos até agora, "desenho" e "imitação" não devem ter um sentido trivial, que é preciso examinar. Para começar, a efígie não é exatamente antropomorfa, e sua condição humana é produzida por meio de seus adornos e pinturas. Para os Kalapalo, uma imitação/desenho de algo não é necessariamente uma "cópia", e isso fica claro no caso dos grafismos. Vários motivos são associados a animais e a maioria carrega apenas poucos traços formais das espécies em que se baseiam. O que faz de algo uma imitação ou desenho não é sua perfeita identidade em relação ao modelo, mas a posse de algumas características consideradas fundamentais e que, não necessariamente, precisam ser formais.

A efígie pode ser pensada segundo a noção de "modelo reduzido" de Lévi-Strauss (2008 [1962]), usada por Lagrou (2002; 2003; 2007) em discussões mais gerais sobre objetos no mundo ameríndio. Lévi-Strauss (op. cit.: 38) define toda obra de arte como um "modelo reduzido", pois trata-se sempre de um produto em proporções menores do que as do modelo real. O autor não se refere ao "tamanho" de uma obra, mas ao fato de que toda produção artística é composta a partir da seleção de certos elementos do real e da exclusão de outros: 
Enfim, mesmo o "tamanho natural" supõe o modelo reduzido, pois que a transposição gráfica ou plástica implica sempre uma renúncia a certas dimensões do objeto: em pintura, o volume; as cores, os cheiros, as impressões táteis, até na escultura; e, nos dois casos, a dimensão temporal, pois a totalidade da obra figurada é apreendida num instante. (ibid: 39)

Assim, na produção artística, "parte-se de um conjunto formado por um ou vários objetos e por um ou vários acontecimentos, ao qual a criação estética confere um caráter de totalidade, pondo em evidência uma estrutura comum" (ibid: 41). Isto caracterizaria uma inversão do processo do conhecimento em relação à ciência: enquanto esta tende a romper a totalidade dos fatos para vencer a resistência da estrutura (isto é, analisa), a arte seleciona fatos para, por meio de suas relações, tornar evidente uma estrutura (sintetiza): "inversamente do que se passa quando procuramos conhecer uma coisa ou um ser em seu tamanho real, com o modelo reduzido o conhecimento do todo precede o das partes" (ibid: 39; grifos no original). Sua redução (a seleção do que se julga relevante para compor um todo) implica no reconhecimento de que, por seu caráter construído, um modelo reduzido nunca é apenas "uma simples projeção, um homólogo passivo do objeto: constitui uma verdadeira experiência sobre o objeto" (id. ibid: 39). Ele põe em evidência uma estrutura que "compensa a renúncia às dimensões sensíveis pela aquisição de dimensões inteligíveis” (ibid: 40).

Como modelos reduzidos, as efígies kalapalo utilizam elementos diversos do mundo xinguano e os reúnem em um único objeto, que não tem a pretensão de ser um "retrato", mas de sintetizar qualidades evocadas pelas pinturas e objetos que a compõem, pondo em evidência suas correlações. A árvore uẽgühi, por si só, tem algumas qualidades que parecem ser apropriadas para seu uso como "imitação de gente": 1) a analogia entre crescimento vegetal, consanguinidade e vida coletiva, que faz de um tronco uma imagem sintética da condição humana; 2) grandeza e beleza, dois ideais inseparáveis que os chefes perseguem em vida; e 3) capacidade de permanência: uma uẽgühi leva muitos e muitos anos para atingir uma altura e espessura razoáveis para seu uso no egitsü, e as efígies desfeitas são ditas durar "para sempre", quase intactas, na água das lagoas e rios, seu destino pós-ritual; os chefes, cuja memória deve permanecer entre os vivos para sustentar sua substituição por seus parentes, também são de alguma forma "eternos".

Além dessas características, toda a ornamentação da efígie é planejada para humanizála e aproximá-la do modelo dos chefes. O umbigo, a pintura corporal, os cintos, a pintura de 
cabelo, o colar e as plumárias fazem da tita algo que pode ser verdadeiramente chamado de efígie, a representação de uma pessoa. A humanidade da tita é produzida por índices e analogias, sem estar presa a qualquer ideia de forma ou representação. E como os conceitos de "gente" e "chefe" coincidem, é compreensível que produzir uma tita seja um procedimento originalmente feito para chefes, e que as efígies das pessoas lembradas como "seus seguidores" sejam apenas versões imperfeitas da efígie ideal (mais "finas" e com menos enfeites).

Há vários contrastes entre as efígies do egitsü e do hagaka. Diferentemente da segunda, representada com tronco, cabeça e braços, uma tita tem sua faceta humana impressa não pela forma, mas por características abstratas sobrepostas por pinturas e objetos que funcionam, sobretudo, como signos indiciais, mas também parcialmente icônicos (Peirce, 1955). Ainda, enquanto a efígie hagaka é construída para ser ao mesmo tempo feia e cômica, a efígie do egitsü deve ser adornada para atingir o máximo da beleza. Por fim, o boneco do hagaka representa um afim potencial, um primo cruzado guerreiro, e a tita é tratada como um super-consanguíneo, um ancestral. Feiura e afinidade potencial vigoram na efígie antropomorfa do hagaka, enquanto beleza e super-consanguinidade marcam as efígies não antropomorfas do egitsü.

O que aconteceu com o espírito da árvore e com o morto a essa altura do ritual? Já discuti no capítulo 4 que fazer um desenho/imitação de algo sempre tem o potencial de tornar presente, atrair, aquilo que ele pretende imitar. É por isso que desenhos de muriçocas ou queixadas feitos por feiticeiros atraem muriçocas e queixadas, e por isso a fabricação da roupa de um espírito permite torná-lo presente em um ritual. A mesma coisa se passa com a confecção da efígie que, quando começa a ser enfeitada pelos tajope, já se torna um desenho/imitação de gente capaz de atrair aquele que ela representa: o morto.

Nesse momento, a alma do morto vem de onde quer que esteja, se juntar aos vivos uma última vez. A divisão entre alma do olho e alma-sombra à qual a pessoa havia sido submetida é temporariamente anulada durante o ritual, e o morto é concebido novamente como tendo apenas uma akũ̃ - assim como os vivos, já que para os Kalapalo, a diferença entre as almas só faz sentido após a morte. Em vida, era possível dizer que a pessoa tinha apenas uma akuã porque ela possuía um corpo, cuja falta provocou uma divisão de sua alma, divisão análoga, como já mostrei (ver capítulo 4), à diferença entre corpo e alma (a alma do 
olho permanece como um corpo humano junto a seus parentes, enquanto a alma-sombra apresenta a capacidade de vagar e se transformar em outros seres).

Agora o morto tem novamente um corpo (a efígie) e, por isso, a dualidade alma do olho/alma-sombra deixa de operar. Mas a alma do morto não se instala na efígie. As pessoas sempre negavam quando eu lhes perguntava sobre essa possibilidade, dizendo que a alma do morto "é chamada" pela efígie e pela música, mas apenas "fica por ali, no meio das pessoas". Ainda assim, enquanto choram no centro, os parentes do morto tratam a efígie como se ela fosse de fato a pessoa homenageada, tocando-a e se dirigindo a ela por termos de parentesco. Isso se deve menos a uma eventual "animação" da efígie (que não ocorre) do que aos efeitos que a manipulação da efígie tem sobre o morto: como seus parentes não conseguem vê-lo, mas sabem que ele está ligado à efígie, tocar nela e dirigir seu choro ritual a ela são formas pelas quais os parentes conseguem fazer seu carinho e sua dor serem sentidos pelo morto.

E o que acontece com o espírito da árvore em meio a tudo isso? Eventualmente, depois das efígies prontas, vez ou outra os pajés sopram tabaco na face exposta do tronco e rezam para que o espírito continue calmo, pedindo que ele não chore. Isso significa que o espírito da árvore continua ali, diretamente ligado aos troncos, e permanece um itseke, apesar de todo o esforço para mantê-lo calmo enquanto se transforma seu corpo (o tronco da árvore) em um corpo humano. A uẽgühi e o morto entram em uma situação que pode ser descrita como um "devir" - "nem metáfora, nem metamorfose” (Viveiros de Castro, 2007a: 116), mas "um movimento que desterritorializa ambos os termos da relação que ele estabelece, extraindo-os da relação que os definiam anteriormente para associá-los através de uma nova 'conexão parcial"". Como no exemplo do xamã - evocado por Viveiros de Castro - que quando ativa um devir-onça não produz uma onça, nem se torna uma onça, mas estabelece uma espécie de aliança, tornando-se um agente múltiplo, portador ao mesmo tempo de características de homem e onça, sem se confundir com nenhum dos termos da relação. Com o devir, diz o autor, retomando Deleuze,

(...) uma zona de indistinção, de indiscernibilidade, de ambiguidade se estabelece entre os dois termos, como se tivessem atingido o ponto que precede imediatamente sua diferenciação respectiva: não uma similitude, mas um deslizamento, um avizinhamento extremo, uma contiguidade absoluta (...). (Deleuze, 1993: 100 apud Viveiros de Castro, 2007a: 119) 
A uẽgühi não se transforma em gente completamente (apesar de ter seu corpo humanizado), o que anularia sua condição de itseke, mas também não age exatamente como um, pois foi aproximada de alguma maneira dos donos do egitsü (sente compaixão por eles, pode chorar por antever sua morte e os ajudará a enfrentar seus adversários). Ela fica na posição de ser ao mesmo tempo humano e itseke, e não no sentido comum de que do ponto de vista dos espíritos eles também são humanos; seu corpo (a madeira) é humanizado, enquanto sua alma permanece como sempre foi. $\mathrm{O}$ morto, em seu turno, também participa desse "avizinhamento extremo" com a uẽgühi, já que ela passa a ser, temporariamente, seu corpo, mas sem que isso implique em um atrelamento da alma ao corpo, como durante a vida. Tanto a uẽgühi quanto a alma do morto se aproximam e se misturam sem se confundir nem se transformar completamente, tornando-se uma espécie de sujeito multiplicado: "o devir e a multiplicidade são uma coisa só" (Viveiros de Castro, 2007a: 117).

É importante notar que a efígie está sujeita a uma dualidade, pois se, para o morto, ela é um corpo, para os vivos ela pode, sob um aspecto, ser chamada de akuã - ela é vista como uma "akuã de chefe", no sentido de "imagem/sombra", semelhante ao de hutoho, "desenho/imitação". Apesar do aspecto genérico das efígies, que evocam uma figura arquetípica do humano, cada tita é considerada a "imagem" (akuã) ou "desenho/imitação" (hutoho) de uma pessoa específica (o morto que representa). Os patrocinadores do ritual também participam desse jogo de espelhos entre corpo e alma/imagem. Ao serem pintados e enfeitados pelos tajope, e serem apresentados perante seus adversários tal como os gêmeos Taũgi e Aulukumã, os donos são feitos como akuã dos chefes mortos: sua alma, sombra, imagem, ao mesmo tempo em que são reconhecidos como ihü, tronco/corpo, de seu povo. Mas mais uma vez, não se trata da imagem de um chefe específico, mas da forma visível do arquétipo do chefe. É isso que estava sendo dito no discurso de recepção de mensageiros que discutimos no capítulo 5 com o termo akuãpütelü, é nesse sentido que ele é, ao mesmo tempo, "homenagear" e "substituir": cria-se uma imagem do nobre morto que evoca sua memória e o presentifica, ao mesmo tempo que os donos da festa são feitos como seus substitutos ("imagens", akuã, dos chefes do passado). Como discutimos no capítulo 2, a ideia de substituição é central nas reflexões que os Kalapalo fazem sobre a chefia, pois é a partir dela que descrevem a continuidade em uma parentela de chefes (que tendemos a chamar arbitrariamente de "descendência" ou "hereditariedade"). O egitsü produz efígies e donos, caracterizados como corpos e imagens segundo diferentes pontos de vista: a efígie é um corpo 
para o morto, e uma imagem para os vivos; os donos da festa são um corpo para os vivos, mas uma imagem dos chefes mortos.

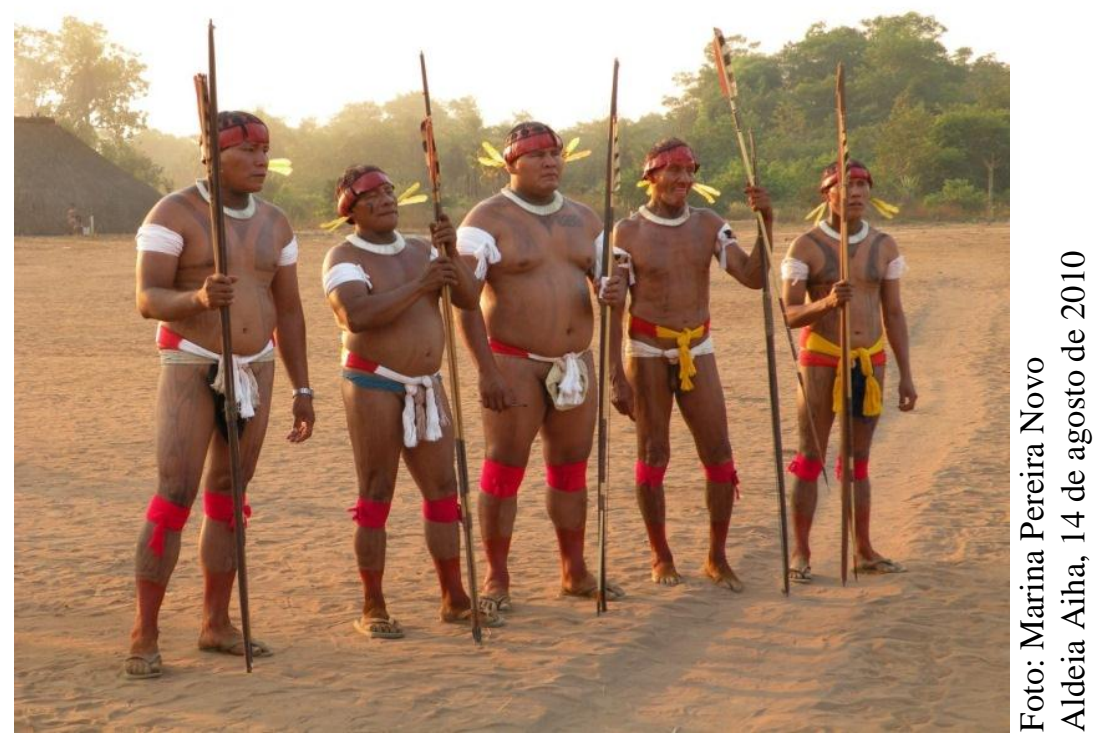

Figura 7.31: donos do egitsü de 2010.

Ao centro, Ugise, o dono principal. À sua esquerda está Omã, primo paralelo de seu falecido pai (homenageado principal) e Aumagi, seu irmão mais velho (que recebeu um dos "nomes famosos" de seu avô materno, o chefe Kambetse). À sua direita estão Lapitsuma e Matula, parentes do outro homenageado principal.

Após a morte consecutiva de três pessoas de sua família, uma mulher dizia a seu irmão mais velho que queria se mudar, abrir uma aldeia longe dali, para se protegerem dos feiticeiros. Seu irmão, dono de egitsü há três anos consecutivos em função de tantas mortes, negou seu pedido, dizendo que eles deveriam permanecer em Aiha, que agora ele estava "à frente da comunidade" e que a aldeia estava homenageando seus parentes para que eles não deixassem o local ${ }^{14}$. E começou a se a queixar comigo a respeito do que havia acontecido com outras pessoas que haviam sido donas de egitsü nos últimos cinco anos, mas que haviam abandonado a aldeia logo após o fím do ritual. Como ele me disse, "a comunidade faz festa para eles ficarem aqui. Mas depois da festa, eles pegam algum dinheiro que receberam de turistas e vão embora, abrir suas aldeias". Quando alguém morre, os parentes corresidentes tendem a destruir ou se desfazer de qualquer coisa que evoque a memória do morto. A

\footnotetext{
${ }^{14} \mathrm{Em} 2008$, quando ele foi indicado por um de seus tios maternos para se tornar dono de um egitsü em seu lugar, ele começou a ser chamado jocosamente de "cacique" por seus amigos, inclusive de outras aldeias, uma brincadeira que mostrava o reconhecimento público de sua nova posição ligada ao patrocínio do ritual.
} 
memória provoca saudade e o desejo de estar perto, que deixa a pessoa vulnerável. Por isso, antigamente, a tendência dos moradores de uma casa onde alguém morrera era abandonar a aldeia temporariamente, passando um período isolado nas roças familiares, mais afastadas. Hoje isso não acontece mais, pois as pessoas deixaram de manter essas roças familiares e, com a existência de recursos como poços artesianos, geradores de energia elétrica, rádio e barcos a motor nas aldeias, ninguém mais tem interesse em se afastar por muito tempo das aldeias principais.

A sugestão de um egitsü é um investimento do grupo na permanência dos parentes do nobre falecido na aldeia, uma forma de evitar sua dispersão após a morte. De fato, uma das características de um chefe é que ele não deve nunca sair de sua aldeia. Quando um filho de chefe é escolhido para ter suas orelhas furadas no ritual tiponhü, se diz que ele não pode se mudar, e se o fizer, será mal visto por seus coaldeões. Os chefes são figuras necessárias de permanência que, assim como árvores e esteios, devem ficar "fincados no chão", vivendo em uma mesma aldeia e, no caso de sua morte, deixando lá seus substitutos - novos troncos e esteios que ficarão "fincados" naquele mesmo chão (o solo da praça). Assim como a pessoa que se fragmenta após a morte, ou uma família que se dispersa após a perda de um parente, com o fim (ou saída) de um tronco/corpo (chefe), uma aldeia também tenderia à fragmentação. E tal como a fabricação de um novo corpo para o morto refaz a unidade da pessoa e lhe garante uma vida eterna junto a seus parentes, a substituição de um "esteio de gente" ou "tronco/corpo de todos" falecido por seus parentes vivos permite a continuidade de uma aldeia, o que é um aspecto da continuidade do processo de produção do parentesco. Ao fazerem troncos-corpos para as almas dos falecidos chefes, os Kalapalo também refazem para si novos troncos-corpos. Aqui as relações entre corpos e almas, em seus sentidos amplos, são tão importantes para o que se chama de "organização social" quanto para outros campos tradicionalmente privilegiados pelos pesquisadores quando se dedicam a esta dualidade, como o xamanismo e a feitiçaria.

Mas, apesar da efígie e dos donos serem "imagens de chefes”, eles não são imagens do mesmo tipo. Quando o nobre morto é identificado ao arquétipo do chefe humano (a mãe dos gêmeos), ele manifesta uma capacidade: englobar todos os humanos e, por isso, o egitsü tem o potencial de reunir toda a humanidade xinguana em uma única aldeia ao redor da efígie. Já os donos da festa, entram em outro registro. Diante de tal capacidade de englobamento, exibem e liberam seu "lado onça" e promovem o conflito ritualizado que reproduzirá, no seio daquela 
humanidade indiferenciada reunida pelo chefe arquetípico tornado presente, as diferenças necessárias para dar continuidade ao processo do parentesco. Por isso a transformação de um nobre em chefe arquetípico e ancestral deve ser concomitante a uma guerra ritualizada: sem a substituição de chefes, o regionalismo pacífico seria impossível, e sem a guerra ritual o sistema seria inerte como a aldeia dos mortos. O egitsü trata da inseparabilidade destes aspectos da sociedade xinguana.

\subsection{A guerra em cena}

Ao entardecer, começam os preparativos para a longa noite que ainda resta pela frente e para a competição na manhã seguinte. O primeiro preparativo, um dos mais importantes, é rachar a lenha que será usada para fazer fogueiras em frente a cada efígie. Elas são chamadas de "fogo do morto", e devem permanecer acesas até pouco antes do dia começar a clarear. Para isso, utiliza-se lenha da melhor qualidade (tahaku) e coloca-se uma tampa de metal ou tacho de cerâmica velha embaixo do fogo, para que ele não apague em contato com o solo. Não é a primeira vez que a ideia de "fogo do morto" aparece. O leitor deve se lembrar da descrição do enterro no capítulo 3, quando o "fogo do morto" é distribuído de casa em casa por um chefe imitando uma onça. Há uma associação entre o fogo e a vida: quando um chefe morre, seu fogo é distribuído, e quanto ele é revivido, seu fogo é refeito e deve-se cuidar para que ele continue aceso. Ele só será apagado quando a alma for embora de vez, pouco antes da alvorada. 


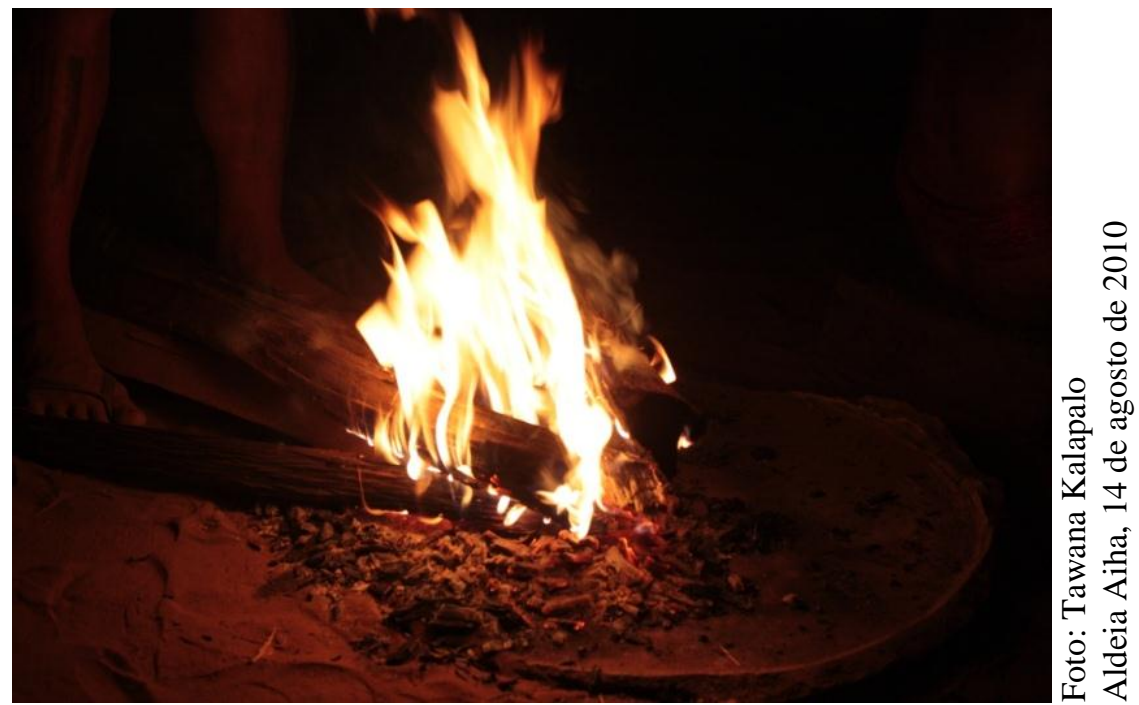

Figura 7.32: "fogo do morto" aceso sobre uma tampa de alumínio, para que não se apague.

O entardecer também é a hora da chegada dos convidados (já suficientemente descrita no capítulo 5), que vão para seus acampamentos. Nota-se que um clima tenso vai se formando na aldeia, pois os Kalapalo têm certeza que os convidados mal chegam e seus feiticeiros já começam a perambular à espreita de vítimas. E a luminosidade do crepúsculo é bastante propícia para se ver vultos de seres estranhos, de forma pouco definida, indo pra lá e pra cá são os temidos feiticeiros circulando em suas roupas de animais. Mas não é só isso: as pessoas ficam muito tensas esperando a entrada dos convidados na aldeia para pegar lenha, à noite. Há obviamente, um aspecto prático: as noites de inverno no Alto Xingu são muito frias e é impossível passar uma noite acampado no mato sem fogo. Antes dos fósforos, isqueiros, facões e machados, as pessoas viajavam com pedaços de tahaku em brasa para fazer fogo e era muito difícil cortar lenha suficiente para suprir as necessidades de um grande acampamento. Mas além disso, as primeiras relações de hostilidade ritual entre anfitriões e convidados começam em torno da posse do fogo.

Depois que anoitece, os ex-mensageiros chamam os coordenadores de cada povo, um a um, para entrarem na aldeia e "roubar" o fogo. Não se trata exatamente de um roubo, já que tudo é coreografado e orquestrado pelos tajope e ex-mensageiros, mas da encenação de um roubo marcado por gestos e sons de ameaça. Os coordenadores (ugihongo) entram um pouco à frente de seu povo, seguidos de todos os homens adultos e rapazes. Os chefes vão para longe do centro, a leste da casa dos homens, onde há três bancos (um para cada ugihongo), e esperam o dono principal do egitsü, que vai a seu encontro. Ele se agacha ou se curva, 
cumprimenta o ugihongo principal brevemente no gênero do anetü itaginhu e depois começa um choro cantado. Nesse momento, espera-se que o ugihongo chore junto com o dono, chamando o morto por um termo de parentesco, se isso for aplicável (geralmente é, pois os chefes de diferentes aldeias sempre se consideram "parentes distantes ${ }^{15}$ "). Enquanto isso, os homens correm em círculo ao redor das efígies e pegam alguns pedaços de lenha, que levarão correndo para seu acampamento, em fila. Os homens da aldeia convidada dão dois tipos de gritos: gritos agudos e curtos de alegria, e gritos graves e mais alongados que estão ligados à luta, são gritos de desafio (os mesmos gritos são dados quando os donos da festa apresentam cada um de seus principais campeões). Apenas os homens ficam no centro nesse momento, observando silenciosos, e as crianças são mantidas em casa, pois acredita-se que a situação tem um potencial violento. Os convidados agitam a lenha em brasa, e os Kalapalo vivem correndo atrás dos turistas presentes para evitar que eles se encrenquem por ficar no meio do caminho.

Isso se repete, aldeia por aldeia, e entre uma e outra faz-se silêncio e os parentes dos mortos se põem a chorar por certo tempo (até que os tajope peçam a eles que parem). A ordem de entrada é escolhida em conjunto pelos tajope e pelos donos da festa, que organizam os grupos de acordo com a qualidade de seus lutadores: os que tiverem mais e melhores campeões entram primeiro, e os que tiverem menos, por último. Essa ordem será mantida durante todo o ritual, mas ela é mais importante durante as lutas no dia seguinte (por razões óbvias, é preferível lutar primeiro com os mais fortes e deixar os mais fracos para o final, quando os lutadores já estão cansados). Em seguida, os ex-mensageiros buscam os cantores de cada povo, também na mesma ordem. O dono da festa deve emprestar arcos, plumárias e chocalhos aos cantores, e colocar em sua cintura um cinto novo, que passa a ser do cantor. Todos param para ouvir os cantores, é um dos raros momentos de silêncio dos participantes. Há uma grande expectativa para ouvir os cantores de outros povos, que têm tradições musicais distintas (usam letras um pouco diferentes, fazem outras coreografias, usam outro tom de voz, têm outra forma de marcar o ritmo com os chocalhos). Quando cada dupla termina, o cantor principal faz um pequeno discurso para o dono, dizendo que está "mentindo" (isto é, que ele não é um verdadeiro mestre do canto); o dono então lhes entrega peixe envolto em beiju, e os cantores voltam para o acampamento. Tão logo os cantores se

\footnotetext{
${ }^{15}$ Ver Guerreiro Júnior, 2008: 50.
} 
retiram, os parentes dos mortos voltam a chorar, e o fazem por um bom tempo, até que os tajope peçam que eles parem e sejam trazidos os próximos cantores.

Terminados os cantos, todos os lutadores se reúnem em frente à casa dos homens para serem rezados (os lutadores dos adversários fazem o mesmo nos acampamentos, se contarem com alguém que conheça as rezas). Um mestre de rezas deve executar uma série de kehege sobre os lutadores, todas referentes aos campeões do egitsü mítico.

\subsubsection{Algumas observações sobre rezas}

As kehege $e^{16}$ são fórmulas mágicas com inúmeras finalidades: atrair amantes, espantar chuva, facilitar o parto, fazer uma casa durar mais, espantar trovão, deixar a madeira mais leve, se proteger dos inimigos, enfraquecer ou confundir os adversários, aliviar a dor de um

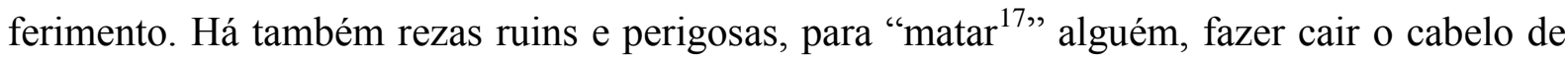
um desafeto, fazer uma criança ficar pequena para sempre. O uso de kehege é uma prática mais comum entre homens e mulheres idosas, é difícil encontrar jovens donos de rezas. Os jovens que têm rezas conhecem apenas as mais simples e práticas, como aquelas para espantar chuva e atrair amantes.

A maioria das rezas é estruturada em duas partes, uma primeira em $\operatorname{arawak}^{18}$ e outra em karib (Mehinaku, 2010: 108-110). A primeira parte deve ser pronunciada em um tom e ritmo específicos "dentro da boca", como os Kalapalo dizem, bem baixo para que "as palavras não saiam". A segunda parte é falada em um tom um pouco mais alto, mas ainda de maneira muito discreta, e intercalada com longos sopros (tudo também com uma musicalidade peculiar das kehege). Essa parte é, via de regra, a enunciação do efeito que se espera da kehege (id. ibid.). Os Kalapalo dizem que as palavras são levadas pelo vento do sopro e ficam "em

\footnotetext{
${ }^{16}$ Kewere em kamayurá e exekeki em arawak (Mehinaku, 2010: 108).

17 Até onde sei, uma reza desse tipo não mata da mesma forma que um feitiço, mas deixa a pessoa mais suscetível a ataques de espíritos ou feiticeiros.

${ }^{18}$ As fórmulas da primeira parte das kehege foram inventadas e ensinadas aos humanos por Aulukumã. Como já mencionei no capítulo 3, Aulukumã fala arawak (diferentemente de seu irmão mais velho, falante de karib), motivo pelo qual as formulas são nessa língua.
} 
cima/junto" daquilo ou daquele que se está rezando. As palavras de uma kehege têm força ${ }^{19}$ (kinhahetungu) e quando são carregadas pelo vento até seus objetos podem agir sobre eles.

Essa força não está dada de antemão nas palavras, mas precisa ser produzida (caso contrário as fórmulas das kehege seriam dispensáveis). O que as torna fortes, eficazes, é a primeira parte da reza (seu componente em arawak). Por isso, ela precisa ser pronunciada "dentro da boca", é como se essas palavras precisassem ficar acumuladas para tornar o enunciado subsequente potente, "forte". Toda kehege tem origem na ação de algum itseke na trama de um mito. A reza do Cupim, por exemplo, teve origem quando o Cupim ajudou um homem a deixar uma tora de nẽgühi mais leve, e sua reza replica este efeito; a reza para espantar trovões teve origem com o Pica Pau, que repeliu o Trovão em um mito; a reza para espantar chuva tem origem com o Caranguejo, que o fez em um mito. Enfim, praticamente qualquer ação interessante de um itseke realizada ainda no tempo mítico possui uma reza correspondente capaz de reproduzir tal ação no mundo atual.

Nas kehege mais simples, a primeira parte é formada pela enunciação do nome do itseke em arawak, intercalada com designações antigas, também em arawak, dos gêmeos Taũgi e Aulukumã. Vejamos por exemplo uma reza para espantar chuva (kongoho agitoho):

\section{Tühoko kehegesü (reza do caranguejo)}

Itsalatu, Itsalatu

Caranguejo, Caranguejo

Kami

Sol

Itsalatu, Itsalatu

Caranguejo, Caranguejo

Kegi

Lua

Itsalatu, Itsalatu

Caranguejo, Caranguejo

\footnotetext{
${ }^{19}$ Segundo Mehinaku (ibid: 109), a força também vem da boca do rezador (dito ser uma pessoa "com boca eficaz", tüdakuhengi), o que se consegue pelo consumo de frutas específicas.
} 
Amugi
Chefe (Sol)
Itsalatu, Itsalatu, Itsalatu
Caranguejo, Caranguejo, Caranguejo

(fu) Ah, ila eteke! (fu) Ah, ila eteke! ( $f u)$

(sopro) Ah, vá para lá! (sopro) Ah, vá para lá! (sopro)

O primeiro bloco é todo em arawak. A reza começa com a enunciação do nome do Caranguejo naquela língua (Itsalatu), seguida de Sol (Kami); em seguida repete-se o nome do itseke, seguido de Lua (Kegi); na próxima repetição, fala-se novamente do Sol, mas com a designação de amugi, palavra yawalapíti que corresponde a amunãu em mehinaku e anetü (chefe) em karib (Mehinaku, 2010: 110). A primeira parte se encerra com a repetição do nome do itseke, mas o executante poderia ainda, se quisesse, repetir mais algumas vezes designações para Sol e Lua. Dizem que a referência aos gêmeos é o que dá força à reza: sem seus nomes uma kehege não tem efeitos.

No caso das rezas para lutadores, há dois tipos: de peixes e de onças. As primeiras podem ser feitas individualmente por qualquer campeão (ou por seus pais) para ter força ou destreza para se desviar das investidas dos adversários, enquanto as segundas são feitas coletivamente, nos acampamentos (pelos convidados) ou no centro, pelos anfitriões. Vejamos um exemplo das rezas do primeiro tipo, executada por Waja:

Ajamu kehegesï̈ ${ }^{20}$ (reza do poraquê - peixe elétrico)

Julaki (5x)

Poraquê

Kapijekei natu

Eu sou campeão

\footnotetext{
${ }^{20}$ Registrada com Waja em 10 de setembro de 2010.
} 


\author{
Jamuna natu \\ (sem tradução) \\ $\operatorname{Julaki}(3 x)$ \\ Poraquê \\ Kapijekei natu \\ Eu sou campeão \\ Jamuna natu \\ (sem tradução) \\ Julaki (3x) \\ Poraquê
}

(Fu) ah, ikindotoha ugei! (fu, fu...)

(sopro) ah, eu sou campeão! (sopro)

Esta é a reza do Poraquê, que dava fortes choques em seus adversários. Ela deve ser feita enquanto o lutador esfrega suas mãos juntas, para que possam ter força para agarrar, repelir e arremessar o adversário. Como se vê, ela repete o nome do lutador mítico em arawak (Julaki, segundo a pronúncia de Waja) intercalado com a frase (também em arawak) "eu sou campeão" (kapijekei natu), cujo significado é conhecido pelo dono da reza. Não consegui obter uma tradução para jamuna natu, mas a proximidade sonora entre jamuna e amunaw (chefe, em arawak) é tentadora, e se for procedente esta expressão significaria "eu sou chefe". Na parte final, a pessoa que reza sopra e diz, agora em karib, "eu sou campeão". Nas rezas kuegitsaha se passa algo semelhante, pois, no único trecho da kuegitsaha da onça branca (Kusutse) cujo significado Waja conhece, diz-se "eu sou branco" em arawak (alaha alahagi, na pronúncia de Waja), indicando que estas rezas, aparentemente, operam da mesma forma: promovendo uma identificação entre os lutadores objetos da reza e capacidades dos seres míticos aos quais estão ligadas.

As kehege são uma forma que os humanos têm de realizar ações de que só itseke são capazes e que já foram realizadas no tempo mítico. A primeira parte da reza tem um caráter 
indicial, pois aponta para o mito ao qual está ligada, sempre de forma implícita ou indireta (ninguém precisa conhecer a relação exata entre um itseke e um mito para aprender uma kehege ou conhecer seus efeitos). Em sua forma mais simples, essa indiciação é feita somente pelo nome do itseke (como na reza do Caranguejo), e em suas formas mais complexas ela é complementada por palavras ou expressões que apontam para o contexto de sua origem. As evocações de Taũgi e Aulukumã por diferentes nomes, e especialmente de Taũgi como "chefe" (amugi), realizam uma espécie de "ponte" entre o mundo mítico, no qual o ato que se quer replicar foi executado pela primeira vez, e o mundo humano. E não é para menos, pois os gêmeos são de fato os itseke a meio caminho entre esses dois mundos/tempos. Talvez essa seja a origem da eficácia de seus nomes, pois só eles, mediadores por excelência, podem permitir que um humano aja como um itseke simplesmente através de sua fala.

\subsubsection{A luta}

Depois de terem sido rezados, os lutadores permanecem um tempo no centro, conversando e, eventualmente, vão para suas casas, mas eles não devem dormir em hipótese alguma. Quando um lutador dorme, ele pode sonhar com lutas futuras, e esses sonhos são presságios. Caso o lutador vença a luta com a qual sonhou, é um sinal de que no dia seguinte ele lutará bem e ganhará de seus adversários; mas caso sonhe que perdeu uma luta, certamente perderá todas. Na realidade, esses sonhos são mais do que presságios, pois uma visão desse tipo não revela algo que vai necessariamente acontecer: a derrota só se tornará inevitável caso

o lutador sonhe com ela. É como se os sonhos com a luta criassem o futuro, e é isso que os lutadores tentam evitar quando passam a noite em claro.

De madrugada, os cantores executam a suíte Imitoho ("feito para amanhecer"), ao fim da qual um tajope pede em voz alta, no centro, que a alma do morto vá embora, e os coordenadores enterram o que sobrou do fogo de cada morto. Amanhecido o dia, a alma se vai, e o enterro do fogo simboliza o fim de sua estadia entre os vivos (assim como a distribuição de seu fogo marcara, após o seu enterro, sua morte). Quando o dia começa a clarear, ouvem-se de longe os gritos dos convidados nos acampamentos, ansiosos para a competição. Os lutadores da aldeia se preparam, pondo seus cintos e arrumando suas pinturas e enfeites: alguns pintam o corpo todo de preto com carvão, outros fazem círculos imitando a 
pele da onça. A primeira pintura pode ser feita por qualquer pessoa e é a pintura padrão da guerra, usada por guerreiros, pajés que enfrentam espíritos e lutadores. A segunda é tai ${ }^{m}$ pane, prerrogativa exclusiva de grandes campeões, mas que hoje é usada mais livremente. Não é preciso dizer que a referência à onça pintada evoca, ao mesmotempo, a afinidade potencial (a onça é o primo cruzado dos humanos) e a inimizade. A pintura da onça e o carvão são ambos um atestado de que os lutadores estão, de certa forma, indo para uma guerra contra seus inimigos/afins potenciais.

Quando os lutadores estão prontos, se reúnem na casa do principal dono da festa. Ao sinal dos tajope, que permanecem no centro, saem em fila, correndo e dando gritos de alegria. Conforme vão chegando ao centro, começam a formar um grande círculo em volta das efígies e dos donos, que ficam no meio de tudo. Formado o círculo, os lutadores começam a gritar $h i$ ou! em uníssono, repetidamente, de forma alongada e com uma pequena pausa entre as execuções - é o grito típico dos lutadores, um grito de desafio. Eles vêm batendo os pés no chão com força e fechando o círculo ao redor dos chefes, até que os tajope digam que é suficiente, e então se aglomeram atrás dos donos.

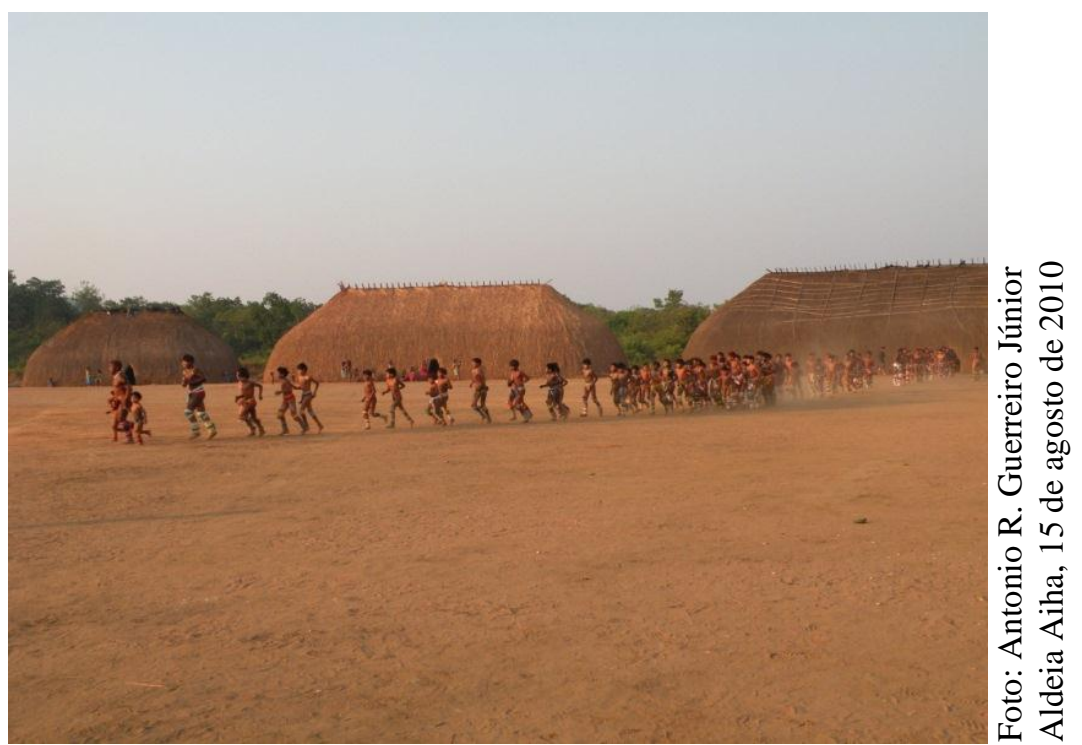

Figura 7.33: lutadores saindo em fila da casa do dono do egitsï em direção ao centro. 


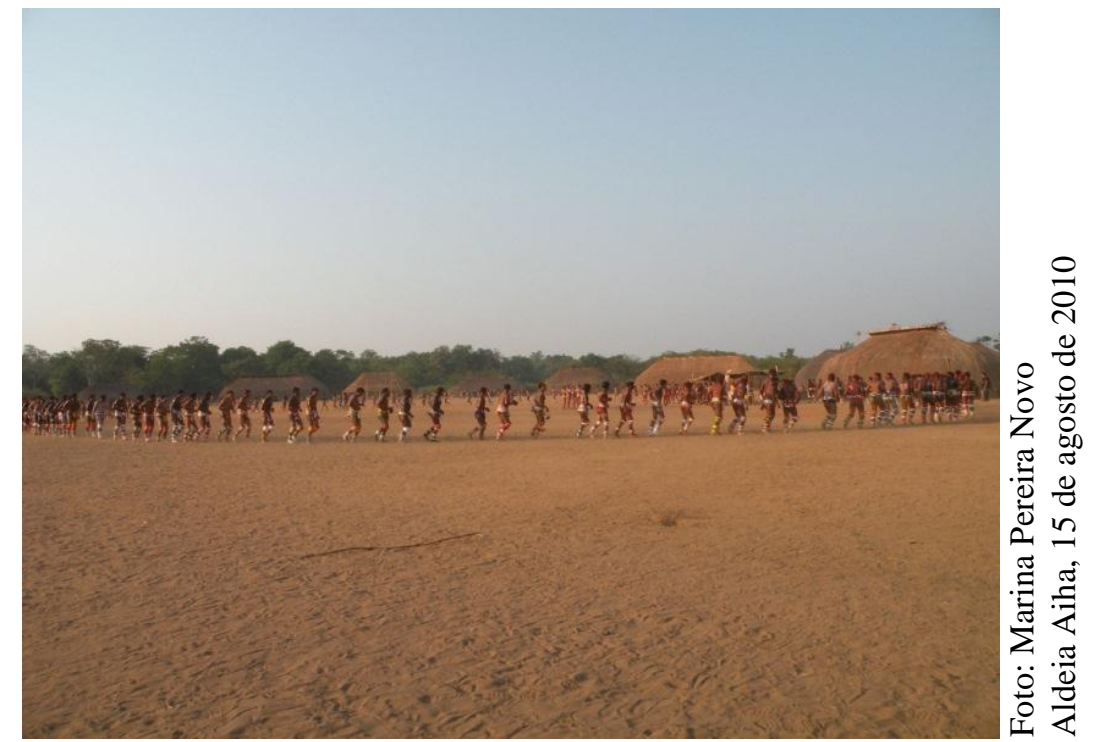

Figura 7.34: lutadores da aldeia correndo em círculo ao redor dos donos do egitsü e das efígies.

Chega a hora dos convidados entrarem. Eles o farão na mesma ordem do roubo do fogo, que também determina a ordem dos enfrentamentos. O principal mensageiro que convidou um povo vai até seu acampamento e chama os ugihongo, que já estão na expectativa. Os homens entram correndo, em fila, e fazem exatamente o mesmo que fizeram os lutadores da aldeia. Os ugihongo, enquanto isso, se dirigem para os bancos indicados pelos ex-mensageiros, um pouco distantes do centro, acompanhados das mulheres. Isso se repete para cada povo, até que todos tenham entrado e apresentado seus lutadores, no tom de desafio que marca a coreografia.

Os donos convocam e apresentam seus campeões. Eles se viram para seu povo, reunido em frente à casa dos homens, para chamar seus campeões um a um, e ficam de costas para os convidados enquanto isso. O chamado é feito de forma musicalizada, do mesmo jeito que os donos chamam os tajope para receber seus pagamentos de alimento no centro, como por exemplo: "Untsi, ilanha etete, ilanha etete, ilanha etete uinha!" ("Meu filho/sobrinho, venha aqui, venha aqui, venha aqui para mim!"). Após ser chamado, o campeão corre até a região do centro onde ocorrerão as lutas, e se põe de joelhos e cabeça baixa de frente para o povo que será enfrentado. Quando o campeão corre, os homens batem os pés repetidamente e gritam hi-ou!, mais uma vez em sinal de desafio. São chamados em torno de dez campeões (mas isso é uma decisão dos donos da festa), e cada um se ajoelha ao lado do outro, formando uma fila. Apenas os lutadores que já foram assim convocados pelos donos de um egitsü são ditos "donos da luta" (ikindoto) em sentido estrito. 


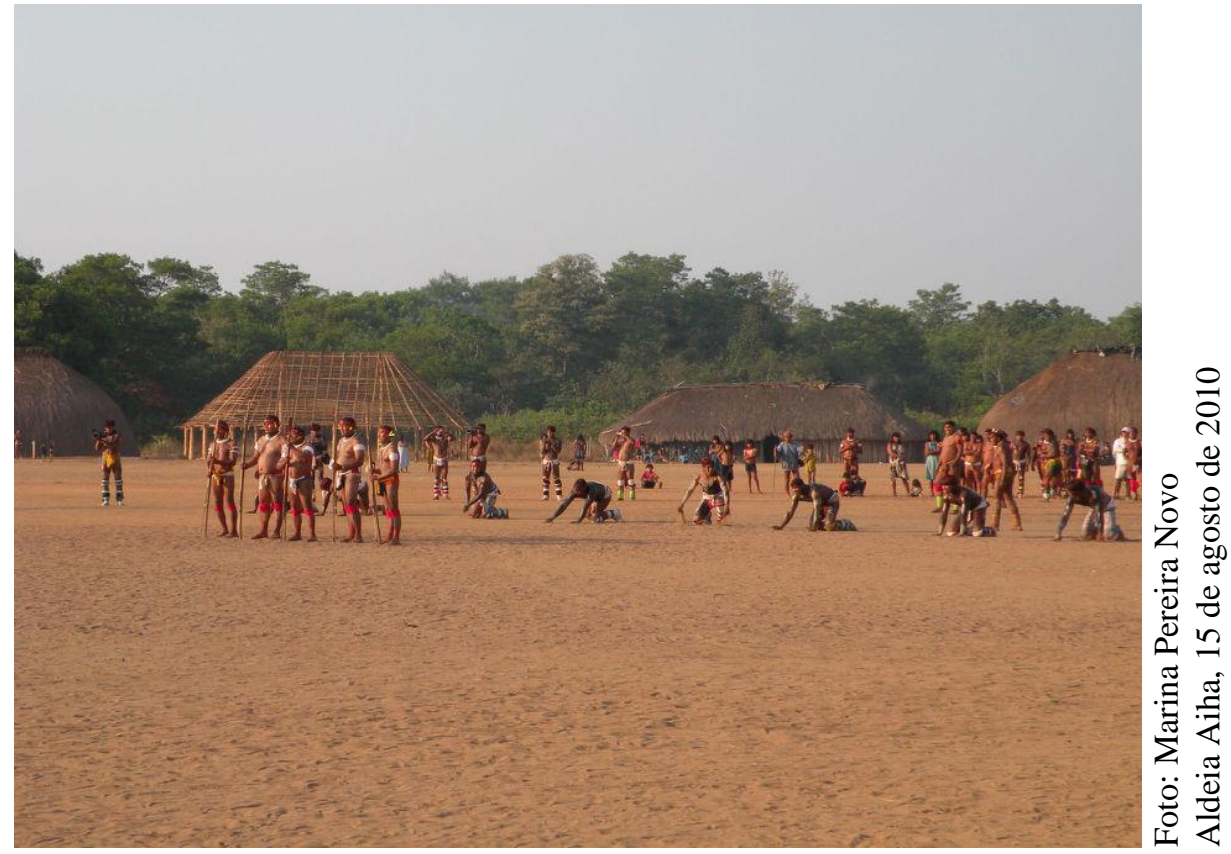

Figura 7.35: campeões ajoelhados, "como onças".

À frente, os donos do egitsü.

Heckenberger (2003: 32) diz que os lutadores "kneel before the anetï sponsors with head to ground, in a graphic gesture of supplication". Súplica é um pedido humilde ou submisso, e não me parece haver nada no contexto do ritual que valide a descrição de Heckenberger. Os lutadores não estão ajoelhados perante os chefes donos da festa (que inclusive ficam de costas para seus lutadores até a convocação do último campeão), mas perante os chefes estrangeiros. Sua posição não é de "súplica", e sim de provocação, pois os ikindoto replicam corporalmente a posição das onças no egitsü mítico: ficam de joelhos como se fossem grandes predadores, como ameaças aos seus adversários. Heckenberger quer enxergar algum tipo de hierarquia e poder entre os donos da festa e seus lutadores, enquanto a estética do ritual me parece apontar claramente para as relações simétricas de confronto com os estrangeiros. Tanto que, após a última convocação, os donos da festa se viram e caminham em direção ao povo que será enfrentado, parando pouco à frente de sua "seleção", quando todos os homens gritam hi-ou em sinal de desafio aos convidados e se desfaz a formação. Há uma assimetria, ou hierarquia, entre os donos e seus lutadores, porque o confronto entre dois 
povos é, na realidade, um confronto entre chefes por meio de seus lutadores ${ }^{21}$. A questão é saber se a assimetria interna pode ser entendida sem se levar em conta a simetria competitiva externa, o que não me parece possível.

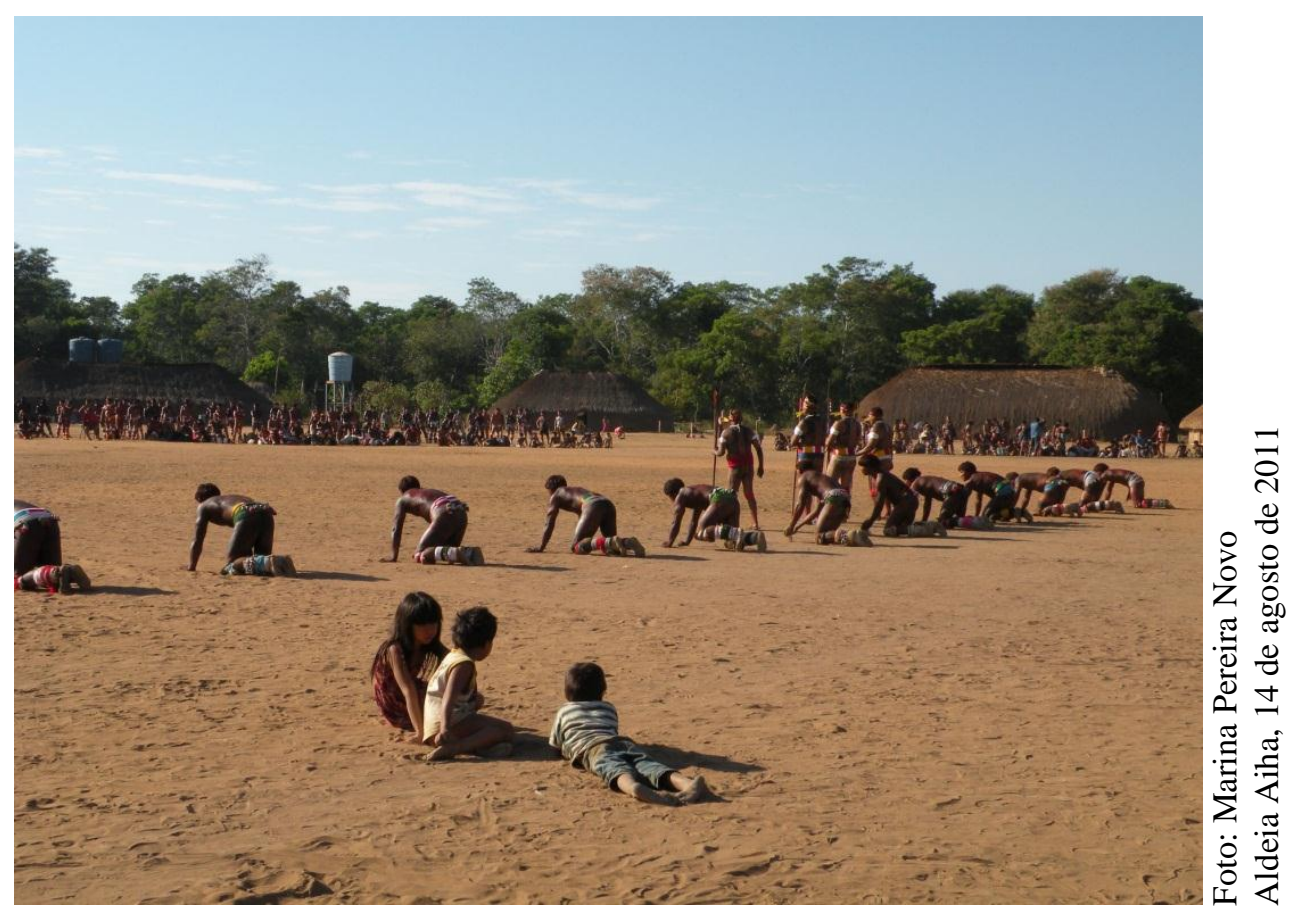

Figura 7.36: donos do egitsü adiante de seus campeões, posicionados de frente para o grupo que será enfrentado.

Os donos da festa voltam a suas posições e os lutadores aguardam atrás deles. Logo, o primeiro lutador convocado se adianta e espera seu adversário, que também é membro de uma "seleção" feita informalmente pelos convidados. Os lutadores ficam de frente um para o outro e começam a girar em sentido horário, batendo os pés no chão e imitando o som do esturro da onça (mais uma evidência de sua posição de onça), até que se atacam e começam a lutar. Ninguém tem olhos para mais nada e cada movimento é observado e comentado com fervor. As pessoas gritam o tempo todo para os lutadores: "Derrube ele! Pegue a perna dele! Cuidado, não deixe ele te agarrar!". Os tajope e outros chefes acompanham cada luta relativamente mais perto do que os outros, pois cabe a eles apartar qualquer eventual briga ou discutir com os chefes do grupo adversário sobre um resultado duvidoso. As mães dos lutadores também costumam assistir a suas lutas de perto, dando conselhos e rezando os

\footnotetext{
${ }^{21} \mathrm{Se}$ os donos estabelecem relações uns com os outros por meio daquilo que possuem, fica claro porque apenas os lutadores da "seleção" são os verdadeiros "donos da luta": permitem a relação competitiva entre dois coletivos através de seu esporte.
} 
adversários para que eles fiquem fracos e sejam derrotados. A agitação de uma mãe nesse momento é enorme, e é comum ouvir mães vociferando quando seu filho perde. Nessa ocasião, a mãe tem o direito de receber como pagamento pela derrota de seu filho o cinto do lutador que o venceu, mas vi isso acontecer poucas vezes. Em certa ocasião, um lutador venceu o principal campeão kalapalo, que até então (dizem) nunca havia perdido uma luta sequer. Sua mãe começou a gritar insistentemente com o outro lutador pedindo seu pagamento, mas, como o rapaz não the deu a menor atenção, ela correu em sua direção e arrancou à força um cinto de miçangas que ele usava (não sem ter que vencer a resistência do lutador).

Primeiro lutam todos os campeões segundo sua ordem de convocação e, em seguida, ocorrem várias lutas simultâneas entre quem quer que queira se enfrentar. Muitos homens arranjam lutas entre seus filhos e os primos cruzados deles, para que os jovens se reconheçam como parentes cruzados e para exibir seus filhos como lutadores promissores. As crianças também lutam, um pouco afastadas dos adultos, e são atentamente observadas e orientadas por seus pais. Até hoje, eu não consigo acompanhar nem metade das lutas que acontecem nesse momento, mas os xinguanos têm uma atenção impressionante e são capazes de relatar o resultado de cada uma. De tempos em tempos, os donos da festa se movem um pouco mais para frente e as pessoas os seguem apertando cada vez mais o círculo. Quando o círculo está muito fechado e os tajope julgam que já houve lutas suficientes, eles encerram o confronto. Nem sempre isso agrada os chefes dos convidados, que querem continuar lutando para deixar os anfitriões cansados ou vingar-se de alguma derrota considerada desleal.

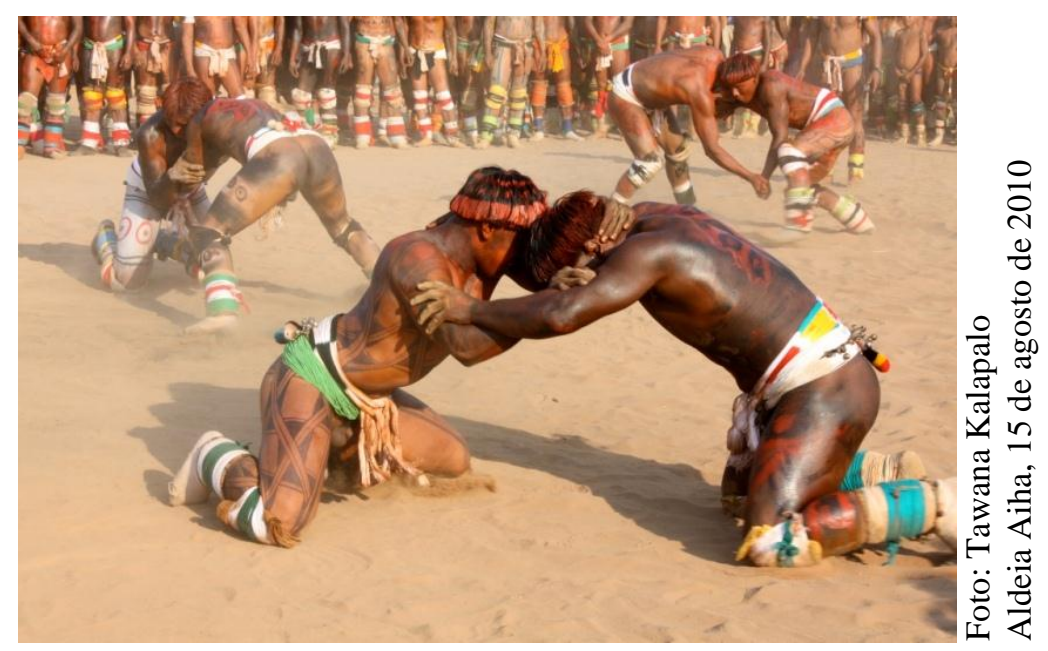

Figura 7.37: três duplas de lutadores se enfrentando. 
Como tudo o mais, o mesmo procedimento se repete com cada povo convidado: convocação dos campeões, lutas ordenadas dos convocados com os melhores lutadores convidados e lutas entre todos os que quiserem lutar. Não é preciso dizer o quanto isso consome as energias dos ikindoto, obrigados a enfrentar sempre os melhores lutadores dos convidados. São frequentes os casos de pessoas machucadas (os braços e ombros estão muito sujeitos a lesões), que passam mal e mesmo desmaiam. Para os(as) enfermeiros(as) da equipe de saúde que atende a região, dia de egitsü significa dia de muito trabalho. E não é para menos: depois de passar a noite em claro, praticamente sem se alimentar e lutar debaixo de um sol muito quente, no auge da estação seca, é compreensível que muitos lutadores passem mal. Mas para os alto-xinguanos não há nada que explique esses infortúnios além da feitiçaria. No egitsü kalapalo de 2010, vários lutadores kuikuro desmaiaram enquanto lutavam, inclusive alguns de seus principais campeões. Os chefes kuikuro estavam visivelmente irritados com a situação, mas ninguém havia dito nada, até que a mãe de um desses lutadores se colocou à frente dos chefes e começou a gritar dizendo que os Kalapalo eram todos feiticeiros, que ela estava cansada de seus feitiços e que eles deveriam parar de atacar seu filho. Nada de mais grave aconteceu, mas os Kalapalo ficaram muito ofendidos com o desabafo da mulher. Como sempre há alguém que passa mal, a feitiçaria desempenha um papel importante na luta, sendo usada como uma arma contra os adversários - apesar de, obviamente, ninguém jamais admitir fazê-lo.

Por trás do caráter esportivo da luta, está uma imensa tensão entre os grupos. Além das agressões invisíveis dos feiticeiros, muitas vezes alguns lutadores se desentendem e ameaçam brigar. Nunca vi um lutador chegar a agredir outro diretamente, pois os chefes e outras pessoas agem o mais rápido possível para apartar qualquer tentativa de violência, mas não é que lhes falte vontade. Com certa frequência, algum lutador joga areia nos olhos de seu adversário, ou executa um golpe mais violento mesmo depois de já ter vencido a luta (como arremessar o adversário de costas no chão com força, considerado desnecessariamente violento e humilhante). Aquilo que é tratado pelos pesquisadores como a marca do pacifismo xinguano (e mesmo pelos índios, em sua autorrepresentação) não deixa de estar imerso em violência - não a violência guerreira, certamente, mas a violência mágica, considerada onipresente, e a violência física que ameaça emergir o tempo todo (e o faz muitas vezes dentro da própria luta). Não é à toa que o mito de origem do egitsü insiste nas intenções 
assassinas de Taũgi em relação a seus convidados, os peixes. Assim como a afinidade potencial pode ser vista como uma "afinidade sem afins", a luta xinguana pode ser vista como uma "guerra sem mortos", uma forma de confronto que obvia a morte.

O enfrentamento precisa ser esportivo porque o ritual deixa claro que o princípio da troca deve se sobressair ao da guerra. Depois de todas as lutas, as jovens reclusas saem publicamente da reclusão. Elas são levadas por suas mães até o centro, e se posicionam atrás dos donos da festa, que permanecem de frente para os coordenadores dos aliados (kataentsokongo). Suas mães amarram belos cintos abaixo de seus joelhos, como se fossem jarreteiras, e as jovens recebem dos donos da festa um pequeno cesto com castanha de pequi torrada. Elas dirigem-se a um dos coordenadores, que retira suas jarreteiras (distribuídas entre os lutadores) e recebe da jovem castanhas de pequi, colocadas ao lado de seus pés. A mãe então coloca novas jarreteiras na filha, para que isso se repita perante os outros dois coordenadores. Não muito tempo depois de retornar à sua aldeia, o ugihongo principal deve pescar para oferecer a todos, pirão temperado com as castanhas moídas. Após a saída das reclusas, os ugihongo chamam os ex-mensageiros para trocar seus objetos valiosos.

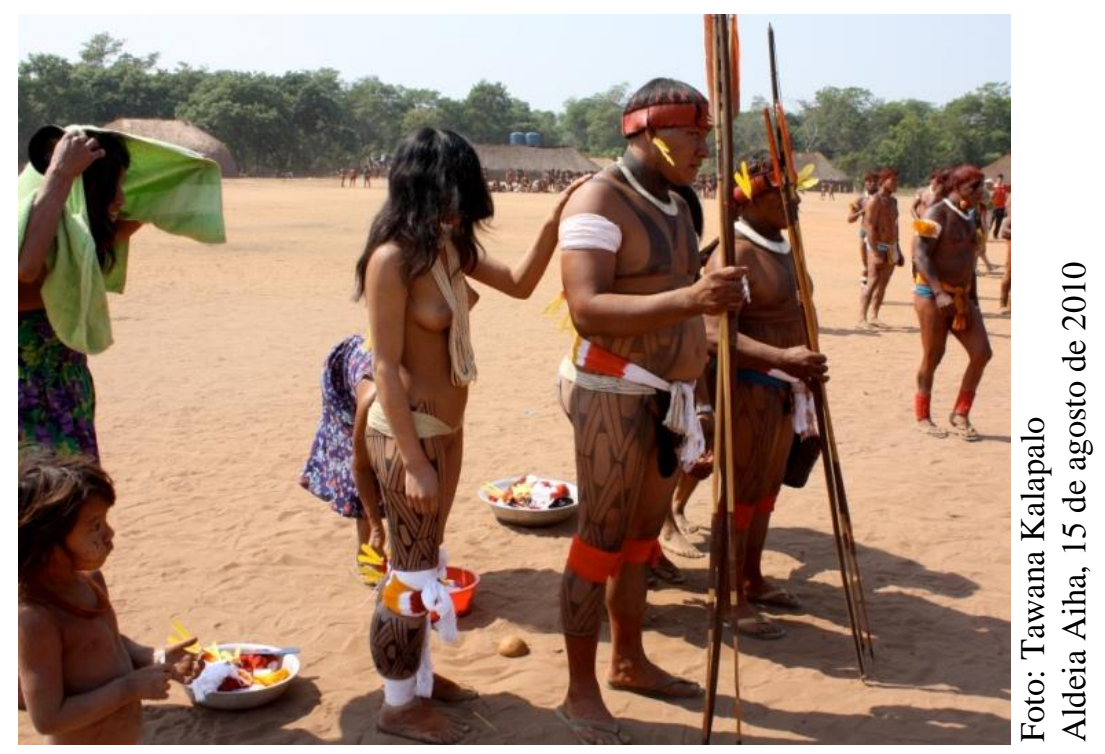

Figura 7.38: jovem saindo da reclusão pubertária em frente aos chefes aliados.

Notem-se os cintos amarrados como jarreteiras abaixo de seus joelhos. Atrás dela, uma bacia com outros cintos.

A partir daí, as jovens passam a ser consideradas mulheres aptas a se casar (algumas se casam logo depois, caso estejam noivas - o que tem se tornado cada vez mais raro), e os 
gestos necessários para o fim da reclusão (a remoção das jarreteiras e a entrega das castanhas) simbolizam o casamento e o sexo (e, portanto, a aliança). Quando um jovem se casa, cabe a ele retirar as jarreteiras de sua noiva, que se tornarão seus cintos; o pequi, de seu lado, é uma fruta associada à sexualidade e, na mitologia, seu aroma teve origem nas vaginas das mulheres. É como se os aliados "recebessem" jovens sob a forma de jarreteiras (transformadas em cintos) e castanha, símbolos da afinidade potencial entre os grupos que, ao invés de focalizarem o confronto, focalizam a aliança. Para a festa, os aliados se unem aos anfitriões como se fossem um único grupo de parentes consanguíneos; terminado o egitsü, marca-se suas relações não pela consanguinidade, mas pela afinidade potencial. Ainda, o final do egitsü também é o momento ideal para a construção de relações de afinidade efetiva dentro do grupo local, pois é quando são realizados muitos casamentos. É a ocasião privilegiada para a concretização dos casamentos arranjados, na maioria uniões entre filhos e filhas de chefes.

A despeito da hostilidade e da necessidade de dramatizar a guerra, o fim do ritual declara que a troca deve prevalecer. Esta não é uma afirmação que põe a troca e a guerra em polos opostos, mas que afirma a necessidade da segunda para tornar a troca possível, já que esta depende da diferenciação da humanidade alto-xinguana segundo diferentes grupos. Como discuti no capítulo anterior, segundo Strathern (1992; 2006 [1988]), a dádiva efetua uma distinção entre os parceiros de troca, os separa enquanto agentes distintos. No Alto Xingu esta separação é promovida tanto pela luta como guerra simbólica quanto pelas trocas de objetos entre os ex-mensageiros e chefes convidados; mas a ordem dos eventos (primeiro luta, depois troca) é um comentário sobre como a capacidade de aparecer como um agente em uma relação de troca depende da possibilidade de aparecer como sujeito (predador) em uma relação (de confronto).

$* * *$

No final do dia, depois que os convidados foram embora e as pessoas já tiveram tempo de tomar banho, comer com calma e descansar, derrubam-se as efígies. Isso é feito sem qualquer cerimônia e, muitas vezes, os homens delegam essa função a algumas crianças, que se divertem bastante. Alguns troncos podem ser levados para a frente da casa de seu dono, onde ser tornarão bancos, mas a maioria é rolada pelas crianças até a lagoa, para que 
"esfrie",22. Tudo o que é dotado de agência e perigos sobrenaturais é "quente", como o sangue animal e os feitiços, por exemplo; a efígie, desde que foi cortada, é "quente" por estar associada a seu espírito e à alma do morto, e precisa ser esfriada para voltar a ser apenas um tronco.

\subsection{Guerra e ritual}

Se, como vimos, os donos são mediadores de relações, o que significa definir os donos do egitsü como "donos do morto"? Por um lado, eles são seus donos porque estão "cuidando" dele de forma ritualizada, a fim de manter suas relações de parentesco. Mas por outro lado, se a figura dos donos só é ativada perante outros donos (ver capítulo 3), poderíamos nos perguntar com quem os donos se relacionam por meio do morto, e para quê. Estão em jogo pelo menos duas relações: com os mortos e com os estrangeiros. Suspender o luto é livrar-se da morte e de tudo aquilo que a evoca: as substâncias corporais expelidas pelo choro, a saudade, a tristeza e, claro, o próprio morto, ou sua alma. O egitsü é a transferência de uma pessoa entre dois coletivos, o dos vivos e o dos mortos. Uma transferência ambígua, é certo, pois integrar-se plenamente à sociedade dos mortos, que é o mundo da consanguinidade perfeita, do parentesco inabalável, tem um preço: desfazer seu parentesco com os vivos, deixando na terra apenas seu componente não humano, sua alma-sombra transformada em itseke.

Já na relação com os estrangeiros, os donos do morto podem ser vistos como os "donos da morte", pois é sua proximidade com a morte que os faz diferentes (estando de luto, ainda correm os perigos de morrer de tristeza e saudade, ou de atrair o morto pronunciando seu nome). Mas sugiro que eles também são os donos da morte porque estão na posição de matadores em potencial - estão na posição de Taũgi e das onças no mito do primeiro egitsü, tentando matar seus convidados. Matar não seria uma forma de se livrar da morte? Ou melhor, se alguém é morto por ter sido colocado na posição de presa (de um feiticeiro e de um espírito), não parece lógico que sair de tal posição implica em se colocar na posição de predador?

\footnotetext{
${ }^{22}$ Onde quer que a antiga efígie seja colocada, ela nunca deve ser posta de pé, pois atrairia raios.
} 
Lévi-Strauss (2008 [1962]) desenvolve um argumento sobre ritos de alguns povos de língua algonkin da América do Norte muito interessante para essa discussão. Alguns deles são ritos para a saída do luto que giram em torno de competições esportivas, que inclusive tematizam uma relação entre a partida definitiva da alma e a substituição do morto: é o caso “dos jogos que se desenrolavam entre os índios fox, quando das cerimônias de adoção cujo objetivo era substituir um parente morto por um vivo, permitindo, assim, a partida definitiva da alma do defunto" (ibid: 46-47). Estes ritos são acompanhados "de jogos de destreza ou de azar, entre dois campos constituídos de acordo com uma divisão ad hoc em duas metades: tokan de um lado, kicko de outro; e afirma-se expressamente, repetidas vezes, o jogo opõe vivos e mortos (...)" (ibid: 47). O curioso é que o resultado dessas competições sempre estava decidido de antemão, pois o grupo do morto sempre era o vencedor. Lévi-Strauss argumenta que o objetivo desses jogos rituais é enganar os mortos, dando a eles o direito a uma última partida e fazendo-os sentir-se como vencedores de um jogo que, na prática, eles nunca podem ganhar:

E, com efeito, qual é a realidade? No grande jogo biológico e social que perpetuamente se desenrola entre vivos e mortos, é claro que os únicos ganhadores são os primeiros. Mas - e toda a mitologia norte-americana aí está para confirmá-lo - de uma maneira simbólica (que inumeráveis ritos descrevem como real) ganhar um jogo é "matar" o adversário. (ibid: 48)

Competições rituais e guerra/morte aparecem associados em vários mitos kalapalo, nos quais a vitória explicitamente simboliza o homicídio (ver também Figueiredo, 2010: 218219, sobre um mito aweti com a mesma associação, e Avelar, 2010: 145, para discussão semelhante). Quando, por exemplo, Taũgi e Aulukumã vão ao céu tentar pegar a água de seu dono Sagankguẽgü, eles se envolvem em algo que parece ser um jogo de dardos. O jogo foi proposto pelo dono da água que, não querendo dar sua preciosa posse aos gêmeos, queria enganá-los e matá-los com dardos pontiagudos. No fim das contas, Taũgi acaba "ganhando" o jogo, cujo resultado é a morte de Sagankguẽgü. A disputa ritual entre o Tamanduá-Mirim (Kangatakugu) e a Onça também é um bom exemplo: 


\section{Mito 7: Hüge oto (O Mestre da Flecha ${ }^{23}$ )}

A Onça e o Tamanduá-Mirim eram grandes amigos e viviam juntos. Um dia eles queriam atravessar um rio, mas só a onça sabia nadar. Ela disse ao seu amigo que ele poderia ir em suas costas que ela o levaria até a outra margem. Chegando ao outro lado, o Tamanduá-Mirim resolveu aprontar com seu amigo e arrancou os olhos da Onça com suas grandes unhas e fugiu. Para a sorte da Onça, o Macuco apareceu e lhe deu olhos substitutos, feitos de água. A Onça foi para sua aldeia e pensou em convidar o Tamanduá-Mirim para uma festa, na qual se vingaria dele.

Como a onça tem muitos seguidores e o Tamanduá-Mirim "não tem pessoal", ela pensou que seria fácil matá-lo. Quando recebeu os mensageiros da Onça ele logo imaginou do que se tratava, mas mesmo assim foi até a aldeia de seu "amigo". No caminho, ele foi tirando pelos de seu corpo e transformando-os em queixadas e macacos-prego, e ele chegou na aldeia da onça acompanhado de muitas pessoas. Os dois grupos começaram a cantar alternadamente e a dançar, o que durou a noite toda. Na verdade, quando o Tamanduá-Mirim cantava, ele estava na verdade atacando a Onça, e vice-versa. Como o Tamanduá-Mirim tinha muitos seguidores, a Onça não conseguiu matá-lo e, por isso, até hoje ela não consegue caçar este animal. A partir daí surgiu a festa hüge oto, na qual se executam os cantos da Onça e do Tamanduá-Mirim.

Mas talvez a ilustração mais clara esteja no mito de Kutsahugu, que narra sua visita à aldeia da Onça. Quando ela o viu, logo quis comê-lo, e o convidou para jogar uma partida de katuga ikugu ${ }^{24}$, um jogo de bola no qual se usa uma pelota feita da seiva da mangaba. Passaram um bom tempo jogando, até que Kutsahugu venceu o jogo, decapitou a Onça e fugiu. As competições rituais, mesmo quando assumem uma forma de "competição musical", como no mito do Tamanduá-Mirim e da Onça, são conflitos mortais. E como estes mitos deixam claro, vencer pode significar matar o adversário perdedor. No conflito entre o Tamanduá-Mirim e Onça ninguém vence, mas também ninguém morre. Outro ponto importante: estas competições só acontecem entre chefes. O mito do ritual do "mestre da flecha" (hüge oto) é interessante porque o Tamanduá-Mirim é inicialmente descrito como chefe de ninguém (que "não tem pessoal"). Apesar da onça não comê-lo (o que o exclui do pessoal do chefe felino), ele também não é nenhum predador (se alimenta de insetos,

\footnotetext{
${ }^{23}$ Um ritual intra-aldeão no qual dança-se a noite toda executando, alternadamente, cantos do Tamanduá-Mirim e da Onça. O ritual é uma guerra disfarçada de música, pois considera-se que os cantos são ataques de um animal contra o outro. Só um homem, já idoso, conhece estes cantos em Aiha, e o ritual não é realizado há 15 anos.

${ }^{24}$ Lit. "seiva de mangaba".
} 
principalmente formigas e cupins), o que faz dele um animal que não é chefiado, mas também não chefia. Contudo, para enfrentar a Onça ele precisa se fazer chefe, pois ambos se confrontam com o apoio de seus seguidores (que o Tamanduá-Mirim produz a partir de seu

próprio corpo). É curioso que o Tamanduá-Mirim se torne chefe do macaco-prego, um animal de pelo, que a Onça não chefia.

O mito de origem do egitsü adquire um novo sentido em relação a este conjunto de mitos ligados pela correlação entre ritual, guerra e homicídio. O primeiro grande confronto de ikindene também era uma competição mortal como várias outras, e se Taũgi tivesse obtido a vitória da forma como ele desejava, teria conseguido matar os peixes. Levando isso em consideração, parece plausível ver as competições atuais como algo equivalente a confrontos guerreiros entre chefes, nos quais os perdedores são simbolicamente mortos. Assim como nos ritos discutidos por Lévi-Strauss (2008 [1962]), o grupo do morto no egitsü sempre é dito sair "vitorioso". Se, por alguma razão, algo der errado, levando a uma grande derrota dos anfitriões, isso pode desencadear descontentamento e mesmo violência. Conta-se (eu não presenciei) que, em 2008, no egitsü que aconteceu na aldeia dos Yawalapíti, quase todos os campeões daquele povo desmaiaram enquanto enfrentavam os Kalapalo. Os Yawalapíti começaram a acusá-los publicamente de feitiçaria, e parece que a gota d'água foi quando o dono da festa resolveu tomar partido e também fez uma acusação. No mesmo ano, os Kalapalo patrocinaram um egitsü, e eu cheguei à aldeia na época da escolha dos mensageiros. Eles estavam decididos a não convidar os Yawalapíti, e o primeiro cacique estava visivelmente irritado, dizendo que agora eles não poderiam mais ir à aldeia dos Yawalapíti porque acabariam discutindo e brigando. Com a ameaça do fim das relações rituais, o risco de irrupção de violência parecia muito real para os Kalapalo. Foi preciso a intervenção de um dos chefes kalapalo, que insistiu na importância do convite para manter as relações "bonitas/boas" (atütü), pedido que foi atendido pelo dono da festa por influência de sua esposa, uma mulher yawalapíti.

\subsection{Parentesco e ritual: produção e transformação}

A imagem do chefe que desafia alguém para uma batalha (assim como a de seus lutadores) é a imagem do chefe-onça, o que significa que realizar um egitsü é produzir uma 
transformação. Mas o que essa transformação tem a ver com a morte? De fato, ela tem a ver com a possibilidade da retomada do processo do parentesco após a morte de um chefe, um daqueles que funcionam como pilares da vida coletiva e das condições para o aparentamento.

Tudo no egitsü está ligado ao processo do parentesco: a morte, o luto e sua suspensão; a perpetuação da chefia entre os vivos; a saída das(os) jovens da reclusão; os casamentos. Mas o que exatamente está em jogo que exige o ritual? Se o objetivo "consciente" do egitsü é relembrar os mortos e separá-los definitivamente dos vivos, a fase final do ritual provoca uma questão: por que para isso é indispensável confrontar povos estrangeiros, temporariamente vistos como inimigos, e por que só se faz isso após a morte de um nobre?

Procurei mostrar que, assim como argumentam outros autores (Coelho de Souza, 2002: 534; Gow, 1997; Vilaça, 2002), fabricar parentes é produzir humanos e vice-versa. Se a fabricação do parentesco é um processo de humanização, a morte pode ser vista como sua conclusão, pois a aldeia dos mortos é o reino do parentesco perfeito e inabalável, e a alma do olho que lá vive não precisa se preocupar com o risco de transformar-se em algo diferente ${ }^{25}$. Já a inversão (ou o fracasso) da fabricação de parentes, como argumenta Coelho de Souza (ibid., loc. cit.), "é a metamorfose, e esta segunda é necessária para que se possam repor as condições da primeira, residindo em tal reposição a chave da reprodução - ou, se se preferir, da transformação - dessas sociedades" (grifos no original). Tais metamorfoses, segundo a autora, são operadas pelos rituais, nos quais os humanos, o tempo todo, assumem identidades de espíritos e animais, evidenciadas por seus adornos corporais, suas músicas, suas coreografias.

Segundo Viveiros de Castro (2002a: 447), "a construção do parentesco é a desconstrução da afinidade potencial; mas a reconstrução do parentesco ao fim de cada ciclo deve apelar para esse fundo de alteridade dada que envolve a socialidade humana". Discutindo a correlação entre produção do parentesco e metamorfose entre os Jê, Coelho de Souza (2002: 580, 637) argumenta que é o retorno a esse mundo de alteridade, a reposição do estado de "diferença infinita" dado no mito, que intentam os rituais jê.

\footnotetext{
${ }^{25}$ Uma alma do olho só morre se pisa em um capim pontiagudo, quando vira fumaça. Ainda assim, dizem que essas almas vão para um segundo céu, no qual há uma aldeia idêntica à aldeia dos mortos, mas onde vivem apenas as almas que sofreram esse acidente.
} 
Penso que, ao invés de fabricar parentes e humanos, o que todo esse aparato cerimonial visa é possibilitar metamorfoses. Em questão está o "problema da alteridade", e do suposto "fechamento" e "autonomia" das comunidades jê; em questão está, igualmente, o de sua transformação. Se sempre foi óbvio que o grau em que as diferenças que outros ameríndios têm de ir buscar "fora" nos aparecem aqui como "introjetadas" depende justamente desse aparato, talvez valha insistir que isso não se deve a serem os Jê mais autosuficientes (e conservadores) que os outros: quase pelo contrário, o que os distingue é apenas a forma particular que tomam seus modos de transformação. (ibid: 637)

O egitsü é um dos eventos (dentre vários outros) nos quais os Kalapalo se colocam na posição de seres míticos: árvores-gente, onças, sucuris, peixes. Minha hipótese é que estamos tratando aqui com um desses momentos dos quais fala Coelho de Souza, nos quais a metamorfose se torna necessária para a continuidade do processo do parentesco. Considerando um chefe como alguém que torna o aparentamento viável, sua morte implica em uma desestabilização desse processo e, para continuá-lo, é preciso substituir o chefe morto. O processo do parentesco tem como fundamento duas operações: a identificação de algumas pessoas à categoria dos "humanos ${ }^{26 "}$ e a introdução de diferenças nessa humanidade aparentemente homogênea (a criação de distinções entre os “povos”). O egitsü é responsável por esse duplo movimento. Ao tornar presente um chefe construído como a primeira chefe humana (a mãe dos gêmeos), a efígie permite reunir todos os povos xinguanos ao seu redor, criando a imagem de uma humanidade indiferenciada perante ela. Contudo, essa posição é antitética à vida humana: o único lugar no qual os xinguanos se reúnem como parentes chefiados pela mãe dos gêmeos é na aldeia dos mortos. O englobamento de toda a humanidade por um chefe implica na consanguinidade absoluta, vista como engessamento das relações, imobilização, anulação do tempo e, logo, o contrário da vida humana.

Por isso os donos da festa (na posição dos gêmeos, meio humanos-árvore, meio onças) convocam a humanidade toda para um confronto e os mensageiros enviados a cada grupo se tornam inimigos rituais dos chefes convidados. A inimizade entre grupos de onças instaura diferenças entre os povos, pois a condição para que todos eles sejam "gente" - e gente viva! é que sejam capazes de se posicionar como sujeitos. Algo semelhante está em jogo nas trocas de dons entre os "inimigos", com a diferença de que agora afirma-se que a predação real deve ser substituída pela predação ritual.

\footnotetext{
${ }^{26}$ Que, lembremos, resulta de sua diferenciação em relação aos animais e espíritos.
} 
Aqui pode ser útil evocar a distinção entre pessoa e agente feita por Strathern (2006 [1988]), como faz Coelho de Souza (2002: 579-582) a respeito da relação entre fabricação do parentesco e metamorfose entre os jê:

A distinção que quero sugerir entre pessoa e agente corresponde em certa medida a esta diferença entre o "ator social ordinário" e o "agente provido dos poderes criativos dos seres míticos". A ação social ordinária corresponde à fabricação do parentesco e assim de seres humanos, mas a metamorfose ritual seria essencial para a reposição das condições desse processo. (ibid: 580)

Enquanto o "ator social ordinário" é uma pessoa que objetiva as relações por meio das quais é constituída, para tornar-se um agente, ele precisa se diferenciar suficientemente de outras pessoas para se relacionar com elas. Tomando isso no plano coletivo, sendo os chefes a personificação dos grupos, são eles que precisam se apresentar como agentes uns para os outros, o que em um contexto no qual a posição de predador e sujeito coincidem, implica que eles devem se apresentar como onças e inimigos. Tornando-se predadores uns para os outros, tornam-se capazes de assumir a posição de sujeitos/gente e agregar ao redor de si outras pessoas, que também se verão como gente e, logo, como parentes. $\mathrm{O}$ fato dos nomes dos mortos serem liberados após a homenagem em um egitsü deixa claro que este processo trata da continuidade do aparentamento: como seria possível fabricar pessoas se não fosse possível lhes dar nomes?

E por que não realizar um egitsü para cada morto, mas apenas para os nobres? Dado que a humanidade alto-xinguana se estende para além de cada comunidade local, e as diferenças aparecem como "externas" (e não internalizadas, como entre os Jê), para repor as diferenças necessárias à retomada do processo do parentesco é preciso recorrer às relações regionais, o que só se torna possível por meio dos chefes - as únicas pessoas capazes de se transformar em agentes no plano regional. Ou ainda: é porque tais diferenças são repostas sob a forma de relações entre chefes, e não entre metades ou outros tipos de grupos cerimoniais, que emerge um sistema "regional", isto é, baseado em diferenças entre "grupos" (em oposição aos "sistemas fechados" jê). Muito mais do que celebrar a unidade da sociedade xinguana "apesar" de suas diferenças, como se costuma dizer, o egitsü cria as diferenças que permitem fragmentar tal unidade, criando ao mesmo tempo as condições para o aparecimento da afinidade e minando as possibilidades de emergência de uma unidade englobante, algo como 
um "Estado xinguano". Só quem celebra a unidade humana são os mortos - sob a condição de não se reproduzirem mais.

Vê-se que a ideia de akuãpütelü, "homenagem", é um processo complexo que mobiliza as relações entre corpo e alma em várias escalas: para os chefes mortos criam-se corpos temporários (as efígies) e almas/imagens/sombras (seus parentes vivos que patrocinam o ritual); e como contrapartida deste segundo aspecto do processo, criam-se troncos/corpos/esteios para os vivos. Por meio destas "homenagens", se produzem as condições da vida coletiva que são, em termos gerais, as condições para a produção de parentes por meio da convivência prolongada em uma aldeia. O egitsü tem a importância que tem não por ser uma situação simplesmente para "lembrar dos mortos", mas porque está ocupado com a continuidade da vida de uma maneira específica: a vida em um mundo de parentes que participam de um mesmo corpo, que vivem juntos por serem ramificações de um tronco, ou que são sustentados por um esteio - um chefe. A necessidade de um ritual que emula a guerra e mergulha os chefes no mundo da inimizade (ainda que seja uma inimizade extremamente polida e, no final das contas, controlada pela dádiva) deixa claro que, entre a afinidade simétrica entre estrangeiros e a consanguinidade assimétrica entre coaldeões, há uma relação de englobamento da segunda pela primeira.

O egitsü reconstrói um mundo no qual são todos afins potenciais, onças e harpias tendenciosos a atacar uns aos outros para, a partir daí, criar formas de identificação em uma escala progressiva: os grupos que se identificam como parentes e não competem nos rituais, aldeias de um mesmo povo que participam de sua realização, as aldeias individualmente e, por fim, as unidades domésticas e as famílias conjugais. E a cada degrau dessa escala encontramos o mesmo tipo de pessoa-relação: um esteio ou corpo, uma forma-chefe responsável tanto pelas identificações em si quanto pelas mudanças de escala. São estas formas-chefe que efetuam a mediação entre a afinidade potencial (a capacidade predatória) e a consanguinidade (relações de cuidado e alimentação), e é esse reconhecimento de que eles são feitos de consanguinidade e afinidade, semelhança e diferença, que lhes concede a designação singela, porém forte, de "gente", kuge: afinal, um misto de similitude e diferença, pacifismo e belicosidade, agregação e separação - é esta a condição dos homens e mulheres xinguanos. 


\section{Epílogo}

Comecei esta tese sublinhando a importância de nos aproximarmos dos conceitos kalapalo de "homenagem" e das formas assumidas pela chefia (isto é, as formas pelas quais a chefia é tornada perceptível e eficaz para os Kalapalo). Como vimos ao longo dos capítulos, o que está por trás da produção de formas-chefe são modos de personificação e objetivação das relações regionais ligados à produção do parentesco. É preciso produzir chefes para se construir diferenças internas à humanidade xinguana, condições para a produção do parentesco em diferentes níveis (local, regional e histórico). Ao chamar a atenção para isso, um de meus objetivos foi produzir uma etnografia da chefia não muito presa a questões sobre a relação dos chefes com seu grupo local (formuladas com frequência em termos de poder e economia política), procurando compreender como tais processos de personificação são ativados em contextos variados (mantidos ligados por sua relevância para a compreensão do egitsii). Vimos que formas-chefe são construídas das formas mais variadas em contextos como narrativas etnohistóricas, depoimentos pessoais, mitos, sepulturas, casas, efígies, discursos, circuitos de dom - e precisam ser constantemente refeitas.

Disso emergiu uma imagem da chefia que a situa em relação a outras formas xinguanas e ameríndias de produção de coletivos humanos e não-humanos por meio das figuras dos donos e/ou chefes (que, como argumentei, para os Kalapalo são figuras que tendem a coincidir). Vimos que a chefia é produzida para sintetizar e exibir ao mesmo tempo um modo vegetal (arbóreo) de socialidade, formulado em termos de cuidados, nutrição e consanguinidade, e outro modo, animal, formulado em termos de relações de confronto, predação e afinidade. Para se produzir enquanto uma "sociedade regional" internamente diferenciada, estes dois modos de socialidade precisam ser constantemente produzidos um a partir do outro, e o locus dessa produção são certos corpos: os chefes, que são ao mesmo tempo tronco-corpos para o seus e inimigos para os estrangeiros, as únicas pessoas que assumem a condição de agentes (sensu Strathern, 2006 [1988]) no sistema regional.

Espero ter deixado claro porque considerei que seria imprudente ter começado pela "face clássica" do ritual (as efígies e a luta), pois o final do egitsü sintetiza os dois aspectos constitutivos da chefia, a capacidade de englobamento pela consanguinidade assimétrica e a capacidade de diferenciação e autonomia ligada à estética predatória. Aqui elas são 
dissociadas segundo os agentes, sendo que a primeira é atribuída ao morto, que assume a forma de chefe humano/vegetal arquetípico, e a segunda aos donos da festa e aos tajope, que precisam confrontar seus adversários sob a forma de uma guerra obviada pela luta e pela troca de dons. Com o egitsü, os Kalapalo viabilizam a continuidade de seu crescimento vegetal e a produção da consanguinidade (a substituição de seus troncos-corpos falecidos por "imagens" imperfeitas dos chefes do passado), mas isso não é possível sem uma transformação: para continuar crescendo como parentes, os anfitriões precisam se apresentar como onças poderosas que tentam capturar seus vizinhos (que, como vimos no capítulo 5, se referem a eles em seus discursos como "pais/donos" ou "irmãos mais velhos").

Este ritual é muito mais do que uma "rememoração" do mito, e repõe as condições a partir das quais o campo da humanidade se define (pela consanguinidade feminina, simbolizada pelo crescimento vegetal) e cria suas diferenças mínimas (pela inimizade ritual masculina, simbolizada pela agressividade animal). Enquanto a produção de um chefe arquetípico (o morto transformado em efígie) tem o potencial de expandir a humanidade de maneira virtualmente infinita (e por isso o egitsü tem um potencial expansivo tão grande), porém indistinta, a guerra ritualizada e a troca (de objetos ou de símbolos da afinidade, como jarreteiras e castanhas de pequi) são capazes de recriar as diferenças entre os grupos de maneira pacífica, permitindo o recomeço do processo do parentesco. A afinidade ritual simétrica entre os grupos cria os limites mínimos do assemelhamento, ao mesmo tempo que garante que a humanidade não seja toda engolida por um único tronco-corpo (o que levaria à inércia da aldeia dos mortos). O egitsü cria assim as meta-relações a partir das quais é possível produzir outras relações, e por isso tem um imenso potencial de expansão e incorporação de novos agentes (dentre eles, os brancos).

A ideologia pacifista dos alto-xinguanos, bem como seu foco na estética impressionante de seu sistema ritual, causa verdadeira fascinação a todos que entram em contato com eles, índios ou não. Como observa Fausto (2007), a máquina xinguana de sedução, de produção de relações cordiais por meio de trocas de objetos e hospitalidades, é uma fina política que, pelo que nos mostra a história na longa duração da área, tem sido extremamente eficaz (se não o fosse, não teriam os alto-xinguanos sido capazes de absorver povos inteiros e moldá-los à sua imagem). Quando nos deparamos com semelhante configuração social, é difícil não opô-la a outras nas quais a guerra, seja como prática real, seja como princípio filosófico-político, possui um lugar reconhecidamente importante e 
constitui mesmo um valor positivo do ponto de vista indígena. Poucos autores, como Menget (1978; 1985; 1993) e Menezes Bastos $(1990 ; 2001)$, questionaram esta diferença de forma sistemática, sendo o que o último já notara que a guerra (ritual) definia, de forma "antihobbesiana" (Menezes Bastos, 2001), o "interior" (aberto e com fronteiras moventes) da sociedade xinguana. A dupla dificuldade sempre foi reconhecer a centralidade dos confrontos internos sem, contudo, ofuscar a diferença que os xinguanos se esforçaram tanto para construir. Afinal, se as relações por trás de outras formas ameríndias também estão aqui, não basta identificá-las, mas é preciso entender os mecanismos pelos quais os xinguanos as escondem de si mesmos, as obviam - e a personificação de coletivos por meio de chefes é um deles.

Figueiredo (2010) argumenta que a feitiçaria estaria no lugar da guerra no Alto Xingu, apesar de não ser institucionalmente central e, mesmo, ter um valor negativo. Penso que esta ideia deve ser recolocada de outra maneira, tendo em vista a discussão precedente sobre as figuras da inimizade no ritual mortuário. Se algo está no lugar da guerra enquanto instituição, os xinguanos sempre disseram que são os chefes com seus rituais; a feitiçaria, penso, é o gatilho que dispara a arma ritual, é onde a relação predador-presa como modo geral de relacionamento "vaza" pelas brechas do pacifismo xinguano - do parentesco, como bem mostra Figueiredo (2010), que precisa então ser refeito ${ }^{1}$. Na visão kalapalo, mesmo os rituais de espíritos são desencadeados por feitiços. Parece consenso que, se não houver a intervenção de um feiticeiro, nenhum espírito mantém a alma de uma pessoa por muito tempo, tornando desnecessários os rituais para estes seres (por isso os Kalapalo possuem uma vida de rituais para espíritos bem mais "fria" que a dos Wauja, como eles próprios reconhecem). Se não houvesse feiticeiros capazes de agredir e matar, não haveria rituais para se fazer. A chefia, como a apresento aqui, não é tanto o oposto da feitiçaria, mas sua contra-partida, a outra face de uma mesma moeda (por isso mesmo chefes e feiticeiros podem se transformar uns nos outros com tanta facilidade, como atestam os rumores). Se a feitiçaria é predação em forma pura (aquilo que é dado), a chefia e seu ritual mortuário são os meios pelos quais a predação é obviada, invertendo a relação entre o que é dado e construído no sistema: o pacifismo ritual passa a ser visto como dado pelos xinguanos, e a feitiçaria como algo da ordem do feito, o resultado da produção intencional de pessoas perigosas.

\footnotetext{
${ }^{1}$ Não quero dizer que a feitiçaria também não seja uma forma de guerra, o que ela certamente é. Porém, é uma guerra local, invisível e que possui um valor negativo, e por isso dificilmente pode ser comparada a formas institucionalizadas ou valorizadas de violência (real ou simbólica), no Alto Xingu ou alhures.
} 
Vê-se assim que a chefia está ligada a questões mais gerais da cosmologia xinguana, sendo inclusive parte da forma pela qual os xinguanos comparam a si mesmos com seus vizinhos. Se esta tese tiver aberto uma possibilidade de comparação que não implique nem em postular uma "especificidade tipológica" ao Alto Xingu, nem na dissolução de sua diferença em modelos mais gerais, seu objetivo terá sido cumprido.

Certa vez eu estava no porto de Aiha com vários não índios que chegavam para um egitsü, inclusive uma mulher que conhece bem os Kalapalo, pois conviveu intimamente com eles durante muitos anos. Enquanto os Kalapalo discutiam como poderiam organizar a vinda dos moradores de suas outras aldeias para a pescaria, ela comentou comigo (em tom baixo, para não ser ouvida pelos outros): "Por que eles não fazem as aldeias umas bem perto das outras, como ali na outra margem do rio? Aqui há tanto espaço, não há necessidade de ir para tão longe! Se as aldeias fossem todas umas dos lados das outras, eles não precisariam se preocupar com barcos, gasolina, fretes". Tal apreço pela distância tem um "espírito", uma "vontade" de autonomia que sempre admirei, e que espero não ter ofuscado em minhas descrições.

A máquina do egitsü se move a pleno vapor, e os Kalapalo dizem que nunca homenagearam tantos chefes como agora, o que se tornou possível e desejável pelo acesso a mercadorias, transporte e pelo que os rituais lhes rendem (dinheiro, objetos, alianças, oportunidades de negociação). Fazer Quarup (o egitsü com a participação dos brancos) os ajuda a pelo menos tentar controlar agentes não indígenas ao mesmo tempo em que investem na reprodução de suas especificidades internas. Talvez por esse motivo os Kalapalo depositem em sua máquina ritual o poder de controlar sua história. Eles deixam claro que, ainda que tudo em suas vidas se transforme (seu corte de cabelo, sua língua, seus hábitos alimentares, suas relações de parentesco), continuarão sendo eles mesmos se preservarem suas festas e tudo o que está ligado a elas (suas pinturas, seus cantos, suas danças). Por mais paradoxal que possa soar a ouvidos produzidos em uma "sociedade para o Estado", enquanto os Kalapalo puderem homenagear e engrandecer seus chefes, talvez consigam fazer resistir uma humanidade fundada na diferença e na autonomia. Para isso decidiram que seus maiores chefes deviam ser transformados em ancestrais anônimos, cópias de um arquétipo inalcançável, formas sem conteúdo, e que seus substitutos não seriam mais que suas imagens imperfeitas, suas sombras. 


\section{Referências bibliográficas}

ABREU, R. M. D. R. M. Eterno quarup, patrimônio da cultura xinguana. In: LOPES, A. H. (Ed.). Religião e Performance ou as Performances das Religiões Brasileiras. Rio de Janeiro: Contra-capa, 2007. p. 185-195.

AgOStinHO, P. Kwarìp - Mito e Ritual no Alto Xingu. São Paulo: E.P.U/EDUSP, 1974.

AGOSTINHO, P. Mitos e outras narrativas kamayurá. Salvador: EDUFBA, 2009 [1974].

ALMEIDA, M. A fórmula canônica do mito. In: QUEIROZ, R. C. e NOBRE, R. F. (Ed.). Lévi-Strauss: Leituras Brasileiras. Belo Horizonte: Editora da Universidade Federal de Minas Gerais, 2008. p. 147-182.

APPADURAI, A. The Social life of things : commodities in cultural perspective. Cambridge and New York: Cambridge University Press, 1986.

AVELAR, G. S. Valores brutos: lutadores do Alto Xingu. 2010. Dissertação de Mestrado. Departamento de Antropologia, Museu Nacional/UFRJ, Rio de Janeiro.

BALL, C. Out of the Park: trajectories of Wauja (Xingu Arawak) language and culture. 2007. Tese de Doutorado. University of Chicago, Chicago.

BALL, C.; FIORINI, M. Le commerce de la culture, la médecine rituelle et le Coca-cola. Gradhiva, v. 4, p. 97-113, 2006.

BARCELOS NETO, A. A arte dos sonhos - uma iconografia ameríndia. Lisboa: Museu Nacional de Etnologia/Assírio \& Alvim, 2002.

BARCELOS NETO, A. Festas para um "nobre": ritual e (re)produção sociopolítica no Alto Xingu. Estudios Latino Americanos, v. 23, p. 63-90, 2003.

BARCELOS NETO, A. Apapaatai: rituais de máscaras no Alto Xingu. 2004. Tese de Doutorado. Departamento de Antropologia, Universidade de São Paulo, São Paulo.

BARCELOS NETO, A. Doença de índio: o princípio patogênico da alteridade e os modos de transformação em uma cosmologia amazônica. Campos - Revista de Antropologia Social, v. 7, n. 1, p. 9-34, 2006.

BARCELOS NETO, A. Witsixuki: desejo alimentar, doença e morte entre os Wauja da Amazonia Meridional. Journal de la Société des Américanistes, v. 93, p. 73-95, 2007. 
BARCElOS NETO, A. Apapaatai: Rituais de Máscaras no Alto Xingu. São Paulo: EDUSP/FAPESP, 2008.

BARROS, E. P. Os filhos do sol. História e Cosmologia na Organização Social de um Povo Karib: os Kurâ-Bakairi. São Paulo: EDUSP, 2003.

BASSO, E. B. The Kalapalo Indians of Central Brazil. New York: Holt, Rimehart and Wineton Inc., 1973.

BASSO, E. B. Kalapalo affinity: its cultural and social contexts. American Ethnologist, v. 2, n. 2, p. 207-228, 1975.

BASSO, E. B. A Musical View of the Universe: Kalapalo Myth and Ritual Performances. Philadelphia: University of Pennsylvania Press, 1985.

BASSO, E. B. Quoted dialogs in kalapalo narrative discourse. In: SHERZER, J. e URBAN, G. (Ed.). Native south american discourse. New York: Mouton de Gruyter, 1986. p. 119168.

BASSO, E. B. The implications of a progressive theory of dreaming. In: TEDLOCK, B. (Ed.). Dreaming: anthropological and psychological interpretations. Cambridge, New York and Melbourne: Cambridge University Press, 1987a. p. 86-104.

BASSO, E. B. In Favor of Deceit: A Study of Tricksters in an Amazonian Society. Tucson: The University of Arizona Press, 1987b.

BASSO, E. B. Kalapalo Biography: Psychology and Language in a South American Oral History. American Anthropologist, v. 91, n. 3, p. 551-569, 1989.

BASSO, E. B. A História na Mitologia: Uma Experiência dos Avoengos Calapalos com Europeus. In: COELHO, V. P. (Ed.). Karl von den Steinen: Um Século de Antropologia no Xingu. São Paulo: EDUSP, 1993. p. 313-345.

BASSO, E. B. The Last Cannibals: A South American Oral History. Austin: University of Texas Press, 1995.

BASSO, E. B. O que podemos aprender do discurso kalapalo sobre a "história kalapalo"? In: FRANCHETto, B. e HECKENBERGER, M. J. (Ed.). Os Povos do Alto Xingu: História e Cultura. Rio de Janeiro: Editora da UFRJ, 2001. p. 293-307.

BASSO, E. B. Civility and Deception in Two Kalapalo Ritual Forms. In: SENFT, G. e BASSO, E. B. (Ed.). Ritual communication. Oxford and New York: Berg, 2009. p. 243269. 
BECKER, E. Xingu Society. 1969. Ph.D. dissertation. Department of Anthropology, University of Chicago, Illinois.

BEIER, C.; MICHAEL, L.; SHERZER, J. Discourse Forms and Processes in Indigenous Lowland South America: An Areal-Typological Perspective. Annual Review of Anthropology, v. 31, p. 121-145, 2002.

BERGÈS, M. Claude Lévi-Strauss et les réseaux: parenté et politique. KLESIS - Revue philosophique, n. 10, p. 1-33, 2008.

BOHANNAN, P. The impact of money on an African subsistence economy. The Journal of Economic History, v. 19, n. 4, p. 491-503, 1959.

BOHANNAN, P.; BOHANNAN, L. Tiv Economy. Evanston, IL: Northwestern University Press, 1968.

BROOKE, A. P. Diet of the fishing bat, Noctilio leporinus (Chiroptera: Noctilionidae). Journal of Mammalogy, v. 75, n. 1, p. 212-218, 1994.

CALAME-GRIAULE, C., Ed. Le thème de l'arbre dans les contes africains. Paris: SELAF, ed. 1969.

CALLADO, A. Quarup. Rio de Janeiro: Nova Fronteira, 1967.

CÂMARA CUNHA, A. A História da Índia Diacuí. São Paulo: Clube do Livro, 1976.

CAMPBELL, S. F. Kula in Vakuta: the mechanics of keda. In: LEACH, J. W. e LEACH, E. (Ed.). The Kula. New Perspective on Massim Exchange. Cambridge and Melbourne: Cambridge University Press, 1983. p. 201-228.

CARDOSO, M. D. Relatório prospectivo de visita à aldeia Aiha - Kalapalo. Relatório de atividades. Universidade Federal de São Carlos. São Carlos, p. 1999

Formação e capacitação para o cooperativismo indígena. Projeto de Pesquisa e Extensão. São Carlos: Universidade Federal de São Carlos 2004a.

Políticas de saúde indígena e relações organizacionais de poder: reflexões decorrentes do caso do Alto Xingu. In: LANGDON, E. J. e GARNELO, L. (Ed.). Saúde dos povos Indígenas: reflexões sobre antropologia participativa. Rio de Janeiro: Contracapa, 2004b. p. 195-215. 
CARDOSO, M. D. Sistemas terapêuticos indígenas e a interface com o modelo de atenção à saúde: diferenciação, controle social e dinâmica sócio-cultural no contexto alto xinguano. Projeto de pesquisa. São Carlos: Universidade Federal de São Carlos/CNPq 2005.

CARDOSO, M. D. Dalla pluralità terapeutica alla logica della differenza - il contesto alto xinguano del Brasile Centrale. In: BAMONTE, G. e BOLLETTIN, P. (Ed.). Amazzonia Indigena - 2007: resoconti di ricerca sul campo. Roma: Bulzoni Editore, 2008. p. 171-190.

CARDOSO, M. D.; GUERREIRO JÚNIOR, A. R.; NOVO, M. P. As flechas de Maria: xamanismo, hierarquia política e transformação no Alto Xingu. Anais da 26a Reunião Brasileira de Antropologia. Porto Seguro: ABA. 12008.

CARNEIRO DA CUNHA, M. Os mortos e os outros: uma análise do sistema funerário e da noção de pessoa entre os índios Krahó. São Paulo: Hucitec, 1978.

CARNEIRO, R. Quarup: A Festa dos Mortos no Alto Xingu. In: COELHO, V. P. (Ed.). Karl von den Steinen: Um Século de Antropologia no Xingu. São Paulo: EdUSP, 1993. p. 405429.

CARSten, J.; Hugh-JONES, S., Eds. About the House: Lévi-Strauss and Beyond. Cambridge: Cambridge University Press, ed. 1995.

CARVAlHO, J. C. D. Relações entre os índios do Xingu e a fauna regional. Rio de Janeiro: Museu Nacional. Publicações avulsas, 71951.

CAYÓN, L. Palabra de vida: Objetos de poder y vitalidad en el Noroeste Amazónico. VII Conferência Sesquianual da SALSA (Society for the Anthropology of Lowland South America). Belém 2011.

CHAUMEIL, J.-P. Bones, Flutes, and the Dead: Memory and Funerary Treatments in Amazonia. In: FAUSTO, C. e HECKENBERGER, M. J. (Ed.). Time and memory in indigenous Amazonia: anthropological perspective. Gainesville: University Press of Florida, 2007. p. 243-283.

CLASTRES, H. La terre sans mal: le prophétisme tupi-guarani. Paris: Éditions du Seuil, 1975.

CLASTRES, P. Da tortura nas sociedades primitivas. In: CLASTRES, P. (Ed.). A Sociedade contra o Estado. São Paulo: Cosac \& Naify, 2003a [1974]. p. 193-204.

CLASTRES, P. Troca e poder: filosofia da chefia indígena. In: CLASTRES, P. (Ed.). A sociedade contra o Estado. São Paulo: Cosac \& Naify, 2003b [1974]. p. 43-63.

CLAUSEWITZ, C. V. On War. New Jersey: Princeton University Press, 1989 [1832]. 
COELHO DE SOUZA, M. S. Faces da Afinidade: um estudo bibliográfico do parentesco xinguano. 1992. Dissertação de Mestrado. PPGAS-Museu Nacional/UFRJ, Rio de Janeiro.

COELHO DE SOUZA, M. S. Da complexidade do elementar: para uma reconsideração do parentesco xinguano. In: VIVEIROS DE CASTRO, E. (Ed.). Antropologia do Parentesco: Estudos Ameríndios. Rio de Janeiro: Editora da UFRJ, 1995. p. 121-206.

COELHO DE SOUZA, M. S. Nós os Vivos: "construção do parentesco" e "construção da pessoa" entre alguns Jê. Revista Brasileira de Ciências Sociais, v. 46, p. 69-96, 2001 a.

COELHO DE SOUZA, M. S. Quarup: a festa dos mortos no Alto Xingu. p. 2001b. (Dossiê para eventual registro de bem cultural imaterial)

COELHO DE SOUZA, M. S. Virando gente: notas a uma história aweti. In: FRANCHETTO, B. e HeCKenberger, M. J. (Ed.). Os Povos do Alto Xingu: História e Cultura. Rio de Janeiro: Editora da UFRJ, 2001c. p. 358-400.

COELHO DE SOUZA, M. S. O traço e o círculo: o conceito de parentesco entre os Jê e seus antropológos. 2002. Tese de Doutorado. PPGAS-Museu Nacional, Universidade Federal do Rio de Janeiro, Rio de Janeiro.

COELHO DE SOUZA, M. S. Parentes de sangue: incesto, substâncie e relação no pensamento timbira. Mana, v. 10, n. 1, p. 25-60, 2004.

COELHO, V. P. Motivos Geométricos na Arte Uaurá. In: COELHO, V. P. (Ed.). Karl von den Steinen: um século de antropologia no Xingu. São Paulo: EDUSP, 1993. p. 591-629.

COSTA, C. E. Rituais interétnicos e fabricação de corpos: a luta no Alto Xingu. $\underline{35}$ Encontro anual da ANPOCS. Caxambu, MG, Brasil 2011.

COSTA, L. A. As Faces do Jaguar: Parentesco, História e Mitologia Entre os Kanamari da Amazônia Ocidental. 2007. Ph.D. dissertation. Museu Nacional, Universidade Federal do Rio de Janeiro, Rio de Janeiro.

CULTURAL, D. P. Primeiro mapa de trabalho para o Corredor Cultural Culuene. 2009.

DAMATTA, R. A Divided World. Apinayé Social Structure. Cambridge, Massachussets: Harvard University Press, 1982.

DAMON, F. H. The kula and generalised exchange: considering some unconsidered aspects of The elementary structures of kinship. Man, n. 15, p. 169-292, 1980. 
DAMON, F. H. Alienating the inalienable (correspondence). Man, n. 17, p. 342-343, 1982.

DELEUZE, G.; GUATTARI, F. Mil platôs. Capitalismo e Esquizofrenia, v. 2. São Paulo: Editora 34, 1995 [1980].

DESCOLA, P. La chefferie amérindienne dans l'anthropologie politique. Revue française de science politique, v. 38, n. 5, p. 818-827, 1988.

DESCOLA, P. In the society of nature: A native ecology in Amazonia. Cambridge: Cambridge University Press, 1994 [1986].

DESCOLA, P. Estrutura ou sentimento: a relação com o animal na Amazônia. Mana, v. 4, n. 1, p. 23-45, 1998.

DOLE, G. Shamanism and political control among the Kuikuru. In: GROSS, D. (Ed.). Peoples and cultures of native South America. New York: Doubleday/The Natural History Press, 1966. p. 294-307.

DOLE, G. Some aspects of structure in Kuikuru society. Antropologica, v. 59-62, p. 309329, 1984.

DRUDE, S. Nasal harmony in Awetí and the Mawetí-Guarani family (Tupí). Amerindia, v. 32, p. 239-276, 2009.

DRUDE, S. Aweti in relation with Kamayurá: the two tupian languages of the Upper Xingu. In: FRANCHETTO, B. (Ed.). Alto Xingu: uma sociedade multilíngue. Rio de Janeiro: Museu do Índio - FUNAI, 2011. p. 155-192.

DUMONT, L. O individualismo: uma perspectiva antropológica da ideologia moderna. Rio de Janeiro: Rocco, 2000 [1983].

DURKHEIM, É. Les formes élémentaires de la vie religieus. Le sustème totémique en Australie. Paris: Les Presses, 1968 [1912].

EMMERICH, C. Pidgin e pidgnização no Alto Xingu, Mato Grosso, Brasil. In: VOTRE, S. e RONCARATI, C. (Ed.). Anthony Julius Nato e a Linguística no Brasil. Rio de Janeiro: Editora 7 Letras, 2008. p. 95-106.

EMMERICH, M.; EMMERICH, C.; VALLE, L. D. S. O Kuarupe - Árvore do Sol. Bradea Boletim do Herbarium Bradeanum, v. IV, n. 49, p. 388-391, 1987.

ERIKSON, P. Faces of the Past: Just How "Ancestral" Are Matis "Ancestor Spirit" Masks? In: FAUSTO, C. e HECKENBERGER, M. J. (Ed.). Time and memory in indigenous 
Amazonia: anthropological perspectives. Gainesville: University of Florida Press, 2007. p. 219-242.

FAUSTO, C. Of Enemies and Pets: Warfare and Shamanism in Amazonia. American Ethnologist, v. 26, n. 4, p. 933-956, 1999.

FAUSTO, C. Inimigos Fiéis: história, guerra e xamanismo na Amazônia. São Paulo: EDUSP, 2001.

FAUSTO, C. Banquete de Gente: Canibalismo e Comensalidade na Amazônia. Mana, v. 8, n. 2, p. 7-44, 2002.

FAUSTO, C. O tempo do ritual: política, economia e xamanismo no Alto Xingu. Projeto de pesquisa. Rio de Janeiro: Universidade Federal do Rio de Janeiro: 24 p. 2004a.

FAUSTO, C. A Ocupação Indígena do Alto Curso dos Formadores do Rio Xingu e a Cartografia Sagrada Alto-Xinguana. Laudo Antropológico para o Ministério Público Federal - MT 2004b.

FAUSTO, C. Entre o Passado e o Presente: mil anos de história indígena no Alto Xingu. Revista de Estudos e Pesquisas, v. 2, p. 9-52, 2007.

FAUSTO, C. Donos demais: maestria e domínio na Amazônia. Mana, v. 14, n. 2, p. 329-366, 2008.

FAUSTO, C.; FRANCHETTO, B.; MONTAGNANI, T. Les formes de la mémoire: arts verbaux et musique chez les Kuikuro du Haut Xingu (Brésil). L'Homme, n. 197, p. 41-70, 2011.

FERREIRA, J. Kuarup. O Cruzeiro. Rio de Janeiro: 58-71 p. 1957.

FIGUEIREDO, M. V. Centralização e faccionalismo: imagens da política no Alto Xingu. 2006. Dissertação de Mestrado. PPGAS-Museu Nacional/UFRJ, Rio de Janeiro.

FIGUEIREDO, M. V. A flecha do ciúme. O parentesco e seu avesso segundo os Aweti do Alto Xingu. 2010. Tese de Doutorado. PPGAS-Museu Nacional/UFRJ, Rio de Janeiro.

FIORINI, M. Terra Indígena Pequizal do Naruvôtu, laudo antropológico. Brasília: Fundação Nacional do Índio (FUNAI) 2005.

FRANCHETTO, B. Falar Kuikuro: Estudo etnolingüístico de um grupo karib do Alto Xingu. 1986. Tese de Doutorado. Museu Nacional/UFRJ, Rio de Janeiro. 
FRANCHETTO, B. A Celebração da História Nos Discursos Cerimoniais Kuikuro (AltoXingu). In: VIVEIROS DE CASTRO, E. e CARNEIRO DA CUNHA, M. (Ed.). Amazônia: etnologia e história indígena. São Paulo: EDUSP/FAPESP, 1993. p. 95-116.

FRANCHETTO, B. Processos fonológicos em Kuikuro: uma visão auto-segmental. In: WETZELS, L. (Ed.). Estudos Fonológicos das Línguas Indígenas Brasileiras. Rio de Janeiro: Editora da UFRJ, 1995. p. 53-83.

FRANCHETTO, B. Tisakisü. Livro da escrita para os povos karib da Terra Indígena do Xingu. Brasília: ISA/MEC, 1997.

FRANCHETTO, B. "O aparecimento dos caraíba": Para uma história kuikuro e altoxinguana. In: CARNEIRO DA CUNHA, M. (Ed.). História dos Índios no Brasil. São Paulo: FAPESP/Companhia das Letras/SMC, 1998. p.

FRANCHETTO, B. Rencontres rituelles dans le Haut-Xingu: la parole du chef. In: MONODBECQUELIN, A. e ERIKSON, P. (Ed.). Les rituels du dialogue. Promenades ethnolinguistiques en terres amérindiennes. Nanterre: Société d'ethnologie, 2000. p. 481509.

FRANCHETTO, B. Línguas e história no Alto Xingu. In: FRANCHETTO, B. e HECKEnBERGER, M. J. (Ed.). Os Povos do Alto Xingu: História e Cultura. Rio de Janeiro: Editora da UFRJ, 2001. p. 111-156.

FRANCHETTO, B., Ed. Ikú Ügühütu Higei. Arte Gráfica dos povos do Alto Xingu. Rio de Janeiro: Museu do Índio-FUNAI, ed. 2003a.

FRANCHETTO, B. L'autre du même: parallélisme et grammaire dans l'art verbal des récits Kuikuro (caribe du Haut Xingu, Brésil). Ameríndia, v. 28, p. 213-248, 2003 b.

FRANCHETTO, B. Les marques de la parole vraie en Kuikuro, langue caribe du Haut-Xingu (Brésil). In: GUENTCHÉVA, Z. e LANDABURU, I. (Ed.). L'Énonciation médiatisée II. Le traitement éistémologique de $I$ information : illustrations amerindiennes et caucasiennes. Paris: Éditions Peeters, 2007a. p. 173-204.

FRANCHETTO, B. Tolo. Narrativa registrada com Ajahi Kuikuro 2007b.

FRANCHETTO, B., Ed. Alto Xingu: uma sociedade multilíngue. Rio de Janeiro: Museu do Índio - FUNAI, ed. 2011a.

FRANCHETTO, B. Evidências linguísticas para o entendimento de uma sociedade multilíngue: o Alto Xingu. In: FRANCHETTO, B. (Ed.). Alto Xingu: uma sociedade multilíngue. Rio de Janeiro: Museu do Índio - Funai, 2011b. p. 3-38. 
FRANCHETTO, B.; SANTOS, G. M. F.; MEHINAKU, M. Concepts and forms of plurality in Kuikuro (Southern Carib, Brazil). In: DEAL, A. R. (Ed.). Proceedings of the 4th Conference on the Semantics of Under-Represented Languages in the Americas. Amherst: University of Massachussets, v.35, 2007. p. 99-116.

FRANCO NETO, J. V. Xamanismo Kalapalo e Assistência Médica no Alto Xingu: estudo etnográfico das práticas curativas 2010. Dissertação de Mestrado. Departamento de Antropologia, Unicamp, Campinas.

GALVÃO, E. Cultura e sistema de parentesco das tribos do Alto Rio Xingu. In: GALVÃO, E. (Ed.). Encontro de sociedades: índios e brancos no Brasil. Rio de Janeiro: Paz e Terra, 1979 [1953]. p. 73-119.

GELL, A. Art and Agency: An Anthropological Theory. Oxford: Claredon Press, 1998.

GELL, A. Strathernograms, or, the semiotics of mixed metaphors. In: GELL, A. (Ed.). The Art of Anthropology: Essays and Diagrams. London \& New Brunswick, NJ: The Athlone Press, 1999. p.

GORDON, C. About the house: Lévi-Strauss and Beyond (Resenha). Mana, v. 2, n. 2, p. 192$195,1996$.

GORDON, C. Economia selvagem: ritual e mercadoria entre os Xikrin. Rio de Janeiro: Editora da UNESP/ISA/NuTI, 2006.

GOW, P. O parentesco como consciência humana: o caso dos piro. Mana, v. 3, n. 2, p. 39-65, 1997.

GOW, P. Piro, Apurinã, and Campa: Social Dissimilation and Assimilation as Historical Processes in Southwestern Amazonia. In: HILL, J. D. e SANTOS-GRANERO, F. (Ed.). Comparative Arawakan Histories. Rethinking Language Family and Culture Area in Amazonia. Urbana and Chicago: University of Illinois Press, 2002. p. 147-170.

GRAHAM, L. R. Performing Dreams: Discourses of Immortality among the Xavante of Central Brazil. Austin: University of Texas Press, 1995.

GREGOR, T. The Mehinaku: The Drama of Daily Life in a Brazilian Indian Village. Chicago, Illinois: University of Chicago Press, 1977.

GREGOR, T. Mehináku: o drama da vida diária em uma aldeia do Alto Xingu. São Paulo: Brasiliana, 1982. 
GREGOR, T. Uneasy peace: Intertribal Relations in Brazil's Upper Xingu. In: HAAS, J. (Ed.). The Anthropology of War. Cambridge: Cambridge University Press, 1990. p. 105124.

GREGORY, C. Exchange and reciprocity. In: INGOLD, T. (Ed.). Companion Encyclopedia of Anthropology. Humanity, Culture and Social Life. London: Routledge, 1994. p. 911939.

GREGORY, C. A. Gifts and commodities. London ; New York: Academic Press, 1982.

GUERREIRO JÚNIOR, A. R. Parentesco e aliança entre os Kalapalo do Alto Xingu. 2008. Dissertação de Mestrado. Departamento de Ciências Sociais, Universidade Federal de São Carlos, São Carlos.

GUERREIRO JÚNIOR, A. R. Assimetria e coletivização: notas sobre chefes e caraíbas na política Kalapalo (Alto Xingu, MT). In: COELHO DE SOUZA, M. e LIMA, E. C. D. (Ed.). Conhecimento e Cultura: práticas de transformação no mundo indígena. Brasília: Athalaia Gráfica e Editora, 2010. p. 119-149.

GUERREIRO JÚNIOR, A. R. Aliança, chefia e regionalismo no Alto Xingu. Journal de la Société des Américanistes, v. 97, n. 2, p. 99-133, 2011.

GUERREIRO JÚNIOR, A. R. et al. Sistemas de trocas indígenas e economia de mercado: elementos para a formulação de uma experiência cooperativista. Anais de Eventos da UFSCar - XIII Congresso de Iniciação Científica, 2005. São Carlos. Outubro de 2005. p. 148.

GUSS, D. M. To Weave and Sing: Art, Symbol, and Narrative in the South American Rain Forest. Berkeley: University of California Press, 1989.

HARRISON, S. Ritual as intellectual property. Man, v. 27, n. 2, p. 224-244, 1992.

HECKENBERGER, M. J. War and Peace in the Shadow of Empire: Sociopolitical Change in the Upper Xingu of Southeastern Amazonia, A.D. 1400-2000. 1996. Tese de Doutorado. University of Pittsburgh, Pittsburgh.

HECKENBERGER, M. J. Epidemias, índios bravos e brancos: contato cultural e etnogênese no Alto Xingu. In: FRANCHETTO, B. e HECKENBERGER, M. J. (Ed.). Os Povos do Alto Xingu: História e Cultura. Rio de Janeiro: Editora da UFRJ, 2001a. p. 77-110.

HECKENBERGER, M. J. Estrutura, história e transformação: a cultura xinguana na longue durée, 1000-2000 d.C. In: FRANCHETTO, B. e HECKENBERGER, M. J. (Ed.). Os Povos do Alto Xingu: História e Cultura. Rio de Janeiro: Editora da UFRJ, 2001b. p. 21-62. 
HECKENBERGER, M. J. Rethinking the Arawakan Diaspora: Hierarchy, Regionality, and the Amazonian Formative. In: HILL, J. D. e SANTOS-GRANERO, F. (Ed.). Comparative Arawakan Histories: Rethinking Language Family and Culture Area in Amazonia. Urbana and Chicago: University of Illinois Press, 2002. p. 99-122.

HECKENBERGER, M. J. The Enigma of The Great Cities: Body and State in Amazonia. Tipití: Journal of the Society for the Anthropology of Lowland South America, v. 1, n. 1, p. 27-58, 2003.

HECKEnBerger, M. J. The Ecology of Power: Culture, Place, and Personhood in the Southern Amazon, A.D. 1000-2000. New York: Routledge, 2005.

HECKENBERGER, M. J. Forma do espaço, língua do corpo e história xinguana. In: FRANCHETTO, B. (Ed.). Alto Xingu: uma sociedade multilíngue. Rio de Janeiro: Museu do Índio - FUNAI, 2011. p. 235-279.

HILL, J. D.; SANTOS-GRANERO, F. Introduction. In: HILL, J. D. e SANTOS-GRANERO, F. (Ed.). Comparative Arawakan Histories: Rethinking Language Family and Culture Area in Amazonia. Urbana and Chicago: University of Illinois Press, 2002. p. 1-22.

HOUSEMAN, M.; SEVERI, C. Naven, ou le Donner à Voir: essai d'interprétation de l'Action Rituelle. Paris: CNRS - Éditions de la Maison des Sciences de 1’Homme, 1998.

HUGH-JONES, S. Clear Descent or Ambiguous Houses? A Re-Examination of Tukanoan Social Organisation. L’Homme, v. 33, n. 126-128, p. 95-120, 1993.

IRELAND, E. M. When a Chief Speaks Through His Silence. PoLAR: Political and Legal Anthropology Review, v. 16, n. 2, p. 19-28, 1993 a.

IRELAND, E. M. Witchcraft accusations and political succession in a Xingu society. Lowland South America Indians Conference. Bennington College, Bennington 1993b.

JANKOWSKY, I. P. et al. Madeiras Brasileiras. Caxias do Sul: SPECTRUM, 1990.

JUNQUEIRA, C.; VITTI, V. T. O Kwaryp kamaiurá na aldeia de Ipavu. Estudos Avançados, v. 23, n. 65, p. 133-148, 2009.

KNIGHT, J. The Second Life of Trees: Family Forestry in Upland Japan. In: RIVAL, L. (Ed.). The Social Life of Trees. Oxford and New York: Berg, 2001 [1998]. p. 197-218.

KOHN, E. Animal masters and the ecological embedding of history among the Ávila Runa of Ecuador. In: FAUSTO, C. e HECKENBERGER, M. J. (Ed.). Time and memory in indigenous Amazonia: anthropological perspectives. Gainesville: University Press of Florida, 2007. p. 106-129. 
LAGROU, E. Kenan, the ritual stool: a reduced model of the cashinhua person during the Nixpupima rite of passage. In: MYERS, T. e CIPOLLETTI, M. S. (Ed.). Artifacts and society in Amazonia / Artefatos y sociedad en Amazonia. Bonn: Bonner amerikanische studien, v.36, 2002. p. 95-113.

LAGROU, E. Antropologia e arte: uma relação de amor e ódio. Ilha. Revista de Antropologia, v. 5, p. 93-113, 2003.

LAGROU, E. A Fluidez da Forma: arte, alteridade e agência em uma sociedade amazônica. Rio de Janeiro: Toobooks Editora, 2007.

LAMAISON, P.; LÉVI-STRAUSS, C. La notion de maison. Terrain: revue d'ethnologie de l'Europe, v. 9, 1987.

LEA, V. R. Nomes e nekrets Kayapó: uma concepção de riqueza. 1986. 587pp. Tese de Doutorado. Museu Nacional/UFRJ, Rio de Janeiro.

LEA, V. R. Casas e Casas Mebengokre (Jê). In: VIVEIROS DE CASTRO, E. e CARNEIRO DA CUNHA, M. (Ed.). Amazônia: Etnologia e História Indígena. São Paulo: EDUSP, 1993. p. 265-282.

LEA, V. R. Casa-se do Outro Lado: Um Modelo Simulado da Alianca Mebengokre (Je). In: VIVEIROS DE CASTRO, E. (Ed.). Antropologia do parentesco: estudos ameríndios. Rio de Janeiro: UFRJ, 1995. p. 321-359.

LÉVI-STRAUSS, C. Guerre et commerce chez les indiens de l'Amérique du Sud. Renaissance, v. I, p. 122-139, 1943.

LÉVI-STRAUSS, C. Paroles Données. Paris: Plon, 1984.

LÉVI-STRAUSS, C. Clã, linhagem, casa. In: LÉVI-STRAUSS, C. (Ed.). Minhas palavras. São Paulo: Brasiliense, 1986 [1984]. p. 183-235.

LÉVI-STRAUSS, C. Histoire de Lynx. Paris: Pocket, 1991.

LÉVI-STRAUSS, C. La geste d'Asdiwal. In: LÉVI-STRAUSS, C. (Ed.). Anthropologie structurale deux. Paris: Plon, 1996 [1973]. p. 175-233.

LÉVI-STRAUSS, C. Do mel às cinzas. São Paulo: Cosac \& Naify, 2004 [1967].

LÉVI-STRAUSS, C. La voie des masques. Paris: Pocket, 2004 [1979]. 
O cru e o cozido. São Paulo: Cosac \& Naify, 2004 [1964].

A origem dos modos à mesa. São Paulo: Cosac \& Naify, 2006 [1968].

. A estrutura dos mitos. In: LÉVI-STRAUSS, C. (Ed.). Antropologia Estrutural. São Paulo: Cosac \& Naify, 2008 [1955]. p. 221-257.

LÉVI-STRAUSS, C. O Pensamento Selvagem. Campinas: Papirus Editora, 2008 [1962].

LÉVI-STRAUSS, C. L'homme nu. Paris: Plon, 2009 [1971].

LIMA, T. S. O dois e seu múltiplo: reflexões sobre o perspectivismo em uma cosmologia tupi. Mana, v. 2, n. 2, p. 21-47, 1996.

LIMA, T. S. Um peixe olhou para mim: o povo Yudjá e a perspectiva. São Paulo e Rio de Janeiro: ISA/Editora Unesp/NuTI, 2005.

LIMA, T. S. Uma história do dois, do um e do terceiro. In: QUEIROZ, R. C. D. (Ed.). LéviStrauss hoje: uma homenagem. Belo Horizonte: Editora da UFMG, 2008. p.

LONGHI, R. A. Livro das árvores: árvores e arvoretas do sul. Porto Alegre: L\&PM, 1995.

LOWIE, R. Some Aspects of Political Organization Among the American Aborigines. The Journal of the Royal Anthropological Institute of Great Britain and Ireland, v. 78, n. 1, p. 11-24, 1948.

MACPHERSON, C. B. The political theory of possessive individualism: Hobbes to Locke. Oxford, : Clarendon Press, 1962.

MARTINI, D. M. Na trilha dos Bororo: um histórico das relações com os paulistas. I Encontro de Pesquisa de Graduação em História. Campinas 2008.

MAUSS, M. Ensaio sobre a dádiva: forma e razão da troca nas sociedades arcaicas. In: (Ed.). Sociologia e antropologia. São Paulo: Cosac \& Naify, 2003 [1925]. p.

MCCALLUM, C. Morte e pessoa entre os Kaxinawá. Mana, v. 2, n. 2, p. 49-84, 1996.

MEHINAKO, M. A hereditariedade tradicional da função de cacique entre o povo Mehinako. 2006. Trabalho de Conclusão de Curso - Licenciatura em Ciências Sociais. UNEMAT, Barra do Bugres. 
MEHINAKU, M. Tetsualü: pluralismo de línguas e pessoas no Alto Xingu. 2010. Dissertação de Mestrado. PPGAS-Museu Nacional/UFRJ, Rio de Janeiro.

MELLO, M. I. C. Iamurikuma: Música, Mito e Ritual entre os Wauja do Alto Xingu. 2004. Tese de Doutorado. Programa de Pós-Graduação em Antropologia Social, UFSC, Florianópolis.

MENEZES BASTOS, R. J. A musicológica Kamayurá. Brasília: FUNAI, 1978.

MENEZES BASTOS, R. J. Sistemas Políticos, de Comunicação e Articulação Social no Alto Xingu. Anuário Antropológico, v. 81, p. 43-58, 1983.

MENEZES BASTOS, R. J. A Festa da Jaguatirica: Uma Partitura Crítico-Interpretativa. 1990. Tese de Doutorado. Departamento de Antropologia, Universidade de São Paulo, São Paulo.

MENEZES BASTOS, R. J. Exegeses Yawalapiti e Kamayura sobre a criação do Parque Indígena do Xingu e a Invenção da Saga dos Irmãos Villas Boas. Revista de Antropologia, n. 30, p. 391-426, 1992.

MENEZES BASTOS, R. J. Indagação sobre os Kamayurá, o Alto-Xingu e outros nomes e coisas: uma etnologia da sociedade Xinguara. Anuário Antropológico, v. 94, p. 227-269, 1995.

MENEZES BASTOS, R. J. Ritual, História e Política no Alto Xingu: Observações a partir dos Kamayurá e do Estudo da Festa da Jaguatirica (Jawari). In: FRANCHETTO, B. e HECKEnBERGER, M. J. (Ed.). Os Povos do Alto Xingu: História e Cultura. Rio de Janeiro: EDUFRJ, 2001. p. 335-357.

MENEZES BASTOS, R. J.; MENEZES BASTOS, H. J. A Festa da Jaguatirica: primeiro e sétimo cânticos. Introdução, transcrição e comentários. Ilha, v. 4, n. 2, p. 133-174, 2002.

MENGET, P. Au nom des autres: classifications des relations sociales chez les Txicao du Haut-Xingu. 1977. Tese de Doutorado. Université de Paris X, Paris.

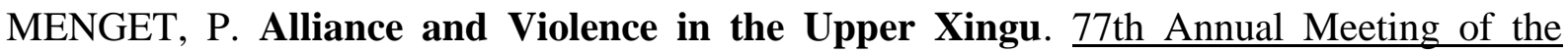
American Anthropological Association. Los Angeles 1978.

MENGET, P. Jalons pour une étude comparative. Journal de La Société des Americanistes, v. 71, p. 131-141, 1985.

MENGET, P. Les frontières de la chefferie: Remarques sur le système politique du haut Xingu (Brésil). L'Homme, v. 33, n. 2/4, p. 59-76, 1993. 
MEYER, H. Bericht ueber seine zweite Xingu - Expedition. Verhandlungen der Gesellshaft für Erdkunde zu Berlin, v. XXVII, p. 112-128, 1900.

MONOD-BECQUELIN, A. La pratique linguistique des Indiens Trumai (Haut Xingu, Mato Grosso, Brésil). Paris: SELAF, 1975.

MONOD-BECQUELIN, A.; ERIKSON, P. Introduction. In: MONOD-BECQUELIN, A. e ERIKSON, P. (Ed.). Les Rituels du Dialogue. Promenades Ethnolinguistiques en Terres Amérindiennes. Nanterre: Société d'Ethnologie, 2000. p. 11-27.

MONOD-BECQUELIN, A.; GUIRARDELLO, R. Histórias trumais. In: FRANCHETTO, B. e HECKENBERGER, M. J. (Ed.). Os Povos do Alto Xingu: História e Cultura. Rio de Janeiro: Editora da UFRJ, 2001. p. 401-443.

MORRIS, I. Gift and commodity in archaic Greece. Man, n. 21, p. 1-17, 1986.

MURPHY, R. F.; QUAIN, B. The Trumai Indians of Central Brazil. Seattle: University of Washington Press, 1955.

NORONHA, R. Exploração e levantamento do rio Culuene, principal formador do rio Xingu. Rio de Janeiro: Departamento de Imprensa Nacional, 1952.

NOVO, M. P. Produção artesanal e dinâmica sócio-cultural entre os Kalapalo do Alto Xingu: elementos para a formulação de uma experiência de cooperativismo indígena. 2005. Monografia de conclusão de curso. Departamento de Ciências Sociais, UFSCar, São Carlos.

NOVO, M. P. Saúde e Interculturalidade: a participação dos Agentes Indígenas de Saúde/AISs do Alto Xingu. R@U - Revista de Antropologia da UFSCar, v. 1, n. 1, p. 122147, 2009.

NOVO, M. P. Os Agentes Indígenas de Saúde do Alto Xingu. Brasília: Paralelo 15, 2010.

NOVO, M. P. et al. Formação e capacitação para o cooperativismo indígena. V Encontro de Extensão da UFSCar. São Carlos 2005.

OBERG, K. Indian tribes of Northern Mato Grosso. Washington: Smithsonian Institution, 1953.

PARRY, J. P. The gift, the Indian gift and the 'Indian gift'. Man, n. 21, p. 453-473, 1986. 
PARRY, J. P.; BLOCH, M. Money and the morality of exchange. Cambridge England ; New York: Cambridge University Press, 1989.

PEIRCE, C. S. Logic as semiotic: the theory of signs. In: BUCHLER, J. (Ed.). Philosophical Writings of Peirce. New York: Dover Publications, 1955. p. 98-104.

PEIRCE, C. S. The Collected Papers of Charles Sanders Peirce, v. 1. Cambridge: Harvard University Press, 1958.

PEIRCE, C. S. The Collected Papers of Charles Sanders Peirce, v. 2. Cambridge: Harvard University Press, 1960 [1932].

PIEDADE, A. T. D. C. O canto do Kawoká: Música, cosmologia e filosofia entre os Wauja do Alto Xingu. 2004. Tese de Doutorado. UFSC, Florianópolis.

PINEDA CAMACHO, R. Los bancos taumaturgos. Boletín Museo Del Oro, n. 36, 1996. Disponível em:

http://www.banrepcultural.org/blaavirtual/publicacionesbanrep/bolmuseo/1994/enjn36/enjn01

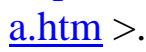

RAMOS, A. R. Projetos indigenistas no Brasil independente. Etnográfica (Lisboa), v. 4, n. 2, p. 267-283, 2000.

RAMOS, A. R. Pulp fictions of indigenism. Série Antropologia, v. 301, p. 1-20, 2001.

RENISI. Distritos Sanitários - DSEI Xingu. 2011. Disponível em: < http://sis.funasa.gov.br/portal/detalhe dsei.asp?strcddsei=32 >. Acesso em: 28 de janeiro.

RIBEIRO, B. G. Os padrões ornamentais do trançado e a arte decorativa dos índios do Alto Xingu. In: COELHO, V. P. (Ed.). Karl von den Steinen: um século de antropologia no Xingu. São Paulo: EDUSP, 1993. p. 563-589.

RIVAL, L. The Growth of Family Trees: Understanding Huaorani Perceptions of the Forest. Man, New Series, v. 28, n. 4, p. 635-652, 1993.

RIVAL, L. Trees, from Symbols of Life and Regeneration to Political Artefacts. In: RIVAL, L. (Ed.). The Social Life of Trees. Oxford and New York: Berg, 2001 [1998]. p. 1-36.

RIVIÈRE, P. The Political Structure of the Trio Indians as Manifested in a System of Ceremonial Dialogue. In: BEIDELMAN, T. O. (Ed.). The Translation of Culture. London: Tavistock Publications, 1971. p. 293-311. 
RIVIÈRE, P. Carib Soul Matters - Since Fock. Journal of the Anthropological Society of Oxford, v. XXVIII, n. 2, p. 139-148, 1997.

RODRIGUES, P. D. M. A caminhada de Tanyxiwè: Uma teoria Javaé da História. 2008. Tese de Doutorado. Department of Anthropology, University of Chicago, Chicago.

SÁ, C. Observações sobre a habitação em três grupos indígenas brasileiros. In: NOVAES, S. C. (Ed.). Habitações indígenas. São Paulo: Nobel / EDUSP, 1983. p. 103-146.

SAHLINS, M. Tribesmen. Oxford: Engelwood Cliffs, 1968.

SAHLINS, M. D. Stone age economics. Chicago, : Aldine-Atherton, 1972.

SANTOS, G. M. F. D. Morfologia Kuikuro: gerando nomes e verbos. 2007. Tese de Doutorado. Faculdade de Letras, Universidade Federal do Rio de Janeiro, Universidade Federal do Rio de Janeiro, Rio de Janeiro.

SANTOS, J. O. Vagares da alma: elaborações ameríndias acerca do sonhar. 2010. Dissertação de Mestrado. Departamento de Antropologia, Universidade de Brasília, Brasília.

SCHMIDT, M. Indianerstudien in Zentralbrasilien: Erlebnisse und ethnologische Ergebnisse einer Reise in den Jahren. 1900 bis 1901. Berlin: Dietrich Reimer (Ernst Vohsen), 1905.

SCHMIDT, M. Die Aruaken: Ein Beitrag zum Problem der Kulturverbreitung. Leipzig: Veit \& Co, 1917.

SCHULTZ, H.; CHIARA, V. Mais lendas Waura. Journal de la Société des Américanistes, v. 60, p. $105-135,1971$.

SCHWARTZMAN, S. The Panará of The Xingu National Park: the transformation of a society. 1988. Tese de Doutorado. Departament of Anthropology, University of Chicago, Chicago.

SEEGER, A. The Meaning of Body Ornaments: A Suya Example. Ethnology, v. 14, n. 3, p. 211-224, 1975.

SEEGER, A. Nature and society in central Brazil : the Suya Indians of Mato Grosso. Cambridge, Mass.: Harvard University Press, 1981.

SEEGER, A. Why Suyá sing : a musical anthropology of an Amazonian people. Cambridge Cambridgeshire ; New York: Cambridge University Press, 1987. 
SEEGER, A.; DAMATTA, R.; VIVEIROS DE CASTRO, E. A construção da pessoa nas sociedades indígenas brasileiras. Boletim do Museu Nacional, n. 32, 1979.

SEVERI, C. Capturing imagination: a cognitive approach to cultural complexity. Journal of the Royal Anthropological Institute, v. N.S, n. 10, p. 815-838, 2004.

SEVERI, C. Le principe de la chimère: une anthropologie de la mémoire. Paris: Presses de l'École Normale Supérieure / Musée du Quai Branly, 2007.

SICK, H. Ornitologia Brasileira. Rio de Janeiro: Nova Fronteira, 1997.

STANG, C. A Walk to the River in Amazonia: Ordinary Reality for the Mehinaku Indians. Oxford: Berghan Books, 2009.

STRATHERN, A.; STEWART, P. J. Ceremonial Exchange. In: CARRIER, J. G. (Ed.). A Handbook of Economic Anthropology. Cheltenham and Massachusetts: Edward Elgar, 2005. p. 230-245.

STRATHERN, M. Qualified value: the perspective of gift exchange. In: HUMPHREY, C. e HUGH-JONES, S. (Ed.). Barter, exchange and value. An anthropological approach. Cambridge: Cambridge University Press, 1992. p. 169-191.

STRATHERN, M. O Gênero da Dádiva: problemas com as mulheres e problemas com a sociedade na Melanésia. Campinas: Editora da Unicamp, 2006 [1988].

SZTUTMAN, R. O profeta e o principal: a ação política ameríndia e seus personagens. 2005. Tese de Doutorado. Departamento de Antropologia, Universidade de São Paulo, São Paulo.

TAMBIAH, S. J. A performative approach to ritual. In: TAMBIAH, S. J. (Ed.). Culture, Thought and Social Action. Cambridge: Harvard University Press, 1985. p. 123-166.

TAYLOR, A.-C. Jivaro kinship - simple and complex formulas: a dravidian transformation group. In: GODELIER, M.;TRAUTMANN, T. R., et al (Ed.). Transformations of Kinship. Washington: Smithsonian Institution Press, 1998. p. 187-213.

TEIXEIRA-PINTO, M. Ieipari: sacrifício e vida social entre os índios Arara (Caribe). São Paulo e Curitiba: Hucitec / ANPOCS / Editora UFPR, 1997.

TURNER, T. Dual opposition, hierarchy and value. Moiety structure and symbolic polarity in Central Brazil and elsewhere. In: GALEY, J.-C. (Ed.). Différences, Valeurs, Hiérarchie: textes offerts à Louis Dumont. Paris: École des Hautes Études en Sciences Sociales, 1984. p. 335-370. 
TURNER, V. The Forest of Symbols: Aspects of Ndembu Ritual. Ithaca, NY: Cornell University Press, 1967.

TURNER, V. The Ritual Process: Structure and Anti-Structure. Piscataway, New Jersey: Aldine Transaction, 1995 [1969].

URBAN, G. Ceremonial Dialogues in South America. American Anthropologist, New Series, v. 88, n. 2, p. 371-386, 1986.

URBINA, F. El hombre sentado: mitos, ritos y petroglifos en el río Caquetá. Boletín Museo Del Oro, n. 36, 1994. Disponível em: < http://www.banrepcultural.org/blaavirtual/publicacionesbanrep/bolmuseo/1994/enjn36/enjn03

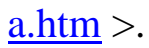

VEIGA, J. Organização Social e Cosmovisão Kaingang: uma introdução ao parentesco, casamento e nominação em uma sociedade Jê Meridiona. 1994. Dissertação de Mestrado. Universidade Estadual de Campinas, Campinas.

VEIGA, J. Cosmologia e práticas rituais kaingang. 2000. Tese de Doutorado. Universidade Estadual de Campinas, Campinas.

VILAÇA, A. Making kin out of others in Amazonia. Journal of the Royal Anthropological Institute, v. 8, n. 2, p. 347-365, 2002.

VILLAS BOAS, O.; VILLAS BOAS, C. Os índios, seus mitos. São Paulo: Círculo do Livro, 1970.

VIVEIROS DE CASTRO, E. Indivíduo e Sociedade no Alto Xingu: os Yawalapíti. 1977. Dissertação de Mestrado. PPGAS-Museu Nacional/UFRJ, Rio de Janeiro.

VIVEIROS DE CASTRO, E. A fabricação do corpo na sociedade xinguana. Boletim do Museu Nacional, Série Antropologia, n. 32, p. 40-49, 1979.

VIVEIROS DE CASTRO, E. Alguns aspectos da afinidade no dravidianato Amazônico. In: VIVEIROS DE CASTRO, E. e CARNEIRO DA CUNHA, M. (Ed.). Amazônia: etnologia e história indígena. São Paulo: EDUSP/FAPESP, 1993. p. 150-210.

VIVEIROS DE CASTRO, E. Os pronomes cosmológicos e o perspectivismo ameríndio. Mana, v. 2, n. 2, p. 115-144, 1996.

VIVEIROS DE CASTRO, E. Atualização e contra-efetuação do virtual: o processo do parentesco. In: VIVEIROS DE CASTRO, E. (Ed.). A Inconstância da Alma Selvagem. São Paulo: Cosac \& Naify, 2002a. p. 401-455. 
VIVEIROS DE CASTRO, E. Esboço de cosmologia yawalapíti. In: (Ed.). A inconstância da alma selvagem. São Paulo: Cosac \& Naify, 2002b. p. 25-85.

VIVEIROS DE CASTRO, E. O problema da afinidade na Amazônia. In: VIVEIROS DE CASTRO, E. (Ed.). A inconstância da alma selvagem. São Paulo: Cosac \& Naify, 2002c. p. 87-180.

VIVEIROS DE CASTRO, E. Perspectivismo e multinaturalismo na América indígena. In: VIVEIROS DE CASTRO, E. (Ed.). A Inconstância da Alma Selvagem. São Paulo: Cosac \& Naify, 2002d. p. 345-399.

VIVEIROS DE CASTRO, E. Filiação intensiva e aliança demoníaca. Novos estudos CEBRAP, n. 77, p. 91-126, 2007a.

VIVEIROS DE CASTRO, E. A floresta de cristal: notas sobre a ontologia dos espíritos amazônicos. Cadernos de Campo, v. 14/15, p. 319-338, 2007 b.

VIVEIROS DE CASTRO, E.; FAUSTO, C. La puissance et l'acte: la parenté dans les basses terres d'Amérique du Sud. L'Homme, v. 33, n. 126, p. 141-170, 1993.

VON DEN STEINEN, K. Entre os aborígenes do Brasil Central. São Paulo: Departamento de Cultura, 1940.

VON DEN STEINEN, K. O Brasil Central: expedição em 1884 para a exploração do rio Xingú. São Paulo: Companhia Editora Nacional, 1942.

WAGNER, R. Lethal speech: Daribi myth as symbolic obviation. Ithaca, N.Y.: Cornell University Press, 1978.

WAGNER, R. The fractal person. In: GODELIER, M. e STRATHERN, M. (Ed.). Big man and great men: personifications of power in Melanesia. Cambridge: Cambridge University Press, 1991. p. 159-173.

WEINER, J. F. The Heart of The Pearl Shell: The Mythological Dimension of Foi Sociality. Berkeley, Los Angeles e Oxford: University of California Press, 1988.

WITTGENSTEIN, L. Remarks on the Foundations of Mathematics. Oxford: Basil Blackwell, 1998 [1956].

WRIGHT, H. B. Brazil 4, Part 2 - August 7, 1948. 38min:39s p. 1948. 
YAN, Y. The gift and gift economy. In: CARRIER, J. G. (Ed.). A Handbook of Economic Anthropology. Cheltenham and Massachusetts: Edward Elgar, 2005. p. 246-261.

ZARUR, G. Parentesco, Ritual e Economia no Alto Xingu. Brasília: FUNAI, 1975.

ZARUR, G. D. C. L. O Kuarup Xinguano e os Universais da Narrativa Religiosa. Brasília: Consultoria Legislativa da Câmara dos Deputados 2003. 
ANEXo 
ANEXO - TERMINOLOGIAS DE PARENTESCO

\begin{tabular}{|c|c|c|c|}
\hline \multicolumn{4}{|c|}{ Ego masculino - consanguíneos } \\
\hline Termo & Marcadores & Vocativos & Glosa \\
\hline \multicolumn{4}{|c|}{$\mathrm{G}^{+3}$} \\
\hline $\begin{array}{l}\text { ngaũpügü } \\
\text { kuе̃gü }\end{array}$ & $\begin{array}{c}\text { FFF, FMF, MFF, } \\
\text { MMF }\end{array}$ & api & bisavô \\
\hline itsü kuẽgü & $\begin{array}{l}\text { FFM, FMM, } \\
\text { MFM, MMM }\end{array}$ & okojo, oó & bisavó \\
\hline \multicolumn{4}{|c|}{$\mathrm{G}^{+2}$} \\
\hline ngaũpügü & $\begin{array}{c}\text { FF, MF, FFB, } \\
\text { FF }^{\lambda} \mathrm{X}, \mathrm{FMB}, \\
\text { MFB, } \\
\mathrm{MF}^{\lambda} \mathrm{X}, \mathrm{MMB}\end{array}$ & api & avô \\
\hline itsü & $\begin{array}{c}\text { FM, MM, FMZ, } \\
\text { FMX, FFZ, } \\
\text { MMZ, } \\
\text { MM甲X, MFZ }\end{array}$ & okojo, oó & avó \\
\hline \multicolumn{4}{|c|}{$\mathrm{G}^{+1}$} \\
\hline ü̈n & $\mathrm{F}, \mathrm{FB}, \mathrm{F} \delta^{\wedge} \mathrm{X}$ & apa & pai \\
\hline isi & $\mathrm{M}, \mathrm{MZ}, \mathrm{M}^{\lambda} \mathrm{X}$ & ama & mãe \\
\hline $\operatorname{sog} u$ & $\mathrm{MB}, \mathrm{M}{ }^{\lambda} \mathrm{X}$ & $a w a$ & tio materno \\
\hline itsügü & $\mathrm{FZ}, \mathrm{F}+\mathrm{X}$ & etsi & tia paterna \\
\hline \multicolumn{4}{|c|}{$\mathrm{G}^{\varnothing}$} \\
\hline 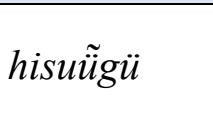 & $\begin{array}{l}\text { B, FBS, MZS, } \\
\mathrm{F}^{\lambda} \mathrm{XS}, \mathrm{M}+\mathrm{XS}\end{array}$ & não se aplica & irmão \\
\hline hinhano & $\mathrm{eB}$ & jaja & $\begin{array}{l}\text { irmão mais } \\
\text { velho }\end{array}$ \\
\hline
\end{tabular}




\begin{tabular}{|c|c|c|c|}
\hline ihis ̈̈ & yB & uhi & $\begin{array}{l}\text { irmão mais } \\
\text { novo }\end{array}$ \\
\hline ingadzu & $\begin{array}{l}\mathrm{Z}, \mathrm{FBD}, \mathrm{MZD}, \\
\mathrm{F}^{\top} \mathrm{XD}, \mathrm{M} \mathrm{XD}\end{array}$ & não se aplica & irmã \\
\hline 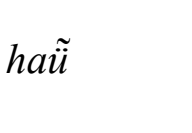 & $\begin{array}{c}\text { FZCh, MBCh, } \\
\text { FoXCh, } \mathrm{M}^{\lambda} \mathrm{XCh}\end{array}$ & não se aplica & $\begin{array}{l}\text { primo(a) } \\
\text { cruzado(a) }\end{array}$ \\
\hline \multicolumn{4}{|c|}{$\mathrm{G}^{-1}$} \\
\hline mugu & $\mathrm{S}, \mathrm{BS}, \stackrel{\jmath}{\mathrm{X}} \mathrm{XS}$ & ipü & filho \\
\hline indisü & $\mathrm{D}, \mathrm{BD}, \stackrel{\circ}{ }^{1} \mathrm{XD}$ & ijü & filha \\
\hline 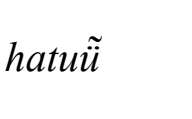 & $\mathrm{ZS}, \stackrel{\text { OXS }}{ }$ & pügi, ipü & $\begin{array}{l}\text { sobrinho } \\
\text { uterino }\end{array}$ \\
\hline hati & $\mathrm{ZD},+\mathrm{XD}$ & $i j u ̈$ & $\begin{array}{l}\text { sobrinha } \\
\text { uterina }\end{array}$ \\
\hline \multicolumn{4}{|c|}{$\mathrm{G}^{-2}$} \\
\hline higü & $\mathrm{ChCh}$ & api, ipü & neto(a) \\
\hline \multicolumn{4}{|c|}{$\mathrm{G}^{-3}$} \\
\hline higü kuẽgü & $\mathrm{ChChCh}$ & ipü & bisneto(a) \\
\hline
\end{tabular}

\section{Ego masculino - consanguíneos}

\begin{tabular}{|c|c|c|c|}
\hline Termo & Marcadores & Vocativos & Glosa \\
\hline \multicolumn{4}{|c|}{$\mathrm{G}^{+1}$} \\
\hline hütisoho & $\begin{array}{c}\text { WF, WM, WF } \bigcirc^{\lambda} \mathrm{X}, \\
\mathrm{WM}^{\lambda} \mathrm{X}, \mathrm{WF} \bigcirc^{\lambda} \mathrm{X}, \mathrm{WM}{ }^{\lambda} \mathrm{X}\end{array}$ & não se aplica & $\begin{array}{l}\text { sogro/sogra; } \\
\text { lit. "feito } \\
\text { para causar } \\
\text { vergonha" }\end{array}$ \\
\hline \multicolumn{4}{|c|}{$\mathrm{G}^{\varnothing}$} \\
\hline haumetigü & $\mathrm{WB}, \mathrm{W}{ }^{\lambda} \mathrm{X}, \mathrm{ZH}, \precsim \mathrm{XH}$ & tecnônimos & cunhado \\
\hline pahene & $\mathrm{WZ}$ & não se aplica & cunhada \\
\hline hitsü & $\mathrm{W}$ & tecnônimos & esposa \\
\hline ijatongo & co-esposa & tecnônimos & \\
\hline
\end{tabular}




\begin{tabular}{|c|c|c|c|}
\hline \multicolumn{4}{|c|}{$\mathrm{G}^{-1}$} \\
\hline uhütisoho & 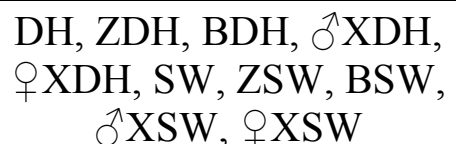 & não se aplica & genro/nora \\
\hline
\end{tabular}




\begin{tabular}{|c|c|c|c|}
\hline \multicolumn{4}{|c|}{ Ego feminino - consanguíneos } \\
\hline Termos & Marcadores & Vocativos & Glosas \\
\hline \multicolumn{4}{|c|}{$\mathrm{G}^{+3}$} \\
\hline $\begin{array}{l}\text { ngaũpügü } \\
\text { kuе̃gü }\end{array}$ & $\begin{array}{c}\text { FFF, FMF, MFF, } \\
\text { MMF }\end{array}$ & api & bisavô \\
\hline itsü kuẽgü & $\begin{array}{l}\text { FFM, FMM, } \\
\text { MFM, MMM }\end{array}$ & okojo, oó & bisavó \\
\hline \multicolumn{4}{|c|}{$\mathrm{G}^{+2}$} \\
\hline ngaũpügü & $\begin{array}{c}\mathrm{FF}, \mathrm{MF}, \mathrm{FFB}, \\
\mathrm{FF}{ }^{\Uparrow} \mathrm{X}, \mathrm{FMB}, \\
\mathrm{MFB}, \\
\mathrm{MF} \curvearrowright \mathrm{X}, \mathrm{MMB}\end{array}$ & api & avô \\
\hline itsü & $\begin{array}{c}\text { FM, MM, FMZ, } \\
\text { FM甲X, FFZ, } \\
\text { MMZ, } \\
\text { MM } \odot \mathrm{X}, \mathrm{MFZ}\end{array}$ & okojo, oó & avó \\
\hline uün & $\mathrm{F}, \mathrm{FB}, \mathrm{F}{ }^{\Uparrow} \mathrm{X}$ & apa & pai \\
\hline isi & $\mathrm{M}, \mathrm{MZ}, \mathrm{M}^{\uparrow} \mathrm{X}$ & ama & mãe \\
\hline $\operatorname{sog} u$ & $\mathrm{MB}, \mathrm{M}{ }^{\lambda} \mathrm{X}$ & $a w a$ & tio materno \\
\hline itsügü & $\mathrm{FZ}, \mathrm{F}+\mathrm{X}$ & etsi & tia paterna \\
\hline \multicolumn{4}{|c|}{$\mathrm{G}^{\varnothing}$} \\
\hline 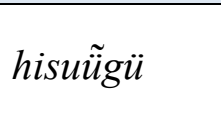 & $\begin{array}{l}\mathrm{B}, \mathrm{FBS}, \mathrm{MZS}, \\
\mathrm{F}{ }^{\lambda} \mathrm{XS}, \mathrm{M}+\mathrm{XS}\end{array}$ & não se aplica & irmão \\
\hline hasü & $\mathrm{eZ}$ & jaja & $\begin{array}{l}\text { irmã mais } \\
\text { velha }\end{array}$ \\
\hline ikene & $y Z$ & - & $\begin{array}{l}\text { irmã mais } \\
\text { nova }\end{array}$ \\
\hline hisü & $\mathrm{yB}$ & uhi & $\begin{array}{l}\text { irmão mais } \\
\text { novo }\end{array}$ \\
\hline
\end{tabular}




\begin{tabular}{|c|c|c|c|}
\hline 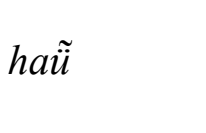 & $\begin{array}{c}\text { FZCh, MBCh, } \\
\mathrm{F}_{+} \mathrm{XCh}, \mathrm{M}^{\lambda} \mathrm{XCh}\end{array}$ & não se aplica & $\begin{array}{l}\operatorname{primo}(a) \\
\text { cruzado(a) }\end{array}$ \\
\hline \multicolumn{4}{|c|}{$\mathrm{G}^{-1}$} \\
\hline mukugu & $\mathrm{S}, \mathrm{ZS}, q \mathrm{XS}$ & ipü & filho \\
\hline indisü & $\mathrm{D}, \mathrm{ZD}$, $+\mathrm{XD}$ & ijü & filha \\
\hline 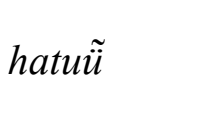 & $\mathrm{BS}, \overbrace{}^{\lambda} \mathrm{XS}$ & pügi, ipü & $\begin{array}{l}\text { sobrinho } \\
\text { uterino }\end{array}$ \\
\hline hati & 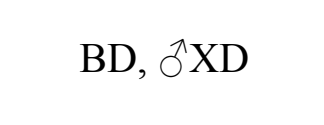 & $i j \ddot{u}$ & $\begin{array}{l}\text { sobrinha } \\
\text { uterina }\end{array}$ \\
\hline \multicolumn{4}{|c|}{$\mathrm{G}^{-2}$} \\
\hline higü & $\mathrm{ChCh}$ & api, ipü & neto(a) \\
\hline \multicolumn{4}{|c|}{$\mathrm{G}^{-3}$} \\
\hline higü kuе̃gü & ChChCh & ipü & bisneto(a) \\
\hline
\end{tabular}

\begin{tabular}{|c|c|c|c|}
\hline \multicolumn{4}{|c|}{ Ego feminino - afins } \\
\hline Termo & Marcadores & Vocativos & Glosa \\
\hline \multicolumn{4}{|c|}{$\mathrm{G}^{+1}$} \\
\hline hütisoho & $\begin{array}{c}\mathrm{HF}, \mathrm{HM}, \mathrm{HF}^{\lambda} \mathrm{X}, \mathrm{HM}^{\lambda} \mathrm{X}, \\
\mathrm{HF}^{\lambda} \mathrm{X}, \mathrm{HM}^{\lambda} \mathrm{X}\end{array}$ & não se aplica & $\begin{array}{l}\text { sogro/sogra; } \\
\text { lit. "feito } \\
\text { para causar } \\
\text { vergonha" }\end{array}$ \\
\hline \multicolumn{4}{|c|}{$G^{\varnothing}$} \\
\hline haumetigü & 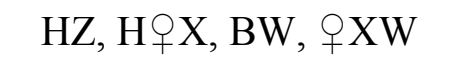 & tecnônimos & cunhada \\
\hline pahene & HB & não se aplica & cunhado \\
\hline inho & $\mathrm{H}$ & tecnônimos & marido \\
\hline \multicolumn{4}{|c|}{$\mathrm{G}^{-1}$} \\
\hline uhütisoho & 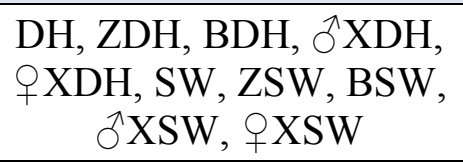 & não se aplica & genro/nora \\
\hline
\end{tabular}

